Caliane Christie Oliveira de Almeida

\title{
Habitação Social: origens e produção (Natal, 1889-1964)
}

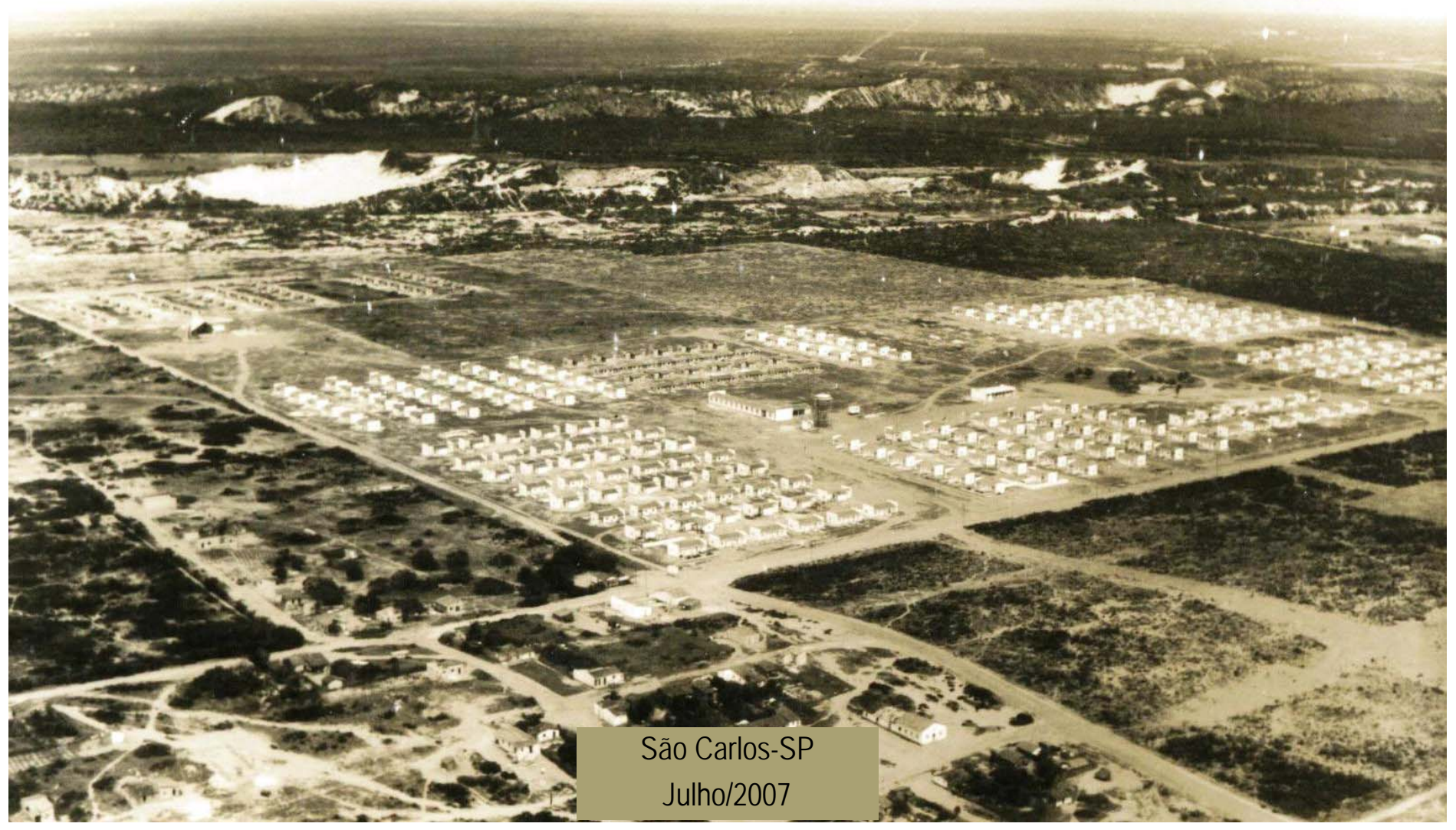




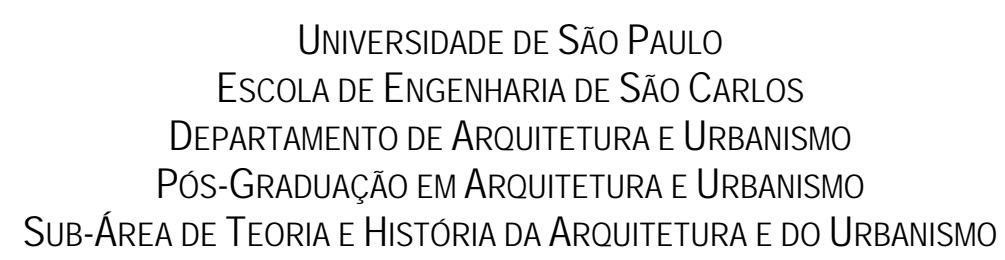

DISSERTAÇÃO

\section{HABITAÇÃO SOCIAL: ORIGENS E PRODUÇÃO. (NATAL, 1889-1964)}

Mestranda: Caliane Christie Oliveira de Almeida Orientadora: Profa. DRa. Telma de Barros Correia

Dissertação apresentada à Universidade de São Paulo, Campos São Carlos (EESC-USP), como requisito à aquisição do título de mestre em Arquitetura e Urbanismo. 
- Hos meus pais.. 


\section{AGRADECIMENTOS}

À Fundação de Amparo à Pesquisa da Cidade de São Paulo (FAPESP) pelo apoio financeiro.

À Profạ. Drạ. Telma de Barros Correia pela orientação e dedicação concedida.

Ao grupo de pesquisa História da Cidade e Urbanismo (HCURB/UFRN) pela disponibilização do material arquivado em seus bancos de dados e pelas contribuições dadas. Em especial às bolsistas de iniciação científica Ana Clara Ovídio e Luíza Maria Lima, ao bolsista de apoio técnico Yuri Simonini, e à Profa. Drạ.

Angela Lúcia de Araújo Ferreira, coordenadora do grupo, mentora e amiga.

Aos responsáveis pelo Setor de Patrimônio Imobiliário do INSS-RN, pela atenção e dedicação concedidas nos dezoito meses de levantamentos.

Aos meus pais, Maria Édna de Oliveira e Carlos Antônio de Almeida, sem o apoio dos quais eu não teria concluído mais essa etapa da minha formação.

Aos meus irmãos Carlos A. de Almeida Segundo e Cáion Cristian de Oliveira, pelo carinho e compreensão.

Às minhas avós, Maria de Lourdes e Maria Almeida, pelos estímulos.

Ao meu primo Eugênio Gondim e aos meus amigos: Débora Forest, Gabriel Mocan, Paula Francisca, Raquel Madéra, Luciana Margoni e Orlando Rodrigues, pelas diversas formas de auxílio concedidas. 


\section{RESUMO}

A presente dissertação tem como tema "políticas públicas habitacionais", tomando a capital norteriograndense - Natal - como estudo de caso. O objeto de estudo conforma-se na relação entre a questão da habitação social no Brasil, as soluções dadas ao problema da habitação por órgãos estatais, os agentes financiadores, propulsores e construtores envolvidos neste processo e a construção e idealização da cidade de Natal. Sendo assim, a pesquisa objetiva entender quais as lógicas e objetivos que impulsionaram as ações estatais no campo da habitação social em Natal, entre 1889 e 1964, como também, o contexto ideológico, econômico e social imbuído nesse processo. A partir dessa análise, buscou-se especificar as origens e delimitar o processo de evolução da produção de moradias pelas administrações públicas, além de registrar e periodizar essa produção, dando especial atenção à atuação dos Institutos de Aposentadorias e Pensões (IAPs) na cidade. Posteriormente procedeu-se a interpretação e a análise das justificativas e discursos que basearam as ações estatais, considerando os diferentes agentes envolvidos no processo, além do estudo da configuração arquitetônica e urbanística dos conjuntos de moradias erguidos na capital no referido período. Para tanto, realizou-se principalmente 0 levantamento de dados primários em arquivos públicos e privados da cidade. A pesquisa se justifica pela insuficiência de historiografia local no que dizia respeito à política pública de habitação no período que antecede a criação do BNH, em 1964, pelo volume significativo de moradias erguidas pelo Estado e por órgãos associados a ele e pelas especificidades da política de habitação em Natal, como as parcerias realizadas pelo governo, inclusive com órgãos internacionais, e a construção e financiamento de casas de taipa. Nesse sentido, foi identificado um número significativo de moradias construída em taipa e inseridas nas ações imobiliárias dos IAPs em Natal, fosse por via de construção, de aquisição e de repasse, ou por meio de financiamentos para a realização de reformas. Tais moradias chegaram a corresponder a $20 \%$ dos financiamentos concedidos pela Carteira Predial do Instituto, como foi o caso IAP dos Industriários. Os IAPs em conjunto com a Fundação da Casa Popular e com a Fundação da Habitação Popular do RN conceberam moradias à aproximadamente 3.100 famílias, entre os anos de 1946 e 1963, o que correspondeu a $8,12 \%$ da população da cidade em meados da década de 1960. Pretende-se nessa pesquisa contribuir para o conhecimento da história da moradia social no Brasil, através da análise das ações realizadas em Natal.

Palavras-chave: Políticas Públicas Habitacionais; Habitação Social; Institutos de Aposentadorias e Pensões (IAPs). 


\begin{abstract}
The subject of this dissertation is "the public politics for habitation", and it has as case of study, the capital of Rio Grande do Norte - Natal. The object of the study consists in the relation between the issues of social habitation in Brazil, the solutions given to the problem by the means of the state, the financial supporters, propelling and constructors involved on this process and the construction and he idealization of the city of Natal. Being thus, the research intend to understand which are the logics and the objectives that stimulated the State actions in the field of social habitation in Natal, from 1889 to 1964, and also, the ideological, economical and social contexts in this process. From this analysis, one searched to specify the origins and to delimit the production's evolution process of the social habitations, and also register and divide in periods that production, standing out the Retirement and Pension's Institute's (IAPs) actuation in the city. Later, the justifications and the speeches based on the State actions were interpreted and analyzed, considering the different agents involved in the process, beyond the study of the housing estate's architectonic and urban configuration, built in this period. Doing so, one realized the primary data survey at the city's public and private archives. The research is justified by the deficiency of local historiography on habitation's public politics in the period before the creation of the BNH, in 1964, by the significant number of houses built by the State and by associated organs and by the habitation's politic particularities in Natal, such as the government partnerships, including those with international organs, and the mud houses' financing and construction. Considering this, it was identified as significant number of mud houses and inserted on IAP's real estate actions in Natal, by meanings of construction, acquisition and repass or by reform's financings. Such housings had arrived to correspond to $20 \%$ of financings granted by the Carteira Predial do Instituto, as the IAP dos Industriários' case. The IAPs in set with the Popular House Foundation and with the Popular Habitation Foundation had conceived housings to, approximately 3.100 families, between the years 1946 and 1963, which corresponds to 8,12\% of the city's population in the middle of the decade of 1960. This research intends to contribute for the social habitation knowledge of the history in Brazil, through the actions' analysis in Natal.
\end{abstract}

Key-words: Public politics, social habitation and Retirement and Pension's Institute (IAPs). 
PÁGINA 22

PÁGINA 24

PÁGINA 24

PÁGINA 26

PÁGINA 26

PÁGINA 27

PÁGINA 27

PÁGINA 29

PÁGINA 29

PÁGINA 29

PÁGINA 29

PÁGINA 32

PÁGINA 33

PÁGINA 34

PÁGINA 34

PÁGINA 36

PÁGINA 36

PÁGINA 41

PÁGINA 42

PÁGINA 44

PÁGINA 44

PÁGINA 46

PÁGINA 47

PÁGINA 84

PÁGINA 84

PÁGINA 84

PÁGINA 84

PÁGINA 85

PÁGINA 85

PÁGINA 85

PÁGINA 85

PÁGINA 86

PÁGINA 86

PÁGINA 86

PÁGINA 87

PÁGINA 86

PÁGINA 93

PÁGINA 94

PÁGINA 97

PÁGINA 98
Figura 01: PARALELOGRAMO DE OWEN. Fonte: BENEVOLO, 1987.

FIGURA 02: ESQUEMA FALANSTÉRIO FOURIER. FONTE: BENEVOLO, 1987.

FIGURA 03: FALANSTÉRIO, DESTACANDO OS NÍVEIS DA EDIFICAÇÃO. FONTE: BENEVOLO, 1987.

FIGURA 04: ESQUEMA CIDADE-JARDIM. FONTE: HOWARD, 1996.

FIGURA 05: ESQUEMA DIFUSÃO CIDADE-JARDIM. FONTE: HOWARD, 1996.

FIGURA 06: LETCHWORTH. FONTE: WWW.LETCHWORTHGARDENCITV.NET.

FIGURA 07: TRAÇADO DA CIDADE INDUSTRIAL DE GARNIER. FONTE: AYMONINO, 1972.

FIGURA 08: EXEMPLAR DE MORADIA DA CIDADE INDUSTRIAL. FONTE: GARNIER, 1917.

FIGURA 09: MORADIAS COLETIVAS DA CIDADE INDUSTRIAL. FONTE: GARNIER, 1917.

FIGURA 10: MORADIAS COLETIVAS DA CIDADE INDUSTRIAL. FONTE: GARNIER, 1917.

FIGURA 11: BAIRRO RESIDENCIAL "ESTADOS UNIDOS", EM LYON. FONTE: GARNIER, 1917.

FIGURA 12: EXEMPLO DE HÖFE VIENENSE. FONTE: AYMONINO, 1973.

FIGURA 13: HÖFE KARL MAX. FONTE: AYMONINO, 1973.

Figura 14: SIEDLUNGEN CONSTRUÍDO POR VAN DER ROHE EM STUTTGARD. FONTE: BONDUKI, 2002.

FIGURA 15: SIEDLUNGEM CONSTRUÍDO POR GROPIUS EM BERLIM. FONTE: BONDUKI, 2002.

FIGURA 16: ESPAÇOS COMUNS NA CASA COMUNAL SOVIÉTICA. FONTE: AYMONINO, 1973.

FIGURA 17: ESPAÇOS COMUNS NA CASA COMUNAL SOVIÉTICA. FONTE: AYMONINO, 1973.

FIGURA 18: UNIDADE DE HABITAÇÃO DE MARSELHA. FONTE: FRAMPTON, 1997.

FIGURA 19: VISTA AÉREA DO JARDIM AMÉRICA NA DÉCADA DE 1930. FONTE: WOLFF, 1999.

FIGURA 20: RESIDÊNCIA DE WARCHAVCHIK, 1928. FONTE: BRUAND, 1981.

FIGURA 21: CASA MODERNISTA, 1930. FONTE: BRUAND, 1981.

FIGURA 22: CONJUNTO PARA OPERÁRIOS NA GAMBOA (RJ). FONTE: GAMBOA, 1933.

FIGURA 23: CIDADE OPERÁRIA. FONTE: FRAMPTON, 1997.

FiguRA 24: CONJUNTO RESIDENCIAL DE PAQUETÁ, NA ILHA DE PAQUETÁ DA BAía dE GUANABARA, EDIFICADO PELO IAPI. FONTE: BONDUKI, 2002.

Figura 25: CONJUNTO PASSO D'AREIA (IAPI), EM PORTO ALEGRE, PROJETADO PELO ARQUITETO MARCOS KRUTER, ENTRE OS ANOS DE 1940 E 1950. FONTE: BONDUKI, 2002.

FIGURA 26: CONJUNTO PIRATININGA. IAPI EM OSASCO (1940). FONTE: BONDUKI, 2002.

FIGURA 27: CONJUNTO VILA GUIOMAR (IAPI), EM SANTO ANDRÉ, PROJETADO PELO ARQUITETO CARLOS FREDERICO FERREIRA, NA DÉCADA DE 1940. FONTE: BONDUKI, 2002.

FIGURA 28: PLANTA-TIPO DO CONJUNTO REALENGO (IAPI), PROJETADO POR CARLOS FREDERICO FERREIRA, NO RIO DE JANEIRO, ENTRE AS DÉCADAS DE 1930 E 1940. FONTE: BONDUKI, 2002.

FIGURA 29: CONJUNTO JAPURÁ (IAPI-SP), DE EDUARDO KNEESE DE MELO, SOBRE INFLUÊNCIA DA UNIDADE DE HABITAÇÃO CORBUSIANA. FONTE: BONDUKI, 2002

FIGURA 30: AS TIPOLOGIAS HABITACIONAIS COLETIVAS DA VILA GUIOMAR QUE SE APROXIMAM DA CONCEPÇÃO DA SIEDLUNGEN ALEMÃ. FONTE: BONDUKI, 2002.

FIGURA 31: O BAIRRO INDUSTRIÁRIO (IAPI-BH), DE WHITE LÍRIO, MOSTRA-SE PROVAVELMENTE O ÚNICO EXEMPLAR NO PAÍS COM INFLUÊNCIA DA HÖFE VIENENSE. FONTE: BONDUKI, 2002

FIGURA 32: ELEMENTOS VAZADOS DA FACHADA DO EDIFÍCIO DOS BANCÁRIOS (IAPB), CONSTRUÍDO EM MARÍLIA (SP), NA DÉCADA DE 1950. PERCEBE-SE TAMBÉM O USO DE PILOTIS E DE PASSARELAS INTERNAS. FONTE: BONDUKI, 2002.

Figura 33: EMPREGO dE ELEMENTOS MOdERNOS NA FACHADA DO CONJUNTO PEDREGULHO (AFFONSO EDUARDO REIDY, RIO DE JANEIRO, 1940-1950). FONTE: BONDUKI, 2002.

FIGURA 34: JOGO DE VOLUMES DADO À FACHADA PELAS SACADAS DOS APARTAMENTOS DO CONJUNTO REALENGO (IAPI). FONTE: BONDUKI, 2002.

FIGURA 35: CONJUNTO DEODORO CONSTRUídO NO ÂMBITO DA FUNDAÇÃO DA CASA POPULAR, NO RIO DE JANEIRO, NA DÉCADA DE 1950. EMPREGO DOS PRESSUPOSTOS MODERNOS NA CONCEPÇÃO DA EDIFICAÇÃO PELO ARQUITETO FLAVIO MARINHO REGO. FONTE: BONDUKI, 2002.

FIGURA 36: BAIRROS DE NATAL NO SÉCULO XIX - CIDADE ALTA E RIBEIRA. FONTE: MIRANDA, 1981.

FIGURA 37: OBRAS DE ABERTURA E NIVELAMENTO DE VIAS, S/D. FONTE: JAECI, 2006.

FIGURA 38: LAGOA MANOEL FELIPE À DIREITA, LIMITE DA CIDADE (1900). FONTE: JAECI, 2006.

FIGURA 39: RUA DA CIDADE NA DÉCADA DE 1910. FONTE: JAECI, 2006.

FIGURA 40: PASSO dA PÁTRIA, 1920. FONTE: JAECI, 2006. 
PÁGINA 99

PÁGINA 101

PÁGINA 102

PÁGINA 102

PÁGINA 103

PÁGINA 103

PÁGINA 103

PÁGINA 104

PÁGINA 104

PÁGINA 108

PÁGINA 108

PÁGINA 111

PÁGINA 111

PÁGINA 114

PÁGINA 116

PÁGINA 117

PÁGINA 118

PÁGINA 121

PÁGINA 121

PÁGINA 124

PÁGINA 125

PÁGINA 125

PÁGINA 127

PÁGINA 129

PÁGINA 133

PÁGINA 134

PÁGINA 134

PÁGINA 135

PÁGINA 136

PÁGINA 137

PÁGINA 138

PÁgINA 138

PÁGINA 139

PÁGINA 139

PÁGINA 153

PÁgINA 155

PÁGINA 155
Figura 41: Prédio da DiRetoria GeRal de Higiene e SaÚde PúblicA, 1930. Fonte: JAECl, 2006.

FIGURA 42: CASARIO DA AVENIDA JUNQUEIRA AIRES, DÉCADA DE 1920. FONTE: POMBO, 1922.

FIGURA 43: RUA DR. BARATA (1930). FONTE: MIRANDA, 1981.

FIGURA 44: RUA DO COMÉRCIO (1930). FONTE: MIRANDA, 1981.

Figura 45: PRAÇA AUGUSTO SEVERO, 1902. FONTE: JAECl, 2006.

FIGURA 46: PRAÇA LEÃO XIII, S/D. FONTE: JAECl, 2006.

FIGURA 47: AVENIDA SACHET, 1910. FONTE: JAECI, 2006.

FIGURA 48: AVENIDA RIO BRANCO. FONTE: JAECI, 2006.

Figura 49: PRAÇA SETE de SeTEMBRo. Fonte: JAECI, 2006.

FIGURA 50: BASE AÉREA DE NATAL, 1942. FONTE: JAECl, 2006.

FIGURA 51: CHEGADA DE MILITARES NA CIDADE NA DÉCADA DE 1940. FONTE: JAECI, 2006.

FIGURA 52: CARTÃO POSTAL DISTRIBUÍDO AOS GOVERNANTES DO PAÍS DURANTE A DÉCADA DE 1940.

FONTE: JAECl, 2006.

FIGURA 53: AVENIDA CIRCULAR, DÉCADA DE 1940. FONTE: JAECI, 2006.

FIGURA 54: VISTA PARCIAL DO BAIRRO DA RIBEIRA. CASAS DA SILVA E JARDIM NO CANTO INFERIOR DIREITO, NA DÉCADA DE 1940. FONTE: JAECI, 2006.

FIGURA 55: MALHA VIÁRIA - CIDADE NOVA. TRECHO DA BASE CARTOGRÁFICA ORGANIZADA PELO ENGENHEIRO HENRIQUE DE NOVAES. FONTE: ACERVO HIDROESB.

FIGURA 56: OBRA DE CALÇAMENTO E ALINHAMENTO DA AV. JUNQUEIRA AIRES. FONTE: DIÁRIO DE NATAL, 1905.

FIGURA 57: RUA 13 DE MAIO, 1912. FONTE: JAECI, 2006.

Figura 58: Plano Geral de SANEAmento - Blueprint, 1924. Fonte: Acervo HidROESB/ Plano GERAL DE SISTEMATIZAÇÃO.

FIGURA 59: TERRENO ONDE PROVAVELMENTE SERIA IMPLANTADO O BAIRRO OPERÁRIO DO PLANO DE SANEAMENTO DE NOVAES (À ESQUERDA ACIMA), S/D. FONTE: JAECI, 2006.

FIGURA 60: PLANO GERAL DE SISTEMATIZAÇÃO (1929). FONTE: DANTAS, 1998.

FIGURA 61: ZONEAMENTO DO PLANO DE SISTEMATIZAÇÃO (1929). FONTE: DANTAS, 1998.

FIGURA 62: BAIRRO DAS QUINTAS, 1925. FONTE: JAECI, 2006.

FIGURA 63: AVENIDA DUQUE DE CAXIAS (DÉCADA DE 1930). FONTE: JAECI, 2006.

FIGURA 64: PLANO GERAL DE OBRAS, 1936. FONTE: ESCRITÓRIO SATURNINO DE BRITO, 1939.

FIGURA 65: SANTOS REIS EM PRIMEIRO PLANO E A PRAIA DO FORTE AO FUNDO E À ESQUERDA (DÉCADA DE 1950). FONTE: JAECI, 2006.

FIGURA 66: TABELA DE ESPECIFICAÇÃO DA LINHA DE ATUAÇÃO GOVERNAMENTAL. FONTE: ELABORAÇÃO PRÓPRIA COM BASE NOS DADOS COLETADOS.

FIGURA 67: TABELA DE ESPECIFICAÇÃO DA LINHA DE ATUAÇÃO GOVERNAMENTAL. FONTE: ELABORAÇÃO PRÓPRIA COM BASE NOS DADOS COLETADOS.

FiguRA 68: LOTEAMENTO "CIDADE CAMPESTRE Do JeQUI", 1963. FonTE: FERREIRA ET AL., 2003.

FIGURA 69: CONJUNTO RESIDENCIAL CIDADE DA ESPERANÇA NA DÉCADA DE 1960. FONTE: ACERVO EM PROCESSO DE CATALOGAÇÃO.

FIGURA 70: TABELA DE ESPECIFICAÇÃO DA LINHA DE ATUAÇÃO GOVERNAMENTAL. FONTE: ELABORAÇÃO PRÓPRIA COM BASE NOS DADOS COLETADOS.

FIGURA 71: TABELA DE ESPECIFICAÇÃO DA LINHA DE ATUAÇÃO GOVERNAMENTAL. FONTE: ELABORAÇÃO PRÓPRIA COM BASE NOS DADOS COLETADOS.

FIGURA 72: TABELA DE ESPECIFICAÇÃO DA LINHA DE ATUAÇÃO GOVERNAMENTAL. FONTE: ELABORAÇÃO PRÓPRIA COM BASE NOS DADOS COLETADOS.

FIGURA 73: TABELA DE ESPECIFICAÇÃO DA LINHA DE ATUAÇÃO GOVERNAMENTAL. FONTE: ELABORAÇÃO PRÓPRIA COM BASE NOS DADOS COLETADOS.

FIGURA 74: REFORMA DAS FACHADAS NAS MORADIAS DO BAIRRO DE APARECIDA, NA DÉCADA DE 1950. FONTE: JAECl, 2006.

FIGURA 75: QUADRO DE CLASSIFICAÇÃO DOS TIPOS DE FINANCIAMENTOS CONCEDIDOS PELOS IAPS EM NATAL. FONTE: ELABORAÇÃO PRÓPRIA COM BASE NOS DADOS COLETADOS NO INSS-RN.

FIGURA 76: QUADRO DE DISTRIBUIÇÃO DA ATUAÇÃO DOS IAPS EM NATAL NO PERÍODO DE 1944-1964. FONTE: ELABORAÇÃO PRÓPRIA COM BASE NOS DADOS COLETADOS NO INSS-RN.

FIGURA 77: QUADRO DE DISTRIBUIÇÃO DA ATUAÇÃO DOS IAPS EM NATAL NO PERÍODO DE 1944-1964.

FONTE: ELABORAÇÃO PRÓPRIA COM BASE NOS DADOS COLETADOS NO INSS-RN. 
PÁGINA 159 FIGURA 78: QUADRO DE CLASSIFICAÇÃO DAS AÇÕES IMOBILIÁRIAS DOS IAPS EM NATAL. FONTE: ELABORAÇÃO PRÓPRIA COM BASE NOS DADOS COLETADOS NO INSS-RN.

PÁGINA 159 FIGURA 79: QUADRO DE CLASSIFICAÇÃO DOS SALÁRIOS DOS ASSOCIADOS DOS IAPS EM NATAL. FONTE: ELABORAÇÃO PRÓPRIA COM BASE NOS DADOS COLETADOS NO INSS-RN.

PÁGINA 159 FIGURA 80: QUADRO DE CLASSIFICAÇÃO DOS VALORES DOS PLEITOS CONCEDIDOS AOS ASSOCIADOS PELOS IAPS EM NATAL. FONTE: ELABORAÇÃO PRÓPRIA COM BASE NOS DADOS COLETADOS NO INSS.

PÁGINA 162 FIGURA 81: QUADRO DE DISTRIBUIÇÃO DOS PLEITOS CONCEDIDOS PELOS IAPS NOS BAIRROS DE NATAL E MUNICÍPIOS DO RIO GRANDE DO NORTE. FONTE: ELABORAÇÃO PRÓPRIA COM BASE NOS DADOS COLETADOS NO INSS-RN.

PÁGINA 165 FIGURA 82: RESIDÊNCIA DO CONJUNTO PAULO GENTILE, DÉCADA DE 40. FONTE: INSS-RN, 2007.

PÁGINA 166 FIGURA 83: PLANTA DA RESIDÊNCIA DA VILA SÃO PEDRO, NO ALECRIM (1946). FONTE: INSS-RN, 2007.

PÁGINA 166 FIGURA 84: FACHADA DA RESIDÊNCIA DA VILA SÃO PEDRO (1946). FONTE: INSS-RN, 2007.

PÁGINA 167

PÁGINA 168

PÁGINA 169

FIGURA 85: PLANTA DA RESIDÊNCIA DA VILA REGIS, NO ALECRIM (1947). FONTE: INSS-RN, 2007.

FIGURA 86: FACHADA DA RESIDÊNCIA DA VILA REGIS, NO ALECRIM (1947). FONTE: INSS-RN, 2007.

PÁGINA 169

PÁGINA 170

PÁGINA 170

PÁGINA 171

PÁGINA 172

PÁGINA 172

FIGURA 87: PLANTA DA RESIDÊNCIA DA VILA GOMES, NO ALECRIM (1947). FONTE: INSS-RN, 2007.

FIGURA 88: FACHADA DA RESIDÊNCIA DA VILA GOMES, NO ALECRIM (1947). FONTE: INSS-RN, 2007.

FIGURA 89: PLANTA DA RESIDÊNCIA DA VILA JANETE, NO ALECRIM (1947). FONTE: INSS-RN, 2007.

FIGURA 90: VILA JANETE, NO ALECRIM (1947). FONTE: HCURB, 2007.

FIGURA 91: RESIDÊNCIAS DA VILA JANETE (1947). FONTE: HCURB, 2007.

FIGURA 92: PLANTA DA RESIDÊNCIA DA VILA PLATINICK (1947). FONTE: INSS, 2007.

FIGURA 93: FACHADA DA RESIDÊNCIA DA VILA PLATINICK(1947). FONTE: INSS, 2007.

PÁGINA 173

PÁGINA 174

FIGURA 94: CROQUI DE LOCALIZAÇÃO DA VILA 19 DE ABRIL (1948). FONTE: INSS, 2007.

PÁGINA 174

PÁGINA 175

FIGURA 95: FACHADA DA RESIDÊNCIA DA VILA HENRIQUE EBOLI (1942). FONTE: INSS, 2007.

FIGURA 96: PLANTA DA RESIDÊNCIA DA VILA H. EBOLI (1942). FONTE: INSS, 2007.

PÁGINA 175

PÁGINA 176

PÁGINA 178

PÁGINA 179

PÁGINA 181

PÁGINA 181

PÁGINA 181

PÁGINA 182

PÁGINA 182

PÁGINA 182

FIGURA 97: FACHADA DA RESIDÊNCIA DO CONJUNTO EBOLI (1947). FONTE: INSS, 2007.

FIGURA 98: PLANTA DA RESIDÊNCIA DO CONJUNTO EBOLI (1947). FONTE: INSS, 2007.

FIGURA 99: FACHADA DE RESIDÊNCIA DO LOTEAMENTO HENRIQUE EBOLI (1948). FONTE: INSS, 2007.

FIGURA 100: FACHADA DA RESIDÊNCIA DA VILA LUSTOSA (1950). FONTE: INSS, 2007.

FIGURA 101: IMPLANTAÇÃO DA PRIMEIRA ETAPA DO CONJUNTO NOVA TIROL (1957). FONTE:INSS, 2007.

FIGURA 102: PLANTA DA RESIDÊNCIA TIPO-A (1957). FONTE: INSS, 2007.

FIGURA 103: FACHADA DA RESIDÊNCIA TIPO-A (1957). FONTE: INSS, 2007.

FIGURA 104: VISTA DA VILA (2007). FONTE: HCURB, 2007.

FIGURA 105: BLOCO DE APARTAMENTOS DO CONJ. NOVA TIROL (1957). FONTE: INSS, 2007.

FIGURA 106: BLOCO DE APARTAMENTOS DO CONJ. NOVA TIROL (1957). FONTE: INSS, 2007.

PÁGINA 182

PÁGINA 183

FIGURA 107: BLOCO DE APARTAMENTOS DO CONJ. NOVA TIROL (1957). FONTE: INSS, 2007.

FIGURA 108: BLOCO DE APARTAMENTOS DO CONJ. NOVA TIROL (1957). FONTE: INSS, 2007.

PÁGINA 184

PÁGINA 184

PÁGINA 184

PÁGINA 185

PÁGINA 186

PÁGINA 189

PÁGINA 192

PÁGINA 195

PÁGINA 196

FIGURA 109: PLANTA-TIPO DO APARTAMENTO (1957). FONTE: INSS, 2007.

FIGURA 110: FACHADA DA RESIDÊNCIA SEGUNDA ETAPA (1959). FONTE: INSS, 2007.

FIGURA 111: PLANTA DO PAVIMENTO TÉRREO DA RESIDÊNCIA $2^{A}$ ETAPA (1959). FONTE: INSS, 2007.

FIGURA 112: PLANTA PAVIMENTO SUPERIOR DA RESIDÊNCIA $2^{A}$ ETAPA (1959). FONTE: INSS, 2007.

FIGURA 113: RESIDÊNCIA DO II CONJ. IPASE (1957). FONTE: INSS, 2007.

FIGURA 114: FACHADA DA RESIDÊNCIA GEMINADA DO III CONJ. DO IPASE (2007). FONTE: INSS, 2007.

FIGURA 115: CIDADE DA ESPERANÇA. FONTE: DATANORTE, 1975.

FIGURA 116: MORADIA DO TIPO EMBRIÃO GEMINADA, 2005. FonTE: ARQUIVO PESSOAL.

FIGURA 117: RESIDÊNCIA CONSTRUÍDA PELO IAPB, TIROL (1961). FONTE: INSS, 2007.

FIGURA 118: RESIDÊNCIA NO ALECRIM (IAPB,1961). FONTE: INSS, 2007.

PÁGINA 196

PÁGINA 196

FIGURA 119: RESIDÊNCIA NO TIROL (IAPB, 1962). FONTE: INSS, 2007.

FIGURA 120: RESIDÊNCIA NO TIROL (IPASE, 1960). FONTE: INSS, 2007.

PÁGINA 197

PÁGINA 197

PÁGINA 197

PÁGINA 197

PÁGINA 198

PÁGINA 198

PÁGINA 199

PÁGINA 199

FIGURA 121: CASA NO ALECRIM (IAPI, 1947). FONTE: HCURB, 2007.

FIGURA 122: RESIDÊNCIA NO TIROL (IAPB, 1961). FONTE: INSS, 2007.

FIGURA 123: VILA JANETE NO ALECRIM (IAPI, 1947). FONTE: HCURB, 2007.

FIGURA 124: RESIDÊNCIA NO ALECRIM (IAPB, 1963). FONTE: INSS, 2007.

FIGURA 125: RESIDÊNCIA EM PETRÓPOLIS (IPASE, 1957). FONTE: INSS, 2007.

FIGURA 126: RESIDÊNCIA NO ALECRIM (IPASE, 1958). FONTE: INSS, 2007.

FIGURA 127: RESIDÊNCIA NO TIROL (IAPC, 1953). FONTE: INSS, 2007.

FIGURA 128: RESIDÊNCIA EM PETRÓPOLIS (IAPB, 1962). FONTE: INSS, 2007. 
PÁGINA 199

PÁGINA 200

PÁGINA 200

PÁGINA 203

PÁGINA 205

PÁGINA 205

PÁGINA 206

PÁGINA 206

PÁGINA 207
FIGURA 129: RESIDÊNCIA NA CIDADE ALTA (CAPESP, 1961). FONTE: INSS, 2007.

FIGURA 130: RESIDÊNCIA NO ALECRIM (IAPI, 1947). FONTE: INSS, 2007.

FIGURA 131: PLANTA BAIXA DE RESIDÊNCIA EM PETRÓPOLIS (IAPB, 1957). FONTE: INSS, 2007.

FIGURA 132: PAREDE EM TAIPA DE SEBE. FONTE: HCURB, 2007.

FIGURA 133: MORADIA EM TAIPA E FACHADA EM ALVENARIA DE TIJOLO, NO ALECRIM (IAPB, 1955).

FONTE: INSS, 2007.

FIGURA 134: MORADIA COM ESTRUTURA EM ALVENARIA E DEMAIS DIVISÓRIAS EM TAIPA, NO ALECRIM (IPASE, 1957). FONTE: INSS, 2007.

FIGURA 135: PLANTA BAIXA DAS RESIDÊNCIAS DA RUA ALÍPIO (IAPI, 1945). FONTE: INSS, 2007.

FIGURA 136: RESIDÊNCIAS DA RUA ALÍPO (IAPI, 1945). FONTE: INSS, 2007.

FIGURA 137: RESIDÊNCIA EM TAIPA (IPASE, 1951). FONTE: INSS, 2007. 


\begin{tabular}{|c|c|}
\hline ABNT & ASSOCIAÇÃo BRASILEIRA DE NORMAS TÉCNICAS \\
\hline $\mathrm{BNH}$ & BANCO NACIONAL DE HABITAÇÃO \\
\hline CAERN & COMPANHIA DE ÁGUA E ESGOTOS DO RIO GRANDE DO NORTE \\
\hline CAPESP & CaixA de APOSENTAdoRIA e PenSÃo dos SeRVIDORES Públicos \\
\hline CAPS & CAIXAS DE APOSENTADORIAS E PENSÕES \\
\hline CARPS & COMISSÃO dE APLICAÇÃO dE RESERVAS DA PREVIDÊNCIA SOCIAL \\
\hline CECAP & CAIXA ESTADUAL DE CASAS PARA O POVO \\
\hline CED & COMISSÃo ESTADUAL DE DESENVOLVIMENTO \\
\hline CEF & CAIXA ECONÔMICA FEDERAL \\
\hline CIAM & CONGRESSO NACIONAL DE ARQUITETURA MODERNA \\
\hline COHAB & COMPANHIA DE HABITAÇÃO \\
\hline CREA & CONSELHO REGIONAL DE ENGENHARIA E ARQUITETURA \\
\hline CSN & COMISSÃO DE SANEAMENTO DE NATAL \\
\hline DSE & DEPARTAMENTO DE SANEAMENTO DO ESTADO DO RIO GRANDE DO NORTE \\
\hline EESC & ESCOLA DE ENGENHARIA DE SÃO CARLOS \\
\hline FCP & FUNDAÇÃO DA CASA POPULAR \\
\hline FDES & FUNDO DE DESENVOLVIMENTO ECONÔMICO E SOCIAL \\
\hline FGTS & FUNDO DE GARANTIA POR TEMPO DE SERVIÇO \\
\hline FUNDHAP & FUNDAÇÃO DA HABITAÇÃO POPULAR DO RIO GRANDE DO NORTE \\
\hline HCURB & GRUPO DE PESQUISA HISTÓRIA DA CIDADE E URBANISMO \\
\hline IAPB & INSTITUTO DE APOSENTADORIA E PENSÃO DOS BANCÁRIOS \\
\hline IAPC & INSTITUTO DE APOSENTADORIA E PENSÃO DOS COMERCIÁRIOS \\
\hline IAPE & INSTITUTO DE APOSENTADORIA E PENSÃO DOS ESTIVADORES \\
\hline IAPFESP & $\begin{array}{l}\text { INSTITUTO DE APOSENTADORIA E PENSÃO DOS EMPREGADOS NOS SERVIÇOS } \\
\text { PÚBLICOS }\end{array}$ \\
\hline IAPI & INSTITUTO DE APOSENTADORIA E PENSÃO DOS INDUSTRIÁRIOS \\
\hline IAPS & INSTITUTOS DE APOSENTADORIAS E PENSÕES \\
\hline IAPTC & $\begin{array}{l}\text { INSTITUTO DE APOSENTADORIA E PENSÃO DOS EMPREGADOS NOS TRANSPORTES E } \\
\text { CARGAS }\end{array}$ \\
\hline IBGE & INSTITUTO BRASILEIRO DE GEOGRAFIA E ESTATíSTICA \\
\hline IDORT & INSTITUTO DE RACIONALIZAÇÃ̃ DO TRABALHO \\
\hline INPS & INSTITUTO NACIONAL DE PREVIDÊNCIA SOCIAL \\
\hline INSS & INSTITUTO NACIONAL DE SEGURO SOCIAL \\
\hline IPASE & INSTITUTO de APOSENTADORIA E PENSÃo dOS SERVIDORES PÚBLICOS ESTAdUAIS \\
\hline IPE & INSTITUTO DE PREVIDÊNCIA DO ESTADO DO RIO GRANDE DO NORTE \\
\hline ISSB & INSTITUTO DE SERVIÇO SOCIAL DO BRASIL \\
\hline JK & JUSCELINO KUBITSCHEK \\
\hline MTIC & MINISTÉRIO DO TRABALHO INDÚSTRIA E COMÉRCIO \\
\hline PC & PARTIDO COMUNISTA \\
\hline RSN & REPARTIÇÃO DE SANEAMENTO DE NATAL \\
\hline$S / D$ & SEM DATA \\
\hline S/E & SEM ESPECIFICAÇÃO \\
\hline $\mathrm{S} / \mathrm{P}$ & SEM PÁGINA \\
\hline SBPE & SISTEMA BRASILEIRO DE PENSÃO \\
\hline SFH & SISTEMA FINANCEIRO dE HABITAÇÃO \\
\hline SUDENE & SUPERINTENDÊNCIA DE DESENVOLVIMENTO DO NORDESTE \\
\hline TELERN & COMPANHIA TELEFÔNICA DO RIO GRANDE DO NORTE \\
\hline UFRN & UNIVERSIDADE FEDERAL DO RIO GRANDE DO NORTE \\
\hline USAID & ALIANÇA PARA O PROGRESSO \\
\hline USP & UNIVERSIDADE DE SÃO PAULO \\
\hline
\end{tabular}




\section{Sumário}

\section{INTRODUÇÃO 13 \\ CAPítulo 01: A QueSTÃO dA HabitaçÃO 21}

1.1. A Revolução Industrial e as Moradias dos Trabalhadores 23

1.2. A Habitação na Cidade do Século XX 34

1.3. A Reforma da Moradia no Brasil $\quad 45$

CAPÍTULO 02: O ESTAdO E A HABITAÇÃO NO BRASIL $\quad 59$

2.1. As Primeiras Iniciativas e Realizações no Campo da Habitação 61

2.2. A Intervenção no Campo da Moradia Social a Partir da Década de $1930 \quad 69$

2.3. A Atuação dos IAPs e da FCP no País: Produção e Arquitetura 84

CAPÍTULO 03: A HABITAÇÃO SOCIAL EM NATAL 93

3.1. Dos Códigos de Postura ao Código de Obras $\quad 95$

3.2. A Ação Estatal no Campo da Habitação: Um Panorama Geral $\quad 119$

3.3. A Política Pública Habitacional: Os Momentos de Atuação 146

CApítulo 04: As VILAS e CONJUNTOS NATALENSES 151

4.1. A Atuação dos Institutos de Aposentadorias e Pensões em Natal 153

4.2. As Moradias das Vilas e Conjuntos dos IAPs 172

4.3. A Atuação da Fundação da Casa Popular e da Fundação da Habitação Popular-RN 194

4.4. A Arquitetura das Moradias em Natal 202

CONSIDERAÇÕES FINAIS 217

REFERÊNCIAS BIBLIOGRÁFICAS 227

ANEXOS 241 


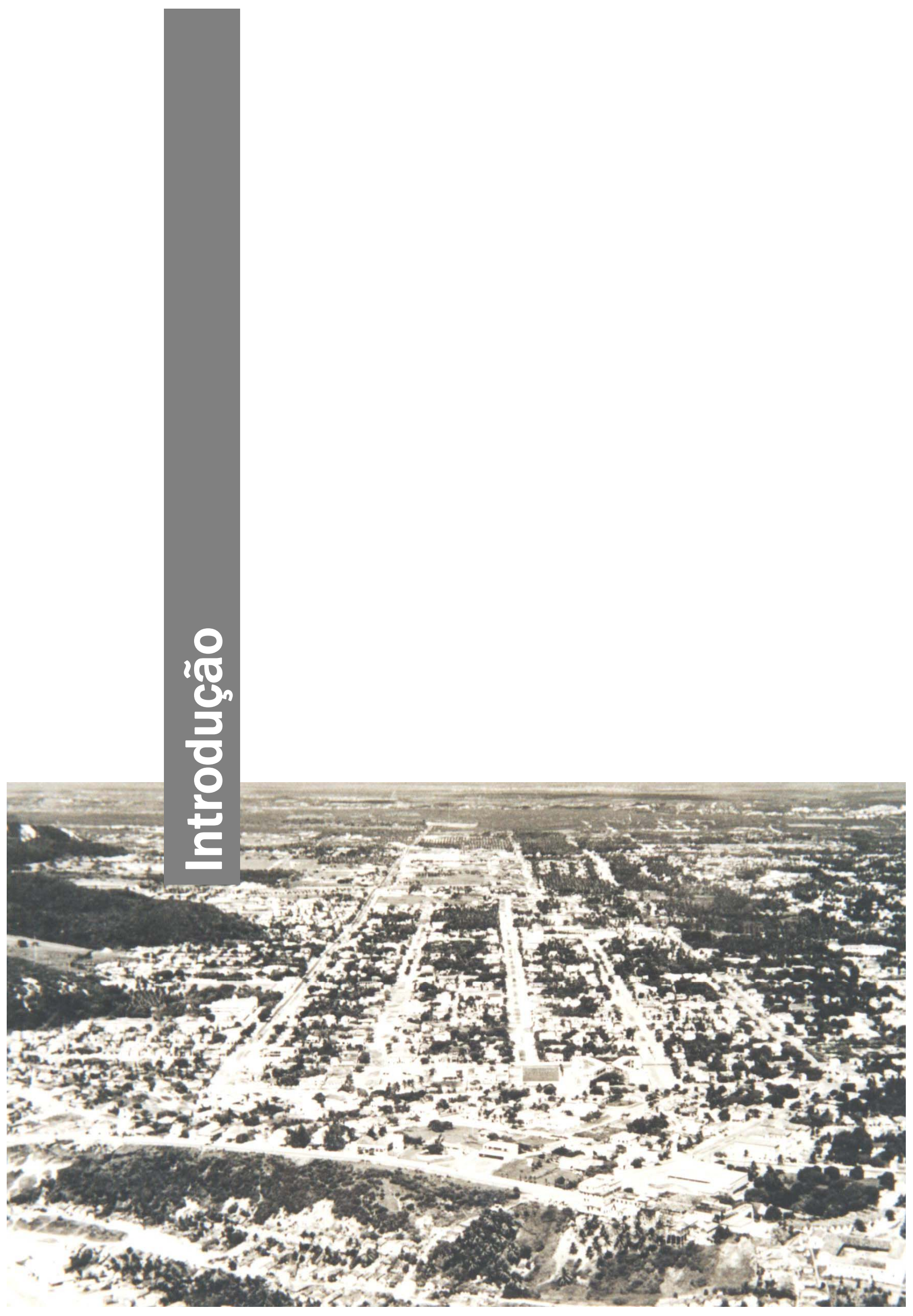




\section{INTRODUÇÃO}

A partir de 1870 difunde-se nas maiores cidades do Brasil a noção de habitação pobre como um problema. Isso ocorreu pelo fato de que as condições de habitabilidade das moradias pobres se chocavam com conceitos de higiene, de ordem, de moralidade e de economia difundidos na época. A reforma recomendada para essas moradias envolveu desde intervenções em unidades construídas à edificação de grupos de casas por industriais, sociedades construtoras e pelo Estado. Nesse contexto, a atuação das administrações públicas no tocante à produção de habitações se desenvolveu ao longo do século XX, tornando-se mais relevante a partir de meados da década de 1930, com a criação dos Institutos de Aposentadorias e Pensões (IAPs). Esta relevância decorre do volume de moradias produzidas e da distribuição delas pelos estados da federação.

A presente dissertação aborda essa produção, se inserindo em um esforço de compreensão da história da moradia no Brasil, mais especificadamente, apresenta a sistematização dos resultados dos estudos, dos levantamentos e da pesquisa, referentes ao tema "políticas públicas habitacionais", empreendidos pela mestranda entre os meses de janeiro/2005 e julho/2007, no Mestrado em Arquitetura e Urbanismo, sub-área de Teoria e História da Arquitetura e do Urbanismo.

Pode-se afirma que as questões relacionadas à temática da habitação social têm muito a revelar sobre o processo de construção e urbanização das cidades brasileiras. Trabalhos como os de Eva Blay (1985), Lílian Vaz (2002), Maria Ruth Sampaio (1993/2002), Nabil Bonduki (2002) e Telma Correia (2004), entre outros, foram de grande relevância para o resgate histórico dessa questão nos principais centros urbanos brasileiros na atualidade, assim como para o conhecimento da história da moradia no país. A temática da atuação planejada do Estado no campo da moradia, representada essencialmente pelo Banco Nacional de Habitação (BNH) a partir de 1964, foi largamente abordada em diversas publicações do gênero, que focaram principalmente às grandes cidades, como São Paulo, Rio de Janeiro, Belo Horizonte e Recife. Porém, em diversas outras cidades ainda é escassa a produção bibliográfica que aborda o papel e a concepção de habitações de cunho social pelo Estado, sobretudo, no período que antecede à criação desse órgão federal.

Em Natal, estudos desenvolvidos pela autora, enquanto bolsista de iniciação cientifica entre os anos de 2001 e 2005, no grupo de pesquisa História da Cidade e Urbanismo (HCURB), do Departamento de Arquitetura da Universidade Federal do Rio Grande do Norte (UFRN), tratavam de questões referentes à habitação na cidade, fosse como problema social ou técnico, que se revelavam como aspectos da história urbana que se fazia necessário um maior aprofundamento. Tais questões balizaram a formulação do trabalho final de graduação em Arquitetura e Urbanismo pela supracitada Universidade, defendido em janeiro de 2005 e intitulado "Os Caminhos da Habitação: um panorama geral das intervenções estatais em Natal", o qual abordou a primeira metade do século XX. Após elaboração do referido trabalho, verificou-se 
uma insuficiência de historiografia local que abordasse o processo de construção da cidade, sobretudo, no que dizia respeito à concepção de habitações por parte do governo e agentes financiadores, propulsores e construtores associados a ele, no período que antecedeu à criação do Banco Nacional de Habitação. Um maior enfoque à moradia social e a delimitação do recorte temporal, entre os anos de 1889 e 1964, deram origem à pesquisa ora apresentada e desenvolvida no Programa de Pós-Graduação da EESC/USP, tendo como orientadora a Profá. Dra. Telma de Barros Correia e financiamento da Fundação de Amparo à Pesquisa do Estado de São Paulo - FAPESP.

Dessa forma, procurou-se entender nessa dissertação, quais as lógicas e objetivos que impulsionaram as ações estatais no campo da habitação social em Natal, entre os anos de 1889 e 1964, assim como, os contextos ideológico, econômico e social, nos quais ocorreu esse processo. A partir dessa análise, buscou-se especificar as origens e delimitar o processo de evolução da produção de moradias sociais pelas administrações públicas, além de registrar e periodizar essa produção, dando especial atenção à atuação dos Institutos de Aposentadorias e Pensões (IAPs) na cidade. Posteriormente procedeu-se à interpretação e à análise das justificativas e discursos que basearam as ações estatais, considerando os diferentes agentes envolvidos no processo, além do estudo da configuração arquitetônica e urbanística dos conjuntos de moradias erguidos na capital no referido período.

Sendo assim, a presente pesquisa constitui-se em um desdobramento da monografia de conclusão de curso, ao mesmo tempo em que se vincula aos estudos sobre a produção privada e pública de moradias para trabalhadores e sobre os debates em torno da habitação popular ocorridos no Brasil no século XX, empreendidos e orientados pela Profạ. Telma de Barros Correia.

Cabe aqui ressaltar, que uma questão que inicialmente se pretendia trabalhar, mas que devido às dificuldades para o acesso aos grupos de residências não foi inclusa no corpo da dissertação, foi a análise das vilas militares erguidas na cidade, essencialmente, nas décadas de 1940 e 1950.

Ao propor aprofundar o conhecimento acerca das ações estatais especificadamente no campo da moradia social, esse trabalho espera fornecer elementos para uma avaliação mais acurada de seus efeitos sobre a cidade, em termos de mudanças nas formas de morar e de alterações na paisagem urbana. Procura contribuir também para o registro da atuação do Estado acerca das moradias sociais no período em estudo, bem como para o registro da memória e construção da história da capital norte-riograndense.

Nesse trabalho, a habitação social é entendida como àquela concebida pelo Estado e destinada às camadas mais carentes da população por meio de ações diretas ou indiretas, sendo considerados os casos de incentivos (isenções fiscais, programas, parcerias, etc.), auxílios parciais (concessão de materiais, mão-de-obra, dentre outros), doações, financiamentos, reformas e construção, além da criação de órgãos e legislação específica. Considerou-se habitação popular as modalidades de moradias produzidas pela iniciativa privada e outros agentes envolvidos com a construção, bem como, as soluções 
empreendidas pela população pobre diante dos problemas relacionados à moradia. As vilas, por sua vez, são tidas como pequenos grupos de casas, isoladas ou geminadas, distribuídas ao longo de uma via, corredor ou pátio. Os conjuntos residenciais são grupos de moradias unifamiliares e/ou coletivas de maiores dimensões, por vezes servidos de equipamentos coletivos e/ou espaços de lazer.

Esta dissertação encontra-se dividida em quatro capítulos. O primeiro capítulo, intitulado $A$ Questão da Habitação, perpassa inicialmente pelas formulações de ideais, modelos e projetos de moradias destinadas aos trabalhadores, elaborados por urbanistas utópicos do século XIX e pelas experiências das sociais-democracias européias da década de 1920. Nele, procurou-se identificar as diferentes formas pelas quais a residência urbana foi representada e compreender como o espaço destinado à moradia operária se situava nas diferentes propostas. Na seqüência expõe-se 0 papel e a importância que a habitação adquiriu nas primeiras edições dos Congressos Internacionais de Arquitetura Moderna (CIAMs) e, mais especificadamente, estudou-se as proposições e os debates formulados nesses Congressos. No tópico seguinte, procurou-se enfatizar as interpretações e as apropriações dessas proposições no Brasil, destacando a contribuição nacional nesse sentido, introduzindo assim, as análises acerca das experiências no país, abordadas no segundo capítulo.

No segundo capítulo, O Estado e A Habitação no Brasil, traça-se um panorama geral das intervenções estatais no campo da habitação social no Brasil, assim como apresenta o contexto em que se deu a evolução e o crescimento dessa atuação ao longo da primeira metade do século $X X$, até a criação do Banco Nacional de Habitação em 1964. Mais especificadamente aponta a origem da intervenção estatal na habitação, por meio de legislação restritiva e punitiva, representada principalmente pelos Códigos de Posturas. Enfoca a luta contra os cortiços e mocambos a partir, sobretudo, da Proclamação da República, em 1889, e apresenta as principais experiências brasileiras no que concerne à parceria público/privada na concepção de moradias, enfocando a construção de vilas operárias. Aborda 0 período em que se deu a mudança de atuação estatal no que concerne à produção direta de moradias e os programas governamentais inovadores efetivados a partir da década de 1930, discorrendo sobre as leis outorgadas ao longo da década de 1940 até 0 ano de 1964, acerca dos deveres e direitos dos inquilinos. Contextualiza o momento em que se deu a criação dos Institutos de Aposentadorias e Pensões e suas Carteiras Prediais, assim como da Fundação da Casa Popular, caracterizando o seu papel e especificando seus objetivos. Trata da quantificação e qualificação da produção dos IAPs e da FCP no campo da moradia social e elabora uma breve análise da arquitetura dos principais conjuntos concebidos por esses órgãos no país. Essa abordagem teve por finalidade permitir a compreensão do processo que culminou na consolidação de uma política pública no setor habitacional, com a criação do BNH, e possibilitar 0 entendimento da postura do Estado perante esta questão, contextualizando e abrindo caminho para as discussões específicas sobre Natal, abordadas nos dois capítulos seguintes. 
O terceiro capítulo, A Habitação Social em Natal, trata das discussões específicas acerca do papel e da importância que a habitação adquiriu ao longo do século XX nos discursos, intenções e ações das administrações públicas locais, como também, as origens da atuação pública no campo da moradia social, apontando, periodizando e analisando as principais realizações nesse sentido. Encontra-se dividido em três partes. O primeiro tópico, intitulado "Dos Códigos de Postura ao Código de Obras", resgata 0 conteúdo e as proposições das determinações públicas e da evolução de suas exigências acerca da habitação no decorrer do século $X X$, analisando 0 discurso das administrações públicas e as conseqüências da outorgação dessas normativas. Em seguida, o tópico "A produção estatal: um panorama geral" trata da atuação e da intervenção das administrações públicas no campo da habitação social, diante da origem e exacerbação dos problemas a ela relacionados, definindo e caracterizando os momentos de crise habitacional na cidade nas cinco primeiras décadas do século XX. O terceiro tópico, "A política pública habitacional: os momentos de atuação", identifica e caracteriza a atuação estatal no setor e periodiza essas ações.

O último capítulo, intitulado As Vilas e Conjuntos Natalenses, enfoca a produção direta de moradias sociais pelo Estado, por meio de órgãos específicos, e o estudo das características dessas habitações. Nesse capítulo, analisar-se-á a atuação dos Institutos de Aposentadorias e Pensões (IAPs), da Fundação da Casa Popular (FCP) e da Fundação da Habitação Popular do Rio Grande do Norte (FUNDHAP) na cidade.

O recorte temporal adotado nesse trabalho é justificado pelo fato de que a partir da Proclamação da República, em 1889, as questões referentes à moradia urbana passaram a receber maior ênfase dos administradores e a serem reconhecidas efetivamente como um problema urbano, enquanto que 1964 mostra-se um marco na história da moradia no Brasil, por corresponder ao ano de criação do Banco Nacional de Habitação (BNH), e a partir de quando se deu o redirecionamento das políticas públicas habitacionais e urbanas no país.

O estudo foi conduzido a partir da análise de duas variáveis: o discurso oficial que justificou a atuação da administração pública local e as ações concretizadas no setor da habitação social. A periodização dos momentos de agravamento das crises habitacionais na cidade, assim como, da atuação estatal se deu por meio de determinantes como: as interpretações do problema pelas administrações locais, pela oposição e pela população em geral; as intenções governamentais indicadas nos documentos oficiais; as intervenções pensadas e concretizadas na cidade no campo da moradia social; os princípios arquitetônicos e urbanísticos que nortearam essas ações; e as soluções implementadas nesse setor pelo Estado. Os agentes vinculados, ou não, às ações do Estado, as soluções dadas por eles, as formas de financiamento e as soluções físico-espaciais conformaram-se aspectos complementares para a determinação da periodização. 
Em se tratando das atividades de pesquisa, esse estudo foi desenvolvido por meio de nove etapas. A primeira delas correspondeu ao levantamento e revisão bibliográfica das obras de arquitetura e urbanismo que abordassem os contornos da questão habitacional na era industrial, assim como, às origens e à evolução da produção da habitação social no país, e às políticas públicas desenvolvidas nesse setor. Em um segundo momento, deu-se ênfase às obras sobre a história de Natal e à questão habitacional na cidade.

A segunda etapa equivaleu ao levantamento de dados em fontes primárias, realizado devido à escassez de fontes bibliográficas que abordem o processo histórico de formação e configuração urbana de Natal no período em questão, assim como, relativa à produção da habitação na cidade. Foram visitadas nesse sentido: a Biblioteca Nacional do Rio de Janeiro; a Biblioteca da Escola de Engenharia de São Carlos/USP; a Biblioteca da Escola Politécnica da USP; a Biblioteca Zila Mamede, em Natal/RN; 0 Memorial Câmara Cascudo (Natal/RN); o Arquivo Público do Estado do Rio Grande do Norte; 0 Instituto Histórico e Geográfico do Rio Grande do Norte; a Fundação José Augusto/RN; 0 arquivo da Cúria da Catedral/RN; e o Arquivo da Câmara Municipal de Natal. Neles, foram pesquisados periódicos locais (revistas, folhetins e, principalmente, jornais) e documentos oficiais - leis, decretos, mensagens de governo e relatórios de intendência municipal (Anexo 01).

Dentre os principais periódicos locais pesquisados estão: A República (jornal oficial do Estado); 0 Jornal de Natal (Direção de Djalma Maranhão, prefeito da cidade por dois mandatos); A Ordem (jornal vinculado à Igreja Católica); Tribuna do Norte (direção de Aluízio Alves, representante da oligarquia oposicionista que subiu ao poder na década de 1960) e Folha da Tarde (oposicionista à época). Entre aqueles que circularam por um curto espaço de tempo estão os jornais: a Gazeta de Natal, o Comerciário e O Dia. Cabe ressaltar que parte dessas informações está contida no acervo documental do Grupo de Pesquisa História da Cidade e do Urbanismo - HCURB/UFRN -, que consta de publicações, documentos oficiais, imagens, registro de entrevistas e de um banco de dados informatizado, onde se encontram as informações levantadas em periódicos locais desde o ano de 1886.

A terceira etapa de desenvolvimento da dissertação correspondeu à pesquisa documental da produção estatal da habitação, realizada nos arquivos do Setor do Patrimônio Imobiliário do INSS-RN, que comporta uma ampla gama de processos relativos às ações dos Institutos de Aposentadorias e Pensões (IAPs) em Natal, além de imagens de diversas vilas e conjuntos construídos na cidade.

Para a efetivação dos levantamentos, fez-se necessária a utilização de fichas específicas para cada categoria de dados: uma para as pesquisas nos periódicos, outra para os documentos oficiais e uma específica para os processos dos IAPs. Para as duas primeiras modalidades de dados utilizou-se 0 modelo padronizado de ficha elaborado pelo HCURB, onde são especificados os dados dos documentos título e/ou subtítulo, data, fonte, localização, administração referente, sessão, ano, número de páginas, 
dentre outros - e resumidos ou transcritos seus conteúdos (Anexo 02). Para o registro dos dados encontrados no Setor do Patrimônio Imobiliário do INSS-RN, por sua vez, foi criada uma nova ficha. Essas fichas constam dos dados de arquivamento do processo, das informações gerais sobre o processo, dos dados do interessado, das características do pleito, das características do bairro, do logradouro e do terreno onde estava (ou viria estar) locado o imóvel, além das especificidades do imóvel pleiteado (Anexo 03). Para 0 armazenamento e sistematização dos dados e imagens levantadas nas instituições públicas e privadas visitadas, foi de suma importância a formulação de um banco de dados no programa Access (Anexo 04).

As demais etapas desenvolvidas equivalem: à pesquisa iconográfica em documentos históricos; busca por mapas e imagens cartográficas na Secretaria de Meio Ambiente e Urbanismo do Rio Grande do Norte - SEMURB -; ao levantamento "in loco" das habitações, conjuntos residenciais e vilas operárias edificados na cidade, principalmente pelos IAPS, pela FCP e pela FUNDHAP, no período em questão; à sistematização dos dados; à análise dos dados; e à redação e estruturação da dissertação.

Quantificando a produção de moradias sociais e analisando suas características urbanas e arquitetônicas buscou-se identificar as particularidades da atuação estatal no campo da moradia social em uma capital de estado, corroborando para o conhecimento mais detalhado da história dessa ação a nível nacional. Espera-se, portanto, que essa pesquisa contribua para o conhecimento da história da moradia social no Brasil, através da análise das ações realizadas em Natal ao longo do período estudado. 


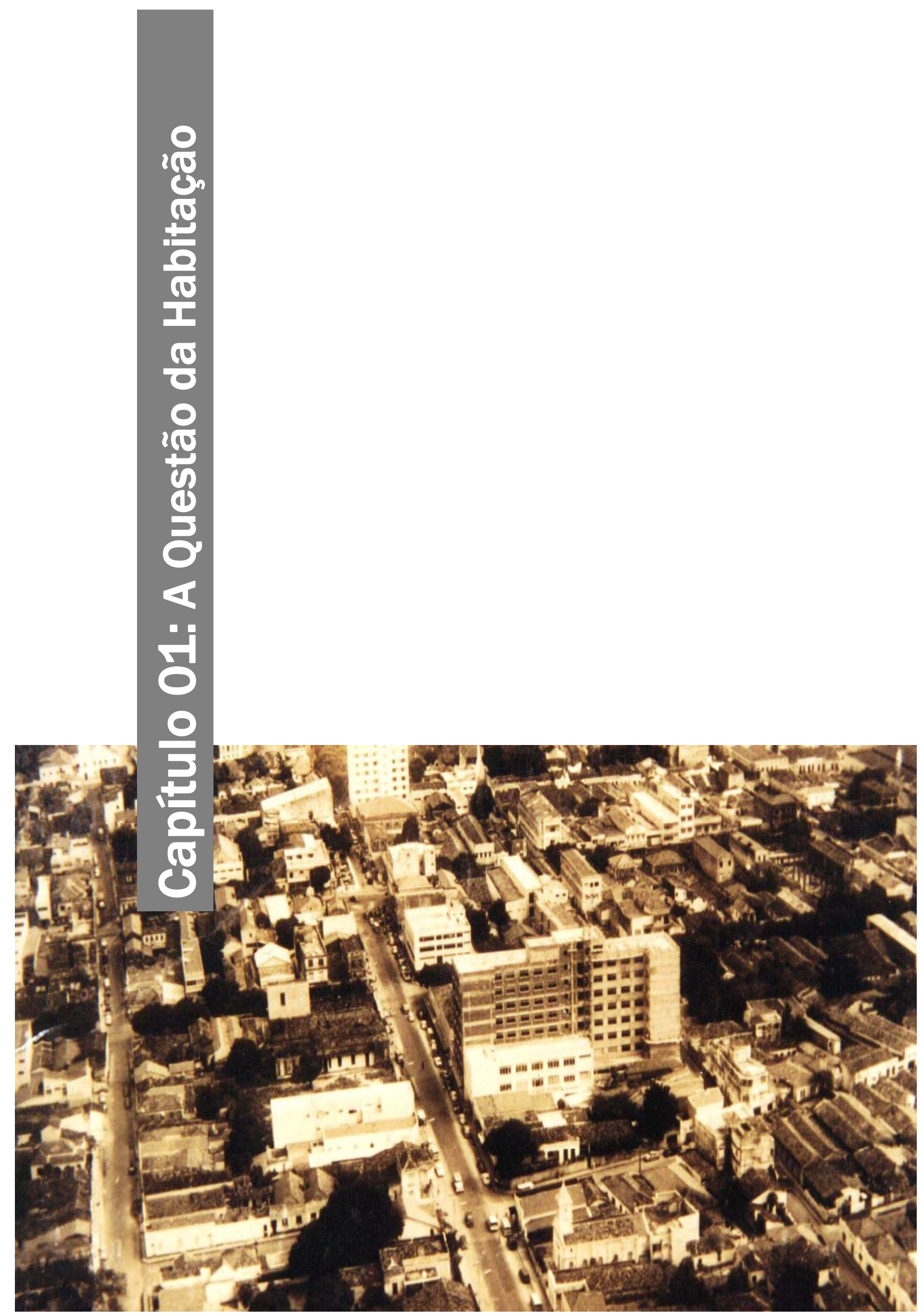




\section{CAPÍTULO 01: A QUESTÃo dA HABitAÇÃo}

\subsection{A ReVOLUÇão IndUSTRIAL E AS MORADIAS dOS TRABALHADORES}

No século XVIII, a Inglaterra tornou-se o berço da indústria. De acordo com Benevolo (1987), em aproximadamente meio século, entre 1760 e 1790, consumaram-se os processos técnicos que tornaram possível um aumento ilimitado da produção industrial, o aumento do número de indústrias e a sua concentração em grandes instalações. Esse processo teve impulso com a invenção da máquina de fiar por Richard Akwrigt, em 1771, da máquina de tear criada por Edmund Cartwright, em 1784, e da máquina a vapor de James Watt, de 1769, que possibilitou uma maior liberdade no tocante à localização das indústrias em relação à proximidade dos rios, permitindo que se localizassem nas cidades. Surgiram na seqüência, devido à necessidade de transporte das mercadorias, as estradas de rodagem e novos canais ligando os cursos dos rios navegáveis e, no século seguinte, em 1825, surgiram as ferrovias (BENEVOLO, 1987). Com 0 advento da Revolução Industrial os principais centros europeus cresceram consideravelmente em número de habitantes, e significativas transformações no modo de vida e na moradia de grande parte da população ocorreram. Essa conjuntura resultou em mudanças no uso do solo e na paisagem das cidades.

A precariedade das residências localizadas na cidade não destoava tanto daquelas situadas no campo. De acordo com Benevolo (1987, p.35), as diferenças decorriam no fato de que nas moradias urbanas, "(...) as paredes eram construídas com tijolos ao invés de madeira, e os telhados em ardósia ou em pedra em vez de colmo; os quartos eram mais acanhados, mas sem o estorvo e a poeira das máquinas fiandeiras domésticas; os sanitários estavam ausentes ou eram igualmente primitivos em ambos os casos (...)". No entanto, as carências higiênicas relativamente suportáveis no campo, tornaram-se insuportáveis na cidade devido à proximidade das habitações e ao elevado número de novas construções. Enquanto que no campo, o distanciamento das moradias possibilitava que os dejetos fossem eliminados com facilidade, 0 adensamento e a grande extensão dos novos bairros industriais operários tornaram quase que impossível o escoamento dos detritos. Ao longo das ruas corriam a céu aberto os esgotos e, nesses mesmos espaços, eram desenvolvidas diversas atividades. A proximidade das habitações de indústrias e das diversas oficinas fez com que o ambiente residencial fosse impregnado de fumaça e a água consumida contaminada por resíduos.

Em 1845, em sua publicação "A situação da classe operária na Inglaterra", Engels descreveu Manchester, o típico cenário industrial:

[...] num bairro quase manifestadamente operário, (...) nem as lojas nem as tabernas se dão o trabalho de mostrarem um pouco de asseio. Mas isto ainda não é nada comparado com as vilas e os pátios que se estendem por detrás, e os quais se chega por meio de estreitas passagens cobertas através das quais não passam nem duas pessoas ao lado 
uma da outra. É difícil imaginar a mistura desordenada das casas, escarnecendo de qualquer urbanística racional, o seu alinhamento de tal ordem que se encontram literalmente em cima uma da outra. (...) onde quer que houvesse um bocadinho de espaço entre as construções da época precedente continuou-se a construir e a remendar, até arrebatar entre as casa a ultima unha de terreno ainda livre susceptível de ser utilizado (...). As ruas não são pavimentadas nem possuem canais de escoamento, mas albergam inúmeras colônias de porcos, fechados em pequenos pátios e chiqueiros, ou percorrendo livremente a encosta. Essas ruas são tão lamacentas que somente quando o tempo está muito seco se tem alguma possibilidade de as atravessar sem afundar os pés até os tornozelos a cada passo. (...) as ilhas de casas tornam-se mais densas, (...) com uma série de interminável de caminhos, becos, ruelas secundárias e pátios, cada vez mais numerosos e desordenados à medida que vamos nos aproximando do centro da cidade. Em compensação, tornam-se mais freqüentes as ruas pavimentadas ou pelo menos com passeios calcados e canais de escoamento, mas as porcarias e as carências das casas, particularmente as caves, mantêm-se exatamente as mesmas [...] (ENGELS, 1975, p.78).

Em se tratando das moradias operárias especificadamente, Engels explanou:

[...] as casas, ou antes, as cottages, encontram-se em estado degradado, sem nunca terem sido reparadas, sujas, com quartos em caves úmidas e insalubres $(. .) /.(.$.$) as quais$ só se tem acesso das ruas através de passagens cobertas (...). $O$ ar não tem qualquer possibilidade de sair de lá, as próprias chaminés das casas constituem, até se acender 0 lume, a única via de escape para 0 ar viciado dos pátios. A isto vem ajudar-se ainda 0 facto de as casas em volta serem (...) unidas pela parede posterior (...) tudo que é arremessado aí pode permanecer tranqüilamente, não é o caso para ficar admirado com a porcaria e os montões de cinzas e de imundícies que neles existem [...] (ENGELS, 1977, p.87).

Essas habitações descritas por Engels eram, em sua grande maioria, concebidas por empreiteiros que optavam por esse tipo de construção uma vez que propiciavam um melhor aproveitamento do espaço e garantiam um maior retorno de lucros. Outra justificativa refere-se ao fato dos empreiteiros não serem os proprietários efetivos dos terrenos, os tendo alugado por anos, passados os quais, retornavam aos antigos donos. Sendo assim, as moradias operárias eram construídas de modo que no fim do prazo contratual estivessem o mais desvalorizadas possível. Cada uma das habitações possuía, em média, dois cômodos e águas furtadas, e em todo o conjunto, uma única latrina.

Dessa forma, as habitações operárias eram vistas por setores das elites como focos de diversos problemas por não se adequarem aos padrões de higiene almejados. Em linhas gerais, as críticas às habitações dos trabalhadores, formuladas pelas elites da época, referiam-se: aos materiais utilizados, essencialmente à madeira, que conservavam a umidade no espaço interno das residências; à escassez de ventilação e iluminação nesses ambientes, devido ao reduzido número, ou até mesmo à inexistência, de aberturas para o exterior; à proximidade das construções que comprometia a circulação do ar; à promiscuidade, originada pela convivência de grande quantidade de pessoas de diferentes sexos e idades numa mesma residência; e à poluição ocasionada pelos resíduos eliminados pelas indústrias, que impregnavam as moradias e a água consumida, originando doenças (CORREIA, 2004). 
Diante das deficiências das cidades em expansão no século XIX emergiram propostas e formulações que objetivavam modificar o seu quadro higiênico e solucionar o problema de falta de moradias para os trabalhadores. De acordo com Benevolo (1987, p.09), as primeiras tentativas de se corrigir os males da cidade industrial recaiam sobre dois grupos: os que se contrapunham à cidade existente e os que se propunham a resolver os problemas isoladamente, "(...) sem uma visão global do novo organismo citadino". Aliavam-se a primeira vertente os chamados "utópicos", que elaboraram diversas concepções de "cidade ideal".

Dentre as teorias e modelos elaborados, os considerados mais significativos do ponto de vista da inovação e enquanto modelo para realizações posteriores, pode-se citar: a Teoria dos Paralelogramos de Owen; as proposições de Falanstério elaboradas por Charles Fourier, por ter influenciado o pensamento e a atuação de muitos urbanistas do seu século e do século seguinte na Europa e na América, no que concerne à habitação coletiva, assim como, a Cidade Industrial de Tony Garnier; além de Ebenezer Howard e seu ideal de Cidade-Jardim, por sistematizar uma série de proposições dos teóricos precedentes e por ter se tornado um modelo de implantação, sobretudo no campo habitacional, bastante aplicado principalmente no pós-guerra nos programas de reconstrução das cidades européias.

Nesse contexto, Owen acreditava que a solução para a situação da moradia para os trabalhadores estava na concepção de um tipo de habitação destinada aos pobres e desempregados que estivesse associado aos trabalhos mecânicos. Nesse sentido, propôs uma série de aldeias com capacidade para 1.200 pessoas em média, com equipamentos para desenvolvimento de atividades de ensino, trabalho e lazer, cujo intuito era manter os

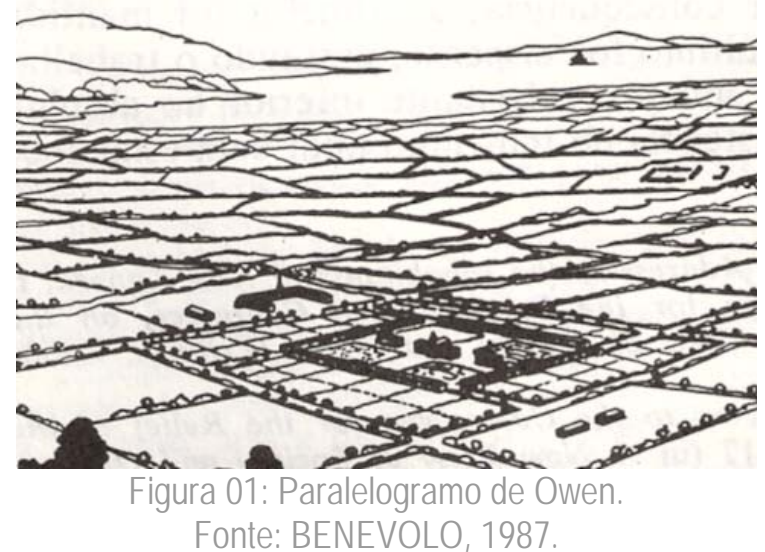
moradores afastados das "tentações inúteis". Esse modelo corresponderia à edifícios cuja disposição conformaria uma figura quadrangular, envolta por áreas livres de 1.000 a 1.500 acres (Figura 01). No centro dessa estrutura, estariam dispostos os equipamentos públicos, como escolas, salas de leitura, sala de reuniões, biblioteca e cozinha. Ao ar livre, estariam os espaços destinados aos exercícios físicos e ao lazer, e fora do perímetro do "quadrado", no terreno livre, se conformariam as hortas, jardins, estábulos, matadouros - separados por plantações -, lavanderia e, mais distantes, as construções rurais, envoltas por campos cultivados e pastagens. O limite das comunidades seria determinado por plantações de árvores frutíferas. Além de determinar as funções, dimensões e localização de cada atividade, Owen especificou desde as obrigações reservadas a cada parcela da população - homens, mulheres, idosos, 
jovens e crianças - ao planejamento orçamentário necessário à implantação do seu modelo de cidade. (CHOAY, 1992).

Em relação à habitação, Owen pregava que as unidades deveriam ter espaço em abundância e divisão interna muito simples. As aberturas dos quartos deveriam apresentar como vista as hortas-jardins e as das salas, o pátio interno. As residências não possuiriam cozinhas, haveria apenas um refeitório coletivo bem ventilado. A dimensão dos "apartamentos" seria especificada de acordo com o estado civil dos indivíduos e o tamanho da família. Sucintamente, três das arestas do quadrado seriam reservadas aos casados, geralmente com quatro quartos cada, e a quarta aresta equivaleria ao alojamento das crianças ${ }^{1}$ maiores de três anos e dos visitantes.

Owen tentou aplicar suas idéias nos Estados Unidos, mas não obteve sucesso. De 1835 a 1845 funcionou uma comunidade owenista em Queenswoord, no Hampshire. Com o passar dos anos, o ideal owenista concretizou-se num sentido puramente econômico, deixando de lado as implicações políticas e urbanísticas que seu fundador considerava inseparáveis (BENEVOLO, 1987). O esquema de Owen, conhecido como "teoria dos paralelogramos", foi largamente criticado pelos especialistas, por quem foi chamado de "cooperativista que queria dividir o mundo em quadrados".

Outro importante modelo de habitação formulado no século XIX foi o Falanstério de Charles Fourier $^{2}$, o qual considerava absurdo o modelo de cidade vigente baseado na competição de interesses individuais e de classes. Nesse sentido, propôs a união dos esforços para alcançar o que definia como harmonia universal, a ser alcançada de modo gradual (BENEVOLO, 1987).

No tratado denominado "Associação Doméstico-agrícola", publicado em 1822, Fourier descreveu como deveria ser a organização espacial de uma cidade num terceiro estágio, o da civilização. Partir-se-ia, nesse sentido, da conformação de três cinturões, separados por cercas e vegetações. A área central dessa estrutura corresponderia à cidade, o segundo cinturão ao subúrbio e às grandes fábricas, e 0 terceiro, à periferia e às avenidas (RONCAYOLO, 1992).

As residências do cinturão central deveriam ser dotadas de jardim, equivalente pelo menos à área construída. No segundo cinturão, essa área deveria ser duplicada e no terceiro, triplicada. As moradias deveriam ainda apresentar fachadas regulares em todos os lados, ornamentos escalonados e deveriam ser desprovidas de empenas nuas. As habitações não poderiam ser pequenas, antes coletivas, pois favoreciam a concentração dos serviços e, portanto, as relações mútuas. A distância mínima entre as edificações deveria ser de "três braças", sendo separadas por muros baixos de modo que 2/3 da

\footnotetext{
${ }^{1}$ Somente seria permitido o número máximo de duas crianças por família em cada unidade (BENEVOLO, 1987).

2 Fourier começou a expor suas idéias por meio de um tratado anônimo que passou a circular em 1808, posteriormente denominado "Teoria dos Quatro Movimentos". Seus ideais foram largamente publicados a partir de 1832, dentre os principais estão: 0 semanário Le Phalansterè ou La Reforme Industrielle, extinto em 1834 e retomado em 1836 com o título de La Phalange, que se tornou uma publicação diária entre 1843 e 1850, sob o título de La Démocratie Pacifique (RONCAYOLO, 1992).
} 
construção fosse vislumbrado. Seus telhados deveriam conformar pavilhões e conter calhas para conduzir as águas das chuvas para debaixo dos passeios. A altura das edificações não poderia exceder a largura da rua.

Fourier abolia o tabuleiro em xadrez, afirmando que algumas das ruas da cidade deveriam ser curvas e serpenteadas para se evitar a uniformidade. Nelas, deveriam ser plantadas árvores de diversas espécies, intercaladas por praças que totalizariam 1/8 da superfície da cidade. A largura mínima das ruas deveria ser de nove braças. As vias para pedestres manteriam essa dimensão, sendo reservadas seis braças para canteiros.

Benevolo (1987), afirma que essa foi a mais importante contribuição de Fourier para a prática urbanística que se seguiu, além de antecipar o conteúdo de construção adotado no século XIX. Para 0 filósofo, isso era um conjunto de regras, um elemento de transição para a harmonia universal. Nessa etapa, a comunidade diferenciada daria lugar a um grupo racionalmente composto, denominado Falange (um aglomerado de 1.500 a 1.600 pessoas), e a cidade diferenciada seria substituída por um dispositivo arquitetônico unitário, chamado Falanstério.

Fourier estabelecia que o terreno para a instalação da Falange deveria possuir uma légua quadrada, a ser locado próximo a um curso de água, atravessado por colinas e próprio para diversos cultivos, à beira de uma floresta e relativamente próximo à cidade. O filósofo chegou a detalhar a quantidade de pessoas que comporia a Falange: 192 pessoas entre crianças e idosos, 450 pessoas de condições diversas em relação à saúde, caráter, etc.; e 168 complémentaires doiblantes, em reforço às classes ativas, provavelmente, compostos por jovens em condições de trabalho. A população adequada sugerida por Fourier era de 1.620 pessoas. A relação entre sexo masculino e feminino na Falange deveria ser de 21 homens para 20 mulheres. Aos pobres, a administração da Falange disponibilizaria alojamento, vestimenta e comida a serem pagos com trabalho.

Como dito anteriormente, a Falange seria estruturada com base em uma única e regular edificação, o Falanstério (Figura 02). O centro desta edificação ou palácio destinarse-ia às funções públicas, às salas de jantar, da bolsa, do conselho, da biblioteca e de estudo. Nele também estariam situados: 0 templo, a tour d'odre, o telégrafo, 0

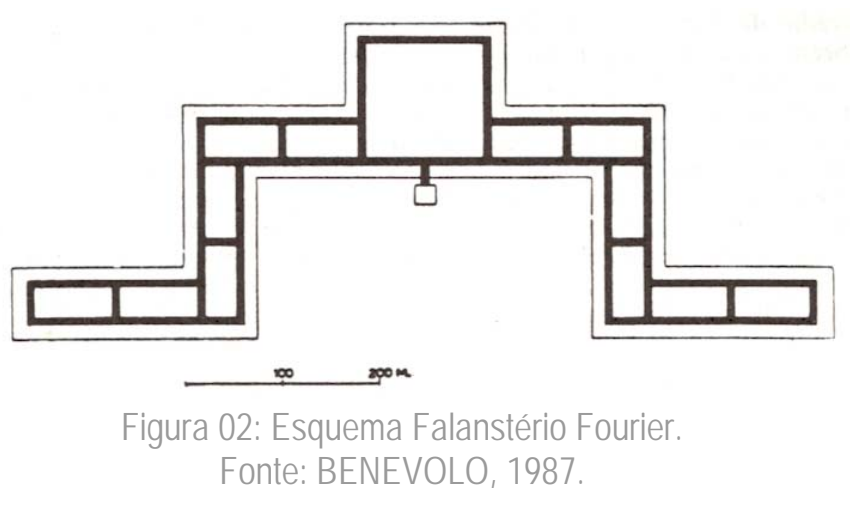
observatório e o jardim de inverno. Uma das alas da edificação deveria reunir todas as oficinas ruidosas e todas as assembléias de jovens, e a outra deveria conter as salas de baile e de relações com os forasteiros, para que esses não perturbassem as relações domésticas da Falange. Fourier propôs uma 
extensão de 500 braças para o corpo central do Falanstério e de 150 braças para as alas que deveriam ser duplicadas à medida que fosse necessário, sendo separadas por pátios de 15 a 20 braças, atravessadas a cada 50 braças por passagens-corredores cobertos.

O Falanstério também deveria ser atravessado por passagens para veículos como, de acordo com Benevolo (1987), se verifica no Louvre, e ser construído com materiais como pedra, cal e areia. Para evitar gastos com material e mão-de-obra com uma estrutura demasiadamente extensa, Fourier propôs a elevação do gabarito da edificação, que deveria possuir pelo menos três pisos, além do sótão, térreo e sobreloja; sendo cada andar dotado de passarelas internas com rampas e escadas, o que ele convencionou chamar de "ruas internas" (Figura 03). Essas passagens conformariam uma espécie de grande galeria que interagiria com o espaço externo por meio de janelas envidraçadas. Nela, a população poderia circular e alcançar todos os espaços da edificação, estando protegida das intempéries. As portas principais de acesso do primeiro, segundo e terceiro pavimento deveriam abrir para a ruagaleria. As funções estariam dispostas por pavimentos. No térreo estariam localizadas as passagens de viaturas, na sobreloja ficariam os alojamentos para as crianças e idosos, e nos outros pavimentos, os demais alojamentos e salas de reuniões. No sótão seria locado 0 albergue para os visitantes e os reservatórios de água para caso de incêndios. O Falanstério teria apartamentos com distintos tamanhos e

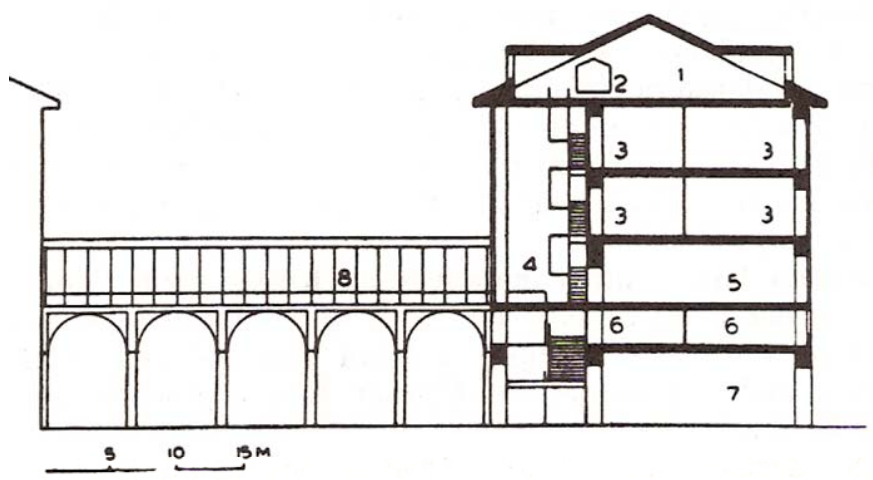

Figura 03: Corte Falanstério, destacando os níveis da edificação. Fonte: BENEVOLO, 1987. preços.

Um dos principais líderes internacionais do movimento fourierista foi Victor Considérant. Formado em engenharia pela Escola Politécnica de Paris, Consideránt foi responsável pela construção de três importantes exemplares de Falanstério: um em Conde-sur-Vesgre na França; outro na Argélia, e um terceiro situado no Texas, denominada de La Réunion, extinto em 1859. Várias tentativas de se consolidar uma comunidade Fourierista foram também realizadas na França, Rússia e, principalmente, na América. Foi especialmente nos EUA que essa prática encontrou adeptos, atingindo entre os anos de 1840 e 1850 o número de quarenta e uma comunidades experimentais, dentre as quais se destaca a comunidade de Brook Farm, próxima a Massachussets, fundada por George Ripley em 1841.

No último quartel do século XIX, surgiu na Inglaterra o conceito de "Cidade-Jardim" com o livro "Garden Cities of Tomorrow", publicado por Ebenezer Howard em 1898. Sua proposição objetivava solucionar os problemas de insalubridade e pobreza encontrados em Londres, por meio de novas cidades 
marcadas pela íntima relação com o campo e por habitações amplas e isoladas em grandes terrenos arborizados. Como afirma o próprio Howard (1996, p.108): "(...) cidade e campo devem estar casados, e dessa feliz união nascerá uma nova esperança, uma nova vida, uma nova civilização".

Em linhas gerais, seu conceito corresponde a uma estratégia de planejamento regional para conter o fluxo migratório em direção às grandes cidades, propondo núcleos auto-organizados conformados a partir do estabelecimento de indústrias e comércios, com cinturões agrícolas, interligados por um sistema de transporte público eficiente.

Em seu livro, Howard especificou todos os passos para se estabelecer uma Cidade-Jardim, desde critérios de escolha do terreno até questões relativas à forma de aquisição e tipo de contribuição dos futuros moradores; revelando que o segredo consistia em agrupar as vantagens oferecidas pelas cidades, como entretenimento e diversidade de serviços, àquelas encontradas nas zonas rurais, tais como tranqüilidade, ar puro e belas paisagens. Dessa forma, o novo núcleo atrairia naturalmente as pessoas das cidades congestionadas como se fossem "imãs".

O terreno onde seria estabelecida a Cidade-

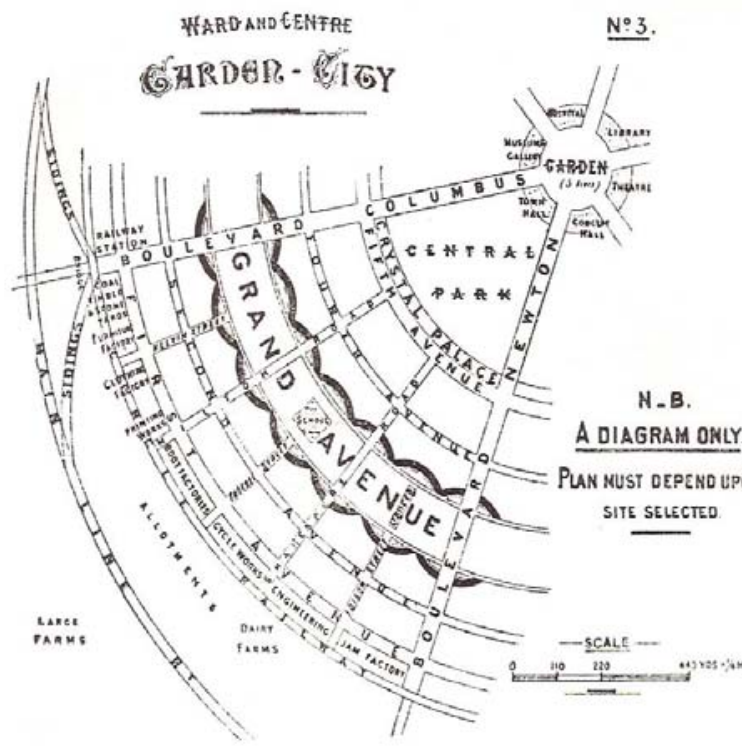

Figura 04: Esquema Cidade-Jardim. Fonte: HOWARD, 1996. Jardim deveria ser adquirido e registrado por um grande empresário e arrendado para os futuros moradores ${ }^{3}$. Em síntese, cada núcleo seria composto por: uma área central onde estariam dispostos os edifícios públicos e institucionais; uma grande área verde central; quarteirões residenciais; uma larga "avenida-parque" com grandes canteiros arborizados, na qual, estaria disposto o comércio; seis grandes bulevares responsáveis pela dinamização e otimização da circulação; uma área destinada às pequenas indústrias; espaços destinados às hortas e jardins; área de habitação rural; e grandes áreas para plantio circundando toda a ocupação, sendo limitadas por linhas de trem, responsáveis pela contenção do crescimento da cidadejardim e ligação com o centro urbano mais próximo4 (FIGURA 04). Ao ser atingido o número máximo de 58.000 habitantes na primeira cidade-jardim ou cidade-central, a população "excedente" seria responsável

\footnotetext{
${ }^{3}$ O lucro obtido pelo "loteador" serviria para amortizar a dívida do empréstimo para aquisição da terra e/ou seria revertido para a comunidade sob a forma de melhoramentos na infra-estrutura e para a construção de edifícios públicos e institucionais; revelando, assim, o teor social de sua proposta.

${ }^{4}$ Seriam aglomerações com dimensões e densidades fixas, totalizando 2.400 hectares a serem destinados a 32.000 habitantes, dos quais, 2.000 hectares corresponderiam à área rural (2.000 pessoas) e 400 hectares, a área urbana a ser dividida em seis bairros destinados a 5.000 moradores cada um (HOWARD, 1996).
} 
pelo estabelecimento de um segundo núcleo (ou primeira cidade-satélite). Quando essa alcançasse 32.000 habitantes, cessar-se-ia o crescimento e partir-se-ia para a conformação de uma segunda cidadesatélite e assim sucessivamente, até a formação de uma espécie de constelação composta por seis cidades interligadas (ideal estabelecido) por ferrovias, rodovias e canais, todas com as mesmas características e princípios norteadores (Figura 05) (HOWARD, 1996).

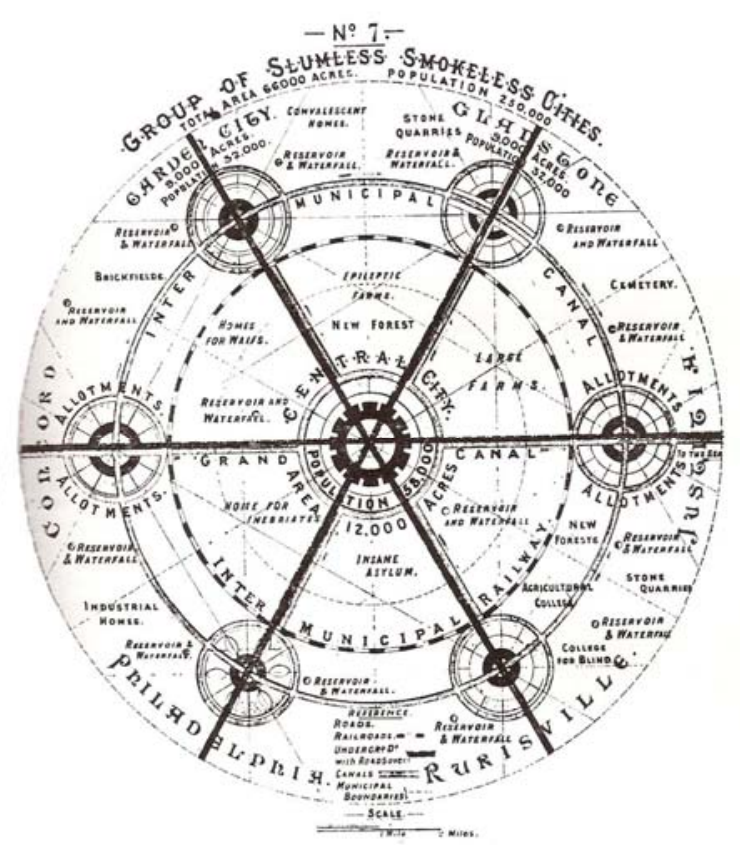

Figura 05: Esquema difusão Cidade-Jardim. Fonte: HOWARD, 1996.

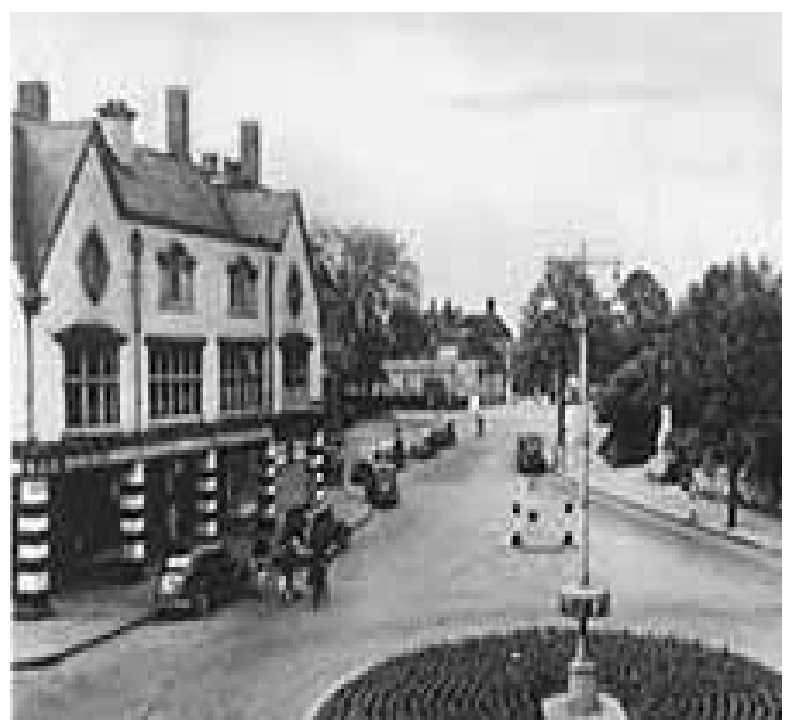

Figura 06: Letchworth.

Fonte: www.letchworthgardencitv.net.

De acordo com Munford (1998), Howard não se interessava em propor um modelo de cidade especificando suas formas físicas, se preocupava muito mais com os processos sociais, privilegiando a participação da população na gestão da cidade, estimulando a organização dos habitantes em cooperativas ou em iniciativas individuais no sentido de promover 0 desenvolvimento de políticas públicas. Nesse sentido, não estabeleceu precisamente nenhum detalhe arquitetônico ou urbanístico, e nenhuma especificação construtiva acerca das moradias, uma vez que não desejava que as questões essenciais colocadas fossem confundidas ou associadas a uma imagem visual. As moradias deveriam necessariamente ser unifamiliares e apresentar generosos espaços internos beneficiados com grandes aberturas (MUNFORD, 1998).

A primeira cidade-jardim construída foi Letchworth (Figura 06), projetada pelos arquitetos Raymond Unwin e Barry Paker, em 1903, sendo caracterizada por seu traçado simples e por seus edifícios públicos situados próximos a uma estação de trem. As habitações para as diversas classes sociais conformam-se em diversos blocos isolados, com recuos e jardins frontais, dispostas em ruas "cul-de-sac" bem arborizadas. Essa cidade foi pensada para ser auto-suficiente em termos econômicos, representando modelo tanto urbanístico quanto arquitetônico para diversos projetos posteriores. 
O ideal de Cidade-Jardim foi amplamente difundido por todo o mundo, principalmente, após a Primeira Guerra Mundial, quando o movimento tornou-se modelo de planejamento de novas cidades para a reconstrução da Inglaterra. Esse conceito foi associado às aglomerações que primavam pelo emprego de jardins nos lotes residenciais, de casas unifamiliares e de ruas arborizadas com traçado sinuoso.

Nos primeiros anos do século XX, Tony Garnier elaborou sua principal obra relacionada ao espaço de morar, o "projeto revolucionário de uma cidade modelo", denominada de "Cidade Industrial" (Figura 07). O plano foi concluído no ano de 1901, as ilustrações em 1904, mas, a obra completa só foi publicada em 1917 (CHOAY, 1965, p.163).

Garnier propôs um esquema para a criação de cidades médias, com cerca de 35.000 habitantes, essencialmente industriais, em uma região montanhosa onde os equipamentos e serviços seriam distribuídos de acordo com a altitude, sendo também atravessada por um rio5. Em ordem crescente de altitude estariam localizados a fábrica principal (na planície), separada da cidade por uma estrada de ferro ${ }^{6}$ e, por trás das montanhas, os equipamentos sanitários ${ }^{7}$, “...) ao abrigo dos ventos frios (...)" (GARNIER, 1917, p.217). Em torno da aglomeração principal haveria outras aglomerações, como áreas de
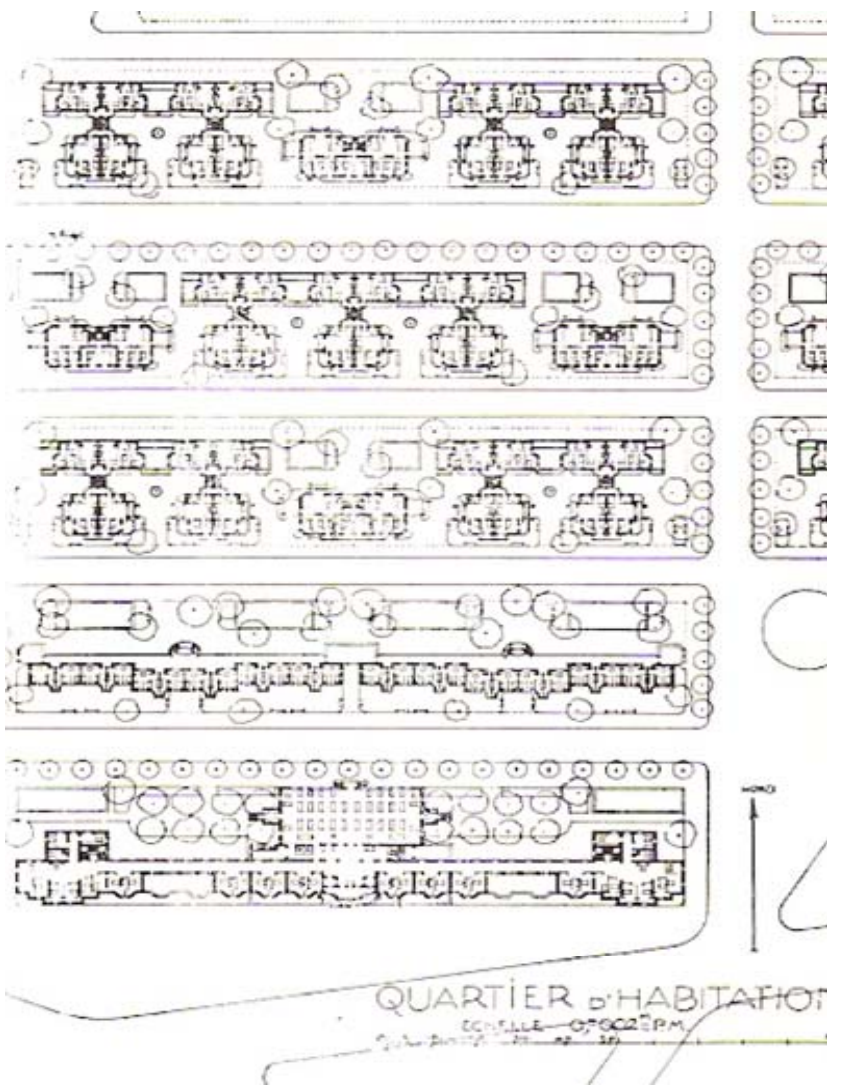

Figura 07: Traçado da Cidade Industrial de Garnier. Fonte: AYMONINO, 1972. moradias rurais e fazendas de exploração agrícola. Na concepção de Garnier (1917), esta disposição seria a mais adequada ao cumprimento das necessidades materiais e morais dos indivíduos e, para garanti-las, seriam elaborados regulamentos sobre estas disposições. Essas normas seriam formuladas de acordo com condições climáticas e geográficas e serviriam tanto para os equipamentos, serviços e infra-estrutura, como para as habitações.

\footnotetext{
50 cenário escolhido pelo arquiteto foi o sudoeste da França. As justificativas apontadas para tal escolha remontam à abundância de matérias-primas, à facilidade de transporte, à proximidade de uma região de minas e, principalmente, à força da torrente, considerada por Garnier (1917, p.217), como o "ponto de partida" do processo. Apropriando-se da torrente, seria instalada uma hidroelétrica, responsável pela distribuição de força, luz e aquecimento para toda a cidade.

${ }^{6}$ A estação seria de médio porte e contaria com os serviços públicos. As linhas estariam situadas no subsolo e estariam atendidas por salas de espera e plataformas. Uma grande torre, visível em toda a cidade, atestaria a sua localização. A estrada de ferro deveria ser totalmente reta de modo a ser destinada para trens de alta velocidade.

7 Os estabelecimentos sanitários totalizariam 715 leitos protegidos dos ventos frios pela montanha e circundados por cinturões de árvores. Equivaliam a um hospital, um setor de helioterapia, outro para doenças contagiosas e um terceiro para inválidos (GARNIER, 1917).
} 
As vias conformariam uma grelha com ruas paralelas e perpendiculares. As vias distribuídas no sentido norte-sul apresentariam 20m de largura sendo arborizadas nos dois lados, as demais possuiriam 13 ou 19m. Na área central da ocupação estariam dispostos os estabelecimentos públicos, classificados por Garnier (1917) em três grupos: os serviços públicos, administrativos e salas de assembléia; os estabelecimentos desportivos e de espetáculos; e as coleções ${ }^{8}$. As escolas primárias estariam distribuídas em pontos estratégicos. Na extremidade nordeste da cidade haveria escolas secundárias onde, para uma pequena parcela da população, seriam ensinadas noções de administração, comércio e artes. A grande maioria receberia um ensino profissional industrial (metalurgia e preparação de seda). Somente os reconhecidamente capacitados seguiriam os estudos numa escola especial ou numa faculdade.

As quadras dos bairros residenciais teriam dimensões pré-definidas, aconselhando-se $150 \times 30 \mathrm{~m}$. Os lotes, por sua vez, teriam uma área de $225 \mathrm{~m}^{2}(15 \mathrm{x}$ $15 \mathrm{~m})$, sempre com uma das faces dando para a rua. Os regulamentos referentes ao espaço destinado às habitações permitiam a fusão de lotes, mas, a superfície da área construída não poderia exceder a metade da área total. 0 restante do terreno do lote deveria ser transformado em jardim público com uma passagem da rua para a construção situada atrás.

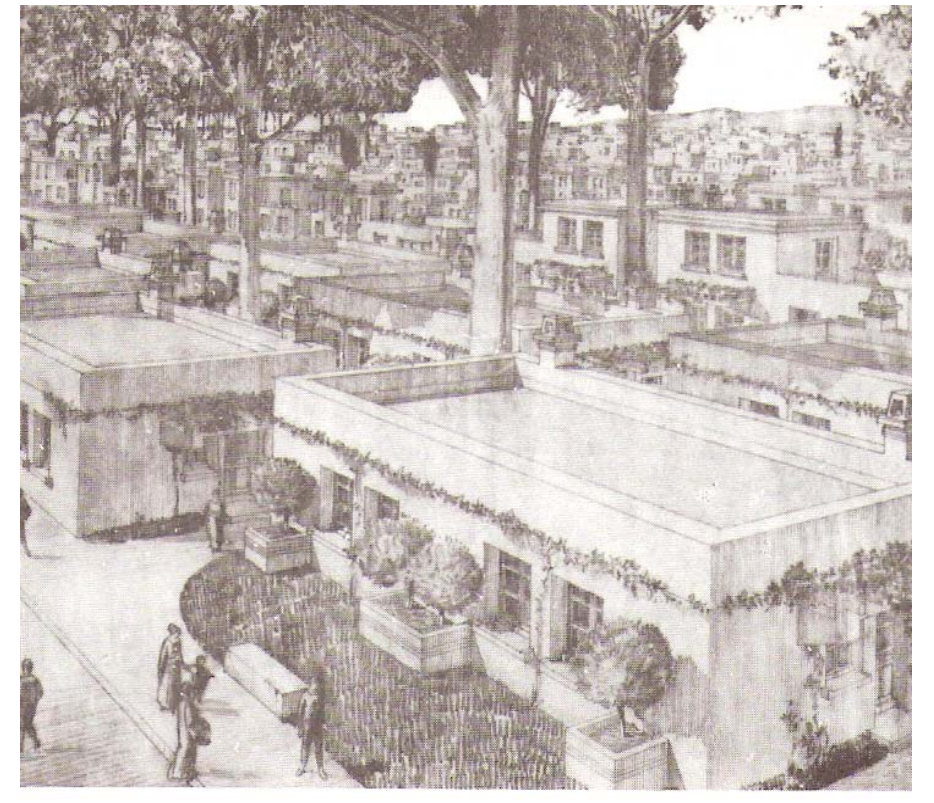

Figura 08: Exemplar de moradia da Cidade Industrial. Fonte: GARNIER, 1917

Nas residências, pelo menos uma das janelas dos dormitórios deveria estar direcionada para o sul e possuir dimensão suficiente para iluminar todo o cômodo (Figuras 08, 09 e 10). Não seria permitida qualquer alternativa de ventilação a não ser, aberturas diretas para o exterior. Dessa forma, estariam proibidas pérgulas, dutos de ventilação ou pátios internos. Dentro das habitações não haveria ângulos retos nos encontros dos elementos construtivos - piso, paredes e cobertura -, todos os cantos seriam arredondados e os materiais de revestimento deveriam ser lisos. Os materiais utilizados nas edificações

\footnotetext{
8 Os serviços públicos compreenderiam quatro prédios: um destinado ao tribunal de justiça e ao conselho da cidade; um segundo com escritórios; outro para os laboratórios de análise; e um último que seria destinado aos arquivos administrativos e ao corpo de bombeiros. Haveria ainda um serviço de organização do trabalho responsável pela distribuição de empregos na cidade, com hotéis e restaurantes para os que esperassem por trabalho. As salas de assembléia seriam destinadas à realização das sessões do parlamento, apresentações musicais, reuniões dos sindicatos, sociedades e grupos diversos, conferências, projeções, etc., pelas quais, os pedestres poderiam circular em passarelas que conformariam uma galeria coberta, estando protegidos das intempéries. Ao grupo das coleções estaria associada à biblioteca, salas de exposição, jardim, estufa e museus. Em se tratando de esporte e lazer, haveria uma grande sala de espetáculos e de conferências com capacidade para 1.900 pessoas; teatro de arena ao ar livre; ginásios; casa de banhos com piscinas, sala de duchas e de massagem, sala de esgrima, ciclovia, restaurante, quadras e pistas de corrida (GARNIER, 1917).
} 
da cidade industrial seriam basicamente dois: 0 cimento, empregado nas fundações e nas paredes, e 0 concreto armado, nos forros e tetos, ambos preparados em formas específicas.

De acordo com Garnier:

[...] quanto mais simples forem os moldes, mais fácil será a construção e, conseqüentemente, menos cara. Essa simplicidade de meios conduz logicamente a uma simplicidade de expressão na estrutura. Salientemos ainda que, se nossa estrutura se mantiver simples, sem ornamentos, sem saliências, toda nua, poderemos depois dispor de arte decorativa sob todas as suas formas, e cada objeto de arte conservará sua expressão, tão mais nítida e pura quanto mais totalmente independente da construção. Quem negará que o emprego de tais materiais permite melhor que outros que se obtenham grandes planos horizontais e verticais, próprios para dar as construções esse ar de calma e equilíbrio que as harmoniza com as linhas da natureza?

Outros sistemas de construção, outros materiais levarão, sem dúvida, a outras formas que será interesse procurar. Este é o resumo do programa de estabelecimento de uma cidade onde todos são conscientes de que o trabalho é lei humana e de que há ideal bastante no culto da beleza e da bondade para tornar a vida esplêndida (GARNIER, 1917, p.222).

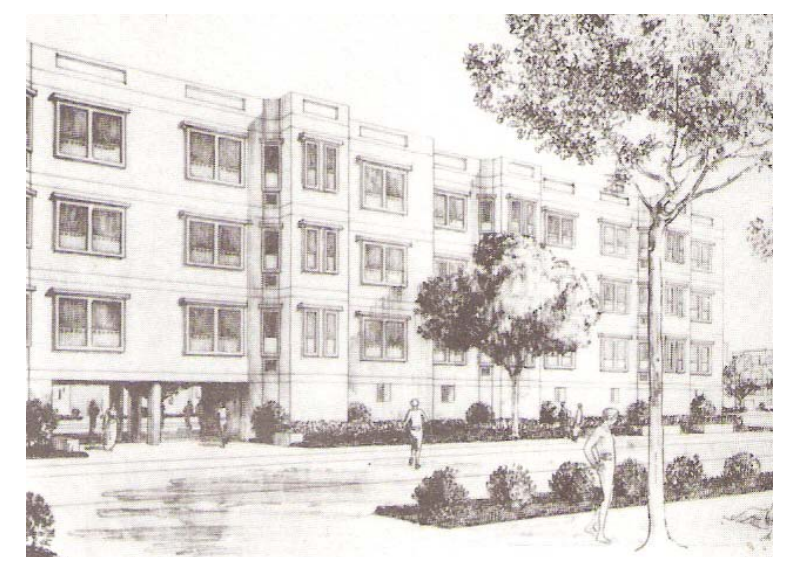

Em 1905, Garnier foi nomeado pelo prefeito da cidade de Lyon, E. Herriot, o arquiteto-chefe, a quem foi garantida a construção de diversos equipamentos públicos e as obras de melhoramentos da infraestrutura e para a expansão da cidade. Dentre as principais obras realizadas por Garnier em Lyon que, segundo Choay (1965), foi na prática a cidade industrial, estão: o matadouro de Mouche (1909-1913), o estádio olímpico (1913-1916), o hospital de Grange Blanche (1915-1930) e o bairro residencial "Estados Unidos" (Figura 11), no qual, as habitações coletivas estão dispostas numa extensa área verde e os pátios internos foram eliminados.

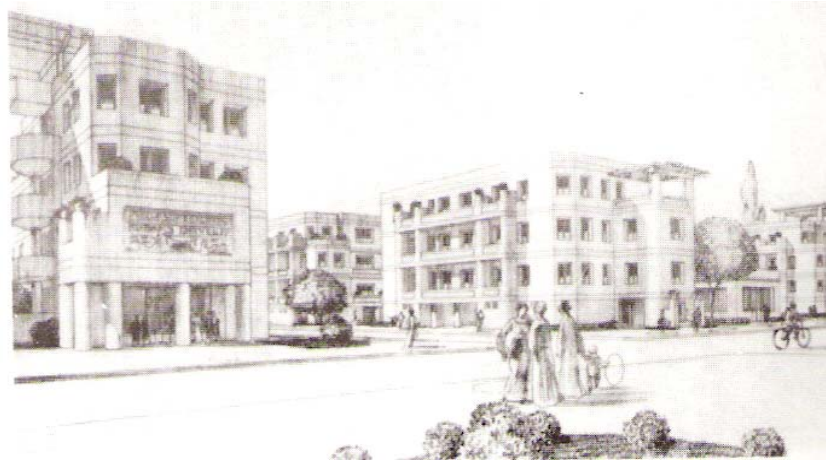

Figuras 09 e 10: Moradias coletivas da Cidade Industrial. Fonte: GARNIER, 1917.

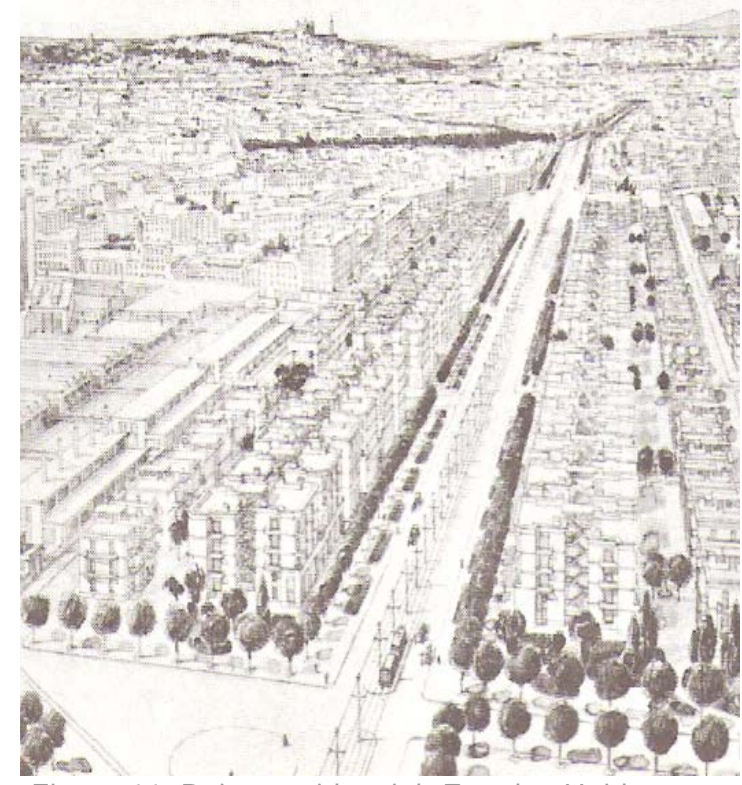

Figura 11: Bairro residencial "Estados Unidos", em Lyon.

Fonte: GARNIER, 1917. 


\subsection{A Habitação na Cidade do SÉCUlo XX}

\section{As experiências européias dos anos 20 no campo da moradia}

No âmbito das ações do Estado perante o problema de moradia resultante, dentre outros fatores, das modificações da sociedade industrial, das migrações e da grande destruição de habitações em decorrência da Primeira Guerra, pode-se destacar as experiências estatais na Áustria, Alemanha e URSS.

Em concordância com Aymonino (1973), a importância dos estudos das experiências sóciodemocratas, Áustria e Alemanha, e do caso da URSS, também consiste no fato de que esses países proporcionaram uma série de possibilidades de alojamentos, organização e disposição de serviços que "(...) intentaram conectar (...) un planejamento político del problema con un programa o con experimentos parciales tendentes a poner las condiciones para su solución (...)" (AYMONINO, 1973, p.13). Proporcionaram grande contribuição aos princípios e proposições modernas elaboradas e expostas nos Congressos Internacionais de Arquitetura Moderna (CIAMs), essencialmente nas suas quatro primeiras edições, como também, à experiência brasileira no campo da habitação social nas décadas de 1930 a 1960.

Essas intervenções remetem aos programas estatais que se propunham a solucionar o problema do déficit de moradias para os trabalhadores consolidados principalmente entre as décadas de 1920 e 1930. A importância dessas ações também consiste no fato de que, até então, nenhuma administração de país capitalista pensou e interveio na questão da habitação em seus termos mais gerais em tamanha magnitude (AYMONINO, 1973).

Na virada do século XIX para o século XX, a cidade de Viena cresceu $22 \%$ em número de moradias, passando de 1.364.584 habitantes, em 1890, para 1.647.957 em 1900. A moradia típica dos operários vienenses era caracterizada por se conformar por pequenos cubículos, muitas vezes sem aberturas, que variavam de dimensões entre 4,5 e 5,5m², com cozinha em alguns casos. Eram dispostas em fileiras que davam para um corredor que, no geral, atendia cerca de 20 apartamentos. Esta tipologia ficou conhecida como kabinett, ou seja, pequenos dormitórios (KOPP, 1990), que correspondia em 1917, segundo Aymonino (1973), aproximadamente a 75\% (o que equivalia a 400.000 unidades) do total de edificações na cidade. O valor desprendido para o pagamento do aluguel dessas moradias variava entre 15 e 25\% do salário médio de um operário vienense. Havia casos, quando a porcentagem beirava o teto estipulado, em que o próprio inquilino sublocava camas em sua habitação para aliviar as despesas para com a locação.

As primeiras ações estatais no campo da habitação em Viena datam de 1911, e referem-se à resolução aprovada pelo Conselho Municipal para a construção urgente de 250 moradias para as famílias 
sem alojamentos, e a criação de um Departamento de Habitação Mínima, em 1913‥ No entanto, segundo Aymonino (1973), o Conselho Municipal de Viena só passou a atuar por meio de programas mais sociais, após a I Guerra Mundial, devido ao agravamento da crise de moradias e à Proclamação da República, ocorrida em novembro de $1918^{10}$. Por outro viés, e como forma de apaziguar os ânimos sociais, foi decretado em 26 de janeiro de 191711, o congelamento dos aluguéis e a limitação das possibilidades de despejo dos inquilinos das moradias e de alguns pontos comerciais localizados em determinadas zonas da capital austríaca.

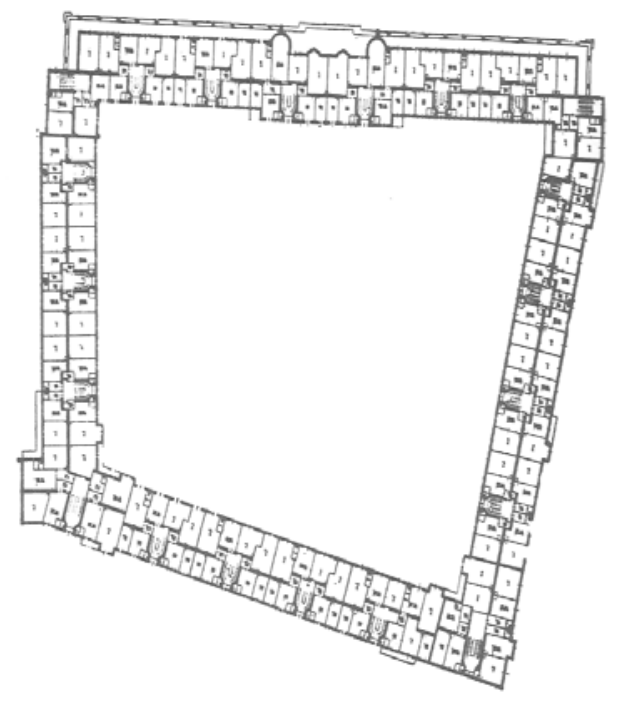

Figura 12: Exemplo de Höfe vienense. Fonte: AYMONINO, 1973.

Dessa forma, o Estado assumido pelo Partido Social-Democrata ${ }^{12}$ passou a intervir no quadro social alocando verbas provenientes de impostos para a construção de grupos de moradias destinadas aos mais carentes, cujo aluguel equivalia ao custo desprendido para a manutenção e despesas básicas do empreendimento. Esses conjuntos, caracterizados por unidades de apartamentos mínimos e espaços comunitários administrados pelos próprios inquilinos, ficaram conhecidos como Höfe (KOPP, 1990) (Figura 12). Para Aymonino (1973), esse modelo de moradia pensado e construído na capital Viena foi resultado da sistematização de idéias e modelos anteriormente elaborados, principalmente, pelos chamados socialistas utópicos do século XIX.

Tipologicamente, a Höfe ${ }^{13}$ conformava-se por grupos de edifícios laminares, dispostos em torno de um pátio, que deu origem a sua denominação, para onde estava voltada a maioria das aberturas. $A$ fachada principal da edificação era voltada para o pátio comum e a fachada posterior para as vias de circulação. No geral, eram edificações isentas de qualquer ornamento, apresentando semelhança com fortalezas e remetendo sensação de confinamento e/ou segurança. Essas moradias construídas pela municipalidade se caracterizavam por apresentar grandes proporções e densidade superior às das moradias coletivas existentes anteriormente em Viena, estando dispostas de modo a ocupar até $50 \%$ do

\footnotetext{
${ }^{9}$ No entanto, esse Departamento não desenvolveu nenhuma atividade no setor de moradias operárias (AYMONINO, 1973).

${ }^{10}$ A construção de moradias por parte do poder público foi decaindo durante a década de 1930 , se esvaindo com a eclosão da Segunda Guerra Mundial (BENEVOLO, 1987).

11 Esse decreto teve vigência de um ano. Em 20 de janeiro de 1918, outro decreto foi publicado nesse sentido, ampliando a abrangência da lei a todo o território Austríaco por mais dois anos (AYMONINO, 1973).

12 Em 1920, a social-democracia assumira tanto o poder da municipalidade de Viena e como da Áustria. Essa supremacia política permaneceu até abril de 1933 (FRAMPTON, 1997).

13 O Höfe já era construído por sociedades privadas antes de 1914 (AYMONINO, 1973).
} 
solo em que eram implantadas, apresentando ainda grandes pátios internos, além de equipamentos coletivos de lazer, como parques, jardins, campos e quadras de esportes.

Todas as unidades eram servidas de água e gás, e variavam no tamanho de acordo com 0 número de pessoas que iria ocupar a moradia, sendo normalmente apresentadas em três variações de apartamentos: de área de $21 \mathrm{~m}^{2}$, com apenas um cômodo, destinadas às pessoas solteiras; de $40 \mathrm{~m}^{2}$, com sala de estar e dois quartos, para famílias pequenas e os recém-casados; e de $57 \mathrm{~m}^{2}$, com sala, três quartos e uma cozinha. As disposições internas das Höfes em muito se assemelhavam às das antigas moradias vienenses e aos "modelos especulativos" construídos até então, complementadas em suas falhas, transformando-se em um "estándar óptimo", a "melhor transformação possível do 'bloco residencial' precedente" (AYMONINO, 1973, p.33). Segundo o autor, foi esse caráter que permitiu que as Höfes fossem aplicadas em ampla escala e não relegados a soluções pontuais segregadas em bairros nas periferias.

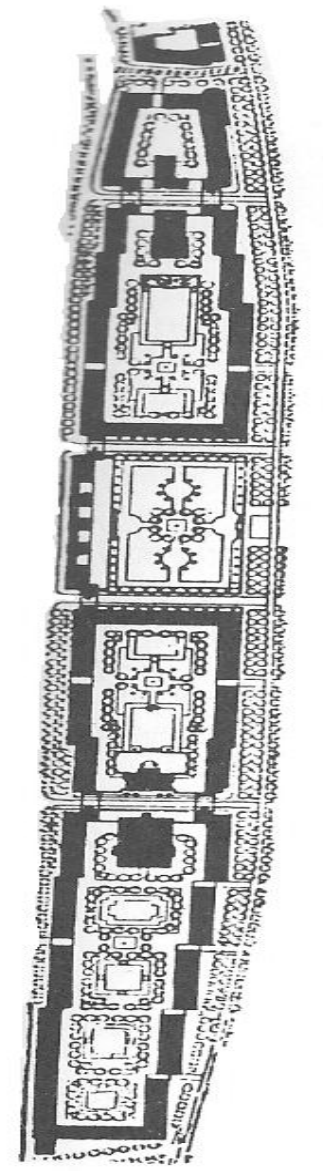

Figura 13: Höfe Karl Max. Fonte: AYMONINO, 1973.

Em 1922, foi prorrogada a vigência da lei que determinava 0 congelamento dos aluguéis, sem que fosse estabelecido um limite específico para sua revogação. Os impostos sobre as construções passaram, a partir de então, a ser creditados nos fundos para financiar novas construções. Outra resolução foi aprovada em 1923, prevendo a construção de 5.000 unidades habitacionais por ano, o que em cinco anos, considerando três moradores por unidade, equivaleria à população de uma cidade média. De acordo com Aymonino (1987), apesar dos empecilhos diversos ${ }^{14}$, em fins da década de 1920 foram desapropriados cerca de 8.000 hectares de terras - 0 que correspondia a 30\% da superfície administrada - e criadas, a partir de incentivos municipais, algumas empresas especializadas na construção de moradias em série com elementos pré-fabricados. Entre as décadas de 1920 e 1930, de acordo com Kopp (1990), foram construídas por volta de 60.000 unidades habitacionais. A partir de então, segundo o autor, passou a vigorar, sob influência alemã, a Siedlungen nas localidades mais afastadas do centro de Viena.

O exemplar mais famoso de Höfe refere-se ao Karl Max (Figura 13), com mais de um quilometro de extensão e 1.400 apartamentos, que ocupavam apenas 30\% do terreno em que se encontrava instalado. Essa edificação abrigava cerca de 5.000 pessoas servidas de grandes espaços verdes, lavanderias mecanizadas, dois jardins de infância, uma biblioteca, uma farmácia, um consultório

\footnotetext{
${ }^{14}$ Como, por exemplo, o rígido controle sobre as ações estatais estabelecido por parte da Sociedade de Nações após a Guerra, que dificultava a execução de planos a longos prazos (AYMONINO, 1973).
} 
médico, um consultório odontológico, um centro para jovens, correios e dois banheiros públicos, com vinte sanitários e trinta duchas cada um. Concomitantemente à construção de moradias, foram projetados e construídos móveis mais modernos, condizentes com os novos apartamentos estandartizados.

À semelhança de Viena, a capital Berlim passou por um significativo crescimento populacional durante as duas primeiras décadas do século XX. Nesse momento, as casas urbanas operárias de aluguel alemãs, conhecidas como Miestkaserne, eram largamente construídas. Além de insalubres, as habitações coletivas privadas não atendiam à demanda de moradias do período e absorviam consideráveis parcelas dos salários dos operários. O aumento dos valores dos aluguéis, dentre outras conseqüências, resultou na procura por moradias mais baratas nas periferias e no agravamento de inquietações sociais (KOPP, 1990). Essa conjuntura despertou 0 interesse de um grupo de arquitetos alemães, conhecidos como Neues Bauen, na formulação de soluções para a moradia dos trabalhadores. Da mesma forma que os arquitetos, os parlamentares mostraram-se conscientes da necessidade de transformações para melhorar as condições de moradia, atendendo às reivindicações operárias ${ }^{15}$. Propunha-se por parte do Estado, entre outras questões, a socialização da terra e em segundo plano da indústria da habitação, a desapropriação em massa, o controle dos aluguéis e, principalmente, a elaboração de um plano por parte de diversas entidades sociais, dentre partidos, associações técnicas, culturais, da arte, da ciência, da imprensa, consócios, representações parlamentares, municipais e o público em geral, para a consolidação dessas ações na cidade ${ }^{16}$ (AYMONINO, 1973).

Os primeiros exemplares no campo da moradia econômica foram esboçados antes da I Guerra Mundial. Mas, segundo Aymonino (1973), foram verdadeiros retratos isolados, fragmentados e esporádicos, que não traduziram uma nova relação entre a moradia econômica e o desenvolvimento de uma cidade como um todo. O ano de 1925, para o autor, corresponde a um marco de mudança nesse contexto. Kopp (1990) também compartilha dessa opinião. Para ele, o auge da produção alemã se deu entre os anos de 1926 e 1930, quando foram realizadas as experiências mais significativas no setor, com ênfase nas pesquisas e inovações projetuais voltadas para a unidade mínima, a tipologia resultante do agrupamento das unidades padrão, o funcionalismo das unidades e as propostas de equipamentos

\footnotetext{
${ }^{15}$ Cabe lembrar que nesse momento, movimentos operários e/ou populares estavam em ascensão. Dentre eles: 0 movimento reformador, que buscava a concepção de um novo homem, de uma nova vida, de uma nova cidade e de um novo futuro; 0 movimento feminista militante, que reivindicava a participação da mulher nas jornadas de trabalho e, conseqüentemente, a redução do trabalho doméstico; e o Deustcher Werkbund, que buscava a inserção dos avanços industriais na arte e na arquitetura (KOPP, 1990).

${ }^{16}$ Nessa conjuntura, Aymonino (1973) destaca a atuação de Martin Wagner e as publicações de kautsky, mais voltadas para a socialização da moradia. Para este, havia três maneiras possíveis para se efetivar a socialização: a intervenção estatal direta, por meio da construção de moradias, não somente de sua administração; a atuação de empresas privadas; ou as organizações de trabalhadores. Kautsky ressalta, no entanto, que a segunda opção ia de encontro aos princípios socialistas e, por esse motivo, era considerada apenas como recurso opcional. A criação de organizações operárias, em contrapartida, além de mais barata que a intervenção estatal direta, mostrava-se uma forma para por fim às empresas privadas, porque estas não teriam condições de concorrer com os baixos custos do produto daquelas. Os benefícios desta ação recaiam sobre os trabalhadores de cada categoria e a sociedade em geral, como ocorrerá no Brasil com as Caixas de Aposentadorias e Pensões dos IAPs.
} 
complementares à moradia. Passaram então, a serem utilizados em grande escala os elementos préfabricados com vistas à produção em massa e à economia de custos.

Foram propostos, nesse sentido, grandes conjuntos com equipamentos coletivos, conhecidos como Siedlungen (Figura 14 e 15), atendendo às reivindicações de simplificação das atividades domésticas e à integração entre os habitantes. Esse modelo de moradia é considerado por Aymonino (1973), como uma solução em âmbito de edificação e não de bairro. Essas estruturas se caracterizam pela especial atenção dada aos passeios e vias de circulação,

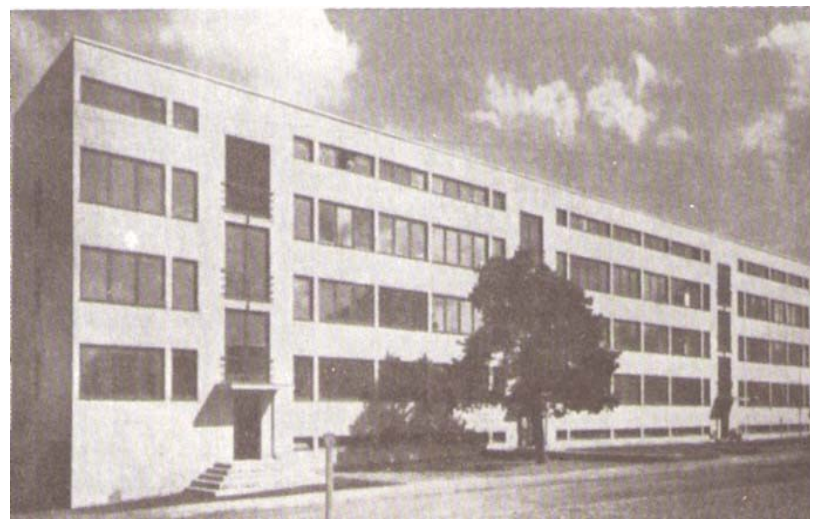

Figura 14: Siedlungen construído por van der Rohe em Stuttgard. Fonte: BONDUKI, 2002. que além de possibilitarem o acesso às moradias, por vezes, se alargavam conformando locais para reuniões. As moradias, por sua vez, apresentavam plantas essencialmente quadrangulares. Dentre os exemplares de Siedlungen, pode-se destacar a Tempil HöferFelde Siedlungen e a Frankenberg Siedlungen. Com o passar dos anos, as experiências foram sendo aprimoradas no tocante à relação entre planejamento urbano, edifício coletivo e tipologias

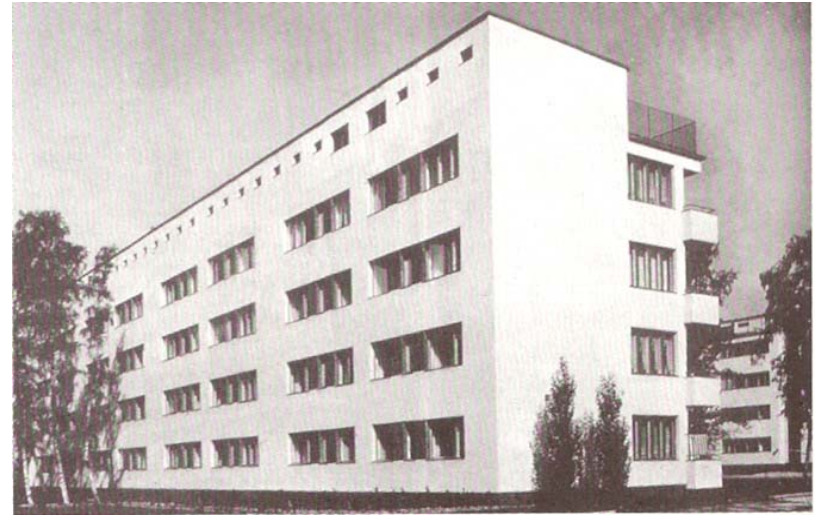

Figura 15: Siedlungem construído por Gropius em Berlim.

Fonte: BONDUKI, 2002 de moradias. Em 1927 foi construído o Siemensstadt. De acordo com Aymonino (1973), foi a partir desse marco que a raiz internacional da arquitetura moderna, organizada posteriormente nos CIAMs, foi plantada.

De acordo com Frampton (1997), os Siedlungens conformavam-se, num primeiro momento, por casas enfileiradas, separadas por distâncias que permitissem a penetração de luz solar e ventilação17, cujas principais aberturas davam para os espaços verdes e comunitários, e com mais intensidade a partir de meados dos anos de 1920, por blocos de apartamentos com três pavimentos, em média, cuja planta era composta por sala de estar e jantar, cozinha, banheiro e uma variação entre três e seis quartos. Contavam com serviços comunitários como lavanderias, bibliotecas, salas de reunião, quadras de esporte, dentre outros. As fachadas se caracterizavam por superfícies planas, com grandes áreas envidraçadas e janelas em aço, alguns exemplares contavam ainda com balaustradas de metal (FRAMPTON, 1997).

\footnotetext{
17 Seguiam de modo geral, o padrão estabelecido por Heiligenthal, no qual, a distância entre as fileiras de moradias não deveria ser inferior a duas vezes a altura da casa (FRAMPTON, 1997).
} 
De maneira geral, as diversas propostas e realizações no campo da moradia operária em Berlim nesse período, se enquadravam no modelo de complexos semirurais de moradias individuais com jardins, herdadas do conceito de Cidade-Jardim, que propunham o descongestionamento populacional do centro urbano a partir da construção desses núcleos, ou referem-se ao melhoramento das moradias de aluguel para os que permanecessem na cidade. A partir de 1927, os modelos baseados nas Cidades-Jardins deram lugar às moradias agrupadas, concebidas por índices mínimos de espaço e em grande número e escala, que também passaram a se localizar na periferia (AYMONINO, 1973).

Em se tratando da experiência soviética no campo da moradia entre as décadas de 1920 e 1930, merece destaque o modelo das "casas comunais", que emergiu no âmbito da Revolução de 1917, na qual, buscou-se a reestruturação do modo de vida e da moradia da população, no sentido de substituir 0 individualismo e a vida familiar isolada, pela vida em comunidade.

Já em 1918 foram publicados decretos que transformaram em propriedade das autoridades municipais, das estatais e das cooperativas, todas as áreas da cidade. $\mathrm{O}$ aluguel passou a ser cobrado de acordo com a área ocupada pelo inquilino na edificação, sendo abolido dessa forma, o direito de propriedade. As novas construções, a partir de então, deveriam seguir os parâmetros estabelecidos pelo Estado. Os proprietários capitalistas foram desapropriados de suas residências, e os operários instalados em grandes quantidades nas moradias burguesas periféricas. Outra iniciativa no sentido de solucionar 0 problema da moradia e, a partir dela, estabelecer as diretrizes para o desenvolvimento da cidade foi a criação, em 1918, do "Serviço para o Planejamento das cidades e dos centros habitados" e do Comitê para construção estatal que propôs, em 1919, a construção de um bairro residencial em Moscou, composto por edifícios dotados de equipamentos coletivos. O referido bairro seria destinado a abrigar entre 100 e 200 habitantes que poderiam optar entre duas tipologias habitacionais, os apartamentos de solteiros (sem cozinha) e os apartamentos de família. Os edifícios deveriam ser de um ou dois pavimentos e os equipamentos coletivos equivaliam a uma cozinha, uma lavanderia, um banheiro público, um asilo, uma escola com aulas para alfabetização, uma sala de reuniões com biblioteca, um centro comercial, uma garagem para carros, escritórios para a administração e uma grande sala de reunião. Segundo Aymonino (1973), o grande número de equipamentos coletivos em detrimento ao número de habitantes a que se destinavam os conjuntos, correspondeu a uma característica presente nas propostas e realizações da URSS no campo da moradia, se conformando como o diferencial das ações soviéticas.

Em 1920, um novo decreto explanava o direito de que todos os trabalhadores tinham de possuir uma habitação, de pelo menos $50 \mathrm{~m}^{2}$ de superfície habitada. A partir de meados dessa década, os níveis de ocupação, ou seja, de coabitação nas unidades habitacionais, assim como, de utilização dos equipamentos coletivos elevaram-se consideravelmente. 
Surgiram assim, modelos coletivos com espaços individuais para o desenvolvimento das atividades básicas (estar e dormir) e diversos espaços de uso comum como cozinha, sala de jantar, lavanderias, salas de estudos, além de espaços para convívio e equipamentos sociais clubes operários, creches, escolas, dentre outros -, interligadas por ruas internas. 0 modelo que mais se destacou no campo das proposições e projetos habitacionais soviéticos, nesse contexto, foi a "casa-comunal", ou moradia coletiva, sendo considerada por Aymonino (1973) como o mais interessante solução nesse sentido (Figuras 16 e 17). Essa tipologia era entendida como um serviço social e base para formação de uma nova cidade ${ }^{18}$.

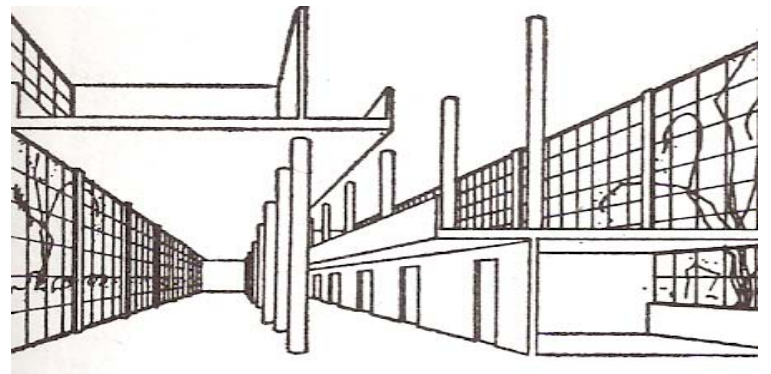

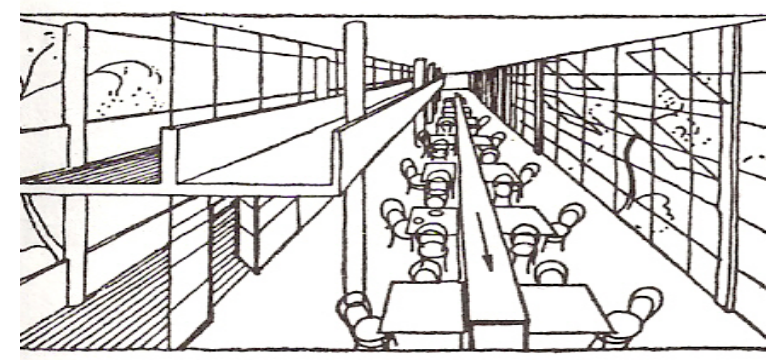

Figuras 16 e 17: Espaços comuns na casa comunal soviética.

Fonte: AYMONINO, 1973.

Os primeiros exemplares foram erguidos em 1919, sob a forma de albergues e aprimorados em 1920, passando a compreender em um só edifício, diversas tipologias de plantas (desde apartamentos individuais a apartamentos com diversos dormitórios), clube, equipamentos coletivos e locais de serviço. As casas-comunais em muito se aproximam das proposições de Le Corbusier para as unidades de habitação, com diversas tipologias habitacionais, dentre elas o apartamento duplex, interligados por verdadeiras ruas galerias (ruas internas), serviços centralizados e equipamentos de uso comum. Por outro lado, de acordo com Kopp (1990), essas realizações foram fortemente influenciadas pelas propostas de Fourier. O exemplo mais conhecido da casa-comunal mostra-se o Narkomfin, construído entre os anos de 1928 e 1929 em Moscou, por Ginzburg e Miljutin (KOPP, 1990). No entanto, diversas críticas foram publicadas acerca do alto custo para produção desse modelo habitacional, tornando-o, dessa forma, incapaz de atender às demandas de moradias.

\section{A habitação nos Congressos Internacionais de Arquitetura Moderna (CIAMs)}

Foi almejando uma transformação na cidade e na forma de se conceber moradias que 0 Movimento Moderno em Arquitetura e Urbanismo se consolidou. A publicação da Declaração de La Sarraz, em 1928, marcou o início das atividades dos Congressos Internacionais de Arquitetura Moderna, os CIAMs, que ocorreram até 0 ano de 195619. Essa Declaração defendia desde a substituição da divisão

\footnotetext{
18 Diversas outras tentativas no sentido de solucionar de maneira "distinta" o problema de moradia em Moscou foram efetivadas na década de 1920, a citar: a Cidade-Jardim de Sokol (1923-1925) e de Dontskoi (1924-1925).

19 Mas somente as quatro primeiras edições enfocam a questão da moradia e sua inserção na cidade, sendo as proposições formuladas nesses quatro primeiros Congressos enfocadas neste tópico do trabalho.
} 
caótica da terra e da especulação imobiliária, por uma política de terra coletiva, até a admissão de métodos mais eficientes para a produção de moradias por meio da racionalização e padronização da construção ${ }^{20}$.

Segundo Frampton (1997), as quatro primeiras versões dos CIAMs, em especial as realizadas em Frankfurt e Bruxelas, em 1929 e 1939 respectivamente, conformavam a primeira fase dos Congressos, caracterizada pelo caráter doutrinário e sua essência mais social. No que concerne à habitação, os Congressos almejavam, de maneira geral, a definição de uma unidade de habitação mínima, a busca por novos modelos e métodos construtivos para a dinamização e economia da construção e a reorganização do espaço urbano ${ }^{21}$ (AYMONINO, 1973).

O primeiro CIAM foi realizado em 1928 na Suíça ${ }^{22}$. Nele, foram defendidas dimensões normativas e métodos de produção eficientes como primeiros passos para se efetivar a racionalização e a indústria da construção, requisito essencial para aumentar a produção de moradias, assim como, superar "os métodos de uma era artesanal". Dessa forma, o "novo" modelo de moradia deveria vim acompanhado da utilização de novos materiais e técnicas de produção, além da ruptura com os princípios formais do passado e com as estruturas sociais anteriores (FRAMPTON, 1997, p.328).

O segundo CIAM teve como palco para suas discussões, exposições e debates, a cidade alemã de Frankfurt, em 1929, e deu ênfase ao chamado modelo mínimo de habitação (FRAMPTON, 1997). Segundo Aymonino (1973), o conceito de moradia mínima nasceu de uma cooperação entre arquitetos interessados na questão social e as intervenções públicas estaduais, municipais e cooperativas contra a especulação construtiva. Sendo assim, a conjuntura do período marcada pela escassez de moradias destinadas às camadas mais carentes da população urbana dos grandes centros europeus influenciou a adoção do referido tema para o Congresso. Os arquitetos participantes do evento almejavam a concepção de um modelo de moradia mínima que oferecesse condições satisfatórias de higiene e habitabilidade a custos reduzidos para a camada carente da população, sendo preponderante para tanto, a intervenção do Estado no processo de produção, principalmente, por meio de financiamentos e regulamentação. Nesse sentido, o novo modelo de moradia deveria ser fundamentado na nova estrutura da família e da sociedade, na qualidade de vida, na participação do Estado e nos métodos de padronização e estandardização. Questões como, renda mínima, valor de aluguel, custo da construção, padrões de

\footnotetext{
${ }^{20}$ Conforme 0 documento, a racionalização e a padronização poderiam ser alcançadas de três maneiras: por meio da formulação de modelos e métodos mais simples para as construções; através da especialização da mão-de-obra; ou poder-seia esperar uma revisão das exigências da população no tocante aos modelos condizentes com a nova vida social (FRAMPTON, 1997).

${ }^{21} \mathrm{~A}$ fim de estabelecer as diretrizes e especificar os temas dos CIAMs, foi criada durante o IV Congresso uma Comissão para Solução dos Problemas da Arquitetura Contemporânea (FRAMPTON, 1997).

$22 \mathrm{O}$ evento teve duração de três dias e reuniu vinte e quatro profissionais arquitetos advindos de diversos países da Europa. As principais discussões envolviam, essencialmente, a transformação da estrutura social e econômica partindo da célula da habitação condizente com o "período maquinista", pelo qual, os centros urbanos europeus vinham passando (FRAMPTON, 1997).
} 
conforto, assim como, normas construtivas e relacionadas à urbanização, foram quesitos amplamente discutidos nesse evento.

A necessidade de repensar a planta da moradia era preponderante para se alcançar os objetivos a que se prestava esse Congresso. Propôs-se, nesse sentido, reduzir as circulações internas, principalmente corredores, e um novo agrupamento das funções da casa a fim de minimizar o tempo gasto para a realização das atividades domésticas garantindo à mulher mais tempo para a realização de atividades de trabalho externo e de lazer, assim como, reduzir o custo com a construção das moradias. Novos modelos de moradias e de conjuntos residenciais foram propostos nesse momento. Os diversos projetos foram expostos enfatizando basicamente, a organização do bloco, as vias de acesso e circulação de pedestres e automóveis, a área ocupada pela edificação, o volume resultante da construção, a abertura de janelas e o número de camas. Foi difundida a concepção de edifício coletivo com grandes alturas e serviços centralizados, atendendo ao problema de grande adensamento das cidades. Para tanto, julgavase essencial o desenvolvimento de novos materiais e a padronização desses para produção industrial. Essas edificações deveriam apresentar, no geral, estruturas independentes dando liberdade para concepção de plantas e fachadas (AYMONINO, 1973).

O CIAM seguinte aconteceu, em 1930, em Bruxelas e teve como tema central, os métodos construtivos racionais dando especial atenção aos diferentes gabaritos das edificações e às disposições mais convenientes das construções (FRAMPTON, 1997). Nesse sentido foram colocadas no bojo das discussões as vantagens e desvantagens da concepção das diferentes tipologias habitacionais, defendendo-se essencialmente a construção de bairros residenciais verticais em detrimento aos demais modelos. Dados estatísticos, econômicos, sociais, ambientais, físicos e urbanísticos foram utilizados em prol dessa proposta. Todas as experiências nesse sentido tiveram a unidade mínima de habitação como base (AYMONINO, 1973). As discussões estabelecidas nesse Congresso giraram, principalmente, em torno da altura ideal do edifício e das distâncias adequadas entre os blocos (FRAMPTON, 1997). As diretrizes para concepção dos blocos laminares também foram delineadas, especificando que: as áreas reservadas para o espaço construído e o espaço livre deveriam ser proporcionais; a incidência solar deveria ser fator determinante na concepção desses modelos, sobretudo na sua implantação; dever-se-ia optar pela disposição paralela dos blocos a fim de proporcionar níveis adequados e homogêneos de ventilação e iluminação natural a todos os apartamentos, o que garantiria segundo Walter Gropius, uma alta densidade aliada às excelentes condições de habitabilidade; e as circulações verticais deveriam ser projetadas de acordo com o número de pavimento e de unidades habitacionais do edifício (AYMONINO, 1973).

O IV CIAM, realizado em agosto de 1933, teve como tema central "A Cidade Funcional". Segundo Frampton (1997, p.328), a partir desse período, os Congressos Internacionais de Arquitetura Moderna 
foram "dominados pela personalidade" de Le Corbusier, que influenciou na mudança do enfoque dessa edição para a questão do planejamento urbano. De acordo com o autor, essa foi a versão mais abrangente do Congresso do ponto de vista urbanístico, que culminou na publicação da Carta de Atenas, em 1942. Esse documento equivale a um verdadeiro manual para concepção de cidades aos moldes modernos. Composta por cento e onze propostas que perpassam pelas drásticas condições das cidades naquele momento e expõem as soluções reparadoras dos problemas relacionados à moradia, ao lazer, ao trabalho, ao transporte e, pela primeira vez, aos edifícios históricos. Dentre as soluções expostas na Carta de Atenas, merecem destaque o zoneamento funcional da cidade, de acordo com as quatro funções (habitação, trabalho, lazer e transporte), separadas por grandes cinturões de área verde, a adoção do modelo de blocos de apartamentos com vários pavimentos como a única solução de moradia adequada para abrigar uma alta densidade populacional, e a hierarquização das vias de circulação (CORBUSIER, 1942). Esses ditames, segundo Frampton (1997), além de comprometerem pesquisas posteriores acerca de novas soluções habitacionais, corresponderam ao abandono das premissas primordiais dos Congressos, principalmente no que se refere ao caráter social de suas propostas.

De qualquer maneira, as formulações e propostas elaboradas nos CIAMs foram reportadas para novos modelos de moradias, de conjuntos residências, de bairros e até mesmo, de cidades.

Algumas das inovadoras propostas de moradia concebidas no século XX foram colocadas em prática, mas suas maiores contribuições situam-se na influência que representaram para os modelos arquitetônicos e urbanísticos que posteriormente surgiram como, o conceito de unidade de vizinhança, 0 de unidade de habitação, os blocos e conjuntos residenciais, bem como, a difusão de procedimentos como o zoneamento de funções, a concentração dos equipamentos coletivos, a priorização pela circulação, as preocupações com a iluminação e a ventilação dos cômodos das unidades habitacionais, o planejamento regional e a valorização dos espaços verdes.

A Unidade de Vizinhança é uma noção importante nos projetos de conjuntos habitacionais erguidos no Brasil e em Natal no século XX. Esse conceito foi formulado por Clarence Perry no contexto do Plano de Nova York, de 1929. De acordo com Peter Hall (1998, p.143), a unidade de vizinhança objetivava retomar por meio do planejamento e desenho das cidades, as relações sociais entre vizinhos, verificadas em bairros antigos; representando "(...) uma grande renovação da confiança e na vitalidade da vizinhança como unidade política e moral". Essa teoria se apoiou no conceito sociólogo de vizinhança, que em seu entendimento clássico, é uma área onde os habitantes se conhecem pessoalmente, com hábitos de visitar, trocar objetos, serviços e de fazer coisas em comum.

Nesse sentido, era determinado o número de moradores das unidades habitacionais, e a partir daí, especificadas às dimensões da área territorial e às disposições mais adequadas dos equipamentos e 
serviços, de maneira que possibilitassem relações comunitárias espontâneas e seguras entre os moradores. Esses serviços deveriam ser concentrados numa área onde não houvesse circulação intensa de veículos, próxima às residências (LAMAS, 1992).

Segundo Lamas (1992), por considerar que a vida social se desenvolve em virtude da utilização dos serviços comuns, Clarence Perry previu uma diversidade de equipamentos, desde escolas primárias, quadras de jogos, lojas, igreja, salas de reuniões e de teatro, clube, piscinas, até museus, nos casos de unidades com mais de 10.000 habitantes. Sua concepção privilegiava, dessa forma, o zoneamento de funções, a distribuição dos equipamentos dentro do bairro, geralmente localizados dentro da área central, e a circulação de pedestres devido ao traçado viário adotado, que conciliava o tráfego de automóveis à proteção dos moradores de seus perigos e inconvenientes, proporcionando 0 isolamento das habitações por meio de ruas cul-de-sac e o aproveitamento dos espaços livres centrais. Esse conceito obteve grande sucesso e fundamentou a organização de áreas residências a partir da década de 1930, tanto pela clareza de seus princípios quanto pela repercussão positiva dos primeiros projetos.

As "Unités d'Habitation", por sua vez, são definidas por Le Corbusier como grandes edifícios modulares, e surgiram durante a década de 1940 no contexto do processo de reconstrução da França após a Segunda Guerra. São edifícios laminares com mais de dez pavimentos e centenas de células habitacionais, dotados de pilotis, teto-jardim, pontos comerciais, equipamentos de serviço e lazer, implantados com o intuito de transformar o edifício em um módulo auto-suficiente (CORBUSIER, 1956).

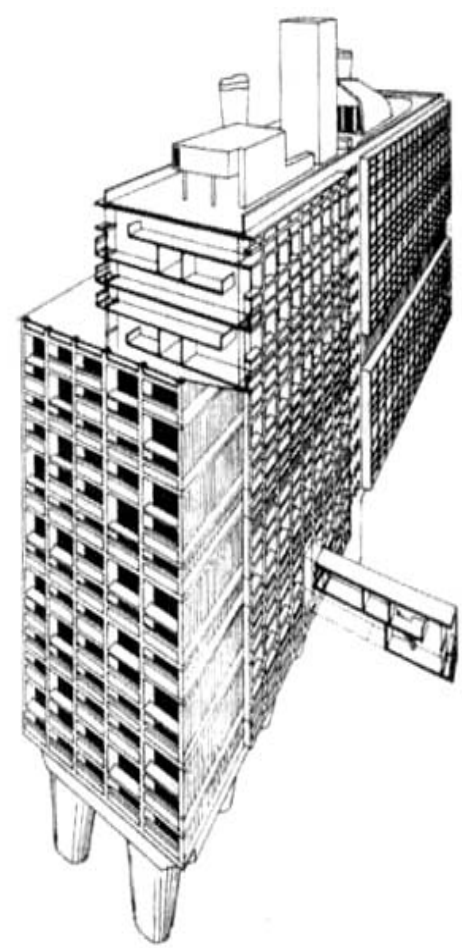

Figura 18: Unidade de Habitação de Marselha. Fonte: FRAMPTON, 1997.

A primeira e mais famosa unidade implantada foi a da cidade de Marselha, que ficou conhecida como tal, construída entre os anos de 1947 e 1953 (Figura 18). A Unidade de Marselha equivale a uma edificação com 15 andares, 55m de altura, 100m de comprimento e $30 \mathrm{~m}$ de largura, destacando-se do entorno pela sua horizontalidade. Nela, o arquiteto implementou diversos experimentos no que concerne à iluminação natural e à ventilação. Os apartamentos são duplex e possuem aberturas nas duas faces, induzindo à ventilação cruzada e permitindo a renovação constante do ar. 0 estudo da incidência dos raios solares ao longo do dia nas fachadas da edificação permitiu que Le Corbusier projetasse dispositivos de controle térmico e de iluminação, que ficaram conhecidos como brise-soleils. Outras famosas Unités d'Habitation são: a Unidade construída em Nantes, em 1955, e a edificada em Berlin, no ano de 1958 (CORBUSIER, 1956). O conceito de unidade de habitação foi adaptado posteriormente em diversos outros projetos em todo o mundo. 
Por meio da análise das descrições esquemáticas de Owen, Fourier e Garnier observa-se semelhanças com diversas das propostas no campo da habitação, como nas Siedlungens, Höfes e Casas Comunais, onde foram concentrados os serviços e equipamentos, e em propostas como a "unidade de habitação" com instalações centralizadas. O número limitado de habitantes estipulado por Owen (1.200) e por Fourier (1.620) também se aproxima daqueles estabelecidos por Le Corbusier na "unidade de habitação". Inclusive Ebenezer Howard, se apropriou das investigações dos reformadores sociais antecedentes, utilizando-as nas suas proposições de Garden Cities. Portanto, muitos foram os profissionais que fundamentaram suas realizações nas proposições oitocentistas, com seus modelos de "cidade ideal" e "cidade-jardim" e suas proposições referentes às moradias em massa, transformando-as em elementos ou esquemas para se conceber cidades modernas. Isso também ocorreu no Brasil, como se verá no capítulo seguinte.

\subsection{A Reforma da Moradia no Brasil}

No Brasil, os ideários de Cidade-Jardim, as experiências das sociais-democracias européias das décadas de 1920 e 1930, e os postulados dos CIAMs encontraram solo fértil para a sua difusão. O estudo da difusão desses modelos e experiências no país mostra-se importante para o entendimento de como se estruturou as formulações brasileiras no campo da moradia social, em especial, a atuação do Estado e as diretrizes morfológicas da produção resultante.

O ideal de Cidade-Jardim, que compilou alguns dos principais preceitos e ensinamentos de teorias antecedentes, foi apreendido e disseminado a partir da segunda década do século XX no país, muito mais como um modelo de desenho urbano de sucesso comercial, perdendo em muito, sua essência social. $\mathrm{Na}$ maioria das vezes foi adaptado à escala do bairro, o que se convencionou chamar de "bairro-jardim" e/ou "subúrbio-jardim"; $\quad$ adaptação essa, empregada principalmente a partir da vinda de Barry Parker ao país (ANDRADE, 1998). $\mathrm{O}$ arquiteto Barry Parker chegou ao Brasil em 1917, onde permaneceu e atuou até 1919 a frente da Companhia City. Dentre as realizações do arquiteto no país, merece destaque a criação do bairro Jardim América, em São Paulo, considerado 0 primeiro bairro-jardim instituído no país (Figura 19). Parker tornou-se referência significativa para as realizações urbanísticas

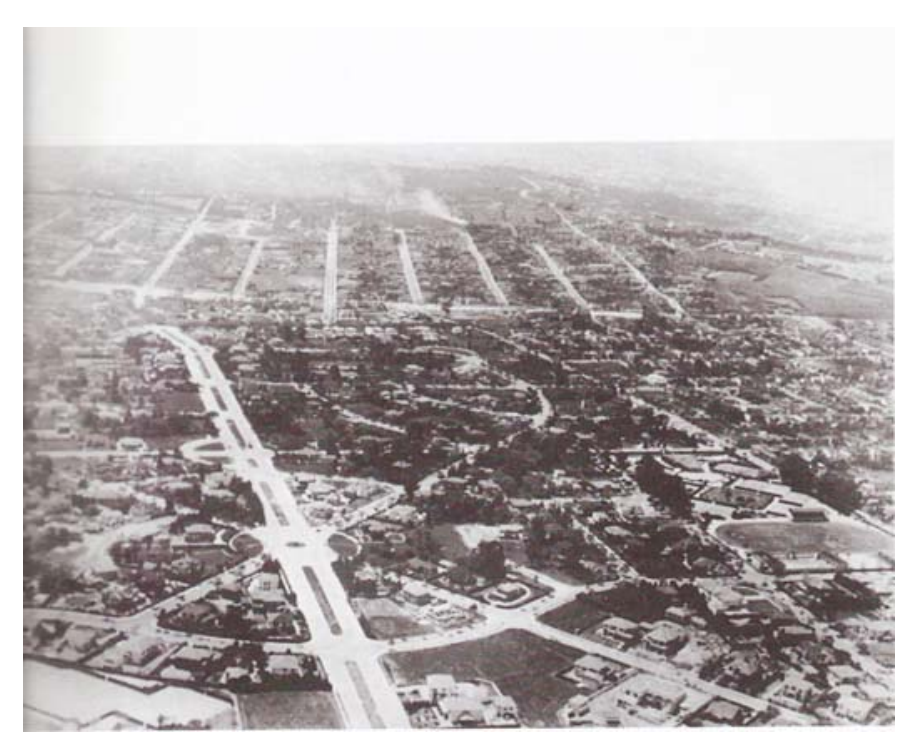

Figura 19: Vista aérea do Jardim América na década de 1930. Fonte: WOLFF, 1999. 
no meio técnico local, e de certa maneira, influência na formação de novos profissionais, como por exemplo, o engenheiro Jorge Macedo de Vieira, considerado pela historiografia especializada como um expoente do modelo de cidade-jardim no Brasil e como discípulo de Parker, em função do trabalho realizado como estagiário da Companhia City. Foi também difusor do tipo residencial bairro-jardim, projetando para São Paulo o Jardim Japão, o Parque da Móoca, a Vila Mariana, a Nova Manchester e 0 Jardim da Saúde.

Percebem-se no Brasil, outras ressonâncias das concepções de cidade-jardim, subúrbio-jardim e bairro-jardim, essencialmente a partir dos anos de 1930. Dentre os exemplos de mais relevância estão: 0 setor sul de Goiana, projetado pelo engenheiro e urbanista Armando de Godoy; o bairro de Laranjal, em Volta Redonda, projetado por Attilio Corrêa Lima; os núcleos fabris de Harmonia e Lagoa, projetados por Abelardo Caiubí para a Fábrica de Papel e Celulose Klabin no Paraná; além de dezenas de núcleos residenciais criados por hidrelétricas como, por exemplo, o de Barra Bonita e o de Bariri erguido pela CESP no estado de São Paulo (CORREIA, 2001;VIANNA, 2006).

Também a partir das primeiras décadas do século XX, os engenheiros passaram a formular planos gerais para as principais cidades brasileiras como meio de viabilizar o ideal de cidade moderna e salubre, aliada à abundância de espaços verdes ${ }^{23}$ - grandes parques, diversidade de jardins públicos, implantação da arborização pública, amplos gramados e sombras aprazíveis - utilizando-se por vezes, os bairrosjardins como partes integrantes desses projetos, como foi o caso do bairro residencial proposto por Saturnino de Brito para a cidade de Natal, em 1935.

Nesse sentido, as intervenções se mostraram vinculadas à "tradição Garden City", mas não ao ideário howardiano "legítimo", na medida em que não estavam inseridas numa perspectiva regional de planejamento, sem estruturarem ou limitarem o crescimento da cidade por meio de elementos, como vias de circulação e/ou cinturões verdes, e sem incorporarem o projeto político social preconizado por Ebenezer Howard.

Em relação à difusão das experiências das sociais-democracias européias no campo da habitação no Brasil, houve a apropriação, por parte do Estado, das diretrizes legais para a normatização das relações entre inquilinos e proprietários, assim como, das questões relativas à propriedade, verbalizadas pelo conjunto de leis outorgadas a partir, efetivamente, da década de 1940 e que ficou conhecido como Leis do Inquilinato. O processo de formulação e de aprovação das referidas Leis, como também, as conseqüências no campo da moradia após as outorgações, será abordado no capítulo que se segue.

Os preceitos de arquitetura e urbanismo moderno se difundiram desde a década de 1920 no Brasil. Nesse contexto, merece destaque a atuação da vanguarda paulista, da escola carioca, e das

\footnotetext{
${ }^{23}$ No escopo de referência de cidade-jardim ligada à tradição sanitarista, destacam-se as atuações dos engenheiros: Lincoln Continentino, Jorge de Macedo Viana, Francisco Batista de Oliveira, Attílio Corrêa Lima, Saturnino de Brito, dentre outros.
} 
figuras dos arquitetos Gregori Warchavchik e Lúcio Costa, tendo como "ponto de partida" a Semana da Arte Moderna de 192224 .

No campo da habitação as primeiras experiências "modernas" foram consolidadas pelo arquiteto Gregori Warchavchik ${ }^{25}$ e são representadas por um grupo de casas, destinadas à classe média, construídas a partir dos primeiros anos de década de 1920. Essas obras foram precedidas pela formulação do artigo intitulado "Acerca da Arquitetura Moderna" em 1925, considerado o primeiro texto sobre arquitetura moderna publicado no país, e que em muito se aproxima das proposições de Le Corbusier e de Walter Gropius. O referido arquiteto propunha nesse sentido, a afirmação do papel do arquiteto, a economia com material, a ausência de ornamentos, 0 comprometimento da fachada com uma planta racional, a originalidade da construção moderna e o emprego do cimento armado. Posteriormente, Warchavchik defendeu a taylonização da moradia, a estandartização dos elementos construtivos e a construção de aranhas-
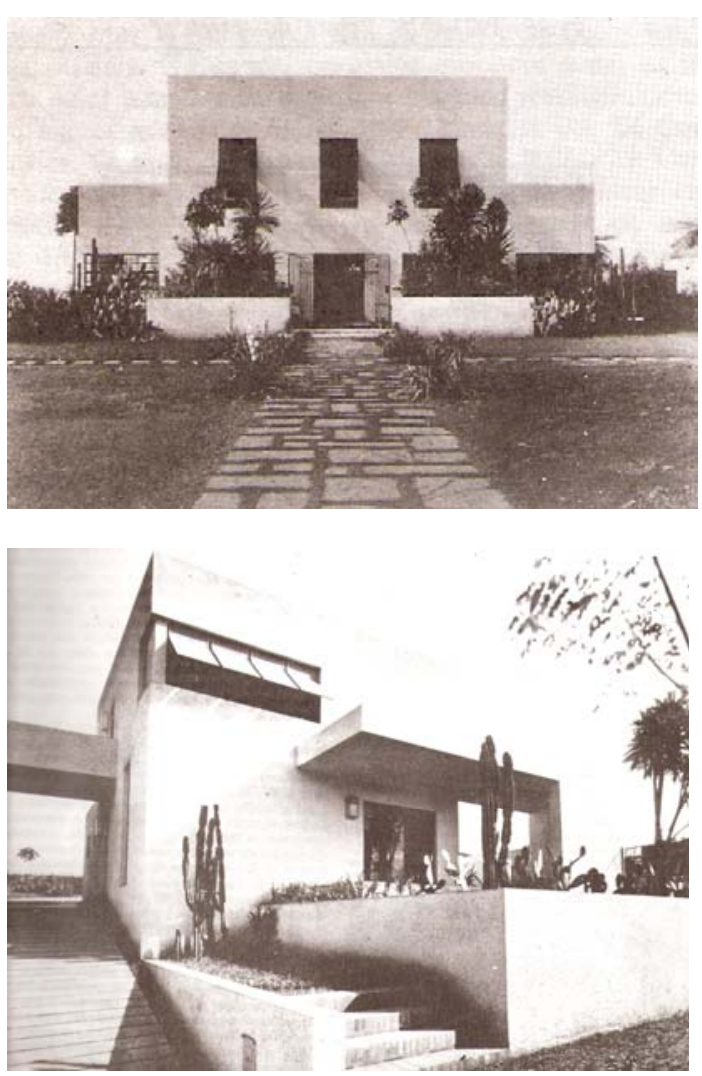

Figuras 20 e 21: Residência de Warchavchik e a Casa Modernista (1928/1930). Fonte: BRUAND, 1981. céus (FARIAS, 1992).

Foram seis os projetos de residências elaborados pelo referido arquiteto entre os anos de $1927 \mathrm{e}$ 1931: a sua própria residência, edificada entre os anos de 1927 e 1928, e considerada pela historiografia especializada como a primeira moradia modernista do país²6 (Figura 20); a "Residência Max Graf"27,

\footnotetext{
${ }^{24}$ Bruand (1981, p.63) afirma que a Semana de 1922 "(...) criou um clima novo, revelou um espírito de luta contra o marasmo intelectual, contra a aceitação incondicional dos valores estabelecidos", fertilizando o terreno para as realizações posteriores.

25 Gregori Warchavchik nasceu na cidade Russa de Odessa e se formou arquiteto no Instituto de Belas Artes de Roma em 1920. O arquiteto chegou ao Brasil em 1923 por convite da Companhia Construtora de Santos, que no momento equivalia à maior construtora do país (BRUAND, 1981).

${ }^{26}$ Para a construção dessa residência, Warchavcik encontrou diversos empecilhos, desde barreiras legais, uma vez que a nudez de seu projeto não era tolerada naquele momento pelos órgãos cabíveis, até questões econômicas em relação à exigüidade de materiais industrializados, essencialmente o concreto. Nessa primeira moradia verifica-se um distanciamento das proposições da arquitetura moderna por apresentar suas especificidades apenas de maneira "camuflada". Nesse sentido, poder-se citar: a sugestão da utilização de concreto armado por meio do emprego de tijolos revestidos com cimento branco; a referência ao teto-jardim através da utilização da platibanda; 0 fato de que a racionalidade da fachada não correspondia à solução interior da planta; e que a liberdade da planta em detrimento a fachada também foram comprometidas pela utilização dos materiais tradicionais. Essas especificidades acarretaram à construção a denominação, por parte de alguns críticos, de "edifício de aparência enganosa" (BRUAND, 1981, p.66).

${ }^{27}$ Essa edificação apresenta uma maior fidelidade aos princípios modernos em voga. Nela o tijolo cedeu lugar ao concreto armado e a varanda a uma marquise audaciosa. Percebe-se também o emprego da impermeabilização e a existência efetiva de uma laje plana, conformando um volume único, um sólido geométrico puro (cubo).
} 
edificada em 1929; a "Casa da Rua Itápolis" ou "Casa Modernista" como ficou conhecida28 em 1930 (Figura 21); a "Residência Luiz da Silva Prado" ou "Casa da Rua da Bahia", também construída em 1930; a "Residência Antonio da Silva Prado Neto" ou "Casa da Rua Estados Unidos", edificada em 1931 - todas construídas em São Paulo; e a "Casa Nordchild" ${ }^{29}$, construída no mesmo ano no Rio de Janeiro. De maneira geral, percebe-se o emprego de platibandas ou de teto-jardim, o jogo de cheios e vazios proporcionados pelas aberturas das janelas, portas e varandas que dão movimento ao plano limpo das fachadas das edificações, a justaposição dos volumes simples, o emprego de ângulos e linhas retas na composição da edificação, a transparência das fachadas garantida pelas grandes superfícies envidraçadas, a utilização de elementos em balanço, o emprego de mobiliário que em muito se aproximava das experiências da Bauhaus, e soluções originais que levaram em conta as imposições materiais do meio ambiente.

Segundo Farias (1992), Gregori Warchavchik a partir da construção da casa modernista em 1930, se tornou uma referência no meio intelectual do país e passou a ser aclamado como 0 arquiteto mais atualizado em sua época. Segawa (1995) complementa afirmando que é indiscutível sua condição de pioneiro, ao postular publicamente posições referenciadas na arquitetura racionalista de vanguarda na Europa e, sobretudo, por introduzir de forma ampla o debate público acerca da modernidade arquitetônica ${ }^{30}$.

No entanto, o passo decisivo para a efetiva consolidação da arquitetura e urbanismo moderno no país se deu no Rio de Janeiro, no bojo da reforma do ensino na Escola de Belas Artes, na década de 1930. A referida instituição representava um importante viés para a disseminação de novas idéias no país, destacando-se nesse sentido, a atuação pioneira de Lúcio Costa a frente de sua administração. 0 arquiteto $^{31}$ foi convidado pelo Ministro da Educação, o jurista Francisco Campos, para administrar a Escola de Belas Artes e, assim como nos demais setores da educação, efetivar a reforma do ensino. Sua contratação teve como objetivo, segundo Bruand (1981), propiciar aos alunos da instituição uma formação acadêmica completa, por professores catedráticos e por professores com "espírito moderno". Contudo, os antigos professores, destacando-se nesse sentido a figura de José Mariano Filho neocolonialista convicto, se empenharam para retirar Lúcio Costa do posto que ocupava, culminando em sua demissão em

\footnotetext{
28 Devido ao evento de mesmo nome realizado em seu interior no momento de sua inauguração e por apresentar forte influência das proposições de Le Corbusier, com a introdução de uma grande sacada em balanço, repetindo as soluções de teto-jardim, panos de vidros horizontais, de economia de espaço e a disposição da planta do pavimento superior.

29 Da mesma forma que a "casa modernista", representou palco para uma exposição, agora puramente arquitetônica, que contou inclusive com a participação de Frank Lloyd Wrigth.

30 Warchavchik também participou do movimento de reforma do ensino de arquitetura da Escola de Belas Artes no Rio de Janeiro e, em 1933, fundou junto com Lúcio Costa uma empresa de "arquitetura e construção" (BRUAND, 1981, p.70).

${ }^{31}$ Apesar da vertente neocolonial que caracterizava sua atuação, resultante de sua formação na própria Escola de Belas Artes, Lúcio Costa divergia dos demais arquitetos de sua geração por não aceitar as cópias de formas e motivos decorativos do passado, largamente empreendidos no período. Identificou-se com as proposições dos arquitetos europeus, em especial de Le Corbusier, após assistir a conferência realizada na Escola Nacional de Belas Artes por esse arquiteto, em visita ao Brasil no ano de 1925 (BRUAND, 1981).
} 
setembro de 1931. Sua rápida permanência na Escola (1930/1931) contribuiu significativamente para uma mudança no ensino de arquitetura no país e, conseqüentemente, para a consolidação das bases da arquitetura moderna brasileira. Após esse episódio, Lúcio Costa se dedicou a sintetizar as linhas do racionalismo internacional com a tradição local, viés que marcou toda a sua trajetória posterior. Segundo Bruand (1981, p.61), essa peculiar dualidade do "modernismo" brasileiro caracterizada pela constante busca para sintetizar as idéias revolucionárias e as especificidades nacionais marcou todo o período de introdução, evolução e consolidação do movimento no país.

Entre os anos de 1931 e 1933 Warchavchik e Lúcio Costa se tornaram sócios e montaram um escritório de arquitetura no Rio de Janeiro. Dentre as obras edificadas pelos arquitetos no campo da moradia, merece destaque o conjunto para operários na Gamboa, projetado em 1932, e considerado pela historiografia especializada como um dos primeiros exemplares de moradia moderna para trabalhadores no país, assim como, uma das primeiras obras modernas de Lúcio Costa, provavelmente influência de seu sócio (Figura 22). A concepção do conjunto se deu no bojo das reformas de reestruturação da área portuária da capital carioca, efetivadas pela municipalidade a partir da década de 1920. Para a construção das unidades habitacionais, os referidos arquitetos levaram em consideração: a topografia acidentada do terreno, adequando-as às curvas de nível; a economia do espaço, concebendo plantas com programas e dimensões reduzidas; a economia de material, concebendo as casas geminadas; e 0 aproveitamento das condições climáticas da região, projetando as unidades escalonadas de modo a ser aproveitada, ao máximo, a iluminação e a ventilação natural.

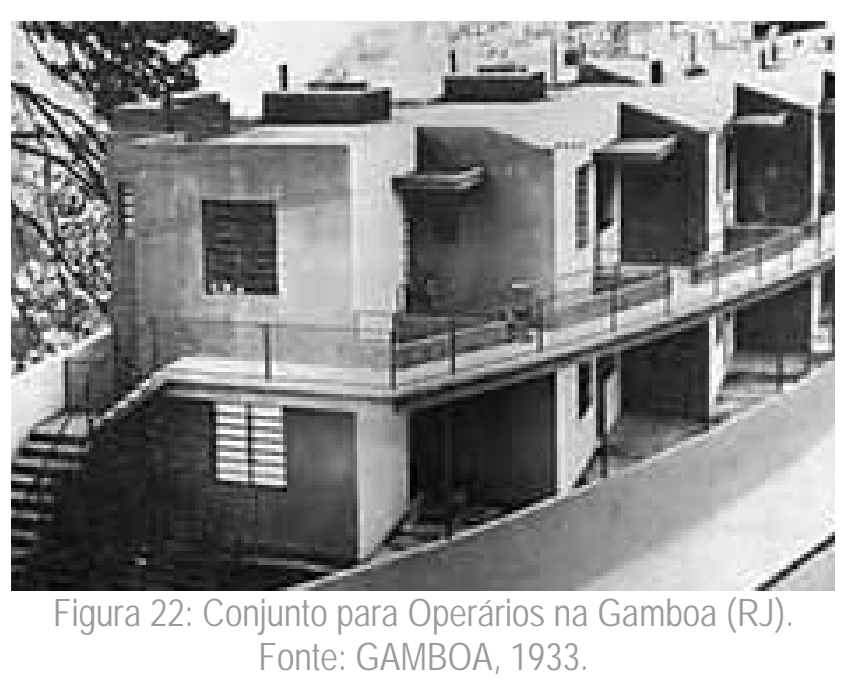

Percebe-se ainda 0 emprego dos pressupostos da arquitetura moderna e uma estreita semelhança da construção com as moradias edificadas por Warchavchik, em São Paulo, entre os anos de 1927 e 1931. Dessa forma, foram utilizados os volumes geométricos simples, as linhas retas, a laje impermeabilizada, as fachadas desprovidas de ornamentos, os elementos padronizados, a correspondência da fachada com 0 interior das edificações, além de uma grande passarela que dá acesso às unidades no primeiro pavimento, típica das residências de Warchavchik (GAMBOA, 1933).

No Brasil, a difusão da idéia de moradia em massa largamente abordada nos Congressos Internacionais de Arquitetura Moderna (CIAMs) recebeu importante contribuição do arquiteto Attílio Côrrea 
Lima $^{32}$. Nesse campo, se destaca as diretrizes do projeto da Cidade Operária da Fábrica Nacional de Motores, formulado em 1941, que contemplava uma parcela do município de Barra Mansa, no Rio de Janeiro. A Cidade Operária fazia parte de um plano que previa além da urbanização do referido município, a organização do trânsito, melhoramentos na infra-estrutura, zoneamento, construção de moradias, escolas, um centro comercial, campos de esporte e outros serviços e equipamentos de lazer, para atender uma população de aproximadamente vinte mil moradores (CORREIA, 2001). Devido à morte de Attílio, outro projeto para a Cidade Operária foi elaborado pelos arquitetos Paul Lester Wiener e Josep Lluis Serte, em 1945 (Figura 23).

Nesse sentido, e fortemente influenciado pelos postulados modernos, Attilio adotou a tipologia de moradia coletiva para os operários, considerada por ele como o modelo condizente com 0 desenvolvimento industrial e com 0 progresso científico daquele tempo, e a residência unifamiliar para os engenheiros, para os quais, a questão econômica não equivalia fator preponderante no projeto, além de alojamentos

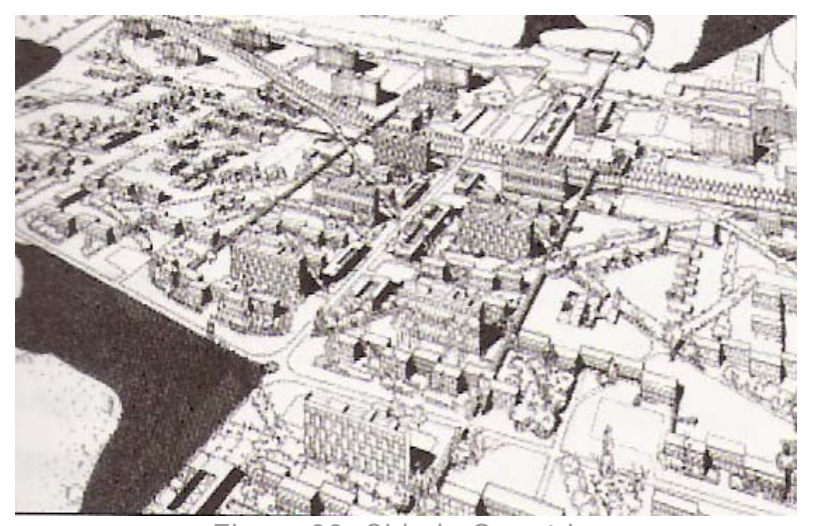
Figura 23: Cidade Operária. Fonte: FRAMPTON. 1997.

para os solteiros. As moradias seriam classificadas de acordo com a posição do funcionário e o cargo que ele ocupava na fábrica, variando em cinco modelos: A - para o setor administrativo; B - para mestres e mecânicos; C - para operadores, ajudantes de mecânico e chefes de equipe; e D - para os operários braçais e serventes. As tipologias B, C e D seriam concentradas nos prédios no centro, enquanto as residências isoladas (A) se situariam em terrenos periféricos. No parecer inicial do arquiteto, os blocos residenciais seriam produzidos em série, com quatro pavimentos, distanciados uns dos outros por parques cuja dimensão correspondia a duas vezes à altura do edifício, dotados de lavanderias e cozinhas coletivas centralizadas. As unidades habitacionais variariam entre 35 e $70 \mathrm{~m}^{2}$ (considerada área ideal para uma família com cinco membros), com sala, cozinha e quartos. Percebe-se, dessa maneira, uma aproximação de sua proposição para com as formulações de Gropius no segundo e terceiro CIAM em relação à moradia coletiva, e da cidade-jardim vertical de Le Corbusier (CORREIA, 1999).

Cabe ressaltar que os altos custos para manuseio e aquisição de alguns materiais adotados pela arquitetura moderna, tais como o concreto e o vidro, assim como, a escassez de mão-de-obra especializada, foram alguns dos fatores que proporcionaram certa restrição à adoção da arquitetura moderna no campo habitacional no Brasil nas primeiras décadas do século XX. Em contrapartida, 0

\footnotetext{
${ }^{32}$ Attílio foi um dos urbanistas mais atuantes no país na primeira metade do século XX, dentre as principais formulações estão os planos para as cidades de Goiânia, de 1933, e Volta Redonda, elaborado em 1941. Projetou o conjunto residencial Várzea do Carmo para o IAPI, em 1938, e lecionou na Escola de Belas Artes durante sete anos na década de 1930, onde graduou em arquitetura em 1925 (CORREIA, 1999).
} 
atrativo formal e funcional das edificações que se enquadravam nessa linha, em muito contribuíram para a adoção desse estilo por diversos órgãos públicos no país.

Em se tratando da produção habitacional por meio do Estado, são largamente conhecidos os conjuntos de Pedregulho (1950) e da Gávea (1952), projetados pelo arquiteto Afonso Reidy a frente do Departamento de Obras do Rio de Janeiro, e diversos projetos pensados e construídos pelos Institutos de Aposentadorias e Pensões (IAPs) e pela Fundação da Casa Popular (FCP), nas décadas de 1930 a 1960 em todo o país, como se verá no Capítulo 2.

A problematização da habitação proletária no Brasil, assim como na Europa, fundamentava-se na teoria de que o meio era responsável pela situação do indivíduo e estava na correção dos seus problemas a solução de todos os males sociais. A moradia dos trabalhadores passou a ser alterada de acordo com os preceitos da higiene e da economia. Concomitantemente, pensava-se em modelos alternativos de moradias.

Nesse sentido, vislumbrou-se no Brasil a possibilidade de "transformar a casa num espaço modelar, base da edificação de um novo trabalhador" (CORREIA, 2004, p.23). O interesse da elite brasileira pela saúde e bem estar da população proletária se deu inclusive quando essa parcela populacional passou a ter consciência de que as epidemias originadas nos aglomerados urbanos pobres se alastravam por toda a cidade. Foi então, que a partir de fins do século XIX teve início uma grande campanha de higienização e moralização das classes pobres. Diversos folhetos, revistas, eventos e congressos foram realizados com 0 intuito de promover e divulgar novos modelos de moradias, essencialmente, para a classe trabalhadora. Dentre eles, merecem destaque a atuação do Instituto de Racionalização do Trabalho (IDORT) e a Jornada Econômica de Habitação realizada pelo órgão, e os Congressos de Arquitetura, em especial a primeira edição, além das diversas publicações no campo, como as Revistas de Engenharia33. Segundo Bonduki (2002), o tema foi abordado em seus diversos enfoques, tais como, racionalização, simplificação dos sistemas construtivos, redução do padrão dos acabamentos e dos pés direitos, mudanças nos códigos de obras do país, estandartização das unidades, normatização dos materiais e combate à especulação imobiliária.

O I Congresso de Habitação foi realizado em São Paulo no ano de 1931, sob a coordenação do Instituto de Engenharia. Nele, tratou-se da questão da importância da redução dos custos da moradia para garantir o acesso por parte da população mais carente. Os profissionais envolvidos no evento sugeriam aos demais profissionais da área que deixassem a forma externa e as fachadas das moradias em segundo plano, para dar maior atenção às plantas. Percebe-se também no bojo das discussões estabelecidas no evento, o incentivo à racionalização do projeto e da construção, recomendadas pela economia de

\footnotetext{
${ }^{33}$ Devido à abrangência dos acontecimentos e diversidade dos meios de divulgação de propostas e soluções no campo da moradia social ao longo de todo o século XX no Brasil, esse tópico da dissertação se deterá ao aprofundamento dos dois primeiros grandes eventos nesse sentido, o I Congresso de Habitação (1931) e a Jornada Econômica de Habitação (1941).
} 
materiais por meio da industrialização e da produção em série, presentes também nos discursos dos profissionais envolvidos no processo de concepção e construção de moradias para trabalhadores no âmbito dos Institutos de Aposentadorias e Pensões, como se verá mais adiante (BONDUKI, 2002).

Com o mesmo intuito de baratear as construções, verificou-se no I Congresso de Habitação, reivindicações para a efetivação de mudanças nas legislações, principalmente nos Códigos de Obras. Sugeriu-se, nesse sentido, a revisão de vários artigos desatualizados de modo que os Códigos se transformassem em manuais para direcionar e balizar as novas construções, perdendo o caráter absoluto de proibição (INSTITUTO..., 1931). Outra questão abordada no Congresso dizia respeito ao crescimento da extensão horizontal das cidades, que acarreta altos custos de urbanização e manutenção dos serviços para os cofres públicos. Por esse viés, foram sugeridas medidas capazes de combater a especulação e reduzir, com isso, o preço dos terrenos, facilitando o acesso das camadas mais carentes à terra.

Um órgão que contribuiu no processo de mudança da moradia brasileira foi o Instituto de Organização Racional do Trabalho (IDORT). O qual correspondia a uma sociedade civil sem fins lucrativos, criada em 1921, com a denominação de Instituto Paulista de Eficiência pela Associação Comercial de São Paulo, recebendo aquele título somente em 1931. A função primordial do IDORT era estimular a adoção de métodos científicos nos diferentes ramos de atividade, inclusive no da construção e no uso das moradias no país. As suas formulações foram amplamente divulgadas entre as décadas de 1930 e 1950 através da Revista de Organização Científica, das proposições das Jornadas pelo órgão patrocinadas, além, de folhetos, conferências, programas de rádio e por meio de uma biblioteca especializada por ele constituída. As Jornadas aconteciam anualmente a partir de década de 1930. Dentre elas pode-se citar a Jornada de Organização Científica na Administração Municipal, a Jornada da Alimentação, a Jornada contra o Desperdício nos Transportes e a Jornada Econômica de Habitação. Segundo Correia (2004, p.81), por volta da década de 1940, o órgão contava com cerca de mil sócios, entre os quais se disseminava a imagem de "pioneiros do movimento de racionalização no país". O IDORT assumiu então o papel de centro intelectual do industrialismo brasileiro no que se concerne ao tema da racionalização. Promoveu a difusão das idéias de taylonização ${ }^{34}$, nas quais, a racionalidade e a eficiência eram tidas como solução ao desperdício, aos acidentes e para redução do tempo gasto na produção.

Em 1941, o Instituto de Organização Racional do Trabalho, realizou a Jornada Econômica de Habitação, reunindo profissionais de diferentes áreas a fim de reavaliar os métodos e explanar acerca das

\footnotetext{
${ }^{34}$ Esse método foi criado pelo engenheiro mecânico Frederick Winslow Taylor no século XIX, e consistia em um processo representado por duas etapas bem definidas: a divisão das atividades de modo específico e a reordenação delas de modo mais eficaz. O objetivo desse processo era reduzir ao máximo o tempo despendido em cada operação e em cada atividade de modo a garantir uma maior produtividade. Foram as conseqüências das prolongadas jornadas de trabalho, o cansaço produzido pelas tarefas repetitivas e monótonas e os conseqüentes acidentes de trabalho, que marcaram a implementação do sistema nas indústrias. De acordo com Correia (2004, p.84), esse método foi implantado no Brasil, sobretudo, a partir da década de 1930 e foi vinculado às justificativas técnicas e científicas para a efetivação dos programas sociais no país, aplicados tanto nos diversos setores da produção, como nas moradias - racionalização dos espaços da casa e das tarefas domésticas - e nas cidades - racionalização dos serviços públicos, do sistema de circulação, dentre outros.
} 
experiências relativas à habitação econômica no país, por meio de conferências e exposição de idéias e projetos (exposição "Casa Popular"). O evento ocorreu simultaneamente nas cidades de São Paulo e Rio de Janeiro. Nele, a habitação econômica foi enfocada sob a ótica social, financeira, técnica e urbanística. Dentre os temas colocados e discutidos, estava a questão das conseqüências que a atividade industrial acarretou aos centros urbanos brasileiros, podendo-se citar as concentrações operárias mal alojadas, que originam e agravam a crise de moradias populares no país e a difusão dos cortiços, associados por observadores da época à dissipação de doenças, à perversão moral e ao crime. Na concepção dos participantes do evento, a solução para a vigente crise de moradias era a substituição das residências insalubres por moradias caracterizadas pelo baixo custo de construção, novas disposições e dimensões de cômodos e por novas rotinas de trabalho doméstico e educação do morador. Correia (2004) coloca que dentre os temas mais enfocados pelas discussões e publicações de responsabilidade do IDORT (Revista de Organização Científica), estavam às questões relacionadas à racionalização da casa e das atividades a ela vinculadas, à economia de tempo, recurso e materiais, além da adequação da casa e dos valores dos aluguéis aos salários dos trabalhadores.

A redução dos custos de construção foi um tema bastante discutido na Jornada Econômica de Habitação. Julgava-se que para a satisfação deste quesito era necessária a aplicação dos métodos de administração científica (planejamento em série, a taylonização do canteiro de obra, a padronização dos elementos construtivos por outros pré-fabricados, o treinamento dos trabalhadores, etc.), a alteração dos códigos de obras, a educação do consumidor, a simplificação dos volumes das residências, a redução das dimensões e a redução dos ornamentos nas edificações, que estavam associadas ao desperdício.

Em se tratando da distribuição dos ambientes da habitação, as publicações defendiam uma moradia compacta e eficiente, com planta simples composta de com sala única, corredores mínimos, quartos pequenos para exerceram as simples funções de dormir e vestir, geralmente em número de três, de modo a separar pais, filhas e filhos e, em algumas vezes, quintal espaçoso, que ocupava segundo alguns profissionais, importante função no processo de criação e educação das crianças. Os cômodos deveriam ser agrupados de acordo com a função, suficientes para abrigar de modo higiênico, privativo e confortável as famílias brasileiras.

Paralelamente à difusão de idéias e intervenções pontuais na cidade ${ }^{35}$ desde as primeiras décadas do século XX, procederam-se significativas mudanças na habitação no país. Procurou-se, nesse sentido, adequá-las aos preceitos de salubridade, solucionar seus espaços e funções, ao mesmo tempo iluminar e arejar os ambientes, além de proporcionar espaços mais privativos.

As intervenções de cunho higienista na casa remetem ao século XIX e se deram por meio de alterações na planta, da introdução de novos materiais na construção e no acabamento da edificação,

\footnotetext{
${ }^{35}$ No plano urbano perceber, principalmente, alterações no traçado da cidade com abertura e alargamentos de vias e a criação de leis e regulamentos para normatizar as construções.
} 
geralmente relacionado à impermeabilização dos espaços, e à ligação das residências às novas redes de água e esgotos. Mais especificadamente, essas alterações eram representadas pela criação de espaços, como a área de serviço, jardins e recuos laterais, que permitiam a abertura de janelas nos cômodos, satisfazendo as necessidades de melhoria da salubridade, os níveis adequados de iluminação e ventilação naturais, além do distanciamento da casa com as vizinhas e com a rua, o que garantia maior privacidade às famílias.

O emprego de novos materiais nas moradias objetivava, sobretudo, reduzir a umidade no interior das casas, julgada responsável pela depreciação da residência, assim como, pela ocorrência de diversas moléstias. Para combatê-la, médicos e engenheiros propunham o arejamento dos ambientes com janelas, a criação de vãos intermediários entre o solo e o primeiro piso das moradias (porões) elevando-a ${ }^{36}$, a drenagem e a impermeabilização do solo, dentre outras alterações que serão detalhadas e melhor analisadas no capítulo seguinte.

Aos poucos, o número de cômodos das moradias brasileiras foi aumentando, como uma maneira de se contrapor à promiscuidade e se adequar às novas noções de conforto. A idéia era de que a habitação fosse "suficientemente pequena para que nenhum 'estranho' pudesse morar e, contudo, bastante grande para que os pais [pudessem] se separar dos filhos e que [tivessem] possibilidade de vigiá-Ios em suas ocupações sem serem observados em sua intimidade" (CORREIA, 2004, p.31).

Lemos (1976, p.153), coloca que se consolidou entre a população mais abastada nos primeiros anos do século XX, o "critério burguês de bem morar, ou melhor, definiram-se certas superposições de funções do esquema vivencial". Nesse sentido, os espaços também foram se agrupando de acordo com a função. O quarto de empregada, o banheiro, o tanque de roupas e a varanda revertida em sala de jantar passaram a ser abrigadas pelo mesmo telhado. Da mesma maneira, consolidou-se a copa anexa à cozinha, sem muitas vezes separação alguma entre os ambientes nas casas burguesas urbanas, uma "versão moderna da velha varanda de estar" (LEMOS, 1976, p.155).

As modificações no tocante à concepção da planta e às técnicas construtivas realizadas principalmente nas moradias dos mais abastados, construídas geralmente por engenheiros e arquitetos, foram sendo assimiladas pela classe média, seduzida pelos argumentos higienistas, mais acessíveis aos valores do alojamento confortável e/ou constrangidos pelas determinações das leis e posturas municipais. Aos mais pobres foram reservadas as normas punitivas e restritivas, de gestão do espaço e do corpo, na medida em que se acreditava que os mais carentes eram incapazes de compreender, por conta própria, a necessidade da adequação das moradias, recaindo sobre o Estado e às camadas mais afortunadas essa tarefa (CORREIA, 2004).

\footnotetext{
36 Os porões foram desaparecendo aos poucos, na medida em que a casa foi se distanciando das vias públicas por meio do aumento dos jardins e recuos frontais (CORREIA, 2004).
} 
De maneira geral, as proposições em relação às modificações "necessárias" na moradia dos trabalhadores de fins do século XIX e primeiras décadas do século $X X$, em muito se assemelhavam às direcionadas às demais habitações urbanas, adicionando-se àquela a ênfase na questão da economia. Dentre as alternativas para redução dos custos para a construção de moradias, propostas principalmente pelos engenheiros do período, pode-se citar a redução de escala, o apoio governamental por meio da isenção de impostos, a utilização de materiais de baixo custo e a preocupação com o programa mínimo da casa.

Influenciada pelas idéias afloradas dos movimentos feministas do século XIX, das proposições advindas da economia doméstica e da engenharia do lar, das idéias difundidas nos CIAMs e pelo crescimento da indústria de equipamentos e utensílios domésticos na segunda década do século XX, a cozinha da moradia brasileira também sofreu processo de reorganização e mecanização a partir da década de 1930. Em certos conjuntos residenciais, algumas das atividades domésticas foram transferidas para equipamentos coletivos, como lavanderias e refeitórios, principalmente a partir da década de 40 . A cozinha, os banheiros e a área de serviço foram agrupados por questões higiênicas e econômicas. Alguns dos blocos de moradia coletiva, como o edifício COPAM, passaram a ser concebidos em edificações com serviços, equipamentos coletivos e inclusive comércio, em concordância com o conceito de unidade de habitação corbusiano. Alguns conjuntos passaram a ser pensados e projetados de acordo com o número de habitantes a que se iria destinar a exemplo da unidade de moradia de Clarence Perry, como o bairro de Cidade Nova em Natal. Um grande número de prédios passou a ser concebido sem ornamentos. As linhas e os volumes retos marcaram diversas das moradias edificadas a partir de então.

\section{Habitação Coletiva versus Habitação Unifamiliar. Moradia Própria versus Moradia Alugada}

As discussões acerca da casa unifamiliar ou moradia coletiva estiveram presentes nas formulações e propostas de pensadores e profissionais engajados em solucionar o problema habitacional das grandes cidades e da qualidade e provimento de habitações às camadas mais carentes da população. Correia (2004) coloca que desde as últimas décadas do século XIX até por volta da década de 1940, combateu-se a produção de habitações coletivas. Segundo a autora, uma das justificativas dessa "antipatia" para com essa tipologia habitacional referia-se à imagem que se associava a ela, principalmente, contra a privacidade.

A separação entre moradores de diferentes idades e sexo em quartos distintos, a distinção de áreas para moradores, visitantes e empregados, a especialização de espaços, assim como, 0 distanciamento da moradia das edificações próximas e da rua, também estavam intrinsecamente ligados ao conceito de privacidade.

A favor do partido da casa isolada e unifaminilar também estava à idéia de bem-estar da vida doméstica que se associava, por sua vez, à noção da casa como uma referência espacial fixa da família, 
como 0 seu "santuário". Essa noção também estava vinculada ao projeto burguês de moralização do trabalhador, que se fundamentava na fixação dele em um ambiente compatível com o desenvolvimento do gosto pelo lar associado à incorporação de hábitos de ordem, de previdência e economia instituídas efetivamente a partir da década de 1930.

Se por um lado, as habitações coletivas eram largamente criticadas pela proximidade entre vizinhos, por outro, eram defendidas pelos termos de redução de custo no processo construtivo e com transporte, por solucionar o problema da alta densidade dos bairros e das cidades, e por favorecer as relações em comunidade, baseadas em grande parte, nas experiências das sociais-democracias e provenientes dos primeiros CIAMs.

As primeiras inclinações projetuais no campo da moradia social no país foram para a tipologia habitacional da moradia isolada no terreno, com quintal. Foi após 1930 que os conjuntos coletivos ganharam campo. Para alguns arquitetos, inclusive Attílio Correia, as casas isoladas com seus espaços livres e jardins representavam depósitos de velharias e remetiam aos tempos e costumes arcaicos, enquanto os conjuntos em série, densos, possibilitavam as vantagens da produção industrial em massa, baixando o custo da construção podendo ser elevado o padrão da unidade de habitação, assim como, possibilitando a construção de grandes equipamentos de uso coletivo e de lazer em concordância com os novos parâmetros da vida moderna (LIMA, 1963).

A discussão entre a moradia de aluguel ou moradia própria também esteve presente nos debates sobre a questão no Brasil. Havia os que acreditavam que a aquisição de moradias próprias por parte dos trabalhadores seria deveras onerosa, o que comprometeria a satisfação de outras necessidades, como alimentação. Sem falar do comprometimento, por um significativo espaço de tempo, do trabalhador com a dívida resultante da compra do imóvel. Para esses, o ideal de moradia para os trabalhadores deveria ser aquela concedida de forma barata e por meio do pagamento de aluguel, ficando o inquilino responsável apenas para a manutenção do imóvel, a exemplo das sociais-democracias. Acreditavam, nesse sentido, que os valores desprendidos pelos trabalhadores para o pagamento das prestações da casa própria, absorviam uma grande parcela dos seus rendimentos mensais e recomendavam o pagamento de aluguéis mais acessíveis. Essa vertente propunha a construção de moradias pelo Estado como serviço de utilidade pública, assim como o abastecimento de água, a coleta de esgotos, os sistemas de transporte, iluminação pública, etc. Tal idéia foi difundida por arquitetos participantes do I Congresso Nacional de Arquitetura, realizado em São Paulo no ano de 1945 (BONDUKI, 2002).

Por outro lado, estavam grupos convencidos de que a posse de uma moradia por parte de um trabalhador pobre contribuía para torná-lo "menos perigoso". Colocavam a questão de como viabilizar 0 acesso do pobre a ela, introduzindo o sonho da casa própria no projeto de vida dessas pessoas (CORREIA, 2004). Da mesma maneira balizava-se o Estado Novo, que defendia contundentemente a 
aquisição da moradia própria pelos trabalhadores e buscava soluções para torná-las mais acessíveis, principalmente pelo barateamento dos materiais e do processo construtivo e pela formulação de linhas de financiamento nesse sentido. A aquisição da casa própria era mostrada como valorização do trabalho e do progresso material do trabalhador, assim como uma possibilidade de ascensão social (ROLNIK, 1997).

A casa própria também era defendida veementemente por participantes da Jornada Econômica de Habitação, promovida pelo IDORT. Adquirindo o significado de propriedade, a casa própria converteu-se em expressão de valor e do direito básico consagrado pela sociedade burguesa, como símbolo de poder e de status. No entanto, essa não foi a pretensão das classes menos favorecidas até a quarta década do século XX. As reivindicações dos trabalhadores em relação à moradia restringiam-se, sobretudo, à luta contra os elevados valores dos aluguéis e às ações de despejo. Conjuntura essa que será abordada no capítulo seguinte. 


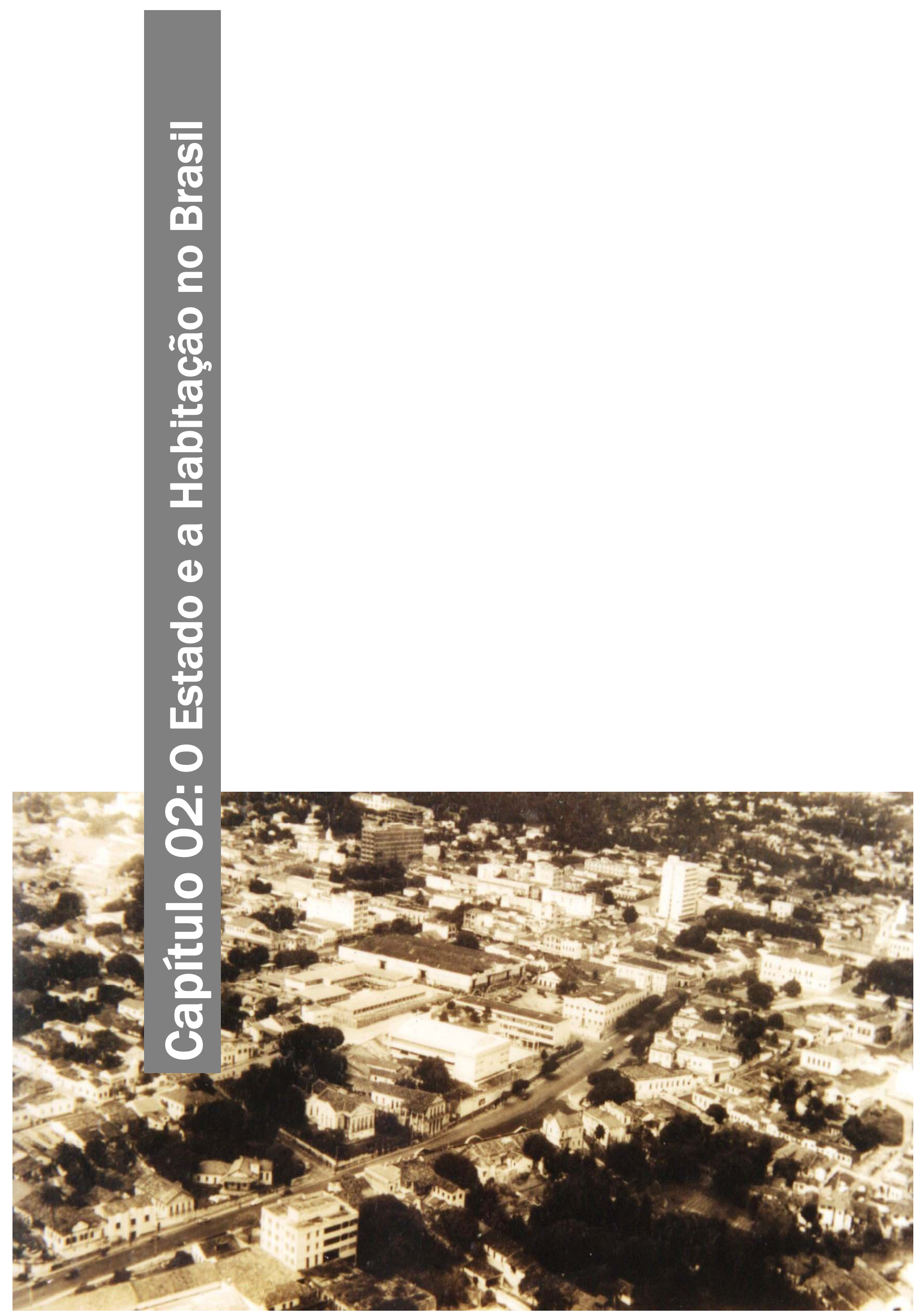




\section{CAPÍtULO 02: O ESTADO E A HABITAÇÃO NO BRASIL}

\subsection{As Primeiras Iniciativas e Realizações no Campo da Habitação}

A Revolução Industrial trouxe como umas de suas conseqüências um movimento que reformulou 0 modelo de cidade e de vida vigentes. Diante do crescente aumento populacional urbano e da necessidade de mão-de-obra para a indústria, empreenderam-se iniciativas para a adequação do espaço das cidades às novas exigências do capital. As intervenções realizadas a partir de então foram guiadas pelos preceitos higienistas e sanitaristas, e resultaram em obras de ordenamento do espaço urbano, no zoneamento de usos e funções e na conformação da cidade para os novos meios de locomoção.

No século XIX, o Brasil se deixou seduzir por essa nova "ordem urbana". Nesse momento, o cenário urbano brasileiro era marcado por péssimas condições sanitárias que propiciaram a freqüente ocorrência de epidemias. Nesse contexto, as políticas públicas republicanas objetivavam a modernização da nação por meio da promoção da higienização e o embelezamento das cidades e de suas habitações (DEÁK, 1991).

O crescimento populacional verificado nesse período desencadeou problemas referentes, principalmente, à falta de infra-estrutura sanitária adequada. $\mathrm{O}$ acúmulo de moradias precárias começou a se configurar para setores da elite como uma grave ameaça à saúde pública. Dentre as formas de moradia dos pobres urbanos, os cortiços eram as que mais preocupações suscitavam entre os higienistas. Segundo Celine Sachs (1999), esse tipo de habitação se caracterizava como uma fileira de moradias exíguas desprovidas de conforto, amontoadas em torno de um pátio, construídas para serem alugadas para as populações urbanas de baixa renda. Conforme Eva Blay (1985), os cortiços eram casas de moradia em comum, transformadas ou adaptadas para tal finalidade, havendo ainda casos de moradias subdivididas. Sidney Chalhoub (1996) mostra que ao cortiço poderiam ser atribuídas diversas definições, mas em todos os casos, se referia a uma moradia coletiva ocupada por pobres, os quais eram associados por setores da sociedade às chamadas "classes perigosas". Dentre as causas associadas ao surgimento e à proliferação desse tipo de residência encontra-se a abolição da escravatura, 0 rápido aumento populacional, a ausência de uma oferta de habitações populares adequadas a baixo custo e os elevados valores dos aluguéis cobrados às classes menos favorecidas.

O estigma dos cortiços como representação física do perigo relacionado às classes pobres e aos locais habitados por elas nas cidades surgiu em meados do século XIX e foi exacerbado no bojo das discussões que precederam à abolição da escravatura no país, em 1888. De acordo com Chalhoub (2004, p.20), essas questões foram colocadas inicialmente pelos Deputados do Império do Brasil e foram balizadas pelas obras de escritores e pensadores franceses da época, cujos discursos eram carregados de preconceito para com as camadas pobres e a ociosidade da população. 0 que, segundo o autor, em 
muito se assemelhava às preocupações da Câmara da Corte para com as cidades brasileiras e suas populações naquele momento.

O gosto pelo trabalho era considerado pelos letrados da época como a principal virtude de um cidadão. Na concepção deles, as pessoas que trabalhavam tinham possibilidade de desenvolver o hábito da poupança, que se revertia em conforto para ela e sua família. Quando um indivíduo não conseguia acumular, isto é, permanecia na pobreza, era sinal de que ele não era um bom trabalhador, mas sim um portador do vício da ociosidade. Acreditava-se, portanto, que aos pobres faltava à virtude social mais essencial, o trabalho, e em cidadãos que não grassavam virtudes acreditava-se abundar os vícios (CHALHOUB, 2004).

Sabe-se que não necessariamente um bom trabalhador conseguiria escapar das "amarras" da pobreza, o que não era claro para os parlamentares de fins dos dezenove. $O$ jogo de conseqüências, que Chalhoub (2004, p.22/23) define como "pressuposto da suspeição generalizada", se formou naturalmente, uma vez que na concepção da época "(...) os pobres carregavam vícios, os vícios produzem malfeitores, os malfeitores são perigosos à sociedade". Dessa forma, para setores das elites, os pobres tornaram-se automaticamente perigosos. A pobreza de um indivíduo era, portanto, utilizada para designá-lo como um potencial malfeitor ${ }^{37}$.

Telma de Barros Correia (2004) mostra que na visão de observadores da época, as moradias coletivas, essencialmente os cortiços, eram vistas como responsáveis por atirar seus moradores às ruas, bares e bordéis, onde estariam expostos aos vícios, à devassidão e ao ócio. À habitação pobre era ainda imputada a responsabilidade de não permitir a perfeita reposição das energias para 0 trabalho, contribuindo para a manutenção da precariedade da situação econômica dos trabalhadores que nela residiam. A autora coloca que os ambientes criados pelos cortiços e outras habitações do gênero eram tidos freqüentemente como favoráveis aos incestos, à prostituição e a todos os tipos de vícios, configurando-se para alguns como ameaça social.

Como forma de coibir a proliferação dos malfeitores e alcançar os objetivos almejados, os parlamentares elaboraram projetos de lei proibindo a ociosidade. Os Deputados estavam preocupados com as conseqüências da abolição para a organização do trabalho no país e questionavam como as administrações conseguiriam garantir esse ordenamento sem recorrer às políticas de cativeiro, até então aplicadas pelos proprietários de escravos. Essa iniciativa verbalizou a posição de parte dos nobres em relação às classes menos favorecidas no período que precedeu à Proclamação da República e que perdurou até as primeiras décadas do século XX. Tais fatores justificaram o caráter violento das ações contra os cortiços efetivadas a partir de então.

\footnotetext{
${ }^{37}$ Outra abstração que, segundo o autor, é evidenciada até os dias de hoje.
} 
Outra justificativa da veemência ao combate dos cortiços reside no fato de que essa tipologia habitacional representava importante cenário da luta dos negros contra a escravidão em meados do século XIX, além de refúgio para onde muitos se dirigiam quando escapavam das senzalas ${ }^{38}$. Uma quinta justificativa ainda pode ser citada. Essa equivalia à necessidade de realização de obras urbanas e de infra-estrutura nas cidades brasileiras, como forma de afirmação de um novo caráter nacional. Do episódio da destruição de um dos mais famosos cortiços do Rio de Janeiro, conhecido como Cabeça de Porco, por exemplo, dependia o prolongamento da Rua dos Cajueiros e a abertura de um túnel no morro do Livramento, serviços contratados pelo engenheiro Carlos Sampaio da empresa de Melhoramentos, em 1893 (CHALHOUB, 2004, p.55).

De acordo com Correia (2004, p.19), as representações da população pobre e do lugar que estes habitavam estavam intimamente relacionadas e recaiam na "noção básica" de que "o meio forma os indivíduos". Segundo a autora, essa teoria permeou o pensamento e as práticas dos letrados do século XIX, sobremaneira os médicos. Nesse momento, era a teoria miasmática que dominava o pensamento médico. Segundo ela, o ar e a água eram meios transmissores de doenças. Acreditava-se que a matéria animal ou vegetal em putrefação, assim como, as águas servidas e estagnadas, as matérias fecais e o lixo acumulado eram causadores de doenças, devido às emanações fétidas e pútridas originadas por eles, chamadas de miasmas. Nos ambientes fechados, onde se verificava acúmulo de materiais, pessoas e objetos, apontava-se a estagnação dos fluídos e, conseqüentemente, a sua contaminação por miasmas. A iluminação e a ventilação deficientes nesses locais eram tidas como agravantes para a contaminação miasmática.

Outras teorias médicas e biológicas foram formuladas ao longo do século XIX como, por exemplo, a teoria microbiana de Pasteur, que conferiram novos direcionamentos teóricos às propostas e às intervenções no meio construído, em especial, às habitações. Mas, tantos os clínicos positivistas quanto os sanitaristas adeptos da bacteriologia concordavam que o meio conformava o indivíduo, estando na solução de seus problemas a chave para o melhoramento do indivíduo.

Percebe-se, portanto, que desde o seu surgimento em meados do século XIX, os cortiços eram considerados como ameaça social, por representar um dos cenários da luta dos negros contra a escravidão. Visto por observadores da época como antros de proliferação de vícios que comprometiam a organização do trabalho e manutenção da ordem pública, como ambientes inadequados higienicamente e causadores de doenças, passando a ser entendidos por setores das elites como "focos de contaminação social".

${ }^{38} \mathrm{O}$ aumento do número de cortiços, essencialmente no Rio de Janeiro, ocorreu na medida em que se deu o aumento do número de alforrias aos escravos e 0 crescente fluxo de migrantes portugueses. De acordo com Chalhoub (2004, p.26) a destruição dessa tipologia habitacional coletiva poderia estar associada também a uma "tentativa de desarticulação da memória recente dos movimentos sociais urbanos". 
Assim, era imprescindível para esses segmentos purificar a cidade, "livrando-a definitivamente (...) desse 'mundo de imundice"' (CHALHOUB, 1996, p.19). Era preciso então, cuidar da "uniformidade urbana", como um todo agradável de viver e zelar pela habitação sã, unifamiliar, digna e confortável representada, na maior parte dos casos, pela moradia da classe patronal (PICCINI, 2004, p.29). Tarefa esta assumida pelo poder público e suas instituições específicas de controle, especialmente a partir da Proclamação da República.

Concomitantemente ao surgimento dos primeiros cortiços na Corte Imperial por volta de 185039 , evidenciou-se a ocorrência das epidemias de febre amarela (1850) e cólera (1855) e, conseqüentemente, a ascensão das questões relacionadas à salubridade pública, mais especificadamente, aquelas vinculadas à higiene das habitações coletivas.

Nesse momento, os médicos analisavam a realidade das cidades equiparando-a, por vezes, a um corpo humano doente, ao qual prescreviam remédios eficazes e específicos ao combate de cada doença evidenciada. Em se tratando do espaço construído das cidades, como dito anteriormente, os médicos acreditavam que as moradias coletivas e os ambientes gerados por elas eram focos de disseminação de epidemias e de vícios de todos os tipos, sendo extremamente nocivos a todo o restante da sociedade, devendo receber atenção especial das autoridades.

Foi criada, nesse sentido, a Junta Central de Higiene que associada à Câmara Municipal da Corte passaram a zelar pelas questões de salubridade pública e a regulamentar a construção e as condições de moradia das habitações coletivas no Rio de Janeiro, por meio de legislação específica que ficou posteriormente conhecida como Códigos de Posturas. Dentre as primeiras disposições elaboradas pela Junta estava o "Regulamento dos Estalageiros", projeto apresentado à Comissão de Posturas da Câmara, em 1853, que tratava da necessidade do cadastro dos moradores e visitantes das estalagens para prevenir a desordem e a ocorrência de crimes, o que facilitaria também a ação da polícia responsável pelas vistorias regulares. No tocante à higiene, ficou proibido o acúmulo de lixo, matérias fecais e águas servidas em tigres ${ }^{40}$, no quintal em covas ou em qualquer parte das estalagens. Apesar de ter sido considerado "urgente e de utilidade pública", esse projeto não foi adotado pela Câmara Municipal do Rio (CHALHOUB, 2004).

Outro projeto de posturas foi apresentado aos vereadores do Rio de Janeiro, em 1855. Esse discorria sobre a origem dos cortiços na cidade, sua relação com os elevados custos para se adquirir uma moradia e com os altos valores cobrados pelos aluguéis devido ao aumento do número de habitantes.

\footnotetext{
39 Em São Paulo, os cortiços começaram a surgir por volta de 1870, mais especificadamente, nos bairros centrais habitados pelas elites, tais como o bairro da Sé, Santa Efigênia, Bela Vista, e nos bairros operários, Brás e Mooca (PICCINI, 2004). 40 Grandes depósitos construídos, geralmente em madeira, que serviam para o transporte e despejo dessas substâncias.

${ }^{47}$ A Higiene a partir de então passou a definir o "grau de civilização de um povo" e para alcançá-la, os políticos deveriam deter o saber técnico-científico pertinente aos engenheiros e médicos, que passaram a ter mais voz ativa em todos os escalões da sociedade (CHALHOUB, 2004, p.44).
} 
Dentre as determinações encontradas no projeto estão: a proibição da coabitação entre homens e animais; a necessidade do calçamento e iluminação de pátios e da instalação de latrinas; o fornecimento por parte da Câmara Municipal de compartimentos para se depositar as águas servidas e as matérias fecais, assim como, a remoção desses vasilhames em determinadas horas do dia; e a proibição da construção de cortiços sem a aprovação da Câmara Municipal. Apesar de extenso e detalhado, apenas uma das determinações expostas nesse projeto foi acatada pela Câmara, correspondendo àquela referente à construção dos cortiços na cidade (PICCINI, 2004).

A partir do terceiro quartel do século XIX, 0 aumento da mortandade ocasionada pela tuberculose, ou tísica como era conhecida na época, colocou a questão da saúde pública ainda mais vinculada às condições da população pobre em geral e, conseqüentemente, às de suas moradias. Essas passaram a ser susceptíveis às técnicas higiênicas, que saturaram o ambiente intelectual do país nas décadas seguintes e concederam suporte ideológico para a ação saneadora dos engenheiros e médicos, que passaram a acumular poder na administração pública, especialmente, após a Proclamação da República, em 188947 .

Também do início do terceiro quartel do século XIX data a primeira determinação direta contra oS cortiços no Rio de Janeiro. Em 18 de dezembro de 1879, o Ministério do Império ordenou que as comissões sanitárias fechassem os cortiços que estivessem em ruínas ou àqueles que se mostrassem nocivos à saúde pública. Tiveram início então disputas e conflitos envolvendo as comissões sanitárias, os proprietários, os inquilinos, as autoridades policiais e a Câmara (CORREIA, 2004).

Cabe ressaltar que nessa "guerra" de interesses, as autoridades policiais e os higienistas estavam quase sempre do mesmo lado contra os cortiços, enquanto os fiscais de freguesia e os proprietários de cortiços estavam juntos contra as incursões dos funcionários da Higiene. A Câmara Municipal (e a partir do ano de 1892 os prefeitos) representava muitas vezes a intermediária dos interesses de ambos os lados, sendo também responsável pela elaboração das políticas públicas acerca das habitações coletivas.

Apesar das diversas propostas, ofícios e projetos elaborados a partir de meados do século XIX, a Câmara Municipal da Corte se deteve, basicamente, as restrições à construção de cortiços. Sendo essa a principal maneira de encarar o problema das moradias coletivas por parte das autoridades até a Proclamação da República, quando se deu efetivamente o início da política de expulsão das classes pobres das áreas centrais da cidade (CHALHOUB, 2004).

Com o início da República, os médicos-higienistas passaram a apontar o controle sanitário como 0 principal instrumento de normalização da sociedade (MACHADO, 1978). Conforma-se a partir de então, segundo Nabil Bonduki (2002), o embrião de uma legislação implementada pelo Estado que regulamentou as construções por meio dos Códigos de Postura. Com a ascensão de Floriano Peixoto à presidência da República, em 1891, o cerco contra os cortiços foi fechado. Dando início a essa ação legisladora do 
Estado, em janeiro de 1892, a Inspetoria Geral de Higiene (antiga Junta Geral de Higiene) foi autorizada pelo Ministério do Interior a fechar, num prazo de 48 horas, todos os cortiços que representassem uma ameaça à saúde pública e a multar os proprietários e sublocatários desses. Decisão essa, irrecorrível por parte proprietários e inquilinos de cortiços.

Nessa mesma linha, por volta de 1894 foi proibida a construção de cortiços sem licença da Inspetoria de Higiene. Para os exemplares existentes, determinou-se a adoção de medidas higiênicas, como a pavimentação de áreas externas, a canalização de água e esgotos, a ampliação da altura do pé direito e das dimensões dos vãos das janelas e portas - de modo a oferecer ventilação e iluminação adequadas aos cômodos -, assim como, alterações dos tipos de revestimentos e imposição de limites de lotação máxima de cada residência. Os funcionários da Higiene agiam, nesse sentido, exigindo 0 fechamento de habitações coletivas até nos casos onde era possível a realização de melhoramentos, afetando inclusive o direito de propriedade garantido pela Constituição publicada em 1891. Essas ações caracterizadas pela violência e arbitrariedade estão associadas às representações dos cortiços nesse período.

Segundo Blay (1985), os sanitaristas propunham desde a reforma completa de cortiços, após aprovação de uma planta pelo órgão de higiene, até a demolição de prédios condenados. Como solução de moradia aos desabrigados sugeriu-se a formulação de uma política destinada a promover a construção de casas higiênicas para a população mais carente, a qual permaneceu no plano do discurso até o século XX (CHALHOUB, 1996).

A partir dos primeiros anos do século $X X, 0$ que se presenciou foi uma luta intensa entre as comissões sanitárias da Inspetoria de Higiene que ordenavam o fechamento dos cortiços; os donos de cortiços que exigiam que apontassem os problemas higiênicos de suas propriedades e recorriam às autoridades administrativas para a obtenção de licenças para realizarem os melhoramentos necessários; os inquilinos indignados com os despejos e sem alternativas adequadas de moradia; e a força policial, responsável por efetivar as ordens de fechamento.

Era urgente que as administrações propusessem uma solução para o eminente problema de moradia dos "despejados". Uma alternativa cogitada foi a substituição dos cortiços por casas com boas condições higiênicas e a construção de vilas operárias. Dessa forma, seria solucionado o "problema" da permanência dos pobres no centro da cidade e o excesso populacional nessa área. Além de que, com a diminuição da demanda seria mais fácil para o Estado controlar os altos aluguéis (BONDUKI, 2002).

Para tanto, foi preciso atrair investimentos para o setor da construção, acenando com vantagens como a isenção de impostos e o aforamento de terrenos. Segundo Chalhoub (2004), a primeira proposta relacionada à construção de habitações destinadas às classes pobres pelo poder público, correspondeu ao ofício enviado ao Ministério dos Negócios do Império, em 1860, pela Secretaria de Polícia da Corte. 
Esse ofício sugeria a adoção de incentivos aos construtores, incluindo empréstimos e isenção de impostos, e propunha que a própria Câmara Municipal disponibilizasse habitações para serem alugadas por quantias modestas pela população menos favorecida. A idéia de promoção de habitações para os trabalhadores pela administração pública também foi defendida em fins do século XIX, por uma comissão encarregada de estudar a questão da moradia proletária em São Paulo, em 1893 (RELATÓRIO..., 1893, p.53). Tais proposições permaneceram no papel até os primeiros anos do século XX.

Em setembro de 1911, por meio de decreto, a administração do Rio de Janeiro isentou, efetivamente, por quinze anos o pagamento de qualquer imposto municipal, de foros, laudêmios e outras despesas em caso de terreno foreiro à municipalidade, além da garantia de desapropriação por utilidade pública, a qualquer empresa, associação ou indivíduo que se propusesse a construir moradias populares, em número superior a duzentas, com programas e dimensões pré-estabelecidos (REVISTA DE ENGENHARIA, 10/08/1911).

Concomitantemente a essa iniciativa ocorreu o despertar de grupos empresariais para as possibilidades de investimentos e, conseqüentemente de lucro, abertas pelos discursos e ações higienistas contra as habitações coletivas. De acordo com Chalhoub (2004), havia imbuído nesse processo um enorme potencial para a especulação na construção de moradias e no provimento de infraestrutura essencial para a ocupação de novas áreas na cidade, principalmente, pela população deslocada das moradias coletivas interditadas e/ou demolidas. Nesse contexto, alguns empresários atuavam nos ramos da construção civil e no provimento de habitações. No entanto, foram poucos os contratantes que chegaram a construir moradias para a população de baixa renda.

De acordo com Correia (2004), a construção de habitações operárias salubres e baratas no Brasil se deu, sobretudo, a partir da década de 1880 por indústrias, empresas de mineração, companhias ferroviárias e empresas imobiliárias. Em sua concepção, o Estado só passou a atuar nesse campo a partir da primeira década do século XX, mormente, a partir de 1920.

Tem-se como um dos mais significativos exemplos de ação privada no campo da construção de moradias operárias, a atuação do engenheiro Arthur Sauer, dono da Companhia de Saneamento do Rio de Janeiro, criada em 1889, que chegou a construir cinco vilas operárias, direcionadas a mais de três mil pessoas. As vilas receberam a denominação de Ruy Barbosa, Arthur Sauer, Senador Soares, Maxwell e Sampaio, das quais, apenas a primeira delas foi construída no centro da cidade - provavelmente destinada à população mais abastada devido às "feições nobres" das construções que fugiam do modelo de casas térreas geminadas comumente adotado -, ficando as demais localizadas nos subúrbios, sendo destinadas aos trabalhadores da Fábrica de Tecidos Carioca e da Fábrica de Tecidos Confiança Industrial (CORREIA, 2004, p.41). 
Nesse contexto, diversas foram as tentativas de incentivar empresários da construção civil a se dedicarem à produção de moradias baratas para os operários, mas a grande maioria dos investimentos privados no século XIX e nas primeiras décadas do século XX não vingou devido à concorrência estabelecida pelos proprietários/construtores de cortiços.

Dentre os exemplos bem sucedidos da atuação público/privada tem-se a cidade do Recife. Nela, esse tipo de parceria já era identificado nas primeiras décadas do século XX. Em 1914, se comentava acerca de tipos de habitações econômicas feitas com blocos e placas de cimento, idealizadas pela Mútua Predial do Recife - uma associação cooperativa local (LIRA, 2002). Em princípios da década de 1920, membros do Clube de Engenharia como, Napoleão Albuquerque, Alde Sampaio, Lauro Borba e Paulo Guedes, já se encontravam envolvidos nas discussões sobre habitação econômica, buscando condições mais rentáveis para os investimentos privados no setor, além do barateamento da construção. Em 1923, 0 Estado por meio da Lei no. 1624 autorizou a firma L. \& U. Borba a construir casas de baixo custo, em terrenos por ele doados, para substituir os mocambos que se multiplicavam na cidade.

Concomitantemente, as Caixas Prediais e os Bancos Hipotecários, com mediação do governo estadual, foram autorizados a conceder empréstimos requeridos por operários que possuíssem terreno para edificar residência (LIRA, 2002). Segundo Farah (1983), iniciativas dessa natureza equivaleram a uma versão precoce do chamado Plano $B$ das Carteiras Prediais dos Institutos de Aposentadoria e Pensões, criadas na década de 1930.

A associação entre o Estado e a iniciativa privada foi uma ação lucrativa e socialmente abrangente no Recife. Ao lado da ação público-privada, a construção direta de habitações pelo Estado também se deu "precocemente". Nesse sentido, pode-se citar a construção Vila do Arraial, em princípios de 1920; a criação da Fundação da Casa Operária, voltada para a edificação de casas de acordo com as especificações higiênicas e destinadas à população reconhecidamente pobre, em 1924; e, a concepção da Vila Operária Paz e Trabalho, por iniciativa do médico Amaury de Medeiros, Diretor do Departamento de Saúde e Assistência do Estado de Pernambuco, em 1925 (LIRA, 2002).

A partir de 1930, em concordância com o cenário nacional, a abordagem higienista da capital pernambucana baseada na segregação física e social da população ganhou corpo, estando associada ao rígido combate aos mocambos e à construção de moradias pelas administrações públicas. Lira (2002, p.56) afirma que a partir desse período foram edificados diversos "paraísos proletários e Vilas populares constituídas pelo Estado ou pelo empresariado local". Outro órgão que merece destaque no âmbito da produção de habitação social e na luta contra as habitações insalubres no Recife é a Liga Social Contra 0 Mocambo, que a partir de plantas-padrão, construiu habitações populares e as distribuiu gratuitamente para a população por intermédio da Diretoria de Reeducação e Assistência Social. 
Por outro viés, nos primeiros anos do século XX, no âmbito da reforma urbana compreendida por Pereira Passos, que envolveu entre outras coisas, a demolição de grande número de cortiços e casas populares no centro do Rio de Janeiro, a administração pública empreendeu a primeira ação direta na construção de habitação popular no Brasil, concluída em 1906. Tratava-se de 120 unidades habitacionais com dois pavimentos independentes, localizadas na Avenida Salvador de Sá e destinadas a operários. Porém, de acordo com Sachs (1999), as intervenções estatais no campo da habitação no Rio de Janeiro começaram efetivamente a partir de 1937, quando foi instituído o Código de Obras da cidade (Decreto ํ‥ 6.000).

A política de habitação no Rio de Janeiro, naquele momento, se concentrava na erradicação de favelas e na substituição delas por habitações higiênicas. Dentre as ações do Estado, pode-se citar a relocação de moradores de várias favelas da zona sul, a partir da década de 1940, para os conjuntos residenciais então chamados de "Parques Proletários" (HABITAÇÃO..., 1985).

Na década de 1930, o Estado também lançou mão de outras medidas para acelerar o ritmo das construções, como o financiamento estatal, delineando, segundo Blay (1985) o embrião da política habitacional posteriormente desenvolvida. Nessa "nova fase", o problema da habitação passou a ser encarado por outra perspectiva. A ação da iniciativa privada - até então a principal "responsável" pela produção de moradia destinada à classe trabalhadora no país - fora reconhecida por setores da elite como insuficiente para enfrentar tal questão, fazendo com que uma intervenção mais ampla do Estado fosse reivindicada.

\subsection{A Intervenção no Campo da Moradia Social a PaRTiR da DéCADA de 1930}

Com a ascensão de Getúlio Vargas à presidência do Brasil, em 1930, a questão da habitação passou a receber uma maior atenção do Estado. Essa mudança pode ser justificada por diversos fatores, dentre eles, a política de desenvolvimento nacional instituída pelo então presidente, que possuía como um dos principais vieses a industrialização do país. Por essa ótica, a moradia destinada aos trabalhadores tornou-se fator primordial para a reprodução da força de trabalho (BONDUKI, 2002).

A estratégia governamental pretendia, num segundo plano, a formação ideológica de um novo homem, de um novo trabalhador. Nesse sentido, diversos órgãos foram criados para a realização de eventos que abordassem 0 assunto, objetivando consolidar esse "novo ideal". Podendo ser citados: 0 Instituto de Engenharia, que em 1931 promoveu o I Congresso de Habitação e o Instituto de Organização Racional do Trabalho (IDORT), que em 1941 realizou a Jornada de Habitação Econômica (CORREIA, 2004). Nessa conjuntura, cabe ressaltar que para a difusão das novas proposições e estruturação do debate acerca da moradia social foi preponderante a realização dos Congressos Brasileiros de Arquitetura. A imprensa diária e as revistas especializadas também deram importante atenção ao tema nesse período (RIBEIRO, 1997). 
De acordo com Bonduki (2002), também se conformam como justificativas para a importância adquirida pela habitação a partir da década de 1930, o fato da crise de moradia evidenciada nesse período ter atingido inclusive a classe média, grande formadora de opinião pública, e à latente necessidade de novas soluções habitacionais frente as existente até então.

Foi no bojo dessas idéias que ganhou força a solução baseada no modelo da casa própria. Para aceitação desse "novo modelo" de moradia condizente com o projeto desenvolvimentista proposto pelo presidente, o trabalhador pagador de aluguéis de cortiços ou de vilas operárias, sobretudo, teria que ser "reeducado", justificando a publicação de uma gama de publicações nesse sentido. Por outro lado, era preciso reduzir os custos das residências populares, alterando os processos de produção e provisão. Assim como, por fim aos abusos da especulação imobiliária e das vantagens alcançadas pelos rentistas, que favoreciam os proprietários controladores do mercado - graças ao direito de propriedade garantido pela Constituição e pelo Código Civil.

Uma das soluções encontradas pelo poder público foi regulamentar a relação entre inquilino e proprietário por meio de leis restritivas e de fixação de valores. Essas leis ficaram conhecidas como Leis do Inquilinato - um conjunto de leis outorgadas a partir da década de 1920. Outra solução foi a criação e 0 fortalecimento de órgãos governamentais, com o objetivo de produzir e/ou financiar habitações populares. Dentre eles, merecem destaque os Institutos de Aposentadorias e Pensões (IAPs) e a Fundação da Casa Popular (FCP), fundadas respectivamente nas décadas de 1930 e 1940. Passando a ser direcionado ao Estado e aos próprios trabalhadores o encargo oneroso de custear as moradias.

De acordo com Conceição Varon (1988), conceder habitações aos trabalhadores se apropriando de parte de seus salários foi a forma encontrada pelo poder público para solucionar o problema de moradia das classes de baixa renda, como também para garanti ar paz social e a continuidade do processo de produção. Nesse sentido, os programas desenvolvidos pelos países europeus, sobretudo, as sociais-democracias dos anos 1920, no que concerne à produção da habitação social, serviram como exemplos que facilitaram a aceitação do novo modelo de intervenção no Brasil.

\section{As Leis do Inquilinato}

O Estado Novo buscou 0 apoio das massas populares urbanas, intervindo incisivamente nas questões sociais, dentre elas, as condições de trabalho, o controle da produção, a comercialização dos gêneros de primeira necessidade e a provisão de moradias para as classes trabalhadoras e carentes. Vargas atuou com autoridade nesse sentido e propôs desde uma significativa modificação na legislação, à reformulação da justiça trabalhista e à montagem de uma estrutura sindical oficial. Segundo Bonduki (2002), essas ações foram consolidadas com o intuito de controlar as organizações operárias de modo a manter a paz social e direcionar as reivindicações populares. 
No tocante à moradia, até o início da década de 1920, as relações proprietário/locatário eram delineadas pelos artigos cabíveis do Código Civil, para o qual, o valor do aluguel deveria ser estabelecido pelo locador quaisquer que fossem seus critérios, tendo o locatário que aceitar essas condições. Enquadravam-se na mesma linha de determinação, os prazos para o término do contrato e as decisões de despejo. Para modificar tal situação foi publicada uma série de determinações, que ficaram conhecidas como Leis do Inquilinato, que objetivavam essencialmente, impedir que o custo dos aluguéis se elevasse ao ponto de comprometer parte considerável do salário do trabalhador.

A primeira Lei do Inquilinato data do ano de 1921 e foi outorgada por meio do Decreto ㄲo. 4.403. Essa Lei determinou que o prazo mínimo para locação passaria a ser de um ano e a rescisão contratual deveria ser anunciada com, no mínimo, três meses de antecedência. Especificou incisivamente, que 0 aumento do valor dos aluguéis só poderia vigorar dois anos depois do ano de anunciação da referida Lei (BONDUKI, 2002). Essa determinação foi instituída em meio a uma crise no campo da construção civil decorrente da Primeira Guerra Mundial, que comprometeu consideravelmente a produção de moradias nas grandes capitais do país, e às manifestações operárias que eclodiram a partir de meados da década de 1910 (ROLNIK, 1997)41.

Em se tratando das conseqüências dessa primeira versão da Lei do Inquilinato, pode-se ressaltar que o impacto no setor rentista pouco foi percebido, uma vez que para driblar as imposições da Lei, os locatários utilizavam-se do "aviso prévio" de três meses e do direito de despejo para relocar seu imóvel. Por outro lado, a gravidade do déficit habitacional evidenciado no período, dava certa margem para a negociação dos valores dos aluguéis entre os proprietários e os locatários, principalmente nos casos das moradias de baixa renda. Os trabalhadores, por vezes, diante da possibilidade de despejo e devido a outros fatores, como proximidade do trabalho e economia com transportes, optavam pelo acordo entre as partes e a pagar valores um pouco acima dos taxados pela Lei. Isso se repetiu por toda vigência das Leis do Inquilinato.

O período compreendido entre os anos de 1921 e 1928, quando a primeira Lei do Inquilinato foi revogada, equivaleu à primeira fase de vigência da Lei. A partir de então, o Código Civil voltou a legislar as transações referentes às moradias de aluguel, e os interesses dos capitalistas no mercado de moradias e seus critérios duvidosos voltaram a delinear as relações inquilino/proprietário (BONDUKI, 2002).

Seguindo o caminho trilhado por países europeus desde a Primeira Guerra Mundial, foi promulgada em 1942, mais uma vez, uma Lei do Inquilinato. Na França, por exemplo, os valores de locação permaneceram fixos por décadas, desde a Primeira Guerra Mundial. No Brasil, foi efetivamente instituída durante a Segunda Guerra e justificada pelo grave momento de crise econômica e habitacional por que vivia o país no período.

${ }^{41}$ Nesse contexto, cabe ressaltar 0 episódio do movimento dos inquilinos em prol do melhoramento das condições das moradias alugadas e da redução dos valores dos aluguéis em diversos países no período (ROLNIK, 1997). 
Diversas versões da Lei foram promulgadas entre os anos de 1942 e 1964, as quais mantiveram fortes restrições aos reajustes de aluguéis e aos despejos. Para Bonduki (2002), esse período correspondeu à segunda fase da Lei do Inquilinato, que perdurou até 1964, e brecou os reajustes e os despejos injustificados de inquilinos, realizados até então.

Pelo Decreto-Lei no. 4598, de 1942, estabelecia-se o congelamento dos aluguéis das residências pelo prazo de dois anos a contar do momento de publicação da determinação. O decreto tomou por base o valor cobrado pelas locações de moradias em 31 de dezembro de 1941. Por ele, também foi proibida a cobrança de qualquer taxa extra (luvas) e estabelecidas às condições em que o imóvel poderia ser retomado pelo seu proprietário - falta de pagamento, necessidade urgente de reforma no prédio, desapropriação do imóvel e solicitação para residência do locador. Essas determinações eram válidas para todas as locações e sublocações baseadas em contratos verbais ou escritos (BONDUKI, 2002).

A resposta do governo à carência de moradias, sob a forma de congelamento dos aluguéis, acabou por agravar ainda mais a "crise de moradia", desacelerando o mercado de locação/construção e favorecendo os despejos (AZEVEDO, 1996). Segundo Dilvo Peruzzo (1984, p.31), o aumento do número de despejos foi proveniente de brechas encontradas pelos locatários para driblar a lei, dentre as quais estava o direito reservado ao proprietário de vender livremente os apartamentos ocupados, desde que fosse dada prioridade de compra aos inquilinos. Essa dinâmica também contribuiu para que as "classes subalternas" se deslocassem para a periferia e áreas precárias - morros, alagados, loteamentos populares, etc. -, favorecendo o crescimento em extensão da cidade e o aumento do número de favelas.

Muitos julgavam necessária a intervenção estatal no setor da habitação por meio de determinações restritivas diante da conjuntura do país (grave crise de moradias marcada pelo déficit habitacional e elevados valores de aluguéis), enquanto outro segmento populacional, formado principalmente por proprietários de imóveis e especuladores em geral, respaldado pelo direito de propriedade garantido pela Constituição, considerava a atuação governamental inconstitucional. As discussões em torno da veracidade e da importância das determinações governamentais também perduraram por todo período de vigência da Lei.

Em 1943, outro decreto-lei foi outorgado reafirmando as determinações estabelecidas em 1942 e estendendo a abrangência da Lei a todos os imóveis de qualquer natureza ou uso. Passaram a ser contemplados pela legislação, dessa forma, todos os edifícios reservados ao comércio, serviço, indústria e lazer. As condições para o despejo também foram alteradas. A partir de então, os proprietários poderiam realizar a demolição do imóvel para construção já licenciada. Isso se tornou outra justificativa para a realização de despejos, conformando-se mais uma brecha para burlar a Lei pelos proprietários de imóveis (BONDUKI, 2002). 
Em 1944 foi publicado o decreto n-. 6.739, que limitou o valor dos aluguéis em 30\% do valor de venda do imóvel, quantia essa que seria definida após avaliação realizada pelas autoridades municipais. 0 inquilino que se sentisse lesado poderia solicitar outra avaliação do imóvel para redução do preço da locação. As moradias reservadas para locação, por esse decreto, não poderiam permanecer desocupadas por mais de 60 dias, sob condição de pagamento de multa. O valor de locação das construções iniciadas a partir de então poderia ser afixado livremente pelo proprietário, provavelmente, uma iniciativa para incentivar o mercado de construção.

A elevação dos valores dos aluguéis só foi permitida em 1946, com a outorgação do Decreto-Lei №. 9.669. Apesar de singela, garantindo $20 \%$ de aumento, a referida disposição brecou a livre taxação de valores de aluguéis concedida às novas construções em 1944, podendo a partir de então, os inquilinos solicitarem sua redução. Essa determinação foi prorrogada até 1949 e renovada até 1961.

Com o término da Guerra, o congelamento dos aluguéis assegurado pela Lei do Inquilinato não poderia mais ser considerado como uma "legislação de exceção". A partir de então, os investidores atentaram que as disposições acerca do congelamento, estabelecimento e fixação das normas das relações entre inquilinos e proprietários não tinha caráter provisório, o que causou o abandono de muitos do setor (BONDUKI, 2002, p.229).

Com o passar do tempo e com 0 aumento da inflação, o mercado de locação deixou de ser atrativo. Alguns industriários responsáveis pela concepção de vilas operárias passaram a desviar os investimentos no setor e direcioná-los para a própria produção. Outros proprietários se desfizeram de seus imóveis e procuraram investir em atividades mais rentáveis, geralmente em ações de indústrias de pequeno e médio porte, que "convenientemente" ofereciam essas possibilidades na época. Havia ainda os que, por condições financeiras estáveis, se garantiam nos processos judiciais para adequarem os valores dos aluguéis aos ditames do mercado. Estavam inclusas nessa categoria, os recebedores de heranças, viúvas, etc. (BONDUKI, 2002).

A prorrogação do tempo de vigência da Lei do Inquilinato, como relata o Deputado Florenciano Paixão, na justificativa do Projeto de Lei №. 230, de 03 de abril de 1961, foi 0 item chave da política habitacional do período:

Não se compreende mesmo porque o Congresso, até agora, não enfrentou o problema. Há projetos em tal sentido, mas lamentavelmente não têm tido vez na pauta, das prioridades. Nós mesmos apresentamos um projeto de lei em abril de 1960 (que tomou 0 número 1.911) tentando estabelecer os pontos básicos de uma política habitacional, e ensaiando uma programação efetiva, agrupando os meios viáveis de dar combate ao 'deficit' de moradia, através de um 'plano nacional de habitação'. Para ter-se uma ligeira idéia da gravidade do problema, (....). 'Por ocasião do último recenseamento concluído 1950 - foram encontradas aproximadamente 10 milhões de habitações rurais e urbanas, para a população recenseada de 52 milhões de habitantes. Mas, como a média dessas habitações compreendia apenas 2 quartos, aproximadamente 12 milhões de pessoas viviam em promiscuidade. A solução, se possível, parecia ser a construção, em 1951, de 
4 milhões de habitações. Mas a população, aumentando anualmente à volta de 1,3 milhões de habitantes, exigia um aumento anual de 260.000 novas residências. Por outro lado, as casas em via de perecimento precisam de ser substituídas à razão aproximada de 160.000 por ano. Ao todo, se em 1951 houvesse atacado o problema, seria necessário construir 460.000 casas por ano. Muito embora tenham sido construídas muitas habitações desde então, nunca foi alcançado aquele nível, e temos todas as razões para acreditar que a situação é de ano a ano pior, o que será amplamente documentado no recenseamento de 1960. É que o índice de construções vem diminuindo no Brasil, ao invés de aumentar, como sucede na Alemanha Ocidental, na França, no Canadá, na Holanda, na Dinamarca, no Japão e em outros países. Estabelecido o índice de construção civil 100 para 0 ano de 1953, em 1956 cai para 87. Várias são as causas para esse quadro desalentador. As peculiaridades da indústria da construção civil que, em seu primitivismo e pela prática imobilidade de seus produtos, não aceita em grande parte os modernos processos de fabricação em massa, vem aliar-se 0 desinteresse dos capitais privados em inversão de módica remuneração, e a escassa e hesitante atividade governamental no campo de habitação. Esta última, limitada à construção ou ao financiamento aqui e ali, por instituições de previdência, de crédito ou pela Fundação da Casa Popular, de reduzidas amostras do que poderia ser um plano habitacional de grande envergadura, padece de falta de ritmo, da carência de programação segundo as reais necessidades, da ausência de estudos sócio-econômicos, em suma, da inexistência de uma política de habitação. Assim, enquanto esse grave problema não tiver solução conveniente, não se deve permitir, de forma alguma, a liberação dos aluguéis, que poderia de um momento para outro, ensejar acontecimentos do custo de vida, notadamente agora, (...) que tendem a agravar, inegavelmente, os já deficitários orçamentos domésticos das classes assalariadas. Daí a nossa iniciativa de, ainda em tempo, procurar evitar o mal maior, sugerindo a prorrogação da Lei do Inquilinato, com algumas restrições à Lei o.. 3.844, de 5 de dezembro de 1960" (CÂMARA..., 1964, p.35).

Para facilitar 0 acesso às moradias através da aquisição por parte dos inquilinos, foi elaborado 0 Projeto no. 3.834, em 14 de setembro de 1961, que propunha a criação de uma Bolsa Oficial de Imóveis que se responsabilizaria pelas vendas dos imóveis a partir de então. Metade do que excedesse 0 valor do lançamento municipal passou a ser recolhido para o Fundo Nacional de Habitação. No caso de venda do imóvel para o inquilino, o proprietário ficaria isento dessa contribuição. O projeto previa também que todos os bancos seriam obrigados a manter, em suas agências, uma Carteira Imobiliária, na qual, seriam aplicados anualmente $20 \%$ de seus depósitos para financiamentos de, pelo menos, $80 \%$ a juros de $1 \%$ ao mês pelo prazo mínimo de dez anos (CÂMARA DOS DEPUTADOS, 1964).

Ainda em 1961, assumindo que as disposições do Código Civil em relação à locação não seriam retomadas, pois, seria uma calamidade a "volta súbita ao regime de livre fixação do aluguel pelo senhorio", foi elaborado o projeto de Lei no. 3.724, em 05 de dezembro (CÂMARA DOS DEPUTADOS, 1964, p.13). Por ele, a elevação dos valores dos aluguéis era apenas autorizada nos casos de acordo entre as partes ou em casos de revisão judicial. Quesitos como a localização do imóvel, estado de conservação, segurança do prédio, benfeitorias, presença de mobiliário e realização de reformas, passaram a ser considerados na avaliação do prédio para os reajustes dos aluguéis, que não poderia ser superior a 12\% e inferior a 8\% do valor atualizado do imóvel. Nos casos de sublocação, o valor não poderia exceder o total 
do aluguel e deveria ser proporcional à área ocupada e à localização na edificação42. Os despejos só seriam concedidos nos casos em que: o locatário não pagasse 0 aluguel; 0 proprietário solicitasse 0 imóvel ou parte dele para moradia própria, de ascendente ou descendente; o inquilino possuísse imóvel próprio; o empregador solicitasse o prédio locado nas vilas operárias ao empregado nos casos de rescisão de contrato de trabalho; o Instituto ou Caixa pedisse a edificação para moradia de seu associado ou mutuário, promitente comprador; o locador solicitasse o imóvel para demolição ou reforma já autorizada pela municipalidade ou para realização de reparos urgentes; e o locatário infringisse obrigações legais ou cometesse infração grave de obrigação contratual ${ }^{43}$. Eram consideradas contravenções susceptíveis a multas que variavam de $20 \%$ a $200 \%$ do salário mínimo da época ou a prisão por cinco dias a seis meses: cobrar aluguéis acima do estipulado por lei; se recusar a oferecer recibo de pagamento do aluguel; e a não realização de reforma ou demolição após sessenta dias de solicitada (CÂMARA DOS DEPUTADOS, 1964).

Em 1963, a Lei o. 4.240 autorizou novamente os proprietários dos imóveis a cobrar, além da taxa de aluguel, as taxas de luz, força, água, saneamento, condomínio, inclusive aquelas referentes à conservação da edificação, perante a apresentação de recibos. Por essa disposição os aluguéis também foram reajustados de acordo com uma tabela específica de percentuais de majoração (Art.4o $)^{44}$, que permaneceram em voga até 1964:

I - aluguéis de prédios locados no período compreendido entre 31 de dezembro de 1962 a 31 de dezembro de $1961-10 \%$.

II - aluguéis de prédios locados no período compreendido entre 31 de dezembro de 1961 a 31 de dezembro de $1959-30 \%$.

III - aluguéis de prédios locados no período compreendido entre 31 de dezembro de 1959 a 31 de dezembro de $1957-50 \%$.

IV - aluguéis de prédios locados no período compreendido entre 31 de dezembro de 1957 a 31 de dezembro de $1955-70 \%$.

$\mathrm{V}$ - aluguéis de prédios locados no período compreendido entre 31 de dezembro de 1955 a 31 de dezembro de $1950-100 \%$.

$\mathrm{VI}$ - aluguéis de prédios locados no período anteriormente a 31 de dezembro de 1950 200\% (CÂMARA DOS DEPUTADOS, 1964, p.05).

As Leis do Inquilinato publicadas a partir de então se mostraram mais brandas. As rescisões de contrato e as outras infrações, consideradas até o momento como crime contra a economia popular sujeitas à penas severas e à multas bastante elevadas, passaram a se configurar como contravenções,

\footnotetext{
42 No caso das moradias coletivas, o valor das sublocações somadas não poderia exceder 0 dobro do valor de aluguel do imóvel (CÂMARA..., 1964), como praticado na URSS nas décadas de 1920 e 1930.

${ }^{43} \mathrm{O}$ despejo teria que se efetuado em 30 dias após decisão judicial. Em alguns casos, o prazo poderia ser prorrogado em até seis meses. E nos casos em que a solicitação de moradia por parte do proprietário não fosse comprovada em 60 dias, o mesmo teria que pagar multa correspondente a 24 meses de aluguel mais 20\% dos honorários dos advogados (CÂMARA DOS DEPUTADOS, 1964).

${ }^{44}$ Os percentuais especificados pelo Artigo seriam reduzidos pela metade nos casos em que os imóveis apresentassem área construída ou habitada inferior a 120m² (CÂMARA DOS DEPUTADOS, 1964).
} 
sujeitas à leves penas. Os valores dos aluguéis permaneceram fixados e algumas poucas alterações puderam ser vislumbradas até 1964.

Percebe-se, que diversas questões podem ser apontadas como justificativas para outorgar das Leis do Inquilinato: como instrumento de defesa do inquilino (já instalado); para brecar o atrativo que 0 mercado de locação exercia sobre os investimentos e redirecioná-los para outras atividades, principalmente para a formação do parque industrial brasileiro; para reduzir a parcela populacional que vivia basicamente da renda de locação e transformá-la em ativa e produtiva; e para reduzir o custo da reprodução da força de trabalho e ampliar a acumulação das empresas e fornecer mão-de-obra barata às indústrias.

De maneira geral, a outorga das Leis tem como uma das principais conseqüências uma significativa mudança no tocante à provisão de moradias no país, que deixou de ser, a partir essencialmente da década de 1940, de responsabilidade da iniciativa privada para competir ao Estado e aos trabalhadores por meio de financiamentos ou do auto-empreendimento da casa própria. Outra conseqüência foi o agravamento da crise de moradias iniciada no início da década de 1940, que fez com que o número de despejos decorrentes dos Códigos de Posturas e das obras de ampliação e abertura de avenidas, da especulação imobiliária e das realizações das incorporações de imóveis, em especial os apartamentos para venda, aumentasse. Também como efeito, pode-se citar a crescente escassez de moradias, essencialmente, para os migrantes e os despejados que passaram a vislumbrar na construção auto-empreendida na periferia, nas favelas e nas demais ocupações irregulares, a solução para seu problema de abrigo.

Os proprietários de casas de aluguel foram os mais prejudicados com a iniciativa governamental. Os investimentos certos e seguros no setor, a fonte garantida de renda e a crescente valorização de seus imóveis assegurada pela expansão horizontal da cidade, cederam lugar à insegurança que passou a acompanhar essas transações e à redução do número de novas aplicações no setor. Sem falar na inibição de suas ações no tocante ao reajuste, e até mesmo à redução, dos valores das locações (BONDUKI, 2002).

Além dos inquilinos, os beneficiados com a Lei foram os empregadores urbanos que passaram a contar com pelo menos parte de seus empregados ou operários abrigados a um custo decrescente, ajudando a reduzir a pressão sobre os salários.

É interessante atentar também para a contradição intrínseca na proposta governamental de congelamento dos aluguéis. Ao mesmo tempo em que se propunha assegurar moradia digna a baixo custo aos trabalhadores e às classes menos favorecidas, as Leis do Inquilinato contribuíram para 0 agravamento da crise habitacional, marcada principalmente pelo déficit de moradias, e para o despejo de muitos. Por outro lado, ao visarem o controle do mercado rentista e o redirecionamento de capital para 
outras atividades, em especial para a indústria, retirou de cena uma série de investidores no setor e incentivaram aqueles que permaneceram nele, a construírem ou adquirirem outras edificações, para nelas, aplicarem as brechas nas determinações que a nova aquisição ou construção garantia para os reajustes de aluguel. Dessa forma, as Leis do Inquilinato não brecaram o mercado de locação, apenas direcionaram parte de seus investidores para outros setores e atividades, e fizeram com que a outra parte se reestruturasse.

Sem dúvidas, essa medida resultou numa ampliação do apoio popular, principalmente das camadas mais carentes, ao governo. No entanto, foram mantidos os elevados índices de inflação, que asseguravam os lucros e interesses dos capitalistas. De qualquer forma, a Lei do Inquilinato resultou numa maior adesão ao modelo de moradia própria isolada por parte dos trabalhadores e da classe média em geral, atendendo assim, a um dos objetivos governamentais.

\section{Os Institutos de Aposentadorias e Pensões (IAPs)}

Um segundo viés da política habitacional no Brasil, após 1930, refere-se à ação dos Institutos de Aposentadoria e Pensões (IAPs) que exerceram importante papel no que diz respeito à concepção e produção de moradias para trabalhadores. Fundados na década de 1930 representam, segundo Bonduki (2002), o início da atuação do Estado na produção direta de conjuntos habitacionais e financiamento de moradias para trabalhadores em grande escala no Brasil. Criados para cada carteira profissional, durante as duas gestões do presidente Getúlio Vargas (1930-1945), com 0 intuito de organizar 0 setor previdenciário do Brasil, os IAPs foram precedidos pelas Caixas de Aposentadorias e Pensões - CAPs-e propiciaram vultosos recursos para o financiamento de residências populares.

Nos primeiros anos da década de 1920, para facilitar o acesso da população carente à casa própria por meio de financiamentos e, em segundo plano, à casa higiênica alugada, o Estado reorganizou o sistema previdenciário do país, até então, sob a responsabilidade de entidades autônomas, principalmente as mútuas. Essa ação começou a ser esboçada em 1923, quando foi outorgada a Lei Elói Chaves que deu origem às Caixas de Aposentadorias e Pensões (CAPs), cuja função era a de efetuar a organização e exercer 0 controle das ações dos sistemas previdenciários privados pré-existentes (BONDUKI, 2002).

Segundo Marta Ferreira Farah (1983), o poder público acreditava que as instituições privadas estavam dando respaldo às greves operárias que começaram a eclodir a partir de meados da década de 1910 e, portanto, era necessário o controle de suas ações, justificando dessa maneira, a criação das Carteiras Prediais.

Inicialmente, as CAPs só poderiam adquirir títulos de dívidas públicas e edifícios para abrigar suas instalações. Aplicar recursos no campo da habitação social na forma de construção de moradias para seus associados sob garantia hipotecária, só foi permitido após a publicação do Decreto oo 19.469 (Art. 2o), de 
17 de dezembro de 1930 (BONDUKI, 2002). No entanto, até a criação das Carteiras Prediais de cada IAP, em 1937, a atuação das CAPs foi ínfima. De acordo com Rubens Porto (1939), foram cerca de 570 unidades habitacionais construídas no Rio de Janeiro e aproximadamente 100 em Belo Horizonte e Porto Alegre.

Para aperfeiçoar o sistema previdenciário do país e atender de forma mais eficaz às necessidades básicas dos trabalhadores foram criados, a partir de 1933, os Institutos de Aposentadorias e Pensões (IAPs), para algumas categorias de trabalhadores, dentre elas: bancários, industriários, comerciários, ferroviários, estivadores, servidores públicos, etc. Inicialmente, os Institutos tinham como enfoque principal, propiciar aposentadorias e pensões aos seus beneficiados, ficando a construção e/ou aquisição de moradias em segundo plano. A atuação dos IAPs no setor da habitação social, mais especificadamente, na provisão de moradias aos seus beneficiados, permaneceu limitada até 1937, quando, por meio do Decreto № 1.749 foram criadas as Carteiras Prediais de cada Instituto. Por esse decreto, os referidos órgãos ficaram autorizados a utilizar até a metade de suas reservas na construção e/ou financiamento de habitações populares. O modo de atuação de cada IAP no setor habitacional, 0 estabelecimento da taxa de juros anual (reduzida de $8 \%$ para 6\%) e a ampliação do prazo para amortização das dívidas (que findava em 15 anos e passou a ser considerada entre 10 e 25 anos), foram outras disposições definidas pelo Decreto no 1.749 (FARAH, 1983).

Segundo Bonduki (2002), as mudanças originadas pelo supracitado decreto facilitaram 0 acesso ao financiamento e aquisição de moradias por parte dos trabalhadores associados mais carentes, que segundo 0 autor, permaneciam até então à margem do sistema. Ao mesmo tempo, atendia interesses das classes mais abastadas ao garantir benefícios àqueles que já possuíam casa própria. De acordo com 0 autor, essa atuação dúbia marcou todo o período de vigência dos Institutos.

Nesse sentido, diversas críticas foram lançadas ao sistema de apropriação de recursos sociais dos IAPs para a edificação de moradias. Cabe ressaltar, que essa oposição não era contra a intervenção do Estado na provisão de moradias, mas sim, à gestão dos recursos da previdência e às políticas instituídas por esses órgãos, como por exemplo, financiar moradias para os contribuintes de classe média e alta. Essa questão foi discutida na Jornada de Habitação Econômica, promovida pelo IDORT (CORREIA, 2004).

Com a intensificação da crise de moradias após a II Guerra Mundial, Vargas ampliou mais uma vez o limite para aplicação das Carteiras Prediais dos IAPs e criou a Comissão de Aplicação das Reservas da Previdência Social (CARPS) para efetuar o controle e fiscalização de suas ações.

Para Bonduki (2002), com o fim do primeiro governo Vargas, em 1945, foi interrompido um processo institucional que caminhava para a criação de uma política habitacional consistente para o país, uma vez que se dispunha de recursos acumulados nos fundos dos IAPs, de capacitação técnica, 
apresentada nos inúmeros projetos dos Institutos no decorrer da década de 1940, de reconhecimento por parte da sociedade da importância e prioridade da questão habitacional, e de vontade política do governo. Segundo 0 autor, interesses e enfoques diferenciados dos adotados por Vargas nos governos subseqüentes, trataram a questão da moradia social mais como uma estratégia política, para assegurar apoio eleitoral, do que elemento preponderante de uma política pública.

Dentre outras conseqüências, intensificou-se à busca por parte da própria população por soluções informais para o problema da habitação, como a favela e a casa auto-empreendida em loteamentos irregulares. No âmbito governamental, por sua vez, a saída encontrada para uma intervenção enérgica no setor habitacional social foi a prorrogação da vigência da Lei do Inquilinato.

A partir da década de 1950, a intensificação da industrialização inserida no projeto desenvolvimentista do governo do presidente Juscelino Kubitschek levou à formulação de outras medidas com o intuito de firmar uma política habitacional no Brasil. Em 1954, intentando a unificação dos Institutos foi criado, por meio do Decreto № 7.536 de 1954, o Instituto de Serviço Social do Brasil (ISSB). Com essa ação governamental, superar-se-ia o cooperativismo que marcava a atuação dos IAPs e que limitava 0 atendimento da demanda habitacional, o que foi chamado de "política redistributiva" (BONDUKI, 2002, p.119).

A unificação dos recursos dos IAPs era vislumbrada como uma possibilidade para ampliar a atuação dos órgãos no território brasileiro, assim como, para aumentar o volume e a dimensão de suas construções. Um motivo da resistência à unificação dos Institutos era a diferença existente entre os recursos acumulados pelas diferentes carteiras prediais das classes trabalhadoras. Entre os bancários e comerciários, por exemplo, havia uma diferença considerável no tocante aos valores acumulados, como se verá mais adiante. Em 1964 o novo governo extinguiu os IAPS e centralizou a previdência no INPS Instituto Nacional de Previdência Social - transferindo, por outro lado, as atribuições das Carteiras Prediais para o $\mathrm{BNH}^{45}$.

Em se tratando da estrutura dos IAPs e sua regulamentação, de modo geral, os Institutos eram responsáveis por garantir pagamentos mensais aos seus associados em caso de doenças, incapacidade ou morte do chefe de família, assistência médica, investimentos em setores diversos, inclusive em obras públicas, além de assistência aos programas sociais governamentais, inserindo-se nessa categoria, a produção de moradias.

Cada Instituto era regulamentado por dispositivos legais específicos, o que resultou numa diversidade de atuação, produção, qualidade e serviços. O controle deles passou a ser de responsabilidade do Estado, que atuava por meio do Ministério do Trabalho, Indústria e Comércio (MTIC). Ao MTIC cabia o controle da gestão e a nomeação dos presidentes de cada Instituto (FARAH, 1983).

${ }^{45}$ As fontes e os recursos para essa instituição eram provenientes do Fundo de Garantia por Tempo de Serviço (FGTS) e do Sistema Brasileiro de Pensão (SBPE). 
Apesar de cada IAP possuir dispositivos legais próprios, eles seguiam um padrão no que condiz às operações imobiliárias, baseando suas ações em três planos: o Plano $A$ - equivalia à locação ou venda de unidades habitacionais adquiridas ou construídas pelos Institutos; o Plano $B$ - era referente ao financiamento para construção de moradia em terreno próprio; e o Plano $C$ - referia-se aos empréstimos hipotecários concedidos à pessoa física ou jurídica e a todas as outras operações imobiliárias pertinentes aos IAPS, com o objetivo de elevar o volume de recursos capitados (BONDUKI, 2002). Esse modelo de organização das ações imobiliárias foi inicialmente aplicado pelo IAP dos Industriários (IAPI) e foi paulatinamente adotado pelos demais Institutos, se tornando a base para a atuação da grande maioria deles no campo habitacional (FARAH, 1983).

Percebe-se que os planos A e B possuíam um objetivo mais social e o plano $\mathrm{C}$ representava a intenção dos Institutos em assegurar a rentabilidade para as reservas acumuladas. Apesar de se destinar à produção de moradias populares os IAPs, por vezes, atendiam os associados de classe média e alta, chegando em alguns momentos, a superar com esta ação o volume de financiamentos sociais (BONDUKI, 2002).

Respaldados pelo Plano C, os IAPs também construíram diversas edificações de usos distintos, desde indústrias a edifícios comerciais, e financiaram obras públicas, como as da Companhia Siderúrgica Nacional de Volta Redonda e a construção de Brasília (FARAH, 1983).

Os IAPs, assim como as CAPs, atuavam de acordo com um regime de capitalização, aplicando os fundos e visando alcançar lucros. Isso garantia uma fonte alternativa de investimentos públicos. O esquema de arrecadação, por sua vez, se estruturava nas contribuições do Estado, dos empregadores e dos empregados. No entanto, as duas primeiras "pernas" do tripé permaneceram quase sempre inadimplentes, sendo os próprios trabalhadores os verdadeiros contribuintes e responsáveis pelos financiamentos de moradias efetivados pelos Institutos e de diversas obras realizadas pelo Estado. Dessa forma, a administração pública não alocou recursos onerosos para solucionar o problema de déficit habitacional evidenciado no período, ficando o encargo maior nas "mãos" dos próprios trabalhadores (BONDUKI, 2002).

Em se tratando dos valores cobrados pelos aluguéis dos imóveis construídos ou adquiridos pelos IAPs, pode-se constatar que não havia uma legislação específica. As transações eram pautadas pelas Leis do Inquilinato. Nesse sentido, a possibilidade de lucro e, conseqüentemente, do aumento das reservas previdenciárias foram prejudicadas com a outorga das Leis do Inquilinato, principalmente, a partir de 1942

A redução dos lucros dos Institutos também advinha das transações que se enquadravam nos Planos A e B. Como os financiamentos concedidos eram acompanhados por baixos juros e por longos períodos para amortização da dívida, entre 10 e 25 anos, as reviravoltas econômicas fizeram com que 
esses valores se tornassem relativamente baixos, ou se depreciassem com o tempo. Isso resultou, segundo Bonduki (2002), numa considerável elevação dos valores das prestações e/ou aluguéis a partir, principalmente, da década de 1950. Segundo o autor, essa foi a maneira encontrada pelos órgãos de se precaverem de perdas futuras. Farah (1983), afirma que nesse mesmo período, o número de imóveis construídos pelos IAPs que permaneceram desocupados aumentou significantemente, assim como, 0 número de invasões a essas unidades habitacionais.

\section{Fundação de Casa Popular (FCP)}

A crise habitacional evidenciada durante a década de 1930 e início da década de 1940, caracterizada pelo déficit de moradias e que atingiu grande parcela da população, inclusive a classe média, agravou-se ainda mais no Pós-Segunda Guerra. Isso ocorreu devido ao aceleramento do processo de urbanização das cidades, resultante do progresso econômico alcançado durante a Guerra e das migrações decorrentes. Nesse contexto, verificou-se a elevação dos preços dos materiais de construção e a redução do número de unidades habitacionais construídas e para locação, em decorrência das Leis do Inquilinato. Outro fator que contribuiu em demasia para a exacerbação da crise no setor de moradias foi 0 fim do Estado Novo e a interrupção dos programas e projetos estabelecidos pelo presidente Getúlio Vargas. Essa conjuntura determinou à perpetuação da crise de 1945 na década de 1950 e gerou, segundo Bonduki (2002), uma grande pressão social para que o governo dinamizasse a produção de moradias para a população.

A gravidade da questão habitacional foi reconhecida pela população, e nas eleições presidenciais seguintes, as propostas em geral cambiavam no sentido de buscar solucionar esse quadro. Dutra, eleito 0 presidente sucessor de Vargas, previu em seu programa de governo a instituição de uma Caixa Nacional de Habitação para a construção de 100 mil casas populares. Sendo assim, em maio de 1946 foi criada a Fundação da Casa Popular (FCP), regulamentada pelo Decreto № 9.218, equivalendo ao primeiro órgão federal a tratar exclusivamente da questão da produção de residências no país (ANDRADE e AZEVEDO, 1982).

A atenção especial dada à habitação pelo novo presidente da República foi justificada, de acordo com Bonduki (2002), por compensar o viés conservador de seu governo. Já Andrade e Azevedo (1982, p.20), acreditavam que a FCP foi parte integrante de uma estratégia política de maior cunho, que objetivava ao mesmo tempo brecar com 0 avanço do Partido Comunista no país ${ }^{46}$ e ganhar a simpatia das camadas populares proporcionando-lhes moradias próprias. Dessa forma, a moradia se mostrava como um meio de "angariar legitimidade e alcançar penetração junto aos trabalhadores". O mandato de Dutra, nesse sentido, foi marcado pela repressão aos movimentos populares, aos sindicatos e ao Partido

\footnotetext{
${ }^{46} \mathrm{O}$ candidato à presidência da República lançado pelo Partido, Fúzia, alcançou 600.000 votos, o que preocupou as elites dirigentes e culminou na declaração de ilegalidade do Partido Comunista (PC) e a cassação de seus parlamentares (quatorze deputados e um senador), no ano de 1947 (ANDRADE e AZEVEDO, 1982).
} 
Comunista em especial. Dessa forma, fortalecer os laços populistas garantidos pela construção de moradias para trabalhadores representava uma forma de apaziguar os ânimos sociais.

A Fundação da Casa Popular objetivava construir milhares de habitações para a população de baixa renda em todo o território nacional, incluindo a produção de habitações rurais num curto espaço de tempo, e realizar obras de abastecimento de água, esgotos e relacionadas à energia elétrica. Visava também, financiar empresas e indústrias no campo da habitação popular - inclusive àquelas de materiais de construção - e realizar estudos buscando o barateamento da construção. Propunha-se ainda, a concentrar as reservas dos IAPs, se responsabilizando por toda a construção de moradias populares no território nacional (BONDUKI, 2002).

De acordo com Andrade e Azevedo (1982), essas iniciativas tinham como propósito principal fortalecer o mercado da construção civil - técnica, profissional e pesquisa - e não apenas suprir as carências de infra-estrutura e saneamento consideradas na época os maiores entraves para 0 desenvolvimento da economia das cidades. Correspondiam à conscientização do poder público de que não bastavam medidas que complementassem as ações das administrações locais, mas também, era imprescindível fortalecer o mercado, estimulando o aumento da produção de materiais de construção, por exemplo, além de qualificar a mão-de-obra, modernizar as estruturas das prefeituras, e estudar as práticas comunitárias de construir, as técnicas e os materiais utilizados nas diferentes regiões do país.

Diversas foram as oposições à criação da Fundação. Dentre elas, pode-se citar o receio dos construtores e demais profissionais vinculados à construção civil em relação à escassez de materiais de construção, em decorrência da Guerra. Bonduki (2002) coloca que o temor se encontrava no fato de que um projeto desse vulto poderia absorver toda a oferta de materiais disponíveis para a construção privada, prejudicando assim o setor. Outras oposições advinham do Partido Comunista, das cooperativas e dos sindicatos trabalhistas que temiam que a necessidade por moradias das classes trabalhadoras não fosse mais assistida com a centralização da produção habitacional brasileira na FCP. Os sindicalistas também se mostravam contra a Fundação por interesse em manter a posição privilegiada que ocupavam no "aparato administrativo dos IAPs", e o Partido Comunista, por acreditar que as propostas da FCP eram ilusórias. No entanto, a maior oposição era em relação à interrupção da produção por parte dos IAPS (RIBEIRO, 1997).

A falta de respaldo político - traduzido em recursos financeiros, apoio dos estados ou de legislação que conferisse ao órgão vantagens para negociar com os municípios - e de recursos não orçamentários nas reservas da Fundação da Casa Popular impossibilitaram a execução de seus propósitos iniciais - a unificação dos fundos de reservas e a produção de moradias populares, até então realizadas pelos Institutos de Aposentadorias e Pensões. Para tentar transpor essa barreira, foram criadas taxas sob a venda e transmissão de bens, a serem arrecadados pelos estados (FARAH, 1983). Contudo, a 
maioria das administrações estaduais se mostrou contra essa política da FCP ou contra o ônus que acarretaria aos cofres públicos mais essa função. E os estados que se prontificaram a arrecadar nem sempre repassavam os valores à Fundação. Simultaneamente, foram fundados por alguns estados e municípios do país, órgãos responsáveis pelo provimento de habitações, como foi o caso da CECAP (Caixa Estadual de Casas para o Povo) de São Paulo, da FUNDAHP (Fundação da Habitação Popular do Rio Grande do Norte), dentre outros (GAP, 1985). Cabe ressaltar, que muitas dessas instituições permaneceram inoperantes por significativos espaços de tempo.

Diante dessa conjuntura, os referidos impostos foram extintos por meio da Lei ㄲo.1.473, de 24 de novembro de 1951, e substituídos por "dotações orçamentárias decrescentes para os dez anos seguintes", dando fim à possibilidade de auto-suficiência financeira da FCP em relação à União (ANDRADE e AZEVEDO, 1982, p.24). Dessa forma, os projetos propostos e desenvolvidos pela Fundação ficaram dependentes exclusivamente dos orçamentos da União, o que em muito limitou a sua atuação no campo da habitação social no país (SACHS, 1999).

No tocante ao acesso às habitações produzidas pela Fundação, os critérios recaiam sobre 0 tempo de permanência do solicitante no país (mais de 10 anos), à nacionalidade brasileira, ao tamanho da família, à renda mensal dela, e ao fato do solicitante não possuir imóvel em seu nome. Dava-se preferência aos trabalhadores com atividades particulares em relação aos servidores públicos ou de autarquias, e às famílias que possuíssem no mínimo cinco pessoas. Ainda poderiam solicitar moradias os cidadãos cuja renda anual não ultrapassasse Cr\$60.000,00 (sessenta mil cruzeiros) (ANDRADE e AZEVEDO, 1982). Dessa forma, o plano da Fundação atendia desde desempregados aos trabalhadores da classe média por não especificar um piso de renda e pelo teto determinado.

A FCP construía residências por empreitada e por administração direta, sendo essa abandonada com o passar dos anos ${ }^{47}$. Mas, todos os projetos arquitetônicos eram desenvolvidos pelos profissionais ligados ao órgão. Nesse sentido, a FCP dispunha de uma grande variedade de tipologias habitacionais que variavam de região para região, dependendo das diversas condições locais (clima, topografia, solo, vegetação, etc.). As unidades habitacionais geralmente eram semelhantes nos conjuntos, e apresentavam cerca de $70 \mathrm{~m}^{2}$ nas casas térreas e $60 \mathrm{~m}^{2}$ nas assobradadas. Em se tratando da planta, as moradias apresentavam sala, três quartos, banheiro, cozinha e área de serviço (ANDRADE e AZEVEDO, 1982).

Os terrenos onde eram construídos os conjuntos e realizadas as obras de infra-estrutura eram de responsabilidade do Estado. Alguns terrenos também foram doados pelos Institutos de Aposentadorias e Pensões (IAPs). Nesses casos, era de responsabilidade da Fundação a realização das obras necessárias de abastecimento de água, distribuição de luz elétrica, pavimentação, coleta de esgotos, dentre outras, e a reserva de uma parcela ou a totalidade das unidades habitacionais aos associados do Instituto "doador". A

${ }^{47}$ A partir da década de 1950, a empreitada por meio de licitação tornou-se exclusivamente o modelo de atuação da Fundação. 
decisão de onde construir os conjuntos residências baseou-se essencialmente nas solicitações da municipalidade e no apoio dado pelas prefeituras.

A partir da década de 1950, a intensificação da industrialização inserida no projeto do governo do presidente Juscelino Kubitschek e a debilidade financeira da FCP culminaram em tentativas de se modificar a estrutura do referido órgão. A primeira tentativa ocorreu em 1953, quando se cogitou a possibilidade de criação de uma carteira hipotecária que permitiria a concessão de empréstimos de até Cr $\$ 50.000,00$ (cinqüenta mil cruzeiros) aos pequenos proprietários de terrenos que almejavam construir casas próprias. Posteriormente, essa carteira seria ampliada à escala de banco, o Banco Hipotecário de Habitações, aos moldes dos IAPs. Outra medida formulada com o intuito de firmar uma política habitacional no Brasil foi a criação de uma estrutura institucional voltada às questões sociais, representada pelo Ministério do Bem Estar Social, incluindo uma subsecretaria para habitação e favela. No entanto, essas mudanças só foram vislumbradas com a criação do BNH. Em 1961, mais uma vez, propôs-se a reformulação da política habitacional com o Plano de Assistência Habitacional e a criação do Instituto Brasileiro de Habitação, formulados durante os sete meses do Governo de Janio Quadros, que devido à sua renúncia nunca saiu do papel.

A Fundação da Casa Popular foi extinta em 1964 e suas atribuições foram transferidas para 0 Banco Nacional de Habitação (BNH), passando a ser considerada pelo novo governo como um "símbolo da ineficiência governamental" (BONDUKI, 2002, p.125).

\subsection{A ATUAÇÃO DOS IAPS E DA FCP NO PAíS: PRODUÇÃO E ARQUITETURA}

Criados inicialmente com 0 intuito de organizar o setor previdenciário do Brasil, os IAPS empreenderam a construção de um número significativo de habitações entre as décadas de 1930 e 1960. No período compreendido entre os anos de 1933 e 1936, embora as reservas do sistema previdenciário tivessem quadruplicado, manteve-se a tendência de aquisição de títulos e a produção de moradias restringiu-se à construção de três conjuntos com 576 unidades habitacionais, no Rio de Janeiro, destinados a funcionários públicos e 118 unidades distribuídas por Belo Horizonte, Rio de Janeiro e Porto Alegre (BONDUKI, 2002).

A partir de 1937, apesar da liberação de uma porcentagem maior das reservas para que os IAPS executassem financiamentos habitacionais, por meio do já citado Decreto № 1.749, os investimentos no Plano $\mathrm{C}$ foram maiores do que nos Planos $\mathrm{A}$ e $\mathrm{B}$. Esse quadro se manteve até meados da década de 1940. Contudo, de 1945 à década de 1950, a habitação social tornou-se efetivamente prioridade. A produção de moradias por parte dos Institutos nesse período correspondeu a 52,1\% das unidades habitacionais produzidas (Plano A) em todo o tempo de existência dos órgãos (BONDUKI, 2002).

Isso pode ser justificado, possivelmente, pelo fato de que nos primeiros anos de atuação, os Institutos tiveram que montar e/ou aumentar suas reservas de fundos para investir na compra de terrenos 
para efetuar as transações a que se propunham. Para tanto, foi necessária a aplicação em atividades mais rentáveis, como a construção de residências e apartamentos para as classes média e alta, e o financiamento de obras públicas. Em contrapartida, as ações efetivadas, a partir de 1945, pelo presidente Dutra no campo social voltaram-se para a satisfação das necessidades básicas populares, em especial a habitação, e garantiram volumosos recursos para aplicação nos Plano A e B dos IAPs. Esse foi o período da construção dos grandes conjuntos habitacionais, como 0 Realengo.

Por atuarem em diversos ramos e atividades, se distanciando do seu propósito social, os IAPS foram criticados, e sua existência e seriedade questionadas em alguns momentos, mais intensamente a partir da década de 1950. Por outro viés, o sistema de concessão de créditos para a realização de obras dos diversos tipos e edificações pelo país, garantido pelo Plano C, transformaram os Institutos de Aposentadorias e Pensões, de acordo com Bonduki (2002), nos maiores detentores individuais de terra urbana do país na década de 1940.

De modo geral, a atuação dos IAPs se caracterizou por uma política social incompleta. Somente os trabalhadores associados tinham o direito de financiar um terreno ou imóvel, ou adquirir empréstimos junto às Carteiras Prediais dos Institutos, ficando a população de mais baixa renda, excluída desse processo. Bonduki (2002) coloca que essa "limitação" de atuação ocorreu devido ao preconceito para com os moradores das favelas e outras ocupações ilegais, considerados pela opinião pública em geral, como marginais não merecedores de atenção por parte do Estado. Somente eram considerados merecedores de assistência habitacional por parte do poder público, os trabalhadores vinculados aos sindicatos.

Apesar de somente assistir aos trabalhadores que possuíssem carteira assinada, excluindo do processo as classes menos favorecidas, os trabalhadores rurais e os trabalhadores informais urbanos, os IAPs exerceram importante papel no que se refere à concepção de moradias em todo o país, representando 0 alargamento da atuação do Estado na produção direta de conjuntos habitacionais e 0 início do financiamento de moradias para trabalhadores.

No âmbito da Fundação de Casa Popular, a produção habitacional foi mais modesta que a realizada pelos IAPs e, até mesmo, àquela que o próprio órgão se propunha inicialmente (100.000 moradias). Segundo Bonduki (2002), de 1946 a 1964, a FCP construiu um total de 18.132 unidades habitacionais ${ }^{48}$, enquanto os Institutos construíram 123.995 moradias, sem contar com os apartamentos financiados para a classe média e alta. Mais especificadamente, a produção da FCP correspondeu a um décimo das habitações sociais concebidas pelos IAPs. Cabe ressaltar, porém, que a produção da FCP foi destinada, principalmente, aos pobres sem emprego regular. Comparada à produção dos IAPs, a ação da Fundação atendeu mais àqueles residentes em cidades do interior, não atendidos pelos programas dos IAPS.

\footnotetext{
${ }^{48}$ Até dezembro de 1960 foram construídos pela Fundação apenas 143 conjuntos, totalizando 16.964 unidades habitacionais.
} Isto é, de 1961 a 1964 apenas 1.168 unidades foram edificadas pelo referido órgão. 
Da mesma forma que os Institutos de Aposentadorias e Pensões, o período de maior produção da FCP se deu nos quatro anos posteriores a 1946, correspondendo a 45\% das moradias construídas pela FCP durante sua existência (BONDUKI, 2002, p.130). A maior parte dos grandes conjuntos habitacionais construídos se concentra nos grandes centros urbanos que apresentavam, na época, mais de 50 mil habitantes. Porém, o maior número de grupos habitacionais foi edificado nas pequenas e médias cidades brasileiras, correspondendo a cento e três conjuntos, cerca de $70 \%$ da produção de conjuntos habitacionais da FCP. A atuação da Fundação se concentrou nas cidades da região Sudeste (11.837 unidades distribuídas em 84 conjuntos), principalmente, nas cidades do Rio de Janeiro e Belo Horizonte, correspondendo a 40\% de suas realizações. O Nordeste foi contemplado com 2.317 moradias distribuídas em 31 conjuntos (14\%). O Centro-oeste com 10 conjuntos, um total de 1.860 unidades habitacionais, correspondendo basicamente às moradias erguidas em Brasília. O Sul recebeu 950 unidades ou 18 conjuntos residenciais, isto é, $5 \%$ da produção da FCP no país. Enquanto a região Norte, assim como, as cidades como São Paulo, Salvador e Porto Alegre foram excluídas do processo (ANDRADE e AZEVEDO, 1982).

Juntos, em um período de 27 anos, entre os anos de 1937 e 1964 (tempo de vigência dos órgãos), excluindo-se os financiamentos realizados para a classe média, os Institutos de Aposentadoria e Pensões e a Fundação da Casa Popular edificaram aproximadamente 140 mil unidades habitacionais, uma média de um pouco mais de cinco mil por ano, atendendo cerca de $10 \%$ da população brasileira que vivia em cidades com mais de 50.000 habitantes (BONDUKI, 2002). Isso, sem contar com as moradias construídas e/ou financiadas por outros órgãos privados, estaduais e municipais atuantes nesse período no país.

Em se tratando da espacialização da produção dos Institutos e da Fundação, os estados da região Sudeste foram privilegiados em detrimento aos demais estados brasileiros. Segundo Bonduki (2002), a referida região recebeu aproximadamente $70 \%$ da produção habitacional desses órgãos estatais. Isso pode ser justificado pelo fato daqueles estados apresentarem uma maior concentração populacional operária e um maior potencial econômico.

Nessa produção, evidenciam-se soluções tradicionais ao lado de empreendimentos com inovações arquitetônicas e urbanísticas. Projetos que simplificaram processos construtivos com a incorporação de tecnologias inovadoras e eliminação de ornamentos, com a uniformização de unidades e blocos e a racionalização do traçado urbanístico segundo os preceitos dos CIAMs. Surgiram novas tipologias como blocos de habitação coletiva e unidades de habitação, além de propostas urbanísticas associadas ao modelo de cidade-jardim. Diversos dos projetos em muito se aproximam das experiências realizadas nos países europeus, em especial as sociais-democracias do Entre-Guerras, e das propostas geradas no debate internacional, sobretudo, provenientes dos Congressos Internacionais de Arquitetura Moderna. 
Nesse sentido, sabe-se que até a década de 1930, predominava no Brasil - no campo da habitação para trabalhadores - a lógica rentista de produção habitacional presente nas vilas com moradias geminadas ou nos grupos de casas isoladas sem o apoio de equipamentos e, por vezes, sem serviços básicos de água, esgotos, iluminação e transporte. A intervenção do Estado no campo da habitação ocorreu concomitantemente com a introdução das propostas modernistas no setor, trazendo um "novo conceito" de moradia. Cabe ressaltar, no entanto, que até mesmo nas décadas posteriores a 1930, alguns Institutos produziam sob diretrizes higienistas, como foi o caso de alguns conjuntos construídos pelo IAP da Central do Brasil e da Light no Rio de Janeiro.

Os profissionais, engenheiros e arquitetos, envolvidos no processo projetual e na construção dos conjuntos habitacionais, adotaram modelos e práticas construtivas que traduziam preceitos da arquitetura e urbanismo modernos. A adoção do "modelo" moderno pelos Institutos também foi justificada pelo fato dessa arquitetura ter sido eleita como condizente com o projeto de desenvolvimento nacional proposto pelo então presidente Getúlio Vargas. Acrescia-se a isso, a latente necessidade de renovação do modo de morar e de novas soluções habitacionais.

Bonduki (2002, p.150) afirma nesse sentido, que a mudança na atuação governamental no setor habitacional e a adoção do "modelo moderno" em algumas de suas realizações também foi resultado da influência do arquiteto Rubens Porto, ligado ao presidente Vargas e assessor técnico do Conselho Nacional do Trabalho, órgão responsável pela "normatização, fiscalização e aprovação dos procedimentos dos IAPs". Foi ele quem formulou a regulamentação para a atuação das Carteiras Prediais desses órgãos. O referido arquiteto era, portanto, um reformador social do Ministério do Trabalho com grande voz sobre a atuação dos IAPS, podendo ter influenciado às realizações desses órgãos. Cabe ressaltar, que ao mesmo tempo em que era ligado à Igreja Católica, Porto defendia uma arquitetura moderna, desprezando 0 supérfluo com materiais e elementos decorativos. Propôs nesse sentido, modelos habitacionais que em muito se aproximavam de propostas corbusianas, defendendo: a construção em blocos coletivos, primando à economia de material, de preferência em espaços afastados no núcleo central da cidade (menor custo dos terrenos), com no máximo quatro andares, não tornando necessária a utilização de elevador o que em muito encareceria as obras; 0 uso de pilotis, para aproveitar o espaço térreo, facilitando a circulação de vento e de pessoas (espaço comum); quando possível à aplicação da tipologia duplex, que além de proporcionar economia garante mais intimidade (separação entre área social da íntima); a construção racionalizada e de preferência auto-suficiente, com assistência básica de equipamentos coletivos e serviços urbanos; e assentamentos privilegiando o tráfego de pedestres em detrimento ao de automóveis, com vias de circulação de carros na periferia. Para o arquiteto, as unidades de moradia deveriam ser pensadas juntamente com o contexto urbano, segundo eixos estruturadores, e de acordo 
com as capacidades naturais do meio (influência do conceito de Cidade-Jardim). As moradias deveriam ser mobiliadas, garantindo vantagens de ordem econômica e higiênica.

Há ainda os que sustentem a afirmativa de que a habitação mínima proposta, a partir de um discurso modernizador, era um intento das elites do país em reproduzir em escala bastante reduzida 0 modelo da casa burguesa (SACHS, 1999; TRAMONTANO, 1998).

De qualquer forma, as unidades habitacionais para os associados dos IAPs deveriam ser mínimas, de modo que o custo para com a sua produção se enquadrasse nos salários dos trabalhadores. As moradias tinham, essencialmente, que ser acessíveis aos trabalhadores de renda mais baixa e, também por esse motivo, se justificava a busca pela economia em suas realizações. Contudo, apesar de baratas, as habitações não poderiam perder a qualidade, a habitabilidade, o conforto e a higiene. Dessa forma, as construções concebidas pelos IAPs se caracterizavam pela qualidade e, conseqüentemente, pela durabilidade, representando a "forma de garantir o investimento" e reaver o capital empregado (BONDUKI, 2002, p.158). A rapidez na construção contribuía para a redução das despesas com a direção e a fiscalização das obras, e equivalia também a uma redução do tempo para reaver os investimentos e, necessariamente, os lucros. A produção em série e padronizada, portanto, não visava somente tornar a moradia acessível a todos os trabalhadores, mas também, sobrelevar os lucros com o empreendimento.

Dentre os profissionais arquitetos engajados na produção habitacional social realizada pelos IAPs, destaca-se Carlos Frederico Ferreira, autor do primeiro bloco habitacional moderno do Conjunto do Realengo, construído entre os anos de 1939 e1943, no Rio de Janeiro. O arquiteto foi chefe do setor de projeto e engenharia do IAPI, desde a sua criação até a extinção do órgão, em 1964, influenciando diretamente na produção do Instituto no campo habitacional. Segundo Bonduki (2002), o IAPI foi o Instituto que mais incorporou os ditames modernos em suas realizações habitacionais. Foi também, de acordo com o autor, o que mais construiu moradias na década de 1940.

No tocante às tipologias habitacionais concebidas pelos Institutos pode-se citar basicamente quatro: os blocos de apartamentos (Figura 24), os conjuntos mistos (moradias isoladas, geminadas e blocos de apartamentos) (Figura 25), as residências coletivas para solteiros e as vilas suburbanas (Figura 26), nas quais, foram aplicados preceitos inovadores em relação à urbanização associados, sobretudo, aos modelos de cidade-jardim e de Unidade de Vizinhança de Clarence Arthur Perry (Figura 27).

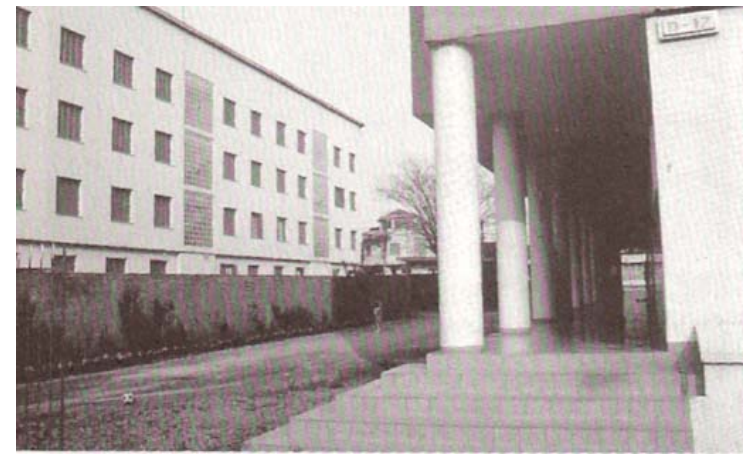

Figura 24: Conjunto Residencial de Paquetá, na ilha de Paquetá da Baía de Guanabara, edificado pelo IAPI. Fonte: BONDUKI, 2002. 
A influência das diretrizes da arquitetura e urbanismo moderno na atuação das Carteiras Prediais dos IAPs variou de Instituto para Instituto, assim como, a opção pelo aluguel ou a construção da casa própria, e entre as soluções por moradias coletivas ou unifamiliares. Cabe destacar, nesse sentido, que o modelo da casa própria não foi adotado pela grande maioria dos Institutos, ficando a massiva parte dos conjuntos construídos concedidos aos associados sob a forma de aluguel. Uma das justificativas para a adoção da moradia de aluguel por parte dos IAPS (Plano A) refere-se à rentabilidade garantida pela transação e às questões acerca da valorização do imóvel. Em contrapartida, a Fundação da Casa Popular tinha a moradia própria como solução básica, sendo poucas às habitações concebidas para locação (FARAH, 1983).

A habitação isolada, por sua vez, era considerada a melhor opção de moradia pelos Institutos. No entanto, devido aos altos custos dos terrenos, sobretudo, em áreas urbanas de grandes cidades onde os terrenos eram relativamente valorizados, optou-se por moradias em prédios de apartamentos. Sendo assim, nas grandes cidades se destacavam as habitações coletivas mínimas, providas de equipamentos coletivos específicos

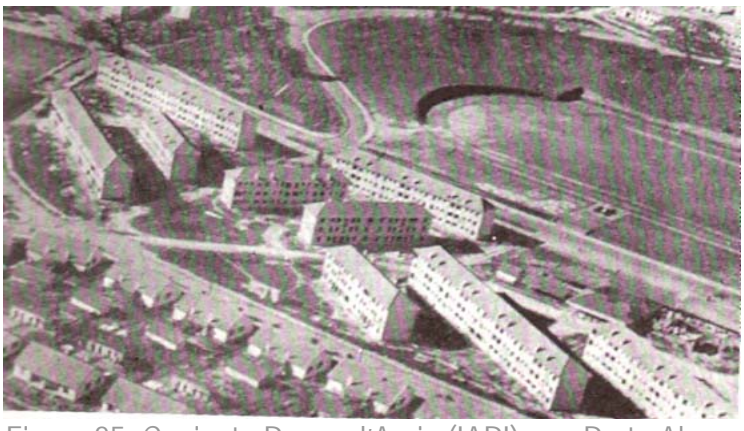

Figura 25: Conjunto Passo d'Areia (IAPI), em Porto Alegre, projetado pelo arquiteto Marcos Kruter, 1940 e 1950. Fonte: BONDUKI. 2002.

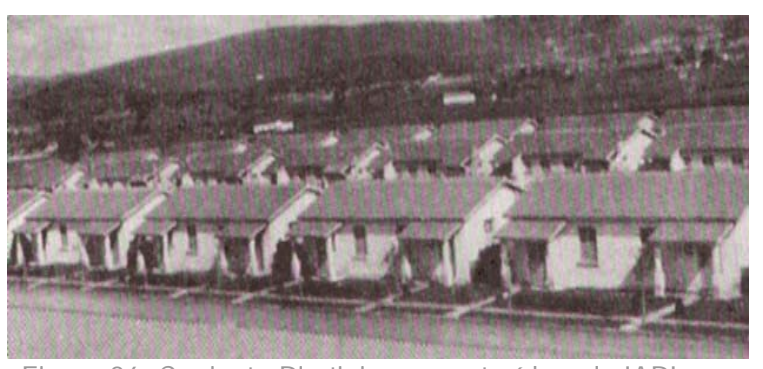

Figura 26: Conjunto Piratininga construído pelo IAPI em Osasco, na década de 1940. Fonte: BONDUKI. 2002.

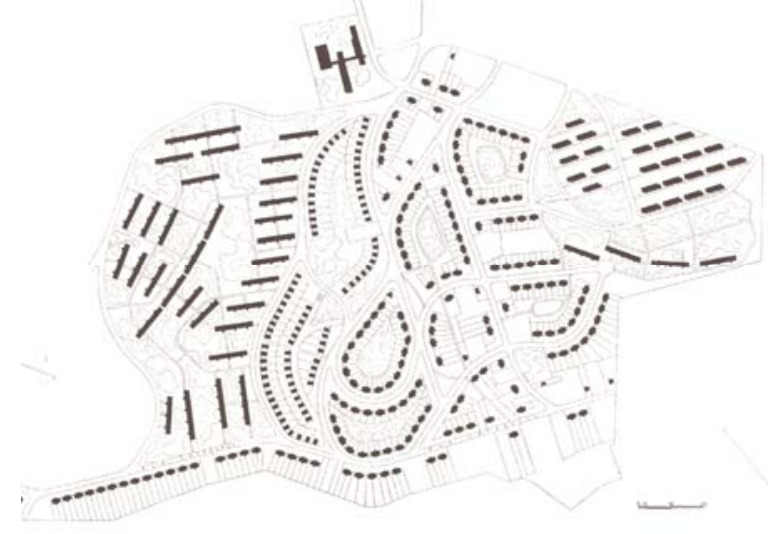

Figura 27: Conjunto Vila Guiomar (IAPI), em Santo André, projetado pelo arquiteto Carlos Frederico Ferreira, na década de 1940.

Fonte: BONDUKI, 2002. como restaurante e lavanderias, mormente construídas pelo IAP dos Comerciários, e os grandes edifícios verticais construídos, na maior parte dos casos, pelo IAP dos Bancários para uma categoria mais bem remunerada (classe média e alta). Isso se justifica pelo maior poder aquisitivo dos associados do IAP dos Bancários, para os quais, o custo "adicional" dos terrenos com melhor localização não se tornava empecilho à aquisição da moradia, o que não ocorreria para as demais categorias (BONDUKI, 2002). 


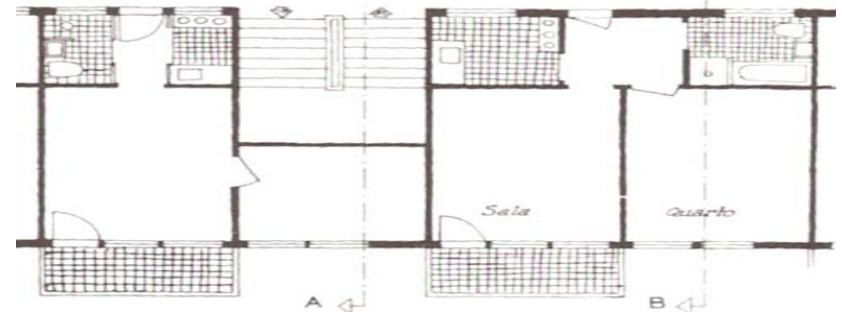

Figura 28: Planta-tipo do Conjunto Realengo (IAPI), projetado por Carlos Frederico Ferreira, no Rio de Janeiro (1930-1940). Fnnte: RONIIJKI. 20ก2.

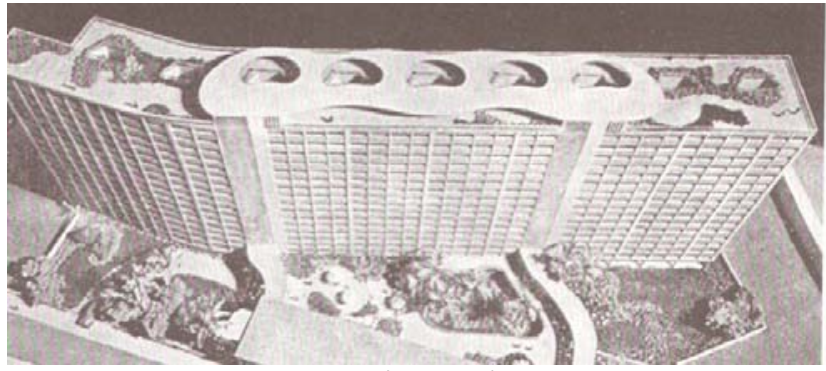

Figura 29: Conjunto Japurá (IAPI-SP), de Eduardo Kneese de Melo, sobre influências da Unidade de Habitação Corbusiana. Fonte: BONDUKI, 2002

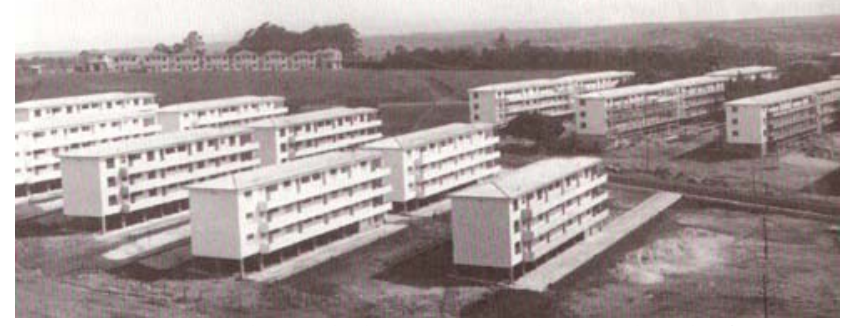

Figura 30: As tipologias habitacionais coletivas da Vila Guiomar se aproximam da concepção da Siedlungen alemã. Fonte: BONDUKI, 2002

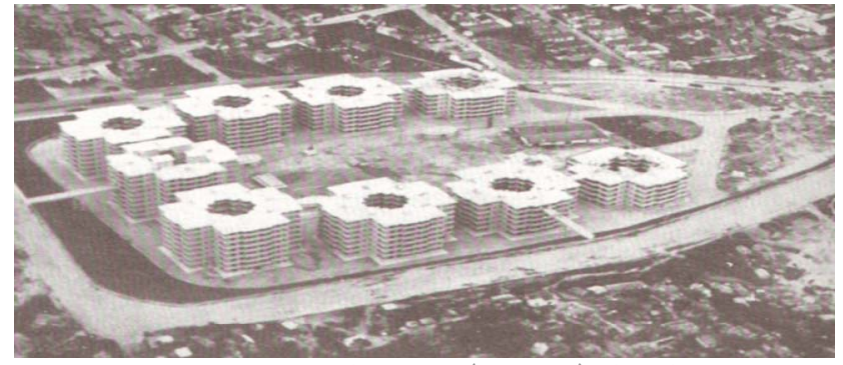

Figura 31: O Bairro Industriário (IAPI-BH), de White Lírio.

Provavelmente o único exemplar com influência da Höfe vienense.

Fonte: BONDUKI, 2002

Buscava-se, tanto para as tipologias habitacionais coletivas como para as unifamiliares, as novas tecnologias construtivas, a redução das dimensões e do número de cômodos na habitação, a eliminação de ornamentos e das áreas de circulação interna (corredores), a estandartização da produção e dos elementos construtivos, além da padronização das construções (Figura 28). Quesitos semelhantes àqueles colocados na 20 edição do Congresso Internacional de Arquitetura Moderna, em 1929, em Frankfurt. Mais especificadamente, primava-se pela funcionalidade da moradia. Ambientes como a cozinha e o banheiro passaram a receber maior atenção dos arquitetos. As plantas tornaram-se livres em contraposição à rígida simetria exigida, as cozinhas mais funcionais e compactas, os espaços mais reduzidos, e os equipamentos da casa e o seu mobiliário adquiriram mais importância.

Surgiram grandes blocos de moradia coletiva, verdadeiras unidades de habitação (Figura 29) e obras que se enquadravam nos pressupostos de unidade de vizinhança, dentre outras (Figuras 30 e 31). De acordo com Bonduki (2002), essa diversidade de soluções foi resultante da incorporação pelo corpo de profissionais brasileiros a partir da década de 1930, dos debates modernos e propostas pensadas e realizadas no campo da habitação social na Europa, nas décadas de 1920 e 1930. 
Dessa forma, os princípios que regeram a edificação de moradias sociais coletivas, assim como, centenas de obras a partir de meados da década de 1930, foram: racionalidade, economia, valorização do espaço coletivo, associação de equipamentos coletivos às obras e verticalização, que passou a ser justificada pelo alto custo dos terrenos. Os antigos quintais dos modelos isolados passaram a dar lugar aos espaços públicos nos edifícios coletivos. Acerca dos aspectos formais, os conjuntos verticais dos IAPs apresentavam, no geral: pilotis, teto-jardim, plantas e fachadas livres, elementos vazados, ângulos retos e jogo de volumes simples e ruas internas (Figuras 32, 33 e 34).

Em se tratando da utilização de novas técnicas e novos materiais construtivos com 0 intento de baratear a obra, alguns projetos encabeçados pela Fundação da Casa Popular se destacam. Pode-se citar, nesse sentido, o Conjunto Residencial construído em Guadalupe, no Rio de Janeiro, entre os anos de 1949 e 1950, no qual foram

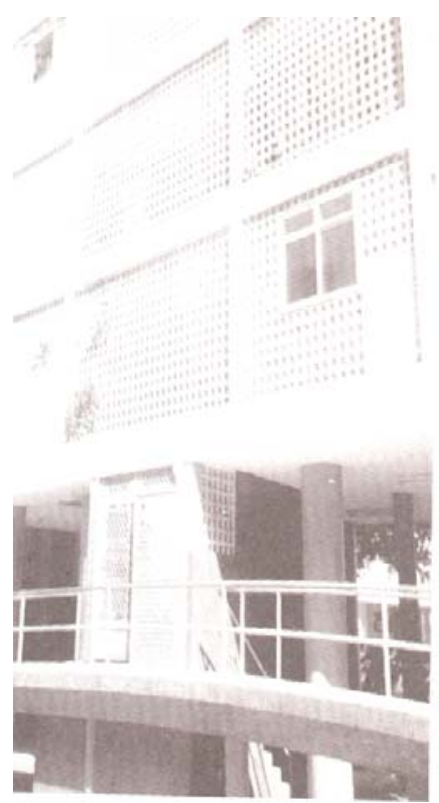

Figura 32: Elementos vazados utilizados na fachada do Edifício dos Bancários (IAPB), construído em Marília (SP), na década de 50. Percebe-se também o uso de pilotis e de passarelas internas. Fonte: BONDUKI, 2002. edificadas moradias em alvenaria padrão juntamente às casas de madeira e de concreto, inclusive uma em formato de iglu, conhecida como "balão" (ANDRADE e AZEVEDO, 1982, p.25).

Ao contrário das inovações arquitetônicas e urbanísticas consolidadas pelos Institutos por meio de seus conjuntos habitacionais, a FCP construiu basicamente moradias unifamiliares isoladas, embora não se deva despreza totalmente a influência da arquitetura moderna em suas construções. Nesse sentido, Bonduki (2002), cita um Conjunto Residencial em Deodoro, edificado na década de 1950, cujo projeto foi concebido pelo arquiteto Flávio Marinho Rego (Figura 35), que em muito se aproxima à solução encontrada em Realengo.

A qualidade arquitetônica das construções dos Institutos e da Fundação da Casa Popular, assim como a essência social de suas ações, foi perdendo o espaço no processo construtivo das moradias com

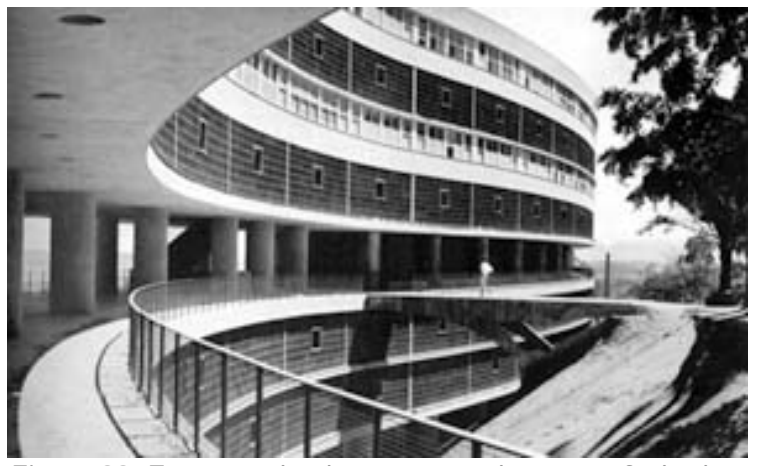

Figura 33: Emprego de elementos modernos na fachada do Conjunto Pedregulho (Affonso Eduardo Reidy, Rio de Janeiro, 1940-1950). Fกnte: RกNIחIIKI 2กก?

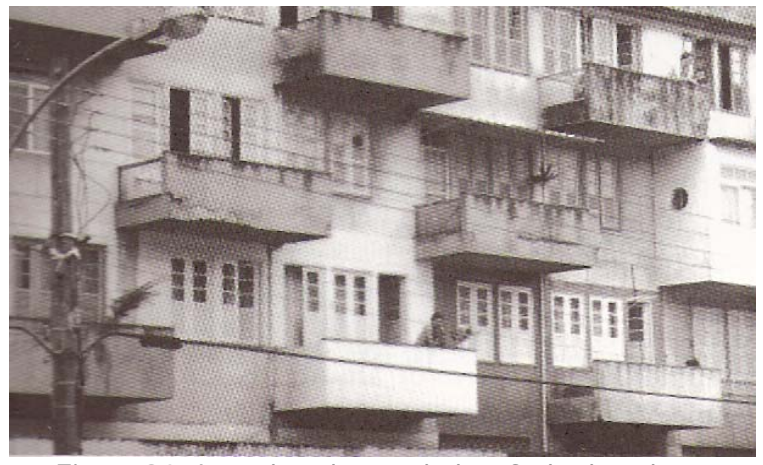

Figura 34: Jogo de volumes dado à fachada pelas sacadas dos apartamentos do Conjunto Realengo (IAPI).

Fonte: BONDUKI, 2002. 


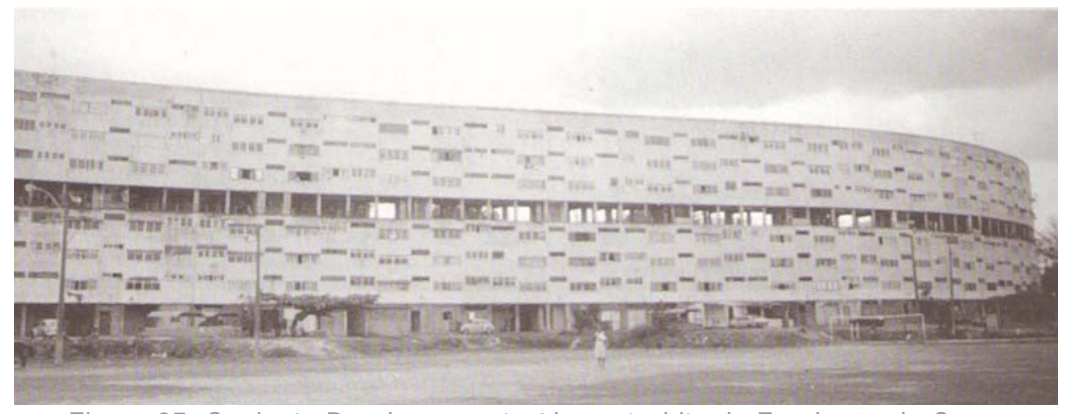

Figura 35: Conjunto Deodoro construído no âmbito da Fundação da Casa Popular, no Rio de Janeiro, na década de 1950. Emprego dos pressupostos modernos na concepção da edificação pelo arquiteto Flavio Marinho Rego. Fonte: BONDUKI, 2002.
0 passar dos anos. Foi graças aos aspectos estritamente econômicos que essa "tendência" iniciada pelos Institutos no campo da habitação social tornou-se realidade, após 1964, no cerne do Banco Nacional de Habitação. A partir de quando se passou a operar um "racionalismo formal desprovido de conteúdo consubstanciado em projetos de péssima qualidade, monótonos, repetitivos, desvinculados do contexto urbano e do meio físico (...)" (BONDUKI, 2002, p.135).

A trajetória dos Institutos de Aposentadorias e Pensões e da Fundação da Casa Popular, assim como, as ações efetivadas pelo Estado no campo da moradia social, em Natal, será estudada no capítulo que se segue. 


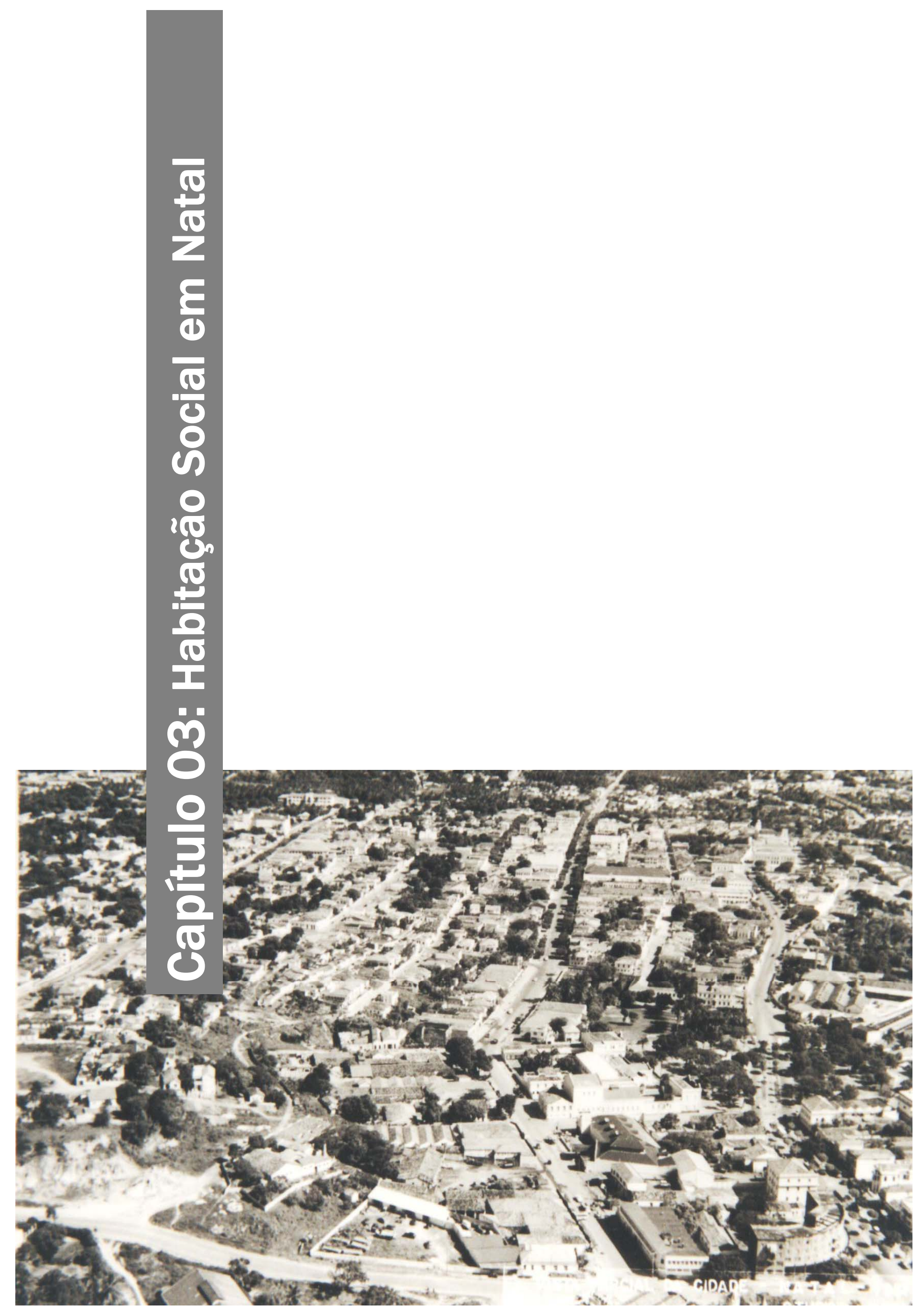




\section{CAPítUlO 03: HaBitAÇÃo SOCIAL EM NATAL}

\subsection{Dos Códigos de Posturas ao Código de Obras}

Natal foi fundada em 25 de dezembro49 de 1599, após a construção do Forte dos Três Reis Magos e da Igreja Matriz, no platô elevado situado à margem direita do rio Potengi50, diante da crescente ameaça de invasão francesa à região e da vontade do rei de Portugal, Felipe II, em instalar pontos estratégicos para vigilância do litoral brasileiro (CASCUDO, 1999, p.25).

Durante muito tempo foi "cidade apenas no nome", sem exercer a real função destinada a uma capital e sede do poder (CASCUDO, 1999, p.37). Dom Diego de Meneses, governador geral do Brasil na época, afirmou em carta endereçada ao rei de Portugal, em 04 de dezembro de 1608, que a "povoação que está feita [quase] não tem gente". Com "quinze anos de vida, a Cidade do Natal do Rio Grande do Norte tinha maior nome que número de moradias" (CASCUDO, 1999, p.31, 74/75).

Aos poucos foram instalando-se casas paralelas voltadas para o Rio Potengi, avizinhando-se à Igreja, num total de 12 residências no ano de 1614 e de 118, em 1719 (SOUZA, 29/07/1943). Passou-se quase um século de crescimento ínfimo e poucas famílias se instalaram na cidade e em seus arredores, em granjas e sítios (CASCUDO, 1999). As residências datadas desse período eram construídas em taipa e assim o foi durante um significativo espaço de tempo diante das dificuldades na fabricação de tijolos e telhas, não só por falta de argila apropriada no perímetro da cidade nascente, mas também pela ausência de oleiros, que somente anos depois vieram diretamente de Portugal ou das capitanias limítrofes (SOUZA, 25/07/1943, p.04).

A partir do primeiro quartel do século XIX, a abertura dos portos brasileiros às nações estrangeiras ocasionou diversas mudanças nos hábitos da população da cidade. Concomitantemente, se deu a eclosão das epidemias de febre amarela (1850), cólera-morbo (1855) e varíola (1877 e 1882), favorecidas pelas precárias condições higiênicas e de habitabilidade verificadas nas poucas ruas irregulares e impregnadas de dejetos.

Nas últimas décadas do século XIX, as regiões povoadas na capital norte-riograndense equivaliam basicamente aos bairros de Cidade Alta, núcleo originário da cidade, área comercial e residencial dos primeiros sobrados e dos moradores ilustres, e ao bairro da Ribeira, conformado por sítios, plantações e pela zona portuária (Figura 36). Havia ainda dois agrupamentos exteriores (as Rocas, povoado de pescadores, e o Passo da Pátria, provavelmente zona de meretrício da época), além de algumas poucas comunidades localizadas na zona periférica, tais como: Refoles, uma zona agrícola; Alecrim; Quintas,

\footnotetext{
${ }^{49}$ Justificando assim a sua denominação.

50 O principal rio do estado que corta a cidade representando um marco na divisa entre as zonas "norte e sul" de Natal.
} 
conformada por pequenas granjas; Barro Vermelho, região de casas de veraneio; e Guarapes, às margens do rio Jundiaí, no caminho que levava ao sertão51 (CASCUDO, 1999/COSTA, 1998).

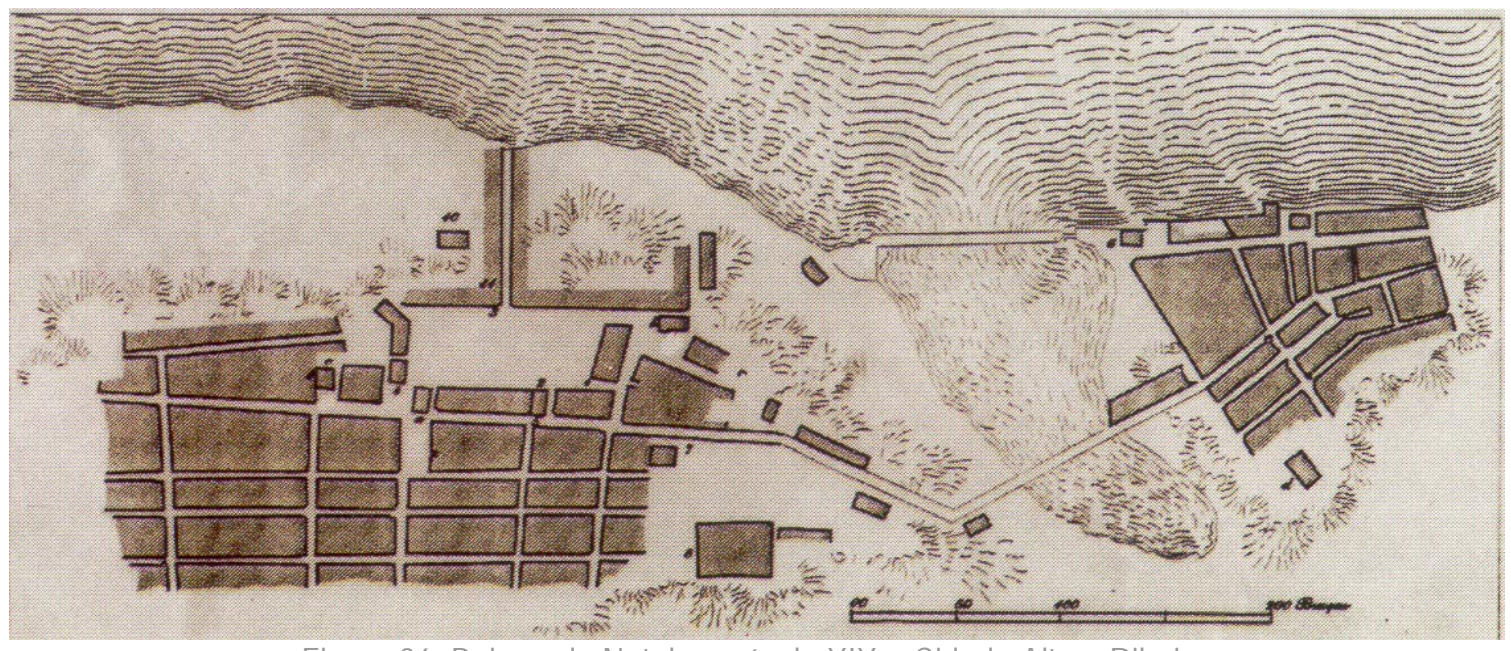

Figura 36: Bairros de Natal no século XIX - Cidade Alta e Ribeira.

Fonte: MIRANDA, 1981

A partir de 1850, Natal passou a ser alvo de "políticas públicas" sanitárias sistemáticas, e essas ações acabaram por introduzir também transformações em sua estrutura física. A partir desse momento, os médicos passaram a assumir as principais propostas de intervenção, cabendo ao Estado promover a edificação dos equipamentos de assistência à saúde coletiva e consolidar medidas pontuais, sobretudo de cunho higienista, na área urbana (EDUARDO, 2000). As demais construções, incluindo as habitações, ficavam a cargo em grande parte da própria população.

Também foi a partir de meados da década de 1850, que se evidenciam os primeiros registros de intervenção estatal no setor da habitação por meio de legislação, denominados pela imprensa da época como "normas imperiais" (A REPÚBLICA, 10 semestre de 1850): um antecipador dos Códigos de Posturas elaborados e implementados efetivamente a partir da Proclamação da República.

De modo geral, as intervenções ocorreram no sentido de modificar a aparência das moradias e qualificar a cidade. Nesse sentido, uma comissão imperial proibiu a construção de edifícios e habitações com materiais comumente utilizados, como a taipa (OLIVEIRA, 1997). A referida "norma" exigiu investimentos na transformação da aparência das moradias, os quais, a população menos favorecida não possuía, obrigando-a a se deslocar para outras áreas, possivelmente para as ocupações periféricas das Rocas, Passo da Pátria e Alecrim, que apresentaram grande crescimento nesta época ${ }^{52}$.

Os discursos segregacionistas e que primavam pela remodelação estética da cidade, presente em diferentes momentos da história da capital norte-riograndense, como será colocado mais adiante, começaram nesse momento a ganhar corpo e a ocupar lugar de destaque na imprensa escrita local. Os artigos focavam essencialmente o bairro da Ribeira, setor comercial e "porta de entrada" para os visitantes

\footnotetext{
${ }^{51}$ A população da cidade de Natal em 1890, segundo o senso, era de 13.725 habitantes (IBGE).

52 Afirmação baseada em artigos publicados nos periódicos da época. Segundo o IBGE, o número de habitações na cidade nesse período era de, aproximadamente, 3.500 unidades.
} 
que chegavam pelo Porto de Natal, onde se acreditava não ser mais admissível a existência de "vivendeiras"53 e cortiços (CIDADÃO..., 08/02/1879, p.01). Na concepção da elite letrada da época, como se pôde constatar, o povo considerado "rústico e ignorante" (OS TIROS..., 07/06/1890, p.04) não podia mais ocupar o espaço que se pretendia "modernizar" (DANTAS G., 2003, p.43). Essas ações equivaleram ao início da normalização do uso e ocupação do espaço urbano de Natal e da segregação social da população pobre residente na cidade e de migrantes que tentavam se instalar.

A cidade de Natal foi assim se consolidando, por bairros dispostos numa trama viária típica de cidades coloniais, com ruas estreitas compostas por pequenas casas construídas sobre o alinhamento frontal e lateral dos lotes e sem numeração (GAZETA DE NATAL, 31/03/1888, p.04), e por alguns povoados "reservados" à população de baixa renda. Dessa forma, percebe-se que os primeiros indícios da normalização do uso e ocupação do solo de Natal - por meio de legislação restritiva e excludente - e do incômodo causado às camadas mais abastadas da população pelas habitações precárias situadas no centro da cidade, passam a ser percebidos nos últimos anos do século XIX.

Para Natal, a Proclamação da República acarretou uma importante mudança na expectativa da população e no quadro político local, devido à ascensão da oligarquia dos Albuquerque Maranhão e das mudanças físicas na capital por ela consolidadas.

Apesar das intervenções realizadas pela administração pública, os serviços na cidade, sobretudo o sanitário, se encontravam deficientes nesse momento. As moradias acompanhavam esse quadro e se mostravam inadequadas do ponto de vista higiênico. Para reverter à conjuntura sanitária de Natal e, por conseguinte a situação de suas habitações, as ações públicas se basearam no modelo de afastamento das classes pobres do centro da cidade e das áreas ocupadas pela elite.

No ano de 1890, dando continuidade às ações promovidas pelas Comissões Imperiais de meados do século, o governo exigiu por meio de publicação de "notas normativas", a transferência de todas as construções "não dignas" edificadas na cidade (casas de cômodos, prostíbulos, dentre outras) (CIDADÃO..., 08/02/1890, p.04), para "(...) detrás do quartel ou para a Rua Camboim" (GAZETA DE NATAL, 08/02/1890, p.04), descampados afastados dos estreitos limites urbanos de então, longe dos olhos das elites locais e dos que visitavam a capital norte-riograndense. Consolidou-se então, o caráter segregacionista da atuação governamental no campo da habitação, que marcou grande parte de sua história, como se verá mais adiante.

Com a promulgação da Constituição Republicana, em 1891, diversas normas relativas ao uso e ocupação do solo e às edificações foram implementadas em diferentes capitais do país. Pela Constituição, determinava-se que os estados deveriam se organizar e assegurar a autonomia dos municípios, tendo estes, que legislar sobre ruas, jardins, praças, vias, serviços e obras de interesse social, além de

530 termo pode referir-se aos bordéis da época ou às edificações destinadas à hospedagem de marinheiros. 
determinar as condições de higiene e estética da cidade, e especificar a arquitetura das edificações públicas e particulares.

Nesse período em Natal, a Intendência Municipal formulou o primeiro grupo de normas, relacionadas essencialmente à organização do sistema de coleta de lixo, dispondo desde a obrigatoriedade de pagamento de taxas mensais até regras de conduta relacionadas à higiene e à limpeza das residências sob pena de multa. A partir de então, todas as construções iniciadas deveriam ser notificadas ao Secretário do Conselho da Intendência Municipal pelos fiscais municipais e cadastradas em livro específico, de modo a ser exercida uma fiscalização mais eficaz. Tais imposições foram publicadas no periódico oficial em circulação no período:

(...) O Conselho da Intendência Municipal da Cidade do Natal, Resolve: Art. $1^{0}$ - Todas as casas encravadas nas praças, ruas, travessas e beccos desta cidade ficam sujeitas ao imposto de 500 réis mensais para a limpeza pública, pago pela pessoa que ocupa a casa; (...); Art. $4^{0}$ - Organizado o serviço de limpeza ficarão obrigados a mandarem varrer diariamente as casas e quintaes e depositar 0 lixo em uma vasilha à porta, pela manhã, para ser conduzido pelas carroças; Art, $5^{0}$ - É extremamente prohibido deixar lixo nas praças, ruas, travessas e beccos da cidade. Os infractores incorrerão na multa (...); Art. $6^{\circ}$ - O imposto (...) só é devido do $1^{0}$ de março de 1891 em diante (...); Art. $7^{0}$ - Para effectiva cobrança desse imposto o secretário deste conselho (...), procederá 0 arrolamento das casas existentes na cidade, (...); Art. $8^{\circ}$ - Concluído 0 arrolamento (...), os Fiscaes logo que se identifique qualquer prédio novo em seu distrito comunicarão ao secretário (...) (A REPÚBLICA, 21/01/1891, p.04) ${ }^{54}$.

Para aperfeiçoar e ordenar as questões relativas à higiene e à fiscalização do saneamento, principalmente das habitações, foi criada pelo governador Pedro Velho (1892-1896), por meio da Lei №. 14, de 11 de junho de 1892, a primeira Repartição Sanitária do Estado, a Inspectoria de Hygiene Pública55 (RIO GRANDE DO NORTE, 1896, p.25-28). Ao inspetor de higiene foi reservada uma posição privilegiada na tomada de decisões relativas ao saneamento da cidade, podendo indicar e/ou balizar as ações do Presidente da Intendência Municipal nesse sentido. Devia apenas ao governador do estado a prestação de contas de suas ações, por meio dos relatórios anuais. Essa autonomia permitiria mais tarde a arbitrariedade no combate a certas tipologias habitacionais populares, como se irá averiguar adiante.

No ano seguinte, por meio do Decreto no. 24, de 22 de maio, os serviços sanitários da cidade foram organizados no Regulamento da Inspetoria de Higiene. Por ele foram especificadas as atribuições

\footnotetext{
54 Optou-se pela conservação do português antigo e dos erros tipográficos dos artigos expostos neste trabalho.

55 Essa Repartição era conformada por um inspetor, um médico ajudante, um "amanuense-secretário", um "contenuo-correio" e trinta e seis delegados de higiene. Ao inspetor de higiene cabia: fazer cumprir as disposições do Regulamento da Repartição, formulado no ano seguinte; inspecionar os trabalhos do policiamento sanitário; apresentar anualmente relatórios ao Governo; organizar e dirigir os serviços de assistência pública; realizar os planos de melhoramentos sanitários na cidade; e propor à Intendência Municipal todas as medidas que julgasse necessárias. Ao médico ajudante, cabia auxiliar o Inspetor em todos os serviços realizados pela Repartição, incluindo a visitação de edificações, e participar das desinfecções realizadas em qualquer habitação. Os delegados eram responsáveis pela fiscalização minuciosa das edificações da cidade, devendo notificar ao Inspetor qualquer fato notável do ponto de vista sanitário averiguado em visita. Aos demais cargos caberiam os trabalhos burocráticos e de escritório (DECRETO №. 24, 22/05/1893, Art. 4이으).
} 
da Inspetoria, dentre as quais, estava a fiscalização do saneamento das localidades, habitações e de qualquer estabelecimento onde houvesse aglomerações de pessoas, por qualquer motivo que fosse julgado prejudicial à saúde pública, além da indicação de melhoramentos sanitários em benefício da população.

Em relação às habitações particulares ou coletivas, o Regulamento decretava que nenhuma edificação pública ou particular poderia ser construída e/ou alterada sem que a Inspetoria de Higiene examinasse a sua planta e indicasse as modificações necessárias ao "bem estar da saúde pública". As moradias novas, reformadas ou as de aluguel que se encontrassem desocupadas teriam que ser examinadas pelas autoridades sanitárias antes de ocupadas, para que obtivessem 0 aval da Repartição liberando o prédio para "servir como residência". Os proprietários das edificações deveriam avisar à Inspetoria a localização exata de seu imóvel para que o mesmo passasse pela supracitada vistoria.

As visitas seriam realizadas após o envio de um aviso prévio ao morador, e no caso de oposição, 0 inspetor ou os delegados de higiene teriam 0 auxílio de forças policiais. Segundo o Art. 71 da referida disposição, o inspetor de higiene nas visitas e determinações sanitárias, teria que estar acompanhado de um agente da força pública. As autoridades municipais e policiais teriam que prestar às autoridades sanitárias todo e qualquer auxílio que estas tivessem necessidade para a execução do colocado pelo Regulamento.

Em caso de acusação de moléstias, ou inadequações nas edificações que comprometessem a saúde de seus moradores (superlotação, precárias condições de higiene, etc.), seria ordenada a desinfecção e o cumprimento das medidas necessárias. Nesses casos, o proprietário do imóvel seria notificado, tendo o prazo de 48 horas para a solução do problema que, se perdurasse, acarretaria 0 fechamento do estabelecimento. Oito dias depois de cumprida a intimação seria realizada uma nova visita por parte dos delegados para averiguar as "novas" condições sanitárias da edificação ${ }^{56}$. Quando os casos fossem julgados como "insanáveis" o imóvel teria que ser fechado definitivamente (DECRETO №. 24, 22/05/1893, Art. 49/59ㅇ).

A partir de então foi iniciada em Natal, uma "ação higiênica e embelezadora" (OLIVEIRA, 1997, p.90), também marcada pela publicação dos Códigos de Posturas - um conjunto de disposições legais que regeram as ações da Polícia Sanitária, a qual cabia prevenir e reprimir o que pudesse comprometer a saúde pública. Seu serviço seria realizado por intermédio de uma severa fiscalização das habitações unifamiliares e coletivas.

\footnotetext{
56 Pelo Regulamento, o não cumprimento das normas estabelecidas pela Inspetoria e referentes às moradias, acarretaria a cobrança de multas que variavam entre $10 \$ 000$ e $500 \$ 000$, cujos valores duplicariam caso houvesse a reincidência do "problema". Essas quantias seriam revertidas para os cofres públicos e pagas, no caso da capital, na Inspetoria de Higiene, e nos demais municípios do estado, nas "coletorias" dentro do prazo de 18 horas contabilizadas a partir da entrega da intimação (DECRETO №. 24, 22/05/1893, Art. 62의63ㅇ).
} 
Foram realizadas, a partir desse momento, uma série de intervenções que objetivavam a adequação do espaço da cidade às normas higiênicas e para "aformoseamento de Natal" (A REPÚBLICA, 16/07/1892, p.04), como o nivelamento e rebaixamento de calçadas das edificações, intervenções nas fachadas e no interior das residências e até nos muros dos terrenos

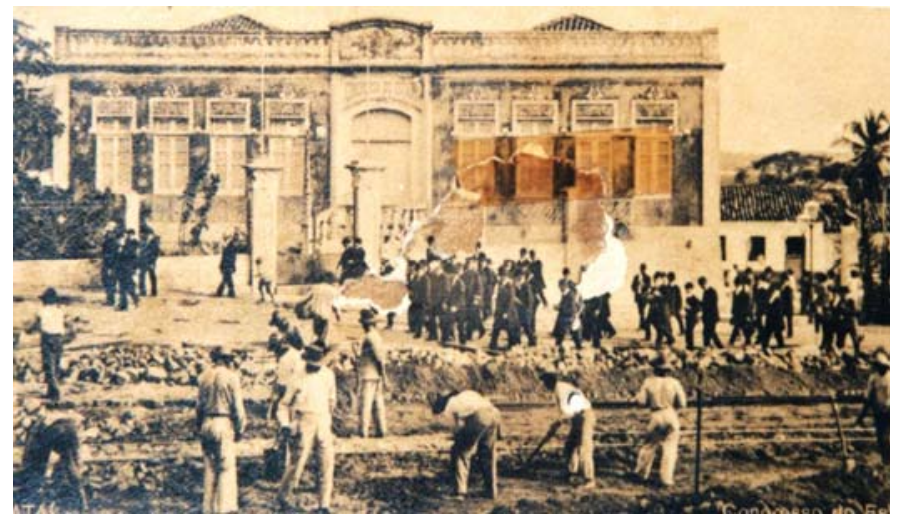

Figura 37: Obras de abertura e nivelamento de vias, s/d. Fonte: JAECI, 2006.

(Figura 37). Obras que muitas vezes a população foi forçada a realizar dentro dos prazos estabelecidos, sob pena de multa, e sem levar em consideração o poder aquisitivo da população.

O primeiro grupo de normas sistematizadas e denominadas pelo termo Código de Posturas foi publicado em 30 de abril do ano de 1904, equivalendo à Resolução no. 54. Essas normas abordavam desde as especificações construtivas para as edificações urbanas, principalmente as habitações, até determinações acerca do espaço público de Natal57. Nesse sentido, as moradias teriam necessariamente que apresentar fachada com 4,20m de altura no caso de construções térreas e 8,40m para os sobrados, portas e janelas com largura de 1,20m e alturas de 3,00m e 2,00m respectivamente, e calçadas com 1,80m de largura e 0,20m de altura. Foi estritamente proibida, a partir desse momento, a construção de degraus externos nas calçadas que fossem rebaixadas e nas edificações que fossem construídas, assim como o fechamento dos quintais das residências situadas no perímetro urbano da cidade com "cerca de faxina" ou qualquer outro sistema que empregasse madeira. Os proprietários de habitações antigas que apresentassem esse tipo de fechamento de terreno teriam o prazo de noventa dias para substituí-lo por muro (RESOLUÇÃO №. 54, 30/04/1904, Art.24/25).

Para exercer a formulação das plantas, o alinhamento das edificações e dos terrenos e a fiscalização das obras, foi instituído pelo governo municipal o cargo de auxiliar técnico, que só poderia ser exercido por profissionais engenheiros ou agrimensores (RESOLUÇÃO №. 54, 30/04/1904, Art.15).

Também por essa Resolução, foi delimitado e subdividido o patrimônio territorial do município de Natal. Segundo ela, a capital estaria dividida em três bairros ${ }^{58}$ (Ribeira, Cidade Alta e Cidade Nova), podendo o governo estadual, a partir de então, cobrar anualmente o imposto - foro por metro quadrado de

\footnotetext{
57 Em relação ao espaço urbano, a Resolução determinou que à medida que a Intendência executasse o calçamento das vias da cidade, os proprietários de imóveis urbanos estavam obrigados a construir ou reparar as respectivas calçadas, e que todas as esquinas das praças, avenidas e ruas da capital teriam que ser curvas, concebidas com 2,00m de raio.

${ }^{58} \mathrm{~A}$ cidade tinha passado durante as últimas três décadas por um crescimento ínfimo, apresentando somente um bairro a mais que o constatado na década de 1880, e mesmo assim, esse ainda estava em vias de implantação, tendo sido criado apenas dois anos antes.
} 
superfície $^{59}$ - pelo uso dos terrenos concebidos por aforamento ${ }^{60}$. Essa disposição veio para complementar o Regulamento elaborado em 1893 e facilitar o trabalho da Inspectoria de Hygiene Pública e da Polícia Sanitária no controle e fiscalização do cumprimento dos Códigos de Posturas. O perímetro da cidade ficou sendo da "(...) linha do sul, da Lagoa Manuel Felippe, estendendo-se pelo curso da corrente do Baldo, até chegar ao rio Potengi" (A REPÚBLICA, 29/09/1904, p.01). (Figura 38)

Exigiu-se, nesse sentido, a legalização dos terrenos e o registro dos aforamentos, assim como, a substituição das antigas cartas para correlação das medidas especificadas no documento com os respectivos lotes:

Art. 13. Os actuais accupantes de terrenos municiaes, que não tenham requerido 0 respectivo aforamento, ou aquelles que os tendo obtido não solicitarem o respectivo titulo deverão fazel-o no praso de noventa dias, contados da publicação da presente resolução, sob pena de multa de $50 \$ 000$ a $100 \$ 000$ reis, (...).

$\S 3$. As antigas cartas deverão ser substituídas por outras de modelo indicado (...), sem mais onus para o respectivo possuidor, alem do sello. (...).

Art. 20. Os possuidores das antigas cartas, que as não tenham substituído por outras, (...), dentro do praso de noventa dias,contados da publicação da presente resolução, ficam sujeitos á multa de $15 \$ 000$ a 30\$000 (RESOLUÇÃO №. 54, 30/04/1904).

A Resolução №. 54 correspondeu à primeira sistematização de normas referentes à construção e reforma das edificações, que culminou anos mais tarde na elaboração dos Códigos de Obras de Natal. Esse dispositivo, juntamente com os Códigos de Posturas outorgados anteriormente $\mathrm{e}$ as disposições do Regulamento da Inspetoria de Saúde Pública, marcaram o princípio da imposição de normas e regras para edificações

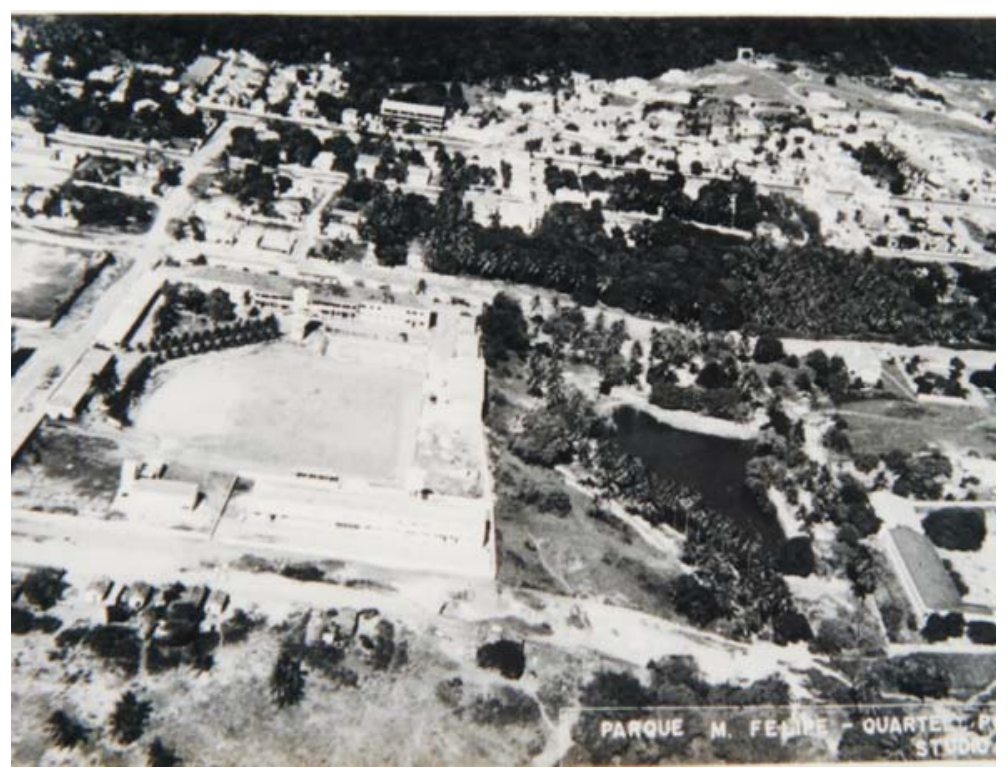

Figura 38: Lagoa Manoel Felipe à direita, limite da cidade na década de 1900.

Fonte: JAECI, 2006

dentro do perímetro da cidade, e de disciplinamento dos hábitos da população, segundo a ordem higienista.

\footnotetext{
59 O foro anual, especificado por essa Resolução, correspondia ao valor de "(...) cinco rees por metro quadrado de superfície (...)", para os terrenos urbanos, e nos subúrbios, de "(...) trinta rees por metro corrente, medindo-se a circunferencia da area concedida" (RESOLUÇÃO №. 92, 30/04/1904, Art.21).

60 Em se tratando dos terrenos foreiros, a referida Resolução previa a concessão gratuita do domínio útil do lote por um prazo de dez anos, mas estabelecia o prazo de um ano para ser efetivada a construção da edificação, contados a partir da data de expedição do título ou carta de aforamento. Nos casos de venda, troca, transferência e doação do aforamento a terceiros, 0 "favor" seria cessado e o concessionário, sujeito ao pagamento das taxas relacionadas à Prefeitura, sendo o novo proprietário obrigado a pagar o foro anualmente (RESOLUÇÃO №. 92, 30/04/1904, Art.9).
} 
Nesse momento, as moradias que não se enquadrassem nas normas impostas pela Inspetoria de Higiene, a partir do constatado nas visitas higiênicas, eram listadas rua por rua nos Editais de Higiene Pública, nos quais se especificava desde o nome do proprietário do imóvel aos reparos e/ou reformas que deveriam ser efetivadas na habitação (HYGIENE..., 24/08/1903, p.03). Esses editais eram publicados mensalmente no periódico oficial, o jornal A República (24/08/1903, n.167, p.03).

Apesar do empenho da Inspetoria de Higiene, o estado sanitário da cidade e de suas habitações em meados da década de 1900, ainda se mostrava bastante precário. Essa conjuntura determinou a persistência dos temas nas medidas formuladas pela administração pública. Ainda em 1905, foi editada e publicada no jornal A República, a Resolução №. 92, que reafirmava as portarias e especificações para residências implementadas no ano anterior, ressaltando ainda mais o caráter excludente e embelezador da legislação empregada na época, utilizando-se da cobrança de altas multas pelo não cumprimento dos artigos:

(...) Art. $48^{\circ}$ - Todo proprietário será obrigado a conservar caiada ou pintada toda a parte exterior de seus prédios, inclusive as portas, janelas, rotulas e vidraças, que enfrentarem para os largos, praças, avenidas, ruas ou travessas da cidade. Feita pelo fiscal, para esse fim, não cumprirem esse preceito, serão multados em $10 \$ 000$ e no duplo nos casos de reincidências. /.../ Art. $49^{\circ}$ - Todos os moradores da cidade são obrigados a: /.../Inciso $1^{0}$ - Depositar todos os dias, pela manhã, nas portas ou portões dos prédios de suas residências, o lixo, que deverá ser conduzido pelas carroças de limpeza publica, multa de $2 \$ 000$ e 0 duplo nas reincidências. I.../ Inciso $2^{\circ}$ - Conservar sempre limpos, sem lamas, ou imundícies os quintais dos prédios de suas residências, a mesma multa do inciso anterior. (RESOLUÇÃO №. 92, 24/05/1905).

Em contrapartida, diversas críticas foram direcionadas a alguns dos Códigos de Posturas, sobretudo, àqueles referentes à cobrança de taxa sobre biqueiras e degraus das residências. Requeria-se a revogação dessas disposições, uma vez que grande parte da população atingida por elas se afigurava de origem pobre. O fato era que a "quase totalidade" das casas de biqueiras era de taipa, não se prestando "para os encanamentos internos para esgottos" (LEl..., 11/12/1906, p.01), o que tornava a lei "inexeqüível e absurda":

(...) O fim da lei criando impostos sobre biqueiras e degraus externos dos prédios - foi (...) acabar com esses incovenientes que se notam nas nossas casas; mas não o conseguirá - porque, alem da maioria dos proprietários ser gente pobre, que não pode suportar as despezas para a transformação de suas casas, accresce que não estando todas as ruas niveladas e com passeios, impossivel se torna fazer os esgottos por baixo dos passeios, como exige a lei.

Ha ruas calçadas mesmo em que os esgottos não podem ser feitos por baixo dos passeios - por serem esses mais baixos que o calçamento do centro. Essa impossibilidade se nota em quasi todas as ruas da Ribeira e em muitas da cidade alta. Mesmo na Avenida Rio Branco, calçada de novo, o calçamento não permite que os esgottos sejam feitos por baixo dos passeios.

- Como tambem retirar os degraus externos de casas em ruas calçadas e por nivelas, que não se sabe em que altura passarão os passeios para rebaixamento ou levantamento das portas de entrada? 
Nivelada e calçada a cidade poderão então os poderes publicos municipaes - marcar aos proprietarios um praso razoavel para dentro d'elle retirarem os degraus de suas casas. Qualquer medida, porem, antes disto é inexequivel e absurda.

- As actuaes casas de biqueiras na sua quase totalidade são de taipa. O que os poderes municipaes podem fazer é não permitir a reconstrução dessas casas sinão com a condição de serem modificadas as suas fachadas, mas nunca crear sobre as mesmas um imposto especial, como o fiseram na lei $n^{\circ} 106$, que deve ser revogada por inexequivel e absurda.

- O que os poderes municipaes devem ter muito em vista são as novas edificações, não consentindo que se edifiquem mais no perimetro desta cidade casas de 12 palmos de altura e de biqueiras, como se está fasendo todos os dias.

O que está feito, embora defeituoso e ruim, (...), não pode ser modificado de um dia para 0 outro. A nossa terra é paupérrima, a mais não poder sêl-o. Não se deve exigir do povo 0 que elle não pode fazer.

$\mathrm{Na}$ impossibilidade de extinção das biqueiras e degraus, (...). O senador Pedro Velho, deve mandar sustar a execução da lei n. 106 nesta parte. (LEI..., 11/12/1906, p.01).

Para auxiliar ainda mais o trabalho da Inspetoria de Higiene foi elaborada, no ano de $1908^{61}$, a "carta cadastral de Natal", pela qual, a cidade foi descrita e detalhada, bairro a bairro, rua a rua, constituindo-se também numa importante base para as obras de melhoramentos realizados na cidade no período (DECRETO №. 177, 22/04/1908).

A realização dos serviços de higiene, principalmente no centro de Natal, acarretou, dentre outras coisas, a criação de outro imposto denominado de "taxa sanitária", que passou a ser cobrada dos proprietários de "prédios urbanos" a partir de 1910 (RIO GRANDE DO NORTE, 1910). Como em outros momentos da história da cidade, diversas famílias se viram obrigadas a abandonar suas residências por não terem condições de arcarem com mais essa despesa orçamentária "em prol do projeto de embelezamento da cidade". A criação da taxa sanitária também contribuiu para a elevação dos preços dos aluguéis e terrenos na área urbana de Natal no final da referida década. Outro fator que em muito contribuiu para a elevação desses preços foi o não cumprimento do Art.20 da Resolução №. 54, de 30/04/1904, referente à determinação do prazo de um ano para se efetuar a construção nos terrenos foreiros por parte de seus proprietários. A imprensa oposicionista denunciou o problema ocasionado pelo não cumprimento dessa disposição:

(...) a falta de cumprimento, tem permitido que os possuidores de centenas de metros de terrenos, em pleno coração da cidade impeçam a edificação, reclamando preços exorbitantes por aquilo que thes não custou mais do que os trezentos reis da estampilha aposta a um requerimento (A CIDADE...,05/06/1919, p.01).

${ }_{61}$ Durante o segundo mandato do governador Alberto Maranhão (1908-1913). 
Por meio da Resolução no. 194, de 20 de abril de 1916, a Intendência Municipal revogou as disposições referentes às construções em voga, tidas como obsoletas ${ }^{62}$. As dimensões exigidas para as portas e janelas também foram alteradas pela Resolução, tendo a partir de então que possuir respectivamente, $3,5 \mathrm{~m}$ e $2,5 \mathrm{~m}$ de altura, $50 \mathrm{~cm}$ a mais do que as medidas exigidas até o momento. As novas cláusulas correspondiam à

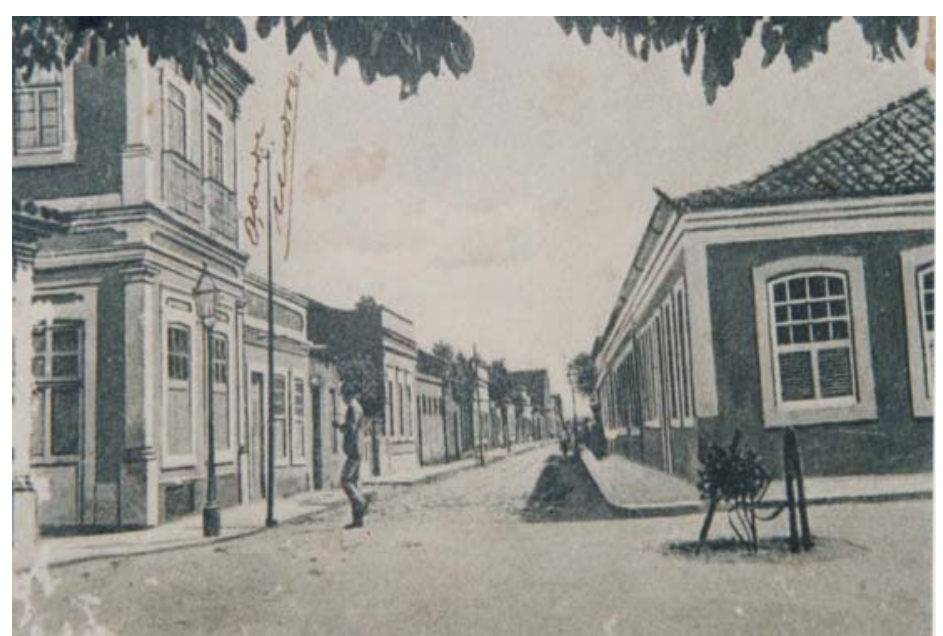

Figura 39: Rua da cidade na década de 1910. Fonte: JAECI, 2006. especificação da dimensão do recuo frontal para as novas edificações, que deveria ser de $5 \mathrm{~m}$ (até 0 momento, fazia-se referência apenas a espaços livres laterais, sem que fosse especificada a dimensão), e à obrigatoriedade da construção de platibandas nas fachadas frontais das novas residências concebidas no perímetro urbano de Natal. O que, na concepção das elites da época, contribuiu para modificar (paulatinamente) o caráter colonial das moradias da cidade, "descolando-as" do alinhamento das ruas e encobrindo as coberturas de "chalezinho" típicas dos tempos passados (Figura 39). Observou-se ainda, a inclusão de um novo capítulo nessa Resolução referente aos "edifícios ruinosos", os quais, quando apontados pelo agrimensor ou engenheiro (consultor técnico da municipalidade), deveriam ser reparados no prazo determinado por eles, ou demolidos nos casos mais graves ${ }^{63}$.

Nos anos de 1920, a habitação coletiva ocupou o cerne da questão habitacional na capital norteriograndense. A atenção de letrados e da elite política voltou-se para a publicação do livro Como Higienizar Natal, de Januário Cicco, Inspetor da Saúde do Porto, Chefe das Clínicas do Hospital de Caridade Juvino Barreto e médico da Empresa Força e Luz. O livro abordava, dentre outras questões, a íntima relação entre a habitação coletiva e o surgimento das epidemias.

Para Cicco, era agravante para o aparecimento de doenças na capital, sobretudo nos bairros mais carentes, a "(...) falta de hygiene corporal, as habitações insalubres, o excesso de habitantes em cada domicilio e a viciação do ar, decorrente daquella promiscuidade" (CICCO, 1920, p.13). O Inspetor da Saúde do Porto apontava a necessidade de modificar o espaço urbano a partir da reforma da residência,

\footnotetext{
${ }^{62}$ Trata-se da primeira alteração verificadas nos Códigos de Posturas de Natal. Nela, não se vislumbra, por exemplo, 0 artigo referente às especificações das alturas das edificações térreas e assobradadas, cláusula preponderante para a adequação estética da cidade nos primeiros anos do século XX, expostas na Resolução №. 54. Também não se verifica nesse documento, alusões à proibição da utilização das cercas de faxina. Nas referências aos fechamentos dos terrenos, a Resolução determina que os lotes teriam obrigatoriamente que ser murados com alvenaria de tijolo com altura de $2 \mathrm{~m}$, 0 que reflete um aumento do rigor das exigências no tocante à qualidade dos materiais empregados nas construções. Não mais se admitia a utilização de materiais pouco duráveis ou insalubres, nem mesmo nas áreas externas das habitações.

63 Até aquele momento essas edificações eram mantidas apenas desocupadas.
} 
essencialmente das classes populares, e por meio da introdução de novos hábitos de higiene. Para ele eram inaceitáveis as moradias caracterizadas por "(...) piso desprotegido (...) por onde se arrasta a filharada amarellenta e nua, mesclando o chão com as proprias dejecções, misturando á sujidade do local ao pão que the cae das mãos (...)"; não havendo para algumas localidades, "(...) remédio contra as infecções, tonicos que reorganizem decadências, nem fossas que eduquem um povo de analfhabetos" (CICCO, 1920, p.17 e 57).

Para George Dantas (2003, p.57), 0 discurso de Januário Cicco reflete o preconceito para com as "práticas populares", sendo até radical em algumas de suas proposições como a relativa à completa destruição do Passo da Pátria, um pequeno bairro periférico da cidade (Figura 40).

As medidas expostas na publicação de Cicco revelam o caráter autoritário da ação higienista e a continuidade do posicionamento discriminatório de alguns setores da elite natalense em relação aos mais pobres e seus espaços de morar. A análise da cidade e as proposições formuladas por Januário Cicco pautaram, direta ou indiretamente, as ações mais significativas pensadas e realizadas na cidade até fins de 1939.

Ainda na década de 1920, ocorreu uma reestruturação administrativa focada

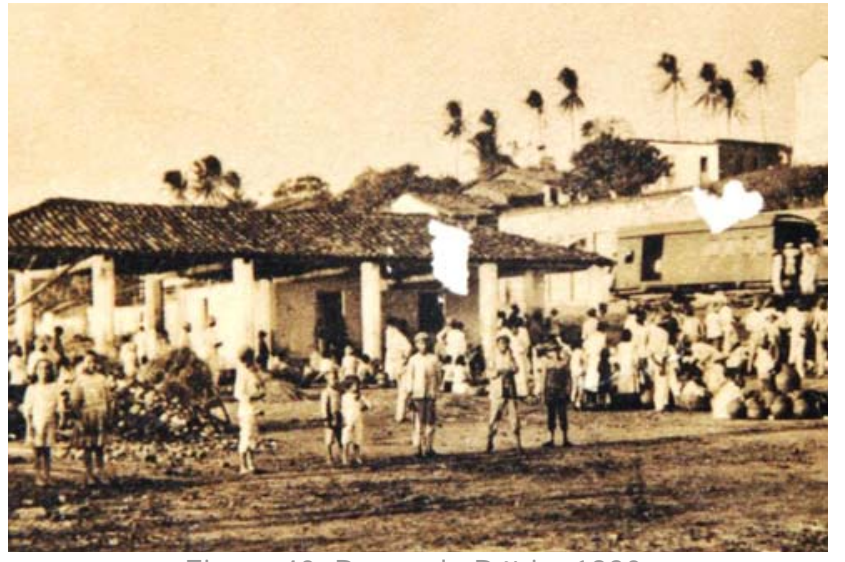

Figura 40: Passo da Pátria, 1920 Fonte: JAECl, 2006.

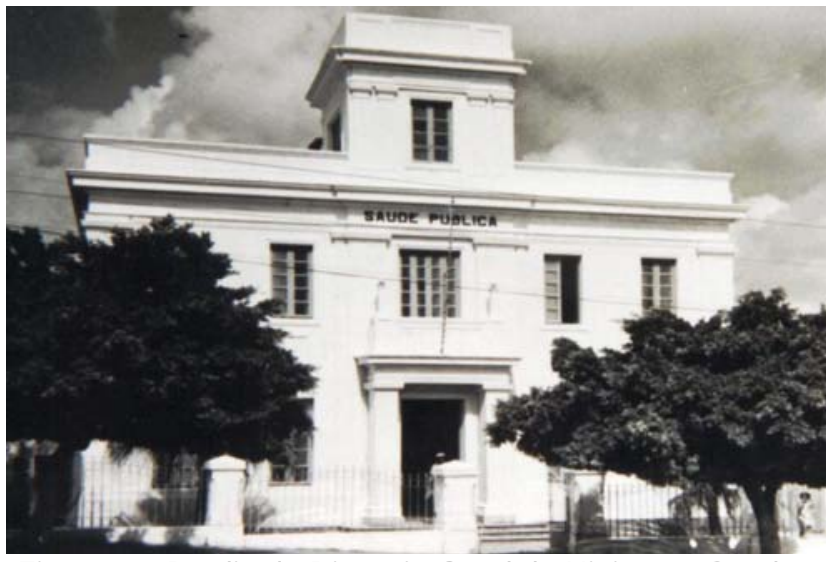

Figura 41: Prédio da Diretoria Geral de Higiene e Saúde Pública, 1930.

Fonte: JAECl, 2006

principalmente nos órgãos de higiene. Foi, nessa linha, elaborado um novo regulamento para a Inspetoria de Higiene, agora chamada de Diretoria Geral de Higiene e Saúde Pública (Figura 41), segundo o Decreto №. 148, de 01 setembro de 1921, sendo diretamente subordinada ao governo estadual e superintendida pelo Diretor Geral. No tocante às atribuições dadas à supracitada instituição, pouco ou quase nada mudou em relação àquelas instauradas em 1892.

No tocante à moradia o "novo regulamento" sistematizou normas que, em 1929, passaram a ser denominadas de Código de Obras para Construção Civil, a serem fiscalizadas pela Polícia Sanitária das Habitações, criada em 1925. Por esse novo dispositivo foi reafirmada a obrigatoriedade da apresentação das plantas da edificação à Intendência Municipal para análise a ser realizada pelas autoridades 
sanitárias, incluindo a partir desse momento, também as obras de reconstrução e/ou reforma de habitações. Passou-se ainda a exigir antes da construção de qualquer habitação no perímetro urbano da cidade, o saneamento do solo (ESTADO..., 1921, p.189-190).

O novo regulamento da Diretoria Geral de Higiene e Saúde Pública determinava que todas as habitações deveriam apresentar canalizações especiais de condução de águas pluviais para os esgotos ou sarjetas das ruas, assim como instalações sanitárias; as "casinhas" e as cozinhas deveriam ser instaladas longe dos aposentos de dormir, as cozinhas não poderiam ter comunicação com as latrinas; e as "chaminés de tiragem" deveriam ser construídas pelo menos a 1,5m de altura dos telhados das casas vizinhas (ESTADO DO RN, 1921, p.189-190).

No que se refere à disposição física das habitações, o novo código exigia que: todos os pavimentos térreos, porões habitáveis ou não, pátios, terrenos, etc. deveriam ser revestidos com materiais impermeáveis, de preferência por uma "camada de concreto de dez centímetros de espessura"; em todas as construções, salvo casos especiais, o piso do primeiro pavimento deveria ser concebido dez centímetros, no mínimo, acima do terreno circundante; todos os cômodos dos imóveis teriam que possuir aberturas - portas ou janelas - para o exterior, de modo a receber "luz e ar diretamente" (ESTADO DO RN, 1921, p.189-190).

Os cortiços foram, por esse Regulamento do Serviço Sanitário do Estado, reconhecidos oficialmente, sendo identificados como as "(...) casas que abrigarem ou serviram de dormitorio, ainda que temporario, a varias familias, ou a muitas pessoas de familias differentes (...)"(ESTADO DO RN, 1921, p.190). Para eles foi especificado que o número de moradores teria que ser proporcional às dimensões das edificações e dos seus cômodos, assim como, à natureza do estabelecimento - comercial, hotel, etc.; sendo estritamente proibida a superlotação nesses casos. As habitações coletivas teriam, ainda, que possuir uma latrina para cada grupo de 15 pessoas.

A reestruturação administrativa realizada nos órgãos de higiene e a normalização das construções realizada na cidade de Natal nesse período, não equivaleram a um caso específico. O mesmo ocorreu em diversas cidades do país (RIBEIRO, 1997).

Em 1924, outras disposições complementares àquelas formuladas em 1921 pela Diretoria Geral de Higiene e Saúde Pública foram elaboradas, sobretudo, acerca das habitações. Essas disposições especificavam que: 1) o pé-direito das construções destinadas à moradia deveria medir 3,5m; 2) 0 solo impermeabilizado por camada de concreto de $10 \mathrm{~cm}$ de espessura deveria ser aplicado para assoalhos de madeira, passando a medir $5 \mathrm{~cm}$ para os pisos em mosaicos; 3) 0 oitão da residência deveria ser livre pelo menos de um dos lados; 4) deveria ser realizada a impermeabilização das paredes contíguas em terrenos de nível superior; 5) todos os compartimentos do imóvel teriam que apresentar portas ou janelas providas de bandeiras basculantes; 6) a ocupação da edificação só poderia ocorrer 15 dias após o término da 
construção; 7) houvesse uma canalização especial de águas pluviais na edificação e no lote; 8) a altura das portas principais fossem de 2,5m a 3,5m, e das janelas fossem de 1,5m a 2,5m - a contar de $1 \mathrm{~m}$ acima do piso - e que a largura das portas e janelas principais fosse de 1m; 9) as residências deveriam possuir uma fossa destinada aos materiais fecais e uma fossa absorvente para águas servidas, quando se tratasse da zona urbana de periferia, equivalente na época aos bairros de Tirol, Petrópolis e Alecrim; 10) 0 barro, por ser uma substância que retém umidade, não deveria fazer parte da constituição da argamassa; 11) a areia empregada para a constituição da argamassa não deveria conter matéria orgânica; 12) as exigências da Repartição de Higiene estariam em concordância com as condições econômicas de cada indivíduo (PELAS..., 17/03/1924, p.01). A última cláusula, no entanto, só ficou no plano do discurso. Na prática, as ações referentes à higienização da cidade continuaram a apresentar um caráter segregador.

Em se tratando da fiscalização de moradias e especificações acerca dos procedimentos da Polícia Sanitária das Habitações, sobretudo relacionadas às intimações, foi formulado em 1924, o Decreto №. 229, de 29 de março, que especificou:

Art. 10 - As intimações relativas á policia sanitaria das habitações, a que se refere 0 Regulamento da Directoria de Hygiene e Saúde Pública, serão feitas por escripto assignado pelo respectivo funccionario, em duas vias, com indicação clara de cada melhoramento ou providencia exigida, citação do artigo, paragrapho e numero do mesmo regulamento, em virtude dos quaes for a intimação expedida, e o prazo em que deverá ser cumprida.

I - A segunda via da intimação ficará em poder do destinatario; a primeira, porém, será restituida á Secretaria da Directoria de Hygiene, depois que o destinatario tiver nella posto a nota de <<sciente >> que datará e assignará.

[...]

- As intimações, em geral, serão entregues por um dos guardas da Directoria de Hygiene (DECRETO №. 229, 29/03/1924)

Também foi a partir de 1924, com a ascensão de Omar O'Grady64 ao poder municipal, que se deu a transferência da arrecadação de impostos, como a décima urbana, a taxa de recolhimento de lixo e a taxa sanitária, para a esfera municipal. Em 1927, O'Grady sistematizou a obtenção e o pagamento do "habite-se" (GOVERNO..., 03/07/1927, p.03) que obrigava os proprietários a pagarem uma "(...) taxa de tres mil reaes sobre cada numero, ao realizar o emplacamento e numeração dos prédios da zona urbana (...)" (VÁRIAS..., 15/01/1925, p.01). O'Grady também incentivou o cumprimento dos "padrões estéticos" para as construções, sobretudo as habitações, para cada bairro da capital; o que segundo observadores da época, em muito contribuía para o "(..) desenvolvimento material desta cidade (...)" (Figura 42) (A REPÚBLICA, 15/01/1925, p.01).

\footnotetext{
${ }^{64}$ Até esse momento, a Intendência Municipal ainda era muito dependente do poder estadual, sem autonomia administrativa, apesar do programa de emancipação política dos municípios precedido pelo decreto o․ 08, de 16 de janeiro de 1890, que a originava. $\mathrm{O}$ início do primeiro mandato de O'Grady foi marcado pela busca por essa autonomia e por uma reforma administrativa, estabelecendo uma nova sessão de obras e atribuições à Intendência (DANTAS, 1998).
} 


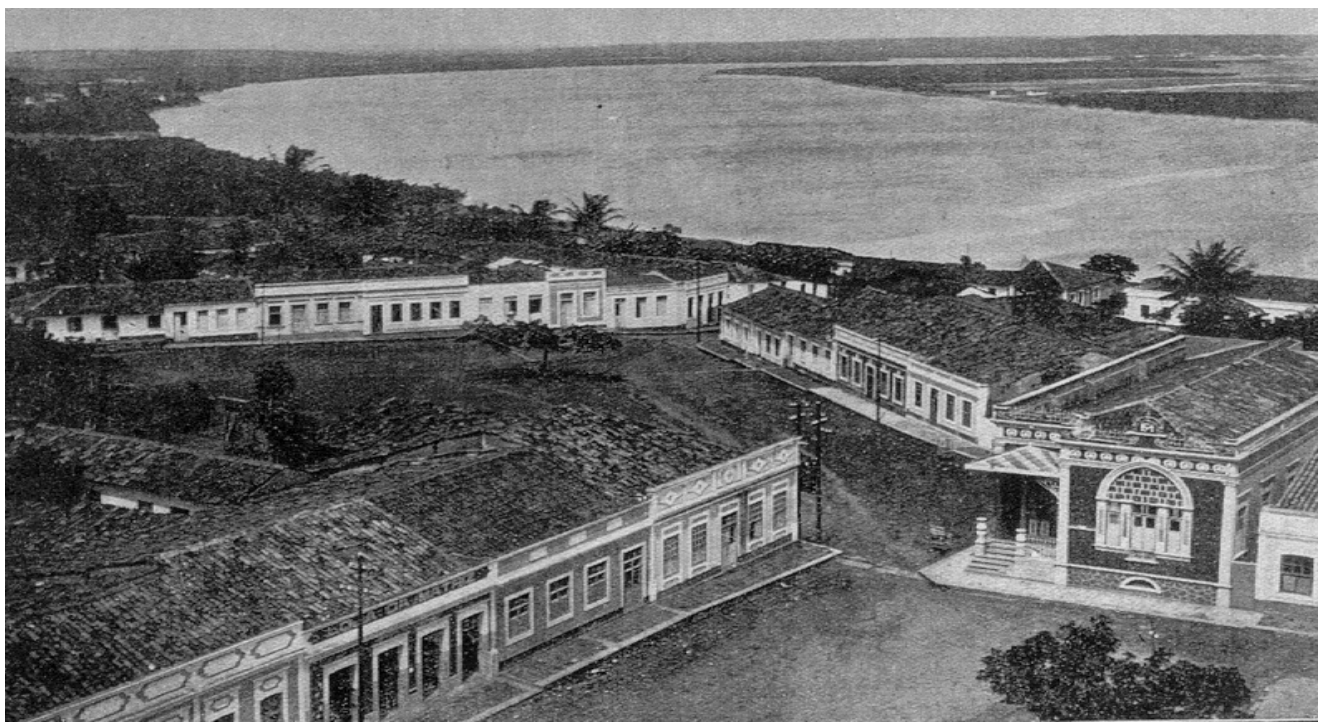

Figura 42: Casario da Avenida Junqueira Aires, década de 1920.

Fonte: POMBO, 1922

Para efetivar a fiscalização e o cumprimento das normas de "boa estética" e higiene nas edificações concebidas em todo o perímetro urbano de Natal, foi criada a Polícia das Construções subordinada à Diretoria de Obras que, semelhante à Polícia Sanitária das Habitações, detinha o poder de indicar modificações e/ou reformas nas construções, e em casos mais extremos, o de embargar obras, despejar moradores e dar voz de prisão para os que se recusassem a cumprir suas determinações (A REPÚBLICA, 15/01/1925, p.01).

A atuação pública, sobretudo no que diz respeito à fiscalização das edificações, de acordo com os jornais pesquisados, era largamente elogiada pela elite, satisfeita com os "padrões convenientes" dos bairros da cidade:

A municipalidade de Natal desde algum tempo vem demonstrando real solicitude no trato dos negócios públicos e o empenho de contribuir, nos justos limites de suas modestas finanças, para o desenvolvimento material desta cidade. (...).

Na polícia das construções, para exemplo, a actuação da Municipalidade é de resultados inestimaveis para o seu progresso, (...).

As providencias para este fim, constituindo restrições legaes ao direito de propriedade, despertam, frequentes vezes, a animadversão de alguns supostamente molestados, mas logo se incubem os factos de registrrar 0 acerto das attitudes assumidas pelo poder público, com a mira exclusiva no interesse geral. (...) (A REPÚBLICA, 15/01/1925, p.01).

Em 1929 mais um livro foi publicado com o intuito de "propagar os conceitos da higiene e divulgar meios de prevenção de doenças" (EDUARDO, 2000, p.94). O médico Alfredo Lyra foi 0 autor do livro intitulado Hygiene: falando e escrevendo, que por uma perspectiva integrada entre a higiene e a pedagogia explanava sobre a regulamentação do ensino, fossas e habitações. Para o médico, as moradias deveriam receber diariamente luz e ar em seus cômodos e, para tanto, teriam que possuir aberturas laterais livres, orientadas no terreno de acordo com o clima de cada região. Cada ambiente deveria receber duas horas diárias de insolação - possuir janelas retangulares, variando em área entre 1/4 
e 1/6 da superfície da parede - e ter ventilação natural contínua (LYRA, 1929). Ao contrário do livro de Januário Cicco, a supracitada publicação pouco repercutiu nas ações da administração da cidade no período.

A publicação do primeiro Código de Obras de Natal, denominado Código de Obras para a Construção Civil, foi também realizada em 1929, por meio da Lei №. 04, de 02 de setembro. Por intermédio desse Código, a administração municipal passou a ter um controle maior sobre 0 processo de urbanização da capital, assim como sobre a estética urbana, necessária segundo alguns setores da elite da época, ao "correto crescimento da cidade" (A REPÚBLICA, 15/01/1929, n.11, p.01).

A municipalidade proibiu, nesse sentido, a construção de prédios com menos de dois pavimentos nas principais ruas da Ribeira (Rua Dr. Barata e Rua do Comércio) (Figuras 43 e 44), nas Praças Augusto Severo e Leão XIII (Figuras 45 e 46), e nas Avenidas Tavares de Lyra e Sachet (Figura 47) (VÁRIAS..., 15/01/1929, n.11, p.01).

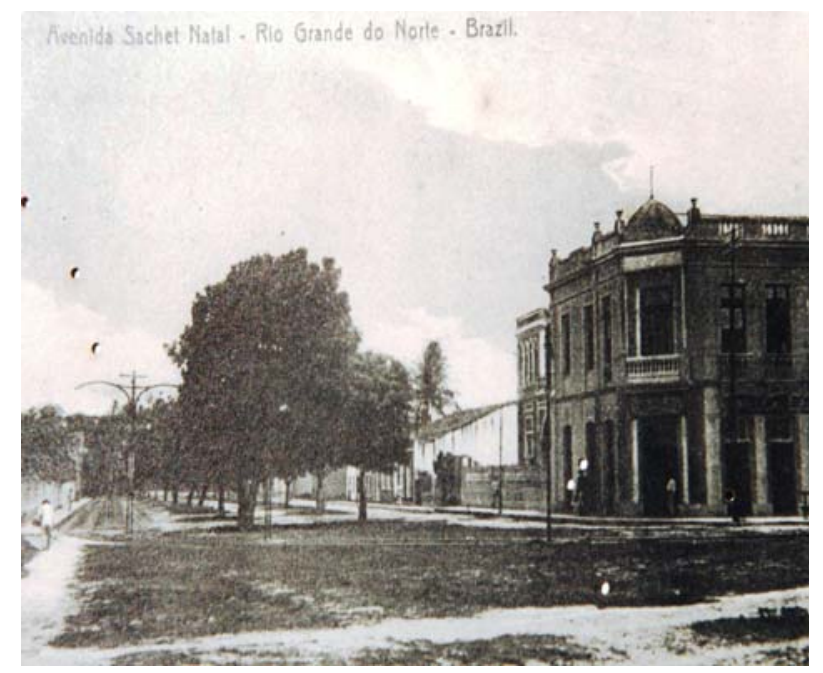

Figura 47: Avenida Sachet, 1910 Fonte: JAECI, 2006.
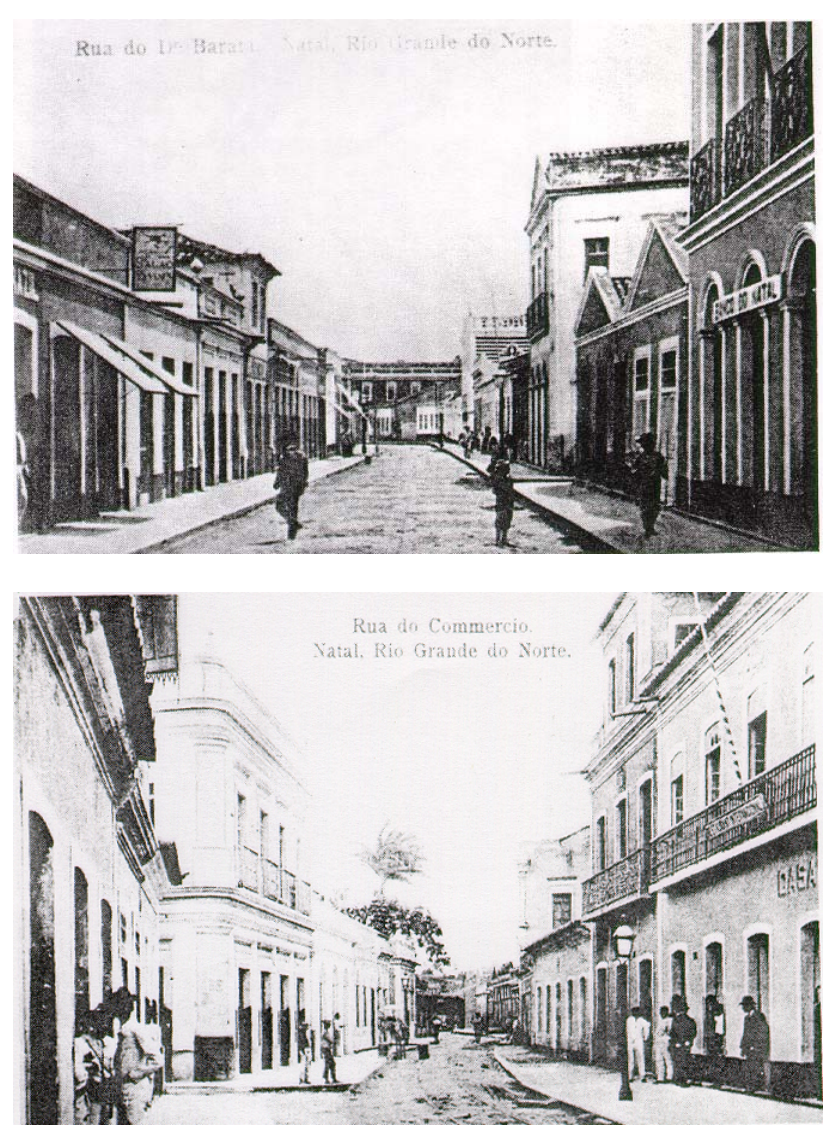

Figuras 43 e 44: Rua Dr. Barata e Rua do Comércio (1930). Fonte: MIRANDA, 1981.
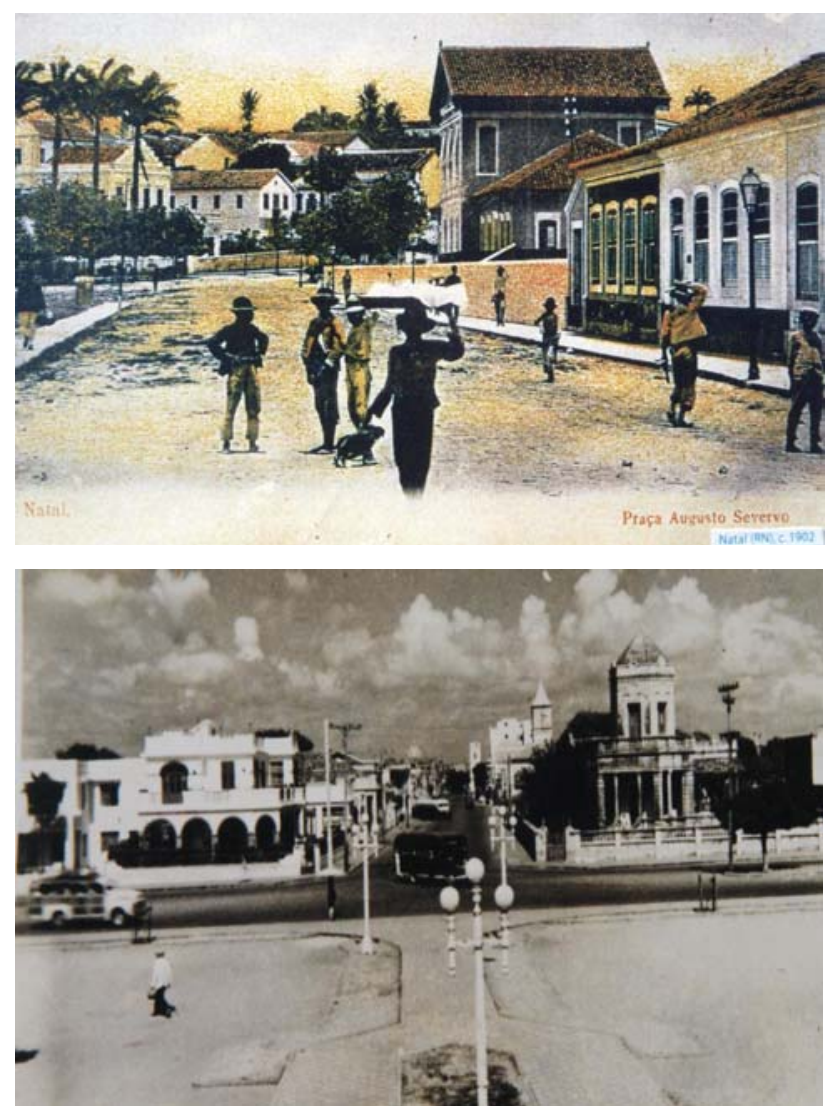

Figuras 45 e 46: Praça Augusto Severo (1902) e Praça Leão XIII, s/d.

Fonte: JAECl, 2006. 
As demais determinações em muito se assemelham àquelas observadas no Decreto no. 148, de primeiro de setembro de 1921. Dentre as conseqüências verificadas com a consolidação do "novo código" pode-se citar a paulatina eliminação de habitações populares do centro da capital.

Apesar dos apelos da população mais carente, publicados nos periódicos da época - geralmente os de oposição ao governo - 0 projeto de embelezamento e melhoramento estético de Natal teve continuidade. Dessa forma, estava novamente proibida a construção de casas em taipa e com outros materiais, como a madeira. Continuava-se a operar a substituição de edificações e a modernização das fachadas (A REPÚBLICA, 27/03/1930, p.01).

A partir de 1930, a cidade passou a ser alvo de intervenções sistematizadas em um programa de âmbito nacional, instituído pelo presidente Getúlio Vargas (1930-1945). Nos discursos e ações ainda predominavam os preceitos do higienismo. As intervenções na habitação seguiam essas diretrizes. Ainda evidenciava-se no início da década, a busca pelo "equilíbrio estético" das edificações por meio da proibição da construção de mocambos, cortiços e casebres no perímetro da cidade, almejando a homogeneidade de suas edificações, e a elaboração de normas restritivas, verbalizadas pelas resoluções municipais. Essa busca pelo embelezamento da cidade, principalmente 0 da fisionomia de suas habitações, ganhou ainda mais vulto em meados da década. Requeria-se, nesse sentido, uma maior rigidez na fiscalização dos projetos pela prefeitura e uma maior atenção para com as fachadas das residências, muitas vezes esquecidas pelos construtores que, segundo a imprensa da época, estavam somente interessados em conceber moradias baratas (A PROPÓSITO..., 04/03/1934, p.07).

Para aperfeiçoar a fiscalização estético-higiênica das construções já concebidas e daquelas em fase de construção, e para que pudesse ser efetuada eficazmente a cobrança do Imposto Territorial, deuse continuidade ao processo de cadastramento de terrenos e edificações, iniciado em meados da década de 1900 na cidade65. Com o mesmo propósito foi ampliada a Lei №. 04, de 02 de setembro de 1929 - 0 Código de Obras de Natal - que dispunha sobre construções, reconstruções, acréscimos e modificações de prédios na cidade. Ficou proibida por essa ampliação a construção de edificações com apenas um pavimento nas principais avenidas e praças da capital: na Avenida Rio Branco (Figura 48), entre ela e a Praça Augusto Severo; nas Praças André de Albuquerque e Sete de Setembro (Figura 49); na Rua Ulysses Caldas; além dos logradouros já mencionados no $\S 3^{\circ}$ do Art. 61, da Lei no. 04. Os reparos e reformas permitidas nas edificações existentes nessas localidades correspondiam aos serviços de limpeza, reparos na cobertura, mudanças de esquadrias sem que fossem alteradas as larguras dos vãos, construções de gabinetes sanitários e serviços inadiáveis referentes à estrutura do prédio, desde que

\footnotetext{
65 Nesse sentido foi aprovado, em 23 de dezembro de 1931, o decreto №. 183, autorizando o poder municipal a convocar os contribuintes a apresentar por escrito a planta de situação do imóvel, onde seriam também especificadas: a sua área total em metros quadrados; 0 valor atual das terras; o valor das benfeitorias e construções; os limites conhecidos ou o nome dos confrontantes; e, se fosse 0 caso, a área cultivada e o número e descrição das espécies de animais existentes (BARBOSA, 09/01/1932, p.03).
} 
estes não importassem em modificações internas ou em mudanças no aspecto da edificação (ACTO №.8..., 29/08/1935, p.06).

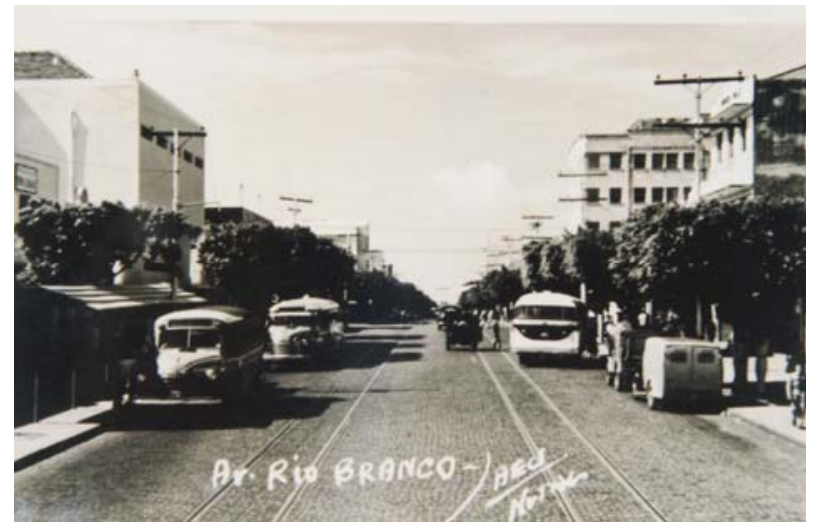

Figura 48: Avenida Rio Branco. Fonte: JAECI, 2006

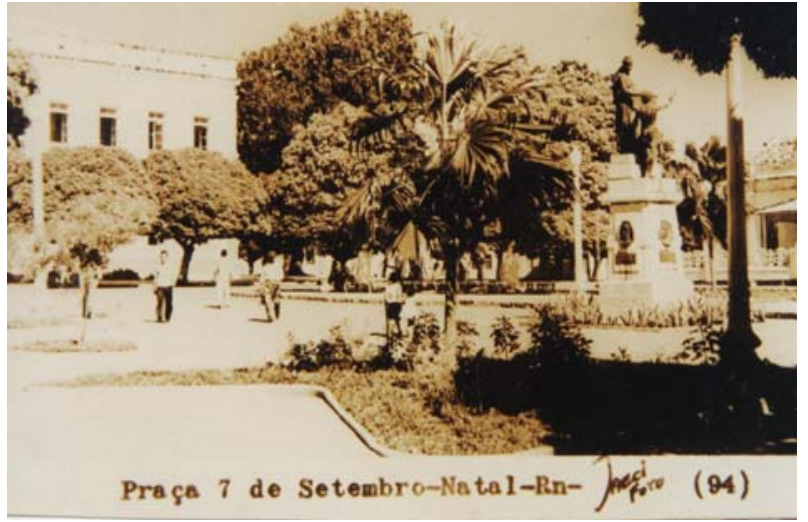

Figura 49: Praça Sete de Setembro. Fonte: JAECI, 2006.

O recuo frontal exigido para as novas edificações concebidas em toda a área urbana da cidade foi reduzido de cinco para três metros frontais, sendo mantida àquela dimensão para as áreas periféricas. Salvo o caso dos terrenos com pouca profundidade, até $22 \mathrm{~m}$, para os quais a edificação poderia ser erguida no alinhamento do logradouro público66. Mudanças nas disposições acerca do desmembramento de terrenos e da dimensão dos lotes resultantes também foram evidenciadas. Na área central da cidade, os lotes teriam que possuir no mínimo sete metros de testada por trinta metros de profundidade, seguidos de oito e dez metros de testada para o restante da zona urbana e na zona suburbana, respectivamente. Quando não fosse possível o desmembramento seguindo esses critérios, a metragem que faltasse na testada, por exemplo, poderia ser compensada na profundidade e vice versa (ACTO №.8..., 29/08/1935, p.06). As demais disposições em voga foram mantidas.

Essa "atualização" da medida disciplinar de controle da concepção de moradias foi aclamada em diversos artigos pela imprensa oficial da época, que ressaltavam o "adiantamento" das ações de seus administradores, principalmente, do prefeito Omar O'Grady, em seu segundo mandato:

O municipio da Capital, mediante resolução do respectivo Prefeito, fixou quaes os logradouros onde não permitirá senão a construcção de predios de mais de um pavimento. A providencia é acertada e oportuna. Natal é uma cidade cujo desenvolvimento nos ultimos tempos é manifesto, e se faz com certa impetuosidade, espraiando-se por terras até bem pouco devolutas e consideradas sem prestimo mas que imprevistamente entraram a se valorizar por uma maneira espantosa. Á municipalidade cabia disciplinar essa expansão, tendo em vista as normas geralmente admittidas em todos os centros para regerem a materia. (...) Assim, a Capital vae assimilando preceitos da urbanistica que fazem parte da legislação das cidades mais adiantadas de todas as partes do mundo, ao mesmo tempo em que se colloca á altura dos destinos com que a

\footnotetext{
${ }^{66}$ Ao construírem novas edificações em todo o perímetro da cidade os proprietários, por meio desse dispositivo, seriam obrigados a conceberem os respectivos passeios e muros de "(...) accordo com a bitola adaptada pela Prefeitura (...)". Para os prédios existentes cujas ruas já apresentassem meio-fio, os proprietários ou responsáveis teriam o prazo de 120 dias, contados a partir da data de intimação da Diretoria de Obras da Prefeitura para fazê-los sob pena de multa de $100 \$ 000$ (cem mil réis) (ACTO N.8..., 29/08/1935, p.06).
} 
laboriosidade do seu povo the acena, e torna-se uma feliz expressão do espirito progressista brasileiro nesta parte do Paiz (...) (A REPÚBLICA, 27/09/35, p.01).

Em fins de 1935, o problema da moradia urbana em Natal ainda era intimamente associado ao "mau gosto" das fachadas das residências. Nesse contexto, foi elaborada a Lei no. 19, de 14 de novembro de 1935, a qual reeditava os padrões construtivos e estéticos das habitações de cada bairro da cidade, "(...) dentro de uma certa uniformidade, própria a cada bairro, não se consentindo que os proprietários edifiquem ao gosto variável dos constructores, alguns dos quaes se cingem exclusivamente ao critério do maior lucro" (COMO..., 15/03/1936, p.01). O artigo refere-se, principalmente, às residências edificadas nos bairros das Rocas e Lagoa Seca67, apontadas como os bairros dos "mucambos" da cidade (COMO..., 15/03/1936, p.01).

Em 1937, por meio do Decreto №. 338 de 26 de novembro foi instituída a Repartição de Saneamento de Natal68 - RSN - responsável pelo planejamento, projeto e execução dos serviços de saneamento da capital, representando mais um instrumento normatizador das edificações e regulador da expansão do espaço urbano da cidade a partir das redes de água e esgoto existente e/ou traçadas (DANTAS, 2003):

Art. 58 - A repartição, (...), fará levantar as plantas dos prédios existentes, para sobre elas projetar o serviço sanitário, ficando o proprietário obrigado a executar as suas custas as modificações indicadas (...) para a situação dos gabinetes respectivos em planta e altitude. (...) (RIO GRANDE DO NORTE, 1939, p.51-59).

Devido às obras de instalação das redes sanitárias foi determinado pelo Decreto №. 362, de 11 de dezembro de 1937, que nenhuma planta de construção ou reforma de edificações nas áreas que seriam capacitadas pela nova rede de esgotos, a ser concebida pela RSN, seria aprovada pela Prefeitura Municipal sem que o proprietário tivesse requerido à Comissão de Saneamento a respectiva instalação sanitária. Também por ele, o Departamento de Saúde Pública (antiga Diretoria de Higiene e Saúde Pública) não estava autorizado a conceder o alvará de habitação, o "habite-se", para as novas construções sem que a Comissão de Saneamento declarasse que o proprietário já havia atendido às exigências referentes aos esgotos sanitários.

Em 22 de dezembro do mesmo ano, por meio do Decreto №. 377, os serviços sanitários do estado foram reorganizados. Em relação às habitações o Regulamento do Departamento de Saúde Pública, reservou dois capítulos: um para especificar as atribuições da Polícia Sanitária das Habitações e outro abordando a higiene das habitações, construções e reformas. Em se tratando das responsabilidades e direitos da Polícia Sanitária, pouco se acrescentou. Em relação às habitações, houve alteração quanto à

\footnotetext{
${ }^{67}$ Ainda considerados a margem do perímetro urbano da cidade.

68 Antiga Comissão de Saneamento de Natal - CSN - criada no ano de 1935, por meio do decreto o. 823 , de 26 de abril. Nesse mesmo ano, foi contratado o Escritório Saturnino de Brito, pelo decreto no. 844, de 20 de maio, que culminou na elaboração do Plano Geral de Obras, em 1939.
} 
dimensão do pé-direito para as moradias a serem construídas nas zonas suburbana e rural do estado, passando de 3,5m para $3 \mathrm{~m}$ a altura exigida.

O Regulamento Geral para os serviços da Repartição de Saneamento de Natal foi baixado pelo Decreto no. 449, em 09 de março de 1938. Por ele foi determinado que as plantas de toda e qualquer construção ou reforma em edificações, incluindo a demolição e a elevação de paredes até aquelas relacionadas ao revestimento de pisos, teriam que receber 0 aval da Repartição, que se responsabilizaria pelas “(...) modificações necessárias e obrigatórias no plano apresentado (...)". Plantas complementares como, por exemplo, de situação e implantação do terreno, apresentados em escala menor, também passaram a ser cobradas nesse momento69. Os projetos solicitados dos proprietários dos imóveis pela Repartição seriam formulados por funcionários especializados da própria RSN, e por esses serviços seriam cobradas taxas que seriam inclusas nas contas de instalação do serviço de esgoto ${ }^{70}$.

Pelo Regulamento, a fiscalização das obras e edificações já concebidas estaria sujeita à fiscalização de funcionários da Repartição de Saneamento sempre que fosse "conveniente", além da inspeção realizada pelos fiscais do Departamento de Saúde Pública, sendo apoiada, quando preciso fosse, pelas autoridades policiais ${ }^{71}$. Em relação à rede de esgoto, a fiscalização a ser realizada pela RSN ultrapassaria o perímetro da rede, tendo a Repartição, competência para inutilizar uma instalação entendia-se habitação - quando essas não satisfizessem os princípios da higiene em relação aos moradores e vizinhos (DECRETO №. 449, 09/03/1938, Art.65, 95 e 108).

Da mesma forma que no regulamento da Diretoria Geral de Higiene e Saúde Pública de 1921, 0 novo regulamento da RSN, se deteve a definir algumas das tipologias habitacionais. Nele, eram consideradas "(...) moradias ou habitações em série ou mocambos (...)", as "(...) habitações populares ou economicas e as villas operárias, cada uma formando economia distincta, alinhadas em vias particulares de typos normaes ou dispostos nos parques particulares". As "habitações colletivas normaes" por sua vez, eram aquelas, nas quais existia a utilização coletiva de equipamentos como a cozinha, a lavanderia e 0

\footnotetext{
${ }^{69}$ Após aprovados, os projetos não poderiam ser modificados. Sua alteração estaria sujeita a multa que variava entre $50 \$ 000$ (cinqüenta mil réis) e $400 \$ 000$ (quatrocentos mil réis), dependendo da influência da "infração" no serviço sanitário, que incluía desde a iluminação e ventilação até a situação do edifício no terreno.

70 Essas taxas equivaliam às importâncias de: a) pelo levantamento da planta do terreno e do prédio existente com um pavimento e redução da planta - 40\$000; b) pavimento excedente ao primeiro - 15\$000; c) pelo levantamento da planta do terreno e das habitações e grupo existente (cortiços, etc.) com redução da planta por moradia - 20\$000; d) pela alteração anterior à construção de planta feita e aprovada, a pedido do proprietário - 15\$000 (DECRETO №. 449, 09/03/1938, Art. 61).

${ }^{71} \mathrm{O}$ proprietário que fosse avisado ou intimado a adequar seu imóvel às exigências da RSN e não comparecesse no prazo determinado pela Repartição, estaria sujeito ao pagamento de uma taxa acumulativa, a contar do segundo mês da data da intimação, somada a multa fixa de $50 \$ 000$ (cinqüenta mil réis). No caso de urgência, se o proprietário se negasse a efetuar as devidas modificações higiênicas, a Repartição estaria autorizada pelo Governo a executar os serviços à sua revelia, sendo nesses casos, cobradas as despesas integralmente. O regimento interno da Repartição de Saneamento estabelecia as condições em que deveriam ser efetuados os serviços de inspeções obrigatórias e requisitadas conforme a tipologia de cada moradia - residências unifiamiliares, habitações coletivas, cortiços, etc. A apuração da responsabilidade por uma infração compreendendo vários moradores seria competência da polícia sanitária, a qual nesses casos caberia: "(...) abrir inquérito, á requisição da Repartição e communicar a esta o resultado para os devidos effeitos; admittida a possibilidade de um accordo entre interessados para nada revelarem, será imposta a multa máxima e por estes subdividida (...)" ((DECRETO №. 449, 09/03/1938, Art.96 e Art.108, § 20).
} 
gabinete sanitário. A definição de "grupos de mocambos", "cortiços" e "quadros" em muito se assemelha à anterior, se diferenciando pelo estado higiênico, que nesses casos era precário. Equivaliam, portanto, às “(...) habitações precárias, dispostas em desordem, no terreno ou em serie, ao longo de viellas, corredores ou pateos, formados por casebres ou quartos sem condições de conforto e salubridade das habitações normaes (...)". Para essa tipologia habitacional, o Regulamento previa uso coletivo ou comum da distribuição de água e dos equipamentos de esgoto a serem instalados em pavilhões ou em gabinetes sanitários (DECRETO №. 449, 09/03/1938, Art. 92).

Em 1939, o Escritório Saturnino de Brito, à frente da Repartição de Saneamento de Natal, elaborou o Plano Geral de Obras, um plano que se propunha a organizar, reformar, expandir e embelezar 0 espaço urbano da cidade de Natal em função das redes de água e esgotos ${ }^{72}$. Esse Plano tornou-se um importante guia para as ações das administrações locais na cidade a partir de então.

A instalação da Base Norte Americana e a chegada das tropas na capital, no ano de 1942, além da entrada de uma grande leva de imigrantes na cidade - atraídos pelo "progresso econômico" evidenciado pelas novas ofertas de emprego e pelo aumento do dinheiro circulante - resultaram em um considerável crescimento populacional de Natal73 (Figuras 50 e 51). Essa conjuntura acarretou uma grande procura por hospedagens, pensões, hotéis e casas para se alugar, e impulsionou a construção de habitações por parte da iniciativa privada, ao mesmo tempo em que inflacionou os preços das locações, negligenciando a Lei do Inquilinato instituída em 1942, que congelava esses valores.

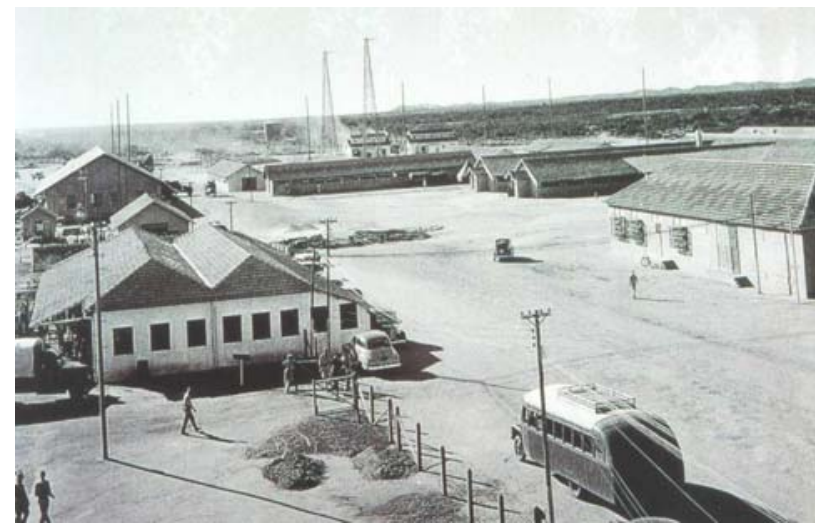

Figura 50: Base Aérea de Natal, 1942. Fonte: JAECI, 2006.

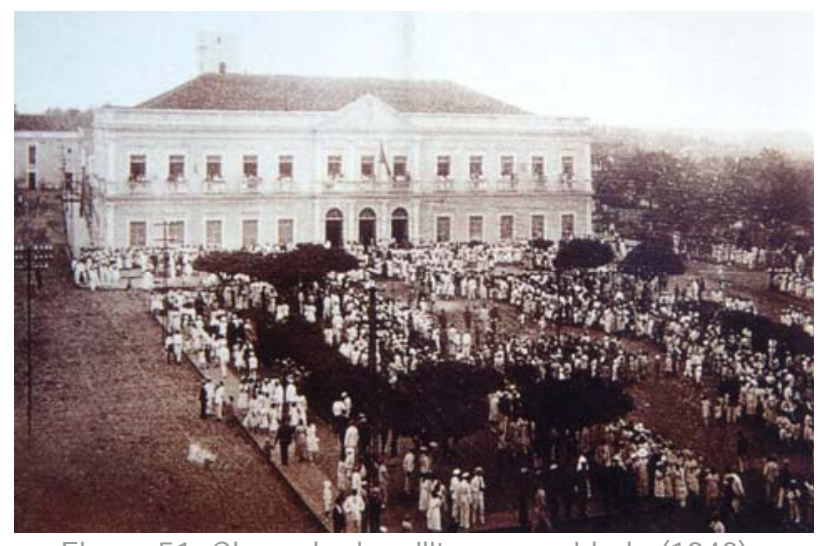

Figura 51: Chegada de militares na cidade (1942) Fonte: JAECI, 2006.

Eram quotidianamente publicadas nos jornais locais, ordens de despejo e notas sobre os exorbitantes aumentos dos preços de aluguéis, considerados por Ferreira (1996), como a outra face da "febre de construções" por que Natal passou na década de 1940:

\footnotetext{
72 Dentre as propostas relacionadas à habitação estava a criação de um bairro operário, a ser estudado no tópico, $A$ Atuação estatal: um panorama geral.

73 No início da década de 1940, Natal possuía cerca de 58.057 habitantes (QUANTOS..., 1942, p.12) aumentando esse número para 123.215 habitantes, de acordo com o censo, nos anos de 1950.
} 
(...) Natal cidade provinciana esquecida, passou a ser o ponto preferido de milhares de pessoas, encarregadas dos mais diversos misteres relativos ao conflito. Militares e civis aqui se instalaram, embora por pouco tempo, porém, o que é certo, ocupando hotéis, pensões, e alugando casas por preços nunca vistos. (...). Alugar casa tornou-se um negócio da China, para o dono de casa... Desde a mais modesta residência até bangalôs suntuósos foram desalojados pelos seus proprietários e ocupados por inquilinos pródigos, que não regateavam alugueis. (...) Intencificou-se, então, a chamada "febre de construções". Em cada bairro da cidade dezenas de edificações se levantaram e continuaram se levantando, ocupando centenas de pedreiros e outros "oficiais" conexos. Nas Rócas, na Ribeira, na Cidade Alta, em Tirol, em Petropolis, no Alecrim podem ser vistas hoje modernas e elegantes edificações. Terrenos que outróra eram somente depósito de lixo, atualmente servem de bases a luxuosos palacêtes. (...). (A GUERRA..., 30/01/1945, p.08).

A referida "febre de construções" retratava um quadro diferente do verificado em âmbito nacional, marcado pela crise na construção civil em decorrência da Lei do Inquilinato e da elevação dos preços dos materiais de construção, devido às altas taxas pagas para importação e a sua posterior interrupção devido à ocorrência da Segunda Guerra. Em Natal, a ascensão de valores dos produtos para edificação foi absorvida pelo custo dos aluguéis, contribuindo também para a sua elevação ${ }^{74}$. De acordo com os periódicos do período: "(...) tudo vai de acordo com a época; si o material era caro, consequentemente, 0 prédio também o seria, justificando os altos alugueis, compensadores para os construtores do período" (EDIFICIOS..., 30/01/1945, p.08).

Frente ao rápido crescimento da cidade e à concepção de inúmeras edificações nesse período, 0 sistema de fiscalização das habitações tornou-se obsoleto. Mais uma vez evidenciou-se no cenário da capital norte-riograndense, diversas edificações de baixos padrões construtivos, resultantes da ação da iniciativa privada com ânsia de lucro e/ou da população sem condições de construir uma residência adequada, o que segundo alguns setores da população, em muito "empobrecia" o espaço urbano de Natal (DANILO, 1942, p.08).

O Plano Geral de Obras de 1939 que balizara as ações das administrações desde sua criação, também se tornou obsoleto frente ao intenso crescimento por que passou a cidade nas décadas de $1940 \mathrm{e}$ 1950 - recorte temporal considerado pela historiografia local como um "período sem planos". Foi um período de transição entre a era dos planos urbanísticos e a institucionalização do planejamento urbano, finalizado pela elaboração, em 1967, do Plano Urbanístico e de Desenvolvimento de Natal75 (DANTAS e ALMEIDA, 2004).

\footnotetext{
74 Para se ter uma breve noção dos custos desprendidos com a construção de uma edificação naquela época basta saber que um milheiro de tijolos que custava, antes da Guerra, Cr $\$ 60,00$ (sessenta cruzeiros) passou a custar nos primeiros anos da década de 1940, cerca de Cr $\$ 130,00$ (cento e trinta cruzeiros) e que uma saca de cimento que valia $\mathrm{Cr} \$ 15,00$ (quinze cruzeiros) teve seu preço elevado para $\mathrm{Cr} \$ 40,00$ (quarenta cruzeiros). Mas, nada disso interrompeu o acelerado ritmo que se dava à construção de novos prédios na capital (EDIFICIOS..., 30/01/1945, p.08).

${ }^{75}$ Plano elaborado pelo arquiteto Jorge Wilheim em conjunto com o Escritório Serete, que objetivava dotar a cidade de infraestrutura necessária à sua industrialização, representando a institucionalização definitiva do planejamento urbano em Natal.
} 
No tocante às edificações, as resoluções municipais (Códigos de Obras) e os regulamentos do Departamento de Saúde Pública e da Repartição de Saneamento de Natal regiam as reformas e a concepção de novas construções na cidade, no supracitado intervalo de tempo.

O controle e ordenamento das construções por parte da Repartição de Saneamento de Natal, assim como dos serviços de água e esgotos, também foi considerado obsoleto. Foi realizada então, uma reestruturação e reorganizadas as funções da RSN, que por meio da Lei o․ 868, de 30 de dezembro de 1952, passou a se chamar Departamento de Saneamento do Estado - DSE - também dirigido pelo Escritório Saturnino de Brito. Ao DSE caberia inclusive coordenar modificações na estrutura urbana e nas habitações da cidade, uma vez que os projetos de arruamento da Prefeitura deveriam ser realizados de acordo com os esquemas gerais projetados para as redes de água e esgotos. O Regulamento que regia as suas ações foi outorgado em 05 de junho de 1953, por meio do Decreto no. 2.370, que semelhante aos outros regulamentos sanitários, determinava que nenhum prédio poderia ser construído, reformado ou habitado sem o aval do Departamento e o certificado de que possuía novas instalações sanitárias (RIO GRANDE DO NORTE, 1952). Especificadamente em relação às moradias, o Regulamento de DSE, ao contrário dos precedentes, fornecia à população um verdadeiro manual de concepção de gabinetes sanitários, restringindo-se a essas disposições no tocante à conformação física das habitações. Por ele:

Art. 84. § 10 - Os gabinetes sanitários deverão obrigatoriamente satisfazer às condições seguintes:

a) - o piso será de mosaico claro;

b) - as áreas mínimas serão as seguintes:

3 metros quadrados $\left(3 \mathrm{~m}^{2}\right)$, quando se tratar de gabinete com aparelho, banheiro e outra qualquer peça conjugada;

2 metros quadrados e vinte $\left(2,20 \mathrm{~m}^{2}\right)$, quando se tratar de gabinete com aparelho e banheiro conjugado;

1 metro quadrado e vinte $\left(1,2 \mathrm{~m}^{2}\right)$, quando no gabinete só houver um aparelho;

c) - as paredes deverão ser revestidas de azulejo branco ou de cor clara, até a altura de um metro e cinqüenta $(1,5 \mathrm{~m})$, a contar do piso, podendo, todavia, a direção do Departamento admitir, a título precário, o revestimento de outra espécie de material impermeabilizante;

d) - os gabinetes deverão ser providos de janelas ou mezaninos, de venezianas e vidro, dispostos com saída livre para uma área, não se compreendendo como meios de condução de ar e luz, portas e janelas, ou mezaninos de folhas inteiriças (...). O vão, para entrada de ar e luz, não deverá ser inferior a um quinto (1/5) da área do piso;

e) - os gabinetes sanitários não deverão ter comunicação com depósitos de gêneros alimentícios e cozinhas, podendo, todavia, comunicar-se com salas de refeições e de estar, copas, terraços, passagens, etc.;

f) - 0 pé direito mínimo dos gabinetes (...) será de dois metros e cinqüenta $(2,5 \mathrm{~m})$, inclusive o frechal (DECRETO №. 2.370, 05/06/1953, Art. 84/85).

Muitas dessas especificações colocadas pelo Regulamento do Departamento de Saneamento do Estado foram incorporadas nos Códigos de Obras Municipais, elaborados posteriormente, ficando assegurada a eles, a quase totalidade das disposições, regras e normas construtivas, acerca das edificações da cidade a partir da década de 1950. Os Códigos de Obras Municipais, juntamente com as 
resoluções que objetivavam a reforma do espaço físico da capital, incluindo as habitações, visando entre outras coisas à instalação de indústrias na localidade, marcaram a atuação da administração pública no campo da habitação no plano legislativo a partir de então.

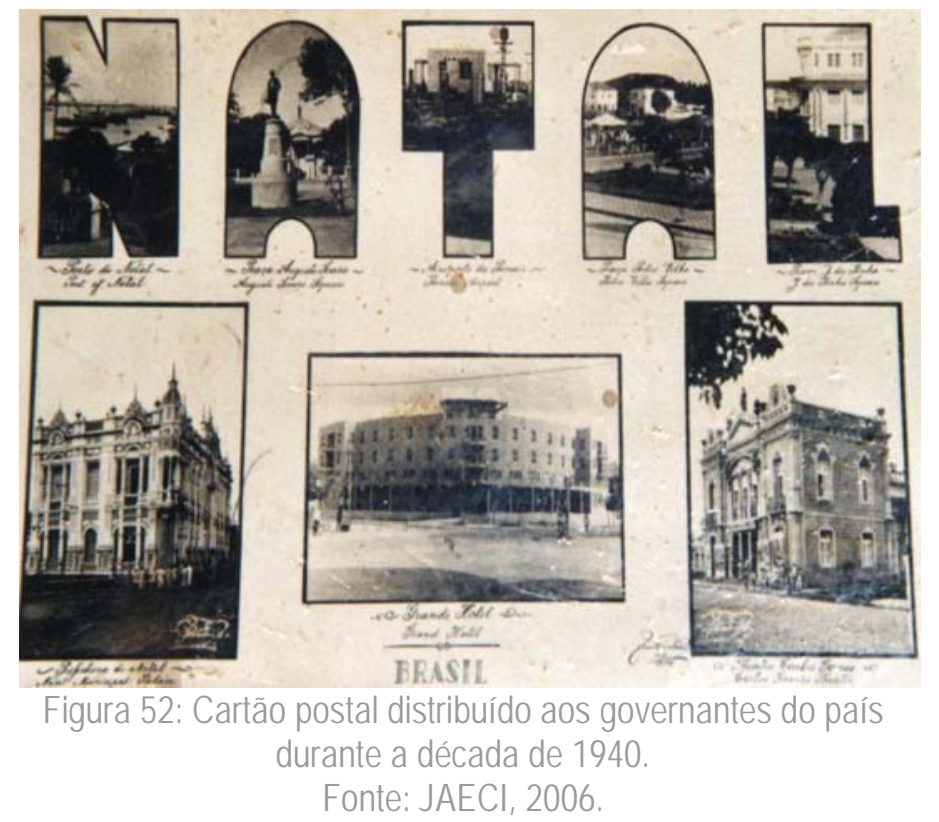

Percebe-se, dessa forma, que 0 saneamento deixou de ser objetivo central no desenvolvimento físico da cidade a partir, essencialmente, da década de 1950. A higiene, por sua vez, não era mais vista como a propulsora principal do progresso de Natal, cedendo lugar ao processo de industrialização e, posteriormente ao turismo, que passaram a ocupar o cerne das políticas públicas justificando muitas das intervenções na cidade (Figuras 52).

Nesse sentido, era preponderante para a consolidação destas atividades, garantir condições básicas de saúde e moradia para a mão-de-obra, ou seja, propiciar condições para a reprodução da força de trabalho e do capital. A habitação tornou-se então elemento de grande força e importância nos discursos e ações públicas do período.

Por outro viés, as críticas à concepção de "habitações esteticamente inadequadas ao progresso da cidade", perduravam nesse período. Ainda eram recorrentes as publicações que abordavam esta temática e que requeriam uma atitude enérgica por parte da Prefeitura:

(...) venho (...) endereçar (...) a minha estranheza pelo fato de se estar construindo na rua João Pessoa, esquina da Princesa Isabel, um grande casarão que só poderia ser plantado numa dessas povoações do interior, (...). Não póde entrar na cabeça de ninguém que, diante do progresso de Natal, seja permitida a edificação de tão teratológico projeto. A fachada do prédio (...), é construida de um paredão lambido, com umas portas baixas, desengonçada, sem ao menos uma marquise para disfarçar o horror. $E(. .$.$) com agravente de estar sendo construido por um engenheiro da prefeitura ...(...).$ (A. Z..., 08/02/1952, p.04)

(...) tivemos oportunidade de clamor contra o mostrengo que está sendo construido na Avenida Rio Branco, perto do Grande Ponto. Trata-se de uma casa feia, de um so pavimento, (...), flagrante infração á lei, que obriga, naquela bela avenida, somente construções de mais de um pavimento (...). (ATENTADO..., 15/10/1952, p.06)

Foram adotadas pela administração municipal, neste sentido, outras medidas restritivas de caráter estético como, por exemplo, a proibição da construção de residências nas principais avenidas da cidade, 
dentre elas a Avenida Circular (Figura 53), fora dos mais "modernos aspectos arquitetônicos", como os das edificações encontradas no Rio de Janeiro e no Recife (ESTABELECIMENTO..., 18/05/1954, p.04).

Até este momento, a ausência de um órgão específico de planejamento urbano em Natal permitiu que parte do crescimento da cidade se desse pela disseminação de loteamentos e conjuntos habitacionais aprovados sem diretrizes urbanísticas. Diante dessa conjuntura e com intuito de controlar a expansão e o uso do solo, o então prefeito Djalma Maranhão (1956-1958), em meados da década de 1950, propôs a elaboração de um "plano"

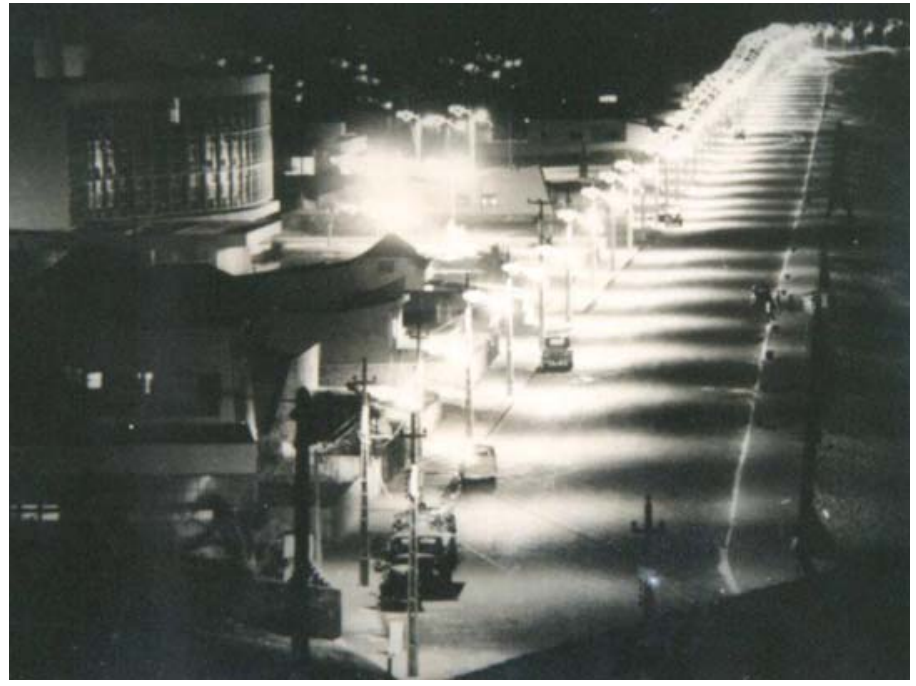

Figura 53: Avenida Circular, década de 1940. Fonte: JAECI, 2006. que conduzisse o crescimento de Natal frente ao considerado obsoleto Plano de Sistematização elaborado por Palumbo, em 1929, que ainda se configurava como baliza para as ações municipais nesse sentido. Segundo o Prefeito, o Plano Palumbo sofreu algumas alterações "pouco felizes", e correspondia naquele momento a um Plano incompleto que necessitava ser ampliado para abranger as novas localidades da cidade, como Parnamirim e Redinha, para que as construções "(...) ali sejam orientadas de modo a não prejudicar a sua beleza natural (...)" (LAMARTINE, 1956, p.04).

Nessa mesma linha, foi proposta pelo prefeito a criação de um Conselho Municipal de Urbanismo, que atuaria como órgão de consulta da administração municipal por meio de uma legislação própria, que passaria a atuar a partir de 1956 (SILVA, 1957, p.05), com o objetivo de consolidar uma identidade urbanística (DANTAS, 2003).

Para as habitações que, segundo Djalma Maranhão, ainda não se enquadravam nas normas arquitetônicas adotadas nos grandes centros, o prefeito contratou o engenheiro Antônio Tejo e o arquiteto Arialdo Pinto para elaborar um novo Código de Obras para Natal à altura de seu progresso e de modo a evitar que "(...) mais tarde se reflitam em sua urbanização os erros que hoje ocorrem (...)" (REUNIDAS..., 1956, p.08). Um dos principais objetivos do novo Código era por fim aos cortiços e às construções realizadas sem licença da Prefeitura, intento antigo, mas que ganhou novo viés. Os proprietários que insistissem em edificar sem o alvará seriam notificados, multados e as obras seriam paralisadas. Em relação à edificação propriamente dita, o novo Código especificava uma taxa de ocupação de 60\% da área do terreno. Para as vilas populares, o Código determinava que seis representava o número máximo de casas que poderiam ser construídas conjugadas. Somente assim, a administração pública acreditava 
poder acabar com "(...) os verdadeiros cortiços que criminosamente se levantam, em nossa terra." (SALVO..., 1955, p.01).

Essa reforma legislativa, no entanto, não foi totalmente concretizada. A fiscalização da concepção de edificações na capital foi assumida pelo Conselho Regional de Engenharia e Arquitetura (CREA), que analisava e impunha, quando necessário, as modificações no projeto, chegando a embargar os casos considerados mais críticos. Contradizendo o discurso que justificou a revisão e elaboração de normas para a construção civil, a administração municipal condenou a atuação do CREA em relação aos tão recriminados mocambos:

Ultimamente vem o CREA multando ou embargando as pequenas construções de proprietários reconhecidamente pobres, que edificam a custa de muitos sacrifícios, pequenas casas de residências, que, antes não careciam de fiscalização daquele conselho por não se incluírem na sua legislação. (O PREFEITO..., 27/03/1958, p. 06)

A tréplica do governo municipal veio com a proposta de controle e fiscalização das construções por meio de órgãos técnicos próprios e, para aqueles que não possuíssem condições de contratar um arquiteto ou engenheiro para projetar e executar a obra, a prefeitura disponibilizaria os serviços de um de seus técnicos (CASAS..., 1958, p.06). Essa iniciativa também não foi concretizada.

Verifica-se, portanto, uma ausência de um instrumento público de fiscalização e controle da ocupação e uso do solo da cidade, essencialmente voltado às moradias, o que se leva a concluir que a produção do solo natalense ficou a cargo em grande parte, nas décadas de 1940 e 1950, como no início do século, dos interesses privados.

Em se tratando dos regimentos para construções de residências, continuava-se a operar os Códigos de Obras, que no decorrer da década de 1950 e meados da década de 1960, permaneceram quase que sem alterações significativas. A redução progressiva da atuação do governo no plano legislativo diante das questões habitacionais em Natal foi resultante da mudança do papel do Estado, que passou paulatinamente ao longo do século $X X$, de mero legislador para atuar por meio de uma ação mais ampla no espaço de morar, como promotor direto de residências, sobretudo, no campo da habitação social. Ações essas, que serão estudadas no tópico seguinte.

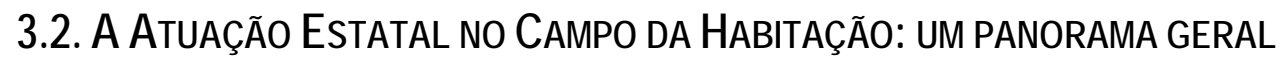

No Rio Grande do Norte a Proclamação da República acarretou na ascensão da Oligarquia dos Albuquerque Maranhão ao poder de sua capital, tendo na figura de Pedro Velho de Albuquerque Maranhão, prefeito da capital entre os anos de 1892 a 1896, o seu primeiro representante político. Foi 
Pedro Velho quem fundou o Partido Republicano ${ }^{76}$ no estado, em 27 de outubro de 1889, e proclamou a República no dia 17 de novembro de 1889.

Nesse momento, como dito anteriormente, foi iniciada em Natal, em concordância com o cenário nacional, uma "ação higiênica e embelezadora", e paulatinamente foi se conformando o "novo" cenário urbano e sendo modificados os "ares coloniais" da capital - caracterizados por vias estreitas e tortuosas, residências sem recuos laterais e com alinhamento de suas fachadas rentes às ruas.

Nesse contexto, a partir de 1892, as ações públicas no sentido de alterar estética e higienicamente as edificações, sobretudo as habitações, foram ordenadas principalmente pelos Regulamentos da recém criada Inspetoria de Higiene e pelas Resoluções da Intendência Municipal (Códigos de Postura). Voltaramse, essencialmente: à proibição da construção de cortiços e habitações em taipa e madeira; ao nivelamento e rebaixamento de calçadas das edificações; à ligação das moradias às novas redes de água e esgotos; às especificações de recuos; às intervenções nas fachadas (elevação da altura e construção de platibandas) e no interior das residências (especificação da altura do pé-direito, do número e dimensões de portas e janelas, das áreas dos cômodos, dos revestimentos, de foros e pisos, etc.); e acerca do tipo de fechamento dos terrenos (proibição das cercas de madeira e determinação da altura dos muros). Obras que muitas vezes a população foi forçada a realizar, dentro do prazo especificado pelos órgãos competentes, sob pena de elevadas multas.

A obrigatoriedade do cumprimento das disposições estatais sem, muitas vezes, levar em consideração o poder aquisitivo da população, ocasionou a saída de diversas famílias carentes - sem condições de arcarem com as despesas que seriam desprendidas para a adequação de suas residências aos preceitos estéticos e higiênicos estabelecidos - para os arrabaldes da cidade ou para ocupações irregulares nas proximidades do centro. Somava-se a essa população, o massivo número de retirantes na capital77, reflexo da seca de 1888/1889, em busca de trabalho e habitação, resultando no primeiro momento de agravamento da crise habitacional em Natal no período estudado.

Diante dessa conjuntura, a Intendência Municipal, em 1892, formulou a primeira medida no sentido de conceber alternativas de moradia à população mísera e necessitada e promover a expansão de Natal incentivando a ocupação das áreas periféricas próximas ao núcleo consolidado da cidade. Essa ação correspondia à reserva de terreno para aforamento nas proximidades da área portuária e de um dos maiores bairros da cidade, a Ribeira, numa localidade denominada Silva Jardim (Figura 54). Tratava-se provavelmente da mesma localidade para onde foram transferidas as vivendeiras e os mocambos dois

\footnotetext{
76 O Partido, ao ser criado, constituía-se de um pequeno grupo de pessoas, que associavam as "idéias republicanas às abolicionistas. (...). Alguns meses depois fundou, com recursos próprios, um jornal, denominado A República, do qual se tornou Diretor-Presidente, transformando-o em órgão oficial de propaganda do Partido" (OLIVEIRA, 1997, p.81).

77 Em fevereiro de 1890, haviam mais de 3.000 flagelados em Natal, "(..) pelas estradas, pelas ruas das vilas (...), e até nas praças dessa capital do Estado (...)", perambulando, se aglomerando e se alojando em condições precárias (NOTAS..., 15/06/1889, p.01).
} 
anos antes. Essa área seria loteada em terrenos com "60 palmos sobre 100", a serem oferecidos à população de baixa renda por doação, para a construção de residências populares (A REPÚBLICA, 16/07/1892, p.06).

A presença dos pobres e retirantes nas áreas "reservadas" às elites, no período em questão, marca a primeira representação de perigo social das multidões, das classes pobres e dos flagelados da seca na cidade, configurando-se também como justificativa para a realização de intervenções públicas e ações sanitárias, e para a outorgação de legislação restritiva às práticas populares.

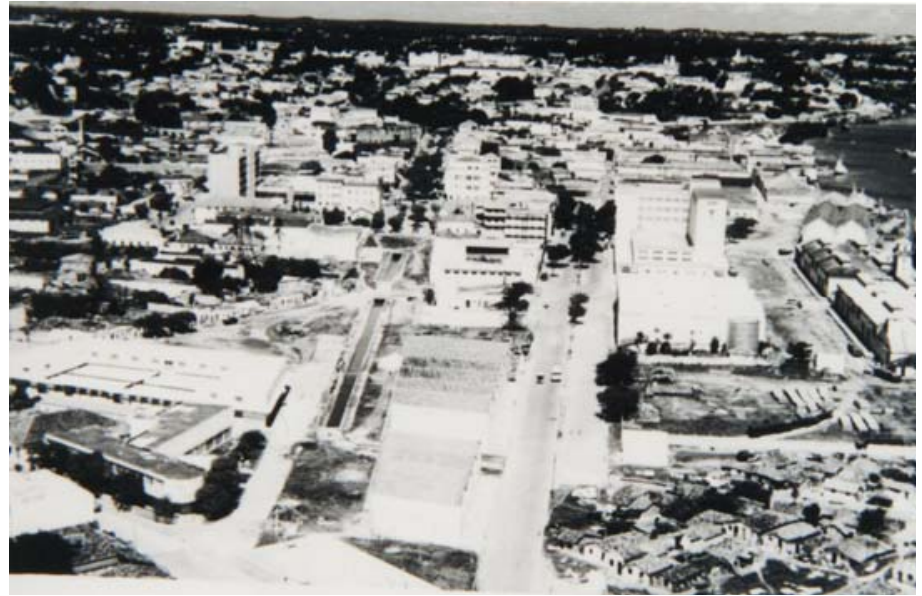

Figura 54: Vista parcial do bairro da Ribeira. Casas da Silva e Jardim no canto inferior direito, na década de 1940. Fonte: JAECI, 2006

No decorrer da década de 1900, a administração da capital deu prosseguimento à sua incessante busca para adequar a cidade aos "ares modernos", pois, apesar das realizações já efetivadas, Natal ainda apresentava muito da estrutura de uma cidade do período colonial. A população mais abastada, por sua vez, passou a criticar os modelos de moradia das camadas mais carentes e a solicitar do poder público medidas urgentes acerca do considerado "problema estético" e higiênico dessas tipologias populares, que em sua concepção, deveriam se adequar aos seus preceitos e se conformar por cômodos espaçosos, arejados e bem iluminados (A REPÚBLICA, 06/01/1900, p.02).

Atendendo a esses anseios, foi elaborado o plano da "Cidade Nova" (Figura 55) em 1901, por meio da Resolução no. 55, de 30 de dezembro, que equivalia à criação do terceiro bairro da cidade. Esse

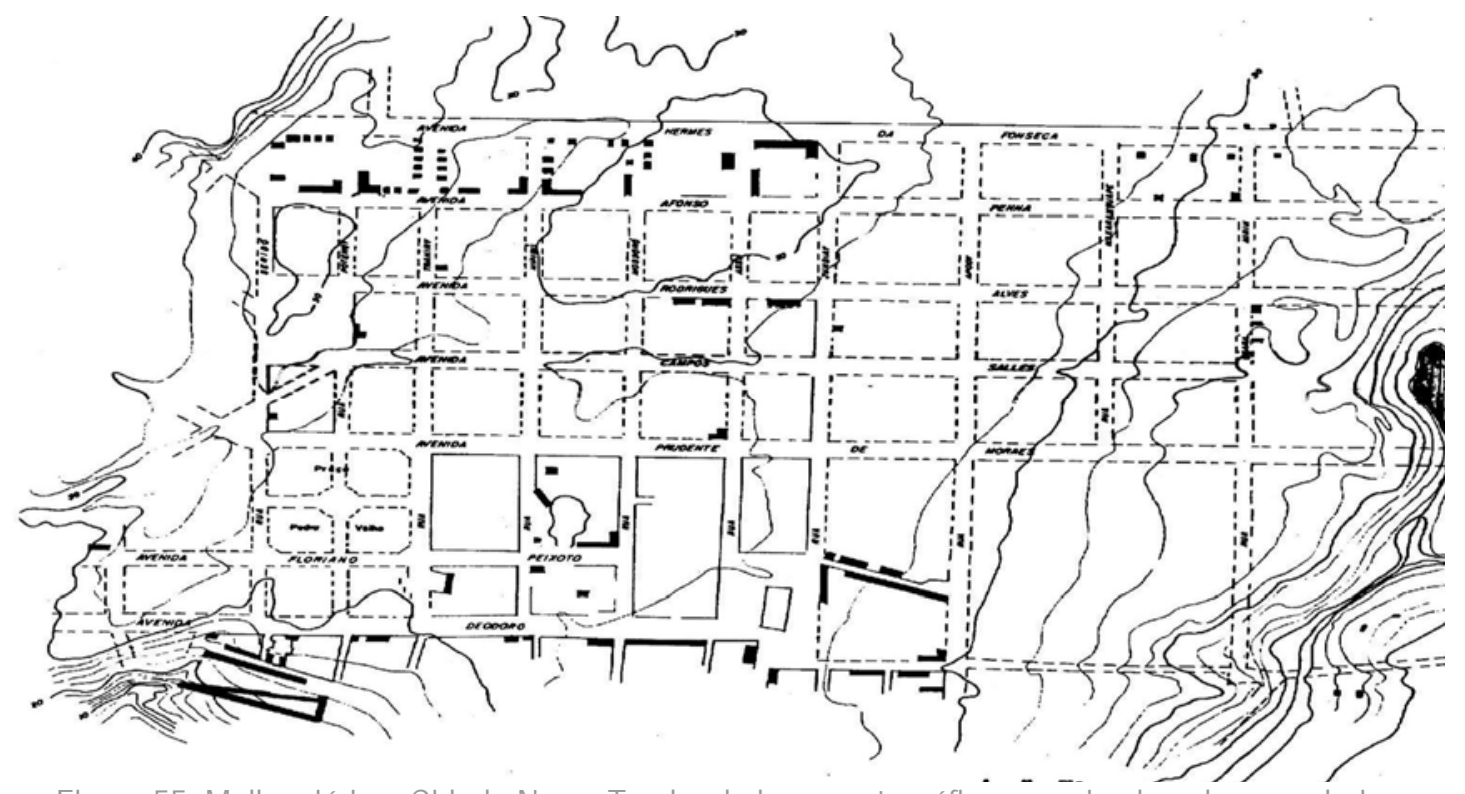

Figura 55: Malha viária - Cidade Nova. Trecho da base cartográfica organizada pelo engenheiro 
bairro seria traçado sobre uma grelha ortogonal inserida num plano de parcelamento e conformar-se-ia por quatro avenidas paralelas (Deodoro da Fonseca, Floriano Peixoto, Prudente de Morais e Campos Sales) cortadas por seis ruas perpendiculares (Seridó, Potengy, Trahiry, Mipibu, Mossoró e Assu) e duas praças denominadas Pedro Velho e Municipal (INTENDÊNCIA..., 04/01/1902, p.02). No entanto, esse plano não foi executado imediatamente por falta de recursos. Somente em 1904, durante o primeiro mandato do governador Alberto Maranhão (1900-1904)78, a "Cidade Nova" foi consolidada (CASCUDO, 1989).

O plano foi reformulado pelo agrimensor italiano Antônio Polidrelli e se restringiu à concepção do bairro de Cidade Nova, concluído em meados da década de 1900, e passou a apresentar oito avenidas paralelas, cada qual com 30 metros de largura, e quatorze ruas perpendiculares, totalizando sessenta quarteirões dispostos em uma área de 164.85 hectares (A REPÚBLICA, 04/01/1902, p.02). O regulamento que regia a construção do terceiro bairro da capital previa a concepção de largas avenidas arborizadas e direcionadas aos ventos dominantes, e a edificação de moradias com afastamentos de até cinco metros, primando pela ventilação, iluminação e salubridade dos espaços públicos e privados:

(...) a lei municipal tomou as providências básicas de edificação urbana, providenciando sobre a orientação das ruas, grande largura das avenidas e ruas transversais, separação das casas, (...) o governo está empenhado (....) na construção de uma cidade que será 0 futuro padrão da glória norte riograndense (A REPÚBLICA, 07/01/1902, p.01).

Para sua consolidação, o governo do estado em parceria com a Intendência Municipal efetuou a retirada de um grande número "cabanas em desordem" instaladas na área, mediante desapropriações ou compra de lotes a preços muito baixos, e as substituiu por uma "série de largas avenidas e ruas, [de] aspecto (...) bastante agradável" e por residências que obedeciam às normas de recuos, boa ventilação, iluminação e às condições de salubridade requeridas pelas elites para Natal (A REPÚBLICA, 14/01/1905, p.01).

A criação do bairro de Cidade Nova equivaleu à principal realização do governo do estado no campo da habitação na primeira década do século XX. Representou a primeira intervenção urbanística sistematizada que promoveu uma expansão significativa da cidade, podendo também ser considerada, por evidenciar a continuidade da prática de desapropriação e derrubada de residências "inadequadas" em prol do embelezamento da cidade, como uma operação imobiliária, na medida em que retirou os posseiros fixados na região, mediante indenizações ínfimas, valorizando as edificações pertencentes à elite da cidade construídas a partir de então.

Sua criação, além de expressar o pensamento higienista característico da época, marca o desejo da elite administrativa da cidade de transformá-la numa grande capital nacional, como colocou a imprensa oficial naquele momento:

78 Alberto Maranhão volta ao poder do estado em 1908, permanecendo nele até 1913. 
Vê-se dessa Resolução que o Governo Municipal compreendeu as vantagens e futuro grandioso da Cidade Nova, como bairro desta capital destinado a ser o núcleo da grande cidade que, neste século será Natal, talvez uma das maiores do Brasil, uma das cidades mais importantes do mundo (...). (A REPÚBLICA, 07/01/1902, p.01).

Paralelamente, percebese a continuidade das ações que objetivavam promover à higienização e o embelezamento de Natal, sobretudo, do centro da cidade, que marcaram o início de um grande projeto de aformoseamento, abertura e alinhamento de ruas e passeios e nivelamento de calçadas, que também resultou em desapropriações (Figura 56).

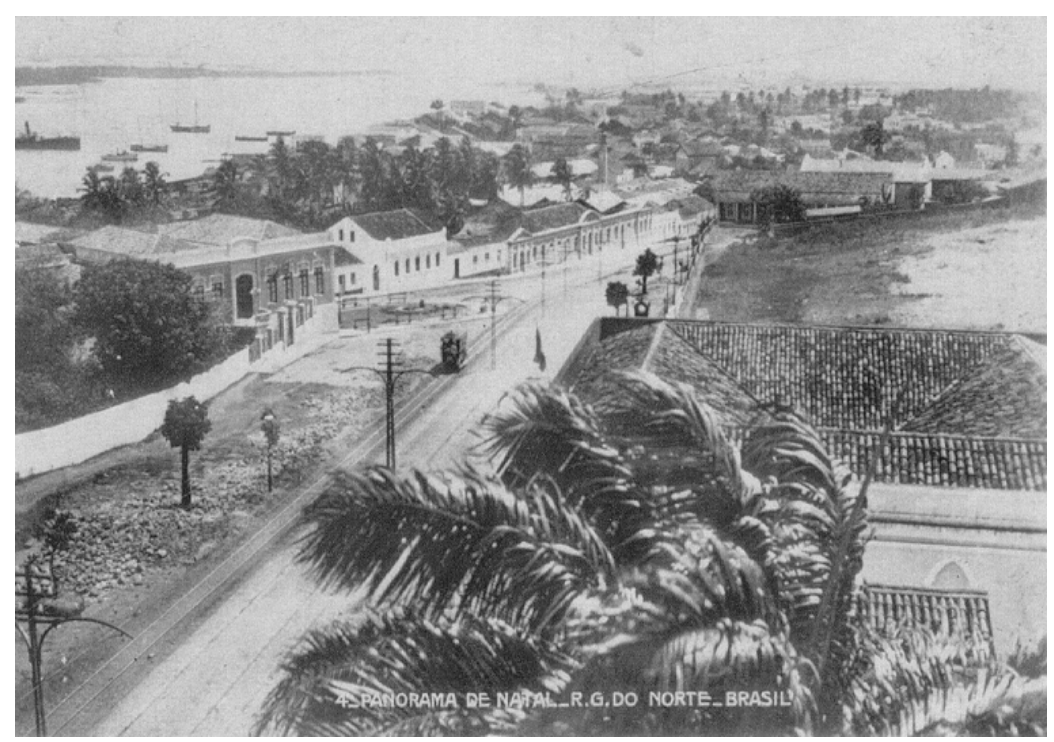

Figura 56: Obra de calçamento e alinhamento da Av. Junqueira Aires. Fonte: Diário de Natal, 1905.

As soluções dadas pela Intendência da Cidade frente ao agravamento do problema habitacional devido às desapropriações ocasionadas pelas reformas por que a cidade vinha passando, principalmente pela criação do bairro de Cidade Nova, da legislação imposta e da grande seca de 1903/190479, foram: a abertura de cinco ruas situadas nas proximidades do cemitério da cidade, situado no bairro do Alecrim Araguay, Manoel Vitorino, Occidental, América e Borburema - e o loteamento dos terrenos para a construção de moradias populares, em 1902, e a indicação de quarteirões reservados para se conceber "loteamentos populares" nos bairros da cidade, em 1904:

Art. 5o - Os quarteirões 11, 21, 52, 53, 54, 55, 56, 57 e 58 da Cidade Nova, 93 da Cidade Alta e 27 da Ribeira serão subdivididos em lotes de sete metros de frente por vinte de fundo, pelo menos, cada um, destinados a habitação das pessoas, cujos recursos, por exíguos, Ihes difficultem ou impossibilitem a acquisição, a titulo oneroso, de terrenos do patrimonio municipal.

$\S$ unico. O presidente fará levantar uma planta especial dos referidos quarteirões, na qual sejam figurados e numerados os lotes (RESOLUÇÃO №. 92, 30/04/1904).

Como alternativa de moradia para os "deslocados" que não tivessem condições de angariar uma residência ou terreno, a administração pública alugou armazéns e construiu ruas de barracões ${ }^{80}$.

\footnotetext{
${ }^{79}$ Para se ter uma real noção da dimensão das conseqüências dessa seca na capital, basta mencionar que mesmo com a eclosão da epidemia de varíola que dizimava aproximadamente vinte pessoas por dia, a população de Natal aumentou para 30.000 habitantes. Encontravam-se nesse momento na cidade, segundo o censo demográfico, um total de 15.000 flagelados que migraram para Natal a procura de comida, trabalho e melhores condições de vida (DIÁRIO DE RIO GRANDE DO NORTE, 06/1999, p.110).

80 Os dados levantados não propiciaram a localização dessas obras.
} 
Com o retorno de Alberto Maranhão ao governo do estado do Rio Grande do Norte, no ano de 1908, foi retomado o "projeto de modernização" da capital, interrompido na administração anterior, caracterizado pela introdução de diversas inovações tecnológicas no meio urbano da cidade - energia elétrica, bonde, telefone e fornos de incineração de lixo - e pela continuidade das reformas e intervenções públicas de cunho higienista e embelezador que objetivavam a adequação de Natal às normas urbanísticas vigentes em outros centros do Brasil. Neste período era clara a influência e o papel de referência que a cidade do Rio de Janeiro ${ }^{81}$ exercia sobre a elite política que administrava a cidade e, conseqüentemente, nas obras concretizadas por ela.

De acordo com o jornal oficial da época, um processo semelhante ao que havia passado a capital nacional estava sendo consolidado em Natal, graças ao "impulso patriótico do governo estadual". Aos poucos o casario desalinhado e insalubre foi cedendo lugar às habitações "saudáveis e alegres", balizadas por uma nova orientação de conforto e higiene que estava passando a "dominar as consciências" dos natalenses (A REPÚBLICA, 30/01/1908, p.01). (Figura 57)

A imprensa colocou que essa reforma estava sendo procedida não obstante a pobreza dos habitantes da cidade. No entanto, sabe-se que da mesma forma que as intervenções precedentes, as obras de higienização e embelezamento consolidadas por Alberto Maranhão em seu segundo mandato, ocasionaram a saída de um grande número de famílias para os subúrbios da cidade. Deslocamentos esses, efetivados contra a vontade da

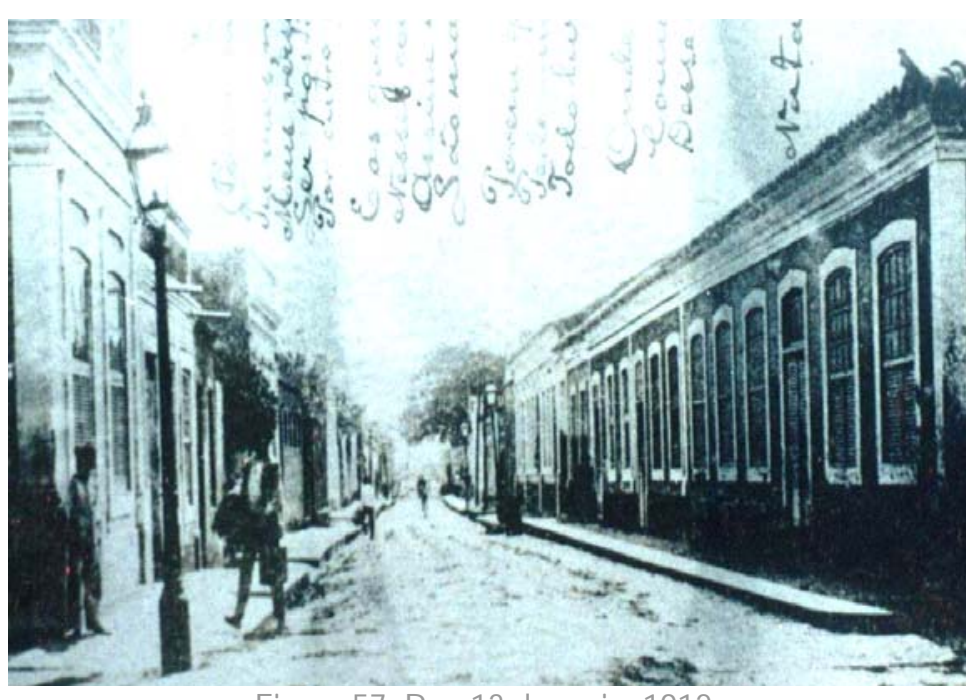

Figura 57: Rua 13 de maio, 1912. Fonte: JAECI, 2006.

população mais carente que residia em cortiços, mocambos e habitações coletivas insalubres interditadas e/ou fechadas pelos órgãos de higiene, ou em moradias que se encontravam no caminho das máquinas responsáveis pela abertura das vias, que se viram obrigadas a se retirar e "abandonar" suas residências. O domínio das consciências pelos preceitos do higienismo, ao qual se referia 0 artigo do jornal, era, portanto, realizado pelas vias mais tortuosas e dolorosas para a população pobre da cidade.

O projeto de embelezamento atingiu inclusive a área situada na região portuária da cidade, denominada pelos periódicos da época de Silva Jardim, reservada no início da década para os habitantes

81 O Rio de Janeiro, após a reforma de sua estrutura urbana, realizada no governo de Pereira Passos (1902-1906) se tornou 0 principal referencial brasileiro, essencialmente no que diz respeito aos embelezamentos estéticos, para as intervenções implementadas nas cidades de todo o país posteriormente. 
pobres e os migrantes. Nesse contexto, o governador Alberto Maranhão interveio no sentido de modificar os aspectos físicos de algumas dessas moradias, por meio de reformas nas fachadas. Essa ação intentava dar "certo gosto de architectura" e por fim à impressão de "(...) abandono e mau gosto que actualmente fere a retina dos que do rio observam (...), a casaria mal amanhada e mal disposta que se agglomera com os fundos para a entrada, numa atitude pouco digna e mal asseiada de impossível impudor (...)", substituindo-a por uma sensação de "vida e de progresso" (MELHORAMENTOS..., 12/02/1908, s/p). Isto é, procurava-se eliminar da visão da população mais abastada os elementos que denunciavam a falácia do projeto modernizador da elite administrativa. Provavelmente nessa mesma área e com o mesmo objetivo, a Intendência Municipal procedeu à demolição e reconstrução de vinte casas, confirmando o intento do poder público em maquiar a cidade.

Paralelamente, no campo da habitação social, o governo estadual indicou a construção, em 1910, de três vilas operárias ${ }^{82}$ com boas condições de salubridade, sendo servidas de água e esgoto, e com um grande pátio central bem iluminado, ventilado e comum às pequenas habitações (RIO GRANDE DO NORTE, 1910, p.19). Foi a partir da formulação dessa proposta que o Estado passou a atuar de forma mais diversa, propiciando soluções aos problemas do habitar, sobretudo, aos relativos às classes mais carentes.

A oligarquia dos Albuquerque Maranhão deixou o governo em 1913. A administração seguinte, a do governador Ferreira Chaves, garantiu maior atenção às classes relacionadas ao comércio, às profissões liberais e, principalmente, às indústrias e seus operários. Suas ações reafirmam a mudança de atuação governamental no campo da habitação social e para com as populações carentes. Foram então inseridas no contexto e nas proposições relacionadas à habitação social, as figuras dos migrantes e dos mendigos, consideradas pelas elites da época, como os principais elementos conformadores das chamadas "classes laboriosas". Como alternativa de moradia para essa população o governo estadual criou centros e abrigos (PORQUE..., 04/05/1919, p.01).

Concomitantemente, notas oficiais eram diariamente publicadas no jornal oficial, com 0 intuito de conscientizar a população da necessidade de "manter a pureza do ar dentro das habitações" (DIÁRIO DO NATAL, 22/10/1912, p.01), assim como, o asseio delas para que "impossibilitasse a entrada de moléstias nas residências", por meio de animais "daninhos e perigosos", como os ratos, atraídos pelo lixo ou partículas de alimentos esquecidas nos ladrilhos e assoalhos das moradias (DIÁRIO DO NATAL, 23/10/1912, p.01). Eram comuns os apelos, em paralelo com a publicação das resoluções, que primavam pela concepção de moradias isoladas com oitões livres, em contrapartida àquelas "contíguas", e pela construção de habitações construídas com grandes aberturas para o exterior:

\footnotetext{
${ }^{82}$ Apesar de bastante comentada pela imprensa local, os dados levantados não possibilitaram a confirmação da construção e localização dessas vilas.
} 
Pela Saude publica (...) Higine das Habitações (...) Diz o povo que na casa em que entra o sol não entra o medico (...) Este adagio tem um grande fundo de verdade. (...) O sol é um poderoso agente de defeza da saude publica. (...) A Habitação que não é banhada por elle, quase sempre, em vez de abrigo de repouso e de bem estar, se transforma em um viveiro de micobrios ou em fóco de doenças. (...) E' lamentavel que, em nosso clima e em nosso meio, com a riqueza de luz solar e de ar atmosferico que temos, haja ainda quem faça casas com compartimentos escuros sem uma só janella que dê para 0 exterior. (...) Para que uma casa seja bem illuminada e bem arejada é preciso que tenha pelo menos um oitão livre e voltado para o nordeste, de onde sopram os aliseos que attenuam os rigores do calor. (...) Uma casa de oitão livres, em tempo de epidemia, está em melhores condições de defeza sanitaria do que as que são contiguas. (...) Além de um ou, melhoramento, dos dois oitões livres, a habitação privada, em nosso clima, deve ter as janellas e portas bem rasgadas de modo que em seu interior penetrem facil e abundantemente 0 ar e a luz (...) (PELA..., 20/03/1924, p.01).

Esses apelos, também eram direcionados ao estado sanitário das moradias e à necessidade de concepção de fossas sépticas nas habitações. Atentar para a curiosa permanência, nas publicações locais, das referências à teoria miasmática na década de 1920:

(...) Os habitantes se acham ameaçados permanentemente de morte. Todo chefe de familia que apezar dos conselhos medicos, descuida do estado sanitario de sua casa, comette um crime e se torna responsavel pelo evenenemento lento porem fatal, que originam os miasmas e putrefacções fecaes (GAMALIEL, 11/06/1924, p.01).

Por meio dessas três vertentes - mudanças no aspecto estético das habitações populares, construção de abrigos e vilas higiênicas e a conscientização da população em geral por meio da imprensa escrita - o poder público pretendia convencer a população da necessidade e importância da efetivação de seu projeto de reforma da moradia.

A partir dos primeiros anos da década de 1920, foi introduzida no processo de reformas das cidades brasileiras uma nova "arte de embelezar" influenciada pelo "city planning" americano, que passou a ocupar lugar de destaque nos jornais em circulação e nos discursos de políticos. Em matérias na imprensa escrita local, esse plano de construção concebido para as cidades e "vilas" estava em sintonia com o progresso da "arquitetura doméstica" e de "todas as coisas", iniciados com a "época automobilística", pela qual, vinha passando o país. No "city planning", a moradia passou a ser considerada uma célula de transformação do espaço urbano, a partir da qual poder-se-ia modificar toda a cidade. Em Natal, as principais intervenções realizadas pelo governo na cidade a partir dessa década passaram a se basear nesse "novo paradigma americano", sendo recorrente a publicação de reportagens que abordavam essa questão (IMPRESSÕES..., 12/07/1923, p.01).

Esse momento também foi marcado pela rigorosidade do inverno na capital. Em 1924, as chuvas torrenciais que caíram em Natal agravaram as precárias condições dos serviços e infra-estrutura da cidade, principalmente nos canais de drenagem, pontes e estradas, além de deixar um grande número de famílias desabrigadas. Foi nesse sentido, instituída pelo governo uma comissão formada pelos engenheiros Henrique de Novaes, Décio Fonseca e Borges de Mello, para a execução de obras julgadas 
urgentes na cidade, que culminaram posteriormente, na elaboração do Plano Geral de Obras de Saneamento para Natal (ESTADO do Rio Grande do Norte, 1924, p.95). (Figura 58)

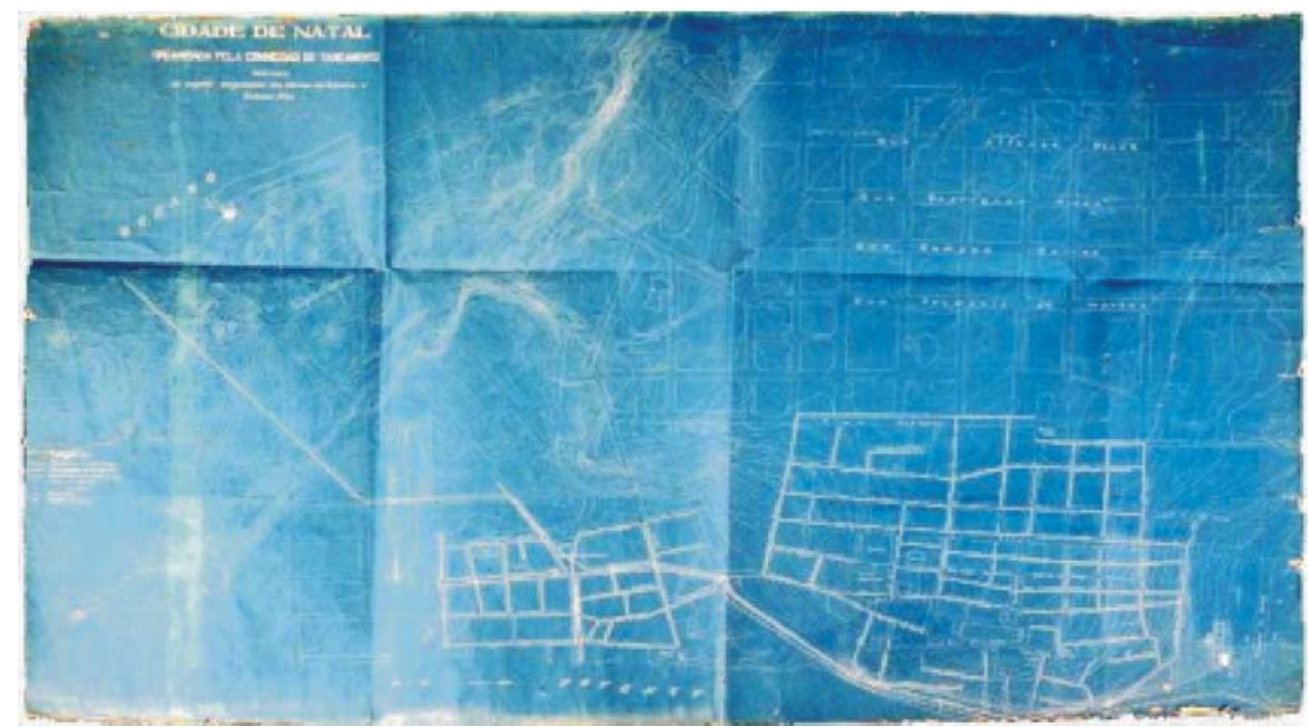

Figura 58: Plano Geral de Saneamento - Blueprint, 1924.

Fonte: Acervo HIDROESB/ Plano Geral de Sistematização.

Esse plano seria executado pela recém criada Comissão de Saneamento de Natal, a CSN, (Decreto №. 231, de 26 de abril de 1926) e previa, dentre outros melhoramentos, a criação de um bairro operário no lugar do bairro das Dunas, nas imediações da Avenida Beira-Mar, no "aglomerado popular das Rocas" (Figura 60) (DANTAS, 1909, p.32-35). No entanto, esse Plano de Obras de Saneamento não foi executado. As propostas de Novaes, entretanto, serviram como embasamento para a formulação do Plano Geral de Sistematização, do arquiteto Giacomo Palumbo, três anos mais tarde.

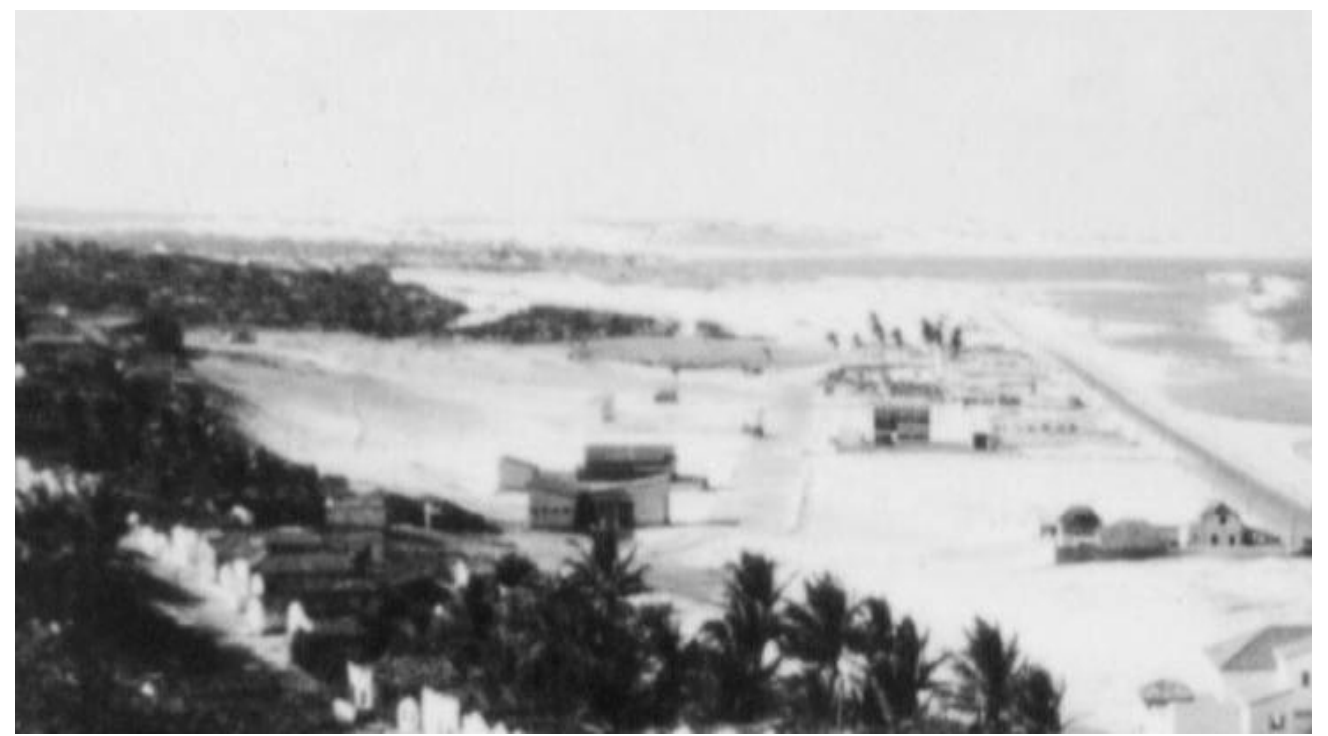

Figura 59: Terreno onde provavelmente seria implantado o bairro operário do Plano de Saneamento de Novaes (à esquerda acima), s/d. Fonte: JAECl, 2006. 
A luta contra os cortiços e habitações coletivas insalubres tomou vulto a partir da segunda metade da década de 1920. Era recorrente nos jornais da época, a publicação de críticas direcionadas à rigorosidade das normas formuladas pelos órgãos de higiene e pela Intendência, assim como, à arbitrariedade dos delegados, fiscais e inspetores de higiene, e da polícia sanitária e das construções, para se fazer cumprir as determinações. A interdição de habitações "problemáticas" para se proceder às devidas adequações, a desocupação de habitações coletivas insalubres e a demolição de edificações concebidas com materiais inadequados e aquelas existentes sem autorização dos órgãos de higiene, tornou-se uma prática comum na época. Ordenava-se a demolição de:

(...) casas de telha e taipa construidas para aluguel, sem a devida permissão, na região das Dunas e adjacencias, nos terrenos de propriedade deste Porto, (...) procederem a demolição das aludidas casas (EDITAIS..., 25/01/1929, p.01).

Como ocorrerá em todo o país, parte da população de Natal, a partir desse momento, passou a exigir do Estado ações mais concretas no sentido de por fim aos "mocambos" e "cortiços", apontados como responsáveis por enfear e comprometer a salubridade da cidade, e a sua substituição por habitações tidas como mais dignas aos desfavorecidos, que primasem pelo modelo higiênico das "casas operárias". Esse desejo era exposto, sobretudo, pelos jornais de oposição:

Natal é uma das cidades a que talvez acuse um coeficiente mais accentuado de inercia, no tocante ás grandes como ás pequenas habitações. (...) É lamentável que assim aconteça. (...) Mister seria solucionar, mesmo em parte, o problema do tecto, cada vez mais premente entre nós (...). A falta de casas em nossa terra é uma consequência do descaso que se vem notando em todo o Brasil, (...), sem , até agora, resolvel-o de forma satisfatoria para as populações mais desfavorecidas. (...). A nossa capital está ainda cheia de 'mocambos'. (...) O que sejam elles, dil-os, perffeitamente, a nossa propria observação (...) portador de males sem conta, para a população e para a cidade, (...). 0 'mocambo' desperta um infalivel ar de nôjo e de penuria, como se fora exclusivo factor de pauperismo, de mendicancia, da miseria (...). As 'casas operarias refletem, positivamente, a plausivel solução para o combate ao mocambo (...) É um gênero de elevada assistencia, que (...) importa grande somma de vantagens à vida hygienica que necessitamos viver (O PROBLEMA..., 17/03/1926, p.01).

Em contrapartida, era recorrente a publicação de críticas contra a discriminação para com essa tipologia habitacional característica da população de baixa renda, assim como, o modo com que Diretoria Geral e seus subordinados abordavam os moradores e exigiam a adequação das edificações.

O projeto de teor elitista de reforma urbana e "melhoramentos" estéticos culminou nessa década no chamado, pela imprensa local, "problema de tecto", o segundo momento de agravamento da crise habitacional em Natal, evidenciado principalmente pela edificação de inúmeros "mocambos" na cidade (O PROBLEMA..., 17/03/1926, p.01). Diante desse quadro, a administração pública passou a incentivar a construção de casas e vilas populares, por meio da concessão de terrenos e isenção de impostos, sobretudo nos terrenos baldios da capital (LEI №.544, 02/12/1926). 
O resultado evidenciado foi o aumento do número de solicitações para construção de moradias nesse período: dos sete registros verificados nos periódicos do ano de 1926, passou-se para trinta só no ano de 1928. Essa ação também incentivou a construção civil e a iniciativa privada, como colocou 0 jornalista carioca Affonso Costa em visita a Natal no ano de 1926, quando destacou, em artigo publicado no jornal A República, a atuação construtora dos irmãos Palatinik e Aureliano Medeiros e de "outros poucos em menor escala" (A NATAL..., 30/10/1928, p.07).

No setor público, no entanto, as ações ficaram restritas ao plano do discurso, às propostas de concepção do bairro operário, inclusas no Plano Geral de Obras de Saneamento do engenheiro Henrique de Novaes, em 1924. Na prática, pode-se citar a criação e capacitação, em 1927, do bairro de Lagoa Nova, situado na periferia da cidade e destinado a abrigar "toda gente pobre" (O NOVO..., 28/03/1926, p.01).

Concomitantemente, deu-se continuidade ao projeto intitulado pela imprensa da época de "processo de construção da cidade para os visitantes", caracterizado essencialmente por diversas restrições à pobreza e intentando por fim às "aglomerações populares" consideradas signos de atraso. Nesse contexto, a Intendência Municipal passou a estimular a substituição das velhas fachadas "(...) de anachronico estylo colonial pelos modelos airosos e estheticos dos centros urbanos de bom gosto (...)" (A NATAL..., 30/10/1928, p.07). Nessa mesma linha, em 17 de março de 1928, foi organizada uma exposição com os projetos do engenheiro Clodoaldo Dantas, construtor do Recife, para incentivar construções condizentes com as linhas modernas, que em muito contribuiriam para o projeto proposto pela elite administrativa para Natal (EXPOSIÇÃO..., 17/03/1928, p.02). Em 1929, foi organizado o concurso anual dos três melhores projetistas e dos proprietários dos mais bonitos e modernos prédios da cidade, cuja premiação era a restituição total do valor da construção e/ou metade dele (O'GRADY, 1929).

Por outro viés, foi terminantemente proibida à permanência de ambulantes nas ruas da cidade e a mendicância em geral, a partir da data de inauguração do Dispensário Sinfrônio Barreto, em 192583. Só seria permitida a livre circulação de mendigos, desempregados e migrantes nas ruas de Natal, se os mesmos possuíssem o registro de inscrição obtido junto à Prefeitura (OBRA..., 07/07/1925, p.01). Esse dispensário atendia, em 1929, cerca de 300 famílias "desvalidas" consideradas "fatores de perturbação social". A municipalidade utilizou-se dos guardas municipais e, por vezes, das autoridades policiais, para fiscalizar essa nova determinação e, assim, sanear a "urbe da legião de pedintes e falsos mendigos" (ALECRIM, 1957, p.220). Essas atitudes foram aclamadas pela população mais abastada.

A partir de dezembro de 1929, afigurou-se o "momento de pôr Natal em sintonia com o mundo, a partir de sua importante ligação como centro aviatório internacional", intento do engenheiro e prefeito da

\footnotetext{
83 Essa instituição era similar à encontrada na Europa pelo padre Kokke, cardeal responsável pela administração do referido abrigo, em viagem no ano de 1923.
} 
cidade, Omar O'Grady84. Era necessário, para tanto, construí-la para o "futuro"85 (DANTAS, 1998, p.95). Nesse contexto, foi elaborado o já citado Plano Geral de Sistematização (Figura 60) por meio da Resolução no. 304, de 22 de abril de 1929, de autoria do arquiteto Giacomo Palumbo, pensado para uma cidade com aproximadamente 100 mil habitantes (DANTAS, 1929c, p.01).

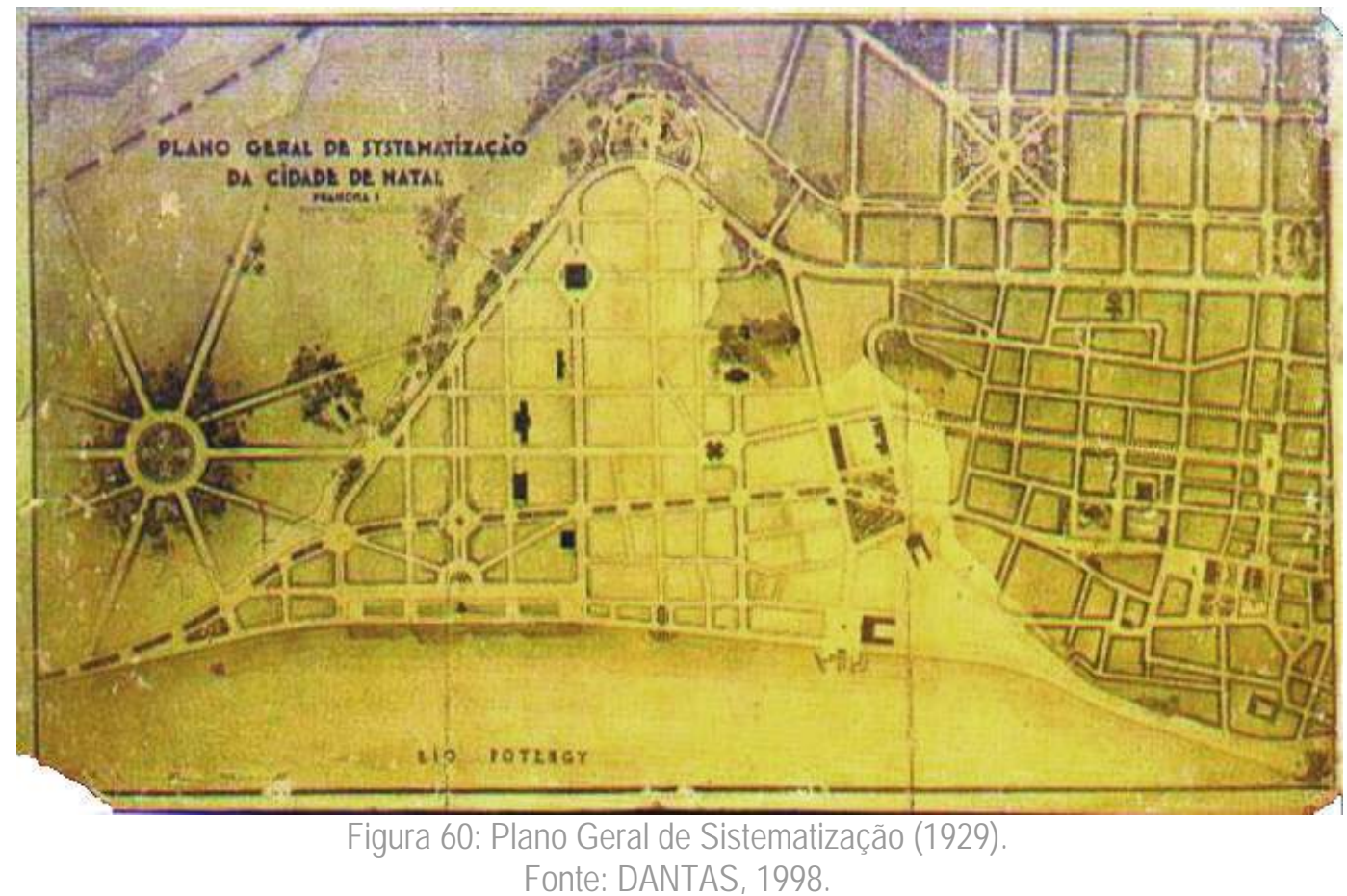

Esse Plano ${ }^{86}$, dentre outras ações, previa o zoneamento da cidade em "(...) quarteirões administrativo, commercial, industrial, a cidade recreio [bairro-jardim] e os bairros residencial e operario (...)" (PREFEITURA..., 1981a), a exemplo das proposições corbusianas formuladas no IV CIAM (Figura 61). Segundo a engenheira Carmem Portinho (1930c, p.02), colaboradora na formulação do Plano, 0 bairro residencial compreenderia a Cidade Nova - Petrópolis e Tirol - e a construção de um estádio de futebol, de um parque de corridas, de praças, áreas de recreação e do Aero-Club. O bairro-jardim seria instalado entre o rio Potengi e o Atlântico, provavelmente onde se situa atualmente o bairro de Santos Reis, cujas construções seriam submetidas a rigorosas normas do urbanismo, aplicando-se o zonning moderno e abertas largas vias. $\mathrm{O}$ bairro operário, por sua vez, seria um bairro inteiramente novo e

\footnotetext{
84 Foi prefeito da cidade por dois mandatos, de 1924 a 1929, quando foi destituído devido à Revolução de 1930.

${ }^{85}$ Foram colocados em circulação os primeiros ônibus coletivos que faziam apenas pequenos trajetos, essencialmente, entre os bairros mais nobres de Natal. As principais vias da capital foram calçadas e tratadas paisagisticamente, e outras tantas foram abertas e/ou alargadas. Essas ações direcionaram a ocupação de áreas da cidade (A REPÚBLICA, 08/06/1930, p.01).

${ }^{86}$ Nele, estariam indicadas as localizações da iluminação pública, viação urbana, arborização, passeios, monumentos, abrigos, jardins, praças públicas, feiras, mercados, matadouros, cemitérios, dentre outros estabelecimentos (PREFEITURA..., 1939). Previa-se também: uma reforma no Porto de Natal, caracterizada pelo aprofundamento e delimitação do canal, fixação de dunas, construção de um ancoradouro e outro cais; o projeto de um aeroporto; a organização de um horto para auxiliar na arborização das ruas e praças da capital; a mudança da nomenclatura das ruas, competida ao Instituto Histórico e Geográfico; 0 aumento do número de vias de acesso aos bairros de Cidade Alta e Ribeira; 0 aproveitamento dos monumentos históricos e belezas naturais da cidade; e a transformação de lagoas em piscinas públicas, como a de Manoel Felipe e a Lagoa Seca. Em todas as intervenções seria empregado o "estilo moderno" (DANTAS, 1998).
} 
afastado do centro (PORTINHO, 1930b, p.02), provavelmente localizado no bairro das Quintas (Figura 62), onde se encontravam instaladas as habitações da população mais pobre da cidade, construídas e/ou transferidas pela administração pública desde fins do século XIX.

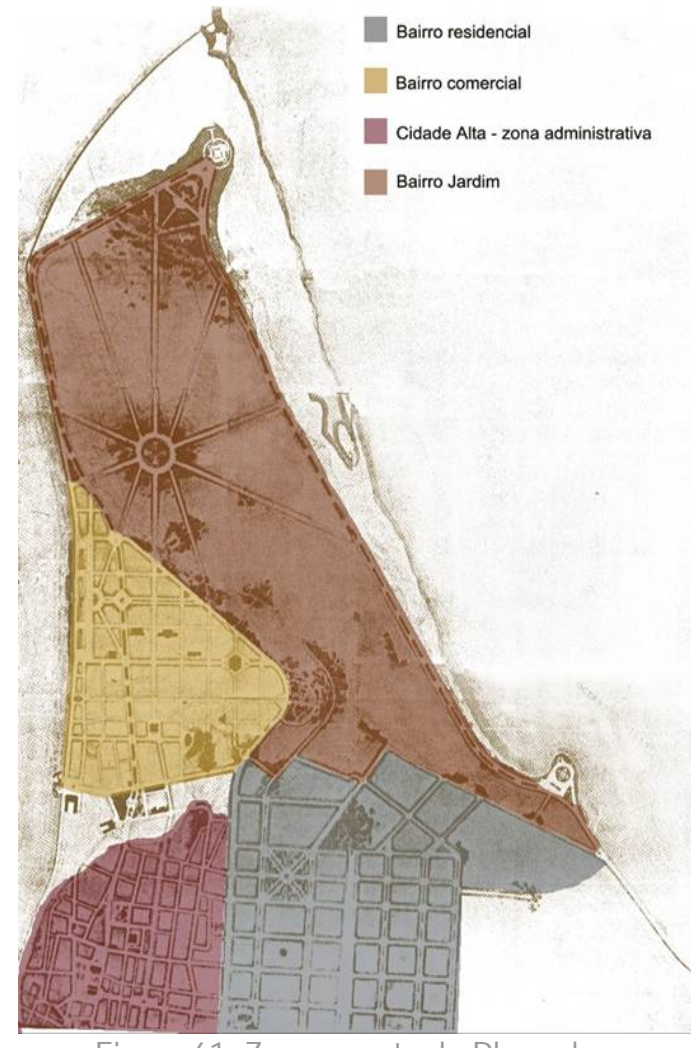

Figura 61: Zoneamento do Plano de Sistematização (1929). Fonte: DANTAS, 1998.

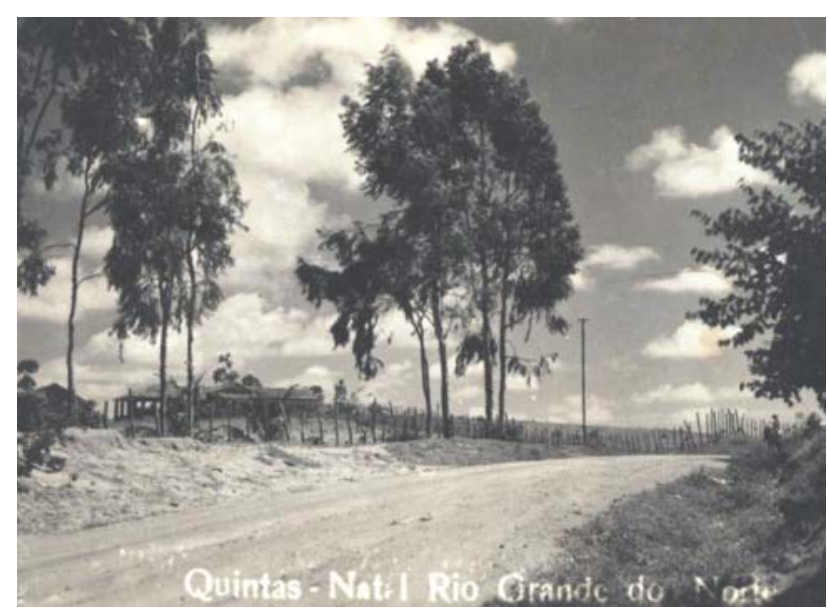

Figura 62: Bairro das Quintas, 1925. Fonte: JAECl, 2006.

Para a concepção do bairro operário citado no Plano de Sistematização, seria necessária a demolição de todas as casas populares existentes junto ao cais, assim como, a transferência de todas as moradias "pobres" situadas na entrada da cidade e das erguidas nos terrenos baldios, para aquele espaço $0^{87}$. Um projeto residencial a ser elaborado de acordo com o número de

habitantes averiguado nessas localidades após levantamento minucioso (PORTINHO, 1930b, p.02). No entanto, a ocorrência da Revolução de 1930 e o conseqüente afastamento dos administradores locais contribuíram para que o bairro não fosse implementado.

Esse Plano equivaleu ao arremate da administração do prefeito Omar O'Grady, representando 0 "(...) fecho das iniciativas desenvolvidas durante mais de cinco anos em prol da modernização da cidade" (DANTAS, 1998, p.96). Foi, dessa maneira, um plano de síntese que ordenou a ocupação, a expansão e a reforma de Natal para dar-Ihe uma feição de cidade mais moderna e avançada. Segundo George Dantas (1998), esse Plano conciliou as necessidades de ordem técnica e econômica com os imperativos de natureza estética que deveriam, de acordo com alguns setores da elite, presidir o desenvolvimento de nossa urbanização.

A elaboração do Plano de Sistematização também marcou uma mudança de atuação da administração na cidade, que passou a elaborar planos de conjunto, incluindo futuras expansões, a exemplo do urbanismo norte-americano:

${ }^{87}$ As famílias receberiam os respectivos lotes e uma indenização referente ao seu deslocamento. 
(...) O urbanismo vem produzindo as formidáveis realizações das cidades velhas transformadas, a golpes de picaretas, nas cidades modernas. Chicago é o maior exemplo (...). No Brasil verifica-se hoje o mesmo movimento. $O$ urbanismo não ficou apenas no Rio com os projetos do prof. Agache, nem em S. Paulo concretizados nas visões intelligentes de Anhaia de Mello (...), a idéia de urbanismo vae espalhando por todo o paiz (...). Agora mesmo, temos em mãos o contracto que a municipalidade de Natal, sob a direcção moderna de seu prefeito - um técnico formado nos Estado Unidos -, (...) acaba de fechar com uma de nossas autoridades urbanistas, afim de levantar a planta futura de Natal de 100 mil habitantes (...) (DANTAS, 1929c, p.01).

Essa influência, aliada ao espírito empreendedor do prefeito, resultaram na repercussão nacional do projeto proposto para a capital norte-riograndense, que apesar de concluído e apresentado à cidade, nunca foi concretizado88. Contudo, deve-se lembrar que permaneceu como baliza ao crescimento da cidade até a década de 1950 (DANTAS, G., 2003). Também é importante atentar para as propostas inovadoras que nele cabiam, sobretudo em relação ao automóvel e ao ônibus.

Ainda em 1929, outra ação estatal no campo da habitação foi empreendida. Correspondia à realização de um loteamento por parte do governo municipal, localizado entre a Rua Alberto Silva e a Avenida Bernardo Vieira, e entre a Avenida Hermes da Fonseca e a Romualdo Galvão, cujos terrenos foram reservados para a edificação de habitações operárias "modernas" (Decreto-lei no. 261,1929).

A partir de 1930, em concordância com o cenário nacional e com o programa implantado pelo presidente Getúlio Vargas (1930-1945), consolidou-se em Natal, um ideal de cidade sã, salubre, moderna e bela, adaptada às necessidades da elite e aos novos recursos tecnológicos como, 0 automóvel (FERREIRA et all. 2006). Esse momento marca também a consolidação da mudança na atuação da administração pública em relação às questões sociais, essencialmente em relação à moradia, que passou a ser inserida nos programas governamentais a partir de então.

Ainda evidenciava-se no início da década, a busca pelo "equilíbrio estético" das edificações. De acordo com a imprensa da época, a censura estética dos edifícios era uma das medidas mais elogiáveis da administração local, imprescindível para manutenção e/ou consolidação da "(...) belesa exterior de uma cidade" (CENSURA ESTETICA..., 12/01/1932, p.01). A homogeneidade, segundo as elites locais, era necessária para a completa formação de "trechos modernizados" e, posteriormente, da cidade alinhada, alta, assobradada (Figura 63), que seria alcançada por meio da proibição a "certas construções", garantida por um serviço de fiscalização organizado, cujo modelo era o Recife (CENSURA ESTETICA..., 12/01/1932, p.01). Para alguns observadores, as construções, essencialmente as habitações, erguidas

\footnotetext{
88 No entanto, diversas foram as críticas lançadas ao Plano, advindas de diferentes localidades e personalidades. As mais corriqueiras diziam respeito ao traçado "aleatório", amplamente recriminado pelos urbanistas modernos, à contratação de um estrangeiro para a elaboração do projeto, e à desnecessária implantação de um plano para uma cidade tão pequena como Natal (DANTAS, 1998). Apesar desses julgamentos, em junho de 1930, O Plano Geral de Sistematização foi exposto numa seção de urbanismo que ocorreu concomitante ao IV Congresso Pan-americano de Arquitetura, no Rio de Janeiro, arrancando elogios diversos publicados nos jornais do Rio e São Paulo e na imprensa local (O PAIZ, Rio de Janeiro, 23 e 24/06/1930, n.16.681-2, p.05).
} 
para assegurar a "uniformização da cidade" deveriam se enquadrar no "(...) estilo novo de ângulos, de arestas e de planos (...)", caracterizado pela conformação de "(...) fachadas simples, de paralelas distanciadas e de traços francos (...)", peculiares à arquitetura "prática e moderna" (VIDA..., 31/08/1932, p.04). As edificações que não se enquadrassem nessa "ordem", apresentando principalmente ornamentos, foram apontadas como absurdas e criticadas:

(...) existem ainda, quem, podendo construir numa geometria impressionante de retas que se encontram ou não se encontram, prefira ordenar que o construtor coloque enfeites incriveis na 'casa nova' e escreva a data da construção em um retangulusinho da ponta dobrada (VIDA..., 31/08/1932, p.04).

No entanto, os "planos" de homogeneização e embelezamento das elites para Natal se distanciaram do propósito inicial e a perspectiva de atingir seus objetivos estava cada vez mais longínqua, corroborando para isso a ocorrência de mais um longo e penoso período de estiagem no ano de 1932 (O PROBLEMA..., 31/03/32, p.01).

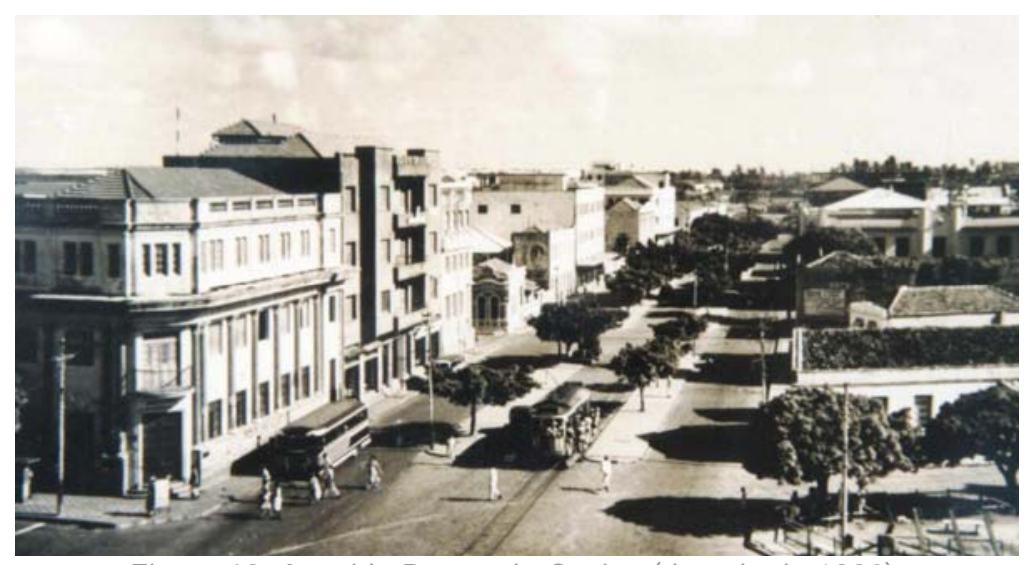

Figura 63: Avenida Duque de Caxias (década de 1930). Fonte: JAECl, 2006.

Nesse sentido, as ações no campo da habitação social, na maioria dos casos, se propunham a garantir moradia para os flagelados da seca. Dessa forma, foram edificados mais abrigos para "(...) recolher [os] famintos e doentes que perambulavam pelas vias da capital (...)" (A PROPÓSITO..., 08/02/1934, p.01), e "(...) sanear as ruas de Natal, retirando os mendigos e internando-os (...), com toda assistência possível" (MEDIDA..., 20/01/1939, p.01). Como medida "complementar" foi, mais uma vez, terminantemente proibida pela Prefeitura à mendicância nas ruas da cidade, a partir do dia primeiro de fevereiro de 1939 , devendo todos se dirigir aos dispensários e abrigos disponibilizados pelo Governo89 (MEDIDA..., 20/01/39, p.01).

A construção da primeira vila operária por parte da municipalidade também data dessa década, mais especificadamente, do ano de 1932. Esse grupo de pequenas habitações ${ }^{90}$ foi edificado no bairro do

\footnotetext{
89 Dentre os novos abrigos construídos, pode-se citar: 0 abrigo José Américo e o novo dispensário Sinfrônio Barreto, ambos construídos no bairro do Alecrim em 1934, o abrigo para mendigos da Prefeitura, no mesmo bairro, de 1939 (MEDIDA..., 20/01/1939, p.01), e o "abrigo dos pobres", localizado no bairro das Quintas, também edificado em 1939 (FERREIRA..., 13/04/1939, p.08). Cabe ressaltar que muitos desses abrigos foram construídos em localidades consideradas não apropriadas e insalubres, como nas proximidades de matadouros, cemitério, etc., revelando o caráter contraditório dos discursos higienistas dos administradores desse período e suas ações. Um exemplo disso refere-se ao chamado "abrigo dos pobres" construído em terreno vizinho ao novo forno de incineração de lixo da cidade.

${ }^{90}$ Os dados levantados nos periódicos locais e nos documentos oficiais acerca dessa vila, não apontavam o número exato de construções, nem as especificações dos ambientes das habitações.
} 
Alecrim e caracterizava-se por apresentar casas “(...) dotadas (...) do conforto indispensavel ás habitações modernas e com predominio de observancia dos preceitos de higiene arquitectural. (...) graciosas e elegantes, (...) serão, (...) abrigo e lar de modestos operarios (...) (A REPÚBLICA, 03/12/32, p.01). Foi a partir desse momento em Natal, que o Estado passou a conceber diretamente moradias, modificando definitivamente o seu papel de atuação no setor habitacional.

O incentivo para a edificação de habitações populares dado pela administração pública através da isenção de impostos, iniciado em 1926, e o incentivo à aquisição da casa própria, com o intuito de amenizar o déficit habitacional evidenciado na cidade, começam a dar frutos significativos nos primeiros anos da década de 1930. Em 1933, de acordo com os periódicos em circulação, foram registrados mais de cinqüenta prédios em construção na zona urbana de Natal, além de inúmeros em reforma ( $A$ PROPÓSITO..., 04/03/1934, p.07) e, em 1936, foram expedidos 112 alvarás para novas construções e 59 para reconstruções quase que totais (MENSAGEM..., 05/09/1936, p.02).

Esses incentivos, por outro lado, aqueceram o mercado de construção civil e atraíram grandes empresas desse ramo para a capital norte-riograndense, como por exemplo: a empresa construtora e de saneamento predial LTD, atuante nos estados de São Paulo, Minas Gerais e Rio de Janeiro, que instalou escritório em Natal, em 1932 (A EMPRESA..., 02/02/1932, p.04); a empresa pernambucana V. Carvalho \& Cia., especializada em sistemas cooperativos de construções, no ano de 1933 (UMA LINDA..., 03/02/1933, p.01); a empresa Promotora da Casa Própria, em 1935 (A PROMOTORA..., 08/11/35, p.02); e a empresa Palatinik \& Irmãos, que edificou dezenas de grupos de casas na cidade (PREFEITURA..., 03/12/1935, p.04). Outros tantos solicitavam autorização para lotear ou edificar vilas e grupos de casas na capital. As petições eram inúmeras e publicadas diariamente no jornal oficial do Estado. As ofertas, principalmente de venda de casas e terrenos, não mais somavam algumas dezenas, ocupavam agora uma sessão especial nos jornais. Esse período foi intitulado pela imprensa da época, de "febre de construções" de Natal (A República, 03/12/1935, p.04) ou "surto de progresso da capital" (BILRO, 1935, p.06).

Até o final da década de 1930, ainda se podia verificar a publicação de críticas formuladas por setores da elite natalense direcionadas aos exemplares considerados de mau gosto, principalmente em se tratando das fachadas das moradias que estavam sendo erguidas na cidade. Enfatizava-se que as construções não eram fiscalizadas pelos funcionários da Prefeitura e, conseqüentemente, não passavam por uma "censura prévia e necessária" (A PROPÓSITO..., 04/03/1934, p.07). Na concepção da população abastada, o que em muito contribuía para a "eclosão de mau gosto das fachadas" era o intento dos construtores em edificar "plantas baratas", não se preocupando com as fachadas, consideradas pelos críticos como de "suma importância para uma impressão geral ou de conjunto" e para a bela homogeneização da cidade (A PROPÓSITO..., 04/03/1934, p.07). 
Requeria-se, nesse sentido, uma maior rigidez na fiscalização dos projetos por parte da Prefeitura e uma campanha de conscientização da população e dos construtores, de modo a evitar as "aberrações estéticas e do gosto que muito depõem contra os foros da cidade civilizada que Natal possui" (A PROPÓSITO..., 04/03/1934, p.07). Os apelos feitos, nesse sentido, eram recorrentemente encontrados nos periódicos em circulação na época. Segundo a administração local, ainda era pequeno o número de casas que possuíam a "frente" com "(...) aspecto elegante, sem ferir os preceitos da arte e sem as extravagâncias de pintura com que os empreiteiros costumam encobrir serviços e obras mal acabados (...)". Para reverter essa situação era preciso educar a população em geral. Somente assim suas moradias passariam a expressar a "(...) boa índole, o caráter e o espírito dos que as habitam" (A PROPÓSITO..., 04/03/1934, p.07).

Percebe-se, dessa forma, que o projeto de embelezamento da cidade proposto e almejado pelas elites para Natal, pretendia modificar não apenas os aspectos físico-construtivos de suas edificações, mas também, pretendia intervir nos modos de vida e costumes de toda a população.

Em 1935, o Escritório Saturnino de Brito foi contratado para chefiar a Comissão de Saneamento de Natal, que elaborou em 1939, 0 Plano Geral de Obras $^{91}$ (Figura 64). No campo da habitação, o Plano previa a criação de um bairro residencial nas proximidades do Forte dos Três Reis Magos, entre as Rocas e a costa, num terreno de aproximadamente $45.000 \mathrm{~m}^{2}$, onde seriam abertas largas avenidas com cerca de 9m de largura, ruas internas do tipo cul-de-sac privilegiando a circulação de pedestres, e criada uma área central com parques, jardins, escolas, quadras de esporte, além de equipamentos coletivos, comércio e serviços. Revela-se assim, a influência do conceito de unidade de vizinhança utilizada pelos arquitetos Clarence Stein e Henry Wright para Radburn e do ideário de cidade-jardim, traduzido no urbanismo de Parket e Unwin.

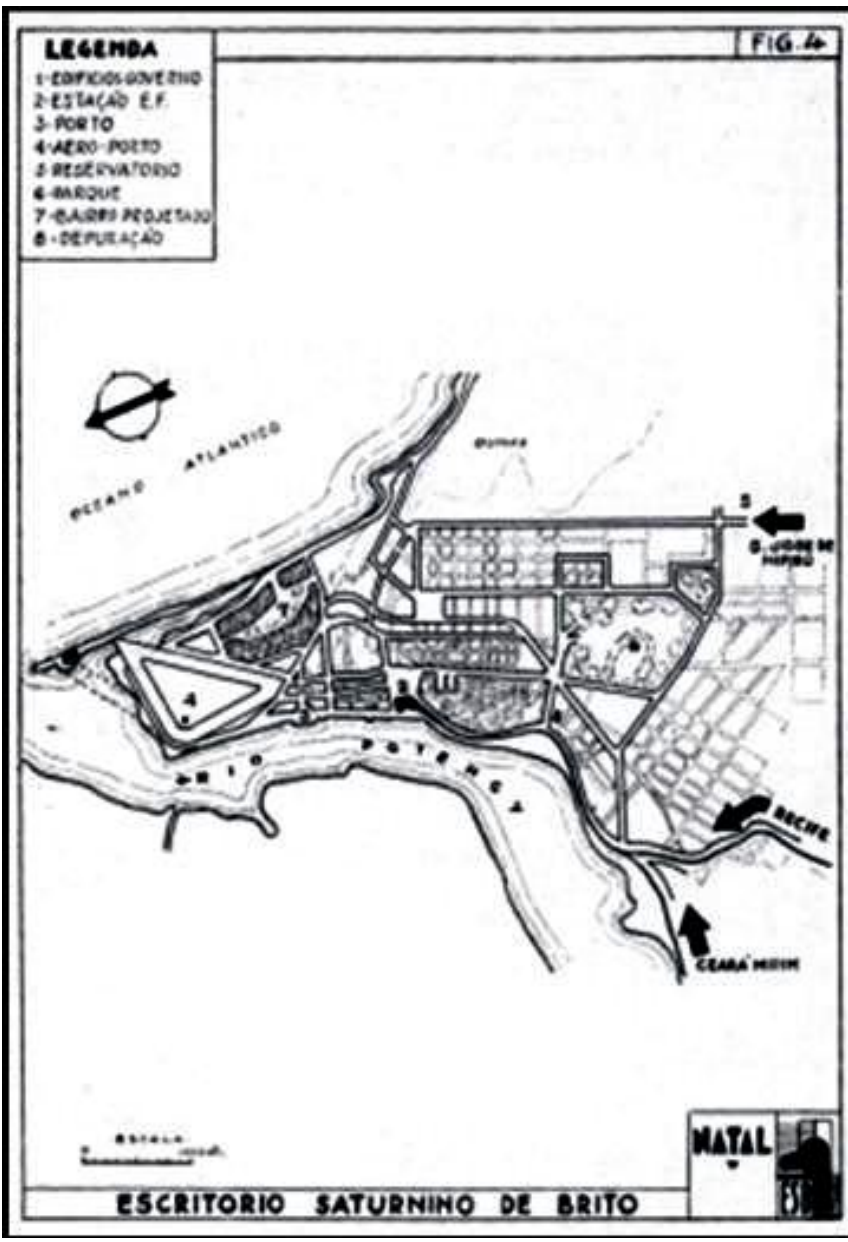

Figura 64: Plano Geral de Obras, 1936. Fonte: Escritório Saturnino de Brito, 1939.

91 O Plano não se restringia apenas ao aspecto sanitário, incluía a organização, a reforma, a expansão e o embelezamento do espaço urbano e das edificações. 
A criação desse bairro objetivava, além da ocupação da área de dunas, possibilitando sua fixação, a substituição do bairro das Rocas, "(...) mudando pra aí a população dos casebres que a compõem" (ESCRITÓRIO..., 1939, p.18). A transferência das moradias para um bairro distante do centro e nas proximidades das dunas da cidade era um intento antigo e diversas propostas nesse sentido puderam ser observadas nas formulações do governo e de profissionais diversos, como Manuel Dantas na década de 1910, Henrique de Novaes, em 1924, Januário Cicco em livro de 1920, e as propostas de bairros residenciais inclusas nos Plano de Sistematização elaboradas em 1929.

O Plano Geral não foi concretizado por não ter sido transformado em lei, porém, mostra-se de suma importância na medida em que revela a sintonia dos administradores locais com as teorias e ações em voga no país e no exterior.

Aos poucos as habitações construídas em Natal foram se adequando aos "ares modernos" e os bairros da cidade foram sendo povoados por edificações modernistas, na mesma velocidade em que a população da capital aumentava:

Sobretudo o bairro do Tyrol, (...). Muito bem, bonito e necessario esse movimento constructor. As exigencias da Prefeitura abrangem varios sentidos, com o fim de evitar aleijões pela cidade afóra. Dois pavimentos aqui, três metros de récuo alli e mais formalidades. Casos singelos só podem ser levantados em taes ruas ou praças. Plantas rigorosamente vistas, revistas e fiscalisadas. Pé direito tanto. Aposentos ventilados. Areas internas descobertas. Imperativos de cidade que se civilisa... (SOCIAES..., 18/12/1935, p.08).

No entanto, a precariedade dos serviços na cidade, sobretudo, no tocante à distribuição de água, evidenciada em fins da década de 1930, comprometeu o tão comentado surto de progresso e brecou 0 ritmo das construções na capital, além de promover o aumento do valor dos aluguéis das casas (ESCRITÓRIO..., 1939, p.09). Essa crise na prestação de serviços foi exacerbada com a eclosão da ॥ Guerra Mundial e pelo impressionante crescimento da cidade nesse período, devido ao papel de base militar norte-americana exercido por Natal a partir de 1942. O déficit habitacional conjugado aos elevados e crescentes valores cobrados pelas locações das habitações, verbalizaram o terceiro momento de agravamento da crise habitacional em Natal.

Esse momento foi marcado, como já citado, pela negligência à Lei Nacional do Inquilinato (1942), que congelava aqueles preços e, a partir de 1943, pelo considerável crescimento do mercado da construção civil que, ao contrário do observado em âmbito nacional, absorveu os altos valores cobrados pelos materiais de construção, superando o elevado custo dos aluguéis e das taxas cobradas pela prestação dos serviços de água e esgotos.

A escassez de moradias para abrigar toda a "nova população" natalense - militares de baixo a alto escalão, brasileiros e norte-americanos, e a população urbana e rural não só do Rio Grande do Norte, mas também de estados vizinhos, atraídos pelas novas ofertas de emprego, comércio e possibilidade de 
crescimento financeiro - fez com que se procedesse à desapropriação de suntuosos palacetes e residências populares, e a superlotação de hotéis, estabelecimentos do gênero, e casas coletivas (A GUERRA..., 30/01/1945, p.08), evidenciando o potencial lucrativo do setor imobiliário, para onde foi direcionado o capital proveniente do comércio (FERREIRA, 1996).

Rapidamente foram surgindo em Natal, "modernas e elegantes edificações", habitações luxuosas, vilas operárias, vilas militares, assim como moradias com baixos padrões construtivos, além dos tão combatidos mocambos. Tipologias essas, segundo a imprensa oficial da época, resultantes dos investimentos da iniciativa privada com ânsia de lucro e da população sem condições de angariar uma residência própria e saudável, que representavam respectivamente, os "vícios do oportunismo econômico" e 0 "flagrante erro de apropriação" (DANILO, 1942, p.08).

Como em outros momentos, eram cobradas das administrações públicas, principalmente por parte das elites da cidade, ações enérgicas para solucionar esse problema. Os apelos para a concepção de vilas e habitações saudáveis econômicas, como também, para a criação de um dispositivo que "controlasse" e brecasse essa avidez de construções, "(...) uma barreira real, intransponível e segura" (CASCUDO, 1946, p.03), continuavam a ser diariamente publicados nos periódicos dessa época. Argumentando-se que, caso contrário, "não haverá trecho de paisagem [...] que resista ao desejo material de transformá-la em lotes-de-casas. [...]" (CASCUDO, 1946, p.03).

Esse momento coincide, de acordo com Bonduki (2002), com o efetivo despertar do país para a indústria. Para a concretização dessa atividade era preponderante disponibilizar condições básicas de moradia e trabalho para a mão-de-obra. A habitação, sobretudo a econômica, tornou-se então elemento de grande força e importância nos discursos, passando ocupar lugar de destaque nas ações públicas em todo o país. Foram criados, nesse sentido, os primeiros órgãos federais responsáveis pela concepção direta de moradias: os Institutos de Aposentadorias e Pensões (IAPS), criados em 1937, e a Fundação da Casa Popular, fundada em 1946. Em Natal, os IAPs e a FCP exerceram importante papel na solução da escassez de moradias no período que compreende os anos de $1942^{92}$ a 1963, por meio de financiamentos para aquisição de terrenos para construção de moradia e pela construção de residências para venda e/ou aluguel. Esse processo correspondeu ao atendimento das solicitações de aproximadamente dois mil beneficiados ${ }^{93}$. Essa produção será exposta e detalhadamente analisada no capítulo seguinte da dissertação.

Paralelamente à ação desses órgãos e para solucionar o problema de moradia dos migrantes e da população pobre da cidade, a municipalidade criou loteamentos em terrenos na região periférica da cidade e construiu em um amplo terreno localizado no "subúrbio de Lagoa Seca" um "abrigo definitivo" onde essa

\footnotetext{
92 Somente a partir de 23 de abril de 1942 foi que os IAPs foram autorizados pelo Governo Estadual a concederem financiamento para construção e/ou aquisição de residência aos seus operários (PARA A CONSTRUÇÃO..., 25/07/1942, p.01). ${ }_{93}$ Dados levantados no INSS-RN.
} 
população encontraria moradia, toda a assistência médica, alimentícia e vestimentas necessárias, além de encaminhamentos para empregos (O PROBLEMA..., 04/04/1943, p.03).

Com o fim da Guerra e a perda do dinamismo das atividades comerciais, resultante da saída de parte dos militares da cidade, Natal sucumbiu a uma crise social e econômica, representada principalmente pelo aumento do número de desempregados, que perdurou por toda a década seguinte. Essa conjuntura equivaleu ao que se considerou o quarto momento de agravamento da crise habitacional em Natal.

Dentre as realizações promovidas pelo governo no período, pode-se citar: o loteamento promovido pelo governo estadual na Rua Coronel Estevão no Alecrim, em 1950; a construção, em 1954, do primeiro grupo de 55 casas da Vila Ferroviária, realizada pelo governo municipal e localizada no bairro das Rocas (VILA..., Jornal de Natal, 24/12/1954, n.1000, p.03); a construção de outras 12 residências na Rua da Tração, no Alecrim, e 10 unidades na Rua General Glicério, nas Rocas, ambas em 1954, também credenciadas à administração municipal. Com o mesmo intuito, o governo do estado ampliou o projeto de incentivo à construção de casas próprias, verbalizado principalmente pelo aumento das concessões de terrenos aos IAPs e CAPs, em concordância com a Lei no. 92, de 24 de novembro de 1951, numa tentativa de se instituir um programa habitacional consistente no estado (TERRENO..., 24/11/1951, p.03). Essa produção quase que duplicou na primeira metade da referida década, como se verá adiante.

Para a população não "atendida" pelas supracitadas ações governamentais, por não deterem condições de adquirir ou financiar uma moradia, foram construídos os chamados "Albergues Noturnos" que se destinavam, diferentemente dos dispensários e abrigos largamente concebidos nas décadas de 1920 e 1930, apenas a "(...) abrigar, durante as horas da noite, aqueles que não tinham onde dormir, (...)". O primeiro deles, localizado na Rua Guaratuba, próximo à Maternidade de Natal, foi concluído em dezembro de 1951, com capacidade para atender cerca de 100 famílias (ALBERGUE..., 15/12/1951, p.04).

Dentre as proposições e realizações ${ }^{94}$ no primeiro mandato do prefeito Djalma Maranhão (19561959/1960-1964) no campo da habitação, estava: a urbanização dos novos bairros da cidade, Praia do Forte e Mãe Luíza, e das vilas de Parnamirim, Ponta Negra, Redinha e Igapó; a continuidade na construção de abrigos para mendigos e flagelados; a ampliação do sistema das linhas de ônibus e da rede elétrica para propiciar condições de habitabilidade nas áreas periféricas da capital; e a elaboração de um plano de urbanização para Santos Reis (Figura 65).

\footnotetext{
94 Para atender à nova demanda da população da capital norte-riograndense, Djalma Maranhão elaborou diversos programas entre os quais se destacam: o de erradicação do analfabetismo; o programa que focava a industrialização de Natal, processo ainda não concretizado até o momento, que justificou diversas intervenções em seu espaço físico; de incentivo ao turismo, que se baseava na valorização das belezas naturais, como as praias e as paisagens, existentes em Natal; e o programa habitacional. O programa de erradicação do analfabetismo obteve grande repercussão nacional na segunda administração do prefeito (1960-1964), e ficou conhecido como "De Pé no Chão Também se Aprende a Ler"; alcançando o número recorde de 31 escolas construídas em trinta dias, no ano de 1957 (A CIDADE..., 1958, p.03).
} 
Em fins dos anos cinqüenta, a ocorrência de outra grande seca no Rio Grande do Norte acarretou a exacerbação do problema da falta de habitação destinada à parcela populacional de baixa renda devido à entrada, mais uma vez, de uma grande leva de migrantes na cidade. Nos anos de 1958 e 1959, Natal foi a cidade que mais cresceu em número de habitantes no Nordeste ${ }^{95}$. O número de flagelados

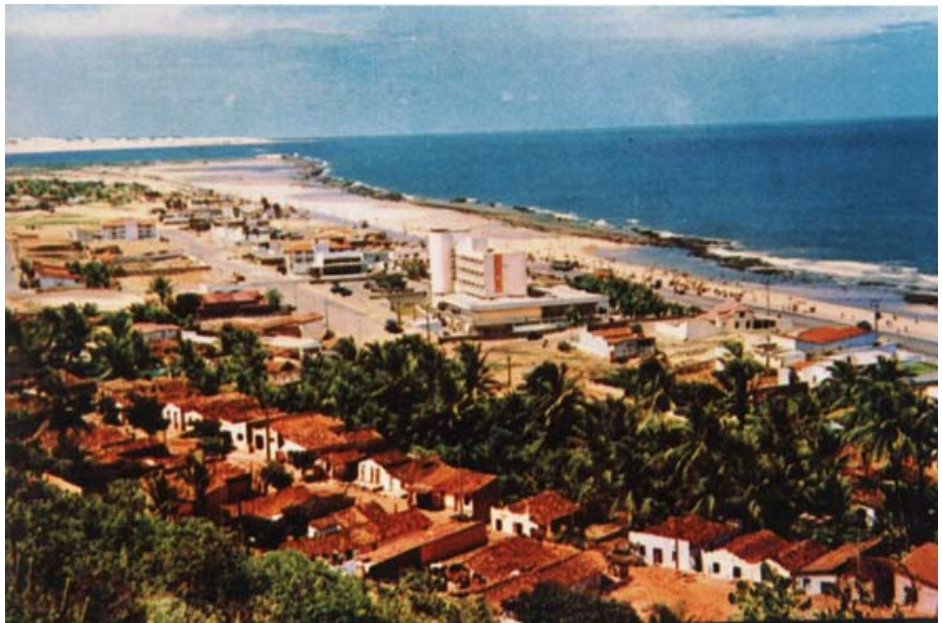

Figura 65: Santos Reis em primeiro plano e a Praia do Forte ao fundo e à esquerda (década de 1950). Fonte: JAECl, 2006 que se encontravam instalados na capital no início da década de 1960 chegou a atingir 30.000 (trinta mil) (DESEMPREGO..., 1960, p.01). Essa conjuntura culminou no surgimento e no crescimento de diversas favelas na cidade, que caracterizaram 0 quinto momento de agravamento da crise de moradias.

Eram consideradas favelas nesse período, pela imprensa da época, qualquer ocupação irregular de traçado espontâneo, assentamentos sem planejamento ou infra-estrutura e grupo de habitações que não condiziam com as normas de higiene e beleza estipuladas para Natal. Dentre as favelas que surgiram na capital pode-se citar: Mãe Luíza, Brasília Teimosa - as primeiras localidades denominadas pela imprensa da cidade como favela -, Novo Mundo, Aparecida, Passo da Pátria, Nazaré e Dom Eugênio.

O projeto de higienizar, modernizar e embelezar Natal, evidenciado a partir de fins do século XIX e que objetivava promover o seu crescimento econômico e privilegiar a camada mais abastada da população da cidade, mudou nesse momento de intento. A elite administrativa almejava agora essencialmente, modernizar a cidade, capacitando-a com a infra-estrutura necessária à consolidação das indústrias na localidade ${ }^{96}$. No entanto, esse "projeto" esbarrava, dentre outras coisas, com os problemas urbanos relacionados à habitação supracitados. Nesse sentido, a administração pública, diferentemente do que ocorrera até então, atuou de forma sistematizada por meio de um programa habitacional coeso em sete frentes: a criação de órgãos e a elaboração de legislação específica; a criação de bairros, conjuntos e loteamentos periféricos; a construção de albergues noturnos e abrigos definitivos; a concessão de terrenos para a construção da casa-própria; a concessão de financiamentos para a edificação de habitações populares por meio das Carteiras Prediais dos Institutos de Aposentadorias e Pensões (IAPs), da Fundação da Casa Popular (FCP) e da Fundação da Habitação Popular do Rio Grande do Norte (FUNDHAP); a remoção e/ou urbanização de favelas; e a reforma higiênica e estética de moradias.

\footnotetext{
${ }_{95}$ Segundo o IBGE, a população de Natal passou de 160.000 habitantes no ano de 1957, para quase $195.000 \mathrm{em} 1959$.

${ }_{96}$ Quase duas décadas depois da consolidação desse ideal nos principais centos urbanos do país.
} 
Em se tratando da frente "criação de órgãos e elaboração de legislação específica" (Figura 66), o prefeito propôs a criação, em 1956, do já citado Conselho Municipal de Urbanismo, que atuaria como órgão de consulta da administração municipal por meio de uma legislação própria com o objetivo, de acordo com Dantas (2003), de consolidar uma identidade urbanística da cidade. No entanto, essa proposta do governo municipal de controle e fiscalização das construções por meio de órgãos técnicos próprios não foi concretizada.

A criação de bairros e loteamentos periféricos (Figura 67) representou uma das principais respostas do governo ao déficit habitacional evidenciado em fins da década de 1950. Estes vieram, por vezes, acompanhados da construção de equipamentos e serviços urbanos básicos como escolas, igreja e ampliação da cobertura de transportes coletivos.

Dentre os loteamentos promovidos pelo governo municipal nessa época, pode-se citar: o loteamento realizado no bairro de Santos Reis, no prolongamento da Avenida Circular, em 1955, cujos lotes mediam "(...) no mínimo, 10 metros de frente por 15 de fundo, ao preço de 50 e 70 cruzeiros o metro quadrado (...)" (NA CAMARA..., Jornal de Natal, 03/08/1955, n.1174, p.04); o realizado na Praia do Forte e o Monte Carlos, ambos situados nas imediações de Santos Reis, datados de 1957; um em Mãe Luíza, em 1958; um loteamento no bairro das Quintas, também efetivado no ano de 1958; e o loteamento "Cidade Campestre do Jequí" (Figura 68), cuja primeira etapa foi concluída em 1964, que equivalia a uma área total de 500 hectares divididos em mais de 300 lotes de grandes dimensões. A proliferação dos loteamentos ocasionou a consolidação de novos bairros na cidade como o de Boa Sorte, próximo ao Tirol, a Vila Popular, onde “(...) diversas famílias desta capital e do interior estão adquirindo lotes de terrenos para a edificação de casas residenciais" (NASCE..., 1957, p.08), Praia do Forte, Mãe Luíza, Rocas e as chamadas, Vila de Parnamirim, Ponta Negra, Redinha e Igapó.

\begin{tabular}{|c|c|}
\hline \multicolumn{2}{|c|}{$\begin{array}{c}\text { CRIAÇÃO DE ÓRGÃOS E ELABORAÇÃO DE } \\
\text { LEGISLAÇÃO ESPECÍFICA }\end{array}$} \\
\hline 1) Tipo de Ação & Indireta \\
\hline 2) Abrangência & Total \\
\hline $\begin{array}{l}\text { 3) Área de } \\
\text { Intervenção }\end{array}$ & Novo Espaço \\
\hline 4) Escala da Obra & Cidade \\
\hline $\begin{array}{l}\text { 5) Meios de } \\
\text { Atuação }\end{array}$ & $\begin{array}{c}\text { Órgãos Específicos e } \\
\text { Legislação }\end{array}$ \\
\hline $\begin{array}{l}\text { 6) Agentes } \\
\text { Envolvidos }\end{array}$ & Governo Municipal \\
\hline $\begin{array}{l}\text { 7)Administrador } \\
\text { Responsável }\end{array}$ & $\begin{array}{l}\text { Prefeito Djalma } \\
\text { Maranhão } \\
\end{array}$ \\
\hline 8) Destino da Obra & Toda a População \\
\hline $\begin{array}{l}\text { 9) Origem da } \\
\text { Verba Utilizada }\end{array}$ & Governo Municipal \\
\hline
\end{tabular}

\begin{tabular}{|c|c|}
\hline \multicolumn{2}{|c|}{$\begin{array}{c}\text { CRIAÇÃO DE BAIRROS, CONJUNTOS E } \\
\text { LOTEAMENTOS }\end{array}$} \\
\hline 1) Tipo de Ação & Direta \\
\hline 2) Abrangência & Total \\
\hline $\begin{array}{l}\text { 3) Área de } \\
\text { Intervenção }\end{array}$ & Novo espaço \\
\hline 4) Escala da Obra & Cidade \\
\hline $\begin{array}{l}\text { 5) Meios de } \\
\text { Atuação }\end{array}$ & Parcerias e incentivos \\
\hline $\begin{array}{l}\text { 6) Agentes } \\
\text { Envolvidos }\end{array}$ & $\begin{array}{l}\text { Governo Municipal e } \\
\text { Estadual, USAID, } \\
\text { FUNDHAP e SUDENE }\end{array}$ \\
\hline $\begin{array}{l}\text { 7)Administrador } \\
\text { Responsável }\end{array}$ & $\begin{array}{c}\text { Governador Aluísio Alves } \\
\text { e } \\
\text { Prefeito Djalma } \\
\text { Maranhão }\end{array}$ \\
\hline 8) Destino da Obra & $\begin{array}{l}\text { População de baixa } \\
\text { renda }\end{array}$ \\
\hline $\begin{array}{l}\text { 9) Origem da } \\
\text { Verba Utilizada }\end{array}$ & $\begin{array}{c}\text { Governo Federal, } \\
\text { Estadual, Municipal } \\
\text { e parcerias internacionais }\end{array}$ \\
\hline
\end{tabular}

Figuras 66 e 67: Tabela de especificação da linha de atuação governamental.

Fonte: Elaboração própria com base nos dados coletados. 


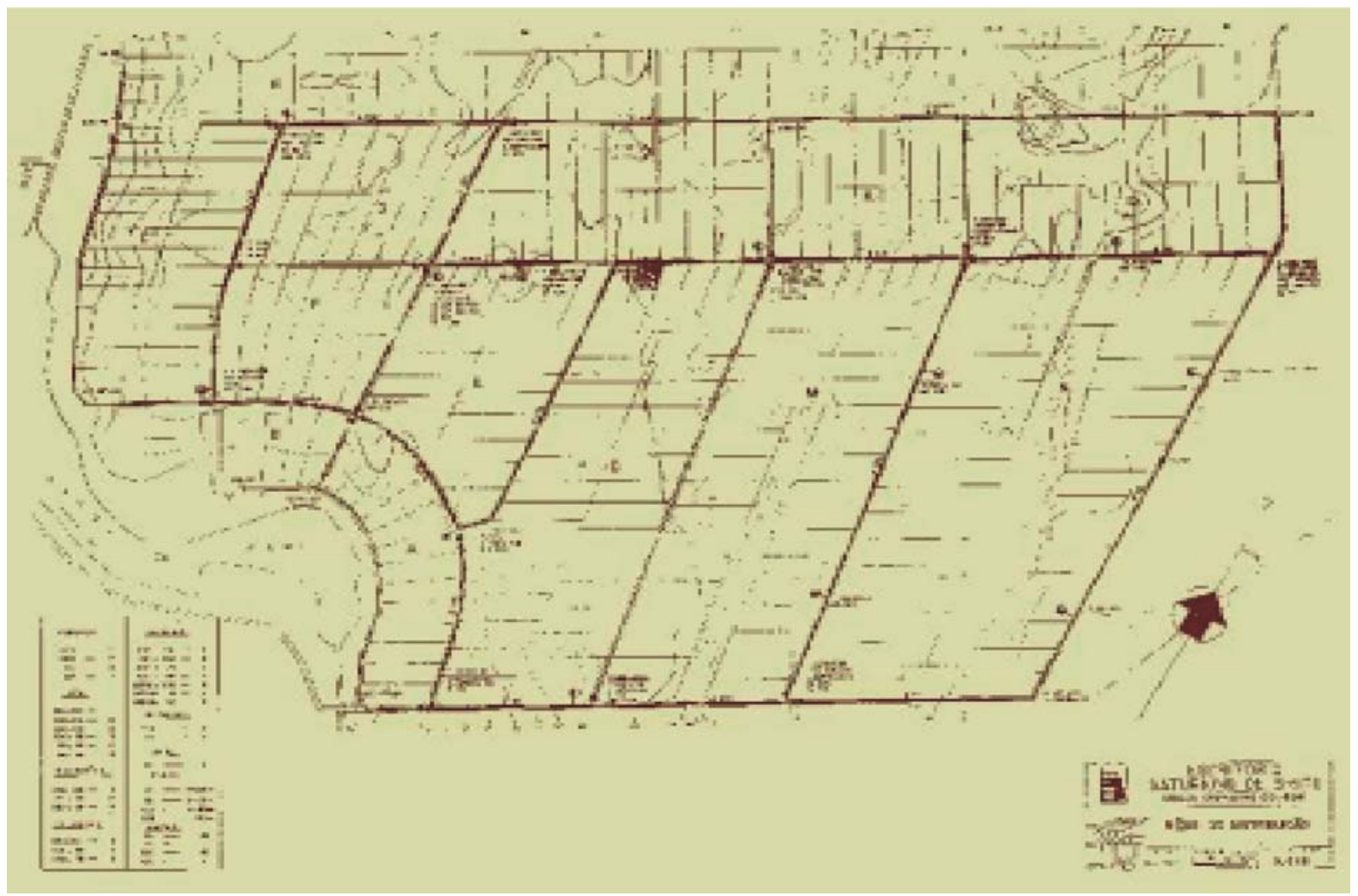

Figura 68: Loteamento "Cidade Campestre do Jequi", 1963.

Fonte: FERREIRA et al., 2003.

Dentre os fatores que contribuíram para a "expansão da cidade" pode-se citar a ampliação da rede elétrica, iniciada na década de 1960 pelo governador Dinarte Mariz e concluída por Aluízio Alves, por meio da Operação Nordeste que trouxe para Natal a energia elétrica da Hidrelétrica de Paulo Afonso. Essa inovação, além de ter sido decisiva para a valorização do solo e intensificação do mercado imobiliário, representou um atrativo às indústrias na região (ALMEIDA, 2005).

Em âmbito estadual merecem destaque os programas habitacionais implementados a partir de 1961 pelo Governador Aluízio Alves. Para efetivá-los, Aluízio buscou financiamentos junto a órgãos nacionais e internacionais, como a USAID - Aliança para o Progresso - que tinha na figura do presidente norte-americano, Kennedy, seu principal articulador, representando uma das mais significativas parcerias neste sentido (ALVES, 2001). É digno de relevância o Plano de Habitação Popular do Rio Grande do Norte, que previa inicialmente a construção de 3.000 (três mil) casas populares. Para a efetivação deste Plano foi imprescindível, além da colaboração da USAID, a instituição da Fundação da Habitação Popular do Rio Grande do Norte - FUNDHAP - em 1963, que será estudada no capítulo seguinte.

Dentre os programas desenvolvidos pela FUNDHAP, destaca-se o "conjunto residencial operário Cidade da Esperança" (Figura 69) cuja primeira etapa foi concluída em 1964 e sua criação foi resultado de uma parceria entre a USAID e a SUDENE. 
A criação desse Conjunto foi associada a um discurso que almejava a construção de uma "cidade com perspectivas mais felizes e mais seguras" (A ORDEM, 02/01/1965, p.02), destinada à população de baixa renda, que possuía em 1966, cerca de 590 casas construídas, 672 em vias de construção (A ORDEM, 20/08/1966, p.05), além de vinte unidades residenciais viabilizadas pelo IPE - Instituto de Previdência do Estado - reservadas aos funcionários públicos (ALVES, 2001).

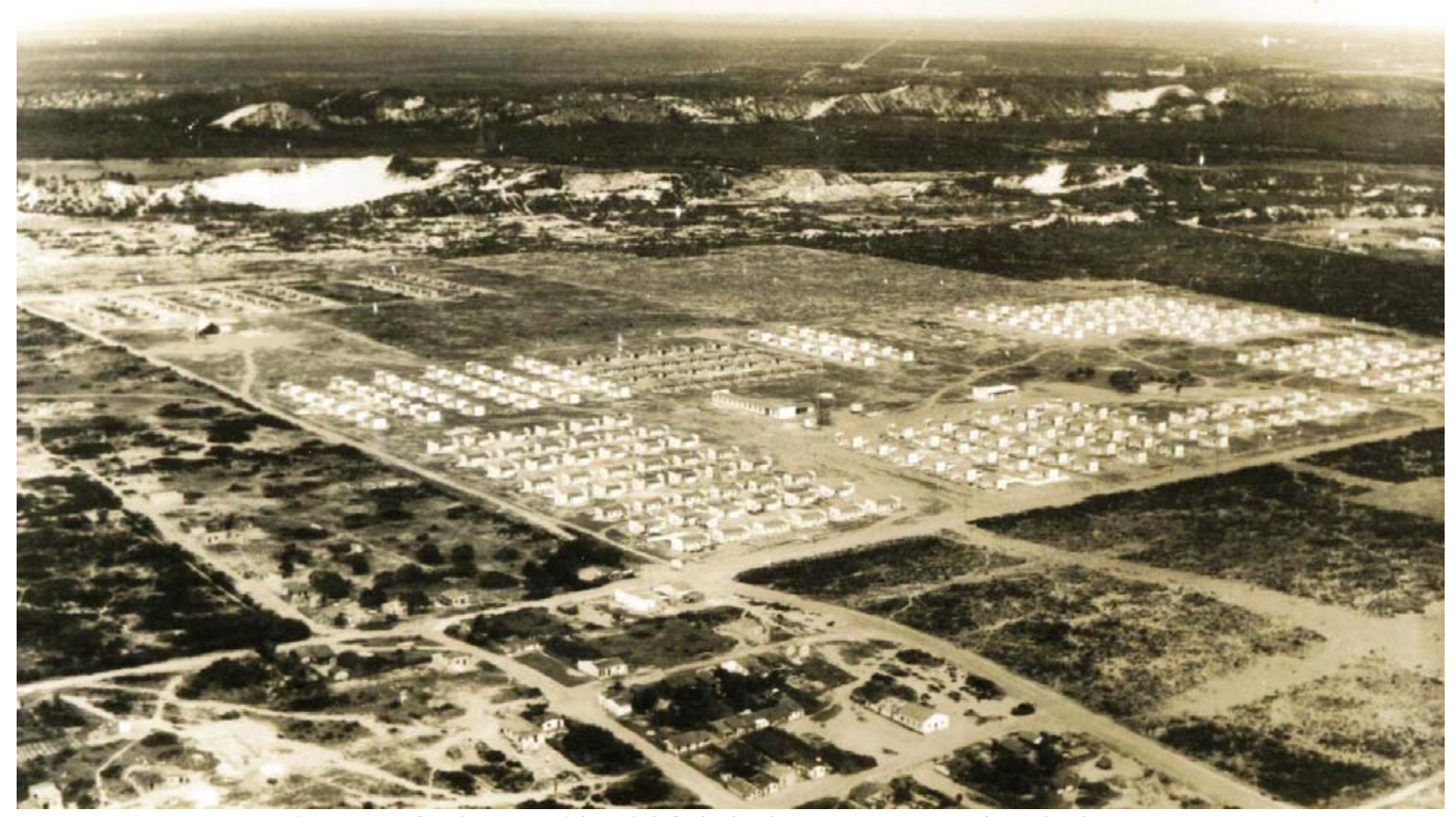

Figura 69: Conjunto residencial Cidade da Esperança na década de 1960.

Fonte: Acervo em processo de catalogação.

Os projetos de reforma urbana e regularização fundiária realizados nas áreas de Mãe Luíza e, principalmente, Brasília Teimosa, marcam a posição do poder municipal nesta frente de combate à crise de moradias, tendo o prefeito Djalma Maranhão como seu propulsor. Essas áreas foram loteadas e arrendadas pelo poder municipal e vendidas à população de classe média a partir de 1954, mas, com 0 passar dos anos foram invadidas pela população sem condições de custear uma residência e por aquela que fugia das secas que assolavam o interior do Rio Grande do Norte. Em fins da década de 19500 quadro de higiene e salubridade das habitações ali instaladas era julgado preocupante (Figura 70).

A situação dessas localidades era freqüentemente exposta em artigos dos jornais locais, principalmente, os de que faziam oposição a Djalma Maranhão. Essas publicações revelavam também 0 desejo político em resguardar a estética das praias da capital desde a formulação do Plano de Sistematização, em 1929:

O Prefeito Municipal de Natal, usando das atribuições que lhe são conferidas (...) e ainda considerando a necessidade de defender o Plano Geral e Sistemático de Urbanização da Cidade; considerando ser vital para a consecução desses objetivos a preservação da orla marítima, pois as praias se constituem parte fundamental da sistemática urbanística de Natal; considerando que a Prefeitura Municipal de Natal promoveu os loteamentos de 
terrenos nas datas de 27 de Dezembro de 1954 e 23 de Janeiro de 1958, sem que até hoje tenham sido atendidas as exigências das respectivas leis autorizativas e dos títulos posteriores expedidos; considerando que muitos lotes (...) já aforados foram ocupados (...) sem que os proprietários (...) adotassem quaisquer providências para resguarde dos seus possíveis interesses, prejudicando com essa omissão o Plano Urbanístico e Habitacional da Cidade; Considerando que, com as sucessivas e desordenadas invasões (...) Brasília Teimosa constitui hoje um problema eminentemente social; Considerando que as condições de moradia em Brasília Teimosa passaram a constituir problema social de reconhecida gravidade pelos seus aspectos de salubridade e higiene (EM BRASÍLIA..., 1962, p.01).

\begin{tabular}{||c|c||}
\hline \multicolumn{1}{|c|}{$\begin{array}{c}\text { CONCESSÃO DE TERRENOS E CONSTRUÇão DE } \\
\text { CASA PRóPRIA }\end{array}$} \\
\hline \hline 1) Tipo de Ação & Direta \\
\hline \hline 2) Abrangência & Total \\
\hline \hline $\begin{array}{c}\text { 3) Área de } \\
\text { Intervenção }\end{array}$ & Espaço existente \\
\hline \hline 4) Escala da Obra & Bairro \\
\hline \hline 5) Meios de Atuação & $\begin{array}{c}\text { Parcerias e } \\
\text { incentivos }\end{array}$ \\
\hline \hline $\begin{array}{c}\text { 6) Agentes } \\
\text { Envolvidos }\end{array}$ & $\begin{array}{c}\text { Governo } \\
\text { Municipal }\end{array}$ \\
\hline \hline $\begin{array}{c}\text { 7)Administrador } \\
\text { Responsável }\end{array}$ & $\begin{array}{c}\text { Prefeito Djalma } \\
\text { Maranhão }\end{array}$ \\
\hline \hline $\begin{array}{c}\text { 8) Destino da Obra } \\
\text { População de } \\
\text { baixa renda, }\end{array}$ \\
\hline \hline $\begin{array}{c}\text { 9) Origem da Verba } \\
\text { Utilizada }\end{array}$ & $\begin{array}{c}\text { Governo } \\
\text { Municipal }\end{array}$ \\
\hline \hline
\end{tabular}

Figura 70: Tabela de especificação da linha de atuação governamental.

Fonte: Elaboração própria com base nos dados coletados
Em 15 de junho de 1962, o prefeito assinou decreto, baseado na Constituição Federal, na Lei Orgânica dos Municípios e na Lei Federal de Desapropriação, declarando de utilidade pública e interesse social os terrenos de Mãe Luíza e Brasília Teimosa (DANTAS, 2003, p.183). A área de Brasília Teimosa foi desapropriada e os quase dois mil lotes distribuídos às famílias de baixa renda. Os lotes eram entregues gratuitamente e em caráter de usufruto às famílias carentes com estado de pobreza comprovado. Impedia-se, dessa maneira, a negociação dos lotes por seus ocupantes permitindo, porém, a transferência dos terrenos de pai para filho. As intervenções realizadas em Mãe Luíza, por sua vez, se inseriram na sexta frente governamental de combate à evidente crise, "reforma e qualificação estética e higiênica das habitações".

O programa de desapropriações de terrenos teve continuidade até o fim do segundo mandato do prefeito, em 196497, revelando sua intenção de regularizar a situação dos flagelados na cidade, que ocupavam terrenos irregularmente, sem condições de higiene e infra-estrutura.

Outro projeto que data do segundo mandato de Djalma Maranhão, refere-se à construção de casas populares para o funcionalismo municipal. Este programa possibilitou a construção no bairro das Quintas, com recursos exclusivos da Prefeitura, de cerca de dez casas, cada qual, com sala com dois ambientes, três quartos, cozinha, banheiro, jardim frontal e quintal, e mais 113 residências no bairro das Rocas.

\footnotetext{
${ }_{97}$ Devido ao Golpe Militar de 1964, o prefeito Djalma Maranhão foi deposto.
} 
Como já foi dito anteriormente, durante toda a década de 1950, Natal recebeu uma grande leva de migrantes em decorrência de estiagens tão comuns nesses anos. A construção de abrigos temporários ou dos chamados "Albergues Noturnos" foi uma solução bastante empregada pelo poder público na época (Figura 71).

Em se tratando da linha "remoção e/ou capacitação de favelas", as intervenções governamentais se baseavam, principalmente, em incentivos à participação popular - mutirões e doações em geral - e no apoio dado pela Igreja Católica, que a partir da década de 1940 mudara seu papel como agente social, intervindo junto ao poder público em questões que afetassem o bem estar da população, essencialmente, aquelas que assistiam à população de baixa renda. Na década de 1960, a Igreja continuou com uma atuação de parceria com o Estado (PAIVA, 2000). Suas ações foram materializadas na forma de Frentes de Trabalhos, que atuavam nas comunidades mais carentes da cidade, como Mãe Luíza, Rocas, Nova Descoberta, Cidade da Esperança, Morro Branco e Carrasco (Figura 72).

O objetivo das Frentes era solucionar os problemas das favelas que surgiam em Natal, dotando-as de infra-estrutura necessária para amenizar as contradições com o entorno e as condições de moradia subumanas verificadas naquelas localidades. Utilizava-se neste sentido, a mão-de-obra da própria comunidade onde a Frente estava atuando, fundamentalmente migrantes das secas, já instalados na capital.

Neste contexto, a Frente de Trabalho que mais obteve destaque foi a denominada de Frente de Trabalho João XXIII atuante na conhecida favela do Morro ou favela do Pinto e dados coletados.
Aparecida, no atual bairro de Mãe Luíza. A importância da atuação desta Frente e sua colaboração na efetivação das obras para o melhoramento da favela puderam ser percebidas em publicações da Igreja, em que a situação da localidade foi exposta antes das intervenções:

Nas favelas existentes (...) Aparecida e Mãe Luiza nos lugares de supra citados sobrevivem em condições sub-humanas, cerca de 14.000 pessoas. Dos 2.500 barracos apenas 100 estão saneados (...). Esses aglomerados humanos estão ligados à
CONSTRUÇÃO dE ABRIGOS TEMPORÁRIOS

\begin{tabular}{|c|c|}
\hline 1) Tipo de Ação & Direta \\
\hline 2) Abrangência & Total \\
\hline $\begin{array}{l}\text { 3) Área de } \\
\text { Intervenção }\end{array}$ & Espaço existente \\
\hline 4) Escala da Obra & Habitação \\
\hline $\begin{array}{l}\text { 5) Meios de } \\
\text { Atuação }\end{array}$ & $\begin{array}{c}\text { Legislação, parcerias } \\
\text { e incentivos }\end{array}$ \\
\hline $\begin{array}{l}\text { 6) Agentes } \\
\text { Envolvidos }\end{array}$ & Governo Municipal \\
\hline $\begin{array}{l}\text { 7)Administrador } \\
\text { Responsável }\end{array}$ & $\begin{array}{l}\text { Prefeito Djalma } \\
\text { Maranhão }\end{array}$ \\
\hline 8) Destino da Obra & $\begin{array}{c}\text { População de baixa } \\
\text { renda, principalmente } \\
\text { migrantes }\end{array}$ \\
\hline $\begin{array}{l}\text { 9) Origem da } \\
\text { Verba Utilizada }\end{array}$ & Governo Municipal \\
\hline
\end{tabular}

REMOÇÃo Elou CAPACITAÇÃo de FaVelas

\begin{tabular}{|c||c||}
\hline \hline 1) Tipo de Ação & Indireta \\
\hline \hline 2) Abrangência & Parcial \\
\hline $\begin{array}{c}\text { 3) Área de } \\
\text { Intervenção }\end{array}$ & Espaço Existente \\
\hline \hline 4) Escala da Obra & Bairro \\
\hline \hline $\begin{array}{c}\text { 5) Meios de } \\
\text { Atuação }\end{array}$ & Parcerias e Incentivos \\
\hline \hline $\begin{array}{c}\text { 6) Agentes } \\
\text { Envolvidos }\end{array}$ & $\begin{array}{c}\text { Governo Municipal, } \\
\text { Igreja Católica e } \\
\text { População }\end{array}$ \\
\hline \hline $\begin{array}{c}\text { 7)Administrador } \\
\text { Responsável }\end{array}$ & $\begin{array}{c}\text { Prefeito Djalma } \\
\text { Maranhão }\end{array}$ \\
\hline \hline $\begin{array}{c}\text { 8) Destino da Obra } \\
\text { População de Baixa } \\
\text { Renda }\end{array}$ \\
\hline $\begin{array}{c}\text { 9) Origem da } \\
\text { Verba Utilizada }\end{array}$ & $\begin{array}{c}\text { Outras (obras } \\
\text { realizadas em } \\
\text { mutirão) }\end{array}$ \\
\hline \hline
\end{tabular}

Figuras 71 e 72: Tabela de especificação da linha de atuação governamental. Fonte: Elaboração própria com base nos dados coletados 
Cirolândia, sendo gritante 0 contraste. Ali 0 que se vê é fome, a mortalidade infantil, 0 desemprego, 0 analfabetismo, a doença, a falta d'água, falta de saneamento, campo fácil à prostituição e à iniciativa ao crime (A ORDEM, 26/02/1966, manifesto).

Dentre as obras realizadas pela Frente nas favelas, pode-se citar: a pavimentação e abertura de $6 \mathrm{~km}$ de estradas e avenidas, como a Guanabara com aproximadamente $2 \mathrm{~km}$ de extensão; a construção de centros comunitários, centros sociais, igreja, cemitério, escolas e centros médico-sanitários; saneamento da área, com a construção de fossas sépticas; incentivos ao estabelecimento de uma indústria artesanal nas imediações da favela; e a construção de habitações populares através do sistema cooperativo e mutirões (A ORDEM, 1966).

Por fim, e voltadas para a conservação da "fisionomia estética da cidade" (FOLHA DA TARDE, 17/03/1961, p.04) estavam às reformas higiênicas e estéticas das residências (Figura 73). Essas intervenções, como já citado anteriormente, também foram realizadas com a justificativa de propiciar 0 embelezamento da cidade para "os olhos dos turistas". Assim, foram legitimadas as obras de infra-estrutura, renovação e

REFORMA E QUALIFICAÇÃO HIGIÊNICO/ESTÉTICA DE HABITAÇÕES

\begin{tabular}{|c|c|}
\hline 1) Tipo de Ação & Direta \\
\hline 2) Abrangência & Total \\
\hline $\begin{array}{l}\text { 3) Área de } \\
\text { Intervenção }\end{array}$ & Espaço existente \\
\hline 4) Escala da Obra & Habitação \\
\hline $\begin{array}{l}\text { 5) Meios de } \\
\text { Atuação }\end{array}$ & Legislação \\
\hline $\begin{array}{l}\text { 6) Agentes } \\
\text { Envolvidos }\end{array}$ & Governo Municipal \\
\hline $\begin{array}{l}\text { 7)Administrador } \\
\text { Responsável }\end{array}$ & $\begin{array}{l}\text { Prefeito Djalma } \\
\text { Maranhão }\end{array}$ \\
\hline 8) Destino da Obra & $\begin{array}{l}\text { Especialmente a } \\
\text { população de baixa } \\
\text { renda }\end{array}$ \\
\hline $\begin{array}{l}\text { 9) Origem da Verba } \\
\text { Utilizada }\end{array}$ & Governo Municipal \\
\hline
\end{tabular}

Figura 73: Tabela de especificação da linha de atuação governamental.

Fonte: Elaboração própria com base nos dados coletados. melhorias das residências, realizadas pelo então prefeito Djalma Maranhão.

Um dos principais alvos das intervenções eram as moradias de taipa que ocupavam ruas inteiras sem infra-estrutura e, segundo observadores da época, agredindo a "vista da população" (Figura 74). As habitações em alvenaria que possuíssem apenas um único grande cômodo, no qual eram desenvolvidas as atividades de habitação e

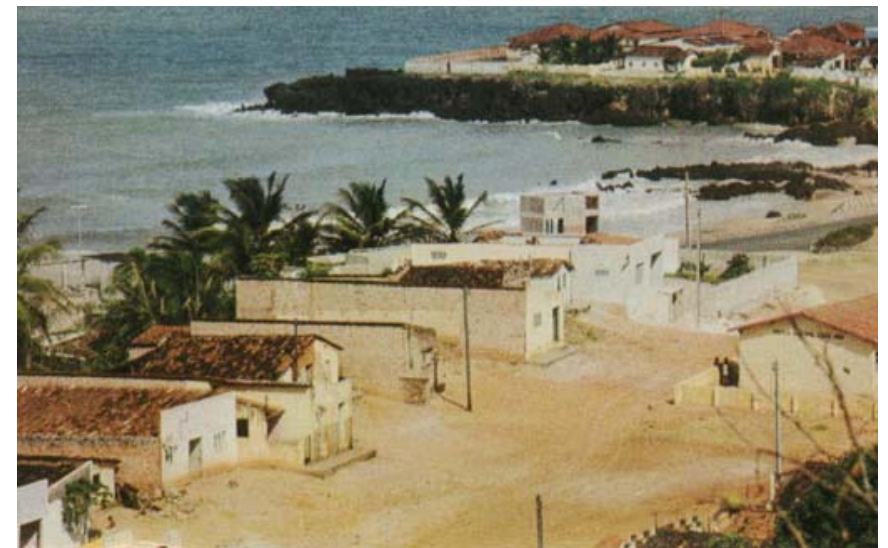
Figura 74: Reforma das fachadas nas moradias do bairro de Aparecida, na década de 1950. Fonte: JAECI, 2006. local de trabalho, também foram focadas por essa linha de atuação.

As intervenções aconteceram principalmente no bairro de Mãe Luíza, Rocas, Nova Descoberta e Morro Branco, próximos aos bairros nobres e a pontos turísticos da cidade - Petrópolis e praia do Pinto. Nesta linha, merecem destaque às obras efetivadas nas favelas de Mãe Luíza e Aparecida. $O$ artigo publicado em um jornal oposicionista exprime bem esta intenção: 
O interesse do Prefeito Djalma Maranhão em concentrar as credenciais das favelas próximas à Praia do Pinto, está na famosa praia [...] que será em futuro não longínquo, 0 mais lindo e mais aprazível recanto da cidade, o encontro do turista e o paraíso da hight society natalense (...) (FOLHA DA TARDE, 18/04/1961, p.02).

As reformas nas moradias eram representadas, na maior parte dos casos, por aberturas de janelas em cômodos com pouca iluminação e ventilação, revestimento de pisos, transferência de latrinas, instalação de fossas sépticas, construção de platibandas nas fachadas principais e caiação das paredes das fachadas.

Os programas governamentais associados à moradia social e à produção delas diretamente pelas administrações locais, pelos IAPs e pela FCP foram reduzidos e/ou interrompidos entre os primeiros anos da década de 1960 e 0 ano de 1964, quando a governo militar, extinguiu os Institutos e centralizou a previdência no INPS - Instituto Nacional de Previdência Social - transferindo, por outro lado, as atribuições das Carteiras Prediais e da FCP para o Banco Nacional da Habitação - BNH (SAMPAIO, 2002).

\subsection{A Política Pública Habitacional: os momentos de atuação do Estado}

Antes de explanar acerca da especificação dos momentos de atuação governamental no campo da habitação social, cabe ressaltar que as condições históricas e a escassez de dados relativos às administrações municipais e intervenções realizadas no espaço urbano no recorte temporal da pesquisa (1889-1964), comprometeram a análise e a confirmação de alguns fatos. Apesar desses empecilhos, 0 levantamento e análise dos dados obtidos, e a releitura de trabalhos realizados e da historiografia específica, permitiram a identificação de quatro momentos de atuação governamental no campo da habitação social em Natal, no recorte temporal trabalhado: o primeiro teve início com a Proclamação da República (1889) e se estendeu até 1909; o segundo iniciado com a década de 1910 se prolongou até fins da década de 1920; o terceiro começou no ano de 1930 e finalizou em meados dos anos de 1950; e 0 quarto e último, correspondeu ao período compreendido entre os anos de 1955 e 1964, sendo finalizado com a criação do Banco Nacional de Habitação (BNH), que marcou o início de um novo período na história da habitação no Brasil, largamente abordado pelas análises sobre a produção habitacional no país.

\section{Primeiro Momento: o Estado legislador}

Verificou-se nesse sentido, que de 1889 até fins de 1909, os problemas referentes à moradia apareceram atrelados à precária situação sanitária da cidade e à necessidade de higienizá-la. Nesse período, não se encarava a questão da falta de moradia destinada aos migrantes e mendigos, que perambulavam pela cidade, como um problema de déficit habitacional; afigurando-se apenas como uma ameaça sanitária e social. 
Nesse primeiro momento, de maneira geral, a intervenção estatal no campo da habitação se dava por meio de uma legislação rigorosa (punitiva e restritiva) para concepção e adequação de moradias. Essas ações foram guiadas por um projeto mais amplo, implementado pelo Governo Federal a partir da formulação de Leis que se propunham a reverter o quadro sanitário das cidades do país e, conseqüentemente, de suas residências. Essas normas apresentavam em seu cerne um conteúdo segregador, uma vez que impunham cláusulas - normalização do uso do solo e investimentos na estrutura e aparência das edificações - que a população carente não tinha condições de cumprir, forçando esses habitantes a se deslocarem para áreas distantes do centro; fazendo emergir os primeiros subúrbios de Natal.

A reforma de fachadas, a adequação de residências insalubres, a substituição de moradias desalinhadas e malsãs por outras mais saudáveis e "modernas", a abertura de vias "reservadas" para a população carente, e o loteamento de terrenos a serem aforados, podem ser citadas como intervenções recorrentes neste período. O objetivo dessas ações era criar um novo cenário da cidade, mais "moderno", higiênico e belo, como forma de atrair investimentos.

Essas intervenções representaram também uma dupla ação: a de modernização da capital e a de auto-segregação das classes dominantes locais. Isto se deu na medida em que se superava 0 antigo desenho da cidade colonial, em que todas as classes conviviam no mesmo espaço.

\section{Segundo Momento: o Estado incentivador e capacitor}

A intenção do governador Alberto Maranhão (1908-1913) de conceber três vilas operárias e a construção de abrigos para mendigos e migrantes pelo governador Ferreira Chaves (1914-1918), marcam 0 início da transição do primeiro momento. No segundo momento (1910-1929), o poder público passa a considerar a existência de um "problema de teto", como chamado na época. O problema habitacional a partir de então, passou a ser relacionado à edificação de mocambos e à escassez de alternativas de moradia para a população que não possuía condições de angariar uma moradia própria julgada adequada ou arcar com os valores cobrados pela locação de imóveis na cidade, sobretudo, em sua área central. No entanto, não se considerava ainda a existência de déficit habitacional. 0 problema era relacionado às "inaceitáveis" tipologias populares e atrelava-se, portanto, às questões essencialmente estéticas.

As soluções dadas pelo Estado nesse sentido se resumiam à reforma de áreas (ruas e terrenos), aos incentivos para construção de habitações operárias e "modernas", e às propostas de concepção de bairros operários situados na periferia da cidade, e inseridos nos Planos de Obras de Saneamento (1924) e no Plano de Sistematização (1929). Essas ações, ainda se baseavam no modelo de afastamento das "classes perigosas" do centro da cidade e das áreas ocupadas pela elite.

A prática da derrubada de "casebres" para a execução de obras inseridas nos princípios de embelezamento e salubridade das cidades, assim como as intervenções nas fachadas dos "mocambos", 
também eram recorrentes no segundo momento. A essas obras, caracterizadas por uma exacerbada preocupação para com os aspectos estéticos da cidade, aliaram-se a partir de 1910 à proibição da mendicância na capital. A presença das classes "perigosas" e "indesejáveis" em Natal, a partir dessa década, passou também a justificar as intervenções estatais no espaço urbano e a elaboração das normas de caráter regulador que objetivavam modificar as edificações.

Na esfera legislativa, evidenciava-se a continuidade na formulação dos Códigos de Posturas e dos Regulamentos de Higiene, que estavam nesse segundo momento, mais voltadas para o cumprimento dos preceitos estéticos estipulados pelas elites para Natal.

\section{Terceiro Momento: o Estado produtor}

A partir da década de 1930, a administração pública passou a reconhecer que a população de baixa renda não detinha condições de angariar uma moradia digna sem o seu auxílio. Isso resultou na transferência, para o Estado, do encargo de mobilizar recursos e mecanismos para conceber habitações que, a partir de então, deixaram de seguir os "moldes tipicamente capitalistas" para serem consideradas uma questão social (BONDUKI, 2002, p.36).

O Estado passou de legislador (controlador e repressor), caráter peculiar do primeiro momento, e de criador das condições de uso e de produção habitacional, especificidade do segundo momento, para produtor de moradias, concebendo de forma direta, habitações para a população mais carente da capital norte-riograndense. Passou, efetivamente, a conceber residências, disponibilizando não somente a infraestrutura necessária, como observado nas décadas de 1910 e 1920, mas também, o financiamento, os materiais de construção e a mão-de-obra para sua edificação.

Esse momento é iniciado com a construção da primeira vila operária por parte da municipalidade, em 1932. Caracteriza-se pela continuidade e intensificação dos "projetos" de proibição da mendicância e construção de abrigos, de incentivo à construção da casa própria, por meio de isenções fiscais e concessão de terrenos, e ainda pelo controle estético das habitações, através da formulação de legislação específica e da fiscalização. Intento antigo, mas que nesse momento, além de objetivar a adequação higiênica das moradias da cidade, pretendia uniformizá-la de acordo com os preceitos em voga no país. Encena-se também, nesse momento, a intensificação da construção de vilas operárias e militares e a profusão dos loteamentos periféricos, assim como, o crescimento da atividade imobiliária na cidade, sobretudo, com a eclosão da II Guerra Mundial e o papel reservado à Natal nessa conjuntura.

A atuação do Estado, principalmente, por meio dos Institutos de Aposentadorias e Pensões (IAPs) e da Fundação da Casa Popular (FCP), representa a principal marca desse terceiro momento. 


\section{Quarto Momento: 0 Estado produtor sistemático}

Nesse momento, as ações estatais voltaram-se ao novo projeto que objetivava a consolidação da atividade industrial e num segundo plano turística, em Natal. Dessa forma, o saneamento passou a ser coadjuvante no desenvolvimento físico da cidade, incluindo a concepção de moradias. Nesse contexto, com a ascensão de Djalma Maranhão ao poder municipal de Natal, no ano de 1955, as questões relacionadas à habitação social passaram a ser inseridas nos programas governamentais, e os problemas associados a elas, combatidos de uma forma sistematizada e planejada.

Concomitantemente, verificou-se que nesse quarto momento, os fluxos migratórios em direção à capital, ocasionados pela seca de 1958, e as obras de modernização e embelezamento efetivadas ao longo da primeira metade do século $\mathrm{XX}$, acabaram por gerar como conseqüência uma aglomeração popular mal alojada em grupos de habitações precárias, culminando no surgimento, em fins da década de 1950, das primeiras favelas da cidade.

Constatou-se, nesse sentido, que apesar de existirem anteriormente em Natal, as habitações precárias só passaram a serem consideradas um "problema urbano" e não somente sanitário pelas autoridades, em meados da década de 1950 e início da década de 1960, quando se mostraram um empecilho ao projeto de industrialização proposto pela elite política na época. Percebe-se, dessa forma, que o surgimento das favelas na cidade incomodava tanto a elite política - por darem visibilidade ao estado de pobreza dos habitantes - quanto à população orgulhosa de sua cidade renovada por novos edifícios "modernos" e largas avenidas.

No tocante às soluções empregadas ao problema da moradia nesse período, observou-se: a continuidade da produção de moradias pelos Institutos e Caixas de Aposentadoria e Pensões (IAPs), e pela Fundação da Casa Popular (FCP), inserindo-se nesse contexto a atuação da Fundação da Habitação Popular do Rio Grande do Norte (FUNDHAP) a partir de 1963; 0 incentivo à autoconstrução de moradias por meio da redução dos preços dos terrenos para facilitar a aquisição do lote; a ação em favelas; e a construção de conjuntos habitacionais instalados longe do centro da cidade, tendo como maior exemplo, a Cidade da Esperança. Cabe ressaltar que a criação de loteamentos e conjuntos habitacionais pela administração pública nesse quarto momento se diferencia das anteriores pelo fato de que os altos preços do solo, na zona urbana de Natal, já incidiam sobre a localização da moradia no espaço urbano.

Para a concretização dessas ações consolidaram-se parcerias entre o governo municipal e estadual, e deles com agentes financiadores nacionais - Caixa Econômica Federal (CEF) e Fundação da Casa Popular (FCP) - e internacionais - USAID - além, do apoio dado pela Igreja Católica e da participação popular. Foram também criadas nesse sentido, instituições de âmbito estadual, como 0 Instituto de Previdência do Estado, em 1962 e a já citada Fundação da Casa Popular do Rio Grande do Norte (FUNDHAP), em 1963. 
Conseqüências das realizações públicas neste campo puderam ser observadas pela proliferação de loteamentos públicos e privados em fins da década de 1950, pela consolidação da periferia, nos primeiros anos da década de 1960, e pela disseminação de casas auto-construídas e das edificadas por mutirões. No contexto geral, percebe-se que apesar da questão da habitação ser considerada de responsabilidade do Estado a partir da década de 1930, interesses contraditórios presentes nos governos não permitiram a implementação de uma política habitacional em Natal, assim como o verificado em âmbito nacional. A trajetória dos Institutos de Aposentadorias e Pensões e da Fundação da Casa Popular na cidade, também reflete essa situação. Tal trajetória será detalhadamente estudada no capítulo seguinte. 


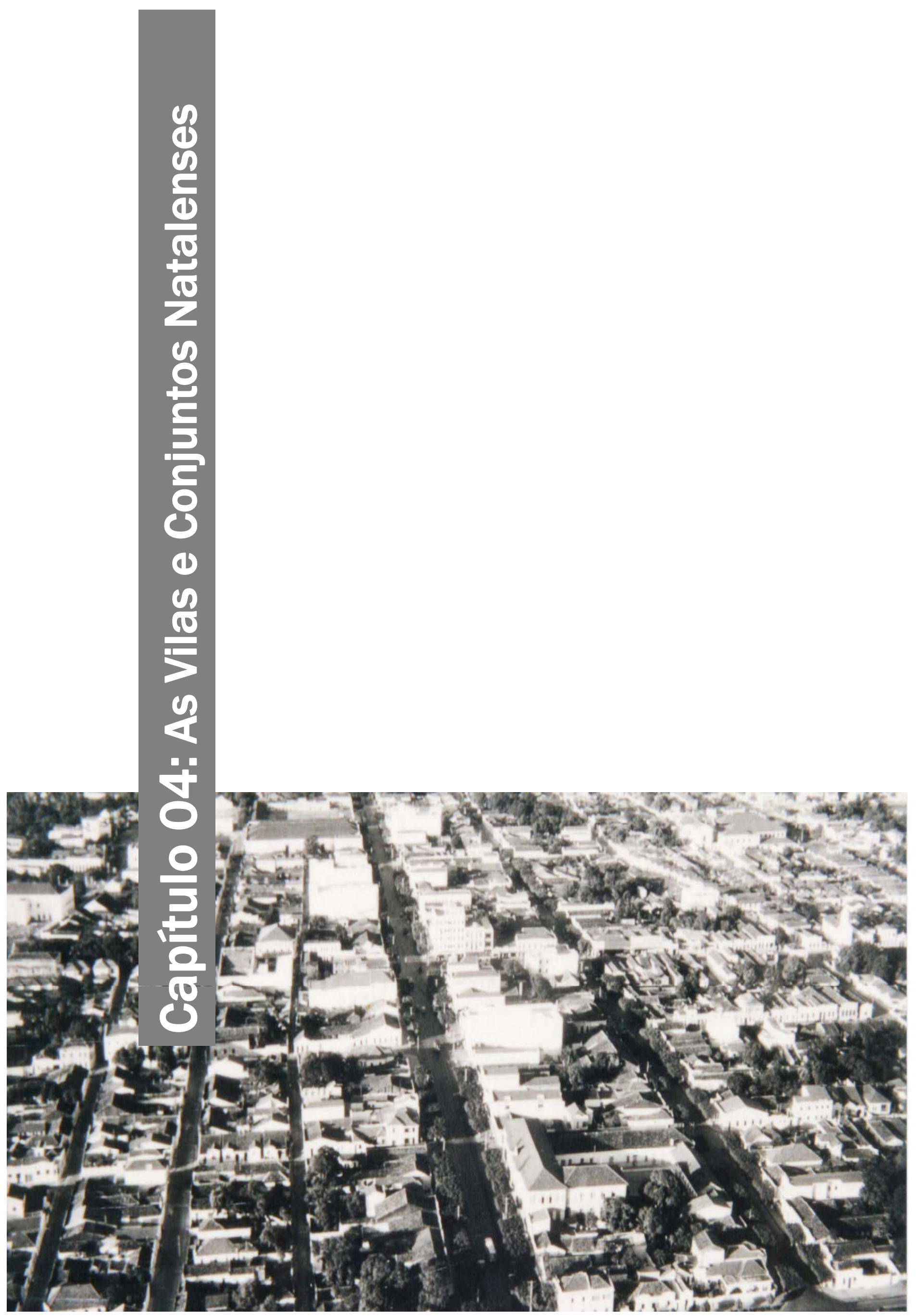




\section{Capítulo 04: As Vilas e Conjuntos natalenses}

\subsection{A AtuaÇão dos Institutos de Aposentadorias e Pensões em Natal}

Antes de identificar a produção de moradias pelos IAPs em Natal, evidenciou-se a necessidade de se determinar as características e especificidades da atuação desses órgãos na cidade, em termos de organização, estrutura, modalidades de financiamentos, tipos de pleitos, dentre outros.

Serão aqui enfocados os Institutos mais atuantes na capital norte-riograndense em relação ao volume de sua produção e à importância desta para o crescimento físico-espacial de Natal. A partir dos levantamentos realizados nos arquivos do Patrimônio Imobiliário do INSS-RN, constatou-se que o IAP dos Industriários (IAPI), seguido pelos IAP dos Comerciários (IAPC), dos Bancários (IAPB), dos Servidores Públicos Estaduais (IPASE), dos Transportes e Cargas (IAPTC) e dos Estivadores (IAPE) foram os Institutos que os mais se destacaram nesse sentido e, dessa maneira, serão aqui abordado ${ }^{98}$.

Cabe aqui recordar que os IAPs possuíam sede na Capital Federal (Rio de Janeiro) e eram representados nos estados brasileiros por agências e delegados. Esses eram determinados pelo presidente de cada IAP e a eles caberiam todos os poderes necessários, inclusive 0 de assinar documentos, para a completa execução das ações dos Institutos em cada estado. Havia ainda procuradores, nomeados pelo delegado estadual, responsáveis pela validação dos registros dos processos e escrituras nos cartórios das cidades.

\section{Quanto às determinações dos Institutos}

Em se tratando das exigências para a concessão e liberação dos financiamentos aos associados, os Institutos de Aposentadorias e Pensões exigiam uma grande quantidade e diversidade de documentos, como também estabeleciam critérios para a liberação das verbas para aquisição e/ou construção de moradias. De maneira geral, as especificações dos IAPs atuantes em Natal em muito se assemelhavam.

Para solicitar um financiamento, 0 associado deveria ser funcionário com carteira profissional (ativo ou inativo), ser contribuinte obrigatório do Instituto há mais de cinco anos, ter encargos de família e possuir margem consignável permissiva à averbação de prestação imobiliária. 0 solicitante obrigatoriamente não poderia ser proprietário, condômino ou promitente comprador de qualquer outro imóvel. A solicitação deveria ser enviada ao escritório estadual do Instituto por meio de carta registrada em nome do solicitante, especificando o pleito e enquadrando-o em um dos planos e/ou classes em que o IAP trabalhava.

\footnotetext{
${ }^{98}$ As informações e análises apresentadas nesse tópico da dissertação se basearam, principalmente, nos dados coletados nos levantamentos realizados no INSS-RN.
} 
Aprovada a requisição do financiamento pelo Instituto, seria então realizada uma avaliação do imóvel pelo engenheiro responsável do IAP ou profissional indicado por ele ${ }^{99}$. O laudo de avaliação constava de informações sobre o solicitante (seu nome completo e o nome completo de seu cônjuge, dados pessoais, empregador, cargo, tempo de contribuição e salário), sobre o pleito (especificação do Instituto, do plano, da classe, da data de abertura do processo, do valor do financiamento solicitado), acerca das características do bairro (natureza, equipamentos e serviços encontrados), do logradouro (natureza, acessos, equipamentos, serviços oferecidos e restrições legais), do terreno onde se encontrava ou viria a ser implantada a residência pleiteada (desde as condições de salubridade, configuração, topografia, dimensões e limites), assim como, do imóvel, determinando a tipologia da edificação, a idade da construção, o estado de conservação, o número de pavimentos, a distribuição dos cômodos em planta e suas respectivas dimensões e as características construtivas (estrutura, fundação, fechamentos, cobertura, revestimentos, esquadrias e aparelhos existentes). O prazo para a realização e para a aprovação dos laudos de avaliação dos imóveis era de, no máximo, trinta dias, chegando em alguns casos, apenas a dois dias.

Realizada a avaliação do imóvel, as divisões de engenharia dos Institutos não poderiam se opor aos laudos elaborados, que teriam necessariamente que estar de acordo com as solicitações endereçadas aos escritórios regionais dos IAPs anteriormente. Após aprovação do laudo, o imóvel ou terreno pleiteado deveria necessariamente ser transcrito no registro de imóveis da cidade. As provas de identificação e de estado civil deveriam ser autenticadas em cartório e 0 associado deveria apresentar as certidões negativas de inexistência de ação ou execução entre as partes e os cônjuges nos últimos dez anos, certidão negativa de existência de protesto de qualquer título ou documento em nome das partes interessadas, cônjuges e proprietários anteriores nos últimos cinco anos ${ }^{100}$. Os associados deveriam também comprovar a plena capacidade para os atos da vida civil das partes e seus cônjuges, e apresentar a quitação dos recibos dos impostos e taxas que recaiam sobre o imóvel, relativos ao último exercício em cobrança, além de prova de quitação do preço da construção.

Mais especificadamente, exigia-se: que o título de domínio deveria está em ordem e regular; que o título de domínio dos proprietários anteriores deveria abranger os últimos vinte anos, incluindo as escrituras de compra e venda, troca, doação, cartas de arrendamento e adjudição, etc., devidamente transcritos no Registro de Imóveis competente; que a Certidão de Registro de Imóveis demonstrasse quais os sucessivos proprietários do imóvel nos últimos vinte anos e que essa Certidão mencionasse as características do imóvel no momento da solicitação do pleito e anteriores a ele; que houvesse escritura,

\footnotetext{
${ }_{99}$ A grande maioria dos laudos de avaliação que apresentava identificação foi assinada pelo engenheiro da prefeitura Wilson de Oliveira Miranda.

100 O tempo exigido para a comprovação de certidões negativas e demais exigências variava de Instituto para Instituto.
} 
título ou documento em nome do associado, seu cônjuge, assim como dos proprietários anteriores e seus cônjuges, que comprovassem a capacidade destes em onerar o imóvel até dez anos antes da solicitação (Tabeliães, Registro de Títulos ou documentos); quitações fiscais relativas ao imóvel e indispensáveis à lavratura da escritura de aquisição; quitação de fôro, carta de aforamento e laudêmio; e quitação ou comprovante de isenção do pagamento do imposto sobre lucros imobiliários, caso houvesse.

Após aprovada e liberada, a proposta deveria ser entregue pelo próprio associado ao setor responsável no escritório do Instituto, que deveria apresentar no ato a caderneta de contribuições do IAP e 0 título de identidade (carteira profissional, carteira de identidade, etc.), além dos documentos referentes à descrição do pleito, citados acima. Uma vez autorizada à proposta de financiamento de imóvel e/ou terreno pela Previdência do Instituto, o assegurado estava comprometido a realizar a operação.

Todas as operações imobiliárias dos IAPs especificavam que:

(...) a falsidade de qualquer declaração inserta na proposta, bem como a renúncia desta ou a recusa de assinatura do contrato acarretará o cancelamento da operação e a obrigação de serem indenizadas as despesas que houver motivado, cobráveis pelo Instituto ao associado mediante desconto em folha (PORTARIA SCM-192 do IAPI, 28/11/1939).

O prazo máximo para amortização da dívida era de vinte anos, a serem contados da data de assinatura do contrato, podendo ser elevado para vinte e cinco se 0 associado tivesse mais de três filhos, ou reduzido para dez anos se o prédio possuísse menos de dois anos de construção. As transações eram acompanhadas de juros que variavam entre $6 \%$ e $8 \%$ ao ano, dependendo do Instituto.

Em se tratando dos valores dos financiamentos, as Portarias relativas à concessão de pleitos especificavam que as solicitações deveriam estar abaixo de $\operatorname{Cr} \$ 75.000,00$ (setenta e cinco mil cruzeiros) até 0 ano de 1944, e inferiores à $\mathrm{Cr} \$ 200.000,00$ (duzentos mil cruzeiros) a partir de então101. Os valores máximos estipulados pelos Institutos em Natal pouco variavam. De acordo com as referidas Portarias, os IAPs não poderiam conceder financiamentos cujas parcelas ultrapassassem $70 \%$ do valor do salário do requisitante, podendo o valor máximo concedido variar de quatro a duzentos e cinqüenta vezes o salário do associado, como se evidenciou no IAPTC e no IAPB, respectivamente. Outra especificidade do IAPTC era que mesmo após 0 aumento das reservas destinadas à construção e à aquisição de moradias concedido por meio de lei em 1944 e, conseqüentemente, do aumento do teto dos financiamentos, 0 referido Instituto só realizava empréstimos imobiliários de, no máximo, Cr\$150.000,00 (cento e cinqüenta mil cruzeiros), para aquisição de terrenos ou imóveis com menos de cinco anos de construção, bem como para a construção em terrenos ou obras de reparos em imóveis de propriedade do associado.

101 Alguns dos IAPs não praticavam esses limites como, por exemplo, o IAPB e o IAPC, cujos valores máximos de financiamentos liberados chegavam a mais de $\mathrm{Cr} \$ 1.000 .000,00$ (um milhão de cruzeiros). 
Os processos aprovados cujos valores dos financiamentos correspondiam a mais de $70 \%$ do valor do imóvel se enquadravam no Art.1, da Lei o. 2.068, de 09 de novembro de 1953, que alterou o DecretoLei no. 7.264, de 22 de janeiro de 1945. Por essa Lei, deveria ser efetuado juntamente com as prestações mensais de amortização da dívida estipuladas, o pagamento de um "seguro de garantia" equivalente a $10 \%$ do valor concedido e uma entrada de $10 \%$ do valor avaliado, como sinal e princípio de pagamento. Para os financiamentos concedidos aos associados de baixa renda não era necessário o pagamento dessa entrada, era somente cobrado um "seguro de suplemento de garantia", de valor equivalente também a $10 \%$ do valor solicitado, cujo prêmio era pago pelo associado durante todo o prazo do contrato, juntamente com as prestações mensais acrescidas dos juros. $O$ assegurado teria ainda que pagar a taxa de seguro contra incêndio, correspondente a $3 \%$ do valor do financiamento liberado. Durante o prazo do contrato, corriam por conta do outorgado os impostos, taxas e foros, que incidiam ou vinham a incidir sobre 0 imóvel, bem como o prêmio do seguro contra fogo do prédio, sendo essas despesas pagas pelo adquirente por intermédio do Instituto, que cobrava, por sua vez, pelos serviços e quotas de administração que equivaliam a $3 \%$ ou $5 \%$ sobre o valor das despesas, dependendo do IAP.

Por exemplo, em um financiamento para compra de moradia de propriedade do Instituto no ano de 1957, no valor de $\operatorname{Cr} \$ 74.500,00$ (setenta e quatro mil e quinhentos cruzeiros) a serem pagos no prazo de vinte anos, com juros de $6 \%$ ao ano, o solicitante pagaria uma entrada correspondente a $10 \%$ do valor solicitado, o que equivalia à Cr\$7.450,00 (sete mil quatrocentos e cinqüenta cruzeiros). As demais taxas eram calculadas com base no valor restante de $\operatorname{Cr} \$ 67.050,00$ (sessenta e sete mil e cinqüenta cruzeiros). O cálculo da prestação era realizado da seguinte maneira: amortização e juros sobre o valor concedido de Cr\$67.050,00, que resultaria em duzentas e quarenta prestações mensais de $\operatorname{Cr} \$ 614,62$ (seiscentos e quatorze cruzeiros e sessenta e dois centes); somados ao seguro complementar de $10 \%$ do valor restante que seria de $\mathrm{Cr} \$ 27,93$ (vinte e sete cruzeiros e noventa e três centes); acrescidos às despesas do seguro contra fogo sobre o valor restante, equivalente à $\mathrm{Cr} \$ 8,83$ (oito cruzeiros e oitenta e três centes), que poderia ser pago anualmente em vinte parcelas de $\mathrm{Cr} \$ 100,56$ (cem cruzeiros e cinqüenta e seis centes); mais a taxa de água do Conjunto ou Vila de $\mathrm{Cr} \$ 24,40$ (vinte e quatro cruzeiros e quarenta centes), os impostos territorial, predial, etc., correspondentes à $\mathrm{Cr} \$ 165,60$ (cento e sessenta e cinco cruzeiros e sessenta centes) e mais a taxa de administração equivalente à $\mathrm{Cr} \$ 55,90^{102}$ (cinqüenta e cinco cruzeiros e noventa centes). A prestação mensal do associado para a solicitação dessa moradia era, portanto, de Cr\$897,28 (oitocentos e noventa e sete cruzeiros e vinte e oito centes).

As prestações poderiam ser pagas mediante a apresentação de boleto no escritório do Instituto ou descontadas na folha de pagamento do associado, após dez dias de assinado o contrato. No caso de

102 Tomou-se como exemplo os valores praticados pelo IAPC no Conjunto Residencial Nova Tirol, construído pelo Instituto em 1957 (INSS-RN, 1957). 
atraso das parcelas mensais, o contrato poderia ser reincidido caso o Instituto decidisse ou seriam pagos juros de 1\% ao mês, de acordo com o Art.42 do Decreto-Lei no. 2865, de 12 de dezembro de 1940. As despesas de contrato estabelecidas entre as partes interessadas, bem como referentes aos contratos de compra e venda do imóvel, registros, transferências, laudêmio, etc., ficariam a cargo do associado.

Em caso de incêndio parcial ou total, as obras de reconstrução e reformas ficariam sob a responsabilidade do Instituto e seriam equivalentes, restritamente, ao valor da indenização (valor pago do seguro contra incêndio). O contrato também poderia ser reincidido além do caso de atraso no pagamento da mensalidade ou de qualquer outra quantia devida ao IAP, quando, no caso de incêndio fosse constatada culpa do associado ou que este, por qualquer motivo se recusasse a cobrir a diferença verificada para a execução das obras de restauração do imóvel. Caso houvesse a quebra do contrato, 0 associado deveria entregar o imóvel em perfeito estado de conservação e habitabilidade ao IAP que, por sua vez, abriria nova concorrência para ocupá-lo.

Em relação à sublocação, essa só seria permitida se 0 associado comprovasse por motivo justo algo que o impedisse de continuar a residir no imóvel pleiteado, sublocando-o sob a sua responsabilidade, após consentimento por escrito do Instituto. Quanto ao uso e à conservação do imóvel, o Instituto obrigava o pleiteante a manter, obrigatoriamente, o imóvel em permanente estado de asseio, de conservação e de habitabilidade, podendo nele serem realizadas as suas custas, quaisquer obras de reparos necessárias ou exigidas pelas autoridades competentes. O IAP poderia vistoriar 0 imóvel sempre que julgasse conveniente verificar o cumprimento dessas obrigações. Quanto à realização de reformas, essas não seriam permitidas sem o aviso prévio do Instituto, além do seu expresso consentimento. Os acréscimos não seriam cobertos pelos seguros anteriormente citados. No caso de financiamento concedido para reforma e/ou ampliação de imóveis, era disponibilizado ao associado um prazo de 180 dias para a conclusão da obra.

Para os conjuntos, vilas ou imóveis isolados de propriedade dos Institutos, enquanto não fossem realizadas as instalações de água e esgotos pelo Estado, bem como as regularizações da energia elétrica pela CIA Força e Luz Nordeste do Brasil, o associado teria a sua disposição, um depósito de água destinado ao abastecimento comum e seria responsável por todas as despesas relativas a ele, inclusive de empregados para o acionamento e conservação das bombas, como também no que diz respeito à energia e à iluminação elétrica, tanto particular como a do logradouro.

No caso de financiamento para a construção de moradias, se o Instituto não possuísse um setor ou órgão específico de engenharia, responsável pela elaboração de projetos e pela execução das obras, a prefeitura disponibilizava o engenheiro ou o IAP indicava profissionais para o cumprimento dessa tarefa. Nos casos em que se contratava um construtor para a edificação das moradias, o pagamento deste equivalia em média a $5 \%$ do valor solicitado, e era feito por meio de contrato, com valor comumente 
parcelado em cinco vezes, referente às cinco etapas da obra: fundação; reboco; colocação de piso e cobertura; esquadrias, pintura e saneamento; sendo a última parcela paga após a entrega da obra.

Caso houvesse qualquer reclamação a fazer com relação aos defeitos construtivos, evidenciados após a entrega do prédio, ou em relação ao funcionamento e ao uso normal de todas as partes dele, 0 associado deveria fazê-lo por escrito em, no máximo, sessenta dias após a data de entrega do imóvel. Passado esse prazo, o Instituto só se responsabilizaria pela solução e/ou reparo de defeito construtivo que poderia por em risco a estabilidade e a segurança do imóvel e de seus moradores, de acordo com 0 Art.125 do Código Civil Brasileiro. Esse especificava que o construtor seria responsável pelos reparos construtivos até o prazo de cinco anos decorridos da data do Habite-se concedido pelo poder público.

O imóvel só seria transmitido para o associado após o pagamento total do valor concedido pelo Instituto ou qualquer outra quantia devida a ele. Após a quitação da dívida referente ao financiamento, valor de venda, o Instituto transmitia todos os direitos, domínio e ação sobre o imóvel vendido ao associado.

\section{Quanto à Definição das Modalidades de Financiamentos}

A classificação das solicitações em planos e classes variava bastante de um Instituto para outro em Natal. Essas diferenças em muito dificultaram as análises referentes ao caráter social dos financiamentos concedidos aos associados na cidade, assim como, acerca das características dos pleitos e da organização das modalidades dos financiamentos nos diferentes institutos abordados nesse trabalho.

No caso do Instituto de Aposentadorias e Pensões dos Empregados dos Transportes e Cargas (IAPTC), por exemplo, só havia dois planos e nenhuma classe: o plano $\mathrm{A}$ equivalia à compra de unidades residenciais e o plano $B$, tratava da compra de terrenos. Da mesma forma eram organizadas as modalidades de financiamentos do IAP dos Estivadores (IAPE) ${ }^{103}$. Na Caixa de Aposentadorias e Pensões dos Servidores Públicos Estaduais (CAPESP), por sua vez, o plano A equivalia à compra de moradia construída ou adquirida pela Caixa, enquanto o plano B correspondia à compra de moradia em que 0 associado já habitava mediante o pagamento de aluguel e o plano $\mathrm{C}$ equivalia ao financiamento solicitado para a compra de terreno do instituto e construção de moradia própria ou à construção de residência em terreno próprio104.

Já no IAP dos Servidores Estaduais (IPASE), o plano A equivalia à venda de habitação compreendida em conjunto residencial, construído ou adquirido por iniciativa do IPASE, mediante contrato de compra e venda. Os financiamentos enquadrados no plano $B$ representavam às solicitações de compra de terreno para a construção de casa. $\mathrm{O}$ plano $\mathrm{C}$ correspondia à construção de casa mediante garantia

\footnotetext{
103 O Instituto de Aposentadorias e Pensões dos Empregados dos Transportes e Cargas (IAPTC) incorporou o IAP dos Estivadores (IAPE) em julho de 1948.

104 Grande parte dos processos referentes a esse Instituto não apresentavam especificações quanto ao plano e à classe.
} 
hipotecária, à compra de casa onde o associado já residia pagando aluguel, ou à solicitação de financiamentos para a aquisição de moradias quando o associado encontrava-se sob ação de despejo da casa em que residia. No entanto, os processos que remetem a esse Instituto não especificam os planos de acordo com a definição acima descrita.

Por outro lado, todos os processos de financiamentos realizados pelo IAP dos Bancários (IAPB) em Natal especificam apenas o plano B e cinco classes distintas. O plano B-I equivalia à compra de casa de propriedade do Instituto, o plano B-II correspondia às solicitações para construção de moradia em terreno próprio, o plano B-III referia-se à compra de casa onde 0 associado residia pagando aluguel, 0 plano B-IV correspondia à construção de casa em terreno do Instituto, e o plano B-V referia-se à compra de residência já construída de propriedade de terceiros.

Da mesma forma que o IAPB, nas especificações contratuais e nos detalhamentos dos processos de financiamentos realizados pelo IAP dos Comerciários (IAPC) na cidade, só foram identificadas transações que se enquadravam no Plano $B$ e em cinco classes distintas, porém que correspondiam à modalidades distintas daquelas praticadas pelo IAP dos Bancários. O plano B-I equivalia à compra de residência isolada de propriedade do Instituto ou à compra de terreno do Instituto para a construção de moradia própria. O plano B-II referia-se à aquisição de apartamento de propriedade do Instituto, o plano BIII correspondia à compra de terreno do IAPC ou não, para a edificação de imóvel ou à compra de casa pertencente a terceiros, o plano B-IV representava o financiamento para liberação de dívida hipotecária contraída pelo associado, e o plano B-V equivalia ao financiamento para a realização de reforma ou reconstrução de casa.

O IAP dos Industriários (IAPI) não classificava os financiamentos por meio de planos, mas apenas em seis classes. No entanto, evidencia-se nos processos a especificação de planos, em sua grande maioria pertencente ao plano B, que abrangia todas as categorias e classes. As instruções do IAPI especificavam como: classe I, aquisição de terreno e construção de casa própria; classe II, construção de casa em terreno de propriedade do associado; classe III, aquisição de casa ou apartamento; classe IV, aquisição ou construção de casa seriada ou apartamento em conjunto com outros associados; classe V, encampação de dívida contraída para aquisição ou construção de casa; e classe VI, remodelação ou ampliação de casa de propriedade do associado.

Percebe-se, dessa forma, que o modelo de ações imobiliárias implementado pelo escritório central do IAPI105 em fins da década de 1930 - que, segundo Farah (1983), foi paulatinamente sendo adotado

\footnotetext{
105 Esse modelo especificava que o Plano $A$ - equivalia à locação ou venda de unidades habitacionais adquiridas ou construídas pelos Institutos; o Plano $B$ - era referente ao financiamento para construção de moradia em terreno próprio; e 0 Plano $C$ - referia-se aos empréstimos hipotecários concedidos à pessoa física ou jurídica e a todas as outras operações imobiliárias pertinentes aos IAPs, com o objetivo de elevar o volume de recursos capitados (BONDUKI, 2002).
} 
pelos IAPs das demais carteiras profissionais em todo o país - não foi aplicado nos escritórios estaduais dos Institutos em Natal.

\section{Quanto ao volume e à atuação dos Institutos}

Sabe-se que até a década de 1930, no quadro da concepção de moradias no Brasil, predominava a lógica rentista de produção habitacional presente nas vilas com moradias geminadas ou nos grupos de casas isoladas sem 0 apoio de equipamentos e, por vezes, sem serviços básicos de água, esgotos, iluminação e transporte. De modo geral, a intervenção do Estado no campo da moradia social nos principais centros do país ocorreu concomitantemente à introdução das propostas de reforma da habitação, trazendo um "novo conceito" de moradia. No entanto, em Natal os Institutos de Aposentadorias e Pensões deram prosseguimento à tendência do mercado privado de provisão de moradias, típico da década de 1930, perdendo somente o caráter rentista dessa produção.

A maior parte dos grupos de moradias edificados ou adquiridos pelos IAPs na capital norteriograndense, da mesma forma que as vilas dos primeiros anos do século $\mathrm{XX}$, era conformada por pequenos grupos de casas geminadas, duas a duas ou em linha, e por um pátio central ou rua ao longo da qual eram distribuídas as moradias, não possuindo equipamentos coletivos ou até mesmo serviços básicos ${ }^{106}$, como determinado pelas portarias que regiam a atuação dos Institutos em todo o território nacional. Dessa forma, a valorização da célula de moradia nas vilas e conjuntos dos IAPs, uma especificidade moderna defendida na segunda edição do CIAM, salvo alguns casos pontuais, não foi observada em Natal.

Num panorama geral, a maior parte das unidades habitacionais financiadas pelos IAPs em Natal foi adquirida diretamente de terceiros ou por meio da administração pública e, posteriormente, transferida às Carteiras Prediais dos Institutos ${ }^{107}$. Processo diferente do que a historiografia especializada afirma ter ocorrido nas grandes e médias cidades brasileiras, principalmente da região Sudeste, no período de atuação dos Institutos no país. A porcentagem de unidades habitacionais construídas pelos Institutos na cidade é de $17,5 \%$ do volume total de moradias financiadas em Natal, porcentagem que corresponde à aproximadamente 350 unidades habitacionais, enquanto 60,98\% correspondem às moradias adquiridas por compra direta dos associados a terceiros ou construídas por eles em terrenos próprios ou do Instituto. Os 15,98\% restantes correspondem aos processos de financiamentos onde não se caracteriza o pleito e 5,54\% refere-se às solicitações de reforma, ampliação, financiamento para liberação da dívida hipotecária contraída pelo associado ou aquisição/construção de pontos comerciais (Figura 75).

\footnotetext{
106 O aprofundamento dessas questões será realizado nos tópicos seguintes da dissertação.

107 A aquisição de imóveis ou terrenos pelos os Institutos era realizada por meio de procuração autenticada em nome do outorgante do Instituto, quase sempre o delegado, para o escritório geral na capital federal. O pagamento estipulado para a compra só era recebido pelo vendedor após o registro do imóvel no nome do IAP.
} 
Esse quadro pode ser justificado por três vertentes. A primeira diz respeito à escassez de verbas nos cofres das Carteiras Prediais dos IAPs em âmbito estadual, o que comprometia a aquisição de terrenos, materiais de construção, pagamento de mão-de-obra, dentre outras despesas que acarretariam à construção de um conjunto residencial. A segunda justificativa recai sobre a economia e a redução do tempo para reaver o capital investido, alcançados comumente por meio da produção em série e, conseqüentemente, na rapidez da execução da obra. No entanto, ao proceder dessa maneira em Natal, os Institutos perdiam em termos de durabilidade do imóvel, visto que estes apresentavam entre cinco a vinte anos de construção, o que resultava em grandes investimentos em reparos e reformas dessas moradias. A terceira explicação remete à latente necessidade de construção de unidades habitacionais para as camadas mais carentes na cidade devido aos momentos de agravamento da crise de moradias ocasionada por diversos fatores, dentre eles, a exacerbação do fluxo de migrantes em direção à capital devido às secas constantes na região.

\begin{tabular}{|c|c|c|c|c|c|c|c|c|c|c|c|c|c|c|c|}
\hline \multicolumn{16}{|c|}{ TIPOS DE FINANCIAMENTOS } \\
\hline \multirow{2}{*}{ Tipo } & \multicolumn{2}{|c|}{ IAPI } & \multicolumn{2}{|c|}{ IPASE } & \multicolumn{2}{|c|}{ IAPC } & \multicolumn{2}{|c|}{ IAPB } & \multicolumn{2}{|c|}{ IAPTC/IAPE } & \multicolumn{2}{|c|}{ CAPESP } & \multicolumn{2}{|c|}{ N.E. ${ }^{*}$} & \multirow{2}{*}{ Total } \\
\hline & №. & $\%$ & NNo. & $\%$ & №. & $\%$ & NNo. & $\%$ & №. & \%\% & No. & $\%$ & № & $\%$ & \\
\hline $\begin{array}{c}\text { Compra de } \\
\text { unidade de } \\
\text { propriedade do } \\
\text { Instituto** }\end{array}$ & 58 & 34,52 & 42 & 36,20 & 32 & 36,78 & & - & 43 & 86 & 46 & 80,70 & 07 & 43,75 & 228 \\
\hline $\begin{array}{l}\text { Compra de } \\
\text { terreno e/ou } \\
\text { construção de } \\
\text { residência }\end{array}$ & 95 & 56,54 & 49 & 42,24 & 30 & 34,48 & 40 & 66,6 & 01 & 02 & 02 & 3,52 & 03 & 18,75 & 220 \\
\hline Reforma & 03 & 1,78 & 09 & 7,75 & 04 & 4,59 & - & $\overline{-1}$ & 01 & 02 & $\overline{-1}$ & $\overline{-1}$ & 02 & 12,50 & 19 \\
\hline $\begin{array}{l}\text { Aumento de } \\
\text { Financiamento }\end{array}$ & - & - & 02 & 1,75 & 04 & 4,59 & - & - & - & - & - & - & - & - & 06 \\
\hline $\begin{array}{c}\text { Compra de ponto } \\
\text { comercial }\end{array}$ & - & - & - & - & 02 & 2,32 & - & - & - & - & - & - & 01 & 6,25 & 03 \\
\hline 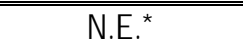 & $\overline{1212}$ & 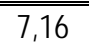 & $\overline{14}$ & 12,06 & $\overline{115}$ & 177,24 & 26 & 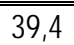 & 05 & 10 & 09 & 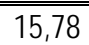 & 03 & $\overline{c 18,75}$ & 84 \\
\hline Total Absoluto & \multicolumn{2}{|c|}{168} & \multicolumn{2}{|c|}{116} & \multicolumn{2}{|c|}{87} & \multicolumn{2}{|c|}{66} & \multicolumn{2}{|c|}{50} & \multicolumn{2}{|c|}{57} & \multicolumn{2}{|c|}{16} & 560 \\
\hline Atuação IAP & \multicolumn{2}{|c|}{$30 \%$} & \multicolumn{2}{|c|}{$20,71 \%$} & \multicolumn{2}{|c|}{$15,53 \%$} & \multicolumn{2}{|c|}{$11,78 \%$} & \multicolumn{2}{|c|}{$8,92 \%$} & \multicolumn{2}{|c|}{$10,17 \%$} & \multicolumn{2}{|c|}{$2,85 \%$} & $100 \%$ \\
\hline
\end{tabular}

Outra especificidade da atuação dos IAPs em Natal refere-se ao fato de que, ao contrário do que se procedeu nos grandes centros urbanos do país na época, as moradias construídas e/ou adquiridas pelos IAPs eram vendidas (promessa de compra e venda) ou hipotecadas aos seus contribuintes, não havendo registros de moradias somente alugadas. Quando vendidas, os associados pagavam mensalmente as parcelas para amortização da dívida ao Instituto e arcavam com as demais despesas e taxas referentes ao terreno e à residência. Quando hipotecadas, os trabalhadores pagavam juntamente com as prestações mensais referentes ao pleito concedido, as taxas de uso do imóvel que eram 
descontadas do valor total concedido, e ao sanarem a dívida para com o Instituto o imóvel era transferido legalmente para 0 associado108.

O Instituto que mais atuou na capital norte-riograndense no recorte temporal estudado foi o IAP dos Industriários, responsável por 30\% dos financiamentos realizados. O IAPI foi um dos Institutos que mais mobilizou verba para a efetivação de financiamentos para aquisição de moradias. No entanto, não se dedicou a construção de casas de modo direto, como a maior parte dos IAPs atuantes em Natal. O único exemplar edificado por esse Instituto corresponde à Vila São Pedro, edificada no ano de 1946. O IAP dos Servidores Públicos Estaduais (IPASE) foi o segundo mais atuante em Natal, responsável por 20,71\% dos financiamentos concedidos entre meados da década de 1940 e meados da década de 1960, mas ao contrário do IAPI edificou três grandes conjuntos na cidade. O terceiro Instituto mais atuante foi o IAP dos Comerciários, com 15,53\% dos pleitos concedidos ${ }^{109}$. O IAP dos Bancários, por sua vez, aprovou 11,78\% dos financiamentos em Natal110, enquanto a Caixa de Aposentadoria e Pensões dos Servidores Públicos Estaduais (CAPESP) financiou 10,17\% dos processos e o IAPE, o IAPFESP e o IAPTC em conjunto,

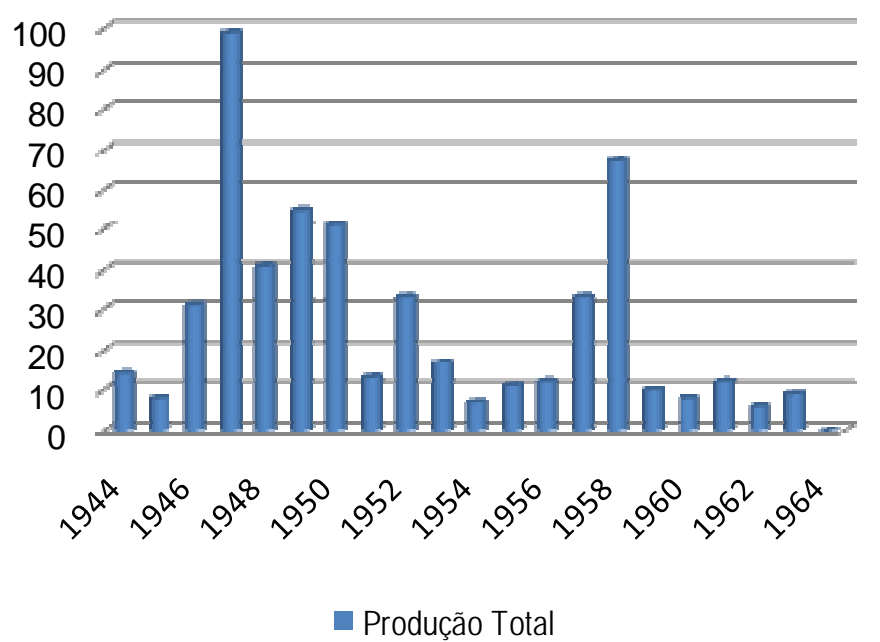

Figura 76: Quadro de distribuição da atuação dos IAPS em Natal no período de 1944-1964.

Fonte: Elaboração própria com base nos dados coletados no INSS-RN. foram responsáveis por 8,92\% dos

processos. Os 2,85\% restantes correspondem aos processos nos quais não foram especificados os Institutos responsáveis pelos financiamentos.

Em se tratando da atuação dos IAPs entre as décadas de 1930 e 1960, o maior volume de financiamentos, em concordância com o cenário nacional, foi concedido entre os anos de 1946 e 1950, decaindo na primeira metade da década e crescendo mais uma vez nos anos de 1957 e 1958. Os anos de 1947 e 1958 equivalem aos maiores

\footnotetext{
108 Em relação aos valores das taxas de uso cobradas pelos IAPs em Natal, observou-se um considerável aumento a partir de fins da década de 1940, da mesma forma que ocorreu no cenário brasileiro. Isso ocorreu devido à outorga do Decreto-Lei no. 9.669, que a parti de 1946 permitiu a elevação dos valores dos aluguéis em 20\% e brecou a livre taxação de valores de aluguéis concedida às novas construções em 1944. Essa disposição foi prorrogada até 1949 e renovada até 1961.

109 O IAPC foi o único Instituto que edificou moradias coletivas na capital norte-riograndense, no Conjunto Residencial Nova Tirol, que equivale ao maior conjunto habitacional erguido pelos IAPs no período estudado, só perdendo para a Cidade da Esperança construída pela FUNDHAP na década de 1960 e que será estudada no tópico referente ao órgão, mais adiante.

1100 IAPB foi um o Instituto que menos construiu e/ou adquiriu moradias isoladas, em conjuntos ou vilas de caráter operário. Edificou apenas um grupo conformado por quinze residências no bairro de Cidade Alta, na década de 1950, e outro na cidade de Mossoró, no início da década de 1960, com aproximadamente trinta casas. A grande maioria dos financiamentos realizados por esse Instituto em Natal correspondia à compra de terrenos a terceiros para a edificação de moradias, geralmente sob responsabilidade de construtores.
} 
picos de agravamento da crise de moradias em Natal, resultantes respectivamente, da crise econômica e social por que passou a cidade com o fim da II Guerra Mundial e perda de considerável parcela de capital circulante, e do grande período de estiagem que culminou no aumento do número de favelas na cidade (Figura 76).

Mais especificadamente, o IAPI concedeu financiamentos em todo o período que se estende entre os anos de 1946 e 1958, quando foi praticamente interrompida a sua atuação na cidade. O período de maior produção do Instituto corresponde aos anos de 1946, 1947, 1949 e 1950 - que somados correspondem a mais de $70 \%$ do volume total de financiamentos concedidos pelo IAPI em Natal -, período imediatamente após a II Guerra Mundial. Essa elevação do número de financiamentos concedidos foi provavelmente uma resposta à conjuntura de crise, sendo também justificada pelo aumento de crédito dos fundos dos Institutos, concedida pelo Governo Federal, para a construção de moradias populares. Posteriormente, percebeu-se uma elevação significativa da produção entre os anos de 1957 e 1958, provavelmente devido ao considerável aumento da população nesse período (Figura 77).

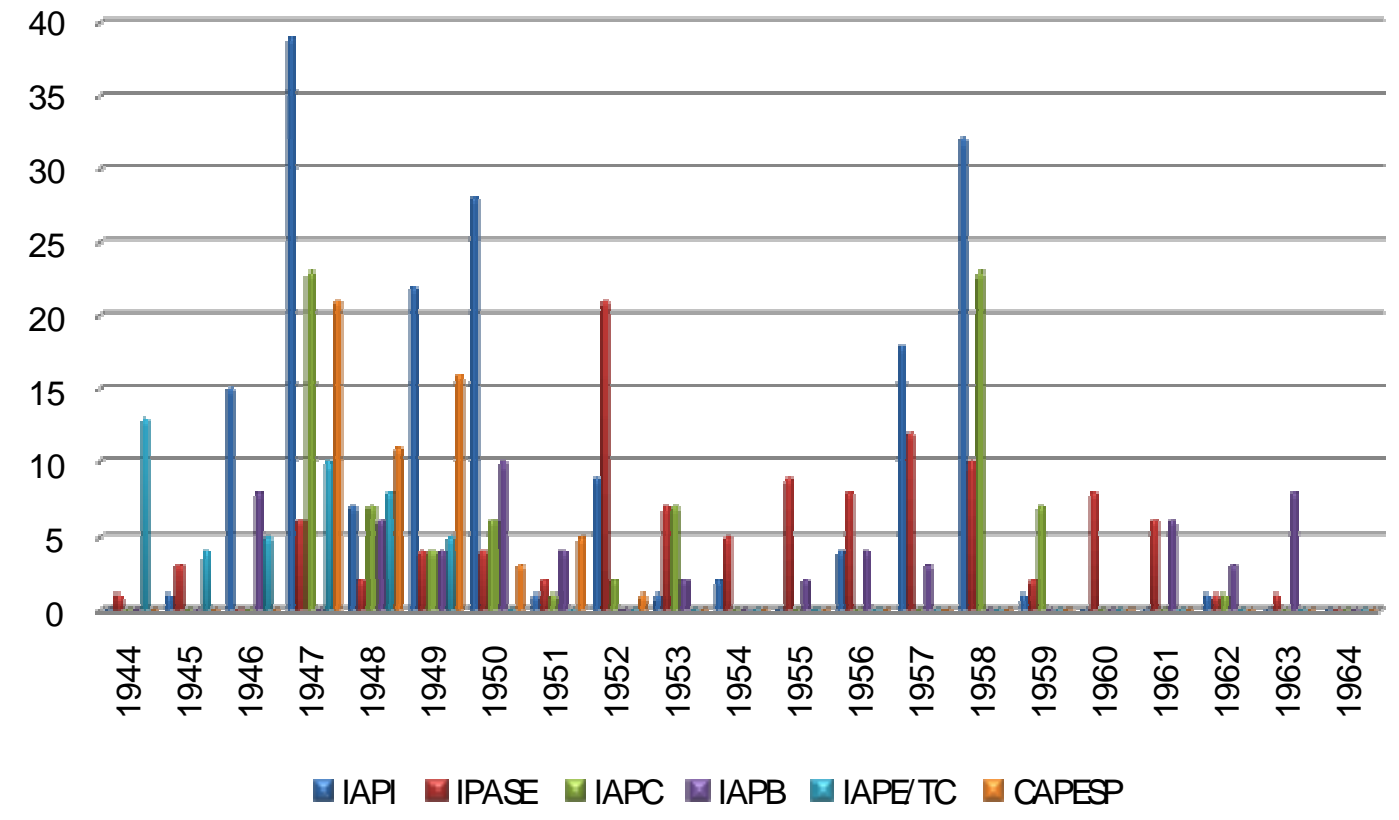

Figura 77: Quadro de distribuição da atuação dos IAPs em Natal no período de 1944-1964. Fonte: Elaboração própria com base nos dados coletados no INSS-RN.

O IAPC apresentou uma considerável elevação do volume de pleitos concedidos especialmente nos anos de 1947 e 1958. As porcentagens correspondem, respectivamente, a 19,54\% e a 34,48\% da produção total do referido IAP na localidade. Já o IAPE e o IAPTC concentraram suas atuações, principalmente, na segunda metade da década de 1940 e nos três primeiros anos da década de 1950, correspondendo a mais de $70 \%$ dos processos liberados aos seus associados natalenses. Em se tratando 
da CAPESP, só foram encontrados processos que datam do período entre os anos de 1947 e 1952 . O IAPB, por sua vez, apresentou ao logo do período estudado uma média anual de financiamentos equilibrada, iniciada no ano de 1946 e findada em 1963, sem apresentar picos nesse sentido. Da mesma maneira equilibrada atuou o IPASE em Natal entre os anos de 1944 e 1963, tendo apresentado uma elevação do número de financiamentos concedidos somente nos anos de 1952, 1957 e 1958. Não foi constatada nenhuma liberação ou aprovação de processos no ano de 1964 na cidade.

\section{Quanto aos valores e às características dos pleitos concedidos}

Os dados encontrados nos arquivos do Patrimônio Imobiliário do INSS-RN revelaram que, em conjunto, os Institutos de Aposentadorias e Pensões dos Industriários (IAPI), dos Bancários (IAPB), dos Comerciários (IAPC), dos Servidores Públicos Estaduais (IPASE), dos Estivadores (IAPE), dos Empregados nos Transporte e Cargas (IAPTC) e dos Ferroviários e Servidores Públicos (IAPFESP), foram responsáveis por um volume de construção e/ou financiamentos que se aproxima de duas mil unidades habitacionais. No entanto, devido às mudanças de sede e aos diversos problemas com 0 armazenamento dos processos de solicitação e concessão de financiamentos, muitos deles se perderam ou encontram-se em estado de precariedade, não sendo possível um levantamento mais preciso das informações. Atualmente, os arquivos do INSS-RN constam de sessenta e nove caixas, cada uma com cerca de dez pastas, totalizando aproximadamente setecentos processos de financiamentos. Desses, cento e quarenta processos foram liberados e/ou aprovados a partir do ano de 1965, transcendendo o recorte temporal da pesquisa (1889-1964). O número exato de processos levantados, sistematizados, analisados e adotados como base nessa dissertação, portanto, foi de quinhentos e sessenta.

Os processos, de maneira geral, constavam de um conjunto de diversos documentos, desde xérox autenticadas de carteiras de identidade e carteira profissional, assim como, certidões negativas, de casamento, diversos contratos e súmulas de contratos, escrituras, além das requisições encaminhadas para os escritórios regionais dos Institutos, do laudo de avaliação do imóvel e do formulário de requisição do financiamento com todos os dados do interessado e do Instituto para o qual ele contribuía.

Cabe lembrar que cada Instituto possuía um modelo de organização para suas ações imobiliárias. Dessa forma, para se analisar as características dos pleitos concedidos e o caráter social das ações dos IAPs em Natal foi preciso se deter ao significado dos planos e das classes, e não apenas às definições deles. Para a apresentação desses dados, porém, optou-se por agrupá-los de acordo com o esquema de organização apresentado por Bonduki (2002), no qual: o Plano $A$, equivalia à locação ou venda de unidades habitacionais adquiridas ou construídas pelos Institutos; o Plano $B$ referia-se ao financiamento para construção de moradia em terreno próprio; e o Plano C, abrangia os empréstimos hipotecários 
concedidos à pessoa física ou jurídica, e todas as outras operações imobiliárias pertinentes aos IAPS, que tinham como objetivo elevar o volume de recursos capitados.

Para a classificação da atuação dos Institutos como atuarial ou social, também foi preciso analisar os valores dos financiamentos concedidos, assim como, os salários recebidos pelos associados. Sendo assim, tomou-se como base o salário mínimo praticado durante os anos de 1945 a 1955 (período de maior volume de financiamentos concedidos pelos IAPs em Natal) que, de acordo com os dados do IBGE, se mostrou praticamente estável em torno de $\mathrm{C}$ \$215,00 (duzentos e quinze cruzeiros). Considerou-se nesse sentido, a classificação sócio-econômica praticada pela Fundação João Pinheiro, que define quatro faixas de renda: a primeira faixa, até três salários mínimos, o que equivalia na época à até Cr\$645,00 (seiscentos e quarenta e cinco cruzeiros); a segunda faixa vai de três a cinco salários míninos, isto é, até Cr\$1.075,00 (mil e setenta e cinco cruzeiros); a terceira faixa de renda corresponde aos trabalhadores que recebem entre cinco e dez salários mínimos, o que resultava em, no máximo, Cr\$2.150,00 (dois mil cento e cinqüenta cruzeiros); e a quarta e última faixa de renda abrange os trabalhadores que recebem mensalmente mais de dez salários mínimos, mais de Cr\$2.150,00 (dois mil, cento e cinqüenta cruzeiros) naquela época. Dessa forma, considerou-se como pertencentes à classe alta os associados que se enquadravam na quarta faixa de renda, como classe média os contribuintes cujos salários correspondiam aos valores especificados na terceira faixa, e classe média baixa e baixa, os trabalhadores cujos salários não ultrapassavam Cr $\$ 1.075,00$ (mil e setenta e cinco cruzeiros) e se enquadravam nas duas primeiras faixas de rendas acima definidas.

No tocante aos valores dos financiamentos concedidos pelos Institutos, considerou-se três classificações, formuladas com base nos dados do IBGE referentes aos anos de atuação dos IAPs em Natal, nas faixas de rendas supracitadas, assim como, nos dados encontrados no levantamento realizado no INSS-RN, nas informações encontradas nos periódicos e nos documentos oficiais da época. Levou-se também em consideração que, de acordo com as portarias que regiam as ações imobiliárias dos IAPs, 0 valor máximo de um financiamento não poderia ultrapassar o limite de duzentas e cinqüenta vezes 0 salário do requerente. Isso corresponde, tomando o valor do salário mínimo de Cr\$215,00 (duzentos e quinze cruzeiros), ao valor de Cr\$53.750,00 (cinqüenta e três mil, setecentos e cinqüenta cruzeiros), aqui considerado como o teto dos financiamentos praticados pelos Institutos que apresentam caráter social. Dessa forma, classificou-se como: financiamento social, aquele que apresentava valor de até Cr\$53.750,00 (cinqüenta e três mil, setecentos e cinqüenta cruzeiros); financiamento intermediário, aquele equivalente à até duas vezes o valor do financiamento social, isto é, à $\operatorname{Cr} \$ 107.500,00$ (cento e sete mil e quinhentos cruzeiros); e financiamento atuarial, aquele cujo valor ultrapassasse os $\mathrm{Cr} \$ 107.500,00$ (cento e sete mil e quinhentos cruzeiros). 
Nesse sentido, percebeu-se no âmbito das ações imobiliárias do IAPI que os financiamentos concedidos para compra de unidades habitacionais (casas ou apartamentos) de propriedade do Instituto, equivalente ao plano A do esquema de organização colocado por Bonduki (2002), correspondeu a 34,52\% do total de financiamentos, enquanto $56,54 \%$ equivaleu aos financiamentos para a compra de terrenos de terceiros (ou pertencentes ao Instituto) para a construção de moradias, à edificação de residência em terreno do associado ou à compra de casa em que o associado já residia (plano B). Os 1,78\% restantes abrangiam as demais ações imobiliárias praticadas, dentre elas: reformas; aumento do financiamento; compra ou construção de pontos comerciais; e pagamento de dívida contraída com compra ou construção de imóvel111. Em se tratando dos valores praticados pelo IAPI pode-se afirmar que $82,73 \%$ dos financiamentos concedidos são considerados de caráter social, isto é, apresentam valores menores que Cr\$53.750,00 (cinqüenta e três mil e setecentos e cinqüenta cruzeiros). Em relação aos salários dos solicitantes, verificou-se que $66,66 \%$ dos associados recebiam menos que cinco salários mínimos. Observa-se, dessa maneira, que a maior parte dos financiamentos concedidos pelo IAPI na cidade se enquadrava nas modalidades dos planos A e B e possuíam caráter social. Cabe ressaltar, no entanto, que 20,83\% dos solicitantes ganhavam mais de cinco salários mínimos e 10,11\% mais que dez salários, o que os classificam como classe média alta e classe alta, apesar de terem solicitado pequenos financiamentos (Figuras 78, 79 e 80).

O IAPE e o IAPTC, que uniram seus fundos de reservas em meados de 1948, concederam financiamentos quase que em sua totalidade abaixo de $\operatorname{Cr} \$ 53.750,00$ (cinqüenta e três mil e setecentos e cinqüenta cruzeiros) caracterizando sua ação como social. Em se tratando da classificação quanto aos planos, observou-se que 86\% dos financiamentos liberados correspondiam à compra de imóveis do Instituto (plano A) e apenas 8\% diziam respeito ao plano B e 6\% ao plano C; 0 que mais uma vez indicaria o teor social das ações. No entanto, a análise foi comprometida pelo fato da grande maioria dos processos (68\%) não especificar os salários dos associados. Não se pode afirmar, dessa maneira, que os associados atendidos eram os de menor poder aquisitivo.

A CAPESP foi outro órgão que apresentou grande porcentagem de financiamentos de acordo com o plano A, cerca de $80 \%$, e apenas 3,5\% de acordo com o plano B, não apresentando nenhum registro de processo com as especificações do plano C. A maior parte dos financiamentos concedidos $(63,15 \%)$, assim como no IAPE e no IAPTC, possuía baixos valores, sendo classificada como financiamento social. Porém, os salários dos trabalhadores contribuintes da referida Caixa atestam que a atuação da CAPESP não poderia ser classificada dessa maneira, uma vez que $89,47 \%$ deles estavam bem acima dos Cr $\$ 2.150,00$ (dois mil, cento e cinqüenta cruzeiros) e os trabalhadores atendidos, portanto, classificados como de classe alta.

${ }^{111}$ Em apenas doze processos não foi possível a identificação do tipo de pleito. 


\begin{tabular}{|c|c|c|c|c|c|c|c|c|c|}
\hline \multicolumn{10}{|c|}{ CLASSIFICAÇÃo AÇÕES IMOBILIÁRIAS } \\
\hline \multirow{2}{*}{ Instituto } & \multicolumn{2}{|c|}{ Plano A } & \multicolumn{2}{|c|}{ Plano B } & \multicolumn{2}{|c|}{ Plano C } & \multicolumn{2}{|c|}{ Não Espec. } & \multirow{2}{*}{ Total } \\
\hline & $\mathrm{N}^{0}$. & $\%$ & $\mathrm{~N}^{0}$. & $\%$ & No. & $\%$ & No. & $\%$ & \\
\hline IAPI & 58 & $34,52 \%$ & 95 & $56,45 \%$ & 03 & $1,78 \%$ & 12 & $7,14 \%$ & 168 \\
\hline IPASE & 42 & $36,20 \%$ & 49 & $42,24 \%$ & 13 & $11,20 \%$ & 12 & $10,34 \%$ & 116 \\
\hline IAPC & 32 & $36,78 \%$ & 30 & $34,48 \%$ & 10 & $11,49 \%$ & 15 & $17,24 \%$ & 87 \\
\hline IAPB & - & - & 40 & $60,60 \%$ & - & - & 26 & $39,39 \%$ & 66 \\
\hline IAPTC/IAPE & 43 & $86 \%$ & 04 & $8 \%$ & 03 & $6 \%$ & - & - & 50 \\
\hline CAPESP & 46 & $80,70 \%$ & 02 & $3,50 \%$ & - & - & 09 & $15,78 \%$ & 57 \\
\hline Não Especif. & 03 & $18,75 \%$ & 02 & $12,50 \%$ & 01 & $6,25 \%$ & 10 & $62,50 \%$ & 16 \\
\hline Total Absoluto & \multicolumn{2}{|c|}{224} & \multicolumn{2}{|c|}{222} & \multicolumn{2}{|c|}{30} & \multicolumn{2}{|c|}{84} & 560 \\
\hline Atuação Instituto & \multicolumn{2}{|c|}{$40 \%$} & \multicolumn{2}{|c|}{$39,64 \%$} & \multicolumn{2}{|c|}{ 5,35\% } & \multicolumn{2}{|c|}{$15 \%$} & $100 \%$ \\
\hline
\end{tabular}

Figura 78: Quadro de classificação das ações imobiliárias dos IAPs em Natal. Fonte: Elaboração própria com base nos dados coletados no INSS-RN.

\begin{tabular}{|c|c|c|c|c|c|}
\hline \multicolumn{6}{|c|}{ CLASSIFICAÇÃo RENDA MENSAL DOS ASSOCIADOS } \\
\hline \multirow[b]{2}{*}{ Instituto } & \multicolumn{5}{|c|}{ Salários dos Associados (Cruzeiros) } \\
\hline & $\begin{array}{c}\text { Até } \\
\text { Cr } \$ 1.075,00\end{array}$ & $\begin{array}{c}\text { Entre Cr } \$ 1.075,00 \mathrm{a} \\
\text { Cr } \$ 2 \cdot 150,00\end{array}$ & $\begin{array}{c}\text { Acima de } \\
\text { Cr } \$ 2.150,00\end{array}$ & $\begin{array}{c}\text { Não } \\
\text { especificado }\end{array}$ & Total \\
\hline IAPI & 112 & 35 & 17 & 04 & 168 \\
\hline IPASE & - & 43 & 64 & 09 & 116 \\
\hline IAPC & 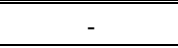 & 34 & 52 & 01 & 87 \\
\hline IAPB & 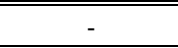 & 20 & 46 & 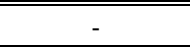 & 66 \\
\hline IAPTC/IAPE & 05 & 11 & 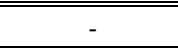 & 34 & 50 \\
\hline CAPESP & 05 & - & 51 & 01 & 57 \\
\hline Não esp. & 05 & 05 & 02 & 04 & 16 \\
\hline Total Abs. & 127 & 148 & 232 & 53 & 560 \\
\hline Atuação & $22,67 \%$ & $26,42 \%$ & $41,42 \%$ & $9,46 \%$ & $100 \%$ \\
\hline
\end{tabular}

Figura 79: Quadro de classificação dos salários dos associados dos IAPs em Natal.

Fonte: Elaboração própria com base nos dados coletados no INSS-RN.

\begin{tabular}{|c|c|c|c|c|c|}
\hline \multicolumn{6}{|c|}{ CLASSIFICAÇÃO VALORES DOS FINANCIAMENTOS } \\
\hline \multirow[b]{2}{*}{ Instituto } & \multicolumn{5}{|c|}{ Valores dos Pleitos Concedidos (Cruzeiros) } \\
\hline & $\begin{array}{c}\text { Até } \\
\text { Cr\$53.750,00 }\end{array}$ & $\begin{array}{c}\text { Entre Cr } \$ 53.750,00 \mathrm{a} \\
\mathrm{Cr} \$ 107.500,00\end{array}$ & $\begin{array}{c}\text { Acima de } \\
\text { Cr } \$ 107.500,00\end{array}$ & $\begin{array}{c}\text { Não } \\
\text { especificado }\end{array}$ & Total \\
\hline IAPI & 139 & 15 & 10 & 04 & 168 \\
\hline IPASE & 12 & 46 & 58 & - & 116 \\
\hline IAPC & 13 & 52 & 22 & - & 87 \\
\hline IAPB & 08 & 19 & 34 & 05 & 66 \\
\hline IAPTC/IAPE & 28 & 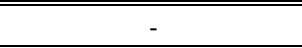 & 04 & 18 & 50 \\
\hline CAPESP & 33 & 03 & 01 & 20 & 57 \\
\hline Não esp. & 04 & 06 & 02 & 04 & 16 \\
\hline Total Abs. & 237 & 141 & 131 & 51 & 560 \\
\hline Atuação & $42,32 \%$ & $25,17 \%$ & $23,39 \%$ & $9,10 \%$ & $100 \%$ \\
\hline
\end{tabular}

Figura 80: Quadro de classificação dos valores dos pleitos concedidos aos associados pelos IAPs em Natal.

Fonte: Elaboração própria com base nos dados coletados no INSS-RN.

Acerca dos financiamentos efetivados pelo IAPC em Natal, 36,78\% se adéquam às especificações do plano A, 34,48\% do plano B e $11,49 \%$ do plano $C^{112}$. Por essa classificação, a atuação do IAPC seria

$11217,24 \%$ dos processos não especificavam em qual plano ou classe o pleito se enquadrava. 
considerada social, porém, nenhum financiamento foi concedido aos trabalhadores cujos salários eram inferiores à Cr $\$ 1.075,00$ (mil e setenta e cinco cruzeiros) e 59,77\% dos trabalhadores atendidos ganhavam mais que $\mathrm{Cr} \$ 2.150,00$ (dois mil, cento e cinqüenta cruzeiros). Além disso, apenas 14,94\% dos financiamentos se enquadravam na categoria "financiamento social". Esse Instituto, em especial, atendeu quase que exclusivamente a classe média e a classe alta de sua carteira trabalhista, em porcentagens que chegam a $85,06 \%$ do total de pleitos.

No tocante ao IPASE, 36,20\% dos financiamentos realizados pelo Instituto se enquadrava no plano A, 42,24\% no plano B e $11,2 \%$ no plano $C^{113}$. No entanto, apenas $10,34 \%$ dos financiamentos mostram-se em valores inferiores à Cr\$53.750,00 (cinqüenta e três mil e setecentos e cinqüenta cruzeiros) e exatamente $50 \%$ referem-se aos financiamentos atuariais, acima de $\operatorname{Cr} \$ 107.500,00$ (cento e sete mil e quinhentos cruzeiros). Os salários confirmam que a atuação do Instituto focalizava os mais abastados dentro da carteira profissional dos servidores. Os trabalhadores classificados como de classe média alta e classe alta totalizavam 92,24\% dos atendidos pelo IPASE em Natal. Alguns dos financiamentos chegavam à $\operatorname{Cr} \$ 2.000 .000,00$ (dois milhões de cruzeiros), destinados à compra de verdadeiras mansões. Outro Instituto que apresentou características semelhantes foi o IAPB, cujos financiamentos atuariais chegaram a representam mais de $50 \%$ do total concedido, e os solicitantes que recebiam renda mensal de mais de dez salários mínimos a quase $70 \%$ dos associados atendidos na capital norte-riograndense. Foi no âmbito do IAP dos Bancários que foram evidenciados os maiores valores de financiamentos concedidos pelos IAPs em Natal, diversos dos quais ultrapassavam os Cr\$3.000.000,00 (três milhões de cruzeiros) ${ }^{114}$.

Sendo assim, observou-se que foram atendidos tanto os associados de menor poder aquisitivo quanto aqueles que recebiam vultosas quantias mensais de seus empregadores, o que correspondeu à perda do caráter social das ações dos IAPs na cidade, previstas por lei no momento da criação das Carteiras Prediais. Mais especificadamente, dos sete Institutos de Aposentadorias e Pensões mais atuantes em Natal, apenas um, o IAPI, apresentou caráter essencialmente social, enquanto os outros seis Institutos se dedicaram a atender os associados cujos rendimentos mensais os classificavam como classe média alta e classe alta, apesar da maior parte dos financiamentos serem classificados como pertencentes dos planos A e B $(79,64 \%)$.

Traçando-se um quadro geral da atuação dos IAPs em Natal, em escala crescente, observou-se que dos 560 associados atendidos, 22,67\% eram pertencentes à classe menos favorecida, 26,42\% à classe média e $41,42 \%$ à classe alta115. No tocante às características dos financiamentos, 42,32\% equivaliam aos pleitos sociais, $25,17 \%$ aos financiamentos considerados como intermediários e 23,39\%

\footnotetext{
${ }^{113} \mathrm{Em} 10,34 \%$ dos processos não foi possível definir o tipo de pleito concedido.

${ }^{114}$ A classificação dos financiamentos por planos não foi realizada uma vez que o IAPB não especifica o tipo dos pleitos nos laudos de avaliação.

115 9,46\% dos processos analisados não especificavam as quantias salariais dos associados.
} 
aos financiamentos tidos como atuariais ${ }^{116}$. Outro aspecto interessante acerca da atuação dos IAPs na cidade corresponde ao fato de não terem sido evidenciados financiamentos para a realização de obras de infra-estrutura ou de serviços em parcerias entre os IAPs e as administrações locais, como verificado em diversas localidades do país, inclusive para a construção de Brasília.

\section{Quanto à localização dos imóveis}

A partir da análise dos dados coletados, pode-se afirmar que $89,83 \%$ dos imóveis financiados pelos escritórios estaduais dos Institutos mais atuantes no Rio Grande do Norte estavam localizados na capital, e apenas 2,5\% em outros municípios do estado, principalmente, Macau, Santa Cruz, Caicó e, Mossoró. Em 7,67\% dos processos analisados não foi possível a identificação da localização do pleito.

Em se tratando da distribuição dos imóveis financiados, fossem eles comprados e/ou construídos pelos IAPs em Natal, percebeu-se que a mesma não se deu de forma homogênea no espaço construído da cidade. A maior parte dos pleitos concedidos encontra-se situada na zona oeste da cidade, correspondendo a $98,17 \%$ do volume total de financiamentos, concentrados mais especificadamente nos bairros da Ribeira (0,35\%), de Lagoa Seca (1,42\%), de Cidade Alta (11,43\%), de Petrópolis (13,93\%), de Tirol (21,96\%) e, principalmente, no bairro do Alecrim (39,10\%). Os demais imóveis estão distribuídos entre as zonas sul $(0,44 \%)$ e leste $(1,38 \%)$ da cidade. Na zona sul, os bairros beneficiados foram apenas dois, Ponta Negra $(0,22 \%)$ e Nova Descoberta $(0,22 \%)$, assim como ocorreu na zona leste, nos bairros das Quintas $(0,59 \%)$ e Cidade Nova $(0,79 \%)$. Não foi identificada nenhuma solicitação de financiamento que indicasse a zona norte da cidade como localização. Isso provavelmente ocorreu pelo fato dos bairros "depois da ponte", como eram conhecidos os bairros da zona norte, serem tidos como locais de veraneio e muito distantes do centro da cidade na época. Somente a partir de meados da década de 1960 foi que 0 mercado imobiliário na zona norte ganhou vulto, culminando em um considerável crescimento da localidade.

Percebeu-se, por outro lado, que quando situados na cidade de Natal, os empreendimentos foram construídos nas localidades mais centrais e nos bairros já consolidados. Apenas 2,02\% dos pleitos especificavam bairros novos e/ou periféricos, representados na época pelos bairros de Ponta Negra, Nova Descoberta e Lagoa Seca. Sucintamente, observou-se que esses imóveis equivaliam aos pleitos concedidos, essencialmente, para a construção de moradias em terrenos dos próprios associados e para a realização de reformas nas residências. Essa conjuntura permite afirmar que os IAPs atuantes na cidade adquiriam a maior parte dos terrenos e imóveis na área central de Natal. Isso pode ser justificado pelo fato de que uma das prioridades das Carteiras Prediais dos Institutos em todo o país era conceder moradias de qualidade, de baixo custo e, de preferência, próximas aos locais de trabalhos dos associados. A existência

${ }^{116}$ Esse quadro se configura dessa maneira devido ao grande número de financiamentos sociais concedido pelo IAPI na cidade, equivalendo a 140 processos. 
de grandes parcelas de terras vazias na área central de Natal no período mostra-se outra justificativa para essa especificidade dos IAPs. Esse aspecto possibilitou a compra de terrenos com consideráveis dimensões por preços condizentes com a construção de moradias sociais. Outro aspecto que merece ser destacado remete ao fato de que em Natal as administrações públicas desempenharam importante papel para amenizar o déficit habitacional, doando consideráveis parcelas de terras aos Institutos para a edificação de moradias aos seus trabalhadores mais carentes, durante todo o período de atuação dos IAPs na capital norte-riograndense (Figura 81).

\begin{tabular}{|c|c|c|c|c|c|c|c|c|c|c|}
\hline \multicolumn{11}{|c|}{ Distribuição dos Pleitos nos Bairros de Natal-RN } \\
\hline & Bairro & IAPI & IPASE & IAPB & IAPC & IAPE/TC & CAPESP & N.E. & Total & $\%$ \\
\hline \multirow{7}{*}{ 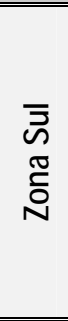 } & Ponta Negra & - & - & 01 & - & - & - & - & 01 & 0,2 \\
\hline & Capim Macio & - & - & - & - & 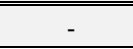 & $\overline{-1}$ & 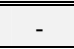 & 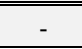 & 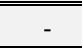 \\
\hline & Neópolis & - & - & $\overline{-1}$ & - & $\overline{-1}$ & $\overline{-1}$ & - & - & $\overline{-1}$ \\
\hline & Lagoa Nova & 01 & - & - & 03 & - & - & - & 04 & 0,71 \\
\hline & Candelária & - & 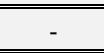 & - & - & 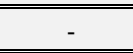 & - & - & - & - \\
\hline & Nova Descoberta & - & 01 & - & - & - & - & - & 01 & 0,2 \\
\hline & Mipimbu & - & - & - & - & - & ב- & - & - & - \\
\hline \multirow{12}{*}{ 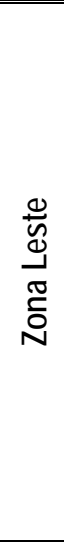 } & Lagoa Seca & 07 & 01 & 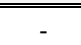 & ב- & ב- & 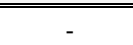 & ב- & 08 & 1,42 \\
\hline & Barro Vermelho & - & - & - & - & - & - & $\overline{-1}$ & $\overline{-1}$ & $\overline{-1}$ \\
\hline & Alecrim & 114 & 32 & 07 & 07 & 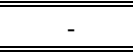 & 51 & 08 & 219 & 39,10 \\
\hline & Petrópolis & 06 & 06 & 17 & 19 & 28 & - & 02 & 78 & 13,93 \\
\hline & Cidade Alta & 10 & 28 & 14 & 08 & - & 03 & 01 & 64 & 11,43 \\
\hline & Tirol & 11 & 44 & 20 & 37 & 07 & - & 04 & 123 & 21,96 \\
\hline & Mãe Luiza & - & - & - & - & - & - & - & - & - \\
\hline & Praia do Meio & - & - & - & - & - & - & - & - & - \\
\hline & Areia Preta & - & $\overline{-}$ & - & - & - & - & - & - & - \\
\hline & Rocas & - & - & - & - & - & - & - & - & - \\
\hline & Ribeira & 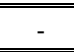 & 01 & - & 01 & - & - & - & 02 & 0,35 \\
\hline & Santos Reis & - & - & - & - & - & 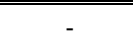 & - & - & - \\
\hline \multirow{8}{*}{ 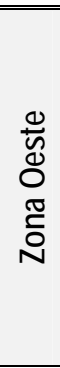 } & Quintas & 03 & - & - & - & - & - & - & 03 & 0,53 \\
\hline & Nordeste & - & - & - & - & - & - & - & 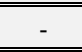 & - \\
\hline & Dix-Sept Rosado & - & - & - & - & - & - & - & - & - \\
\hline & Nazaré & $\overline{-1}$ & $\overline{-1}$ & $\overline{-1}$ & - & - & $\overline{-1}$ & $\overline{-1}$ & $\overline{-1}$ & $\overline{-1}$ \\
\hline & Bom Pastor & - & - & - & - & - & - & - & - & - \\
\hline & Felipe Camarão & - & - & - & - & - & - & - & - & - \\
\hline & Guarapes & - & - & - & - & - & - & - & - & - \\
\hline & $\begin{array}{l}\text { Planalto } \\
\end{array}$ & $\overline{-1}$ & $\overline{-1}$ & 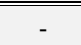 & $\overline{-1}$ & $\overline{-1}$ & $\overline{-1}$ & 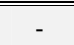 & $\overline{-1}$ & 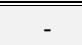 \\
\hline \multirow{5}{*}{$\frac{\text { o. }}{\frac{0}{\frac{2}{0}}}$} & Macau & 02 & $\overline{-1}$ & 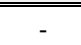 & $\overline{-1}$ & $\overline{-1}$ & $\overline{-1}$ & 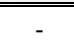 & 02 & 0,35 \\
\hline & Santa Cruz & 01 & - & - & - & - & 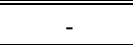 & - & 01 & 0,2 \\
\hline & Caicó & 03 & - & 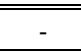 & - & - & - & - & 03 & 0,53 \\
\hline & Mossoró & - & - & 03 & 04 & - & 01 & - & 08 & 1,42 \\
\hline & Não especificado & 10 & 03 & 04 & 08 & 15 & 02 & 01 & 43 & 7,67 \\
\hline & Total Absoluto & 168 & 116 & 66 & 87 & 50 & 57 & 16 & 560 & 100 \\
\hline
\end{tabular}

Figura 81: Quadro de distribuição dos pleitos concedidos pelos IAPs nos bairros de Natal e municípios do Rio Grande do Norte.

Fonte: Elaboração própria com base nos dados coletados no INSS-RN. 


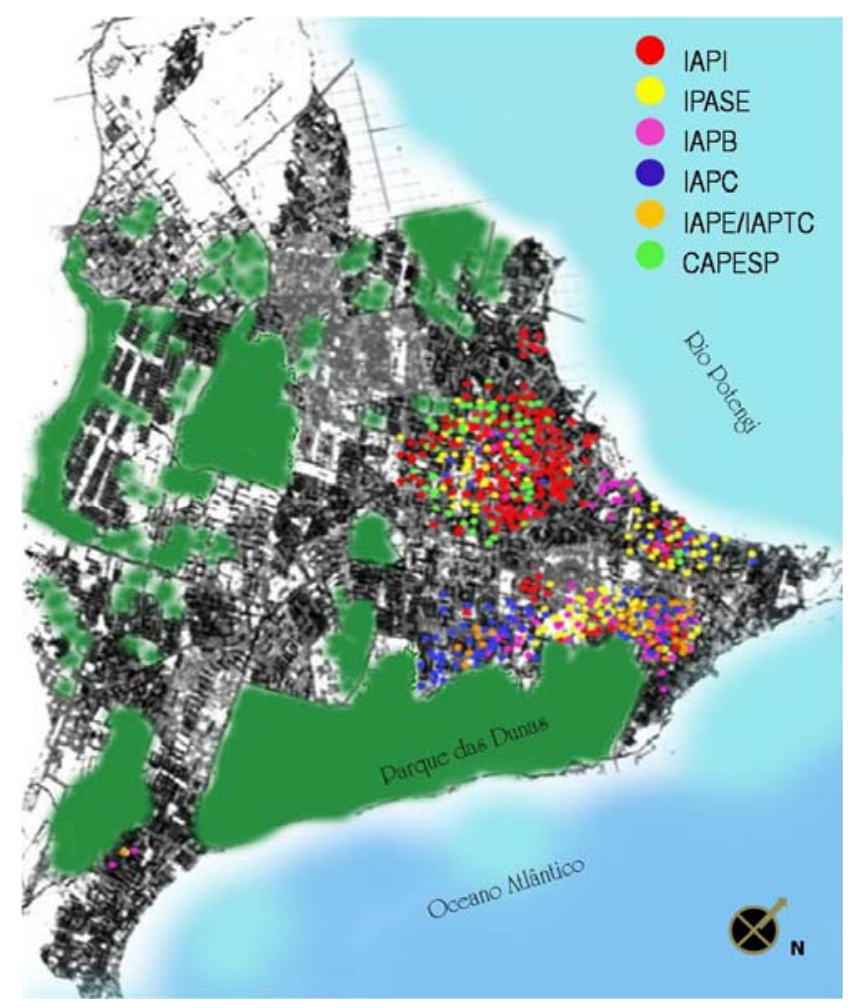

Figura 82: Espacialização da produção habitacional dos IAPs em Natal.

Fonte: Elaboração própria, com base cartográfica da Prefeitura e dados coletados no INSS-RN (década 1970).
Observou-se ainda que, no caso de Natal, a localização dos imóveis financiados pelos Institutos se dava de acordo com 0 caráter da ação de cada IAP. Os pleitos concedidos aos trabalhadores cujos rendimentos mensais eram pequenos e as ações imobiliárias que se caracterizavam como sociais correspondiam, em sua grande maioria, aos imóveis situados nos bairros mais carentes, centrais, de natureza urbana e mista, principalmente comercial e residencial, como os bairros do Alecrim e da Cidade Alta, que juntos abrigam 50,53\% do volume total de financiamentos liberados pelos IAPs na cidade. A grande maioria desses financiamentos equivalia à compra de imóveis, isolados ou em grupos, de propriedade dos Institutos. Enquanto os financiamentos cujos altos valores

os caracterizam como atuariais, concedidos essencialmente aos associados de maior poder aquisitivo dentro das carteiras trabalhistas, eram reservados à edificação de grandes e modernas residências e para a compra de moradias localizadas nas áreas mais "privilegiadas da cidade", geralmente dotadas de boa infra-estrutura (equipamentos e serviços), modernas, de natureza essencialmente residencial e bem arborizadas. Os bairros que melhor se enquadravam nessa categoria na época eram o de Tirol e Petrópolis, cujos imóveis financiados e nesses bairros localizados somam 35,89\% do total concedido em Natal117.

Em se tratando dos grupos de moradias de propriedade dos Institutos, a escolha para a localização das vilas ou conjuntos também dependia da classe social e trabalhista às quais os associados pertenciam. Nesse contexto, observou-se que no âmbito das ações imobiliárias do IAPI os imóveis pleiteados estavam localizados em sua maioria nos bairros de Cidade Alta (5,95\%), Tirol (6,54\%) e Alecrim (67,85\%). Mais especificadamente, os pleitos referentes à compra de moradias de propriedade do Instituto e de terceiros, assim como, a compra de terrenos para a edificação de moradias, que apresentavam caráter social, estavam em sua quase totalidade localizados no Alecrim. Por outro lado, as solicitações

117 Cabe ressaltar, no entanto, que algumas das moradias consideradas como sociais foram edificadas em bairros como Tirol, da mesma forma, que grandes moradias foram construídas também no Alecrim. 
caracterizadas pelos altos valores de financiamento, como também, dos rendimentos mensais dos associados, remetiam aos bairros de Cidade Alta e Tirol. As mesmas especificidades quanto à localização dos imóveis financiados puderam ser observadas no âmbito do IPASE, no qual, 24,17\% dos imóveis financiados mostravam-se localizados no bairro de Cidade Alta, 27,58\% no bairro do Alecrim e 37,93\% no bairro do Tirol.

Cabe destacar que tanto o IAPI quanto o IPASE correspondiam aos Institutos que financiaram imóveis no maior número de bairros da cidade, enquanto os demais concentraram a sua produção em bairros específicos e considerados "mais adequados" à sua clientela, como foi o caso do IAPC e do IAPB, cujas produções se resumem às unidades habitacionais e terrenos situados nos bairros de Cidade Alta, Petrópolis e Tirol. A atuação desses Institutos nos referidos bairros corresponde, respectivamente, a $76,56 \%$ e a $77,27 \%$ da produção total de cada Instituto em Natal. Coincidentemente, esses Institutos juntamente com o IPASE foram os que mais atenderam às classes mais abastadas de suas carteiras trabalhistas, como também foram os que mais concederam financiamentos atuariais para a compra e/ou a construção de residências que chegavam a apresentar mais de $500 \mathrm{~m}^{2}$.

Outros órgãos que apresentaram uma ação espacialmente concentrada foram a Caixa de Aposentadorias e Pensões dos Servidores Públicos Estaduais (CAPESP), com 89,47\% de sua produção situada no bairro do Alecrim, e o IAP dos Estivadores (IAPE) em conjunto com o IAP dos Transportes e Cargas (IAPTC), cujos pleitos concedidos no bairro de Petrópolis correspondem a $56 \%$ do total de processos liberados na cidade.

\subsection{As MORADIAS DAS VILAS E CONJUNTOS dOS IAPS}

As unidades habitacionais construídas e/ou adquiridas pelos sete Institutos de Aposentadorias e Pensões mais atuantes em Natal correspondem à aproximadamente $30 \%$ do volume total de moradias financiadas na cidade ${ }^{118}$. Foram identificados dezessete grupos de moradias edificadas e/ou compradas pelos Institutos na cidade. Desses, seis eram de propriedade do IAPI (Vila Gomes, Vila São Pedro, Vila Janete, Vila Seabra, Vila Regis e Vila São João), cinco pertenciam ao IPASE (Conjunto Paulo Gentile, II Conjunto do IPASE, Vila Lustosa, Conjunto Manoel Miranda e III Conjunto do IPASE), os demais eram propriedades do IAPC (Conjunto Nova Tirol), da CAPESP (Conjunto Henrique Eboli), do IAPB (Vila Palatinick) e do IAPE/IAPTC (Vila 19 de Abril), totalizando aproximadamente 350 unidades habitacionais, 0 que corresponde a $17,5 \%$ dos financiamentos realizados em Natal, tomando como base 0 total apresentado nos laudos e documentos encontrados no INSS-RN119. Os demais processos diziam respeito à compra de moradias a terceiros, compra de terrenos dos Institutos para a construção de residências,

118 Cabe lembrar que essa porcentagem corresponde tanto às moradias situadas nas vilas e conjuntos na cidade, como àquelas construídas ou adquiridas pelos Institutos e que pertencem a nenhum grupo (moradias isoladas).

119 Nem todos os processos de compra de unidades habitacionais encontram-se arquivados no INSS-RN. 
construção de casas em terrenos pertencentes aos associados, reformas de moradias, restituição da dívida, dentre outros.

\section{Conjunto Residencial Tirol ou Paulo Gentile (IPASE-1946)}

De acordo com documentos enviados à agência estadual do IPASE em Natal para a homologação do processo, o Conjunto Paulo Gentile estava localizado nas imediações das Ruas 29 de Março e 17 de Novembro, no bairro do Tiro|120. De acordo com a escritura lavrada em 29 de dezembro de 1945, no Terceiro Ofício de Notas, o terreno onde se encontram implantadas as moradias foi adquirido pelo Instituto por compra feita à Sociedade de Construções Gerais LIDA. Posteriormente, em fins da década de 1940, 0 IPASE edificou aproximadamente mais quinze moradias. Não se tem informações acerca dos serviços, da infra-estrutura ou da disposição das moradias na vila, uma vez que esta foi praticamente demolida.

O valor do financiamento concedido pelo IPASE para compra das residências do primeiro conjunto construído em Natal variava entre Cr\$74.500,00 (setenta e quatro mil e quinhentos cruzeiros) e Cr\$76.300,00 (setenta e seis mil e trezentos cruzeiros), a serem pagos dentro do prazo máximo de vinte anos em prestações mensais descontadas nas folhas de vencimentos dos associados, de acordo com 0 Plano A do Instituto (compra de prédio e respectivo terreno de propriedade do Instituto).

A maior parte dos lotes do conjunto possuía área de 198m², com 9,00m de largura e 22,00m de extensão. As moradias eram conformadas por terraço, sala, três quartos, banheiro, conzinha e lavanderia, totalizando aproximadamente $100 \mathrm{~m}^{2}$. As casas do Conjunto apresentavam fundação em alvenaria de pedra, fechamento de tijolo comum, cobertura em telha colonial, forro em madeira, piso em ladrilho hidráulico na cozinha e no banheiro, e piso em taco nas demais dependências da casa.

De acordo com as escrituras públicas das residências da referida Vila, uma vez que o registro fotográfico não foi possível devido à descaracterização das moradias por reformas ou à demolição, as casas eram do tipo "meia-morada" ou porta-e-janela, com platibanda simples obstruindo a visão do telhado em duas águas de telha colonial (Figura 82). A planta apresentava solução de cômodos

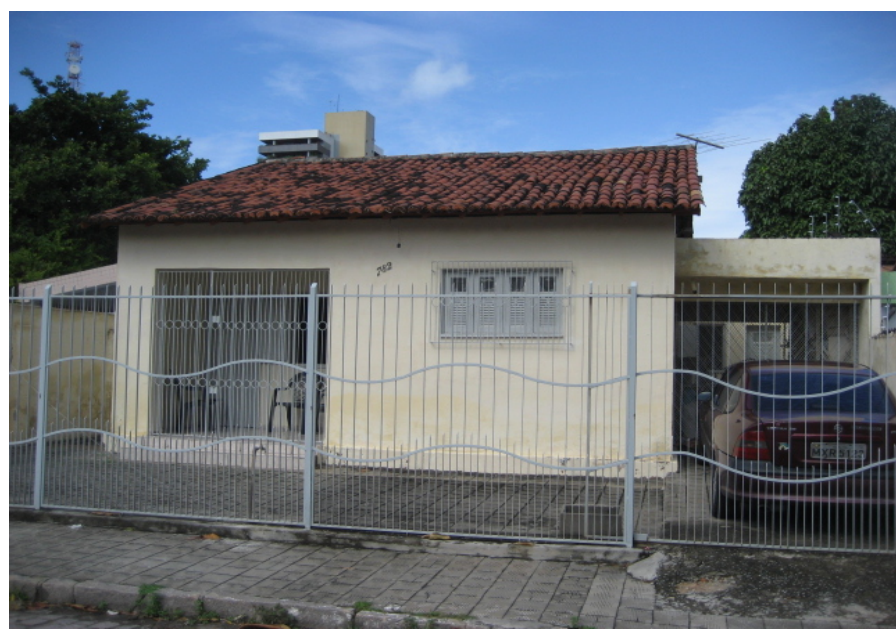

Figura 82: Residência do Conjunto Paulo Gentile, década de 40 Fonte: INSS-RN, 2007.

120 O número exato de unidades habitacionais que conformam o referido Conjunto não pode ser afirmado ao certo. De acordo com artigo publicado no Jornal A República, equivalia a um grupo de aproximadamente trinta residências (A REPÚBLICA, 12/1945, sn.). 
alinhados ao longo de um corredor, adaptando-se ao lote. A cozinha e o banheiro encontravam-se no corpo da casa, porém, recuados no fundo da residência. Há relatos de problemas de iluminação e ventilação nos cômodos. Sendo assim, a implantação e a disposição da planta seguem a tradição colonial brasileira, acrescida da inovação da cozinha e sanitário incorporados ao corpo da moradia.

\section{Vila São Pedro (IAPI-1946)}

A vila está situada na Rua Amaro Barreto, no bairro do Alecrim como a maioria dos grupos residenciais construídos ou adquiridos pelo IAP dos Industriários na cidade, sendo conformada por nove residências distribuídas em torno de um pátio central. A Vila foi construída pelo próprio Instituto no ano de 1946 e equivale ao primeiro grupo de residências concebido pelo IAPI em Natal.

A supracitada vila equivale a uma das poucas servidas de água, luz e esgoto encontradas em Natal nesse período. As ligações de água e esgotos só foram permitidas devido às novas redes que passavam pela Avenida Amaro Barreto na época de construção do grupo de residências. No entanto, as moradias ainda apresentavam problemas em relação à ventilação e à iluminação natural em alguns dos cômodos devido às pequenas aberturas das janelas. Verifica-se também que as residências foram construídas com divisórias em taipa e em terreno com declive para o quintal, permitindo em períodos chuvosos o acúmulo de água naqueles espaços.

Os lotes possuíam em média $79 \mathrm{~m}^{2}$, sendo $56 \%$ desses construídos. As moradias foram financiadas de acordo com o Plano B, variando o valor entre $\mathrm{Cr} \$ 26.000,00$ (vinte e seis mil cruzeiros) e Cr $\$ 29.000,00$ (vinte e nove mil cruzeiros) e apresentavam: sala, dois quartos, cozinha e banheiro $\left(45 m^{2}\right)$ (Figura 83). Em relação aos materiais utilizados para revestimento, percebe-se em todos os cômodos das casas o emprego de ladrilho hidráulico, uma inovação para a época na cidade. Eram consideradas moradias proletárias apesar do alto valor de compra. Uma das justificativas para os valores de venda praticados reside no fato de que a vila foi construída pelo Instituto e estava

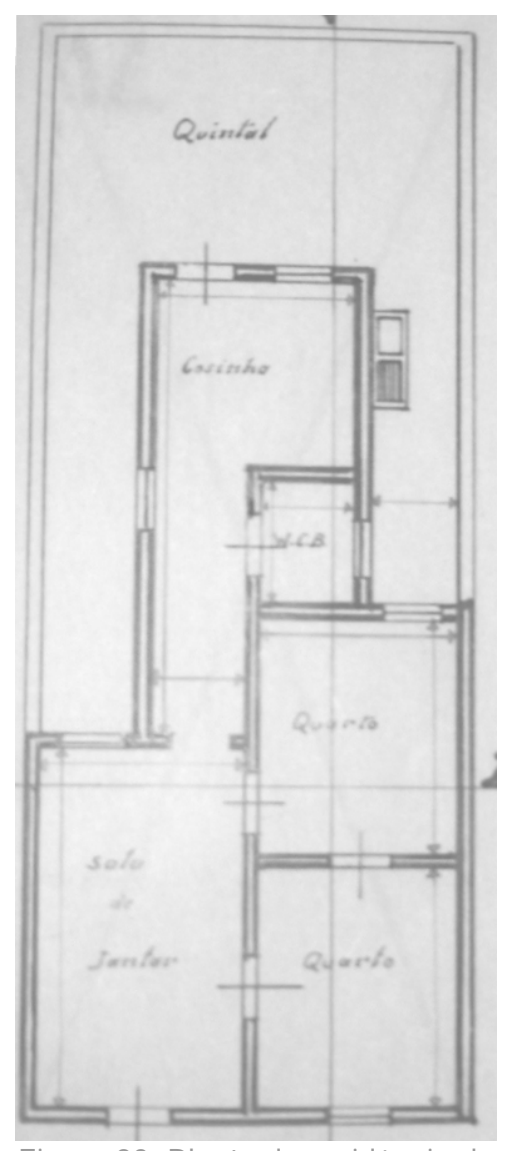

Figura 83: Planta da residência da Vila São Pedro, no Alecrim (1946). Fonte: INSS-RN, 2007.

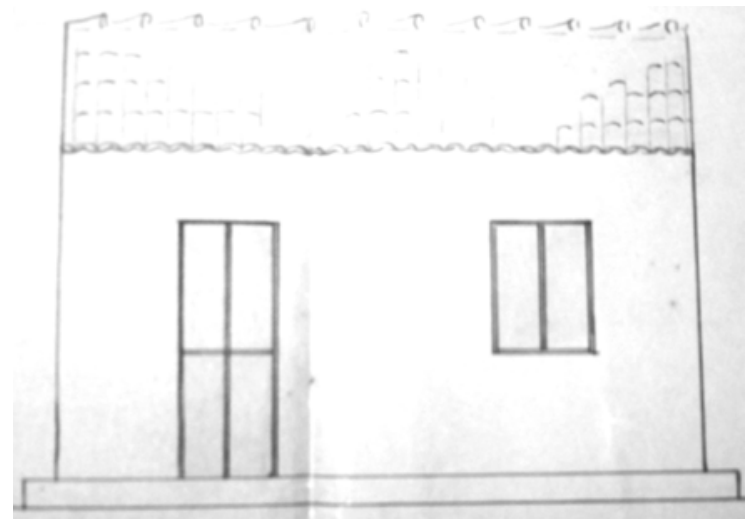

Figura 84: Fachada da residência da Vila São Pedro, no Alecrim (1946). Fonte: INSS-RN. 2007. 
em concordância com as exigências higiênicas em voga, uma exceção a regra, como se poderá perceber no tocante à concessão de moradias realizadas pelo IAPI em Natal.

Apesar de ter sido construída pelo IAPI, as residências não apresentam características marcantes de uma moradia "moderna", uma das "exigências" do escritório central. A fachada principal das habitações da referida vila adota o modelo tradicional porta e janela, com acabamento em caiação simples (Figura 84). Em planta, os quartos são interligados. A circulação de acesso ao banheiro e a cozinha integra esses ambientes à casa, não se mostrando mais isolados do corpo principal da residência no fundo do lote ou na área posterior da moradia. A área de serviço não apresenta mais nenhuma semelhança com 0 alpendre da casa colonial. Mostra-se, nesse exemplar, representada pelo aparelho de lavanderia em cimento armado, situada não mais em área coberta, mas agora no recuo lateral, próximo ao acesso da cozinha da residência, um aspecto recorrente nas casas construídas pelos Institutos e pela FCP em todo o país nesse período, e pelas COHABs e pelo BNH, posteriormente.

As moradias dessa vila, portanto, conciliam aspectos da arquitetura urbana colonial (tipo de fachada e implantação no lote), com demandas higienistas, como a criação de recuos laterais que permitem a ventilação e a iluminação natural em todos os cômodos e a incorporação da cozinha e do sanitário no corpo da casa, permitidas pelas inovações como a água encanada, esgotos e sifão.

\section{$\underline{\text { Vila Regis (IAPI-1947) }}$}

A Vila está localizada na Rua Coronel Estevão, no bairro do Alecrim. Foi construída em 1946 por Francisco Regis de Farias, que deu origem ao nome do grupo de casas, e vendida ao IAPI em 1947121. Instalada em área pobre da cidade, sem saneamento ou calçamento, a Vila Regis mostra-se conformada por cinco casas geminadas, servidas apenas de energia elétrica, com instalações precárias e aparentes. A água consumida pelos moradores advinha apenas de uma torneira instalada no pátio central.

Os terrenos onde foram construídas as moradias variavam de tamanho entre $42 \mathrm{~m}^{2}$ e $64 \mathrm{~m}^{2}$, apresentando elevados índices de ocupação do terreno, aproximadamente $80 \%$, chegando a $88 \%$ em alguns casos. As casas foram financiadas aos associados pelo valor de Cr\$11.000,00 (onze mil cruzeiros) a serem pagos em quinze anos, de acordo com as especificações da classe III (aquisição de casa e

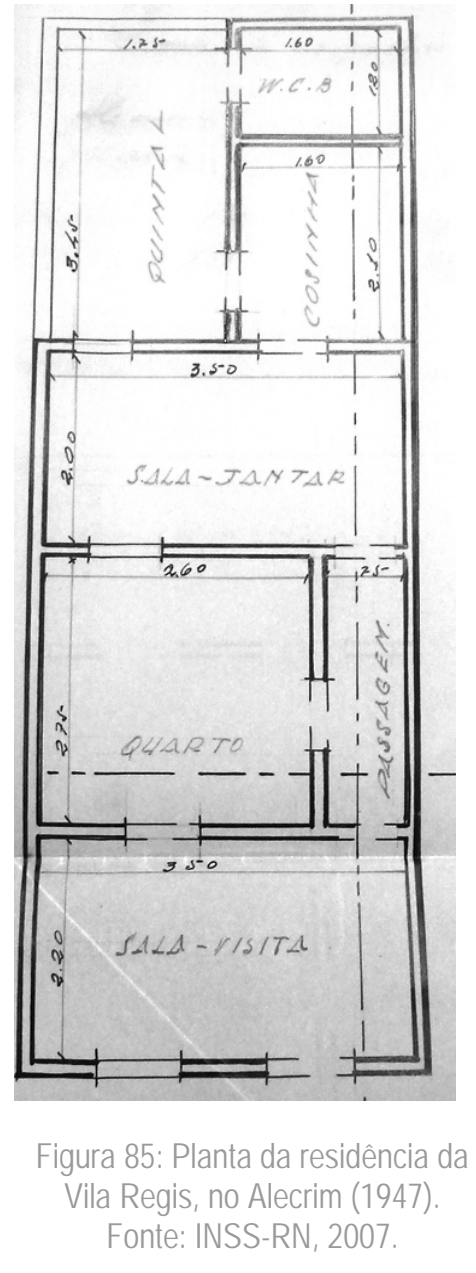

121 O valor de compra não pode ser afirmado devido à escassez de dados. 
respectivo terreno) das determinações do Instituto. As casas apresentavam área construída de $40 \mathrm{~m}^{2}$ em média.

A distribuição dos cômodos era considerada deficiente em se tratando da iluminação e da ventilação, não existindo recuos laterais e aberturas suficientes. As moradias apresentavam duas salas, quarto, cozinha e banheiro (Figura 85). Os banheiros possuíam apenas um aparelho sanitário em barro, sem ligação com o esgoto. A planta assume a disposição tradicional - lote estreito e comprido, corredor interligando as duas salas, separadas por uma alcova, e puxado com cozinha e sanitário. A fachada também segue o mesmo modelo que remete à arquitetura colonial (Figura 86).

As paredes externas das edificações da vila são em alvenaria de tijolo, enquanto as paredes da cozinha e despensas são em taipa. Em se tratando dos acabamentos, as moradias apresentavam piso cimentado nas salas e de ladrilho de tijolo nos demais cômodos. As moradias eram consideradas nos laudos de avaliação como sendo "casa típica de cortiço". Apesar disso, a vila foi adquirida pelo Instituto e repassada aos seus associados por altos valores e sem nenhum melhoramento.

A fachada era simples, definida nos laudos como "pobre e sem vida", do tipo porta-e-janela, com a água do telhado voltada para a testada do lote. Analisando a distribuição dos cômodos em planta, percebe-se que se trata de uma moradia tipicamente colonial, com extensas circulações, quartos interligados e situados na região frontal da residência, cômodos enfileirados, cozinha nos fundos da casa, e banheiro - ou casinha como se costumava definir na parte posterior do lote e isolado do corpo da casa.

\section{Vilas Gomes (IAPI-1947)}

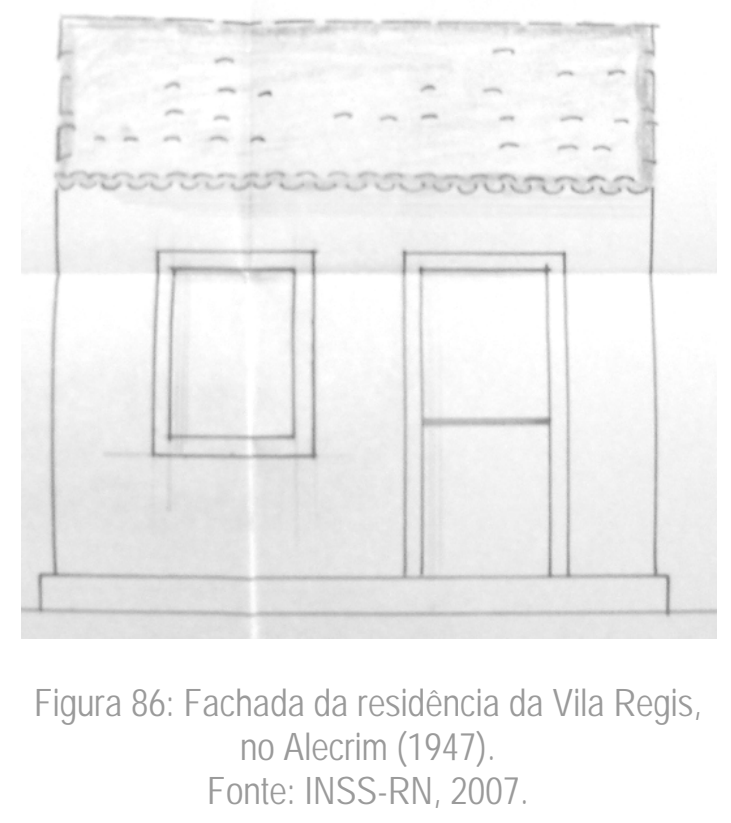

Esse grupo de residências mostra-se implantado no bairro do Alecrim, mais especificadamente, na atual Avenida Amaro Barreto. A Vila Gomes foi construída no ano de 1942, por Pedro Gomes, quem deu origem ao nome do grupo de casas, e comprada por Manoel Gadelha de Freitas em 1944. O IAP dos Industriários adquiriu as dezessete casas que constituem a vila pelo valor de $\operatorname{Cr} \$ 269.000,00$ (duzentos e sessenta e nove mil cruzeiros). As residências foram compradas por $\operatorname{Cr} \$ 16.000,00$ (dezesseis mil cruzeiros) cada uma, com exceção de uma que custou Cr\$13.000,00 (treze mil cruzeiros) ao IAPI. Há contradições acerca da data de compra da referida Vila. Em algumas escrituras de compra e venda, a data especificada é o dia 21 de maio de 1947, em outras, 11 de setembro de 1947, e ainda verificou-se a data 
de 18 de janeiro de 1948, o que pode indicar que a compra das moradias pelo Instituto foi realizada em etapas.

Situada numa área pobre da cidade, a vila não era saneada. As águas servidas eram lançadas no quintal e escoavam para a rua. Apenas as águas das bacias sanitárias eram direcionadas à fossa séptica. Não havia pia, chuveiro ou lavatório nas residências, e a água consumida advinha de um chafariz instalado pela prefeitura em terreno vizinho. A área comum da vila não era calçada, o que causava uma série de transtornos aos seus moradores em épocas chuvosas. As instalações elétricas eram aparentes e a ventilação e a iluminação insuficientes; um dos quartos não apresentava inclusive abertura para o exterior (Figura 87).

De acordo com os laudos de avaliações referentes às moradias, a vila era composta por dezessete residências "enfileiradas" e do "tipo operário", construídas em alvenaria de tijolo e cobertas com telha colonial. Dos dezessete lotes que compunham a vila, quinze possuíam $75,64 m^{2}(6,15 \times 12,30 m)$, um lote possuía $60,27 m^{2}(4,9 \times 12,30 m)$ e outro $71,64 m^{2}(6,15 \times 11,00 m)$. Os lotes apresentavam taxa de ocupação equivalente a $85 \%$ do terreno em que se encontravam implantadas.

As moradias foram financiadas de acordo com a classe III122 (aquisição de casa e respectivo terreno) e os valores do financiamento variavam entre $\operatorname{Cr} \$ 16.000,00$ (dezesseis mil cruzeiros) e Cr $\$ 18.000,00$ (dezoito mil cruzeiros), a serem descontados na folha de pagamento dos associados mensalmente, no prazo máximo de quinze anos.

As casas possuíam entre $40 \mathrm{~m}^{2}$ e $62 \mathrm{~m}^{2}$, variando em relação ao tamanho dos cômodos, número de salas (uma ou duas) e quartos (dois ou três), ou a existência ou não da área de serviço. Apresentavam geralmente: sala, dois quartos,

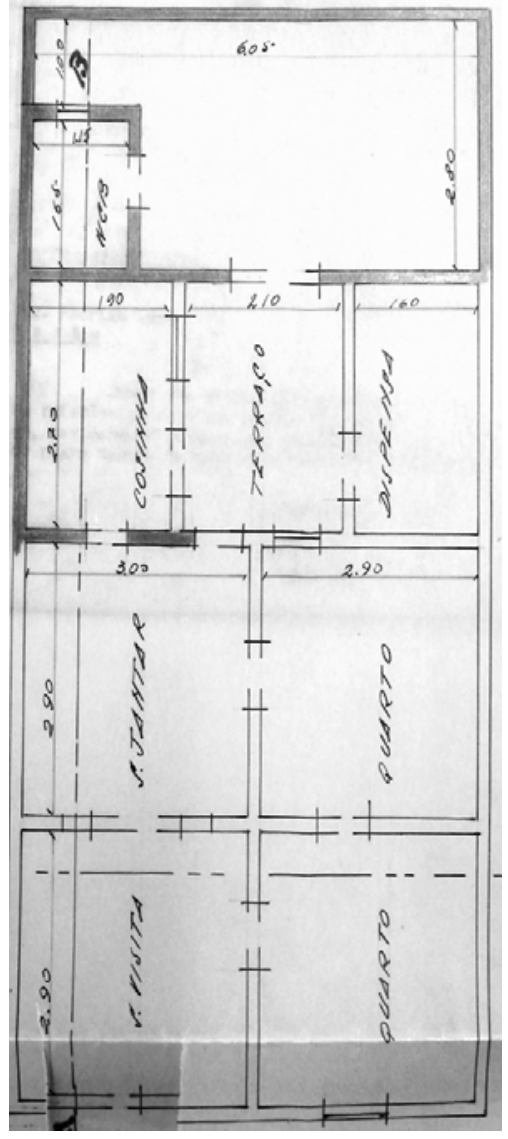

Figura 87: Planta da residência da Vila Gomes, no Alecrim (1947). Fonte: INSS-RN, 2007.

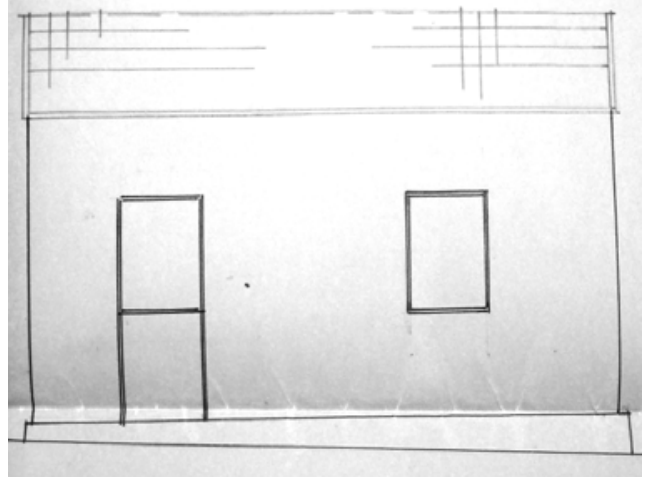

Figura 88: Fachada da residência da Vila Gomes, no Alecrim (1947). Fonte: INSS-RN, 2007. cozinha e banheiro; ou duas salas, três quartos, cozinha, banheiro e área de serviço. Em se tratando dos acabamentos, a cobertura das unidades era em telha colonial sem forro e os pisos de todos os cômodos eram de tijolo rejuntado.

122 Nos laudos de avaliação especificava-se o plano B-II para essa ação imobiliária do IAPI. 
As residências apresentavam fachada simples (porta-e-janela), sem ornamentos ou acabamentos mais apurados, somente caiação (Figura 88). A implantação e a fachada remetem ao modelo colonial123. A planta, entretanto, segue uma nova disposição, na qual o corredor desaparece, enquanto as salas e a cozinha são dispostas alinhadas, ladeadas pelos quartos.

\section{Vila Janete (IAPI-1947)}

Localizada na Rua Manoel Miranda, no Alecrim, a vila foi construída em 1945 por Eliseu Marques Carneiro e adquirida pelo IAP dos Industriários mediante contrato de compra e venda, em 11 de novembro de 1947. A vila é conformada por dezoito casas de alvenaria de tijolo dispostas ao longo de uma via central, de aproximadamente $3 \mathrm{~m}$ de largura e passeios de 1,2m de largura. As moradias da vila contavam com instalações precárias de água e luz, com fiação aparente. Existia uma torneira e um banheiro no terreno vizinho (de fundo) (Figura 89). A fossa séptica da vila também estava situada nesse terreno limítrofe. Outro aspecto que denunciava a precariedade higiênica da vila refere-se ao local em que a mesma foi edificada, nas proximidades de uma vacaria, local considerado ainda na década de 1940, como insalubre; o que contrariava as determinações de higiene estipuladas pelo escritório central do Instituto.

As casas eram conjugadas e os valores dos financiamentos variavam entre $\mathrm{Cr} \$ 12.000,00$ (doze mil cruzeiros) e Cr $\$ 16.000,00$ (dezesseis mil cruzeiros), de acordo com o Plano B (laudo de avaliação) e classe III (compra de casa e respectivo terreno), a serem pagos no prazo máximo de quinze anos, com juros de $1 / 2 \%$ ao mês. As residências estão encravadas em lotes de 66,70m² a 77,40m², apresentando área construída de $42 \mathrm{~m}^{2}$ a $57 \mathrm{~m}^{2}$, com sala de visita, sala de jantar, dois quartos, cozinha e banheiro. Alguns dos laudos atentam para os altos coeficientes de aproveitamento do terreno que chegavam algumas vezes a atingir $84 \%$ de utilização do lote. Não se percebe recuo frontal, estando à moradia encravada na testada do lote (Figura 90). O recuo posterior também é

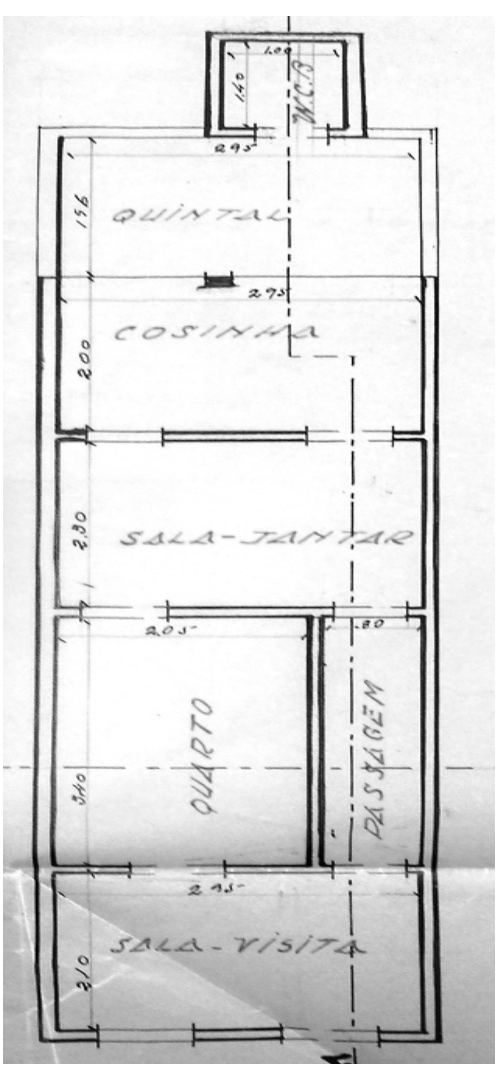

Figura 89: Planta da residência da Vila Janete, no Alecrim (1947). Fonte: INSS-RN, 2007.

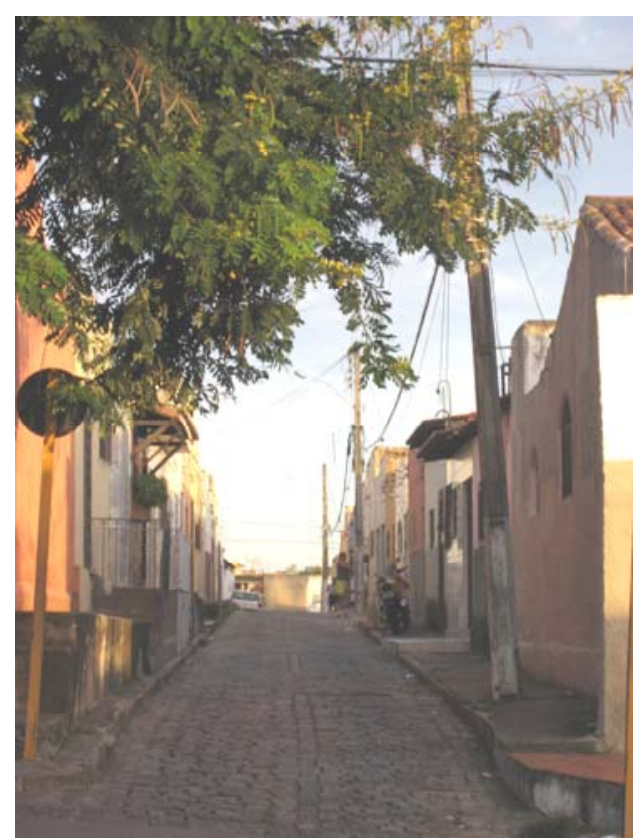

Figura 90: Vila Janete, no Alecrim (1947). Fonte: HCURB. 2007.

${ }^{123}$ As moradias apresentavam inclusive fogão de alvenaria sem chaminé na cozinha. 
reduzido e, dessa maneira, contrariava as determinações legais referentes à construção de moradias naquela área da cidade, que especificava $3 m$ para os quintais.

O fechamento das casas era em tijolo, algumas divisórias internas em taipa e a cobertura em telha colonial, sem forro. $\mathrm{O}$ piso de todas as unidades era em cimento queimado e desnivelado. As fachadas principais das moradias eram simples, características das moradias proletárias, como especificado na escrituras de compra e venda. No entanto, o grupo de residências se destaca do entorno por apresentar características tidas como modernas no período de sua construção. Evidencia-se o uso de linhas retas, do

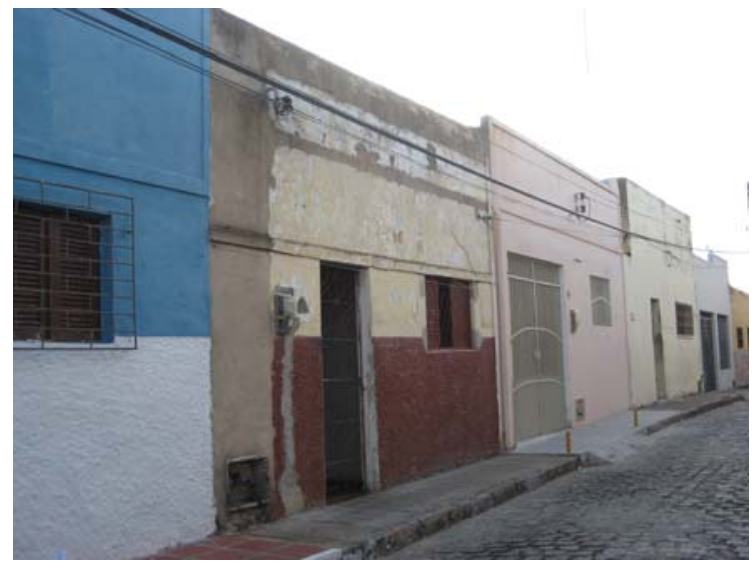

Figura 91: Residências da Vila Janete (1947). Fonte: HCURB, 2007. volume simples e a existência de platibanda, sem apresentar os ornamentos tão comuns até então. No corpo do imóvel, percebe-se, além de uma janela e a porta de acesso, que o embasamento se dá em diversos materiais, cerâmica, pedra e pinturas em cores fortes, chegando até o nível dos peitoris das janelas. Há ainda uma moldura na platibanda reta, por meio de linhas, ou gigante como eram comumente chamadas (Figura 91).

Em se tratando da distribuição dos cômodos em planta, observa-se a ausência de circulação, estando à maioria dos cômodos interligados entre sim, como se averiguava nas residências coloniais. $\mathrm{A}$ concentração das áreas frias (cozinha, área de serviço e banheiro) na parte posterior da casa é outra característica que remete a esse período. Dessa forma, a planta abole o corredor da arquitetura colonial, mas mantém a cozinha e o sanitário em um puxado. Outra inovação é o pequeno recuo lateral.

\section{Vila Platinick (IAPB-1947)}

A vila foi construída na Rua General Varela, no bairro de Cidade Alta, em uma área bastante valorizada da cidade na época de sua implantação, por volta de 1947. Situa-se próxima a comércio, escola secundária e superior, igreja, cinema, inclusive à Prefeitura e ao Palácio do Governo Estadual. 0 logradouro era pavimentado e servido de água e luz. No entanto, a vila não era saneada e a canalização do esgoto despejava os detritos diretamente na rua.

De acordo com a escritura pública de compra e venda, o terreno onde foi edificada a Vila Platinick foi comprado pelo IAP dos Bancários em 16 de janeiro de 1946, pelo valor de Cr\$60.000,00 (sessenta mil cruzeiros). Os lotes mediam 7,45m de largura por 17,00m de extensão, totalizando $123 \mathrm{~m}^{2}$ de área. 
De acordo com o laudo de avaliação das residências, necessário para a concessão de financiamentos, os processos para aquisição de moradias da referida vila se enquadravam nas especificações do plano $B$, na categoria I (compra de residência isolada de propriedade do Instituto ou à compra de terreno do Instituto para a construção de moradia própria). Os valores médios dos financiamentos eram de $\operatorname{cr} \$ 250.000,00$ (duzentos e cinqüenta mil cruzeiros). Tal quantia estava bem acima daquelas apuradas nos demais financiamentos concedidos para aquisição de moradias operárias localizadas em vilas de propriedade das Carteiras Prediais, pelos Institutos de Aposentadorias e Pensões na capital norteriograndense.

As moradias possuíam duas salas, dois quartos, banheiro, copa, cozinha, alpendre de serviço, terraço e tanque, totalizando $86,56 \mathrm{~m}^{2}$ de área construída (Figura 92). Os laudos citam o bom aproveitamento do espaço e o cumprimento das exigências de ventilação e iluminação natural alcançada por meio do número e dimensão das aberturas para o exterior. Uma das especificidades das residências dessa Vila era a existência de um pé direito de $3 m$, que

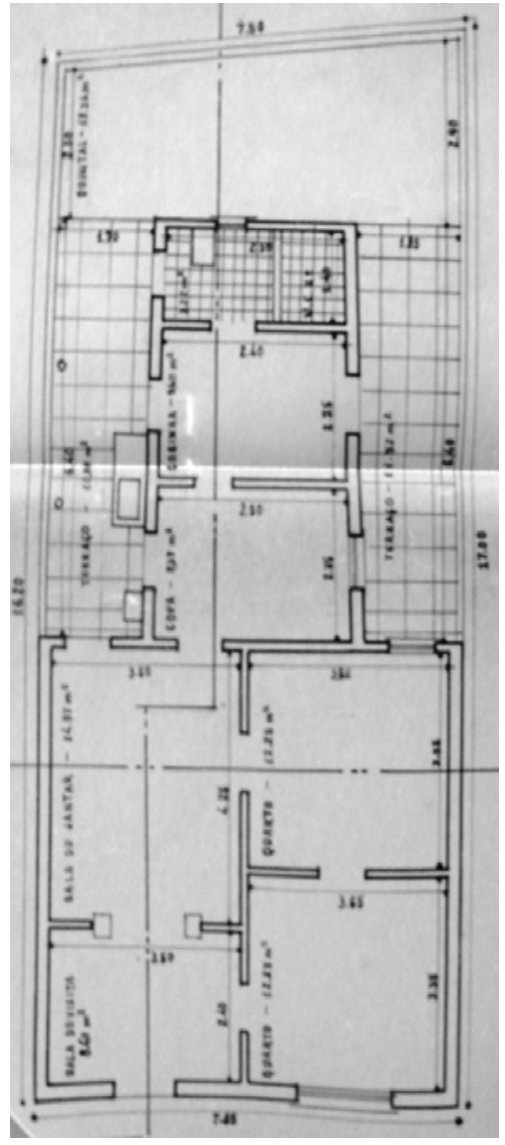

Figura 92: Planta da residência da Vila Platinick (1947). Fonte: INSS, 2007 não se mostrava comum nas casas edificadas no período.

Em se tratando dos materiais utilizados para revestimento de piso, as moradias apresentavam tacos nos quartos e ladrilho hidráulico nas demais dependências da casa, material comumente empregado somente nos cômodos tidos como frios (cozinha, banheiro e área de serviço), como se pode atentar nos conjuntos e vilas citadas na presente dissertação. As paredes receberam caiação simples e não havia forro na cobertura de telha colonial.

Em se tratando da análise da planta-tipo das

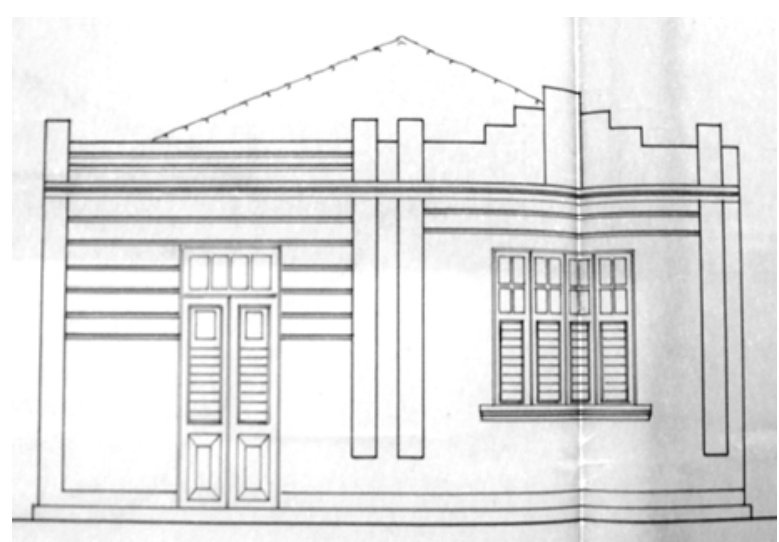

Figura 93: Fachada da residência da Vila Platinick(1947).

Fonte: INSS, 2007 moradias da Vila Platinick, percebe-se características remanescentes do período colonial, como a interligação dos ambientes, especialmente dos quartos, por meio de aberturas com ou sem portas, o que comprometia a privacidade dos moradores das residências, e a locação do banheiro no fundo da residência. Evidencia-se, por outro lado, a existência de copa-cozinha, de área de serviço com lavanderia 
em cimento armado e a ausência de circulações do tipo corredor, especificidades tidas no período como modernas. As fachadas por sua vez, remetem ao estilo déco (Figuras 93), sendo composta por diversas linhas em relevo e elementos decorativos, como os falsos entalhamentos em massa na platibanda escalonada e peitoril trabalhado.

\section{Vila 19 de Abril (IAPTC-1948)}

A Vila 19 de Abril foi construída em 1948, em terreno doado pelo Governo do Estado em 11 de junho de 1938, por meio do Decreto №. 476. Está localizada em uma área exclusivamente residencial, tida como privilegiada na época de sua implantação, sendo destinada às classes média e alta. As moradias se limitam com a Avenida Floriano Peixoto e com as Ruas Valdemar Falcão e Joaquim Manoel, atual Rua Cordeiro de Farias, no bairro de Petrópolis (Figura 94).

A vila era dotada de instalações de água e de energia elétrica (aparente), e foi construída em terreno com topografia com declividade acentuada, o que exigiu maiores cuidados por parte do Instituto em relação à canalização das águas servidas, apesar da vila não ser saneada. Os dejetos e águas das chuvas eram despejados no logradouro sem

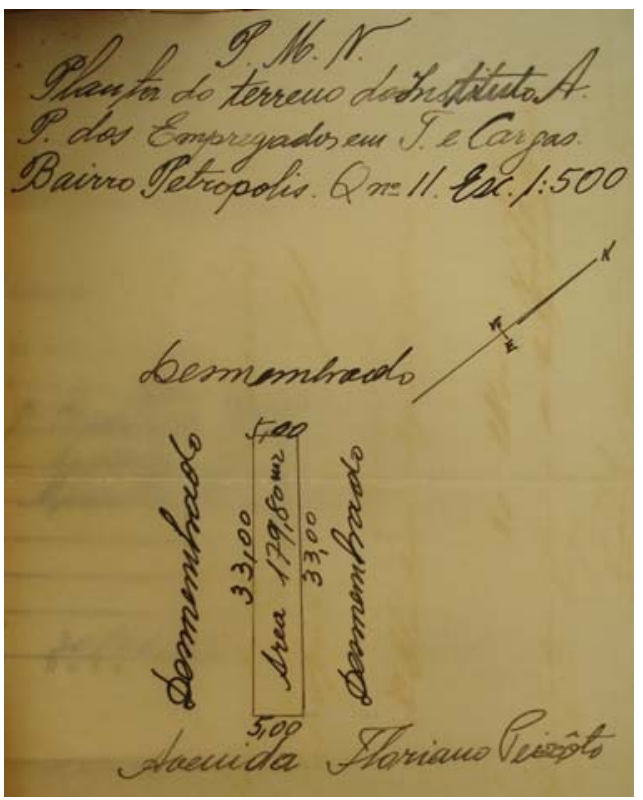

Figura 94: Croqui de localização da Vila 19 de Abril (1948).

Fonte: INSS, 2007 pavimentação.

Os financiamentos para a aquisição das moradias dessa Vila inseriam-se nas especificações do plano A (compra de unidades residenciais), com valores que variavam entre $\operatorname{Cr} \$ 9.000,00$ (nove mil cruzeiros) e Cr $\$ 11.000,00$ (onze mil cruzeiros), a serem pagos no prazo máximo de dez anos, a metade do que se praticava comumente nos demais Institutos no período. A taxa de uso das casas era de Cr\$62,00 (sessenta e dois cruzeiros) entre os anos de 1946 a 1950, e de $\operatorname{Cr} \$ 150,00$ (cento e cinqüenta cruzeiros) a partir de então. Os valores correspondentes ao pagamento dos "aluguéis" eram amortizados do valor total da dívida do associado.

Os terrenos apresentavam $165 \mathrm{~m}^{2}$, sendo $5 \mathrm{~m}$ de largura por $33 \mathrm{~m}$ de extensão, e $138 \mathrm{~m}^{2}$, com $6 \mathrm{~m}$ de largura e $23 m$ de extensão. As moradias possuíam jardim frontal, recuo lateral de $2 \mathrm{~m}$, sendo edificadas em tijolo sob fundação de tijolo e cobertura em telha canal. Em planta, se percebe varanda $\left(3 m^{2}\right)$, sala $\left(12 m^{2}\right)$, dois quartos $\left(17 m^{2}\right)$, banheiro $\left(2 m^{2}\right)$ e cozinha $\left(6 m^{2}\right)$, num total de $40 m^{2}$. O banheiro era chamado em alguns laudos de avaliação de "quarto sanitário", possuindo chuveiro e vaso sanitário com caixa de descarga. 
Em se tratando dos materiais utilizados para revestimentos nas casas da vila, pode-se citar ladrilho hidráulico no banheiro e piso cimentado nos demais cômodos. Não havia forro e as paredes receberam caiação. A disposição dos cômodos em planta, assim como as características das fachadas das residências que compunham a Vila 19 de Abril, não pode ser aqui apresentada pelo fato das moradias não existirem mais e por não se ter localizado as plantas nos arquivos pesquisados. Atualmente, no local da vila há um centro comercial edificado na década de 1980.

\section{Conjunto Henrique Eboli (CAPESP-1948)124}

O conjunto mostra-se conformado por uma vila de aproximadamente dez casas, por um grupo de casas edificadas pela Caixa125 e por um loteamento realizado em parceria com a IAPFESP e o IAPTC em fins da década de 1940.

A Vila Henrique Eboli está localizada na Rua Capitão Silveira Barreto, antiga Rua Henrique Castriciano, no bairro do Alecrim. Possuía instalações de água e de energia elétrica aparentes. o logradouro onde a Vila foi implantada não

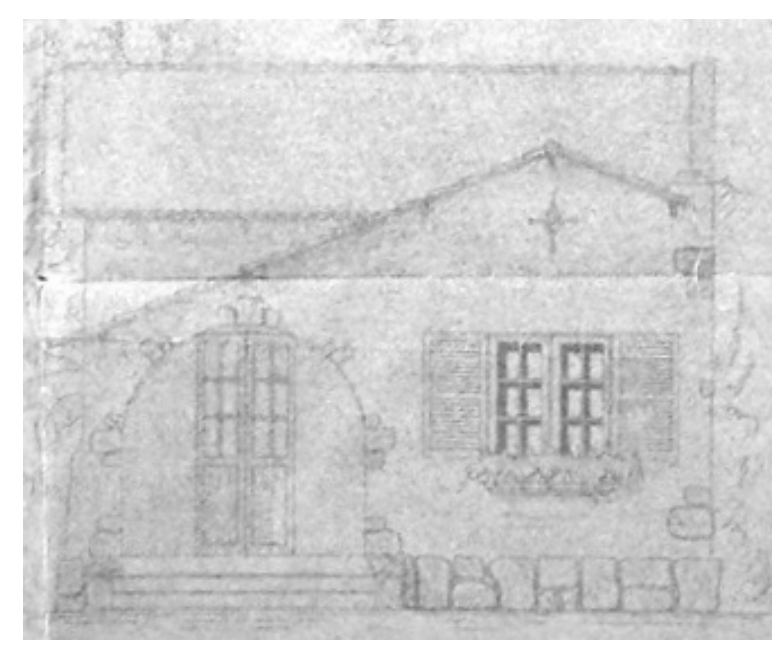

Figura 95: Fachada da residência da Vila Henrique Eboli (1942). Fonte: INSS, 2007. apresentava na época arborização ou sequer pavimentação. Somente em fins da década de 1950 a vila foi saneada. As moradias da Vila foram construídas no ano de 1942 e foram adquiridas pela CAPESP por volta de 1945. As fachadas das moradias da respectiva vila foram erguidas com paredes duplas e apresentavam terraços com arcadas (Figuras 95 e 96).

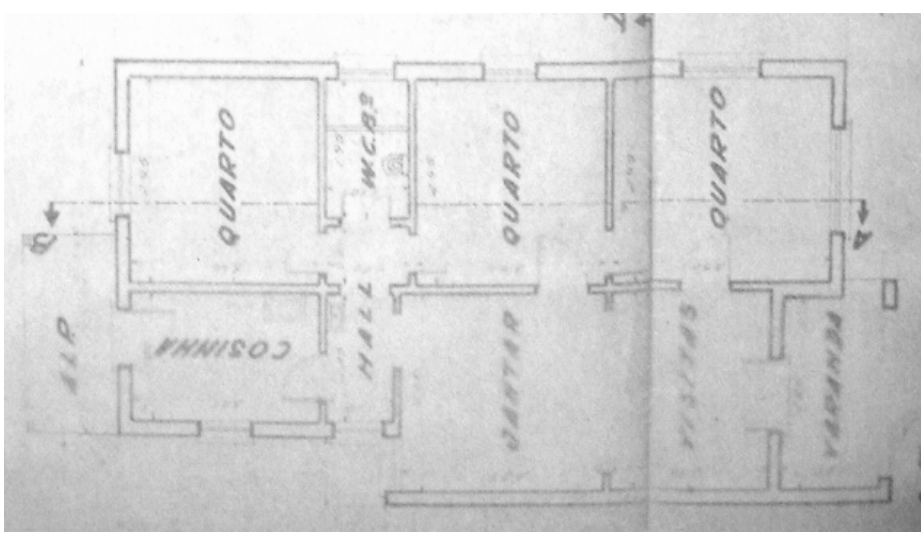

Figura 96: Planta da residência da Vila H. Eboli (1942). Fonte: INSS, 2007.

Em 13 de dezembro de 1946, o Interventor Federal do Rio Grande do Norte autorizou 0 Departamento da Fazenda a fazer a doação de terreno à CAPs dos Servidores Públicos, para a construção de casas do "tipo proletário", de acordo com o Decreto-Lei o. 655:

\footnotetext{
124 Em 03 de setembro de 1948 a Caixa de Aposentadorias e Pensões dos Servidores Públicos do Estado do Rio Grande do Norte vendeu a Vila Henrique Eboli ao IAP dos Ferroviários e empregados em Serviços Públicos.

125 O número exato de moradias construídas pela Caixa na localidade não pode ser apontado, pois, o Conjunto mostra-se bastante descaracterizado e os dados encontrados nas escrituras públicas contraditórios. Acredita-se que foram cerca de 30 casas edificadas naquele momento.
} 
Art.2 - 0 terreno a que se refere o Art.1 destina-se à construção de uma vila operária, de acôrdo com as plantas já aprovadas, ficando estabelecido que a transferência do aludido terreno, aos associados do C.A.P., após a construção pretendida, será feita a titulo gratuito, não podendo a Caixa de Aposentadoria onerar o valor dos imóveis (RIO GRANDE DO NORTE, 13/12/1946, Art.2).

O terreno se limitava: ao norte e ao leste com a Avenida do Saneamento, medindo respectivamente 318,30m e 35,00m; ao sul com a Rua Coronel José Bernardo, com 106,25m; e ao oeste com diversos lotes, medindo 189,50m.

Pelo Art.4 do supracitado decreto-lei, exigia-se que os trabalhos de construção fossem iniciados em, no máximo, trinta dias a contar da data de sua publicação, sob pena do terreno ser revertido ao Estado. Foram então construídas residências operárias para a venda, por meio de financiamentos aos seus assegurados. Em 23 de abril de 1948 foram concluídas as quinze primeiras casas construídas pela CAPESP (Figuras 97 e 98).

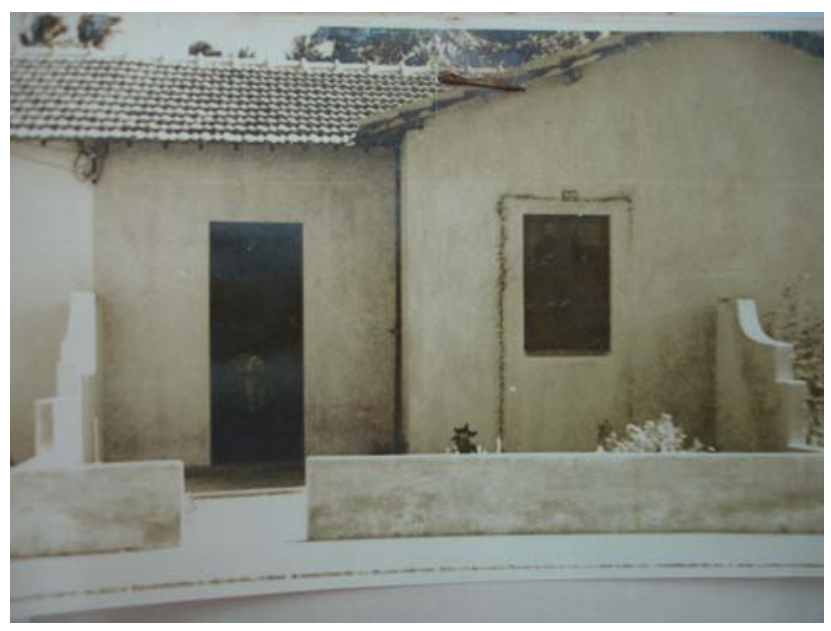

Figura 97: Fachada da residência do Conjunto Eboli (1947). Fonte: INSS, 2007.

Essas foram reservadas para venda aos funcionários da Repartição de Saneamento de Natal. Os lotes dessas moradias possuíam entre $150,00 \mathrm{~m}^{2}$ e $200,00 \mathrm{~m}^{2}$ em média, havendo lotes de 5,70m de largura e 33,50m de extensão, 10,00m de largura por 20,00m de extensão, $7,5 \mathrm{~m}$ por $20 \mathrm{~m}$ e $8,00 \mathrm{~m}$ por $22 \mathrm{~m}$ de extensão.

Os preços das casas situadas na Vila e no primeiro grupo construído variavam de

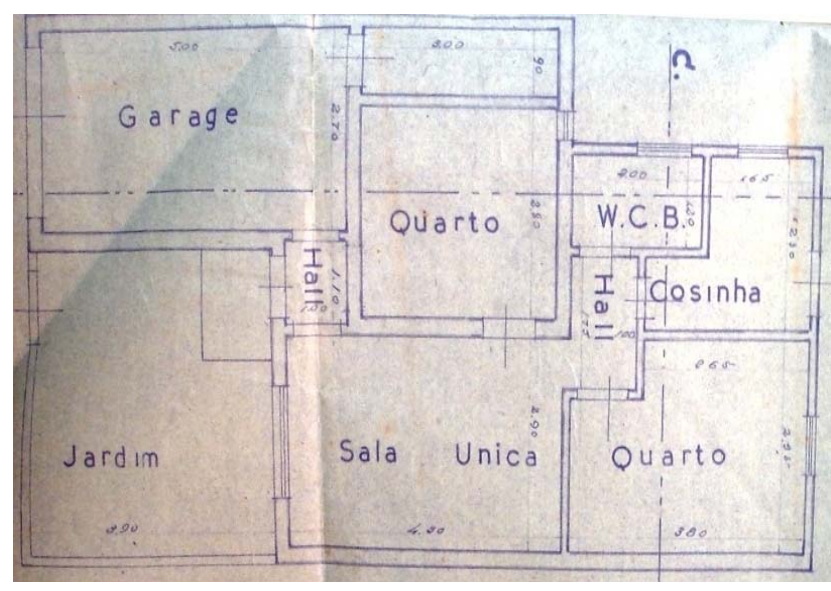

Figura 98: Planta da residência do Conjunto Eboli (1947). Fonte: INSS, 2007. acordo com a localização do lote, entre os valores de $\operatorname{cr} \$ 24.000,00$ (vinte e quatro mil cruzeiros) e Cr $\$ 50.000,00$ (cinqüenta mil cruzeiros), a serem pagos no prazo máximo de vinte anos, de acordo com as determinações do plano C: compra de terreno de propriedade da Caixa.

O loteamento, por sua vez, se limitava às Ruas Capitão Silveira Barreto e Coronel José Bernardo, situado no bairro Vermelho, nas proximidades da Vila com mesmo nome. Os lotes apresentavam 7,5m de largura por $20 \mathrm{~m}$ de extensão. A maior parte das residências do loteamento foi edificada por construtores 
indicados pela Caixa de Aposentadorias e Pensões dos Servidores Públicos Estaduais, os nomes mais recorrentes eram os de Aristides Benigno de Morais, Manoel Henrique Trigueiro, Raimundo Nonato Gomes de Oliveira, Pedro Lucas Cunha e Pedro Teixeira.

Também nesses casos, os financiamentos se enquadravam nas especificações do plano C, compra de terreno do Instituto para construção de moradia própria. O valor dos financiamentos variava entre $\operatorname{cr} \$ 20.000,00$ (vinte mil cruzeiros) e Cr\$50.000,00 (cinqüenta mil cruzeiros), a serem pagos em duzentos e quarenta meses, mediante desconto mensal na folha de pagamento do associado. As

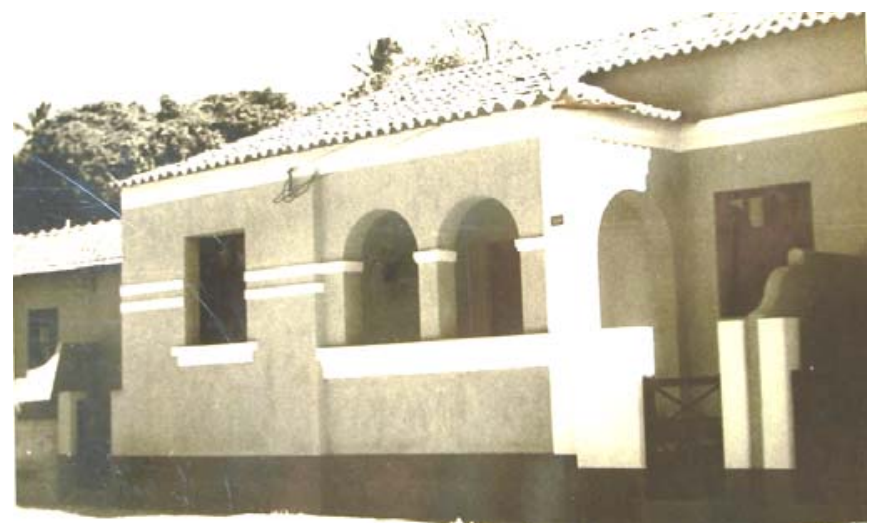

Figura 99: Fachada de uma residência do Loteamento Henrique Eboli (1948). Fonte: INSS, 2007. residências se assemelhavam em muito àquelas que conformavam a Vila e o grupo de casas erguido pela CAPESP na década de 1940, em se tratando dos materiais utilizados e das características tipológicas das fachadas e plantas (Figura 99).

De modo geral, as moradias foram construídas em tijolo, sob fundação de pedra e cobertura de telha colonial ou em tijolo, telha canal e beiral de cimento armado. Apresentavam, em média, áreas de $70 m^{2}$. Em planta havia variação quanto à dimensão, ao número e distribuição dos cômodos. Possuíam: sala de estar e jantar, dois ou três quartos, banheiro, copa-cozinha, quarto de empregada, tanque e garagem. Em se tratando dos materiais empregados para revestimento de piso, paredes e forro, pode-se citar: tacos de sucupira nos quartos, ladrilho hidráulico nas copas, cozinhas, áreas de serviços e banheiros, forro de madeira nas salas e quartos, e caiação nas áreas externas e internas em todas as moradias.

De acordo com o relatório de avaliação, exigidos para a liberação dos financiamentos, assinados pelo engenheiro Wilson de Oliveira Miranda, no ano de 1949, "os prédios possuíam boa distribuição em planta e circulação, isolação e ventilação aceitáveis, proporcionando moradia com satisfatórias condições de segurança e higiene e conforto". Percebe-se, nesse sentido, uma preocupação com a distribuição dos cômodos em planta e com os espaços mínimos devido à ausência de grandes áreas ociosas e destinadas à circulação. Apesar de referências às inovações tipológicas, a maior parte das moradias é do tipo chalezinho porta-e-janela, com telhado em duas ou mais águas paralelas a testada do lote. Algumas moradias também se apresentam em estilo missões, com terraços em arco pleno, apliques em pedra na fachada, beirais e jardineiras (ver figura 95). Em outras casas, elementos neocoloniais - arcos plenos e beirais - aparecem onde esse estilo é menos evidente (ver figura 99). 
Vila São João (IAPI-1948)

A vila encontra-se localizada no bairro do Alecrim. Foi comprada pelo Instituto em 14 de janeiro de 1948, de Pedro Canuto de Lima, pelo valor de Cr\$20.000,00 (vinte mil cruzeiros) e vendida mediante promessa de compra e venda aos associados pela quantia total de $\operatorname{Cr} \$ 86.000,00$ (oitenta e seis mil cruzeiros), de acordo com as determinações intrínsecas na classe III do IAPI. Essa Vila corresponde a um exemplo de ação atuarial do IAPI na cidade. No tramite de "revenda" o IAPI lucrou quatro vezes o valor de compra. Tal lucro não foi repassado aos seus associados por meio de melhorias nas moradias e na estrutura da vila, como aconselhado pelo escritório central. As unidades foram vendidas aos interessados sem que fossem realizadas reformas, apenas pintura e modificação de alguns pontos elétricos, pois as moradias da Vila São João, segundo os profissionais do referido Instituto, se encontravam em bom estado de conservação apesar de terem sido construídas no ano de 1933.

O número de casas que compunham a vila não pode ser apontado ao certo, pois parte delas foi demolida para a construção de novas edificações. Os lotes eram de aproximadamente $70 \mathrm{~m}^{2}$, sendo $63 \mathrm{~m}^{2}$ construídos. As unidades apresentavam dimensões e distribuição dos cômodos em planta padrão, composta de sala $\left(7,5 m^{2}\right)$, dois quartos $\left(7,5 m^{2}\right.$ cada um), cozinha $\left(6 m^{2}\right)$, copa $\left(7,5 m^{2}\right)$, banheiro $\left(2 m^{2}\right)$ e terraço $\left(16 \mathrm{~m}^{2}\right)$. As fachadas eram simples, do tipo porta-e-janela como a maior parte das vilas e conjuntos edificados pelos Institutos em Natal.

\section{Vila Seabra (IAPI-1949)}

Localizada na Rua Mossoró, no bairro de Cidade Nova, a Vila Seabra equivale a um dos únicos grupos de casas construídos e/ou adquiridos pelo IAPI em área considerada nobre da cidade de Natal, sendo destinada às camadas mais abastadas da carteira profissional. A vila foi comprada pelo Instituto em 27 de março de 1949, por Cr\$15.000.000,00 (quinze milhões de cruzeiros), do Capitão Apolônio Augusto Seabra de Melo, que como nos demais casos deu origem ao nome da vila.

A referida vila era servida de água, luz e esgotos. As residências foram vendidas mediante garantia hipotecária por Cr $\$ 180.000,00$ (cento e oitenta mil cruzeiros), de acordo com a classe III, a partir do ano de 1952. Os lotes apresentavam 289,40m² (11,36 x 25,5m), ocupando as residências $164,00 \mathrm{~m}^{2}$, distribuídas em duas salas, três quartos, escritório, copa, cozinha, dois banheiros, quarto de empregada, lavanderia e terraço. A Vila não existe mais, e os registros fotográficos foram perdidos com o tempo.

\section{Vila Lustosa (IPASE-1950)}

Há apenas dois registros nos laudos de avaliação em que a Vila Lustosa é citada, o que em muito dificultou a afirmação das especificidades desse grupo de moradias, que se encontra situado na Rua Ceará-Mirim, no bairro do Tirol. Essa localidade era considerada urbana, saudável e "residencial moderna", destinada à classe média. A data de construção remete ao ano de 1950. 
O logradouro era servido de água, luz, telefone e iluminação, não havendo saneamento básico. A coleta das águas servidas se dava por meio de fossa séptica. A Vila foi edificada em terreno com aclive de $3 \mathrm{~m}$ em relação à rua, apresentando configuração irregular de $11,2 \mathrm{~m}$ de testada, $6,3 \mathrm{~m}$ do lado direito, $19,35 \mathrm{~m}$ do lado esquerdo e $3,8 \mathrm{~m}$ de fundos, num total de $116,55 \mathrm{~m}^{2}$. Verifica-se altas taxas de ocupação do solo, chegando em alguns lotes a 80\% de área construída. Os valores dos financiamentos solicitados para aquisição de moradias na supracitada vila eram em média de $\operatorname{Cr} \$ 130.000,00$ (cento e trinta mil cruzeiros), a serem descontados na folha de pagamento dos associados no prazo de dez anos. As solicitações se enquadravam nas especificações do plano $A$, compra de prédio e respectivo terreno mediante garantia hipotecária.

Em planta, percebe-se: um pátio $\left(4,20 \mathrm{~m}^{2}\right)$, dois terraços $\left(14,90 \mathrm{~m}^{2}\right)$, duas salas $\left(17,31 \mathrm{~m}^{2}\right)$, três quartos $\left(25,40 \mathrm{~m}^{2}\right)$, um depósito $\left(3,40 \mathrm{~m}^{2}\right)$, cozinha $\left(6,80 \mathrm{~m}^{2}\right)$ e banheiro $\left(3,40 \mathrm{~m}^{2}\right)$, totalizando $92 \mathrm{~m}^{2}$ de área construída. As moradias foram construídas em tijolo sobre fundação em pedra. A cobertura, segundo um dos laudos de avaliação, era de telha colonial "de segunda" sobre madeiramento roliço. Em se tratando dos revestimentos, o piso era em mosaico de pedra em todos os cômodos e 0 tratamento das paredes, tanto externas quanto

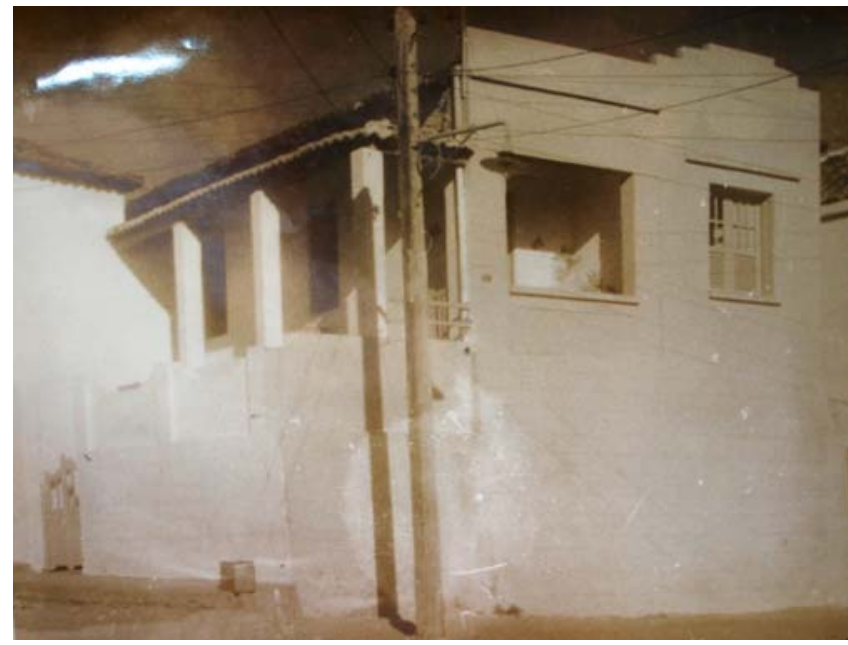

Figura 100: Fachada de uma residência da Vila Lustosa (1950).

Fonte: INSS, 2007. internas, era de caiação simples.

As fachadas eram simples, sem muitos ornamentos. O plano principal era composto por duas aberturas, uma referente à janela de treliça de madeira e vidro, e outra correspondente ao terraço frontal. Há uma platibanda escalonada, com alguns emolduramentos, também identificados nas caixas de porta e janela, que remetem ao déco (Figura 100).

\section{Casas da Rua Manoel Miranda (IPASE,1953)}

O terreno onde se encontram encravadas as casas foi comprado pelo IPASE a Wandick Ferreira Lopes, conforme escritura lavrada em notas no Terceiro Ofício de Natal, em 27 de abril de 1945. As operações de financiamento foram realizadas de acordo com a Lei №. 2.068, de 09 de novembro de 1953. A vila se encontrava localizada na Rua Manoel Miranda, no bairro do Tirol, e apresentava instalações de água, luz e saneamento. 
Os lotes mediam 9,00m de largura por 36,00m de comprimento. 0 valor dos financiamentos era de $\mathrm{Cr} \$ 240.000,00$ (duzentos e quarenta mil cruzeiros), de acordo com o plano $\mathrm{A}$, a serem pagos em 20 anos (240 meses) e descontados mensalmente em folha de vencimentos. O valor mensal pago pelos associados para residir nas casas era de $\mathrm{Cr} \$ 1.678,00$ (mil seiscentos e setenta e oito cruzeiros), posteriormente descontados do valor total da dívida.

As casas foram construídas de tijolos sobre pedras, tendo jardim e mureta de frente. As residências possuem beiral na fachada principal e eram compostas por: sala única, três quartos, hall, banheiro, cozinha, terraço com lavanderia e quintal. O piso era em cimento, tacos de madeira e mosaico. O forro era em madeira de lei e a cobertura em telha francesa sobre madeiramento serrado. As moradias não existem mais.

\section{Conjunto Residencial Nova Tirol (IAPC-1957)}

Construído em 1957, o Conjunto Residencial Nova Tirol encontra-se localizado em área nobre da cidade, em um bairro novo na época, destinado à população de média e de alta renda. Equivalia a uma nova proposta para a ocupação definitiva do bairro do Tirol, criado em 1914, que deu nome ao conjunto. De autoria do arquiteto Moacyr Maia, parte do Conjunto Residencial Nova Tirol é atualmente chamado de Condomínio São Sebastião.

O terreno onde foi construído o Conjunto possuía aproximadamente $10.440,00 \mathrm{~m}^{2}$ e foi adquirido pelo IAP dos Comerciários em 09 de fevereiro de 1942, por compra feita ao desembarcador Rômulo da Fonseca Tinoco, pelo valor de Cr $\$ 36.543,00$ (trinta e seis mil e quinhentos e quarenta e três cruzeiros). Em síntese, o metro quadrado do terreno foi comprado por $\mathrm{Cr} \$ 3,50$ (três cruzeiros e cinqüenta centes), valor que de acordo com o projeto inicial do conjunto, "não tem nenhuma expressão em vista da valorização dos terrenos nos últimos quinze anos". O Conjunto apresentava boas instalações de energia elétrica e era saneado.

Trata-se de um conjunto residencial misto, em que se percebem moradias isoladas, geminadas duas a duas, além de edifícios de apartamentos, correspondendo ao único exemplar do gênero na cidade. De acordo com o projeto urbanístico, o Conjunto era conformado por quarenta lotes residenciais para a construção de casas do "tipo proletário", oito blocos de apartamentos com quatro pavimentos, cada um com dois apartamentos por andar, uma escola e um centro social, incorporando a noção de unidade de vizinhança. Na primeira etapa do Conjunto foram edificadas as quarenta residências inicialmente propostas e apenas quatro blocos de apartamentos, sendo dois com oito unidades e dois com seis apartamentos e quatro lojas (Figura 101). 
Os critérios de escolha dos associados que ocupariam as novas unidades foram especificados nos processos e, em síntese, se referiam ao tempo de contribuição ao IAPC, à faixa de renda e ao cargo exercido. Teoricamente, as primeiras moradias seriam destinadas aos contribuintes com rendas mais baixas e com famílias mais numerosas. No entanto, percebeu-se ao analisar os processos de compra dos imóveis que grande parte das unidades habitacionais, mais especificadamente, as que conformavam os blocos de apartamentos com melhores implantações do que as

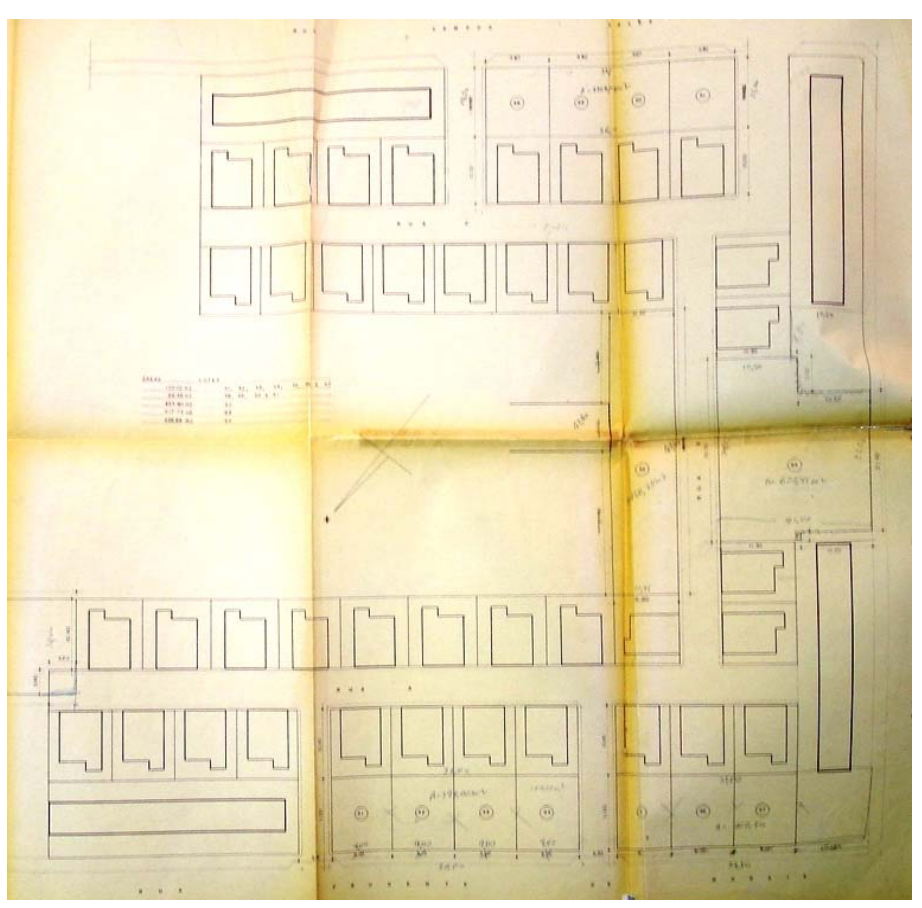

Figura 101: Implantação da primeira etapa do Conjunto Nova Tirol, Tirol (1957). Fonte: INSS, 2007 moradias isoladas, por estarem localizados à margem das avenidas - foram concedidas aos associados que ocupavam altos cargos em empresas, e não àqueles a que inicialmente o IAPC se propunha a atender.

A área destinada aos blocos correspondia a $2.000 \mathrm{~m}^{2}$, a área destinada às moradias era de $4.000 \mathrm{~m}^{2}$, enquanto o espaço reservado para a construção dos equipamentos de uso comum era de $1.500 \mathrm{~m}^{2}$. A área restante seria reservada às vias de acesso e circulação e aos grandes espaços arborizados. No entanto, apesar de terem sido propostos, esses equipamentos nunca foram construídos.

O valor de venda considerado para os lotes onde foram construídas as unidades de moradia correspondia à $\mathrm{Cr} \$ 30.000,00$ (trinta mil cruzeiros) para as quarenta residências unifamiliares e Cr $\$ 160.000,00$ (cento e sessenta mil cruzeiros) para o terreno de cada uma das quatro unidades coletivas construídas, totalizando Cr\$1.840.000,00 (um milhão oitocentos e quarenta mil cruzeiros). Isto é, a valorização do terreno do Conjunto corresponde a aproximadamente cinqüenta vezes o custo desprendido pelo IAPC para adquirir toda a área do desembarcador.

Os cálculos para definição dos valores para construção e comercialização das residências e apartamentos do Conjunto partiram do valor da construção das unidades e do valor considerado (supervalorizado) dos terrenos. O valor da construção equivalia à soma do custo de construção das moradias, correspondente à $\operatorname{Cr} \$ 2.458 .000,00$, dos apartamentos ${ }^{126}$ que foi de $\operatorname{Cr} \$ 3.302 .000,00$, e das quatro lojas, equivalente à $\mathrm{C} \$ 3.143 .000,00$. Esses valores, acrescidos aos custos desprendidos com os

\footnotetext{
${ }^{126}$ Essas unidades estavam situadas na parte periférica do terreno, o que também justificava seu maior custo.
} 


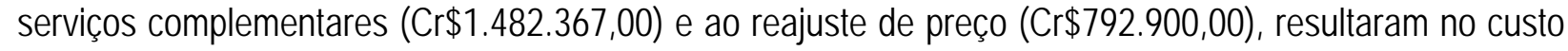
total para a edificação do empreendimento, equivalente à Cr $\$ 178.267,00$. Tomando os supracitados valores como base de cálculo, os custos unitários para comercialização das unidades residenciais foi de $\mathrm{Cr} \$ 118.000,00 \quad(\mathrm{Cr} \$ 30.000,00$ do terreno + Cr\$77.000,00 da construção + Cr\$11.000,00 de encargos), dos apartamentos foi de Cr\$310.000,00 $(\operatorname{Cr} \$ 20.000,00$ do terreno $+\operatorname{Cr} \$ 258.000,00$ da construção + Cr\$32.000,00 de encargos), enquanto as quatro lojas foram financiadas pelo valor de $\mathrm{Cr} \$ 128.000,00 \quad(\mathrm{Cr} \$ 10.000,00$ do terreno + Cr\$105.000,00 da construção + Cr\$13.000,00 de encargos). Sendo assim, 0 valor gasto para a implantação do Conjunto Nova Tirol pelo IAPC foi de Cr\$14.520.000,00 (quatorze milhões, quinhentos e vinte mil cruzeiros).

Os terrenos em que se encontravam as moradias isoladas apresentavam áreas que variavam de $94,5 \mathrm{~m}^{2}$ (9m de largura por 10,5m de extensão) e $101,85 m^{2}$ (9,7m de largura por 10,5m de extensão). Dimensão considerada pelo próprio Instituto como sendo ideal para comportar uma moradia mínima de modo a atender às necessidades da classe operária. Essa reduzida área também foi justificada pelo IAPC pelo fato de estarem propostas no projeto a instalação de equipamentos coletivos e de lazer, 0 que reduziria a necessidade de grandes quintais nas residências, porém, não a sua extinção. Os financiamentos das casas variavam entre Cr\$120.000,00 (cento e vinte mil cruzeiros) e Cr $\$ 130.000,00$ (cento e trinta mil cruzeiros), a serem pagos no prazo máximo de vinte anos, contados após dez dias da assinatura do contrato de compra e venda,

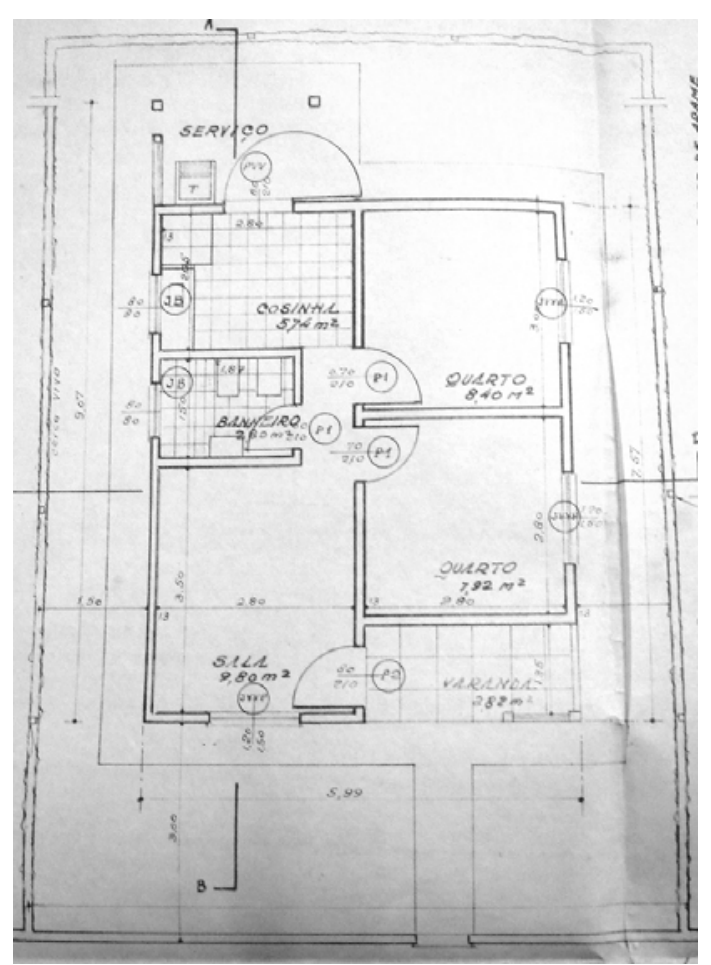

Figura 102: Planta de residência tipo-A (1957). Fonte: INSS, 2007.
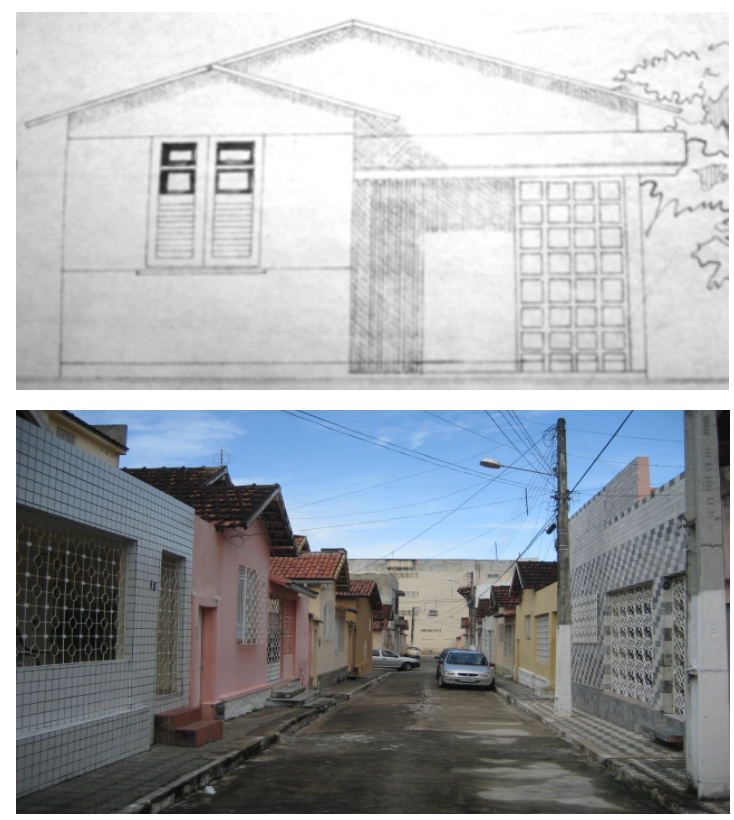

Figuras 103 e 104: Fachada de residência tipo-A (1957) e vista panorâmica da vila (2007). Fonte: INSS, 2007; HCURB, 2007. conforme o plano B-II. As taxas de ocupação dos imóveis praticadas pelo IAPC com base na rentabilidade de $6 \%$ e taxa de administração de 25\%, correspondiam à $\mathrm{Cr} \$ 800,00$ (oitocentos cruzeiros). 
As moradias isoladas possuíam: área de entrada, sala, dois quartos, copa-cozinha, banheiro, lavanderia e área de serviço (Figura 102). As casas eram construídas em alvenaria de tijolo sob fundação de pedra (Figuras 103 e 104). Em relação aos revestimentos empregados, destaca-se a ausência de forro na cobertura e a utilização de tacos de madeira nos pisos da sala e quartos, e de ladrilho hidráulico nas demais dependências da casa. A análise da planta revela a sintonia do projeto com os preceitos da arquitetura moderna em voga. O programa da casa é simplificado, e as dimensões dos cômodos mínimas. A circulação na forma de corredor, comum nas moradias do período, praticamente inexiste. A disposição dos ambientes se dá de acordo com a insolação local, com os espaços frios situados na parte oeste da planta e os quartos no sentido oposto, sendo privilegiados pela insolação diurna. Nas fachadas observa-se também a utilização de elementos modernos, em especial a laje plana que protege o terraço frontal, o jogo de volumes e a parede de combogós, em conjunto com elementos tradicionais, como a cobertura do tipo "chalezinho" em duas águas furtadas em telha colonial.

A área ocupada por cada bloco de apartamento, por sua vez, era de $393,75 \mathrm{~m}^{2}$, um terreno de $10,5 \mathrm{~m}$ de largura por $37,5 \mathrm{~m}$ de extensão. Dois dos quatro blocos de apartamentos construídos pelo Instituto estão localizados na Rua Ceará Mirim, outro na Avenida Campos Sales e 0
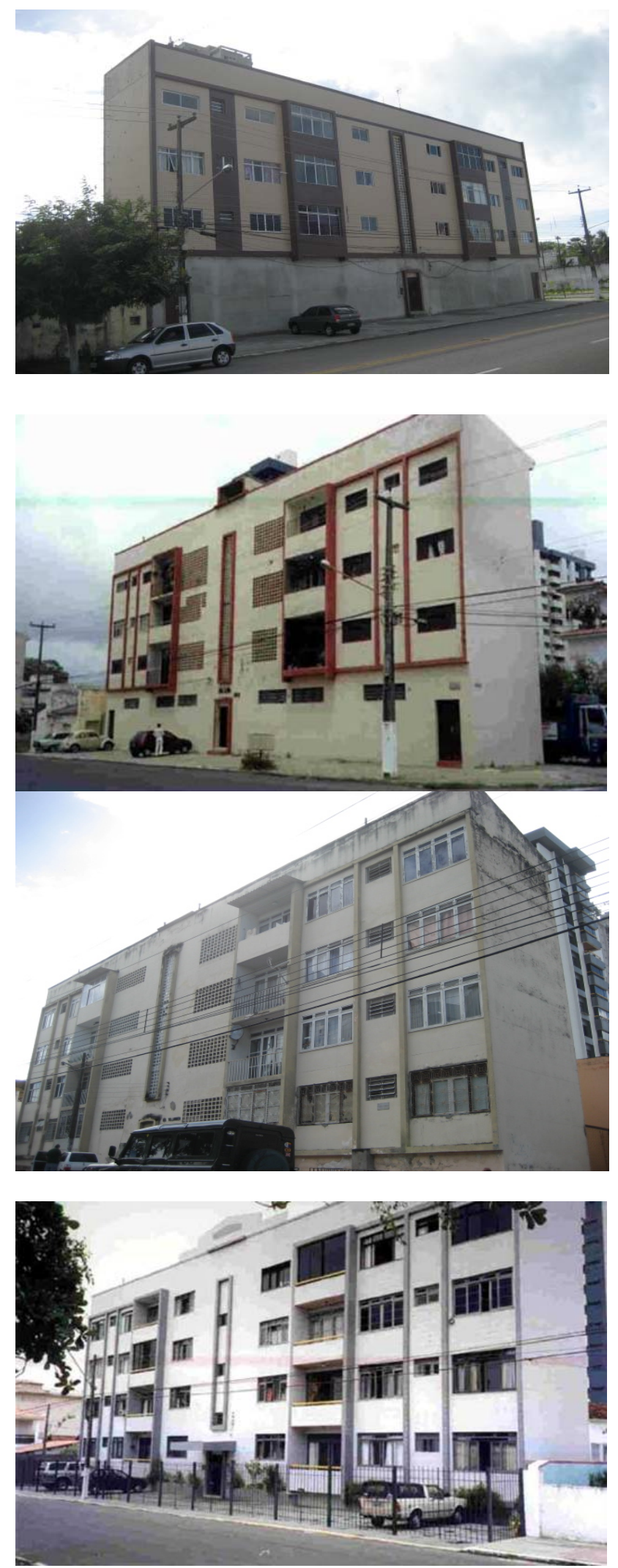

Figuras 105 a 108: Blocos do Conj. Nova Tirol (1957). Fonte: ALMEIDA, 2006; HCURB, 2007. quarto na Avenida Prudente de Morais (Figuras 105, 106, 107 e 108). O valor do financiamento dos apartamentos variava entre $\mathrm{Cr} \$ 300.000,00$ (trezentos mil cruzeiros) e $\operatorname{Cr} \$ 310.000,00$ (trezentos e dez mil 
cruzeiros), dependendo do pavimento em que se localizava o apartamento. A prestação mensal era, em média, de Cr\$3.850,00 (três mil oitocentos e cinqüenta cruzeiros) e o aluguel era de $\operatorname{Cr} \$ 2.000,00$ (dois mil cruzeiros). Para aquisição dos apartamentos, o associado deveria apresentar, no mínimo, vinte e quatro contribuições ao IAPC ${ }^{127}$. A planta-tipo das unidades dos blocos possuía: sala $\left(16,25 \mathrm{~m}^{2}\right)$, varanda $\left(3,36 m^{2}\right)$, dois quartos $\left(9,59 m^{2}\right.$ e $\left.12,15 m^{2}\right)$, banheiro $\left(5,62 m^{2}\right)$, circulação $\left(3,56 m^{2}\right)$, cozinha $\left(6,37 m^{2}\right)$, área de serviço $\left(2,86 \mathrm{~m}^{2}\right)$ e quarto de empregada $\left(4,01 \mathrm{~m}^{2}\right)$, totalizando $64 \mathrm{~m}^{2}$ de área útil (Figura 109). Observando-se a dimensão e a distribuição dos cômodos na planta-tipo dos apartamentos do Conjunto Residencial Nova Tirol, percebe-se que apesar dos espaços se organizarem ao longo de um corredor com quase $5 \mathrm{~m}$ de extensão, os cômodos apresentam-se dispostos de modo não tradicional, com concentração dos espaços frios (cozinha, área de serviço e banheiro de empregada) e separação física e visual entre as áreas íntimas, daquelas comuns e de serviço. A varanda, de certa forma sacada do corpo do edifício, mostra-se um novo elemento que compõe a planta.

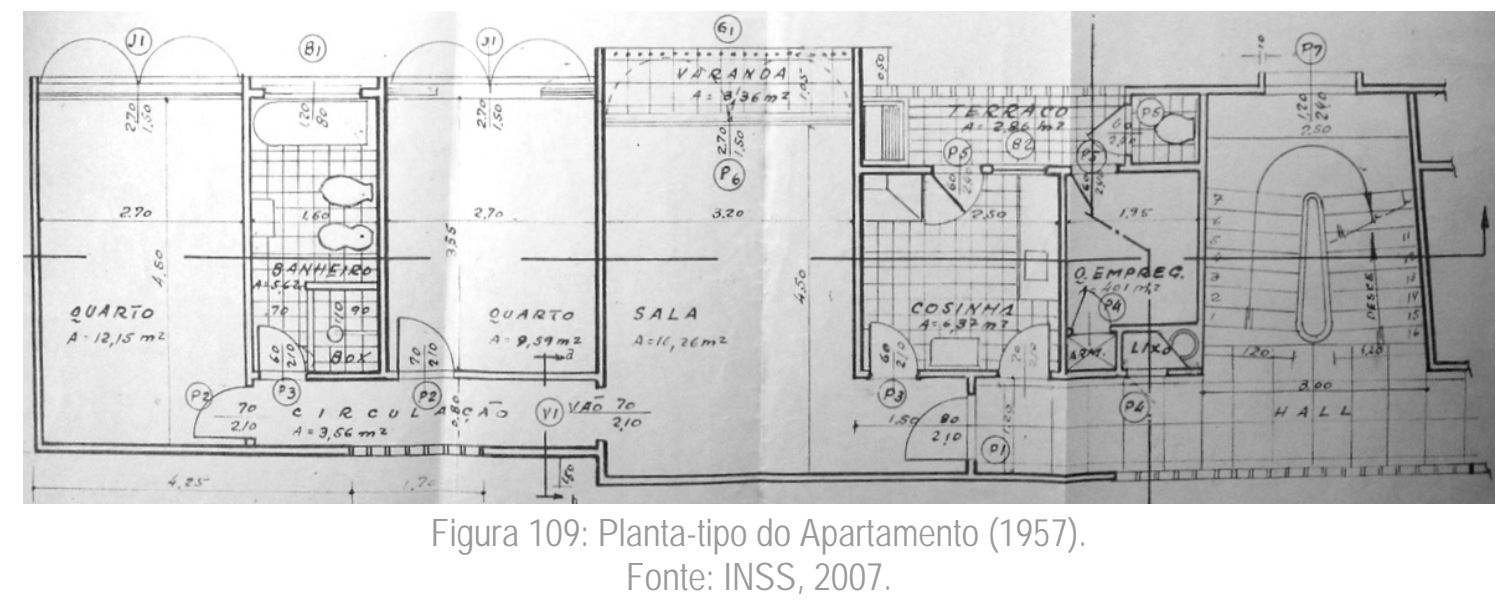

Os blocos de apartamentos do Conjunto são volumes prismáticos com três pavimentos - sem a presença de elevador por questões de economia de projeto. Percebe-se o emprego de alguns elementos da linguagem moderna como a platibanda, o teto-jardim e a utilização de elementos vazados para vedação, mas, verifica-se ainda a existência de alguns ornamentos, como o frontão sobre a platibanda, no caso do bloco IV. Os blocos foram implantados diretamente sobre o solo, sem que fossem utilizados pilotis. O destaque dado pelo arquiteto à caixa da escada por meio da utilização de um pano vazado utilização de combogós, nos Blocos II e III -, especifica a mudança de função nesse espaço da edificação e confere movimento à fachada principal, quebrando juntamente com o volume saliente das sacadas, a horizontalidade resultante das aberturas das janelas e varandas do prédio.

Os quatro pontos comerciais possuíam $32 \mathrm{~m}^{2}$ cada um e ocupavam o térreo de um dos blocos de apartamentos, como especificado anteriormente. O valor do financiamento era de Cr $\$ 350.000,00$

${ }^{127}$ A maior parte dos beneficiados possuía trinta prestações pagas. 
(trezentos e cinqüenta mil cruzeiros), de acordo com as especificações do plano C (financiamentos diversos), e o custo mensal era de $\mathrm{Cr} \$ 860,00$ (oitocentos e sessenta mil cruzeiros).

A segunda etapa do Conjunto foi iniciada em fins da década de 1950, e concluída por volta do ano de 1963. Correspondeu à construção de 26 casas geminadas, duas a duas, com “(...) varanda, sala, dois quartos e demais dependências (...)" (EM NATAL..., 11/12/1954, p.01-04), além de casas com programas mais amplos. As unidades foram vendidas por concorrência realizada pelo Instituto, como se verifica em artigo publicado no Diário Oficial em 25/10/1956. Essas moradias não seguiram o mesmo padrão do projeto das primeiras residências unifamiliares, formulado pelo arquiteto Moacir Maia. As habitações nesse segundo momento foram destinadas aos trabalhadores com melhores condições financeiras; apresentando em alguns casos, até dois pavimentos, sem fazer nenhuma referência à habitação mínima. Percebe-se ainda a presença do telhado convencional (Figuras 110, 111 e 112).

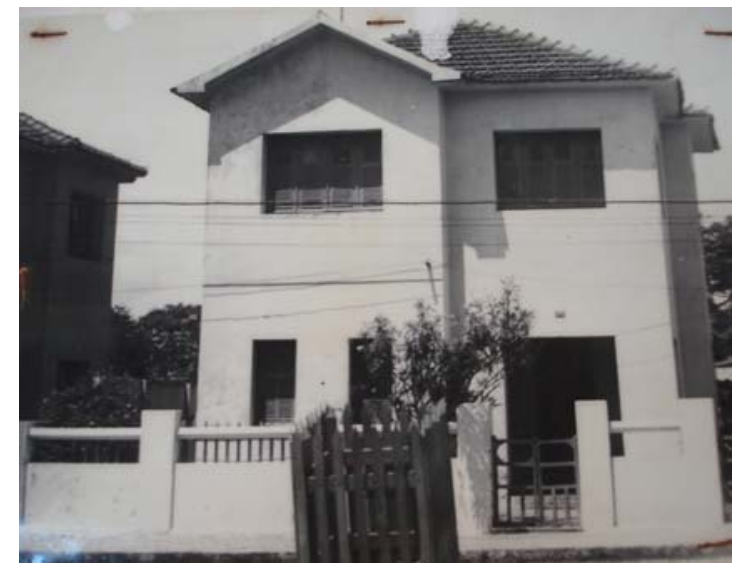

Figuras 110, 111 e 112: Fachada, planta baixa pavimento térreo e superior da residência seaunda
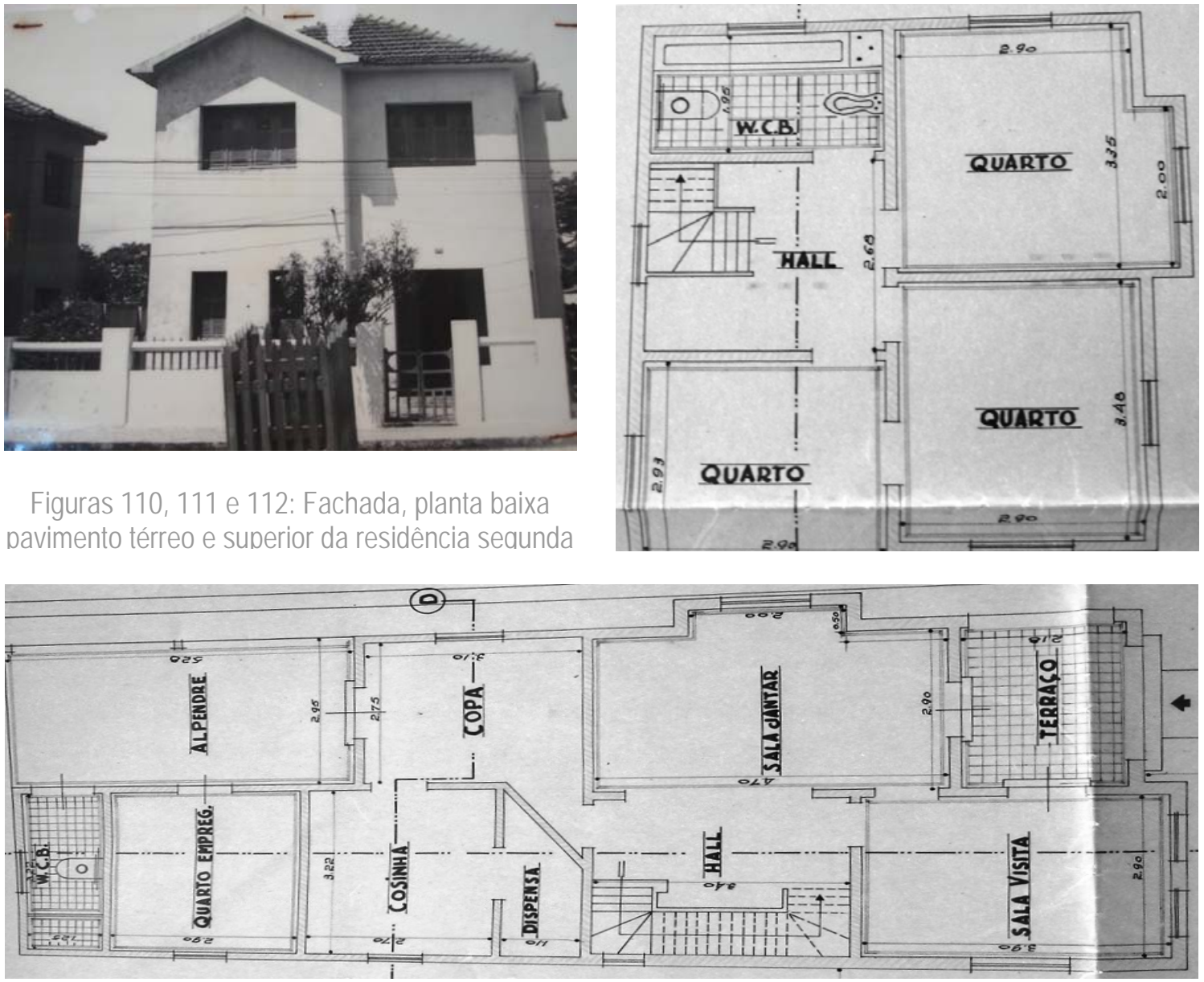

\section{Conjunto do IPASE (IPASE-1957)}

O segundo grupo de moradias construído pelo IPASE está localizado na Avenida Hermes da Fonseca e na Rua João Lindolfo, no bairro do Tirol. De acordo com a escritura do imóvel, algumas das residências que conformam o Conjunto foram adquiridas pelo IPASE de Wandick Teixeira e João Bezerra de Melo, pelo valor de Cr\$150.000,00 (cento e cinqüenta mil cruzeiros), no dia 27 de abril de 1945. As 
residências foram implantadas em um terreno de $36 \mathrm{~m}$ de largura por $230 \mathrm{~m}$ de extensão $\left(8.280 \mathrm{~m}^{2}\right)$. 0 restante das moradias foi edificado pelo próprio Instituto, sendo concluída por volta de 1957, quando se deu início ao processo de concorrência para aquisição de residências pelos associados. O número certo de moradias adquiridas e daquelas construídas pelo IPASE não pode ser apontado ao certo devido à imprecisão das informações catalogadas e à descaracterização atual do grupo de moradias, mas acreditase que ultrapassa o número de trinta.

O conjunto era saneado e servido de água e luz. Os lotes variavam em se tratando das dimensões, possuindo em média 200 $\mathrm{m}^{2}$, sendo 10,00m de fundo e 20,00m de comprimento, chegando em alguns casos à área de $324 m^{2}$ (9,00 x 36m de extensão). Os financiamentos para aquisição de uma moradia no conjunto eram de dois tipos, em torno de $\operatorname{Cr} \$ 93.000,00$ (noventa e três mil cruzeiros) ou na faixa de Cr\$240.000,00 (duzentos e quarenta mil cruzeiros), a serem pagos no prazo máximo de vinte anos e descontados nas folhas de vencimentos dos solicitantes, de acordo com as especificações do Plano $\mathrm{C}$, que correspondia à compra de casa e terreno mediante garantia hipotecária. Cabe ressaltar que em alguns dos laudos de avaliação da residência pleiteada e em alguns dos documentos de liberação do financiamento, especificava-se o pleito como incluso nas especificações do Plano $A$, que também correspondia à compra de imóvel do IPASE. O custo de uso das residências era de Cr\$585,00 (quinhentos e oitenta e cinco cruzeiros).

As moradias possuíam terraço, sala, três quartos, banheiro, cozinha, lavanderia e quintal, com distribuição e dimensões semelhantes às do Conjunto Paulo Gentile. Em relação aos materiais utilizados para fechamentos, revestimentos e acabamentos, pode-se citar: alvenaria em tijolo; cobertura em telha colonial; forro de madeira de lei; cimento queimado no piso do terraço; e tacos e mosaico em pedra nos demais ambiente. As moradias possuíam ainda grande jardim

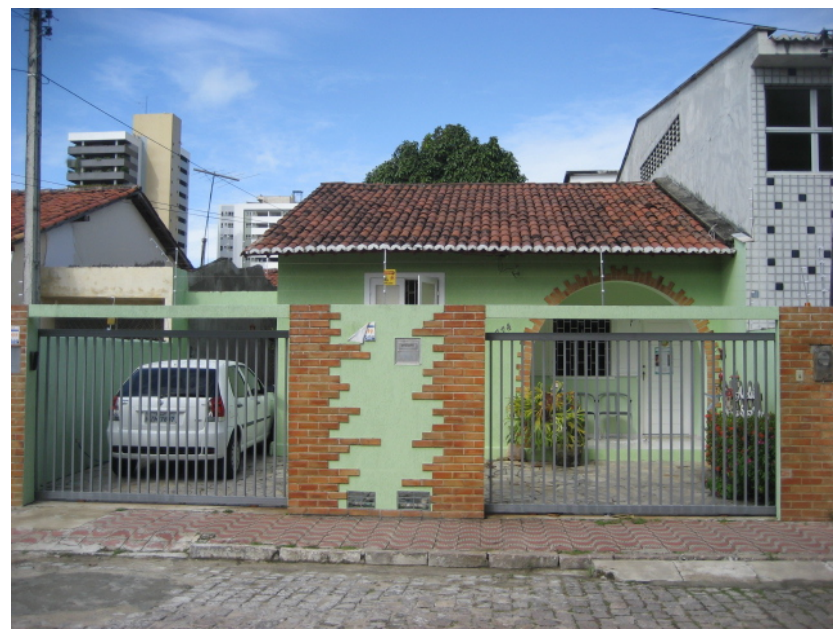

Figura 113: Residência do II Conj. IPASE (1957). Fonte: INSS, 2007. frontal e uma mureta trabalhada. A fachada principal apresenta beiral e área de arcada com janela e porta. No laudo de avaliação especifica-se, residência do "tipo popular, com fachada estilo 'beiral"' (Figura 113). 


\section{Conjunto do IPASE (Década de 1960)}

O supracitado Conjunto equivale à parte do atual Conjunto de Potilândia, situado no bairro de Nova Descoberta. O terreno onde se encontra implantado o grupo de vinte e seis casas foi adquirido pelo Instituto em meados da década de 1940, por compra feita à Companhia de Rádio Internacional de Brasil. Porém, somente nos primeiros anos da década de 1960 foi que as moradias começaram a ser financiadas. Parte das unidades era destinada aos ex-combatentes da Marinha. A primeira etapa com Conjunto foi concluída no ano de 1965 (Figura 114).

O valor do financiamento era em média de $\mathrm{Cr} \$ 7.700,00$ (sete mil e setecentos cruzeiros), a serem pagos no prazo máximo de vinte anos, e valor correspondente ao uso do imóvel. O pagamento era realizado diretamente na agência do Instituto por meio de boletos. Os lotes eram de $250 \mathrm{~m}^{2}$, sendo 10,00m de largura e 25,00m de extensão. A área construída era de $51,45 \mathrm{~m}^{2}$, correspondente a terraço, sala, dois quartos, cozinha e banheiro. As residências foram construídas em tijolo comum sobre fundação em pedra, a cobertura era em telha canal, o piso era em taco de madeira (sala e quartos), mosaico de cerâmica (terraço) e ladrilho hidráulico (demais dependências).

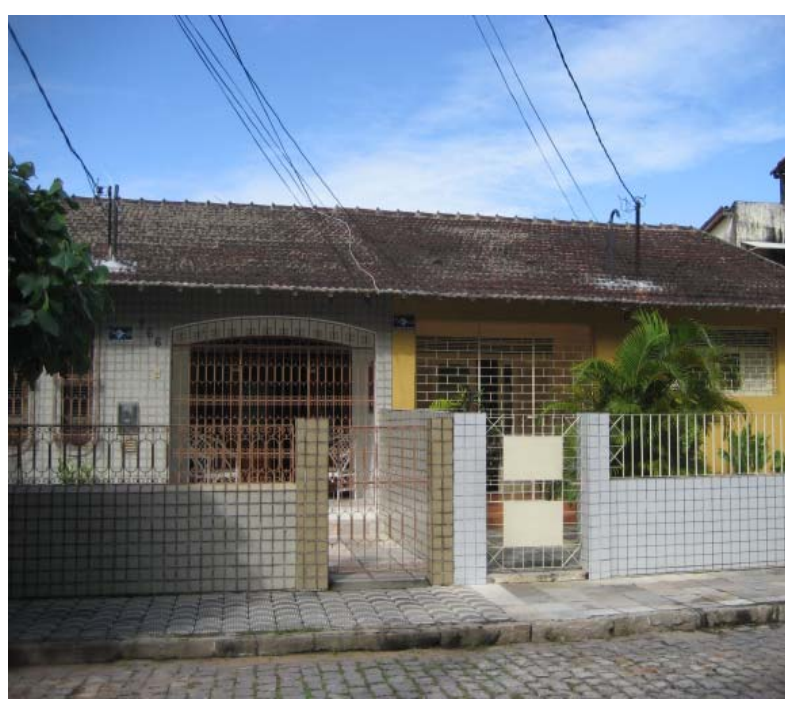

Figura 114: Fachada de uma residência geminada do III Conjunto do IPASE (2007). Fonte: INSS, 2007.

\subsection{A Atuação da Fundação da Casa Popular e da Fundação da Habitação Popular do RIO GRANDE DO NORTE}

A produção de moradias sociais pela Fundação da Casa Popular na capital norte-riograndense, como ocorrido na maior parte das capitais do país, foi ínfima. Das 2.317 unidades habitacionais distribuídas nos trinta e um conjuntos residenciais erguidos no Nordeste, apenas 240 foram locadas no Rio Grande do Norte, equivalendo a sete conjuntos habitacionais ou a $5 \%$ da produção da Fundação no país (ANDRADE e AZEVEDO, 1982).

Grande parcela dessa produção encontra-se distribuída pelos municípios do estado, em especial nas cidades de Areia Branca, Assu, Arez, Pau dos Ferros, Martins, Macaíba, São Paulo do Potengi, São Pedro do Potengi e Serra Caiada. Mais especificadamente foram erguidas: 187 casas nos municípios de Assu, Areia Branca, Pau dos Ferros e Martins, em 1957; mais de 100 residências nos municípios de São Paulo do Potengi, Arez e Macaíba; 50 moradias em São Pedro do Potengi; e 50 unidades habitacionais 
em Serra Caiada (CASAS..., 28/05/1957, p.04/SERÃO..., 01/03/1957, p.01). Na capital, a Fundação da Casa Popular construiu aproximadamente duzentas moradias distribuídas por toda a cidade.

As moradias seguiam o padrão de construção e dimensionamento estipulado pelo órgão e aplicado em grande parte da produção em todo o país. Esse modelo era chamado no estado do Rio Grande do Norte de "tipo simples", e possuía sala com dois ambientes, dois ou três quartos, cozinha, banheiro e área de serviço, variando em área entre $25 \mathrm{~m}^{2}$ e $40 \mathrm{~m}^{2}$. As casas eram em sua quase totalidade do tipo unifamiliar e isoladas no lote, com jardim frontal e grande quintal. Eram edificadas em alvenaria de tijolo, com cobertura em telha colonial em duas águas, do tipo chalé porta e janela, não apresentando grandes variações quanto às fachadas, nem grandes inovações acerca da tipologia, materiais e aspectos construtivos.

Cabe ressaltar que no estado do Rio Grande do Norte, assim como em diversas localidades do país, a administração estadual se mostrou contra a política da FCP de unificação das reservas dos Institutos e de cobrança de taxas sobre a venda e transmissão de bens que seriam arrecadados pelo Estado, decretada em fins da década de 1940. Como forma de coibição foi então criada a Fundação da Habitação Popular do Rio Grande do Norte (FUNDHAP) nesse período. O órgão permaneceu inoperante até 0 ano de 1963 e possuía objetivos que em muito se assemelhavam aos da Fundação da Casa Popular. Por esse motivo, os dados referentes à construção de unidades habitacionais pela Fundação da Casa Popular no estado do Potengi remetem apenas às décadas de 1940 e 1950, ficando a cargo da FUNDHAP, a partir de então.

Entre os anos de 1961 e 1964, a administração do Governador Aluízio Alves criou o primeiro órgão de planejamento do Estado, a CED - Comissão Estadual de Desenvolvimento - por meio do Decreto №. 3.804 de abril de 1961, transformado em Conselho Estadual de Desenvolvimento, em maio de 1962 pela Lei no. 2.796 (ALVES, 2001). Competia ao órgão, a elaboração do I Plano de Desenvolvimento Econômico e Social, que objetivava a superação da "estagnação econômica" a qual o estado se encontrava em virtude da precariedade da infra-estrutura existente, da escassez de recursos e do baixo nível de renda da população (DANTAS, 2003, p.186).

Dessa forma, as obras para melhoramento e otimização da infra-estrutura e dos serviços foram prioridade no mandato do então governador do estado. Dentre elas destaca-se: a ampliação e a modernização da rede elétrica, tanto no meio urbano quanto no rural; a extensão da rede telefônica; a recuperação e extensão da rede viária; e, principalmente, os programas habitacionais, educacionais e de saúde. Assim, foram elaborados o I Plano de Telefonia do Estado, marcado pela criação da TELERN (Companhia Telefônica do Rio Grande do Norte); o I Plano de Previdência dos Servidores, no âmbito do qual foi criado o IPE (Instituto de Previdência do Estado); o I Plano de Poços e Açudes, marcado pela 
criação da CASOL, empresa responsável pela execução e gerenciamentos de obras, e vários outros para a agricultura, pecuária, crédito móvel e turismo (ALVES, 2001).

Essas obras foram caracterizadas pelo estabelecimento de diversas parcerias com agentes financiadores nacionais e internacionais. Dentre as instituições que se destacam nesse sentido pode-se citar a Caixa Econômica Federal, a Superintendência de Desenvolvimento do Nordeste ${ }^{128}$ (SUDENE) e a Aliança para o Progresso (USAID), parceria do governo estadual com o norte-americano firmado por Aluízio Alves em meados de 1961'29. Nesse contexto, o governador criou em maio de 1962 por meio da Lei no. 2.795, o Fundo de Desenvolvimento Econômico e Social (FDES) para administrar os recursos arrecadados pelo Estado advindos do Imposto sobre Vendas e Consignações - uma exigência dos órgãos financiadores dos programas (ALVES, 2001).

No cerne do programa habitacional destaca-se o Plano de Habitação Popular, que constava da criação de um órgão responsável pelo provimento de moradias às camadas mais carentes da sociedade, a construção de mais de 30.000 (trinta mil) moradias populares, além de melhoramentos nos serviços e nas infra-estruturas das áreas residenciais da cidade. Dessa forma, em 12 de agosto de 1963 por meio do Decreto estadual №. 1.102, o governo do estado tornou operante a Fundação da Habitação Popular FUNDHAP - órgão responsável por amenizar as conseqüências do problema da moradia. Os principais objetivos da Fundação eram: atender parte do déficit de habitações das camadas mais pobres; contribuir para a estabilização dos custos de locação e a melhoria na oferta regular de casas; possibilitar que 0 incremento da renda resultante da estabilização dos gastos com a habitação fosse dirigido para a elevação dos padrões de vida; e controlar a execução de uma experiência pioneira cujos efeitos em curto prazo, permitiriam formular um programa habitacional dinâmico, que reduziria as pressões originárias desse setor (SÉRGIO, 1965, p.02-05).

\footnotetext{
${ }^{128}$ A SUDENE foi criada no ano de 1959 diante do quadro de precariedade econômica e social em que se encontrava a maior parte das cidades do Nordeste. O propósito desse órgão era o de substituir a política assistencialista, até então desenvolvida, por medidas mais sociais a fim de modificar a região, com a implantação de obras de infra-estrutura, desenvolvimento industrial e reestruturação agrária.

129 A USAID surgiu em fins da década de 1950 durante uma reunião dos países americanos em Punta Del Leste e equivalia à aliança entre esses países e o governo norte-americano para a execução de projetos assistencialistas e julgados urgentes. No Brasil, os projetos eram repassados pelos governos estaduais à SUDENE e por ela, entregues à Comissão nos EUA. A Aliança brasileira passou quase um ano inativa após a assinatura do convênio, mas começou pelo Nordeste, mais especificadamente pelo estado do Rio Grande do Norte. Após a assinatura do primeiro convênio Aliança-Rio Grande do Norte, reservou-se inicialmente vinte e cinco milhões de dólares para a execução dos planos de educação e moradia previstos. Cabe ressaltar que o convênio Brasil-Aliança determinou que os programas deveriam ser realizados por meio da SUDENE e não diretamente da Aliança com os estados do país, mas uma intervenção direta de Aluízio Alves com o Ministro Tancredo Neves fez com que fosse redigida e aprovada uma Resolução que definia a "solução" do RN como pioneira e, portanto, útil como experiência para os convênios dos demais estados brasileiros. 0 assassinato do presidente Kennedy em 22 de novembro de 1963 deu início à desmobilização da USAID. Os Programas governamentais de Aluízio Alves, essencialmente 0 de habitação, foram considerados por alguns revolucionários como comunistas apesar de ter sido destinado aos recrutas do 16-RI (Batalhão de Engenharia), assim como, instrumentos de colonização com os quais os EUA pretendiam impor seus interesses aos demais países (ALVES, 2001).
} 
Em março do ano seguinte foi assinado o primeiro Convênio de Habitação Popular entre a FUNDHAP, a USAID, o governo estadual e a SUDENE, que previa a construção de 1.000 casas até junho de 1965 (ALUÍZIO..., 07/03/1964, p.05), que equivaliam à parte do conjunto Cidade da Esperança e outras moradias distribuídas pela cidade. A criação do supracitado bairro foi justificada por um discurso que almejava a construção de uma "(...) cidade com perspectivas mais felizes e mais seguras" (A ORDEM, 02/01/1965, p.02) para a população de baixa renda configurada por desempregados e migrantes que se instalaram em Natal em decorrência das grandes secas.

\section{O Conjunto Residencial Cidade da Esperança (1963-1974)130}

A Cidade da Esperança foi o primeiro grande conjunto habitacional de Natal e marcou os primórdios da produção de conjuntos habitacionais na cidade, intensificada nas décadas de 1970 e 1980 , e se tornou o maior marco da administração do governador Aluízio Alves (Figura 115). Até a data de sua construção, só havia na capital norte-riograndense pequenos grupos residenciais de até 100 unidades habitacionais, construídos ou adquiridos pelos IAPs ou vilas militares edificadas na cidade a partir da II Guerra Mundial.

O Conjunto equivale a uma experiência pioneira na América Latina em se tratando da forma de produção de moradias nas periferias das cidades, devido às parcerias com órgãos financiadores estabelecidas nesse sentido. 0 objetivo de sua construção foi o de proporcionar casa própria a uma grande parcela da população de baixa renda, conformada essencialmente de migrantes, marginalizada do processo de concessão de financiamentos pelos IAPs na cidade e que se instalavam, principalmente, nas localidades de Mãe Luiza, Carrasco, Quintas e Brasília Teimosa.

O Conjunto foi projetado em duas etapas e executado em quatro fases, entre os anos de 1963 e 1974. A primeira etapa, de autoria do arquiteto Ubirajara Galvão, funcionário da FUNDAHP, correspondia à

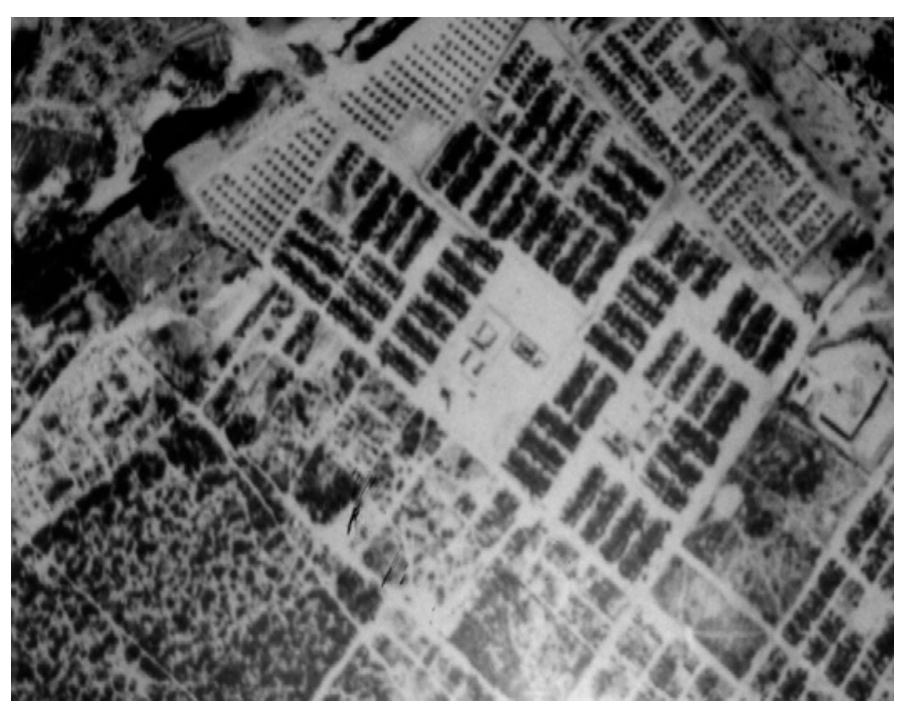

Figura 115: Cidade da Esperança. Fonte: DATANORTE, 1975. construção de quinhentas casas, espaços verdes para uso comum, equipamentos comunitários e uma Igreja Católica. No momento de sua elaboração não se vislumbrava a possibilidade de expansão do

130 As informações e análise apresentadas nesse tópico da dissertação basearam-se no ante-projeto e no partido urbanístico elaborado pela Companhia de Habitação Popular do Rio Grande do Norte (COHAB-RN), elaborados no ano de 1975 (Ver anexo). 
conjunto. Essa primeira etapa foi entregue aos moradores em fins de 1963, durante o mandato do governador Aluísio Alves. O terreno onde foi implantada a primeira etapa do referido Conjunto foi adquirido pelo Governo do Estado em fins da década de 1950 de Gerold Geppert, um comerciante local, e repassado para os domínios da recém criada Fundação da Habitação Popular do Rio Grande do Norte (FUNDHAP) $)^{131}$ no mesmo ano. Possuía aproximadamente 120.000 ha que foram zoneados por funções específicas de acordo com as premissas urbanísticas em voga na década de 1960. Para os lotes foi reservada uma parcela equivalente a 47,11\% do terreno, isto é, 43,81ha. As vias de circulação tanto de pedestres quanto de automóveis correspondiam a uma área de 18,08ha (19,44\%), enquanto aos equipamentos comerciais e comunitários foram reservadas parcelas de 0,87ha (0,94\%) e 12,69ha (13.65\%), respectivamente. Havia ainda 7,65ha (8,13\%) destinados às áreas verdes e 9,98ha $(10,75 \%)$ às áreas livres.

A segunda etapa, por sua vez, foi projetada pelo arquiteto Jorge Vargas Solíz, também profissional da FUNDHAP e posteriormente da COHAB, no ano de 1966, durante a administração do Governador Cortez Pereira. Essa etapa previa a construção de mais duas mil residências. A área onde foi implantada a segunda etapa do Conjunto foi adquirida pelo Governo Estadual por volta de 1965, nas proximidades do núcleo originário da Cidade da Esperança. Essa etapa diferencia-se da primeira pela existência de três fases $^{132}$ e pela redução das áreas verdes e livres e, conseqüentemente, pelo aumento do número de moradias; exigências do Banco Nacional de Habitação (BNH) para a concessão do financiamento. Outro argumento utilizado para justificar a redução de espaços de uso comum era 0 de que o Conjunto se destinava à população carente, não necessitando a construção de grande número e diversidade de equipamentos coletivos e de lazer.

A primeira fase da segunda etapa do Conjunto foi concluída em 1967 e contava com a construção de 980 unidades habitacionais destinadas à população de poder aquisitivo mais elevado que a contemplada na etapa anterior. Diversos dos moradores dessa etapa eram aposentados da marinha. As moradias dessa fase apresentavam acabamento mais apurado, com pintura e revestimentos internos e externos. A partir dessa fase, o BNH ${ }^{133}$ financiou toda a implementação do Conjunto. As 446 moradias que conformavam a segunda fase da segunda etapa da Cidade da Esperança foram entregues no ano de 1970. A terceira e última fase do Conjunto Cidade da Esperança foi concluída em 1974 e constava de 408 unidades habitacionais, além de um horto público e quadras de esporte. A tipologia das moradias permaneceu a mesma em todo o processo de implantação do Conjunto.

\footnotetext{
131 A FUNDHAP antecedeu a COHAB-RN no que diz respeito à produção de moradias na cidade de Natal.

132 Toda a segunda etapa do Conjunto, ou projeto final como era por vezes definido, teve como agente promotor a COHAB.

133 Para a nova área construída, o BNH estabeleceu as porcentagens de $50 \%$ a $60 \%$ da área destinada às moradias, $25 \%$ a áreas verdes e equipamentos coletivos e $15 \%$ para as vias.
} 
Em todo o Conjunto, a relação espaço público/privado permaneceu de acordo com o modelo tradicional, no qual a separação se mostra bem definida, com ruas que definem a malha ortogonal e os limites das quadras. No projeto, observa-se a valorização dos passeios (com grandes dimensões) e das esquinas, que receberam tratamento especial e foram utilizadas como jardins bem arborizados e espaços para convívio social, não sendo ocupadas com lotes residenciais.

A malha regular apresenta poucas variações quanto ao tamanho e à forma. As quadras residenciais apresentam formas retangulares, com dimensões aproximadas que variavam entre 126m, $150 \mathrm{~m}$ e $176 \mathrm{~m}$, e larguras constantes de $44 \mathrm{~m}$. Havia ainda duas superquadras destinadas a abrigar os equipamentos coletivos, com $278 \mathrm{~m}$ e $316 \mathrm{~m}$ de largura e comprimento de $44 \mathrm{~m}$. O parcelamento das quadras é uniforme e distribuído de acordo com a topografia local. De acordo com o projeto inicial, aspectos como a ventilação e a insolação não foram levados em consideração para a locação dos lotes e, conseqüentemente, das residências. $O$ fator determinante era o maior aproveitamento do terreno de modo a comportar o maior número de lotes residenciais. Percebe-se que os aspectos sociais definidos na proposta de construção do bairro cederam lugar aos fatores econômicos de rentabilidade. As quadras possuíam as variações de 20, 24, 32 e 36 lotes residenciais. Os lotes residenciais possuíam dimensão padrão de $180 \mathrm{~m}^{2}$, sendo $9 \mathrm{~m}$ de largura e $20 \mathrm{~m}$ de extensão.

As principais ruas do Conjunto receberam a nomenclatura dos estados do país e as ruas adjacentes os nomes de municípios desses estados. As larguras variavam entre $23 \mathrm{~m}, 17 \mathrm{~m}$ e $12 \mathrm{~m}$, sendo $16 \mathrm{~m}, 12 \mathrm{~m}$ e $7 \mathrm{~m}$, respectivamente, ocupados pelas vias de circulação de automóveis. Há uma hierarquização das vias (estruturais, coletoras e locais), que reduzem de largura e dimensão na medida em que se aproximam das unidades residenciais. 0 projeto inicial previa apenas a pavimentação das vias que margeavam o Conjunto, as demais permaneceriam sem calçamento, o que resultou em grandes problemas com inundações nos períodos de maiores precipitações.

O projeto como um todo previa cerca de 2.500 unidades habitacionais, distribuídas entre moradias isoladas e geminadas duas a duas, em três modelos distintos: o chamado "embrião", com apenas um dormitório; e casas com dois ou três quartos, a serem aplicadas quaisquer que fosse a orientação do lote. As primeiras moradias foram construídas com material doado por empresários, pela população em geral e financiados pelas parcerias, e foram erguidas sob a forma de mutirão, composto pelos moradores a serem beneficiados. Essa se mostrou uma das exigências da USAID para a concessão do financiamento para a construção da primeira etapa do Conjunto. Nesse contexto, os moradores não desprenderiam recursos para a aquisição de residências e, em troca, ofereceriam a mão-de-obra. No entanto, a partir da segunda etapa do projeto, as moradias foram adquiridas por famílias de classe média, por meio de compra efetivada junto ao governo. 
As moradias seguiram os padrões mínimos, os equipamentos públicos foram distribuídos sobre a grelha, assim como as áreas verdes. Em planta possuíam entre $25 m^{2}$ (tipo embrião) e $40 m^{2}$ (casas com três quartos). Em algumas quadras foram edificadas moradias geminadas como forma de baratear os custos da construção e, conseqüentemente, reduzir os valores das prestações a serem pagas pelos moradores (Figura 116). Por esse mesmo motivo não

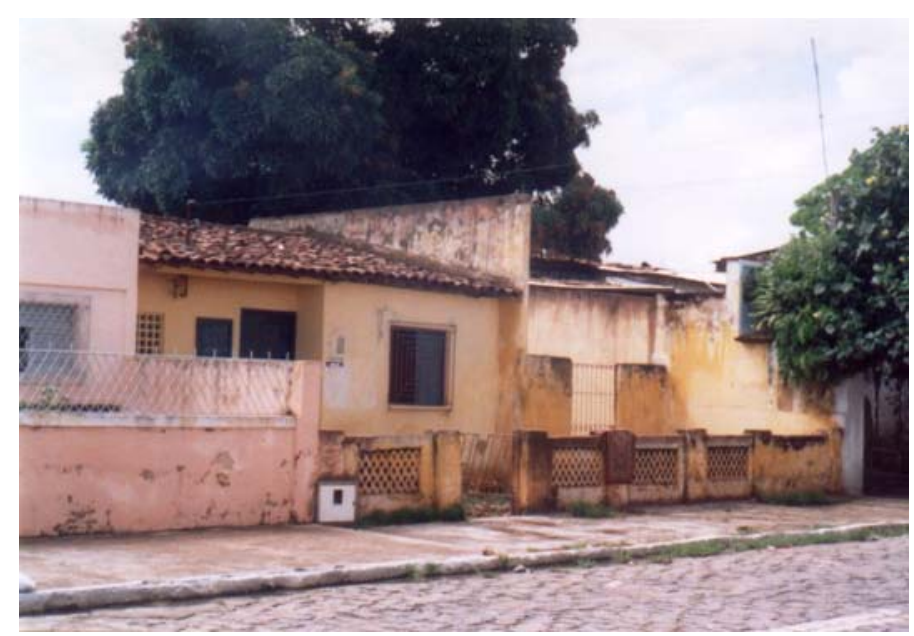

Figura 116: Moradia do Tipo Embrião geminada, 2005. Fonte: Arquivo Pessoal.

se optou por blocos de edifícios. Cabe ressaltar que nesse momento ainda existia em Natal grandes quantidades de espaços vazios, o que não tornava o custo para a aquisição de terrenos uma barreira para a construção de moradias sociais, como também, uma determinante para a escolha das tipologias habitacionais, como se verificou nos grandes centros urbanos do país desde a década de 1930, onde em algumas localidades a opção por edifícios de apartamentos se mostrava a solução mais econômica.

A Cidade da Esperança foi projetada como um conjunto de casas em que os equipamentos coletivos eram tidos como uma extensão das moradias. Os equipamentos coletivos propostos para 0 conjunto seriam instalados nas duas superquadras e equivaliam basicamente às escolas de primeiro grau, igreja, mercado público, áreas de comércio, campos de futebol e quadras de esporte, ginásio de esportes, delegacia de polícia, clube social, clube das mães, centro comunitário e posto de saúde. No entanto, a falta de infra-estrutura marcou a implantação do Conjunto Cidade da Esperança desde 1963. A distribuição de água entre os moradores se dava por meio de um único chafariz'134. Não havia transporte público que assistisse à população. Dos equipamentos comunitários previstos no projeto urbanístico, apenas a Igreja Católica, o mercado público e a Escola Estadual Raimundo Soares foram edificados na primeira etapa. Na primeira fase da segunda etapa, foi construída uma escola primária (Escola Municipal Celestino Pimentel) e um posto de saúde. Na segunda fase da segunda etapa foram edificados o centro comunitário e o clube das mães, e na terceira fase, o horto público e quadras de esportes.

A inexistência de pontos comerciais que atendesse às necessidades básicas da população, associada às grandes distâncias do novo Conjunto ao centro da cidade e à falta de transportes coletivos contribuiu para que diversas das residências fossem adaptadas a pontos comerciais para a venda de

\footnotetext{
134 Somente na primeira fase da segunda etapa começou a ser implementada a infra-estrutura (transporte, distribuição de água e coleta de esgotos). Por volta de 1970, as redes de água e esgotos já haviam sido instaladas pela Companhia de Água e Esgotos do Rio Grande do Norte (CAERN), porém, os problemas referentes à distribuição ainda eram constantes. A pavimentação das ruas do Conjunto teve início apenas no ano de 1982.
} 
produtos de primeira necessidade. As praças e espaços verdes pensados pelos projetistas, não passaram de grandes vazios urbanos, sem tratamento paisagístico ou arborização. As quadras destinadas aos equipamentos de lazer, pensadas desde a primeira etapa, só foram executadas quase uma década mais tarde.

Em nenhum momento da implantação do Conjunto da Cidade da Esperança foi evidenciada a preocupação com a arborização do local, realizada ao longo dos anos (1963-1974) pelos próprios moradores. Os espaços livres, assim como as áreas verdes, são os espaços mais degradados do Conjunto, reflexo do descaso do poder público. Tal situação levou ao abandono ou uso inadequado dos locais. Muitos dos espaços destinados às áreas livres foram pouco a pouco sendo apropriadas pelos moradores para diversos fins. O espaço urbano do Conjunto foi bastante alterado no que diz respeito tanto às residências quanto às formas de apropriação dos espaços coletivos. A vontade de um ambiente não padronizado e mais personalizado levou os moradores a promoverem alterações diversas.

Ao se analisar a planta do Conjunto Residencial percebe-se que foram seguidos os padrões tradicionais de urbanização, como o uso de quarteirões parcelados, lotes alinhados às ruas e a predominância de espaços privados em detrimento aos espaços coletivos, essencialmente na segunda etapa do projeto. Apenas na primeira etapa do projeto, que consta de amplas áreas de lazer, verdes e de uso comum, a influência do urbanismo moderno se mostra mais clara.

A Cidade da Esperança foi oficializada como bairro em 09 de junho de 1967, por meio do DecretoLei no. 1.643. Atualmente, o conjunto possui uma área de 190ha, ocupados por quase 5.000 domicílios, abrigando aproximadamente 22.000 pessoas.

\section{Casas do IPE (1964)}

Concomitantemente à construção da primeira etapa do Conjunto Residencial Cidade da Esperança, por volta do ano de 1963, o Governo do Estado edificou residências destinadas aos funcionários do Instituto de Previdência do Estado (IPE), também construídas em parceria com a FUNDHAP. Esse Instituto foi criado em 1962, devido ao programa de Assistência Social proposto pelo Governo do Estado no mesmo ano, cujo intuito era o de "prestar serviços de assistência médica, auxílio maternidade, pensão, pecúlio e assistência financeira" (ALVES, 2001, p.90).

As edificações apresentavam as mesmas características construtivas e tipológicas daquelas residências encravadas no Conjunto Cidade da Esperança, sendo conformadas por sala, dois ou três quartos, cozinha e banheiro. As casas estão localizadas nas proximidades do Conjunto e correspondem ao número de noventa e seis moradias.

A atual descaracterização das casas do Conjunto Cidade da Esperança e do grupo do IPE, como ficaram conhecidas, impossibilitou a afirmação exata das especificidades construtivas, assim como 0 
registro fotográfico dessas moradias, que hoje comportam em sua grande maioria serviços e pontos comerciais.

\subsection{A ARQuitetura das Moradias em Natal}

Dentre as especificidades tipológicas e construtivas dos imóveis edificados e/ou financiados pelos Institutos de Aposentadorias e Pensões (IAPs), pela Fundação da Casa Popular (FCP) e pela Fundação da Habitação Popular do RN (FUNDHAP) na capital norte-riograndense, se destacam a utilização do concreto armado, inserida no contexto do emprego dos princípios modernos da arquitetura e, principalmente, a utilização da taipa - técnica construtiva em terra - em um grande número de residências financiadas e, inclusive, construídas pelos IAPs na cidade.

As determinações do Conselho Nacional do Trabalho (órgão responsável pela normatização, fiscalização e aprovação dos procedimentos dos IAPs) ligado ao Ministério do Trabalho, pregavam uma arquitetura moderna, desprezando o supérfluo com materiais e elementos decorativos, defendendo: a construção em blocos coletivos, primando à economia de material; a localização das obras, de preferência, em espaços afastados do núcleo central da cidade (menor custo dos terrenos); blocos com no máximo quatro andares, não tornando necessária a utilização de elevador o que em muito encareceria as obras; 0 uso de pilotis, para aproveitar o espaço térreo, facilitando a circulação de vento e de pessoas (espaço comum); quando possível à aplicação da tipologia duplex, que além de proporcionar economia garante mais intimidade (separação entre área social da íntima); a construção racionalizada e de preferência auto-suficiente, com assistência básica de equipamentos coletivos e serviços urbanos; e assentamentos privando pelo tráfego de pedestres em detrimento ao de automóveis, com vias de circulação de carros na periferia (BONDUKI, 2002).

Em Natal, no entanto, poucos foram os exemplares de arquitetura moderna construídos pelos Institutos. Os únicos exemplares de moradia moderna coletiva equivalem aos quatro edifícios de apartamentos que conformam o Conjunto Residencial Nova Tirol, construído pelo IAP dos Comerciários na década de 1950. Eles possuem quatro pavimentos, teto-jardim, volumes e linhas retas, fachadas sem ornamentos, elementos vazados como, combogó e brise, plantas mínimas, além de equipamentos coletivos.

A maior parte dos exemplares de arquitetura moderna, financiados pelos órgãos entre as décadas de 1930 e 1960 na cidade, corresponde às moradias isoladas e unifamiliares, cuja construção foi de responsabilidade dos proprietários de acordo com os distintos planos e classes nos quais as ações imobiliárias de cada Carteira Predial mostravam-se organizadas. Apesar de não construírem diretamente moradias modernas, os Institutos em Natal financiaram a construção e disponibilizaram seus engenheiros para a elaboração de diversos projetos que estavam de acordo com os ditames da arquitetura moderna, 
que foram executados por dezenas de construtores atuantes na cidade entre as décadas de 1940 e 1960. Os Institutos que mais promoveram a edificação de moradias de arquitetura moderna foram o IAP dos Bancários (IAPB) e o IAP dos Servidores Públicos Estaduais (IPASE), que financiaram respectivamente, $25 \%$ e $15 \%$ de moradias modernas do volume total pleitos concedidos por esses Institutos na cidade. Cabe destacar que grande parte desses projetos não se destinava às camadas mais carentes da população.

De acordo com os jornais em circulação no período, havia por parte dos profissionais dos IAPs e de setores das elites em Natal, o estigma de que a arquitetura moderna era deveras cara para atender às necessidades das camadas carentes, além de requerer mão-de-obra especializada, o que em muito encarecia a obra. Por esse motivo, provavelmente, grande parte das residências modernas encontradas foi financiada e/ou edificada pelos Institutos cujas reservas imobiliárias eram as mais vultosas. Porém, comparando-se os valores concedidos para financiamentos pelos IAPS atuantes na cidade, oS financiamentos para a construção de exemplares da arquitetura moderna não diferiam daqueles direcionados para a edificação de residências tidas como "convencionais" ou "comuns".

Por outro viés, observou-se que as adequações das moradias aos princípios da arquitetura moderna eram empregadas mais nas fachadas e nos volumes das unidades residenciais que na planta propriamente dita. Evidenciaram-se casos em que os associados solicitavam verbas aos IAPs para a realização de reformas somente nas fachadas da edificação. Nesse sentido, a redução das dimensões dos cômodos e das circulações, assim como, a simplificação do programa da casa, quesitos colocados nas duas primeiras edições do CIAM, não representavam a prioridade dos projetistas da época e nem equivaliam ao intento das camadas mais abastadas da população, a quem se destinava grande parte dessas residências. Contudo, o elemento em planta mais recorrente nos exemplares encontrados referese à copa-cozinha e à cozinha americana, que passaram a receber grande atenção dos profissionais da construção civil a partir da década de 1930.

O emprego de linhas retas, dos volumes cúbicos, a eliminação dos ornamentos e da rígida

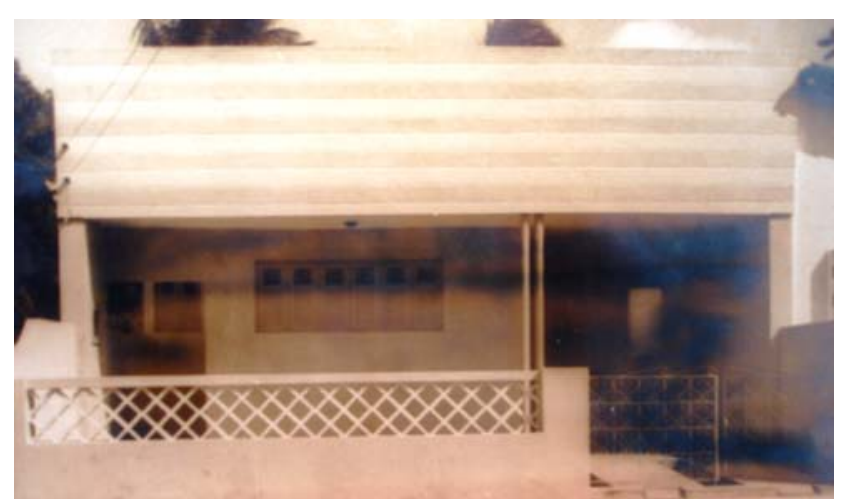

Figura 117: Residência construída pelo IAPB, Tirol (1961). Fonte: INSS, 2007. simetria das fachadas era recorrentemente utilizada nas moradias em Natal (Figura 117). Ainda acerca dos aspectos formais, as moradias financiadas pelos IAPs apresentavam, no geral: pequenas varandas e/ou terraços onde aparecem os pilotis ou pilares esguios em "V" aos moldes de Niemeyer (Figura 118); fachadas livres; elementos vazados; ângulos retos e jogo 
de volumes simples (Figura 119). Outra peculiaridade das construções modernas na cidade, a semelhança com algumas cidades litorâneas do nordeste em especial Maceió e Recife, refere-se ao emprego de azulejos no tratamento das fachadas das casas. 0 teto-jardim, por outro lado, foi pouco utilizado nas moradias encontradas. Na grande maioria das edificações se utilizava platibandas para ocultar as águas do telhado em telha de amianto ou em telha colonial, provavelmente pelo alto custo para aquisição do material e execução daquele elemento, além da necessidade de mão-de-obra especializada (Figura 120).

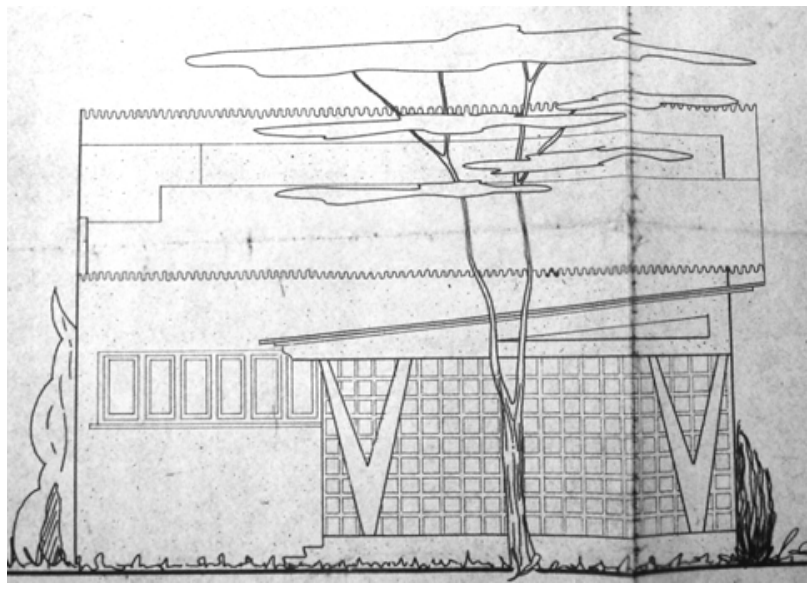

Figura 118: Residência no Alecrim (IAPB,1961). Fonte: INSS, 2007

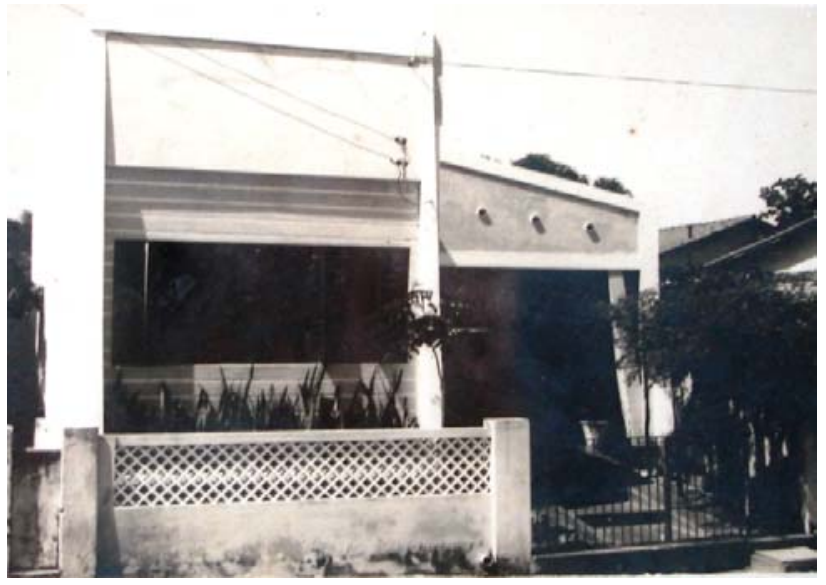

Figura 120: Residência no Tirol (IPASE, 1960). Fonte: INSS, 2007

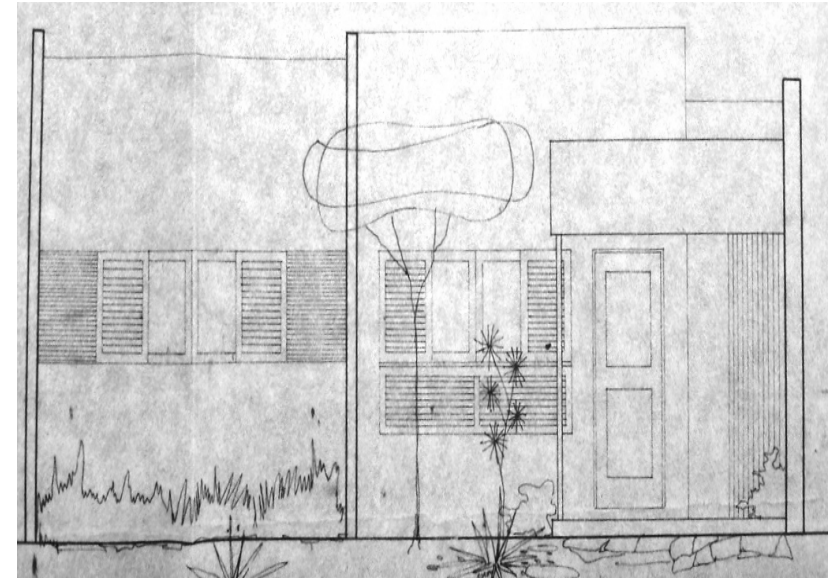

Figura 119: Residência no Tirol (IAPB, 1962). Fonte: INSS, 2007

Diversas das moradias correspondiam às casas de porta-e-janela, ou casas de meiamorada como eram conhecidas (Figura 121). Em se tratando da composição das fachadas dessas habitações, de modo geral, observava-se a sobressalência de três partes: 0 embasamento, 0 corpo e a platibanda. O embasamento era comumente resguardado de materiais que são associados à idéia de resistência como a pedra, principalmente em tons de rosa e cinza, 0 ladrilho hidráulico e o marmorite, remetendo à sua função primeira de sustentação da edificação (Figura 122). O corpo da casa, onde se encontram as aberturas das portas e janelas em madeira ou ferro ao invés dos largos planos de vidro modernos, de modo geral, não recebia tratamento qualquer e estavam livres de ornamentos. Em alguns casos, o embasamento chegava até a altura dos peitoris das janelas ou até a linha da platibanda (Figuras 123). Esse artifício foi bastante utilizado nas moradias edificadas na década de 1950 em Natal. As platibandas, por sua vez, não recebiam tratamento algum, por vezes eram destacadas por linhas, conhecidas como gigantes, em azulejos, auto-relevos e/ou pintadas com cores 
marcantes, que serviam como uma espécie de moldura, essencialmente, para a distinção dos limites das casas quando geminadas (Figura 124).

Ainda em se tratando da composição das fachadas das moradias natalenses, muitas vezes, 0 limite entre o corpo da edificação e a platibanda era salientado pela diferença de planos ou apenas de cores. Por vezes, as esquadrias também recebiam em seu contorno a distinção de planos, cores ou ladrilhos cerâmicos ou hidráulicos. Em algumas residências percebe-se também o emprego dos elementos vazados na platibanda, cuja função primeira era a de ventilar e iluminar, como o combogó, notadamente destituído dessa função.

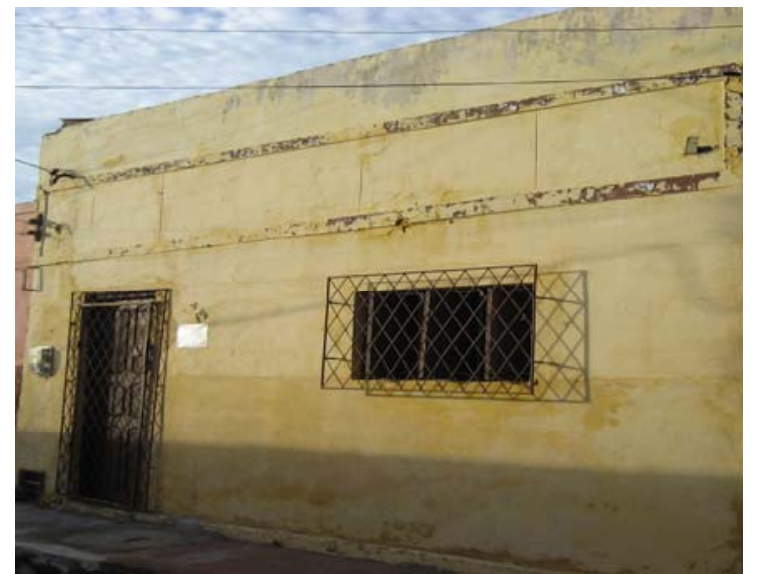

Figura 121: Casa no Alecrim (IAPI, 1947) Fonte: HCURB, 2007.

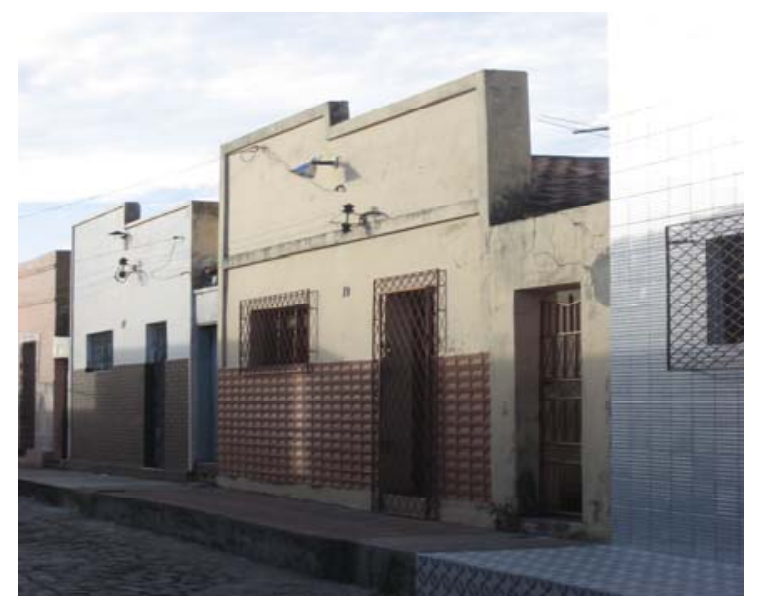

Figura 123: Vila Janete no Alecrim (IAPI, 1947). Fonte: HCURB, 2007.

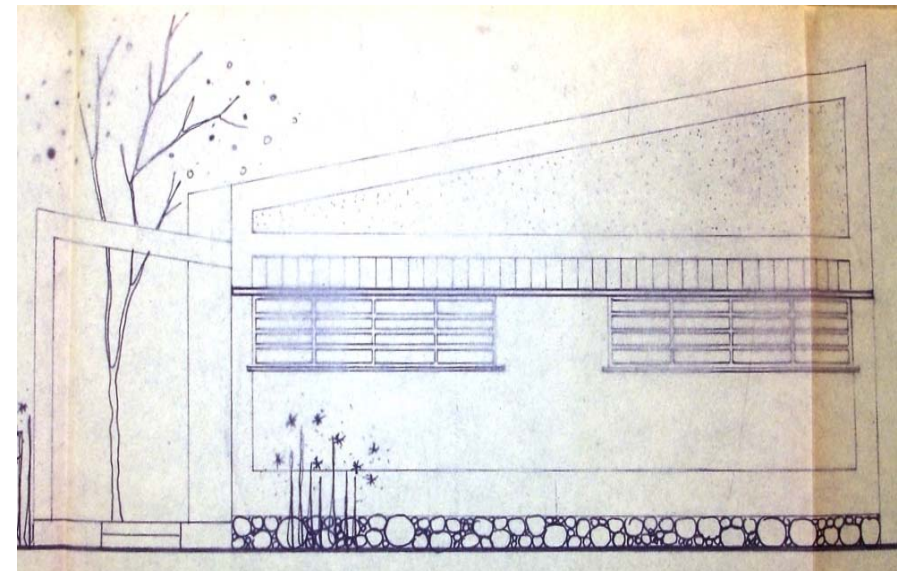

Figura 122: Residência no Tirol (IAPB, 1961). Fonte: INSS, 2007.

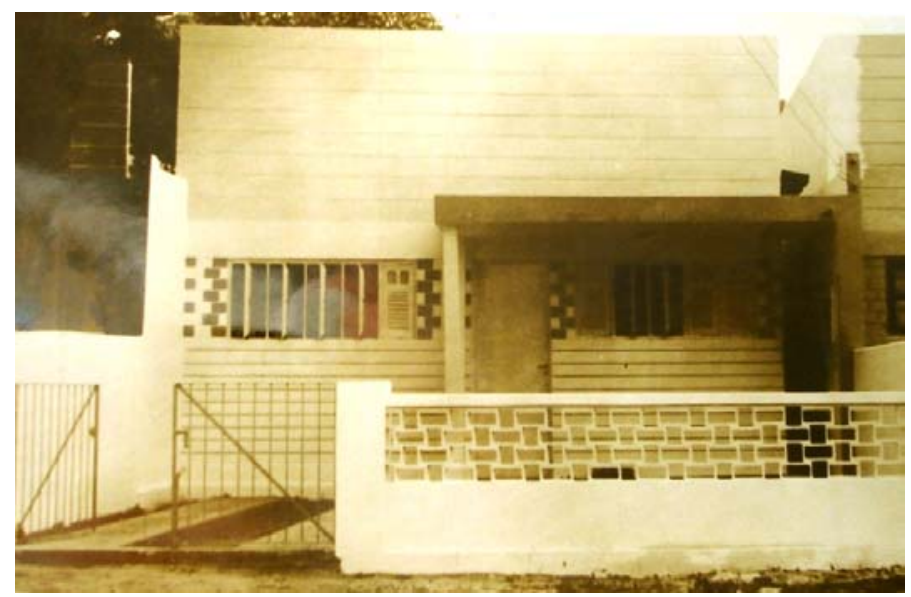

Figura 124: Residência no Alecrim (IAPB, 1963). Fonte: INSS, 2007.

No tocante à arquitetura das moradias construídas pela FCP e pela FUNDHAP na capital norteriograndense pode-se afirmar que, de maneira geral, elas apresentavam alguns elementos da arquitetura moderna, essencialmente os elementos vazados como percebido nas residências do Conjunto Cidade da Esperança. As demais unidades encontradas seguem o padrão tradicional tanto no que concerne às plantas quanto às fachadas. 
A utilização do concreto armado foi observada na construção de algumas residências edificadas essencialmente pelos IAPs em Natal, principalmente, pelo Instituto de Aposentadorias e Pensões dos Servidores Públicos Estaduais (IPASE). Essas moradias foram construídas principalmente a partir da década de 1960, quando a arquitetura moderna passou efetivamente a ocupar importante papel no campo da construção e na ideologia dos profissionais envolvidos com a construção civil em Natal, concomitantemente ao início do processo de verticalização da cidade.

As casas foram endereçadas aos funcionários da prefeitura e equivaliam aos financiamentos que variavam entre Cr $\$ 700.000,00$ (setecentos mil cruzeiros) e Cr $\$ 750.000,00$ (setecentos e cinqüenta mil cruzeiros), de acordo com as determinações do plano C do Instituto que correspondia à construção de casa mediante garantia hipotecária. As residências foram implantadas essencialmente no bairro de Petrópolis e se aproximam de vinte unidades (Figura 125). Pode-se citar ainda a casa no. 644, localizada na esquina da Rua dos Canindés e a Rua Alexandrino de Alencar, no Alecrim, dentre outras (Figura 126).

Em se tratando da tipologia construtiva adotada na edificação das residências

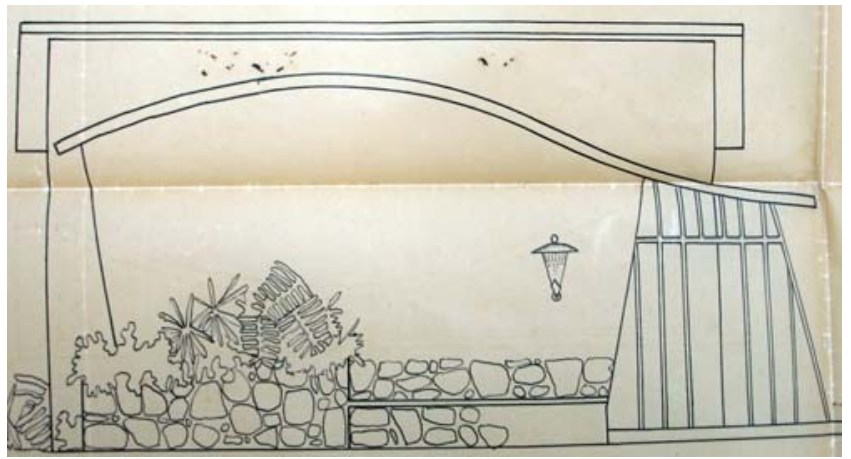

Figura 125: Residência em Petrópolis (IPASE, 1957). Fonte: INSS, 2007.

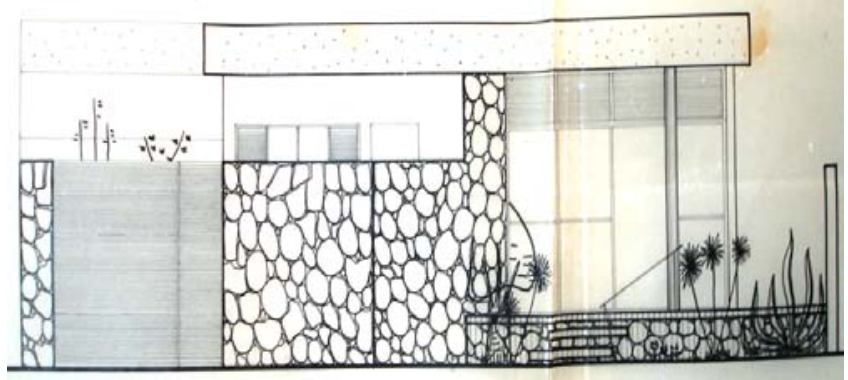

Figura 126: Residência no Alecrim (IPASE, 1958). Fonte: INSS, 2007. diretamente e indiretamente pelo IAP dos Comerciários (IAPC), de aproximadamente noventa financiamentos realizados na cidade ${ }^{135}$, não considerando os edifícios de apartamentos que conformam 0 Conjunto Residencial Nova Tirol edificado pelo Instituto na década de 1950, apenas quatro moradias foram construídas utilizando-se do concreto armado nas lajes e/ou paredes. As moradias estão encravadas no bairro do Tirol e foram erguidas nos três primeiros anos da década de 1950 por valores que variavam entre $\mathrm{Cr} \$ 100.000,00$ (cem mil cruzeiros) e $\mathrm{Cr} \$ 250.000,00$ (duzentos e cinqüenta mil cruzeiros) adquiridos por financiamentos para compra de residência isolada de propriedade do Instituto ou para a compra de terreno do Instituto para a construção de moradia própria, de acordo com o plano $\mathrm{B}$, classe I (Figura 127).

135 Número referente à quantidade de processo encontrada nos arquivos do Patrimônio Imobiliário do INSS-RN. 
No tocante à produção de moradias utilizando-se concreto armado pelo IAP dos Bancários, dos sessenta e seis financiamentos efetivados pelo Instituto em Natal, somente dois deles especificaram o emprego do supracitado material. As moradias foram construídas nos anos de 1950 e 1962, nos bairros de Petrópolis (Figura 128) e Ponta Negra, e foram financiadas pelos valores de $\mathrm{Cr} \$ 121.000,00$ (cento e vinte e

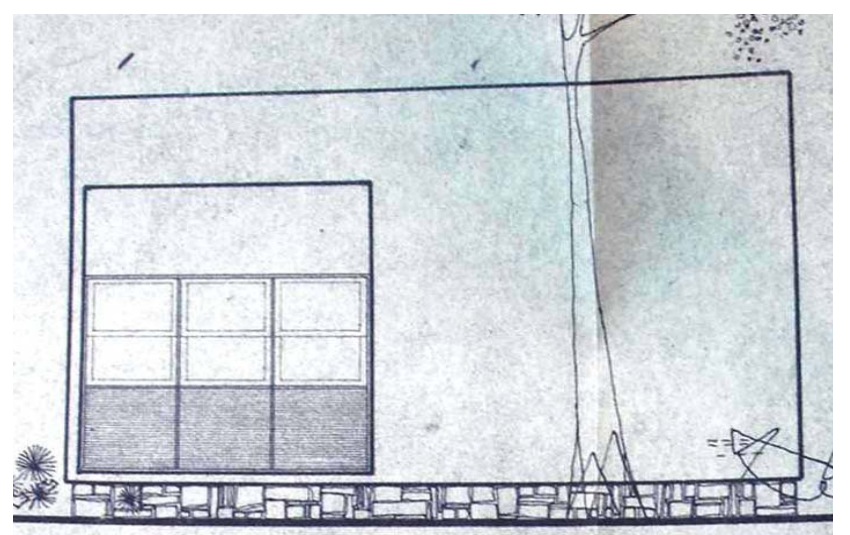

Figura 127: Residência no Tirol (IAPC, 1953). Fonte: INSS, 2007 um mil cruzeiros) e Cr $\$ 600.000,00$ (seiscentos mil cruzeiros), respectivamente. Ambas se enquadravam na modalidade B-II, referente aos financiamentos para a construção de moradias em terrenos dos associados.

No âmbito da Caixa de Aposentadorias e Pensões dos Servidores Públicos Estaduais (CAPESP), dos cinqüenta e sete registros de financiamentos encontrados nos Arquivos do Patrimônio Imobiliário do INSS-RN, apenas em um processo foi especificado a construção do imóvel com cimento armado (Figura 129). Essa moradia foi construída no ano de 1961 e encontra-se encravada no bairro de Cidade Alta, sendo financiada por $\operatorname{Cr} \$ 50.000,00$ (cinqüenta mil cruzeiros). 0 plano no qual 0 financiamento se enquadrava não foi especificado.

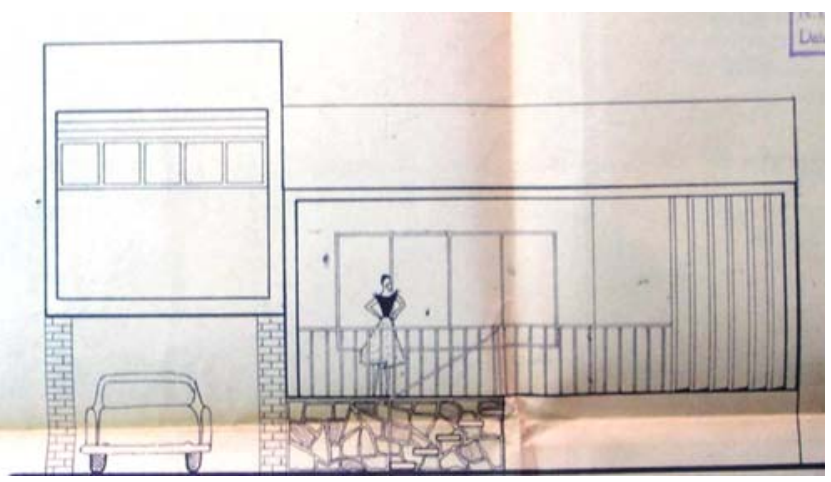

Figura 128: Residência em Petrópolis (IAPB, 1962). Fonte: INSS, 2007

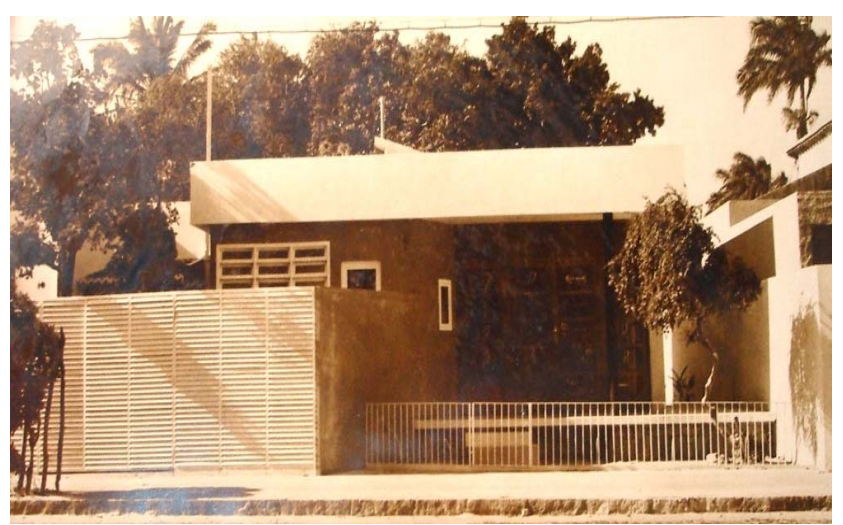

Figura 129: Residência na Cidade Alta (CAPESP, 1961). Fonte: INSS, 2007.

Apenas um registro de moradia erguida utilizando-se o concreto armado foi encontrado nos processos de financiamentos do IAP dos Industriários. Remete à residência de dois pavimentos construída no ano de 1947, de acordo com a classe I do Instituto, e encravada na Avenida Coronel Estevão, no bairro do Alecrim (Figura 130).

No entanto, houve Institutos que não fizeram uso, parcial ou total, do concreto armado para a edificação de unidade habitacionais na capital norte-riograndense, como foi o caso do IAP dos Estivadores 
(IAPE), do IAP dos Funcionários de Transportes e Cargas (IAPTC) e do IAP dos Ferroviários e Servidores Públicos (IAPFESP).

De modo geral, as residências que utilizavam concreto armado possuíam de $200 \mathrm{~m}^{2}$ a $400 \mathrm{~m}^{2}$ e apresentavam mais de um pavimento em sua grande maioria. Observa-se nas plantas das casas a preocupação com a redução das circulações e com a distribuição dos cômodos de acordo com as condições físicas (principalmente a topografia e a vegetação circundante) e ambientais, como a direção dos ventos dominantes e da insolação em especial (Figura 131). A maior parte dos projetos foi elaborada pelos engenheiros

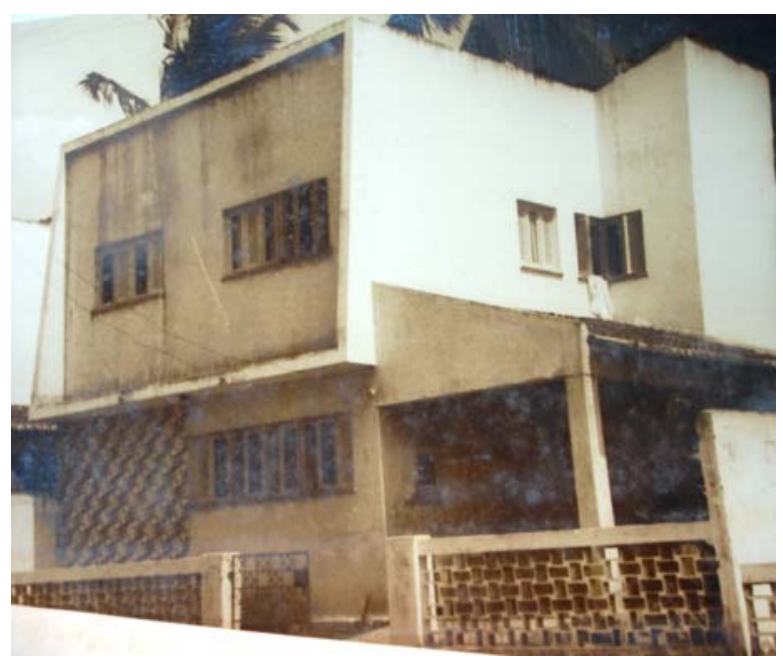

Figura 130: Residência no Alecrim (IAPI, 1947). Fonte: INSS, 2007. dos próprios Institutos, não havendo nenhum caso em que se procedeu à contratação de outros profissionais nesse sentido. Em se tratando da localização, a grande maioria das unidades acima especificadas está situada em bairros destinados à classe média alta e a classe alta, essencialmente no bairro de Petrópolis.

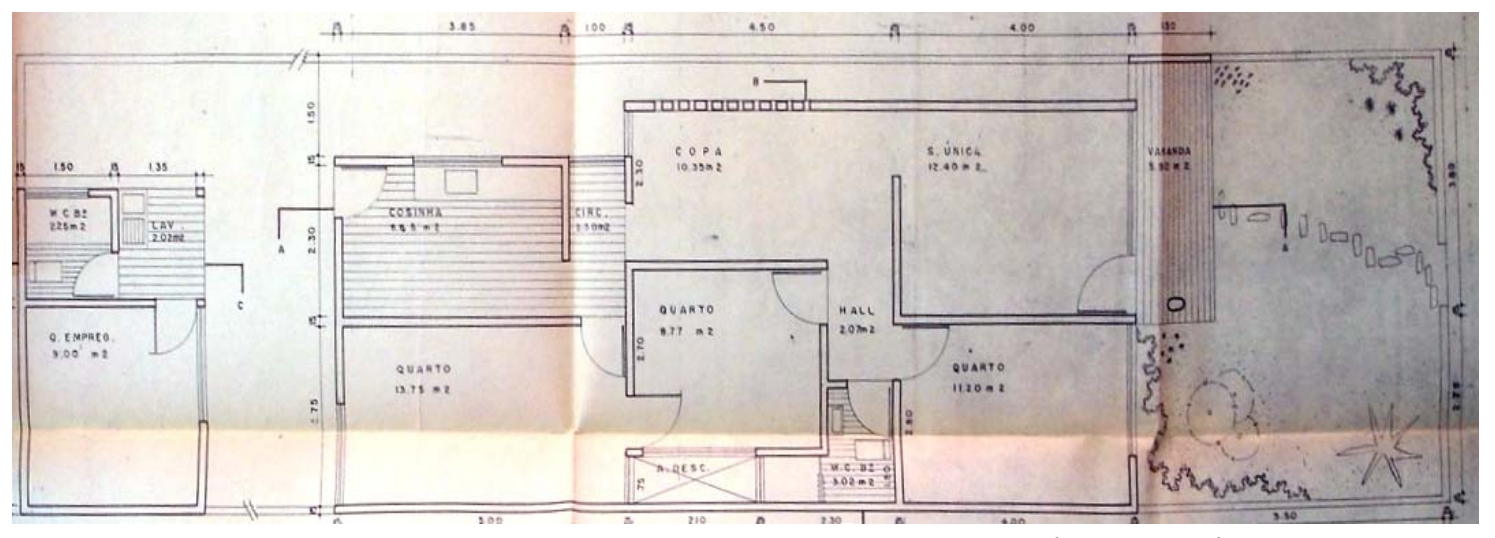

Figura 131: Planta baixa de residência em Petrópolis (IAPB, 1957).

Fonte: INSS, 2007

Em relação à produção de unidades habitacionais pela Fundação da Casa Popular (FCP) e pela Fundação da Habitação Popular do Rio Grande do Norte (FUNDHAP), não foi encontrado nenhum projeto que fizesse uso do concreto ou do cimento armado.

Percebe-se, dessa forma, que a atuação dos Institutos de Aposentadorias e Pensões na cidade de Natal, ao contrário do que se evidenciou nos grandes centros urbanos do país largamente abordados pela historiografia especializada, não correspondeu, salvo exceções, a uma ação inovadora no sentido do emprego de novas técnicas construtivas, materiais e soluções arquitetônicas e urbanísticas modernas, uma vez que o número de moradias de arquitetura moderna e daquelas em que se utilizou o concreto 
armado não chega a representar $15 \%$ da produção local. Uma significativa parcela das moradias financiadas e/ou edificadas pelos Institutos em Natal, pertencentes ou não a conjuntos e vilas, apresentava tipologias e plantas tradicionais, nas quais eram empregados materiais comumente utilizados na região, inclusive a taipa.

A maior curiosidade da atuação dos Institutos de Aposentadorias e Pensões em Natal é, sem dúvida, a larga utilização das técnicas construtivas em terra, essencialmente a taipa de pilão e a taipa de mão ou pau-a-pique, na edificação e/ou financiamento de moradias aos seus associados.

As determinações do Conselho Nacional do Trabalho, dos Escritórios Centrais dos Institutos e das Resoluções que guiavam suas atuações, especificavam que as Carteiras Prediais deveriam primar pela utilização de novas técnicas construtivas e materiais, visando o barateamento da construção de modo que as prestações se enquadrassem nos salários dos trabalhadores sem, porém, prejudicar a qualidade, a habitabilidade, a higiene e o conforto. As casas deveriam, portanto, apresentar: espaços mínimos de modo a atender satisfatoriamente às necessidades de seus habitantes; espaços bem iluminados e ventilados naturalmente; materiais baratos; materiais que não acumulassem umidade e que facilitassem as trocas de calor; dentre outros (BONDUKI, 2002). Dessa forma, na visão dos profissionais envolvidos com a construção civil no âmbito dos IAPS, a taipa não se enquadrava nos preceitos e não se mostrava condizente com a construção de moradias sociais pelos Institutos.

Os estigmas que acompanham essa técnica foram formulados, essencialmente, a partir do século XIX. Um grande número de moradias naquela época era edificado em taipa apresentando poucas aberturas para o exterior e, por vezes, nenhuma divisória interna. Por esse motivo, essas moradias eram consideradas por especialistas como anti-higiênicas e promíscuas. Muitas delas não eram isoladas adequadamente, especialmente na base próxima ao piso, o que fazia com que em períodos chuvosos 0 barro da taipa acumulasse umidade, ou ainda servisse de abrigo para insetos e roedores, contribuindo para a proliferação de doenças. No entanto, quando utilizada de modo adequado, a taipa se mostra bastante econômica e resistente, própria para a edificação de moradias em climas áridos. Características essas desfrutadas em Natal.

Tida como típica moradia da população pobre no Brasil na primeira metade do século $X X$, a taipa é uma forma milenar de construção que possui mais de nove mil anos. A sua origem é desconhecida, mas grande parte dos autores remete à cultura mediterrânea. Há ainda hoje em todo o mundo edifícios construídos em taipa desde o século XIII136. A taipa chegou ao Brasil por meio dos portugueses e se tornou uma característica típica da arquitetura colonial e do século XIX, e em diversas cidades do norte e

\footnotetext{
${ }^{136} \mathrm{Na}$ França a técnica é chamada de terre pisé e foi largamente utilizada nos séculos XV ao XIX. Na Alemanha, a moradia mais antiga edificada em taipa data do ano de 1795. Após a II Guerra Mundial, quando os materiais de construção se mostraram escassos na Alemanha, foram construídas milhares de moradias utilizando blocos de barro e taipa (MINKE,1999). No Brasil, muitos casarões, igrejas e mosteiros foram construídos em taipa no período colonial.
} 
do nordeste do Brasil é utilizada até os dias atuais. As técnicas existentes são as mais variadas, desde as mais tradicionais àquelas readaptadas aos diversos climas. No país, são diversas as técnicas construtivas em taipa empregadas, tais como, a taipa de pedra, a taipa de madeira com bolas de barro, a taipa feita com sobras de madeiras, de mistura de tijolos, a taipa de carnaúba, mas as mais conhecidas são a taipa de pilão e a taipa de pau-a-pique, encontradas principalmente no nordeste brasileiro.

Um dos primeiros registros de moradias edificadas em taipa de mão e de pilão no país remete à chamada Casa Bandeirista (LEMOS, 1999). Posteriormente, muitos arquitetos baseando-se na valorização vernacular das obras corbusianas de fins da década de 1920, como a Vila Mandrot, fizeram uso de técnicas como a taipa, como foi o caso dos arquitetos Lúcio Costa, com o projeto para a vila operária em Monlevade (MG) da década de 1930137, e Álvaro Vital Brasil em diversas obras no Norte e Nordeste durante a II Guerra Mundial (FORT e ANDREOLI, 2004). No âmbito da Fundação da Casa Popular, foram realizadas experiências com pau-a-pique e taipa de pilão na Bahia (ANDRADE e AZEVEDO, 1982) e, em 1963, Acácio Gil Borsoi coordenou uma experiência com pré-fabricação em taipa junto às comunidades carentes do estado de Pernambuco (FORT e ANDREOLI, 2004).

Segundo Lemos (1999), ao longo de três séculos a taipa passou por diversas ressignificações, principalmente a partir do período de prosperidade do café em São Paulo. Paralelamente, a referida técnica começou a perder espaço no mercado de construção civil para o tijolo. O preconceito associado à industrialização da construção civil foi determinante para o declínio dessa tradicional técnica de construção. A taipa, durante décadas, foi considerada como técnica primitiva, descriminada pelas elites e até mesmo pelas camadas mais pobres, sendo associada à miséria, à falta de higiene, às doenças, à precariedade, à penúria e à promiscuidade. No entanto, quando preparada e utilizada em locais apropriados, a taipa pode gerar construções de baixa renda de qualidade social e ambiental, além de ser duradoura, acessível e econômica, equivalendo a uma resposta e/ou alternativa possível aos déficits de moradias evidenciados há séculos no país.

Para a edificação de uma estrutura em taipa de pilão deve-se em primeiro lugar extrair e transportar a terra para o local da construção. Posteriormente ela é peneirada e misturada, com as mãos ou com auxílio de uma enxada, com água, pedras, areia, barro, palha, cal e outros diversos materiais ${ }^{138}$, dependendo da região, chamados de estabilizantes. A porcentagem comumente trabalhada é de $30 \%$ de argila e $70 \%$ de areia, mais os agregados, resultando em uma mistura perfeitamente homogênia. A base para 0 assentamento de uma estrutura em taipa geralmente é feita com alvenaria de pedra local onde são

\footnotetext{
137 Projeto apresentado no Concurso promovido pela Companhia Siderúrgica Belgo-Mineira para a construção de um Conjunto Residencial na cidade de Monlevade, em Minas Gerais, com residências, igreja, armazém e cinema para os empregados da Companhia. As moradias propostas por Costa apresentavam pilotis devido ao terreno acidentado. O projeto, no entanto, não foi executado (BRUAND,1981).

138 Observa-se ainda a utilização de baba de cupim sintética, cimento e até esterco de animal.
} 
fincados os taipais, varas de madeira ou bambu que dão suporte à mistura de terra. Em seguida, a terra é colocada em camadas de aproximadamente $10 \mathrm{~cm}$, e batida com ajuda de um pilão com peso que varia entre quatro e seis quilos ${ }^{139}$. Depois os moldes são retirados e fixados em outra posição, dando início ao levantamento de outra parede. Quando prontas e secas, as paredes recebem tratamento de reboco, ou somente uma aplicação de cal de modo a aumentar a impermeabilidade da estrutura, e são abertos os vãos de portas e janelas.

A taipa de mão, sopapo, barro armado, taipa de sebe ou paua-pique, por sua vez, mostra-se uma técnica de construção onde as paredes são armadas com madeira (elementos roliços ou ripas), bambu, varas de palmito ou outro material, de modo que forme uma trama de varas verticais e horizontais, geralmente estruturadas em uma viga horizontal, o baldrame, e uma viga vertical, o esteio, amarradas com cipó, sisal, tiras de couro, pregos ou arames. As vigas verticais são as de maior espessura e conhecidas como pau-a-pique, enquanto os elementos horizontais são fixados com menores espaçamentos, e chamados de tiras ou ripas. Posteriormente à montagem da trama faz-se o preenchimento dela com uma mistura de

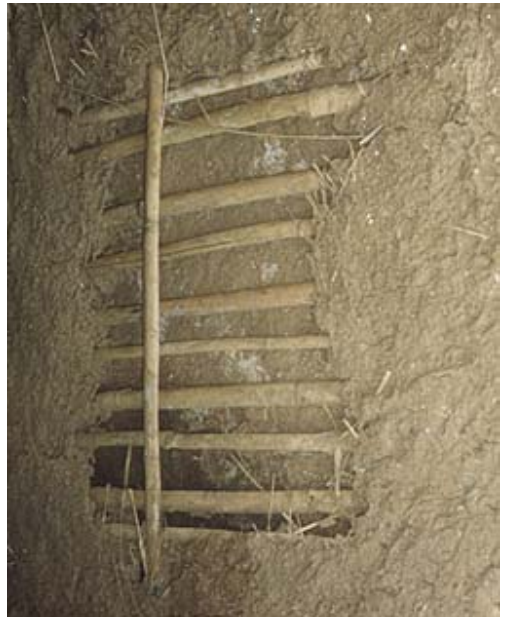

Figura 132: Parede em taipa de sebe.

Fonte: HCURB. 2007. barro, água e fibras (palha, capim, esterco, etc.). Depois de secas, as paredes recebem a impermeabilização necessária (Figura 132).

Nesse contexto, cabe ressaltar que existem algumas desvantagens na construção de moradias em taipa. Uma delas é que o barro não é um material padronizado, dependendo das características do solo de onde foi retirado pode apresentar maior granulosidade e impurezas. Ele também se contrai ao secar, podendo apresentar fissuras em sua superfície devido à evaporação da água140. 0 barro não é impermeável e, principalmente em regiões de clima frio, as paredes devem receber tratamentos em sua superfície podendo ser caiadas ou a elas aplicadas barras impermeabilizantes, além de isoladas termicamente. Apresenta ainda uma fraca resistência à atividade sísmica. Por outro lado, e quando supridas essas carências, a taipa como técnica de construção natural tem qualidades excepcionais (MINKE, 1999).

Essa técnica se mostra uma ótima opção para a edificação de moradias populares quando empregada de forma adequada, por ser: econômica; resistente; por permitir ser construída em mutirão, podendo ser utilizada mão-de-obra não qualificada, inclusive a população a quem vai ser destinar as

\footnotetext{
${ }^{139}$ Atualmente, o processo de compressão é feito com ajuda de pilões pneumáticos (MINKE, 1999).

140 A retração linear, o quanto de água é evaporada no processo de secagem das peças construídas com misturas que envolvem barro, varia entre 0,4 e $2 \%$ em técnicas com misturas secas utilizadas para a taipa e nos blocos compactados (MINKE,1999).
} 
unidades residenciais; por permitir construções de caráter provisório; por ser resistente ao fogo; por representar um bom isolante acústico; por mostrar-se uma opção construtiva a ser utilizada em locais de difícil acesso para transporte de materiais; e por não haver desperdício de material. A utilização do bairro na construção civil também não evidencia agressão ao meio ambiente, não envolve combustão ou poluição industrial, economiza energia e diminui a contaminação ambiental141, absorve contaminantes dissolvidos em água, e regula a umidade e a temperatura dos ambientes - apresentando capacidade de absorver ou expelir umidade mais rápido e em maior quantidade que outros materiais construtivos, regulando o clima interior, armazenando calor em locais onde as diferenças de temperatura são amplas. A taipa também é de fácil manuseio e é reutilizável. Quando necessário, as paredes podem ser demolidas e o barro moído e umedecido com água pode ser empregado para diversos fins, e o próprio morador pode abrir e fechar vãos, assim como, ampliar a estrutura dependendo de suas necessidades.

Essas especificidades são, de maneira geral, ignoradas pelas administrações públicas que consideram as moradias em taipa como sendo habitações sub-humanas, não existindo nem linha de crédito nos órgãos do governo que realizem financiamentos para a aquisição desse tipo de moradia. Sem falar nos estigmas que essa técnica remete e que resultaram em verdadeiros programas de erradicação dessa tipologia construtiva nos séculos XIX e XX.

Em Natal, especificadamente, são diversos os casos de moradias financiadas pelos IAPS (construídas pelos Institutos, pelos associados e/ou adquiridas de terceiros) em que se evidencia o uso da taipa. Essas moradias apresentaram paredes externas ou as divisões internas em taipa, ou são completamente edificadas com essa técnica. Os casos mais recorrentes na cidade remetem à estrutura externa em alvenaria e paredes internas em taipa ou à fachada em alvenaria e as demais paredes externas e internas em taipa (Figuras 133 e 134).
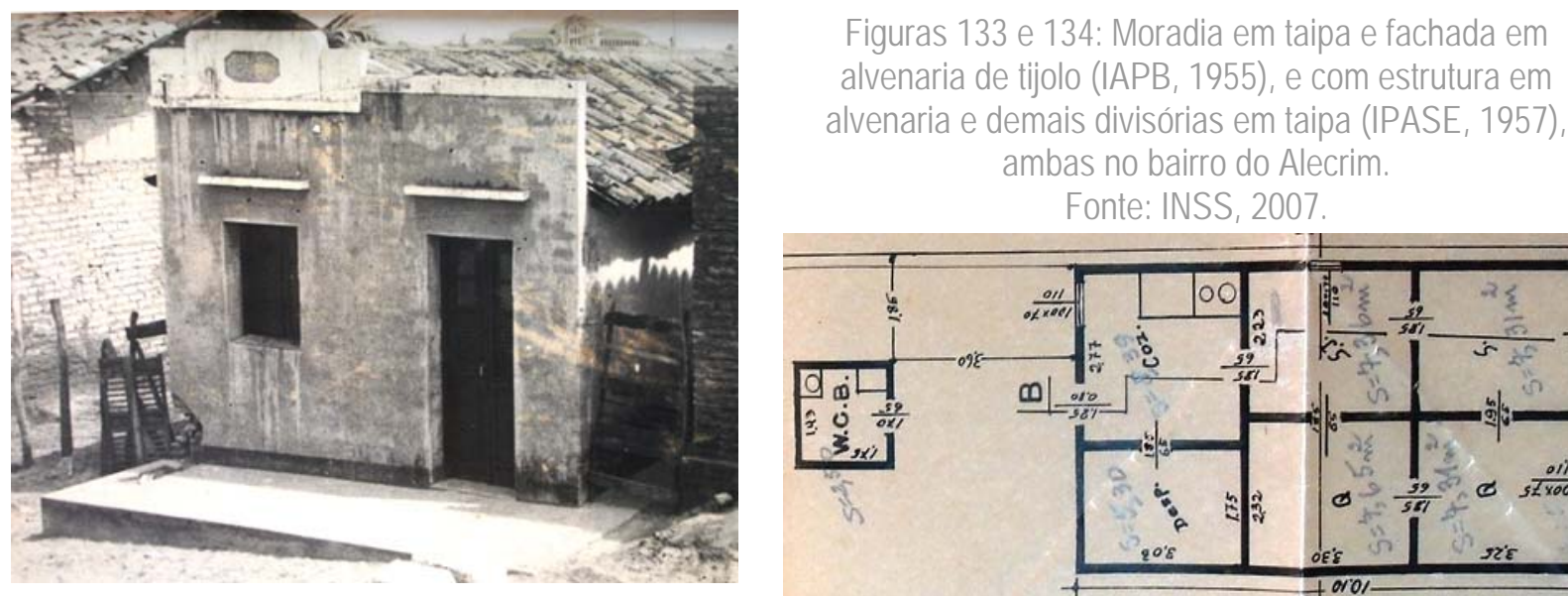

Figuras 133 e 134: Moradia em taipa e fachada em alvenaria de tijolo (IAPB, 1955), e com estrutura em alvenaria e demais divisórias em taipa (IPASE, 1957), ambas no bairro do Alecrim. Fonte: INSS, 2007.

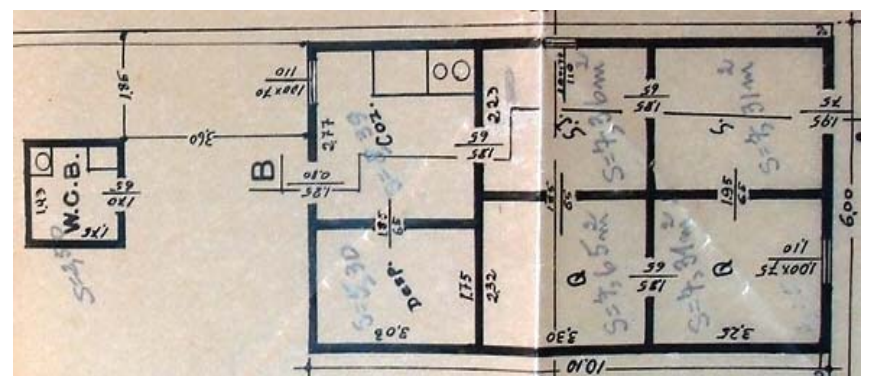

\footnotetext{
${ }^{141}$ As construções em taipa praticamente não produzem degradação ambiental. Para preparar, transportar e trabalhar com 0 material no local da construção necessita-se apenas cerca de $1 \%$ da energia gasta com outros materiais como, por exemplo, 0 concreto armado e o tijolo comum.
} 
As solicitações dos associados não se restringiam essencialmente à construção e à aquisição de moradias em taipa, mas também às solicitações para a realização de reformas de casas de taipa, retelhamento, substituição de cobertura, substituição de paredes e construção de fossas. Cabe ressaltar que muitos dos casos indicavam no laudo de avaliação dos imóveis, exigido para dar prosseguimento aos financiamentos, estruturas em alvenaria e/ou pedra, mas as escrituras públicas e, em alguns casos os registros fotográficos e os projetos arquitetônicos, revelavam que as moradas foram efetivamente construídas em taipa. A comprovação de certos casos foi prejudicada pelo fato de muitas das residências construídas, principalmente entre as décadas de 1940 e 1950, terem sido demolidas ou terem passado por reformas.

O Instituto que mais apresentou registro de residências parcialmente ou totalmente construídas em taipa foi o IAP dos Industriários. Cerca de $20 \%$ dos financiamentos realizados pelo referido Instituto em Natal, encontrados nos arquivos do Patrimônio Imobiliário do INSS-RN, indicam nos laudos de avaliação construções em taipa. Em 10\% dos processos levantados não foi possível afirmar qual o tipo de estrutura e fechamento das residências. Dentre as moradias edificadas em taipa, 78,26\% foram adquiridas por compra a terceiros pelos associados, 13,04\% equivale ao número de casas de propriedade do Instituto construídas ou adquiridas -, 4,35\% equivale à porcentagem de financiamentos concedidos para construção de moradias em terrenos dos próprios associados utilizando-se essa técnica e em 4,35\% dos processos não foi possível a identificação do tipo de pleito142.

A grande maioria das casas encontra-se localizada no bairro do Alecrim, enquanto os demais registros apontam o bairro de Lagoa Seca. A maior parte dos financiamentos, cerca de $90 \%$ deles, data das décadas de 1940 e 1950, principalmente dos anos de 1946 e 1958 (coincidindo com os picos da produção dos IAPs na cidade), sendo 13,04\% dos financiamentos foram concedidos na década de 1950. Não se observou nenhum registro de financiamentos nas décadas de 1930 e 1960 onde a taipa foi empregada. De modo geral, as moradias não apresentavam mais de $50 \mathrm{~m}^{2}$. As casas apresentavam dimensões mínimas e a distribuição dos cômodos em planta se dava de modo convencional, apresentando na maior parte dos casos apenas um quarto, o que retrata moradias bastante modestas. Os valores dos pleitos variavam entre $\mathrm{Cr} \$ 7.000,00$ (sete mil cruzeiros) e $\operatorname{Cr} \$ 32.000,00$ (trinta e dois mil cruzeiros), mas a maior parte dos financiamentos se enquadra na faixa dos $\operatorname{Cr} \$ 16.000,00$ (dezesseis mil cruzeiros). Os valores solicitados e concedidos pelo IAPI para a aquisição ou construção de moradia em taipa não diferem dos valores concedidos para as demais moradias, o que revela que a escolha pela moradia em taipa não equivalia à questão de economia ou à redução dos custos com o financiamento.

\footnotetext{
${ }^{142}$ A determinação do número exato de moradias edificadas em sua totalidade utilizando-se da técnica em taipa não foi possível de ser apontada devido à falta de dados.
} 
O único grupo de casas edificado utilizando-se taipa pelo próprio IAP dos Industriários no período em que atuou na capital norte-riograndense equivale à Vila São Pedro, o primeiro grupo de nove casas edificado pelo Instituto em Natal, no ano de 1946. A Vila corresponde a uma das únicas edificadas pelos Institutos que possuía os serviços de distribuição de água e coleta de esgotos, além da energia elétrica.

Em se tratando das moradias em taipa adquiridas pelo IAPI e repassadas aos seus associados, merecem destaque a Vila Regis e a compra de um grupo de seis casas pertencentes a Alfredo Edeltrudos de Souza, em 03 de agosto de 1946, pelo valor de Cr\$38.100,00 e repassadas para os associados por Cr\$7.500,00 cada uma. As moradias estão situadas na Rua Alípio Bandeira, no bairro do Alecrim. Os terrenos possuíam testada estreita, com $6 \mathrm{~m}$, e comprimento de aproximadamente $25 \mathrm{~m}$. As casas foram construídas por volta de 1945 e possuíam duas salas, dois quartos, cozinha e banheiro externo, com $45 \mathrm{~m}^{2}$, além de cobertura em telha colonial (Figuras 135 e 136). Outros exemplos de moradias de taipa adquiridas pelos associados do IAPI podem ser citados. São eles: a residência encravada à Rua Manoel Miranda, №. 1614, no Alecrim, cujas paredes divisórias, da despensa e da cozinha foram erguidas em taipa; a casa №. 1384, situada na Rua Presidente Mascarenhas, no Alecrim, com duas salas, dois quartos, cozinha e banheiro externo, totalizando $43 \mathrm{~m}^{2}$ e construída toda em taipa.

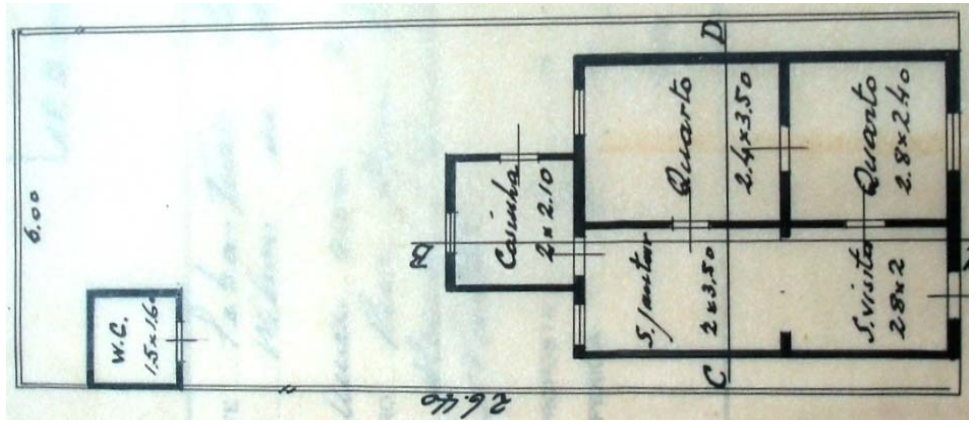

Figura 135: Planta baixa das residências da Rua Alípio (IAPI, 1945). Fonte: INSS, 2007.

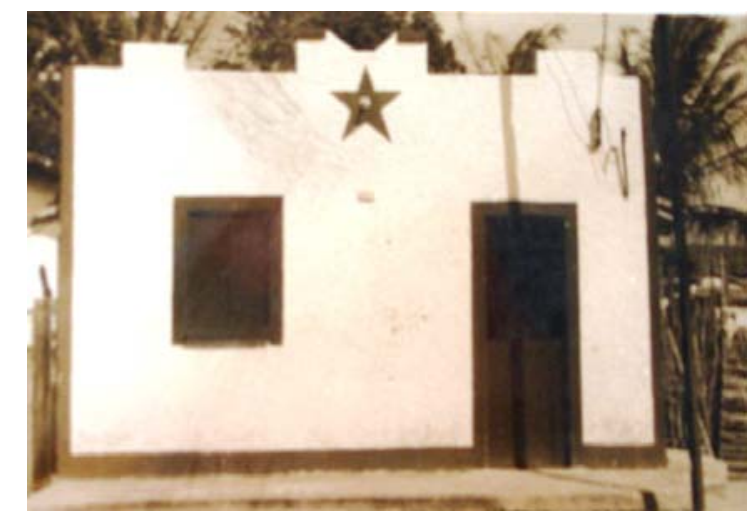

Figura 137: Residência em taipa (IPASE, 1951). Fonte: INSS, 2007.

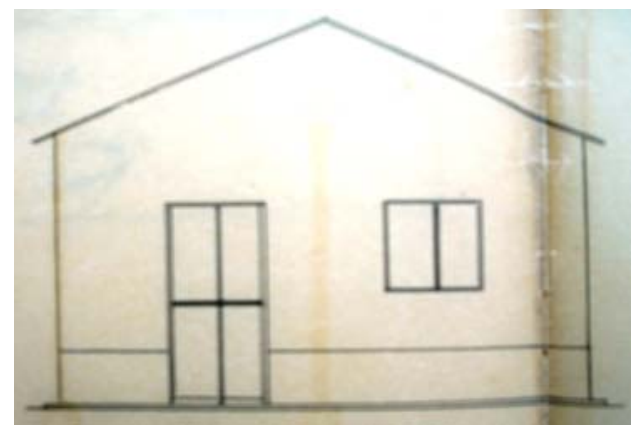

Figura 136: Residências da Rua Alípo. Fonte: INSS, 2007.

O Instituto de Aposentadorias e Pensões dos Servidores Públicos Estaduais (IPASE) também apresentou uma significativa porcentagem de moradias erguidas em taipa. Dos financiamentos realizados pelo IPASE em Natal, aproximadamente $5 \%$ correspondem às residências em que essa técnica construtiva foi empregada, mas diferente do caso do IAPI a totalidade dos pleitos equivale à compra de casa por meio de hipotecas. Todas as moradias encontram-se encravadas no bairro do Alecrim e foram construídas em meados da década de 1950 (Figura 137). Os valores dos financiamentos variam entre $\operatorname{Cr} \$ 58.000,00$ (cinqüenta e oito mil cruzeiros) e 
Cr\$78.000,00 (setenta e oito mil cruzeiros), o que leva a concluir que não se tratava de moradias destinadas à camada mais carente da carteira profissional. Algumas chegavam a possuir $200 \mathrm{~m}^{2}$. Os salários dos associados e promitentes proprietários oscilavam entre $\operatorname{cr} \$ 1.000,00$ (mil cruzeiros) e Cr $\$ 7.000,00$ (sete mil cruzeiros), enquanto os rendimentos mensais dos associados do IAPI acima referidos não passavam dos Cr $\$ 1.000,00$ (mil cruzeiros), comprovando assim que os pleitos se destinavam a uma camada mais abastada de trabalhadores do que os casos evidenciados no âmbito do IAPI. Todos os financiamentos se enquadravam nas especificações do plano $C$, que correspondia à construção de casa mediante garantia hipotecária, à compra de casa onde o associado já residia pagando aluguel, ou à solicitação de financiamentos para a aquisição de moradias quando o associado encontravase sob ação de despejo.

No âmbito dos financiamentos concedidos pelo IAP dos Comerciários aos seus associados em Natal e que se referiam às construções em taipa, apenas poucos registros foram encontrados. Esses correspondiam ao grupo de casas localizadas na Rua Coronel José Bernardo, no bairro do Alecrim. As moradias apresentavam apenas a fachada principal em alvenaria, sendo as demais paredes externas e internas em taipa. O valor dos financiamentos para a aquisição dessas unidades era de $\operatorname{Cr} \$ 29.500,00$ (vinte e nove mil e quinhentos cruzeiros), de acordo com o plano B-III do Instituto (correspondia à compra de terreno do IAPC ou não, para a edificação de imóvel ou à compra de casa pertencente a terceiros). Os pleitos datam de 1948, mas a data de aquisição do grupo de casas pelo IAPC, assim como, a data de construção e maiores informações sobre ele não puderam ser precisadas devido ao fato de que essas moradias foram demolidas para a construção, principalmente, de pontos comerciais. As casas possuíam em planta: terraço, duas salsas, dois quartos, cozinha e banheiro, totalizando $90 \mathrm{~m}^{2}$. Nos financiamentos efetivados pelos demais Institutos atuantes em Natal não foram encontrados registros de compra, construção e reforma em moradias construídas parcialmente ou totalmente em taipa. 


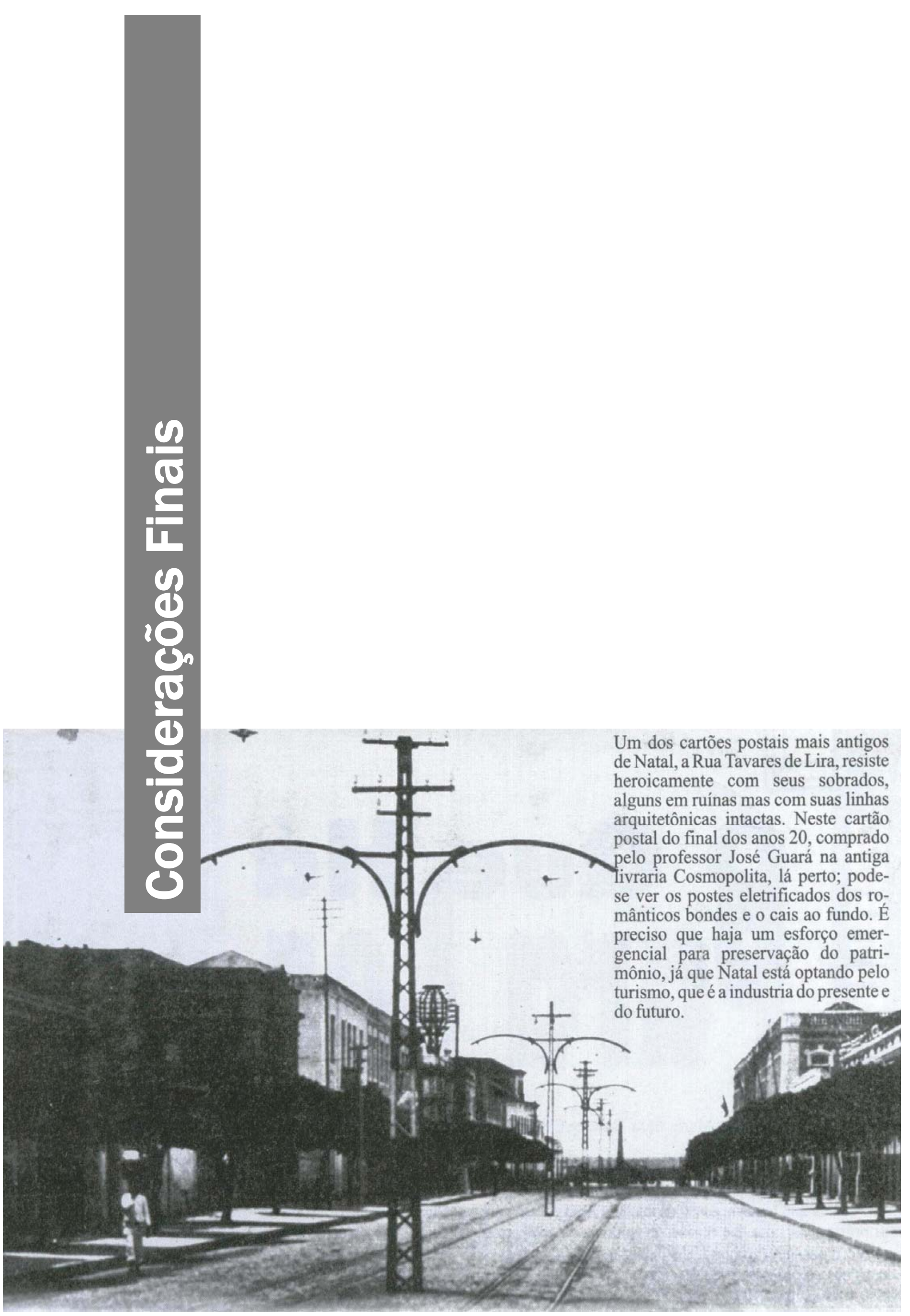




\section{CONSIDERAÇÕES FINAIS}

O rápido crescimento das cidades brasileiras em fins do século XIX, as altas concentrações de trabalhadores carentes sem condições de angariar moradias e a escassez de habitações de aluguel com valores acessíveis ocasionaram, não somente, uma população mal alojada, mas também resultaram no aumento da concentração de moradores por residência e na popularização de tipologias habitacionais alternativas, como os cortiços e os mocambos.

De modo geral, as interpretações e os registros das moradias populares no país, ou das alternativas dadas a elas, são acompanhadas por uma visão elitista acerca das precárias condições higiênico-sanitárias e "morais", assim como, por discursos arraigados de preconceitos que desconsideravam essas soluções como condizentes com o conceito de cidade sã e bela compartilhado por setores das elites. Essa conjuntura impulsionou uma gama de ações promovidas pelos setores públicos e pela iniciativa privada que almejavam a melhoria ou a erradicação das tipologias habitacionais das camadas populares, ou ainda, a transferência delas para locais distantes dos centros das cidades, nos arrabaldes, subúrbios e periferias. Em outro plano, essas ações também pretendiam reformular o modo de morar e a própria moradia no Brasil. No bojo dessas transformações procedeu-se, principalmente, à incorporação de novas técnicas e materiais a fim de tornar a habitação mais econômica, padronizando os elementos construtivos e acelerando o processo de produção.

Em Natal, a ação estatal no campo da moradia social foi estruturada como resposta imediata aos problemas evidenciados e/ou intensificados nos momentos de agravamento da crise habitacional na cidade ao longo do século XX. A habitação social, por outro lado, se afigurou como um elemento comum nos discursos dos governantes e por diversas vezes foi utilizada como justificativa para a realização de obras no âmbito da cidade, sobretudo, referentes à sua modernização.

Entre os anos de 1889 e 1909, o poder público interveio no campo da habitação por meio de uma legislação rigorosa para construção e adequação de habitações, que objetivava reverter o quadro sanitário da cidade de Natal. As ações ocorreram concomitantemente e com as mesmas especificidades daquelas implementadas nos grandes centros urbanos do país. Isso ocorreu devido ao considerável interesse das administrações locais e de setores da elite em manter as realizações no espaço construído da cidade em sintonia com as efetivadas no campo da moradia e infra-estrutura naquelas localidades do Brasil. A formação acadêmica e as constantes viagens realizadas pelos governantes locais às cidades européias, norte-americanas e no país, também contribuíram para tanto. As obras realizadas nesse primeiro momento são caracterizadas por uma exacerbada preocupação para com os aspectos físicos da cidade e guiadas por normas de caráter regulador e punitivo.

Entre os anos de 1910 e 1929, a administração pública passou a identificar a existência de um problema de habitação das camadas mais carentes da população, essencialmente mendigos e migrantes, 
mas ainda bastante vinculado às questões higiênicas e à estética da cidade. Nesse período foram formulados os primeiros projetos para a construção de grupos de moradias, que apesar de não terem sido construídas, indicaram uma mudança na ação governamental no campo da moradia social em Natal.

A partir da década de 1930, o Estado passou a considerar a existência do problema de déficit habitacional, bem como passou a incluir em suas ações nesse setor a concessão de moradias aos pobres e/ou migrantes, configurando-se assim, o terceiro momento de intervenção estatal no setor habitacional da cidade (1930-1954). O Estado passou dessa forma a se afigurar como um agente que disponibilizava não somente a infra-estrutura necessária e a implantação de moradias, mas também, financiava a sua compra ou possibilitava a aquisição de materiais e a contratação da mão-de-obra para edificação delas. Esse momento foi marcado pelo crescimento do mercado imobiliário na cidade e pelas crescentes elevações nos valores de locação, resultantes da escassez de moradias durante a II Guerra Mundial. A partir de meados da década, encenou-se a intensificação da construção de vilas operárias e militares na cidade, principalmente, pelos Institutos de Aposentadoria e Pensões (IAPs) e pela Fundação da Casa Popular (FCP).

Com a inserção da habitação nos programas governamentais, em 1955, observou-se outra mudança da atuação da administração pública frente aos problemas habitacionais, representados nesse momento (1955-1964), principalmente pelo surgimento e diversificação das favelas na cidade, como também, pela intensificação do mercado imobiliário informal, loteamentos irregulares e ocupações diversas, responsáveis pela considerável expansão horizontal de Natal. O Estado continuou a conceber moradias por meio dos já consolidados IAPs e da FCP, como também pela Fundação da Habitação Popular do Rio Grande do Norte (FUNDHAP), a partir de 1963.

As ações estatais no recorte temporal abordado nessa dissertação foram acompanhadas pela limitação dos instrumentos públicos de fiscalização e controle da ocupação e uso do solo da cidade, essencialmente voltados às moradias, o que levou a concluir que a produção do solo natalense ficou a cargo em diversos momentos, como no início do século, sobretudo, dos interesses privados. Em se tratando dos regimentos para construções de residências no período estudado, operaram-se as Resoluções Municipais, verbalizadas pelos Códigos de Posturas, os regulamentos dos órgãos de Higiene, Saúde Pública e Saneamento e, a partir de 1929, dos Códigos de Obras Municipais, que no decorrer da década de 1950 e meados da década de 1960, permaneceram quase sem alterações significativas e se tornaram obsoletos frente ao rápido crescimento por que a cidade passou. Nota-se, portanto, uma mudança do papel do Estado, que passou paulatinamente ao longo do século $X X$, de mero legislador para uma ação mais ampla no espaço de morar, como promotor direto de residências, sobretudo, no campo da habitação social. 
No tocante à construção propriamente dita de moradias sociais em Natal, merece destaque a atuação do Estado por meio dos Institutos de Aposentadorias e Pensões (IAPs) que, através da concessão de financiamentos para aquisição de moradias aos trabalhadores das carteiras profissionais, contribuíram para amenizar o déficit habitacional na cidade, essencialmente entre os anos de 1945 e 1950 e 1956 e 1958, em especial nos anos de 1946 e 1958, quando foram evidenciados os maiores picos das atuações dos Institutos na cidade.

No entanto, essa ação do Estado se configurou, na realidade, como uma medida excludente uma vez que não incorporou a população como um todo, deixando à margem do processo as camadas mais carentes. Tal situação pode ser constatada pelo crescimento e diversificação das favelas já existentes, pela proliferação de ocupações de terrenos vazios na cidade, bem como pela intensificação do mercado informal de terras, marcada principalmente pela proliferação dos loteamentos clandestinos.

Em se tratando da organização das ações imobiliárias dos IAPs em Natal, observou-se que 0 modelo de planos e classes não se mostrou semelhante ao esquema largamente conhecido e adotado na historiografia especializada, no qual são especificados os planos A e B como referentes aos financiamentos sociais, e o plano C como condizente com as ações que visavam lucros. Na capital norteriograndense, o arranjo dessas ações variou bastante de Instituto para Instituto, não existindo em alguns casos inclusive a distinção em planos. Essas variações também foram observadas quanto: às exigências e documentos exigidos para a liberação dos processos; aos prazos para amortização da dívida; aos valores máximos e mínimos liberados para os financiamentos; aos juros praticados; e às demais taxas cobradas aos associados. Dessa forma, constatou-se ao longo do trabalho a impossibilidade de classificar a produção dos Institutos na cidade de Natal utilizando-se do modelo que define os planos A, B e C, aplicado por autores como Nabil Bonduki e Marta Ferreira Santos Farah, por exemplo.

Outra especificidade da atuação dos IAPs em Natal refere-se aos financiamentos concedidos aos trabalhadores natalenses. Percebeu-se, nesse sentido, um processo diferente daquele que a historiografia especializada afirma ter ocorrido nas grandes e médias cidades brasileiras no período de atuação dos Institutos no país. Diferentemente do verificado em cidades como São Paulo e Belo Horizonte, onde os IAPs atuaram quase que exclusivamente para atender a demanda por habitações sociais sob a forma de construção de unidades habitacionais, em Natal, a maior parte dos processos aprovados referia-se à aquisição de moradias de terceiros pelos Institutos e o repasse delas aos associados, ou à compra de habitações realizada diretamente entre proprietários (terceiros) e beneficiados. O número de moradias e grupos delas edificado na cidade por esses órgãos é ínfimo (cerca de 10 grupos) se comparado à quantidade total de pleitos concedidos, que se aproxima de duas mil unidades habitacionais.

Da mesma forma, percebeu-se que a essência social das ações imobiliárias dos IAPs em Natal foi perdendo o espaço e a significância no processo construtivo das moradias com o passar dos anos. 0 
maior volume de ações sociais executadas na capital norte-riograndense remete ao IAP dos Industriários (IAPI), que também corresponde ao órgão que mais edificou moradias na cidade. Os demais Institutos apresentaram, principalmente, ações caracterizadas como atuariais, financiando moradias de alto padrão ou concedendo pleitos aos associados de alto poder aquisitivo como foi o caso do IAP dos Bancários (IAPB), do IAP dos Comerciários (IAPC) e do IAP dos Servidores Públicos Estaduais (IPASE). O que correspondeu a uma perda significativa do caráter social das ações dos IAPs na cidade, prevista por lei no momento da criação das Carteiras Prediais.

Outra particularidade observada foi que na capital norte-riograndense as moradias construídas e/ou adquiridas pelos IAPs eram vendidas ou hipotecadas aos seus contribuintes, quase não havendo registro de moradias somente alugadas. O objetivo principal das ações dos Institutos na cidade era 0 de prover a casa própria, assim como verificado no âmbito da FCP e da FUNDHAP. Sendo assim, o acesso às moradias sociais em Natal entre as décadas de 1940 e 1960 foi viabilizado pelo mercado de imóveis e não pelo mercado de aluguéis, por meio de financiamentos realizados pelo Estado ou subsidiados pelo poder público.

Apesar da retórica e do largo debate acerca das moradias econômicas, mínimas e sociais, observou-se que os projetos endereçados aos trabalhadores natalenses, assim como o próprio modelo de habitação social, estavam muito mais presentes nos discursos que nas obras dos arquitetos e engenheiros dos IAPs e da Prefeitura na cidade, ao longo do recorte temporal estudado. Verificou-se que alguns dos grupos de moradias construídos ou adquiridos pelos IAPs, pela FCP e pela FUNDHAP em Natal se assemelhavam às vilas construídas nos primeiros anos do século $X X$, que quando ocupadas pela população de baixa renda eram comumente chamadas de "cortiços-pátio". Esses empreendimentos se conformavam geralmente, por moradias geminadas (duas a duas ou em fila) distribuídas ao longo de um corredor ou pátio, com cômodos quase sempre sem iluminação ou ventilação adequadas, interligados entre si e por grandes circulações (corredores), possuindo latrinas no quintal. Eram moradias instaladas, mormente em áreas impróprias, propícias à alagamentos, abaixo do nível do arruamento e próximas aos locais tidos ainda naquela época como insalubres (vacarias, cemitérios, matadouros, lixões, dentre outros). Ainda assim, essas unidades habitacionais foram consideradas pelos próprios Institutos e pela opinião pública em geral, como moradias que supriam as necessidades básicas dos trabalhadores humildes natalenses e ofereciam condições aceitáveis de habitabilidade, conforto e higiene. Em outras situações, no entanto, seriam imputadas como cortiços, casebres, dentre outras várias denominações.

Também ao contrário do evidenciado no cenário nacional, a maior parte dos imóveis construídos pelos IAPs, pela FCP e pela FUNDHAP em Natal não costumavam prever equipamentos coletivos, sendo desprovidos em diversos casos até de infra-estrutura básica. Os únicos conjuntos edificados por esses órgãos na cidade onde se observou a preocupação com esses aspectos foi o Conjunto Residencial Nova 
Tirol, construído pelo IAPC em 1956, e o Conjunto Residencial Cidade da Esperança, erguido em 1964 pela FUNDAHP.

Os locais onde foram implantadas as moradias - muitas vezes sem infra-estrutura de transportes e serviços básicos -, a ausência de uma atuação efetiva do poder público no tocante à implantação de serviços, comércio e lazer quando previstos nos projetos e a inexistência de instrumentos urbanísticos reguladores adequados à realidade das transformações dos grupos de moradias adquiridos ou edificados pelos IAPs e pelas Fundações, foram fatores que contribuíram para a descaracterização das construções em Natal. O resultado dessa política foi a construção de conjuntos e grupos de moradias sem arborização, sem conforto ambiental, com moradias que não ofereciam, por vezes, uma boa qualidade de vida à população.

Essa conjuntura ocasionou também transformações nas moradias, equipamentos e espaços públicos pelos moradores, com o intuito de atender às carências e funções não previstas inicialmente nos projetos habitacionais, o que muitas vezes resultou na descaracterização completa dos conjuntos, dificultando a análise dos grupos de moradias existentes e a precisão de alguns aspectos, essencialmente do número exato de moradias e das características de seus espaços comuns. Cabe também ressaltar as dificuldades enfrentadas para a realização dos levantamentos, sobretudo, nos arquivos públicos da cidade de Natal - Instituto Histórico e Geográfico do Rio Grande do Norte, Arquivo Público do Estado, Arquivo da Cúria da Catedral e INSS-RN - devido às precárias condições físicas para pesquisa e à desorganização do material arquivado.

No tocante às inovações arquitetônicas dos grupos habitacionais erguidos pelos Institutos e pelas Fundações, pouco se pode citar no caso natalense. Apesar das determinações do Conselho Nacional do Trabalho (órgão responsável pela normatização, fiscalização e aprovação dos procedimentos dos IAPs, ligado ao Ministério do Trabalho) quanto à utilização dos pressupostos da arquitetura moderna, apenas um exemplar foi edificado em Natal de acordo com esses ditames, correspondendo ao Conjunto Residencial Nova Tirol (conjunto misto de edifícios coletivos, casas isoladas e geminadas), cujos quatro blocos laminares de três e quatro pavimentos sem ornamentos se aproximam das soluções alemãs de Siedlungen. Apesar de não construírem largamente moradias modernas em Natal, os Institutos financiaram a construção e disponibilizaram seus engenheiros para a elaboração de diversos projetos que se aproximavam em certos aspectos dessa forma de projetar, e que foram executados por dezenas de construtores atuantes na cidade entre as décadas de 1940 e 1960. Cabe destacar que grande parte desses projetos não se destinava às camadas mais carentes da população. Os Institutos que mais promoveram a edificação de moradias de arquitetura moderna foram o IAP dos Bancários (IAPB) e o IAP dos Servidores Públicos Estaduais (IPASE). Observou-se também que as adequações das moradias aos princípios da arquitetura moderna eram empregadas mais nas fachadas das unidades residenciais do que 
na planta propriamente dita, revelando a incorporação apenas parcial dos pressupostos de arquitetura moderna na cidade nesse setor.

Considera-se que para a historiografia da habitação social no Brasil, a principal contribuição dessa dissertação foi a identificação de um número significativo de moradias construída em taipa e inseridas nas ações imobiliárias dos Institutos de Aposentadorias e Pensões (IAPs) em Natal, fosse por via de construção, de aquisição e de repasse, ou por meio de financiamentos para a realização de reformas. Tais moradias chegaram algumas vezes a corresponder a $20 \%$ dos financiamentos concedidos pelo Instituto, como foi o caso IAP dos Industriários. A taipa, ao longo do recorte temporal estudado, foi por diversas vezes tida como material não condizente com a edificação de moradias, por ser pouco resistente $\mathrm{e}$ insalubre. Essas características foram expressas em diversas formulações publicadas na cidade, inclusive em algumas resoluções e portarias que balizavam às ações imobiliárias das Carteiras Prediais dos Institutos em Natal. Publicações essas, que primavam essencialmente pela edificação de unidades habitacionais condizentes com os pressupostos do urbanismo e da arquitetura moderna em voga no país. Essa peculiaridade, por outro lado, revelou a adaptação das moradias às especificidades regionais e climáticas nordestinas, assim como, a formulação de alternativas de moradias mais acessíveis às camadas mais carentes da população natalense.

Face ao exposto acima, classificar a atuação dos IAPs no Brasil de maneira homogênia e inovadora mostra-se, portanto, um procedimento precipitado. No caso de Natal, a significativa parcela das moradias financiadas e/ou edificadas pelos Institutos, pertencentes ou não aos conjuntos e vilas, apresentavam tipologias e plantas tradicionais e empregaram materiais comumente utilizados na região, com destaque para a taipa.

Em conjunto, os Institutos de Aposentadorias e Pensões (IAPs), a Fundação da Casa Popular (FCP) e a Fundação da Habitação Popular do Rio Grande do Norte (FUNDHAP) atenderam, entre os anos de 1944 (data do primeiro financiamento) e 1964, aproximadamente 3.100 famílias. Esse volume de concessões assistiu a 8,12\% da população residente em Natal em meados da década de 1960. Comparando à produção nacional, a atuação dos Institutos na cidade equivaleu a $2 \%$ do volume de financiamentos concedidos pelos IAPs no país, enquanto a FCP edificou na capital norte-riograndense 2,75\% das unidades erguidas no território nacional.

Em todo o recorte temporal estudado verificou-se que a ação estatal no campo da moradia social foi acompanhada por indícios de segregação espacial e social, que impossibilitaram que diferentes camadas da população sofressem da mesma maneira com os efeitos da crise urbana. De modo geral, a segregação garantiu às classes mais abastadas áreas de uso exclusivo, livres de deterioração, capacitadas de toda infra-estrutura e equipamentos necessários, como os bairros de Petrópolis e Tirol. As camadas mais carentes, por sua vez, foram resguardadas em áreas específicas, distantes do centro da 
cidade ou em bairros reservados para elas, como Lagoa Seca, Dix-Sept Rosado, Quintas e Alecrim, destino da maior parte das realizações dos IAPs na cidade.

Observou-se também, que a casa própria nos arrabaldes da cidade passou a se mostrar uma alternativa mais viável do que o aluguel de uma casa nos bairros centrais de Natal a partir da década de 1940. Vislumbrando isso, as administrações públicas passaram a construir conjuntos residenciais e a incentivar a ocupação das áreas periféricas da cidade. No entanto, apesar da ousadia de alguns projetos urbanísticos e da variedade de equipamentos, esses empreendimentos esbarravam na precariedade do sistema de transporte, fazendo com que essa alternativa perdesse um pouco do atrativo para as camadas mais carentes da população. Sendo assim, a perspectiva de urbanização (regulamentada) da periferia foi mais direcionada às classes médias e altas devido aos altos custos de implantação de serviços e equipamentos absorvidos pelo preço de venda dos lotes. Somente após a reestruturação do sistema de transportes caracterizada pela total substituição dos bondes por ônibus e da abertura e capacitação de vias, concluída na década de 1950, foi que se deu a ocupação das áreas limítrofes e a difusão da casa própria auto-construída na periferia da cidade de Natal. O maior exemplo equivale à criação do Conjunto Residencial Cidade da Esperança, na década de 1960.

A construção de moradias para os segmentos mais carentes da população por parte do poder público no recorte temporal estudado, ainda que não tenha transformado a condição social, possibilitou consideráveis melhorias de vida para os natalenses contemplados. Por outro lado, reduziu o déficit habitacional em Natal.

Como ocorreu nas demais cidades brasileiras, os programas governamentais postos em prática pelos governantes da cidade, especialmente a partir de meados da década de 1950, assim como a concepção de moradias por meio dos IAPS, da FCP e pelos demais órgãos de âmbito estadual foram interrompidos com o Golpe Militar. Após 1964, a provisão de habitações para a população menos abastada tornou-se uma vertente importante na política social implementada pelo governo militar. Foi nesse contexto instituído o Sistema Financeiro de Habitação (SFH), cujo principal órgão era representado pelo Banco Nacional de Habitação (BNH) que, entre os anos de 1964 e 1986, financiou cerca de quatro milhões e meio de moradias no país. No entanto, de acordo com Sachs (1999), apenas 13\% dos recursos do $\mathrm{BNH}$ foram efetivamente destinados à promoção de habitações populares para famílias com renda mensal de até cinco salários mínimos. Essa conjuntura se assemelha ao caráter da atuação dos IAPs na cidade de Natal. O aprofundamento dessa questão, assim como, a averiguação das especificidades das ações imobiliárias dos Institutos de Aposentadorias e Pensões em toda a região Nordeste do país, e a compreensão das especificidades e dos dilemas das políticas sociais nas capitais nordestinas, enquanto responsabilidade do Estado, contextualizado-as no cenário das mudanças sociais contemporâneas, 
226 ||CONSIDERAÇÕES FINAIS

mostram-se outras vertentes que merecem ser aprofundadas, configurando dessa forma, possibilidades de trabalhos futuros. 


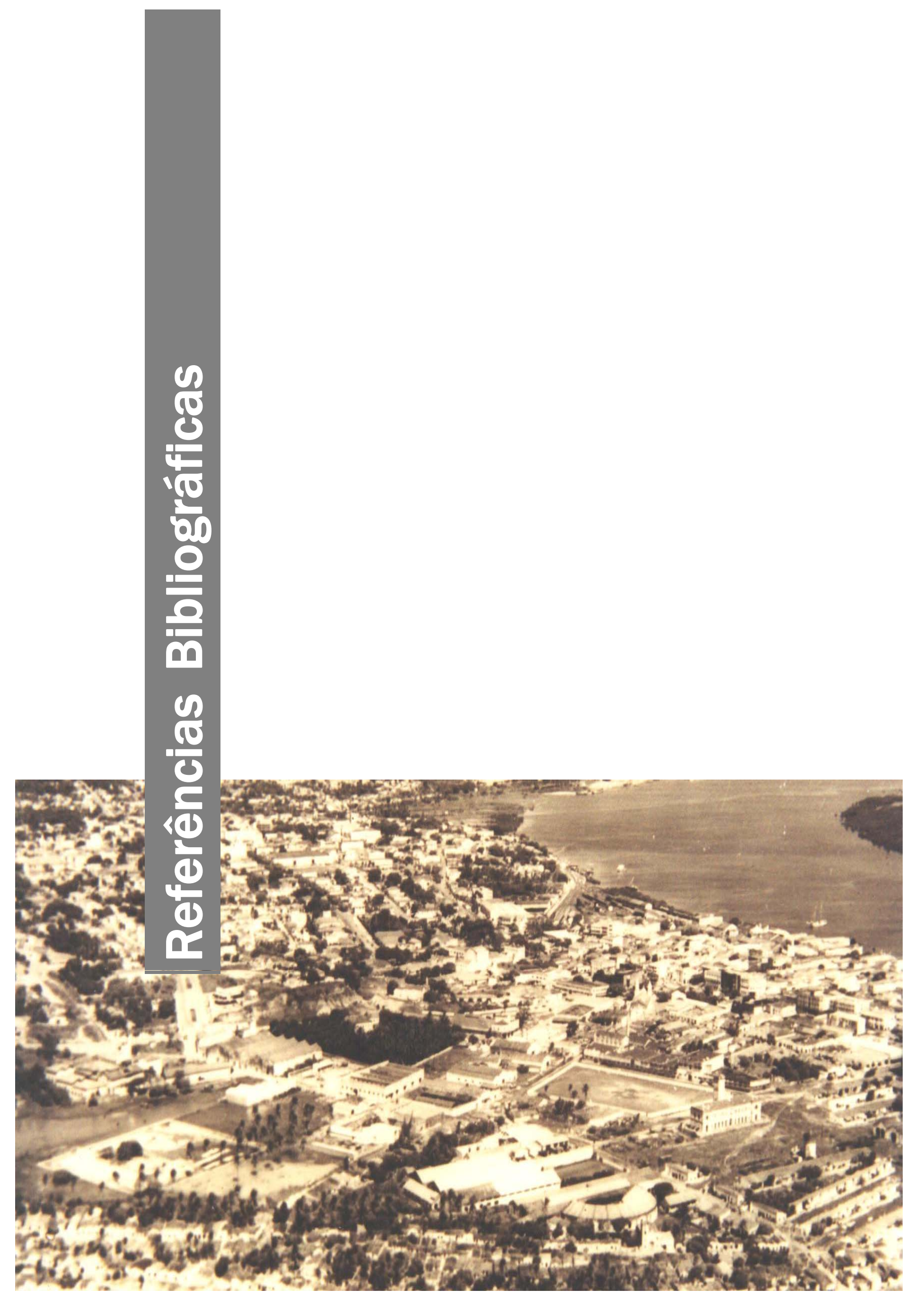




\section{REFERÊNCIAS BIBLIOGRÁFICAS}

A CIDADE. A República, Natal, 13 fev.1914. n.37, p.01.

A CIDADE. A República, Natal, 05 jun. 1919. s/n, p.01.

A CIDADE e os latifundios. A República, Natal, 16 mar. 1949. n.38, p.01.

A CIDADE infestada de mendigos e vagabundos. Jornal de Natal, 25 jan. 1955. n.1026, p.01.

ACTO N.8. A República, Natal 29 ago.1935. n.1396, p.06.

A EMPRESA Construtora e Saneamento Predial LTD e suas credenciais. A República, Natal, 02 fev. 1932. n.375, p.04.

A GUERRA tudo transforma. Diário de Natal, Natal, 30 jan.1945. n.937, p.08.

A INAUGURAÇÃO do calçamento da avenida Nísia Floresta. A República, Natal, 04 ago.1934. n.1089, p.01.

ALBERGUE noturno: A "Campanha do Tijolo" será iniciada amanhã. Jornal de Natal, Natal, 15 de dez.1951. n.575, p.04.

ALECRIM, Otacílio. Província submersa. Rio de Janeiro: Country Club, 1957.

Retractos da cidade. A República, Natal, 27 abr. 1929, n. 95, p. 01. (a)

. Retractos da cidade II. A República, Natal, 03 maio 1929, n. 99, p. 01. (b)

01. (c)

O plano da Cidade de Natal - standard da Propaganda. A República, Natal, 22 ago. 1929, n. 190, p.

ALMEIDA, Caliane Christie Oliveira de. "Caminhos da Habitação": um panorama geral das ações estatais em Natal, no século XX. Trabalho de graduação (monografia). Natal: UFRN, 2005.

ALUÍZIO. Vai construir casas. A República, 07/03/1964, n.87, p.05.

ALVES, Aluízio. 0 que eu não esqueci: reminiscências políticas (1933-2001). Rio de Janeiro: Leo Cristiano Editorial, 2001.

ANDRADE, Alenuska Kelly G, OLIVEIRA, Manuela Dantas de FERREIRA, Angela Lúcia de Araújo. Os hábitos de higiene e a "cidade moderna". In: 54a Reunião Anual da SBPC, 2002, Goiânia - GO.

ANDRADE, Carlos R. M. de. Barry Parker: um arquiteto inglês na cidade de São Paulo. São Paulo: FAUUSP, 1998. (Tese de Doutorado)

Ressonâncias do tipo cidade-jardim no urbanismo de cidades novas no Brasil. IN: Seminário de História da Cidade e do Urbanismo, 6, 2000, Natal. Anais... Natal: PPGAU, 2000. 1CD.

ANDRADE, Ilza Araújo Leão de (coor.). Igreja e política no RN: momentos de uma trajetória. Natal: Sebo Vermelho, 2000.

ANDRADE, Luis Aureliano Gama de; AZEVEDO, Sérgio de. Habitação e poder: da Fundação da Casa Popular ao Banco Nacional da Habitação. Rio de Janeiro: Zahar Editores, 1982. 135p.

ANTES de chegar a energia de Paulo Afonso. Jornal de Natal, Natal, 29 jan.1957. n.1533, p.01.

A ORDEM. Natal: 1950-1965. Publicação diária.

A PROMOTORA da casa própria. A República, Natal, 08 nov.1935. n.1453, p.02.

A PROPÓSITO das estéticas das casas de Natal. A República, Natal, 04 mar.1934. n.966, p.07.

A PROPÓSITO: da mendicância em Natal, a construção do "Dispensário Sinfronio Barreto". A República, Natal, 08 fev.1934. n.647, p.01.

ARAÚJO, Humberto H. de. Modernismo: anos 20 no Rio Grande do Norte. Natal: Universitária, 1995.

A REPÚBLICA, Natal, 21 jan.1891. s/n, p.04.

A REPÚBLICA, Natal, 16 jul.1892. s/n, p.04.

A REPÚBLICA, Natal, 24 ago.1903. s/n, p.03.

A REPÚBLICA, Natal, 15 jan.1925. n.11, p.01.

A REPÚBLICA, Natal, 03 dez.1932. n.608, p.01.

A REPÚBLICA, Natal, 27 set.1935. n.1420, p.01.

A REPÚBLICA, Natal, 03 dez.1935. n.1469, p.04. 
A REPÚBLICA. Natal: 1890-1964. Publicação diária.

AS NOVAS realizações da Prefeitura. A República, Natal, 19 fev.1932. n.388, p.01.

AS REALIZAÇÕES da administração revolucionária no Rio Grande do Norte. A República, Natal, 04 jan.1933. n.631, p.01.

ATENTADO à estética da cidade. Tribuna do Norte, Natal,15 out.1952. n.734, p.06.

AYMONINO, C. Origenes y desarrollo de la ciudad moderna. Barcelona: Gustavo Gili, 1973. 232p.

1973.

La vivienda racional. Ponencias de los congressos CIAM 1929-1930. Barcelona: Gustavo Gili,

A. Z. Observação do dia. Tribuna do Norte, Natal, 08 fev.1952. n.544, p.04.

BALZAC. Scenas e factos. Gazeta de Natal, Natal, 27 jun.1898. n.128, p.04.

BANCO DE DADOS HCURB. Natal: UFRN Departamento de Arquitetura, 2005.

BARBOSA, Reinaldo. Recebedoria de rendas: Imposto Territorial. A República, Natal 09 jan.1932. n.356, p.03.

BARCELLOS, Vicente Quintella. A clientela escolar no conceito de unidade de vizinhança: a experiência do

Plano Piloto de Brasília. 1993. Dissertação (Mestrado) - FAU/UnP, Brasília.

BENEVOLLO, Leonardo. Historia de La architectura moderna. Barcelona: Gili, 1974.

As origens da urbanística moderna. 2ed. (Tradução: Conceição Jardim e Eduardo L. de Nogueira).

Lisboa: Perspectiva, 1987.

BILRO, Miguel. Prefeitura de Natal/Acto n.8. A República, Natal, 29 ago. 1935. n. 1396, p.06.

BLAY, Eva Alterman (org.). A luta pelo espaço: textos de sociologia urbana. Rio de Janeiro: Vozes, 1978, 179p.

BLAY, Eva Alterman. Eu não tenho onde morar: vilas operárias na cidade de São Paulo. São Paulo: Nobel, 1985.

BONDUKI, Nabil (org.). Habitat: as práticas bem sucedidas em habitação, no meio ambiente e gestão urbana nas cidades brasileiras. São Paulo: Studio Nobel, 1996.

BONDUKI, Nabil. Origens da habitação social no Brasil: arquitetura, Lei do Inquilinato e difusão da casa própria. São Paulo: Estação Liberdade: FAPESP, 2002.

BRUAND, Yves. Arquitetura Contemporânea no Brasil. São Paulo: Perspectiva, 1981. 400p.

CALLEDO, Letícia. A revolução Industrial. São Paulo: Atual/UNICAMP, 1987.

CÂMARA DOS DEPUTADOS. Inquilinato (Lei n.4240, de 28-06-63). Câmara dos Deputados/Diretoria de Documentação e Publicidade. Brasília: Departamento de Imprensa Nacional, 1964.

CARPINTERO, Marisa Varanda Teixeira. Imagens do conforto: a casa operária nas primeiras décadas do século XX em São Paulo. In: BRESCIANI, Stella (org.). Imagens da cidade - séculos XIX e XX. São Paulo: Marco Zero/FAPESP, 1993.

CAMPOS, Cristina de. São Paulo pela lente da Higiene: as propostas de Geraldo Horácio de Paula Souza para a cidade (1925-1945). São Carlos: Rima, 2002.

CARVALHO, J. M. de. A formação das almas: o imaginário da república no Brasil. São Paulo: Cia das Letras, 1990.

CARVALHO, Rodrigues de. A Cidade de Natal. A República, Natal, 27 ago.1906. n.178, p.01.

CASA própria para os aeroviários / O Governo doou o terreno à CAPSATC. Tribuna do Norte, Natal, 03 jan.1953. n.799, p.04.

CASAS populares para o Rio Grande do Norte: construirá a Fundação da Casa Popular no interior do estado. A República, Natal, 28 mai.1957. n.119, p.04.

CASCUDO, Luís da Câmara. História da cidade de Natal. 2 ed. Rio de Janeiro: Civilização Brasileira; Brasília: INL; Natal: UFRN, 1980. Musicalerias. A República, Natal, 14 jun. 1929, n. 132, p. 01.(a) . O novo plano da cidade I, a cidade. A República, Natal, 30 out. 1929, n. 247, p 01. (b)

(c) O novo plano da cidade II, a Ribeira no "Master Plan". A República, Natal, 3 nov. 1929, n. 252, p. 01. Proteção aos monumentos naturais. A República, n. 73, p.03, 29/09/1946. 
História da Cidade do Natal. Natal: IGH/RN, 1999.

CENSURA estética. A República, 12 jan.1932. n.358, p.01.

CHALHOUB, Sidney. Cidade febril: cortiços e epidemias na Corte Imperial. São Paulo: Cia das Letras, 1996.

CHOAY, Françoise. A regra e o modelo. Sobre a teoria da arquitetura e do urbanismo. (Tradução Geraldo Gerson de Souza). São Paulo: Perspectiva, 1985.

. 0 urbanismo: utopias e realidades. Uma antologia. 3 ed. São Paulo: Perspectiva, 1992.

CHRONICA do dia: nos cinemas. A República, Natal, 06 abr.1937. n.1853, p.02.

CICCO, Januário. Como se higienizaria Natal: algumas considerações sobre o seu saneamento. Natal: Atelier Typ. M. Victorino, 1920.

CIDADÃO, Dr. Chefe de Polícia. Gazeta de Natal, Natal, 08 fev.1879.n.154, p.04.

CIDADE das lágrimas. A República, Natal, 28 jan.1904. n.2442, s/p.

CIFRAS que falam bem alto. Diário de Natal, Natal, 30 jan.1945. n.937, p.08.

CLEMENTINO, Maria do L. Complexidade de uma urbanização periférica, 1990. Tese (Doutoramento) Departamento de Ciências Sociais, Universidade Federal do Rio Grande do Norte, Natal.

COISAS da nossa terra. A República, Natal, 14 out.1906. n.3051, p.01.

CONJUNTO RESIDENCIAL CIDADE DA ESPERANÇA. Projeto urbanístico do conjunto. Companhia de Habitação do Rio Grande do Norte (COHAB-RN). Natal: Prefeitura Municipal de Natal, Secretaria de Planejamento, 1975.

COMISSÀO DE SANEAMENTO DE NATAL. Relatório do Saneamento de Natal. Publicação comemorativa da inauguração das obras. Natal, 1939.

CONSTRUÇÃO nas Rocas da Vila Ferroviária. Tribuna do Norte, 07 mai. 1953. n.896, p.01.

CORREIA, Telma de Barros. Pedra: plano e cotidiano operário no Sertão. Campinas: Papirus, 1998.

. 0 modernismo e o núcleo febril: o Plano da Cidade Operária da FNM de Attilio Correia Lima. Trabalho apresentado no III Docomomo Brasil. São Paulo, dezembro de 1999.

O modernismo e o núcleo fabril: o Plano de Attilio Correia Lima para Volta Redonda. Anais do IX Encontro Nacional da ANPUR. Rio de Janeiro, janeiro de 2001.

A construção do habitat moderno no Brasil - 1870-1950. São Carlos: Rima, 2004.

COSTA, Madislene. Quando a modernidade vinha de bonde. Natal, 1997. Monografia (Graduação em Arquitetura e Urbanismo) - Departamento de Arquitetura, Universidade Federal do Rio Grande do Norte.

DANILO. Bairros - Petrópolis. A República, n. 3227, p.08, 11/02/1942.

DANTAS, Ana Caroline de Carvalho. O Plano Geral de Obras: o ideário de Saturnino de Brito na Natal dos anos 30. Trabalho de graduação (Monografia). Natal: UFRN, 2000.

Sanitarismo e planejamento urbano: a trajetória das propostas urbanísticas para Natal entre 1935 e 1969. Tese (Mestrado em Arquitetura e Urbanismo) - Departamento de Arquitetura, Universidade Federal do Rio Grande do Norte. Natal: UFRN, 2003. 243p.

DANTAS, Ana Caroline; ALMEIDA, Caliane C. Oliveira. Uma cidade sem planos? O processo de institucionalização do planejamento urbano em Natal. Seminario Nacional de História da Cidade e Urbanismo. Niteroi, 2005.

DANTAS, Garibaldi. O "Vegecreto". A República, Natal, 8 maio. 1929, n. 102, p. 01. (a)

. A utilidade dos planos grandiosos. A República, Natal, 18 jun. 1929, n. 135, p. 01. (b)

. O urbanismo. A República, Natal, 17 set. 1929, n. 211, p. 01. (c)

. "Natal daqui a 50 anos". A República, 28 jun. 1957. n.142, p.03.

DANTAS, George Alexandre Ferreira. Natal "Caes da Europa": o Plano de Sistematização no Contexto da Modernização da Cidade (1920-1930). Monografia de Graduação. Natal, UFRN, 1998.

. Linhas convulsas e tortuosas retificações: transformações urbanas em Natal nos anos 1920. Tese (Mestrado em Arquitetura e Urbanismo) - Departamento de Arquitetura, Escola de Engenharia de São Carlos EESC-USP. São Paulo, 191p.

DEÁK, Csaba. A cidade: do burgo à metrópole. Espaço e Debates, São Paulo, n. 34, ano XI, p. 113-120, 1991. 
DEBATIDO em mesa redonda o problema mendicancia : o governador Silvio Pedroza, reuniu, na Vila Potiguar, autoridades e tecnicos, sugeridos medidas para enfrentar a situação. Jornal de Natal, Natal, 26 mai.1953. n.745, p.01.

DECCA, Edgar de, el all. Depoimentos - Cidade e História. In: Espaços e Debates: Revista de Estudos Regionais e Urbanos. São Paulo: FAPESP, 1991. Ano XI, n 34, p. 07 - 22.

DIÁRIO DE NATAL. Natal: 1960-1965. Publicação diária.

DIÁRIO DO NATAL. Natal: 1899-1960. Publicação diária.

DIÁRIO OFICIAL. Natal: 1889-1964.

DIAS, Márcia M. Lúcia Rebello Pinho. Desenvolvimento urbano e habitação popular em São Paulo (18701914). São Paulo: Nobel, 1989.

EDIFÍCIOS dignos de nota. Diário de Natal, Natal, 30 jan.1945. n.937, p.08.

EDITAES/ Ministério da Fazenda/ terrenos da Marinha. A República, Natal, 11 mar.1926. n.56, p.02.

EDITAES / Terrenos da União. A República, Natal, 25 jan.1929. n.24, p.01.

EDUARDO, A. R. B. Do higienismo ao saneamento: as modificações do espaço físico de Natal, 1850-1930. Trabalho de graduação (Monografia). Natal: UFRN, 2000.

EM BRASÍLIA Teimosa e Mãe Luíza: reforma urbana e agrária! Folha da Tarde, 15 jun. 1962. n.722, p.01.

EMPRESA construtora. A República, Natal, 15 jan.1933. n.640, p.01.

EM NATAL o presidente do IPASE. Jornal de Natal, Natal, 11 dez.1954. n.991, p.01-04.

ENGELS, Friedrich. Situação da classe trabalhadora na Inglaterra. Lisboa: Presença, 1975.

El problema de La vivienda: y las grandes ciudades. Tradução de Esther Donato y Margarita Lümker. Barcelona: Gustavo Gili, 1977. 129p.

A questão da habitação. São Paulo: Acadêmica, 1988. 88p.

ESCRITÓRIO Saturnino de Brito. Relatório do Saneamento de Natal. Publicação comemorativa de inauguração das obras. Natal: 1939.

ESCRITÓRIO Saturnino de Brito. Relatório do Saneamento de Natal. Natal: 1935.

ESTABELECIMENTO de normas para construções na Avenida Circular. Jornal de Natal, 18/05/1954, n.851, p.04.

ESTADO SANITÁRIO. Relatório apresentado pela Diretoria Geral de Higiene e Saúde Pública à Intendência Municipal. Natal, 1921.

EXPEDIENTE do Governador. A República, Natal, 05 nov.1937. n.2013, p.05.

EXPOSIÇÃO de plantas para construcções na prefeitura desta capital, hoje às 13 horas. A República, Natal, 17 mar.1928. n.60, p.02.

FARAH, Marta Ferreira Santos. Estado, Previdência Social e Habitação. Dissertação de Mestrado em Sociologia. São Paulo: FFLCH-USP, 1983.

FARIAS, Agnalo Aricê Caldas. Gregori Warchavchik: introdutor da Arquitetura Moderna no Brasil. Oculum, n.2, setembro de 1992.

FARRET, Ricardo Libanez. 0 espaço da cidade, contribuição à análise urbana. São Paulo: Projeto, 1985.

FERNANDES, Rafael. Diário Oficial/ expediente do governador/ Decreto n.177. A República, 04/08/1936, n.1661, p.03.

Decreto No 324 - de 3 de novembro de 1937. A República, Natal, 07 nov.1937. n.2013, p.05.

A República, Natal, 07 nov.1937. n.2013, p.05.

Decreto No 362. A República, Natal, 12 dez.1937. n.2042, p.05.

FERREIRA, Angela Lúcia de Araújo. De la producción del espacio urbano a la creación de territorios en la ciudad: un estudio sobre la constituición de lo urbano en Natal, Brasil. Tese de doutorado. Barcelona: Universidade de Barcelona, 1996.

FERREIRA, Angela Lúcia de Araújo; DANTAS, George A. F. Os "indesejáveis" na cidade: as representações do retirante da seca (Natal, 1890-1930). In: Colóquio Internacional de Geocrítica 3, 2001. Barcelona/Espanha. Anais eletrônicos...(www.ub.es/geocrit/sn-94-96.htm).

FERREIRA, Angela Lúcia de Araújo. et al. Uma cidade Sã e Bela: a trajetória do saneamento de Natal entre 1850 e 1969. Natal: CAERN, 2003. (Livro em vias de publicação). 
FERREIRA, Angela Lúcia de A; DANTAS, Kleyne R. de S; EDUARDO, Anna R. B. e DANTAS, Ana Caroline de C. L.. Dois olhares, duas propostas e uma solução: contribuição para o estudo do meio ambiente urbano em Natal/RN. In: SEMINÁRIO DE HISTÓRIA DA CIDADE E DO URBANISMO, 6., 2000, Natal. Anais... Natal: PPGAU, 2001. 1CD

FERREIRA, Angela Lúcia de A.; DANTAS, Ana Caroline de C. L.; DANTAS, George Alexandre F.; EDUARDO, Anna Rachel B.; A paisagem criada pelo saneamento: propostas arquitetônicas para Natal dos anos 1930. Rio de Janeiro: Anais do XVII Congresso Brasileiro de Arquitetos. 2003.

FERREIRA, Gentil. Decreto n.23. A República, 13/04/39, n.2417, p.08.

FICHER, Silvia. Arquitetura Moderna Brasileira. São Paulo: Projeto, 1981.

FOLHA DA TARDE. Natal: 1958-1965. Publicação diária.

FORT, Adrian; ANDREOLI, Alizabetta. Tectônica Tropical. p.58-105. In: FORT, Adrian; ANDREOLI, Alizabetta. Arquitetura Moderna Brasileira. Nova York: Phaindon Press L., 2004. 239p.

FRAMPTON, Kenneth. História Crítica da Arquitetura Moderna. São Paulo: Martins Fontes, 1997.

FRASSON, Alexandra de Souza. Habitação Social e Arquitetura Moderna: a apropriação dos conjuntos residenciais dos IAPs. Dissertação (Mestrado em Arquitetura e Urbanismo). São Carlos: EESC/USP, 2000.

FUNDAÇÃO da Casa Popular: Venda de Casas. A República, n. 211, p.08, 19/09/1948.

GAMALIEL. Pela Hygiene. A República, 11/06/1924, n.130, p.01.

GAMBOA. Revista Base, n.1, p.13. Rio de Janeiro, ago. de 1933.

GAP. HABITAÇÃo POPULAR: inventário da ação governamental. Rio de Janeiro: FINEP, 1985.

GARNIER, Tony. Une Cité Industrielle. Étude pour la Construction dês Villes. Paris: 1917. IN: AYNOMINO, C. Orígenes y desarrollo de la ciudad moderna. Barcelona: Gustavo Gili, 1971.

GAZETA DE NATAL. Natal: 1889-1913. Publicação diária.

GAZETA DE NATAL, 31/03/1888, n.145, p.04.

GAZETA DE NATAL, 08/02/1890, n.154, p.04.

GOMES, Gustavo Maia. Velhas secas em novos sertões: continuidade e mudanças na economia do semi-árido e dos serrados nordestinos. Brasília: Instituto de Pesquisa Econômica Aplicada (IPEA), 2001. 294p.

GOMES, Paulo César. 0 espaço na modernidade. São Paulo: AGB/Marco Zero, 1988.

GOVERNO do Estado / Notas officiaes. A República, 04/07/1924, n.148, p.01.

GOVERNO do Município. A República, 01/04/1925, n.74, p.01.

GOVERNO do Município - Construcções de Muros. A República, 19/02/1924, XXXVI, n. 35, p.02.

GOVERNO do Município - Resolução n.277. A República, 03/07/1927, n.143, p.03.

GOVERNO do Município - Resolução n. 278. A República, 05/07/1927, n.144, p.02.

GOVERNO do terror. Gazeta de Natal, 22/07/1898, n.1409, p.01.

GOZAR a vida. A República, 10/07/1936, n.1642, p.02.

HABITAÇÃo POPULAR: inventário da ação governamental. Rio de Janeiro: FINEP/GAP, 1985.

HALL, Peter. Cidades do amanhã. (Tradução Pérola de Carvalho). São Paulo: Companhia das Letras, 1998.

HCURB - Grupo de Pesquisa História da Cidade e Urbanismo. Banco de Imagens (1886-1970). Natal: UFRN, 2007.

HISTÓRIA do Rio Grande do Norte. Natal: Tribuna do Norte, Fundação José Augusto, n.12, 1998.

HOWARD, E.. Cidades-Jardins de amanhã. (Tradução Marco Aurélio Lagonego, Introdução: Dácio A. B. Otoni). São Paulo: Estudos Urbanos, Série Arte e Vida Urbana, Hucitec, 1996.

HYGIENE Publica. A República, 24/08/1903, n.167, p.03.

IANNI, Octavio. Estado e Planejamento econômico no Brasil (1930-1970). 2 ed. Rio de Janeiro: Ed. Civilização Brasileira, 1977.

IMPRESSÕES da América - a arte de embelezar as cidades. A República, 12/07/1923, n.196, p.01.

INQUILINATO (LEI N.4.240, de 28-06-63). Câmara dos Deputados/Diretoria de Documentação e Publicidade. Brasília: Departamento de Imprensa Nacional, 1964. 
INSS-RN. Processos de concessão de financiamentos (1942-1964). Levantamento realizado nos anos de 2006 e 2007. Natal: 2006/2007.

INSS-RN. Processos de concessão de financiamentos (1942-1964). Imagens. Levantamento realizado pela autora no primeiro semestre de 2007. Natal: janeiro/maio de 2007.

INTENDÊNCIA Municipal. A República, 11/02/1903, n.30, p.01.

INTENDÊNCIA Municipal. A República, 15/05/1924, n.107, p.01.

INTENDÊNCIA Municipal de Natal/ Resolução n.55. A República, 04/01/1902, n.03, p.02.

KOPP, Anatole. Quando o movimento moderno não era um estilo e sim uma causa. São Paulo: Nobel/EDUSP, 1990.

KOSTOF, Spiro. A History of Architecture: settings and rituals. New York: Oxford University Press, 1985.

LAMARTINE, Hypérides. Assentamentos da família Lamartine. Revista Província. Reedição revis. complet. Natal, n. 3, p. 67-76, 1994.

LAMARTINE, Oswaldo. Juvenal Lamartine, meu pai. Revista Província. Reedição revis. complet. Natal, n. 3, p. 11-15, 1994.

LAMAS, J. M. R. G.. Morfologia urbana e desenho da cidade. Lisboa: Fundação Calouste Gulbenkian, 1992.

LAURENTIZ, Luiz Carlos de. Considerações sobre a preocupação social na arquitetura moderna no Brasil: das origens a 1945 no eixo São Paulo e Rio de Janeiro. Tese (Doutorado em Arquitetura e Urbanismo). São Carlos: EESC/USP, 2000.

LE CORBUSIER. A Carta de Atenas. São Paulo: EDUSP, 1942.

. Urbanismo. São Paulo: Martins Fontes, 1992.

LEI INIQUA. A República, 11/12/1906, n.3091, p.01.

LEIS E DECRETOS DE GOVERNO. Natal: 1889-1964.

LEMOS, Carlos A. C. Cozinhas, etc. São Paulo: Perspectiva, 1978.

. Alvenaria burguesa: breve histórico da arquitetura residencial de tijolos em São Paulo a partir do ciclo econômico liderado pelo café. 2 ed. São Paulo: Nobel, 1985.

Casas Proletárias em São Paulo. São Paulo: FAU-USP, 1993.

1999. 264p.

Casa Paulista: história das moradias anteriores ao ecletismo trazido pelo café. São Paulo: EDUSP,

LIMA, Attilio Correa. Parecer sobre o Plano de Cidade Operária da FNM (24/08/1943). In: Arquitetura, n.14, 1963.

LIMA, Pedro A. de. Natal no século XX: do urbanismo ao planejamento urbano. Natal: EDUFRN, 2001.

LIRA, José Tavares de. Mocambo e cidade. Tese (Doutorado em Arquitetura e Urbanismo). São Paulo: FAUUSP, 1996.

Modernidade e economia de morar no Recife (1930-1964)... In: SAMPAIO, Ruth Amaral de. A promoção privada de habitação econômica e a Arquitetura Moderna. São Paulo: Rima, 2002.

LOPES, Wilza Gomes Reis. Taipa de mão no Brasil. Dissertação (Mestrado). São Carlos: EESC-USP, 1998.

LYRA, Alfredo. Hygiene: falando e escrevendo. Natal: M. S. de Aguiar, 1929.

MACEDO, F. A. de. Mensagem apresentada pelo governador Rafhael Fernandes Gurjão á Assembléia Legislativa do estado em $1^{\circ}$ de setembro de 1936. A República, 05/09/1936, n.1687, p.07.

MACHADO, Roberto. Da (n)ação da norma. Rio de Janeiro: Graal, 1978.

MARICATO, Ermínia. A produção capitalista da casa (e da cidade) no Brasil industrial. São Paulo: Editora Alfa - Omega, 1979.

. Habitação e cidade. São Paulo: Atual, 1997.

MASCARÓ, Lucia (coord.). Tecnologia e Arquitetura. São Paulo: Nobel, 1989.

MEDEIROS FILHO, Olavo de. Terra natalense. Natal: Fundação José Augusto, 1991.

MEDIDA de Alto Alcance Social. A República, 20/01/39, n.2350, p.01.

MELHORAMENTOS da cidade. A República, 12/02/1908, n.34, s/p.

MELO, Veríssimo de. Juvenal Lamartine. Revista província. Reedição revis. complet. Natal, n. 3, p. 43-49, 1994. 


\section{MENSAGENS DE GOVERNO. Natal: 1889-1964.}

MINKE, Gernot. Manual de Construccion em terra. Barcelona: 1999.

MIRANDA, João Maurício F. de. 380 Anos de História Foto-Gráfia da Cidade de Natal - 1599 - 1979. Natal. Editora Universitária, 1981.

Evolução Urbana de Natal em 400 anos: 1599-1999. Natal: Governo do Rio Grande do Norte/Prefeitura de Natal, 1999.

MOTA, Valter T. et al.. Normas Técnicas: para apresentação de trabalhos científicos. Caxias do Sul: EDUCS, 2004.

NA CAMARA Municipal. Jornal de Natal, 03/08/1955, n.1174, p.04.

NATAL. Expediente do Prefeito - Decreto n.379 - de 30 de novembro de 1932. Baixa dispositivos sobre a ocupação territorial. Natal: Departamento de Imprensa, 1932.

NATAL. Expediente do Prefeito - Decreto n.304 - de 06 de abril de 1935. Cria a Comissão de Saneamento de Natal. Natal: Departamento de Imprensa, 1935.

NATAL. Decreto n.859, de 19 de junho de 1935. A República, Natal, 20 jun.1935. n.1340, s/p.

NATAL. Decreto № 327 - de 6 de novembro de 1937. A República, Natal, 07 nov. 1937. n.2015, p.05.

NOTA da Semana. A República, 31/01/39, n.2359, p.02.

NOTAS do dia - A seca. Diário de Natal, 15/06/1889, n.1111, p.01.

OBRA PHILANTHROPICA. A República, 07/07/1925, n.148, p.01.

O EMBELEZAMENTO da cidade. A República, 10/07/1936, n.1642, p.02.

OLIVEIRA, Giovana Paiva de. A Elite Política e as Transformações no Espaço Urbano: Natal - 1889/1913. Natal, 1997. Dissertação (Mestrado em Ciências Sociais) - Departamento de Ciências Sociais, Universidade Federal do Rio rande do Norte.

De cidade a cidade: o processo de modernização de Natal 1889/1913. Natal: EDUFRN, 1999.

O'GRADY, Omar. Os problemas da cidade. A República, Natal, suplemento especial, 01 jul. 1929, n. 121, p. 01.

O NOVO ramal. Diário de Natal, 28/03/1926, n.73, p.01.

O NOVO quartel da Policia. A República, 02/06/1950, n.126, p.06.

O PAIZ, Rio de Janeiro, 23 e 24/06/1930, n.16.681-2, p.05.

O PROBLEMA da fome - Como socorrer, de momento, as levas de famintos que procuram a nossa cidade. A República, 31/03/32, n.415, p.01.

O PROBLEMA da mendicancia em Natal - O serviço E. de Reeducação e Assistência Social procura solucionar-

lo. A República, 04/04/1943, n.76, p.03.

O PROBLEMA DO TECTO. Diário de Natal, 17/03/1926, n.63, p.01

O RIO GRANDE DO NORTE. A administração de Ferreira Chaves. A República, 01/08/1914, n.169, p.01.

OS TIROS de roqueiras. Gazeta de Natal, 07/06/1890, n.170, p.04.

OTONI, Dácio A. B.. Introdução. In: HOWARD, E.. Cidades-Jardins de amanhã. (Tradução Marco Aurélio Lagonego). São Paulo: Estudos Urbanos, Série Arte e Vida Urbana, Hucitec, 1996.

O URBANISMO natalense. A República, 28/07/1928, n.167, p.01.

PAIVA, Marlúcia. Igreja e política no RN. Natal: Sebo Vermelho, 2000. 203p. p.15-40.

PARA A CONSTRUÇÃO de residências destinadas aos operários. A República, 25/07/1942, n.3458, p.01.

PARA CONSTRUÇÃO da casa propria dos segurados o IAPC. A República, 01/02/1950, n.25, p.01.

PARTE OFFICIAL/ Regulamento do Serviço Sanitário do Estado do Rio Grande do Norte. A República, 24/09/1921, n.206, p.01.

PECHMAN, Robert Moses (org.). Olhares sobre a cidade. Rio de Janeiro: Ed. UFRJ, 1994.

PELAS Repartições - Directoria de Hygiene. A República, 17/03/1924, n. 52, p.01.

PELA Saúde Pública - Higiene das Habitações. A República, 20/03/1924, n.63, p.01.

PERUZZO, Dilvo. Habitação: controle e espoliação. São Paulo: Cortez Editora, 1984. 133p.

PICCINI, Andrea. Cortiços na cidade: conceito e preconceito na reestruturação do centro urbano de São Paulo. 2ed. São Paulo: Annablume, 2004. 
POMBO, Rocha. História do Rio Grande do Norte. Edição comemorativa do centenário da independência do Brasil (1822-1922). Rio de janeiro: Annuario do Brasil; Porto: Renascença portuguesa, 1922.

PORTARIA SCM-192. Especifica as determinações das ações do IAPI. INSS, Natal, 28/11/1939. Processo 879B, p.5.

PORTINHO, Carmem Velazcos. Os progressos constantes da aviação. A República, Natal, 16 abr. 1929, n. 85, p. 01.

A participação do RN no $4^{\circ}$ Congresso Pan-americano de Architectura (em entrevista ao Jornal do Brasil, RJ). A República, Natal, 02 jul. 1930, n. 150, p.01. (a)

A remodelação de Natal. A República, Natal, 13 jul. 1930, n. 160, p.02. (b)

PORQUE aparecemos [programa]. Natal Jornal, 04/05/1919, n.01, p.01.

POSTO DE observação. Jornal de Natal, 15/01/1955, n.1016, p.01.

PREFEITURA da capital - expediente do dia 23 de novembro de 1935 - despachos do Sr. Prefeito. A República, 03/12/1935, n.1469, p.04.

PREFEITURA da capital - expediente do dia 25 de outubro de 1935. A República, 05/11/1935, n.1450, p.04.

PREFEITURA da capital - expediente do dia 10 de dezembro de 1935 - despachos. A República, 14/12/1935, n.1479, p.05.

PREFEITURA de Natal/Decreto n.4, de 11 de junho de 1935. A República, 12/06/1935, n.1334, p.08.

PREFEITURA de Natal. A Ordem, 27/01/1939, n.1014, p.04.

PRIMEIROS passos para a construção da cidade do funcionário. A República, 18/09/1957, n.65, p.06.

QUANTOS mais vão sofrer. A República, 28/08/1942, n.864, p.12.

RADBURN. A town for the moter age in fair lawn. Nova Jersey, EUA. Pesquisado em: www.radburn.org. Acessado em julho de 2005.

RAGO, Margareth. Do cabaré ao lar: a utopia da cidade disciplinar. Brasil 1890-1930. 2ed. Rio de Janeiro: Paz e Terra, 1987.

REGULAMENTO a que se refere o decreto n. 377, de 22 de dezembro de 1937. A República, 08/03/1938, n.2110, p.05.

RELATÓRIO. Commissão de Exame e Inspectoria das Habitações Operárias e Cortiços no Districto de Santa Ephigenia. Anexo do Relatório de 1893. São Paulo: Espindola, 1984.

RELATÓRIOS DE INTENDÊNCIA MUNICIPAL. Natal: 1889-1964.

RELATÓRIO DE INTENDÊNCIA MUNICIPAL. Relatório apresentado pelo Prefeito Omar O`Grady. Natal, Diário Oficial, 30/01/1929.

RELATÓRIO especial aos cidadãos. A Ordem, p.01, 19/03/1966.

RELATORIO DO PRESIDENTE OMAR O'GRADY. A República, 08/01/1926, n.05, p.02.

RELATORIO DO PRESIDENTE OMAR O'GRADY. CEMITÉRIO DO ALECRIM. A República, 10/01/1926, n.07, p.02.

RESIDENCIAS para oficiais do exército / Inaugurados os primeiros conjuntos de quatro casas, no bairro do Tirol. Jornal de Natal, 09/09/1955, n.1202, p.04.

REUNIDAS as intenções. A República, caderno especial, 1956, p.08.

REVISTA DE ENGENHARIA, n.18, 10/08/1911.

RESOLUÇÃO N. 92. A República, 24/05/1904, n.105, p.01.

RIBEIRO, Luiz César de Queiroz. Dos cortiços aos condomínios fechados: as formas de produção da moradia na cidade do Rio de Janeiro. Rio de Janeiro: Civilização Brasileira, 1997. 358p.

RIBEIRO, Luiz César de Queiroz; AZEVEDO, Sérgio de. A crise da moradia nas grandes cidades: da questão da habitação à reforma urbana. Rio de Janeiro: EDUFRJ, 1997. 283p. p.13-32.

RIBEIRO, Luiz C. de Queiroz; PECHAMAN, Robert M.. 0 que é questão da moradia? São Paulo: Brasiliense, 1992.

RIO GRANDE DO NORTE. Expediente do Governador - Lei n.14 - de 11 de junho de 1892. Cria a Inspetoria de Higiene Pública. Natal: Departamento de Imprensa, 1892. 
RIO GRANDE DO NORTE. Expediente do Governador - Decreto n.24 - de 22 de maio de 1893. Modificações da Lei n.14 e dá regulamento à Inspetoria de Higiene e Saúde Pública. Natal: Departamento de Imprensa, 1893.

RIO GRANDE DO NORTE. Mensagem apresentada à Assembléia Legislativa do Rio Grande do Norte pelo Governador Pedro Velho. Natal: Departamento de Imprensa, 1896.

RIO GRANDE DO NORTE. Expediente do Governador - Resolução n.54 - de 30 de abril de 1904. Delimita 0 território do município de Natal e dispõe sobre aforamentos, construções, dentre outros. Natal: Departamento de Imprensa, 1904.

RIO GRANDE DO NORTE. Expediente do Governador - Resolução n.92 - de 30 de abril de 1904. Dispõe sobre aforamentos e construções em Natal. Natal: Departamento de Imprensa, 1904.

RIO GRANDE DO NORTE. Expediente do Governador - Decreto n.177 - de 22 de abril de 1908. Organiza comissão encarregada de organizar a planta cadastral de Natal. Natal: Departamento de Imprensa, 1908.

RIO GRANDE DO NORTE. Expediente do Governador - Lei n.335 - de 29 de novembro de 1912. Isenta de impostos da décima urbana os prédios que fossem construídos para residência por quinze anos na capital. Natal: Departamento de Imprensa, 1912.

RIO GRANDE DO NORTE. Expediente do Governador - Resolução n.183 - de 26 de outubro de 1914. Determina limite da área urbana. Natal: Departamento de Imprensa, 1914.

RIO GRANDE DO NORTE. Expediente do Governador - Resolução n.194 - de 20 de abril de 1916. Reformula a Resolução n.54 de abril de 1904. Natal: Departamento de Imprensa, 1916.

RIO GRANDE DO NORTE. Expediente do Governador - Decreto n.148 - de 01 de setembro de 1921. Regulamento da Diretoria Geral de Higiene e Saúde Pública, antiga Inspetoria de Higiene. Natal: Departamento de Imprensa, 1921.

RIO GRANDE DO NORTE. Expediente do Governador - Lei n.544 - de 02 de dezembro de 1922. Isenta de impostos estaduais as empresas que construírem grupos de casas. Natal: Departamento de Imprensa, 1922.

RIO GRANDE DO NORTE. Expediente do Governador - Decreto n.229 - de 29 de março de 1924. Dá instruções sobre as intimações relativas à polícia sanitária das habitações. Natal: Departamento de Imprensa, 1924.

RIO GRANDE DO NORTE. Expediente do Governador - Lei n.04 - de 02 de setembro de 1929. Dispõe sobre construções, reconstruções, acréscimos e modificações nos prédios. Natal: Departamento de Imprensa, 1929.

RIO GRANDE DO NORTE. Expediente do Governador - Lei n.728 - de 29 de outubro de 1929. Permite que a Intendência Municipal realize a venda de qualquer lote de terra para obras de urbanização de Natal. Natal: Departamento de Imprensa, 1929.

RIO GRANDE DO NORTE. Expediente do Governador - Lei n.08 - de 04 de dezembro de 1929. Autoriza 0 Prefeito a vender lotes de terras. Natal: Departamento de Imprensa, 1929.

RIO GRANDE DO NORTE. Expediente do Governador - Decreto n.146 - de 13 de abril de 1936. Modifica dispositivos do hospital dos alienados. Natal: Departamento de Imprensa, 1936.

RIO GRANDE DO NORTE. Expediente do Governador - Decreto n.176 - de 30 de julho de 1936. Cria a Repartição de Saneamento de Natal. Natal: Departamento de Imprensa, 1936.

RIO GRANDE DO NORTE. Expediente do Governador - Decreto n.174 - de 27 de julho de 1936. A República, Natal, 28 jul.1936, n.1656, p.03.

RIO GRANDE DO NORTE. Expediente do Governador - Decreto n.362 - de 11 de dezembro de 1937. Regulamento da Repartição de Saneamento. Natal: Departamento de Imprensa, 1937.

RIO GRANDE DO NORTE. Expediente do Governador - Decreto n.377 - de 22 de dezembro de 1937. Dá nova organização aos serviços sanitários. Natal: Departamento de Imprensa, 1937.

RIO GRANDE DO NORTE. Expediente do Governador - Decreto n.449 - de 09 de março de 1938. Baixa Regulamento geral para os serviços da Repartição de Saneamento. Natal: Departamento de Imprensa, 1938.

RIO GRANDE DO NORTE. Expediente do Governador - Decreto n.483 - de 20 de maio de 1938. Baixa novos dispositivos sobre o imposto territorial. Natal: Departamento de Imprensa, 1938.

RIO GRANDE DO NORTE. Expediente do Governador - Decreto-Lei n.75 - de 18 de dezembro de 1940. Decreta que todos os prédios com valor locatário superior a 4:000\$ estavam obrigados à realizar ligação com a rede de esgotos. Natal: Departamento de Imprensa, 1940.

RIO GRANDE DO NORTE. Expediente do Governador - Decreto-Lei n.655 - de 13 de dezembro de 1946. Doação de terreno ao IPASE para construção de vila operária. Natal: Departamento de Imprensa, 1946. 
RIO GRANDE DO NORTE. $2^{\text {a }}$ mensagem apresentada à Assembléia Legislativa do Rio Grande do Norte pelo Governador Dinarte Mariz. Natal: Departamento de Imprensa, 1952.

RIO GRANDE DO NORTE. Expediente do Governador - Decreto n.2370 - de 05 de junho de 1953. Dispõe sobre a construção de gabinetes sanitários em residências. Natal: Departamento de Imprensa, 1953.

RIO GRANDE DO NORTE. Mensagens de Governo. Natal: Departamento de Imprensa, 1889-1964.

RIO GRANDE DO NORTE. $2^{\mathrm{a}}$ mensagem apresentada à Assembléia Legislativa do Rio Grande do Norte pelo Governador Aluízio Alves. Natal: Departamento de Imprensa, 1963.

RIO GRANDE DO NORTE. 1 $1^{\text {a }}$ mensagem apresentada à Assembléia Legislativa do Rio Grande do Norte pelo Governador Walfredo Gurgel. Natal: Departamento de Imprensa, 1966.

RIO GRANDE DO NORTE. $2^{\text {a }}$ mensagem apresentada à Assembléia Legislativa do Rio Grande do Norte pelo Governador Walfredo Gurgel. Natal: Departamento de Imprensa, 1967.

ROLNIK, Raquel. História Urbana: História na cidade?. In: FERNANDES, Ana, GOMES, Marco A. de A. F. (orgs). CIDADE \& HISTÓRIA: Modernização das cidades brasileiras nos séculos XIX e XX. Salvador: UFBA, ANPUR, 1992. p. $27-29$.

. A cidade e a lei. São Paulo: Nobel, 1997.

RONCAYOLO, M.; PAQUOT, T. (org.). XVII-XX Sìecle. Paris: Larousse, 1992.

RONCAYOLO, Marcel. Villes e Civilisation urbaine. Paris: Larousse, 1992.

SACHS, Celine. São Paulo: políticas públicas e habitação popular. São Paulo: EDUSP, 1999.

SAMPAIO, Maria Ruth Amaral (org.). A promoção privada de habitação econômica e a arquitetura moderna. São Paulo: Rima, 2002.

SAMPAIO, Maria R. A; LEMOS, Carlos A. C. Casas Proletárias em São Paulo. São Paulo: FAUUSP, 1993. 169 .

SAMPAIO, Maria R. A. A promoção privada da habitação econômica e a arquitetura moderna (1930-1964). São Paulo: Rima, 2002.

SANTOS, Paulo P. dos. Evolução econômica do Rio Grande do Norte (século XVI ao XXI): 500 anos de história do RN. 2ed. Natal: Departamento de Imprensa do Estado, 2002.

SECÇÃO editorial. A República, 01/01/1901, n.1766, p.01.

SECÇÃO livre. Diário de Natal, 11/08/1898, n.1126, p.01.

SEGAWA, Hugo. Arquitetura no Brasil: 1900-1990. São Paulo: EDUSP, 2002.

n. $\overline{191, p .73-85 .}$

Modernidade pragmática: uma arquitetura dos anos 1920/40 fora dos manuais. Revista Projeto, 1995,

SERÁ construída mais. A República, 11/08/1957, n.36, p.08

SERÃO construídas no Rio Grande do Norte quinhentas casas populares. Jornal de Natal, 01/03/1957, n.1566, p.01.

SÉRGIO, Ivan. "Cidade da Esperança" é realidade. A Ordem, n. 5628, p.2-5, 02/01/1965.

SOCIAIS/ E.F.C.R.G.N.. A República, 11/01/1950, n.07, p.02.

SOCIAES - feiuras da cidade... A República, 18/12/1935, n.1482, p.08.

SOMEKH, Nadia. A cidade vertical e o urbanismo modernizador. São Paulo: EDUSP; Estúdio Nobel; FAPESP, 1997.

SOUZA, Alberto. Do mocambo à favela. Recife, 1920-1990. João Pessoa: Ed. Universitária, 2003.

SOUZA, Ângela Godilho. Limites do Habitat: segregação e exclusão na configuração urbana contemporânea de Salvador e perspectivas no final do século XX. Salvador: EDUFA, 2000.

SOUZA, Itamar de. As moradias em Natal. Tribuna do Norte, 29/07/1943, n.765, p.06.

1989.

A República Velha no Rio Grande do Norte (1889 - 1930). Natal: Centro Gráfico do Senado Federal,

STEIN, Clarence. Toward new towns for América. Nova York: Reinhold. Co., 1956.

TÓPICOS. A Ordem, 28/10/1952, n.5004, p.04.

TRAMONTANO, M. Paris-São Paulo-Tokyo: novos modos de vida, novos espaços de morar. Tese de Doutorado. São Paulo: FAUUSP, 1998. 
UMA LINDA iniciativa. A República, 03/02/1933, n.656, p.01.

VALADARES, Licia do Prado. Habitação em questão. Rio de Janeiro: Zahar, 1981.

VAI CONSTRUIR o IAPC um grupo residencial no Tirol. Tribuna do Norte, 26/03/1953, n.864, p.08.

VÁRIAS. A República, 15/01/1929, n.11, p.01.

VÁRIAS - Intendência da Capital. A República, 16/01/1924, XXXVI, n. 13, p.02.

VARON, Conceição. E a história se repete... As vilas operárias e os conjuntos residenciais dos IAPs no Rio de Janeiro. Dissertação de Mestrado em Arquitetura e Urbanismo. São Paulo: FAU-USP, 1998.

VAZ, Lílian Fessler. Modernidade e moradia: habitação coletiva no Rio de Janeiro, séculos XIX e XX. Rio de Janeiro: 7Letras, 2002. 180p. p.145 - 172.

VIANNA, Mônica Peixoto. Núcleos residenciais da CESP: 0 processo de desmonte. Dissertação de Mestrado em Arquitetura e Urbanismo. São Carlos: EESC-USP, 2006.

VIDA social de arquitetura. A República, 31/08/1932, n.534, p.04.

VILA FERROVIARIA... Jornal de Natal, 24/12/1954, n.1000, p.03.

VILA NAVAL de 400 casas em Igapó: solução da Marinha de Guerra visando o aproveitamento de vários hectares de terras da Armada. A República, 11/05/1957, n.105, p.12.

WOLFF, Silvia Ferreira dos Santos. Jardim América: o primeiro bairro-jardim de São Paulo e sua arquitetura. São Paulo: EDUSP/FAPESP/Imprensa Oficial do Estado, 1999. 


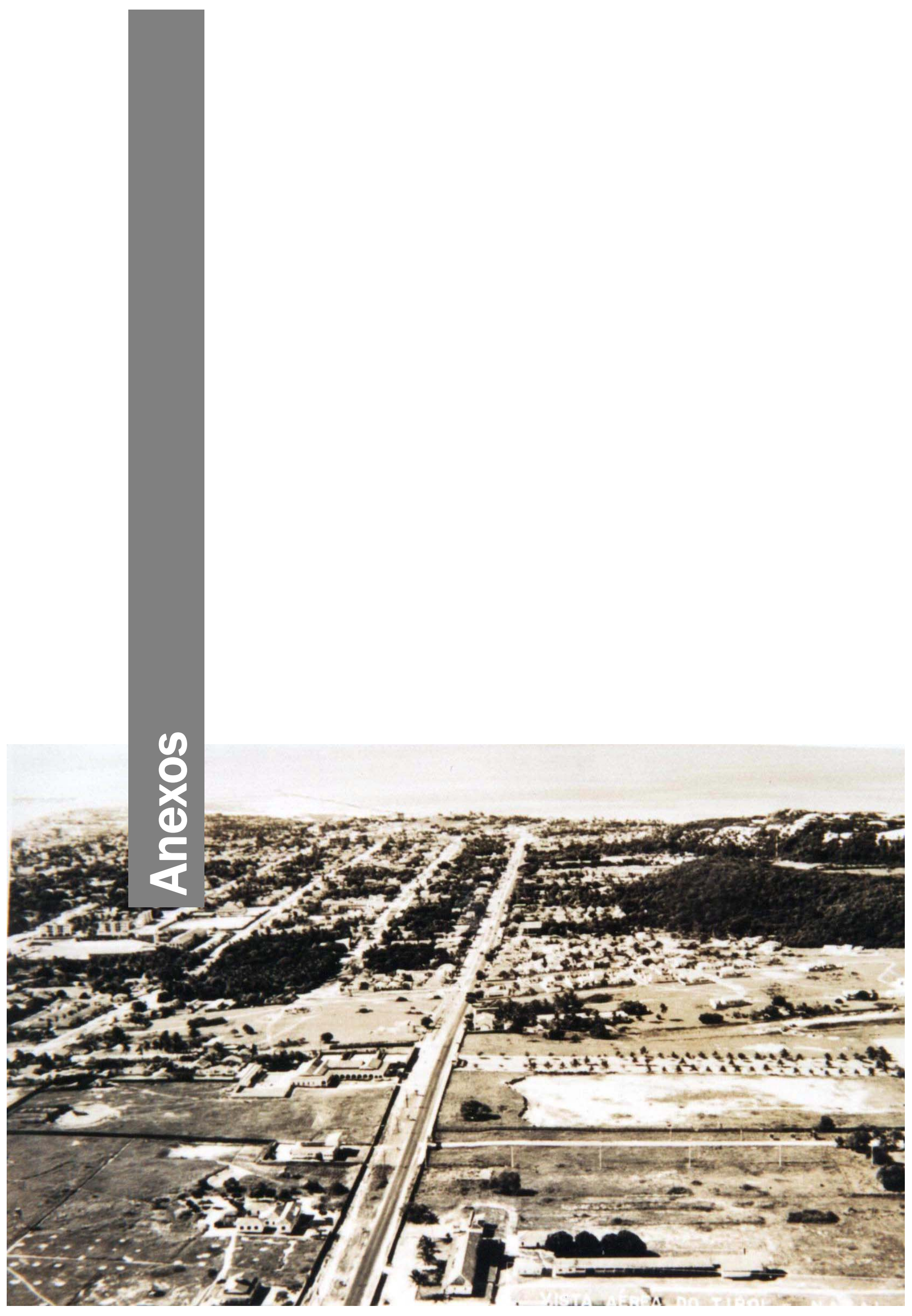




\section{ANEXO A - Instituições visitadas e documentos levantados.}

\begin{tabular}{|c|c|c|}
\hline Instituições & Cidade & Material Pesquisado \\
\hline Biblioteca Nacional & Rio de Janeiro/RJ & $\begin{array}{l}\text { Bibliografia da pesquisa. } \\
\text { Periódicos locais raros. } \\
\text { Resoluções Nacionais. }\end{array}$ \\
\hline $\begin{array}{l}\text { Biblioteca da Escola de Engenharia de } \\
\text { São Carlos-USP }\end{array}$ & São Carlos/SP & $\begin{array}{c}\text { Bibliografia da pesquisa. } \\
\text { Bibliografia específica das disciplinas. } \\
\text { Dissertações e Teses sobre habitação. }\end{array}$ \\
\hline Biblioteca da Escola Politécnica da USP & São Paulo/SP & $\begin{array}{c}\text { Bibliografia da pesquisa. } \\
\text { Bibliografia específica das disciplinas. } \\
\text { Dissertações e Teses sobre habitação. }\end{array}$ \\
\hline $\begin{array}{l}\text { Arquivo da REFESA - Rede Ferroviária } \\
\text { Federal }\end{array}$ & Recife/PE & $\begin{array}{l}\text { Dados acerca da Vila Ferroviária construída em Natal, na } \\
\text { década de } 1940 . \\
\text { Plantas e iconografias sobre a referida Vila. }\end{array}$ \\
\hline Biblioteca Central Zila Mamede & Natal/RN & $\begin{array}{c}\text { Bibliografia rara acerca de Natal. } \\
\text { Periódicos Criptografados. } \\
\text { Dissertações e Teses sobre habitação na cidade. }\end{array}$ \\
\hline Memorial Câmara Cascudo & Natal/RN & $\begin{array}{l}\text { Publicações do Historiados sobre Natal } \\
\text { (Poesias, resenhas, artigos e livros). } \\
\text { Iconografia sobre o crescimento da cidade. }\end{array}$ \\
\hline Arquivo Público do Estado & Natal/RN & $\begin{array}{c}\text { Documentos Oficiais } \\
\text { (Leis, Decretos, Mensagens de Governo, Relatórios Técnicos } \\
\text { e Regulamentos de Higiene). } \\
\text { Periódico A República. }\end{array}$ \\
\hline INSS-RN & Natal/RN & $\begin{array}{c}\text { Processos de concessão de financiamentos realizados pelos } \\
\text { IAPs em Natal. } \\
\text { Resoluções e Portarias. } \\
\text { Projetos e imagens das residências erguidas em Natal. }\end{array}$ \\
\hline $\begin{array}{l}\text { Instituto Histórico e Geográfico do Rio } \\
\text { Grande do Norte }\end{array}$ & Natal/RN & $\begin{array}{c}\text { Periódicos Locais } \\
\text { (A República, Jornal de Natal, Jornal do Natal, Tribuna do } \\
\text { Norte, O Nortista, O Comerciário, etc.). } \\
\text { Cartas da Intendência Municipal. }\end{array}$ \\
\hline Fundação José Augusto & Natal/RN & Iconografia acerca de Natal. \\
\hline Cúria da Catedral & Natal/RN & $\begin{array}{l}\text { Jornal A Ordem. } \\
\text { Publicações relacionadas à atuação social da Igreja em } \\
\text { Natal. }\end{array}$ \\
\hline Arquivo da Câmara Municipal & Natal/RN & Relatórios, Atas e Cartas da Intendência Municipal. \\
\hline $\begin{array}{l}\text { Arquivo do Setor de Patrimônio } \\
\text { Imobiliário do INSS-RN }\end{array}$ & Natal/RN & $\begin{array}{l}\text { Processos de financiamento realizados pelos IAP's nas } \\
\text { décadas de } 1930 \text { a 1960, em Natal. } \\
\text { Iconografia sobre a produção dos IAP's. } \\
\text { Mapas e Plantas relacionadas. }\end{array}$ \\
\hline Núcleo Temático da Seca & Natal/RN & $\begin{array}{c}\text { Dados estatísticos e históricos sobre as secas ocorridas no } \\
\text { estado do RN. }\end{array}$ \\
\hline $\begin{array}{l}\text { Secretaria do Meio Ambiente e } \\
\text { Urbanismo - SEMURB }\end{array}$ & Natal/RN & Mapas e imagens cartográficas de Natal. \\
\hline
\end{tabular}


ANEXO B - Modelos de fichas para levantamento de documentos oficiais e periódicos.

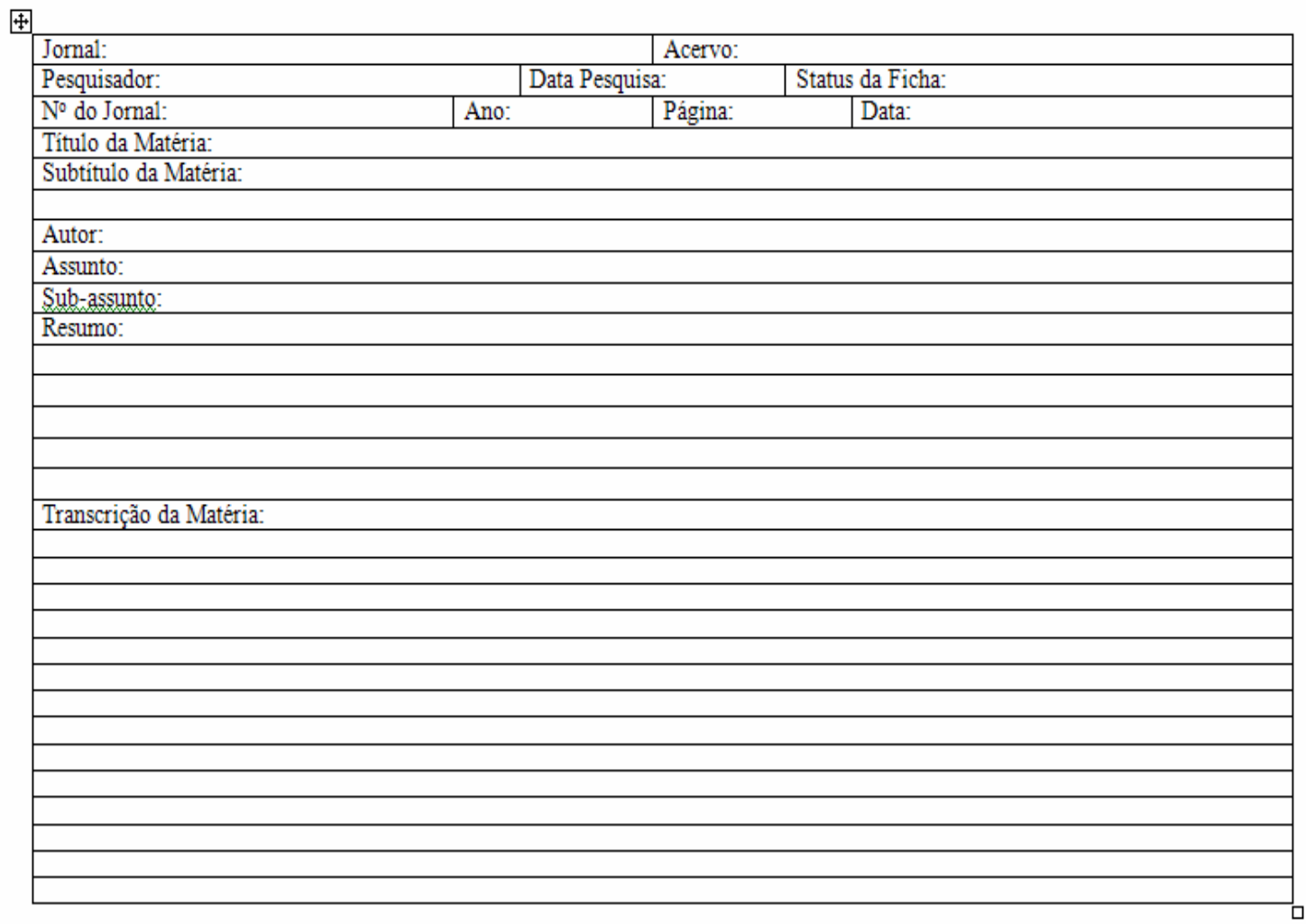

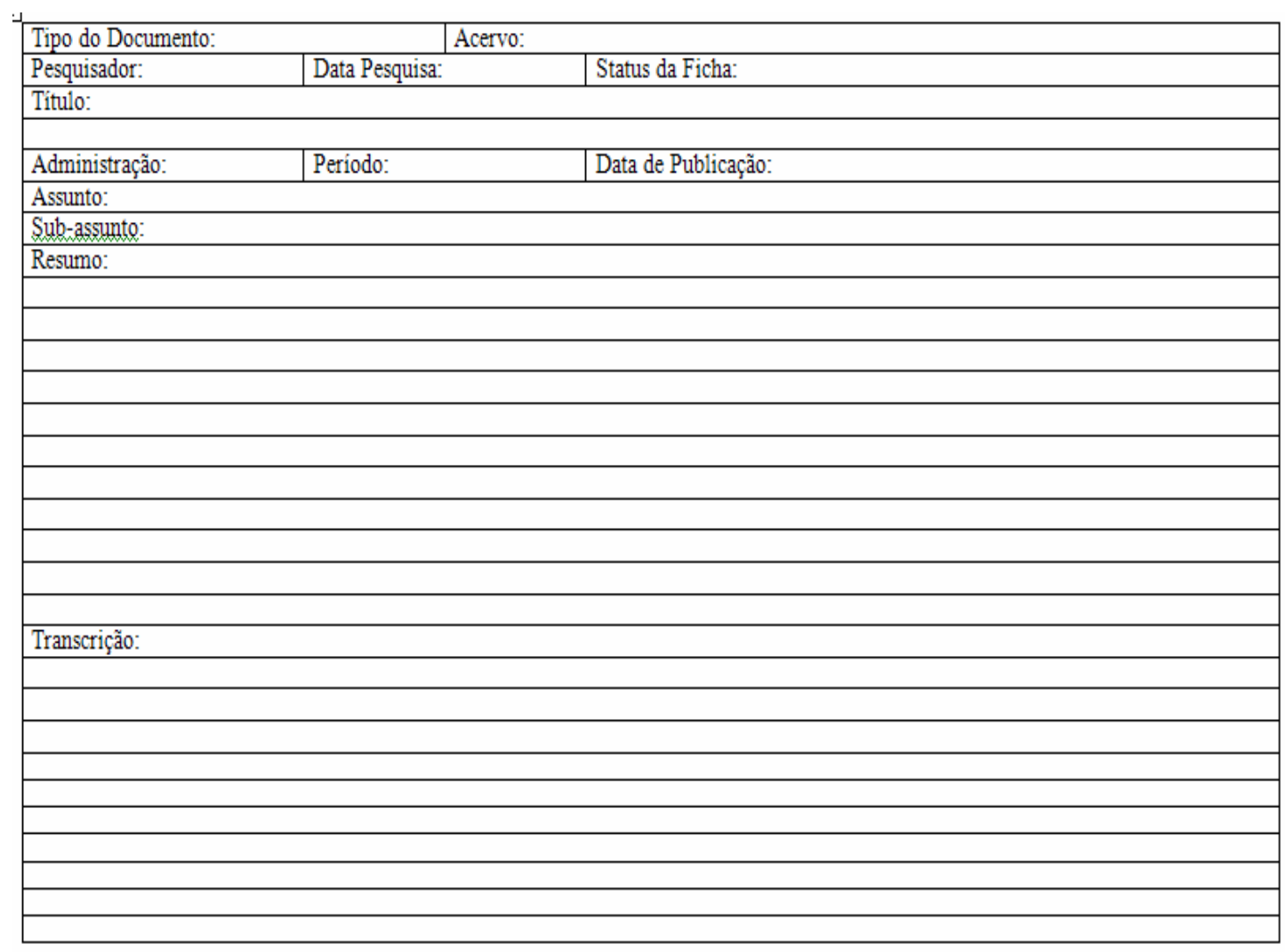




\section{ANEXO C - Modelo de ficha para levantamento dos processos de financiamentos do INSS-RN}

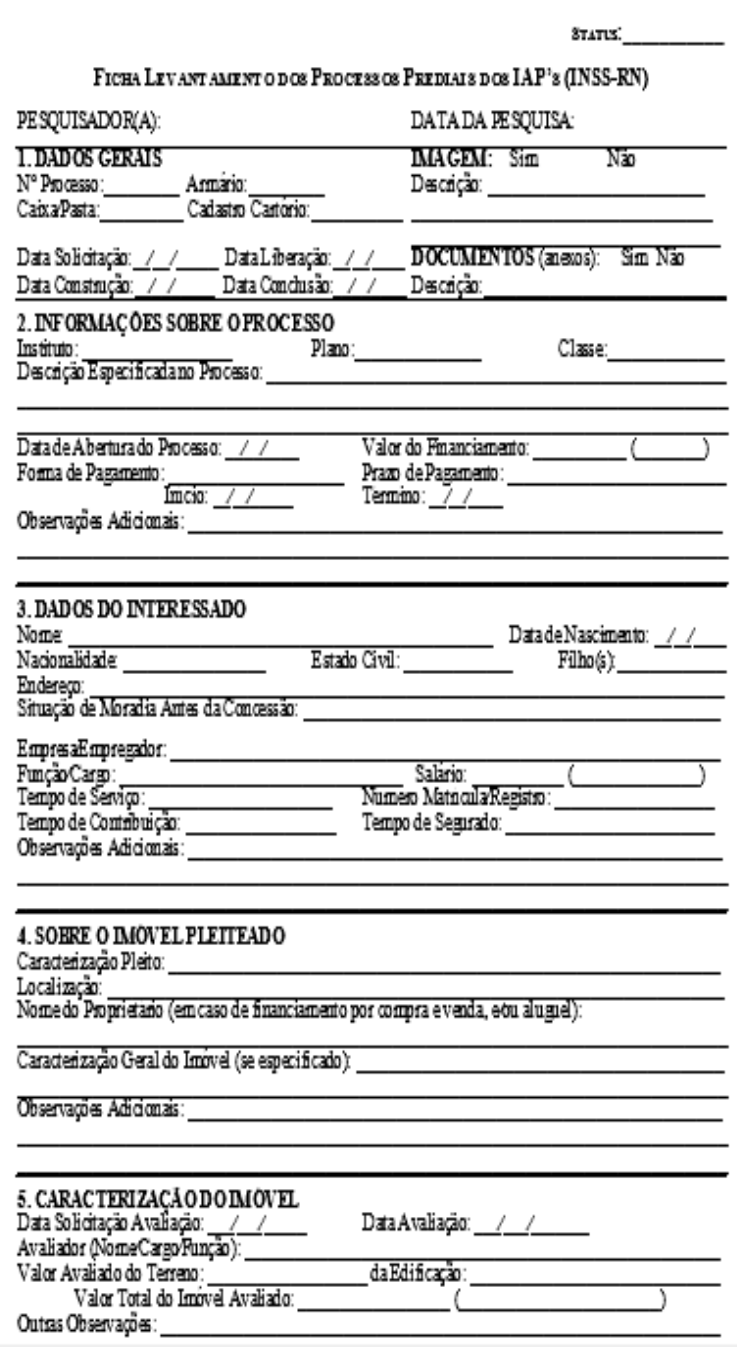

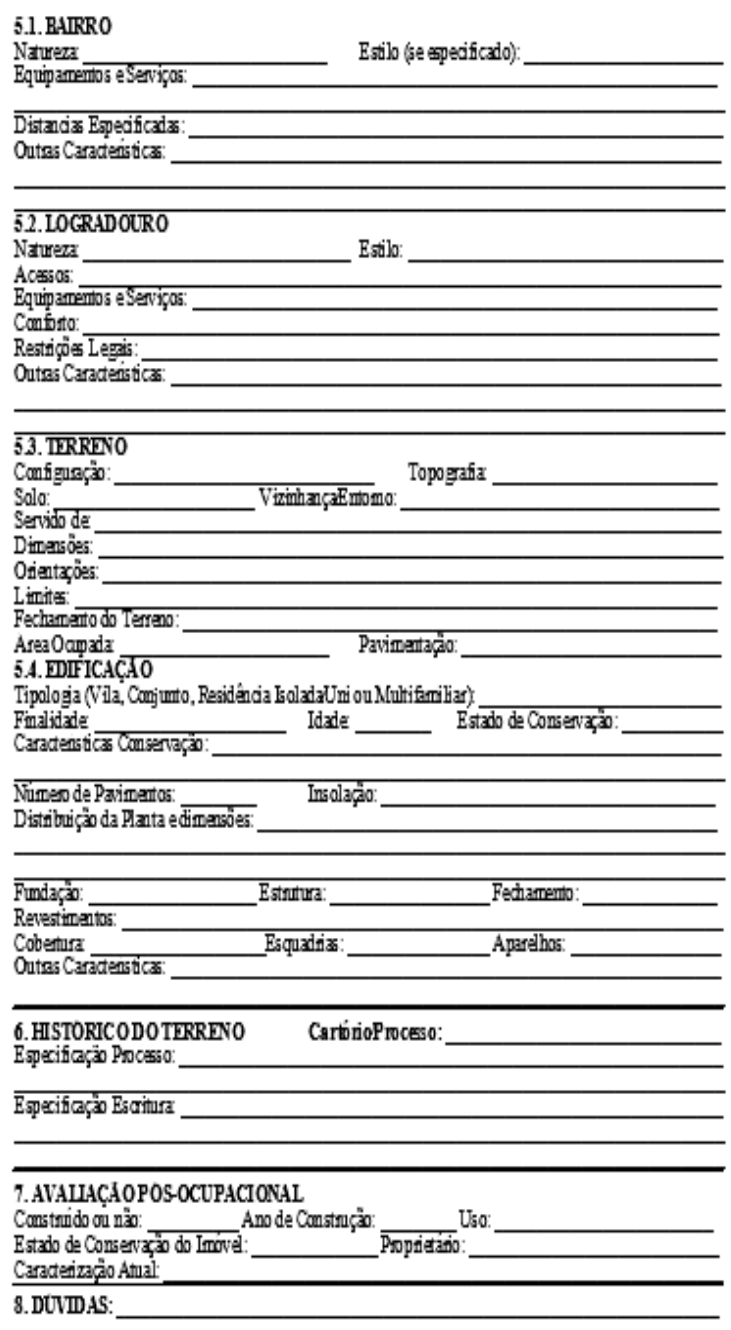




\section{ANEXO D: Print Screen do banco de dados elaborado para o armazenamento dos dados levantados no INSS-RN.}

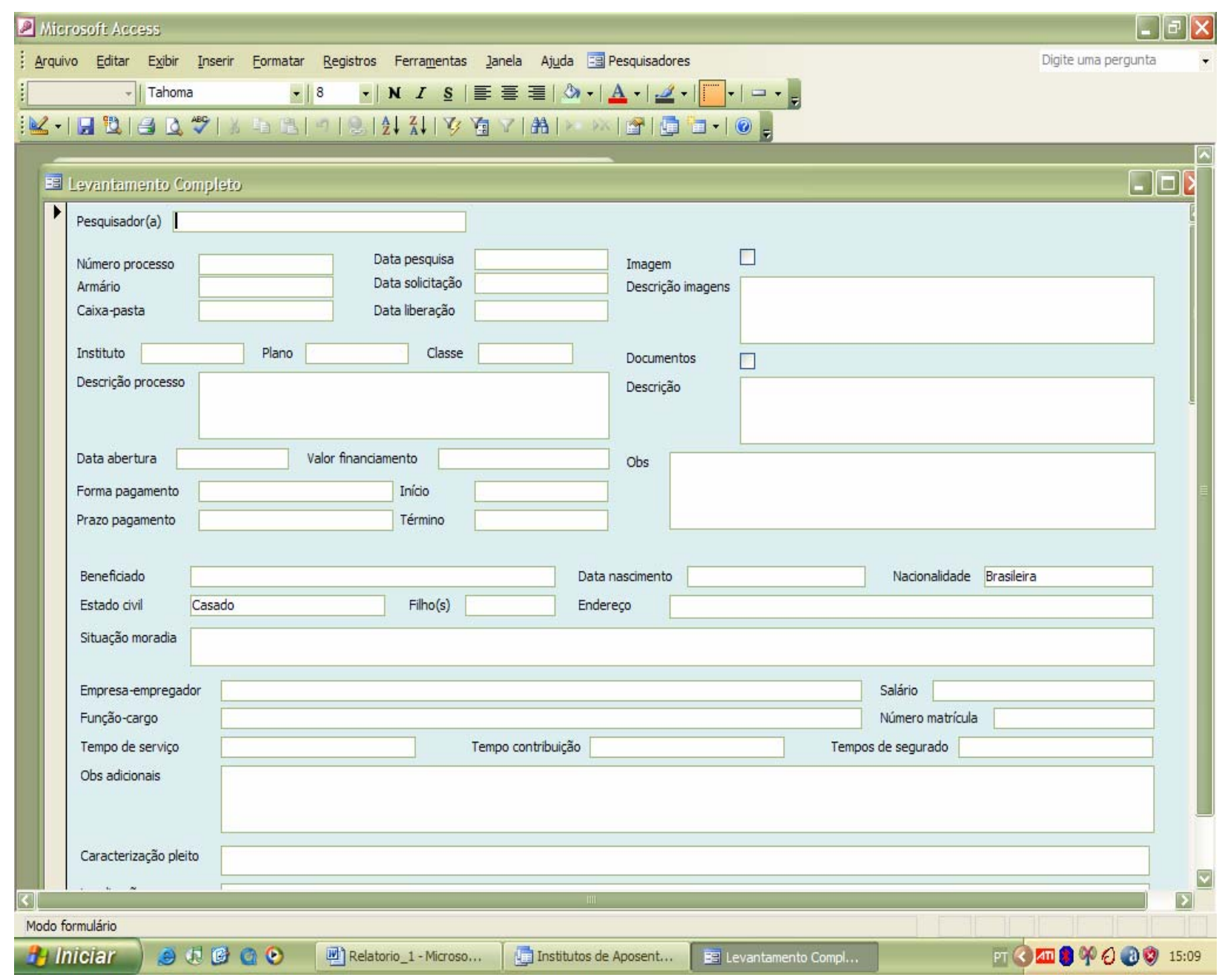

